\title{
FEMINISMO/S 17
}

La arquitectura y el urbanismo con perspectiva de género María Elia Gutiérrez Mozo (Coord.)

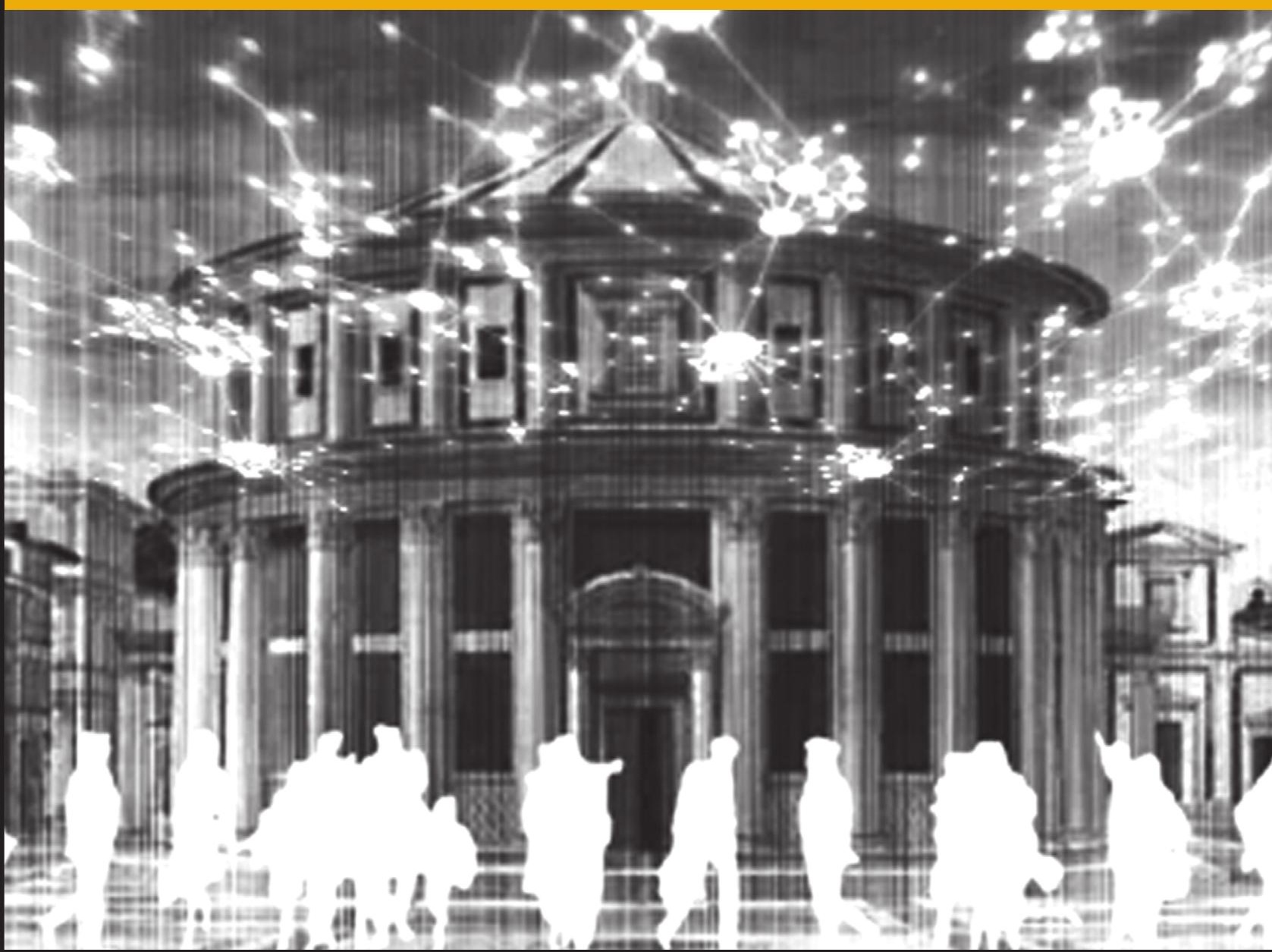

CEM Centro de Estudios 



\section{FEMINISMO/S}

Revista del Centro de Estudios sobre la Mujer de la Universidad de Alicante

Número 17, junio de 2011

\section{La arquitectura y el urbanismo con perspectiva de género}

María Elia Gutiérrez Mozo (Coord.) 



\title{
FEMINISMO/S \\ Revista del Centro de Estudios sobre la Mujer de la Universidad de Alicante
}

\author{
Revista Semestral \\ Editada por el Centro de Estudios sobre la Mujer de la Universidad de Alicante \\ con la colaboración del Vicerrectorado de Planificación Estratégica y Calidad
}

Número 17, junio de 2011

\section{CONSEJO EDITORIAL}

Directoras: Carmen MAÑAS VIEJO y Ma del Mar ESQuembre VALdÉs (Universidad de Alicante) Secretaria: Nieves MONTESINOS SÁNCHEZ (Universidad de Alicante)

Vocales: $\mathrm{M}^{\mathrm{a}}$ Teresa Ruíz CANTERo (Universidad de Alicante)

Purificación HERAS GONZÁLEZ (Universidad Miguel Hernández)

$\mathrm{M}^{a}$ Isabel PeÑalver Vicea (Universidad de Alicante)

Carmen OlaRIA DE GUSI (Universitat Jaume I)

\section{CONSEJO ASESOR}

Mabel Burín (Universidad de Ciencias Empresariales y Sociales, Buenos Aires)

Silvia CAPORAle Bizzini (Universidad de Alicante)

Angels CARABí (Universitat de Barcelona)

Pilar CUder Domínguez (Universidad de Huelva)

Joaquín DE JUAN (Universidad de Alicante)

$\mathrm{M}^{\mathrm{a}}$ José Frau Llinares (Universidad de Alicante)

Eddy GIL DE MEjÍA (Fachhochschule Oldenburg/Ostfriesland/Wilhelmshaven University

of Applied Sciences)

$\mathrm{M}^{\mathrm{a}}$ Victoria Gordillo Álvarez-Valdés (Universidad Complutense de Madrid)

Albert GRAS (Universidad de Alicante)

Marina MAYORAL (Universidad Complutense de Madrid)

Montserrat PALAU (Universitat Rovira i Virgili)

$\mathrm{M}^{\mathrm{a}}$ Dolores Ramos (Universidad de Málaga)

$\mathrm{M}^{\mathrm{a}}$ Dolores ReVEnTós (Universidad de Murcia)

Carmen RIERA (Universitat de Barcelona)

Ana SÁNCHEZ TORRES (Universitat de València)

Begoña San Miguel Del Hoyo (Universidad de Alicante)

Marta SegarRa (Universitat de Barcelona)

Cristina SEgURA GRAiÑo (Universidad Complutense de Madrid)

Julia Sevilla (Universitat de València)

$\mathrm{M}^{\mathrm{a}}$ Carmen SIMÓN (CSIC)

Ruth TeubÁl (Universidad de Buenos Aires)

Meri TORRAS (Universitat de Barcelona) 


\section{REDACCIÓN}

Centro de Estudios sobre la Mujer de la Universidad de Alicante

Campus de Sant Vicent del Raspeig

Apdo. 99 E-03080 Alicante

Tel. 965909415 - Fax 965909658

e-mail: cem@ua.es - web: http://www.ua.es/cem

\section{SUSCRIPCIÓN}

Centro de Estudios sobre la Mujer de la Universidad de Alicante

Campus de Sant Vicent del Raspeig

Apdo. 99 E-03080 Alicante

Tel. 965909415 - Fax 965909658

e-mail: cem@ua.es - web: http://www.ua.es/cem

Precio de cada ejemplar: $12 €$

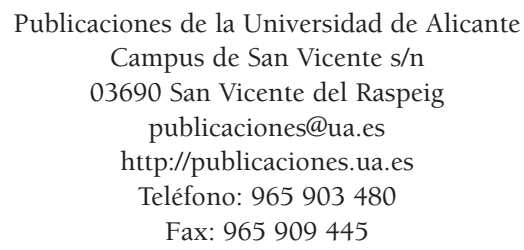

Edita:

Centro de Estudios sobre la Mujer de la Universidad de Alicante con la colaboración del Vicerrectorado de Planificación Estratégica y Calidad

Cuenta con una Ayuda para la Publicación de Revistas Científicas del Vicerrectorado de Investigación, Desarrollo e Innovación

ISSN: 1696-8166

Depósito legal: A-910-2003

Diseño de portada: candela ink Preimpresión e impresión:

\section{E Espagrafic}

Feminismo/s no se identifica necesariamente con los contenidos de los artículos firmados. Prohibida

la reproducción total o parcial de los artículos sin la autorización previa.

Feminismo/s se encuentra indexada en la base de datos del ISOC del CINDOC y en el LATINDEX.

También se encuentra recogida en DICE, In-RECS y MLA. 


\section{ÍNDICE}

María Elia Gutiérrez Mozo

Introducción a la arquitectura y el urbanismo con perspectiva de género .... 9

Javier Ruiz Sánchez

¿Qué ciudad ....? Acerca de la necesidad de reformular la pregunta

Pilar Vallalta Martínez y Francisco J. Sánchez Medrano

Hay una ciudad bajo la ciudad. El Proyecto de Conservación

Temporal de los restos medievales del Jardín de San Esteban (Murcia) ...... 45

Carlos Hernández Pezzi

La visión de género y el espacio inteligente

Pilar Chías Navarro

Estudiantes de arquitectura: ¿un ámbito de igualdad?

Zaida Muxí Martínez, Roser Casanovas, Adriana Ciocoletto,

Marta Fonseca y Blanca Gutiérrez Valdivia

¿Qué aporta la perspectiva de género al urbanismo?

Zaida Muxí Martínez y Adriana Ciocoletto

La ley de Barrios en Cataluña: la perspectiva de género como

herramienta de planificación

Yolanda Agudo Arroyo y Inés Sánchez de Madariaga

Construyendo un lugar en la profesión: trayectorias de las arquitectas

españolas

Juan Bravo Bravo

Así en la cocina como en la fábrica 
María Melgarejo Belenguer

De armarios y otras cosas de casas...

Andrés Martínez Medina

Higiene, vivienda y ciudad: cifras, imágenes y palabras femeninas

Carlos L. Marcos

Crítica de género. E. 1027: Eileen gray vs. Le Corbusier en Cap Martin.... 259

Laura Muñoz Pérez

Singularidad, naturalismo y movimiento. La aportación de Zaha Hadid al contexto arquitectónico actual

$$
* * *
$$

\section{RESEÑAS}

Asunción Oliva Portolés

Vetas de Ilustración. Reflexiones sobre feminismo e Islam, de Cèlia Amorós Puente, (Madrid, Cátedra, 2009, 312 p.)

José Laborda Yneva. "Compartir la vida»

La ciudad compartida de María-Ángeles DuRÁn y Carlos HERnÁndeZ

PEzzi; (Consejo Superior de los Colegios de Arquitectos de España, Madrid, 1998, 245 y 331 páginas.)

Eloi Grasset Morell. «Literatura i feminisme»

Lhora violeta de Montserrat Roig (Tarragona, Ed. Arola, 2010, 328 p.) ... 335

Reseña bio-bibliográfica 339

Normas editoriales de Feminismo/s 345 


\title{
INTRODUCCIÓN A LA ARQUITECTURA Y EL URBANISMO CON PERSPECTIVA DE GÉNERO
}

\author{
MARÍA Elia GutiÉRREZ MoZO \\ Universidad de Alicante
}

De la pertinencia del tema de este número 17 de la Revista Feminismo/s del Centro de Estudios sobre la Mujer (CEM) de la Universidad de Alicante (UA), dedicado a la Arquitectura y el Urbanismo con perspectiva de género, da buena cuenta la colección de doce artículos que lo componen y que siguen a continuación de la presente Introducción a los mismos, todos ellos sumamente interesantes y llenos de aportaciones originales al asunto central. Vaya, pues, mi agradecimiento, en primer lugar, a todos y cada uno de sus autores que han dado lo mejor de sí para participar en esta convocatoria.

En segundo lugar, quisiera agradecer al CEM de la UA la acogida, sin reservas, que, en su día, le dispensó a la propuesta, con el apoyo que ello significa, y la designación con la que me honró para coordinar este número. Ha sido un trabajo intenso y enriquecedor cuya contemplación final provoca la sonrisa de la satisfacción y, sobre todo, impulsa las ganas de seguir trabajando en la construcción de una igualdad, efectiva y real, entre las mujeres y los hombres. Una igualdad que es derecho constitucional y que posee ley específica al efecto. Pero que reclama de todos nosotros un compromiso inaplazable e incansable para su consecución. Reconocerlo es sólo cuestión de mirar, sin prejuicios, alrededor.

Los doce artículos aludidos han sido ordenados por bloques temáticos. Así, el primero de ellos está formado por las aportaciones dedicadas a la ciudad, a su cielo (skyline llamamos a la línea con la que se recorta contra él), a su suelo, ese espacio vivo donde compartimos la vida, y a su subsuelo, cuyas redes palidecen ante la potencia de las virtuales; el segundo recoge los artículos sobre urbanismo, la disciplina (teoría y práctica) que ordena y proyecta la ciudad y reflexiona, con otras, sobre ella y sobre sus habitantes, entre los 
cuales dedicamos especial atención a los estudiantes de arquitectura y a los profesionales; el tercero está compuesto por el par de aportes que versan sobre arquitectura, en particular, sobre la casa y sus cosas; y, el cuarto y último, trata sobre arquitectos y arquitectas.

Abrimos con el brillantísimo el artículo de Javier Ruiz Sánchez «¿Qué ciudad...? Acerca de la necesidad de reformular la pregunta», cuya tesis es más que compartible. Frente al espacio mercantil en que se ha convertido la ciudad moderna, el autor reivindica, de la mano de Margaret Mead, una visión compleja que se dirija a los puntos neurálgicos sobre los que se construye: la seguridad, por un lado, y la familia como célula social, por otro. Reivindica asimismo la ciudad como espacio de convivencia de lo familiar y lo extraño, de la seguridad y la incertidumbre.

Hemos demostrado saber hacer la ciudad funcional al dictado, mal interpretado, de la Carta de Atenas, pero todo funcionalismo establece relaciones biunívocas entre espacios y funciones, con lo que la flexibilidad está descartada de partida. Todo funcionalismo implica, pues, simplificación y homogeneización. Es estático. No resiste la evolución, de ahí los fracasos de sus soluciones al poco tiempo de ser puestas en marcha. El reto, por tanto, es transformar lo que se tiene más que decidir lo que se quiere, clave en los procesos de participación.

Javier Ruiz cita a Jane Jacobs y su apología de la acera como transición entre lo público y lo privado, como espacio comunicativo dinámico. Y nos recuerda que el discurso de género lo es sobre la diferencia, la complejidad y la incertidumbre, que no son los enemigos a batir, sino los valores a compartir. No se trata de salvaguardar la seguridad, instrumentando el miedo como mecanismo de control. El espacio complejo es difícil de dominar y su apropiación deriva del conocimiento como indagación. La misma apropiación, mucho más allá de las reformas del interior, que reclama el hacer nuestras las viviendas, incluso sus mecanismos de relación con el exterior.

Los actuales modelos de urbanización son funestos para la calle, reducida a canal de comunicación. La acera es el espacio adonde el ser humano conquista, primero en el juego de niños, luego en el deambular adolescente y más tarde en la exploración del adulto, su independencia, su autonomía y su identidad. La acera es una conquista de la libertad.

El autor, en definitiva, reivindica el derecho a complicarse la vida, lo cual no es posible sin la conquista de la complejidad urbana, en cualquier escala, en todas las escalas, pero, sobre todo, en la proximidad. Para facilitar las tareas y favorecer su distribución equitativa. Una ciudad justa es aquella en la que la 
justicia es posible. Nuestras actuales ciudades dificultan, cuando no impiden directamente, este derecho. Son el producto más expresivo de un capitalismo cuya crisis posee una componente espacial ausente en la otra gran crisis del sistema, la del 29. El urbanismo capitalista es aún más internacional que la arquitectura etiquetada con esta denominación.

Esa arquitectura que, por ser de todas partes, no es de ninguna en particular, arquitectura utópica en el sentido literal de la palabra (sin lugar) que nos advierte tanto de las precauciones que hemos de tomar respecto a nuestra capacidad de construir utopías como del innegable peso de las mismas, suministradas por el género literario de la ciencia-ficción, en el urbanismo.

Pilar Vallalta Martínez y Francisco José Sánchez Medrano cuentan, con conmovedora sencillez y máximo rigor, su experiencia de trabajo en «Hay una ciudad bajo la ciudad. El Proyecto de Conservación Temporal de los restos medievales del Jardín de San Esteban (Murcia)» que ha dirigido la primera (restauradora) al frente de un equipo mayoritariamente femenino e interdisciplinar (una arqueóloga, tres técnicas de empresa constructora, dos arquitectos -uno de ellos, el coautor del artículo- y un aparejador).

Los autores no ocultan que quizá la relación de su discurso con el género no vaya más allá de esta circunstancia y de un paralelismo no buscado, pero muy expresivo, entre la decisión de dejar parcialmente cubiertas las estructuras del yacimiento para que se sigan viendo y, por tanto, no caigan en el olvido, y la necesaria visibilidad que requieren las mujeres para alcanzar los puestos que les corresponden y asumir las responsabilidades para las que están capacitadas.

El artículo se estructura en ocho partes, a saber: Puesta en situación: los antecedentes próximos; Perspectivas asonantes: femenino plural (consideraciones sobre el equipo de trabajo); Desmontando el pasado: destapando muñecas rusas (no hay una ciudad bajo la ciudad: hay muchas. Entonces, ¿con cuál nos quedamos y por qué?); Factor asombro: el valor del tamaño (más de 10.000 $\mathrm{m}^{2}$ de excavación); De patologías y deterioros: toma de pulso (alteración, degradación, ruina); Conservación temporal: cuidados de mantenimiento hasta el quirófano (protección, sectores y zonas del yacimiento, consolidación); Lucha por la visibilidad: los debates pendientes (en los restos y en el género); Bajando el telón del primer acto.

La reflexión final a propósito de nuestra propia historicidad y de los referentes que nos suministra, válidos o rechazables, es de todo punto pertinente al tema que nos ocupa.

Interesante la caracterización prolija que Carlos Hernández Pezzi hace en «La visión de género y el espacio inteligente» sobre el espacio virtual y 
aventuradas sus hipótesis de traslación a la construcción del espacio real. Un discurso que se articula en seis partes, de las cuales la primera mitad trata de desglosar los conceptos de espacio europeo como un espacio de derechos y deberes (Europa y las ciudades); de espacio físico y virtual como recipiente accesible y poroso (La ciudad digital) y de espacio inteligente como el resultado de la superación de las tres brechas digitales: del conocimiento, del uso y del acceso (Espacio inteligente).

El autor contextualiza su análisis en el marco de la profunda crisis estructural en la que estamos sumergidos y reclama la armazón de un nuevo modelo productivo (inaplazable) basado a su vez en un nuevo modelo social y urbano. El cambio, que ya se ha producido en la red, se debe fundamentar sobre un modelo de interculturalidad e intergeneracionalidad, un modelo que proporciona nuevos entendimientos de la identidad, individual y colectiva, y que parece que ha encontrado en la esfera una metáfora idónea de lo global y lo digital. Quizá por ello las arquitecturas de última generación posmoderna sientan predilección por las amebas y otras formas bulbosas, impensables sin la asistencia (que deviene tiranía) del ordenador.

Hernández Pezzi imagina El urbanismo de las redes como aquel capaz de generar espacios porosos, esto es, accesibles y participativos adonde la democracia representativa conviva y madure con el impulso vital y comprometido de la democracia deliberativa, y de conformar La ciudad interactiva, que es la ciudad digital, inteligente, cuyos espacios públicos son los lugares de la libre expresión por excelencia y de las identidades digitales, las cuales precisan del juego limpio para no pervertir estas nuevas maneras de vivir y de convivir.

Acaba el artículo con un epígrafe dedicado a Valores e indicadores, adonde destaca situaciones de hecho como la inmigración digital o el aprendizaje inverso (de hijos a padres), frente a deseables situaciones de derecho que rubriquen el cambio de paradigmas urbanos: la inteligencia, demostrada en los valores de igualdad y de democracia.

Cuando uno lee, al final, la fecha en que fue escrito este texto (septiembre de 2010) no puede dejar de pensar cuántas de esas mujeres que están protagonizando el cambio de paradigma en la red y cuyo reflejo en la ciudad Hernández Pezzi no duda, no son también las secretas impulsoras del movimiento revolucionario que sacude el norte de África y que representa, inequívoca, contundentemente, la fuerza de las personas que, juntas, deciden cambiar las cosas.

Pilar Chías Navarro nos presenta un documento de apreciable valor estadístico que fundamenta el optimismo de su respuesta a la pregunta del título «Estudiantes de Arquitectura: ¿Un ámbito de igualdad?» en la franja 
académica a la que se refiere. A través de una Introducción, a modo de declaración de intenciones, y después del pertinente estudio La presencia de la mujer en los estudios universitarios relacionadas con la Arquitectura, articulado en cuatro epígrafes (El marco académico actual, El perfil del alumnado, El entorno de trabajo y El perfil del egresado), nos conduce a las Conclusiones que reflejan el aumento constante, en la última década, del porcentaje de mujeres que estudian Arquitectura, superando, desde el curso 2003-2004 el 50\% y llegando, en el presente curso académico 2010-2011, al 54\% en la Universidad de Alcalá de Henares, datos similares a los que se producen en otras escuelas del territorio nacional.

La presencia ya mayoritaria de mujeres tiene su correlato en los expedientes académicos, de los cuales se toma como muestra significativa los resultados obtenidos en los tribunales del Proyecto Fin de Carrera. Tampoco se aprecian diferencias en el comportamiento académico respecto al liderazgo de los grupos de trabajo y a la brillantez de las defensas públicas de las propuestas de los alumnos. La autora del artículo señala que, en los primeros cursos, las mujeres aventajan a los hombres en liderazgo, mientras que ellos lo hacen en las intervenciones públicas: ambas situaciones se invierten en cursos superiores. La causa puede estar en el diferente grado de madurez que, a la misma edad, presentan las mujeres y los hombres.

Este panorama es en el que fundamenta Pilar Chías su optimismo a la hora de contemplar el futuro profesional de las arquitectas suponiendo que será una proyección de lo que ocurre en las escuelas. Nuestra experiencia al respecto es que, en efecto, las alumnas de arquitectura no perciben ninguna desigualdad en las aulas, salvo que se las invite a mirar a la tarima adonde descubren, no sin sorpresa, que la mayoría de sus profesores son hombres, o a repasar los componentes de los equipos directivos, adonde ocurre más de lo mismo.

El enfoque de género en el período de formación corre el peligro de aparecer como un discurso obsoleto y afuera de la realidad de nuestro tiempo; sin embargo, entendemos que es un compromiso ineludible habida cuenta de que el ámbito laboral, al que no es en absoluto ajeno el ejercicio de la arquitectura, lo es de profunda desigualdad.

Zaida Muxí, Roser Casanovas, Adriana Ciocoletto, Marta Fonseca y Blanca Gutiérrez sientan, en «¿Qué aporta la perspectiva de género al urbanismo?», las bases de los aportes que, al análisis, diseño y construcción de la ciudad, ofrece este enfoque el cual, tal y como reza en la Introducción, lo es desde la complejidad, la diversidad y la inclusión de todas aquellas personas 
que, tradicionalmente, no han contado ni para los responsables técnicos ni políticos en la planificación urbana.

Aplicar la perspectiva de género en el urbanismo supone posicionar en igualdad de condiciones el mundo productivo y el reproductivo. Supone un urbanismo de proximidad adonde la experiencia de las personas constituye una fuente básica de conocimiento. Se trata, además, de un trabajo transversal, transescalar e interdisciplinar.

Las Recomendaciones para la aplicación de la perspectiva de género, una suerte de manual de buenas prácticas, se articulan en cinco puntos: Un análisis diferenciado e integrado (un trabajo de ida y vuelta constantes en cada escala y para cada problema); las Variables de análisis de la realidad (espacios públicos de relación, equipamientos y servicios, movilidad, vivienda, seguridad y participación); la Participación desde la experiencia: La experiencia de las mujeres como conocimiento urbano (que requiere corresponsabilidad, refuerza el sentimiento de pertenencia y acrecienta la democratización de la sociedad); las Metodologías de análisis urbano desde una perspectiva de género (cuantitativas -datos- y cualitativas. La observación participante apoyada en tres pilares: el análisis secuencial de un tema en distintos espacios y tiempos, las entrevistas -espontáneas y en profundidad- y fotografías, diagramas y dibujos); y las Conclusiones (pensar la ciudad desde la diferencia y colocar en igualdad de condiciones todas las demandas).

Una aplicación práctica y concreta de la exposición de principios que se contienen en el anterior artículo es lo que nos ofrecen Zaida Muxí y Adriana Ciocoletto en su muy interesante e ilustrativa aportación «La Ley de Barrios en Cataluña: la perspectiva de género como herramienta de planificación», estructurada nuevamente en tres partes, la primera de las cuales, a modo de Introducción, explica someramente tanto el espíritu y los contenidos de esta ley de rehabilitación urbana, cuyo $6^{\circ}$ punto de actuación da nombre al colectivo que integran nuestras autoras, como el contexto político en el que se redactó. El subapartado de Aplicación de la perspectiva de género en el proyecto urbano es un pertinente resumen del artículo precedente.

La sección central del trabajo recoge el Estudio de casos concretos, tres en particular: el Barrio Collblanc/Torrassa, L'Hospitalet de Llobregat (2004-2008); el Barrio de l'Erm, Manlleu (2004/2008) y el Barrio El Congost, Granollers (2006-2010).

De las Conclusiones sobre los proyectos analizados destacamos las consideraciones relativas al diseño de espacios públicos y equipamientos desde la perspectiva de género: atender a la sección de las calles (plantas bajas, aceras); vincular los equipamientos públicos a los espacios públicos; mejorar la 
accesibilidad, la visibilidad y, con ellas, la seguridad; promover la mezcla de usos que garantiza la presencia de personas y optimiza desplazamientos y visibilizar a las mujeres, de antes y de ahora, en la ciudad.

Inquietante el diagnóstico aportado por Yolanda Agudo Arroyo e Inés Sánchez de Madariaga en su artículo «Construyendo un lugar en la profesión: Trayectorias de las arquitectas españolas», antídoto, para quien lo quiera tomar, contra el olvido y la ocultación de la desigualdad que existe en las carreras profesionales de las arquitectas frente a sus compañeros.

Se trata del avance de los resultados de una investigación empírica cualitativa basada en las entrevistas en profundidad a 21 arquitectas de tres generaciones (25-40, 40-60 y >60 años), cruzada con la actividad que desempeñan (asalariadas, profesoras de universidad, profesionales liberales y administraciones públicas). El estudio se articula en cuatro apartados con una suerte de conclusión final que prefiere titularse como Futuro.

Dichos epígrafes recorren los siguientes aspectos: La formación: acceso a la universidad, en el que se dibuja con claridad el desplazamiento de la razón para estudiar Arquitectura, desde la poderosa influencia del entorno en las mayores hasta el gusto y/o a vocación en las jóvenes. Sigue gravitando, no obstante, en el tramo 40-60 años, el peso de la presencia de arquitectos en la familia o entre las amistades próximas.

El segundo apartado se dedica al paso De la formación al empleo, adonde se visibilizan las dificultades no sólo de acceso sino, sobre todo, de mantenimiento. En las académicas se repiten los consabidos diagramas en tijera, lo que priva a las alumnas de referencias femeninas. El mito del arquitecto, representado por Howard Roark en «El manantial» (King Vidor, 1949), poco o nada tiene que ver con nosotras.

El tercer epígrafe se centra en El ejercicio de la profesión que las mujeres prefieren desarrollar en la administración cuyo acceso, por oposición, les da presencia mayoritaria, aunque los puestos por designación vuelven a estar copados por hombres. Hay menos mujeres en el ejercicio liberal y hallan en los concursos (anonimato) una posibilidad de trabajo en igualdad de condiciones.

Otro tema que aparece es el de las famosas parejas de arquitectos en las que normalmente ellas se dedican al estudio y, dentro de él, a organización, gestión y diseño, y ellos a las relaciones sociales y a la obra.

El último apartado es El desarrollo profesional cuyas dificultades para las arquitectas argumentan las autoras en las siguientes causas: Asignación diferencial de roles en el sistema de las relaciones de género (aflora siempre el asunto de la maternidad y, con él, el de la culpa por no llegar a todo, cuando no directamente el abandono); Invisibilidad versus sobreesfuerzo ante el modelo 
masculino de la profesión (las arquitectas adoptan o bien un perfil bajo para «no molestar» o se desgastan para "parecerse a ellos» en una cultura del trabajo que las mujeres subliman y se adjudican como seña de identidad); $L a$ promoción en la profesión: ¿techo de cristal y/o suelo pegajoso? (tendemos a justificar nuestra limitada promoción como algo voluntario, nos retraemos ante el liderazgo y, si lo ejercemos, o somos boicoteadas o reaccionamos con insolidaridad); Negación de la evidencia/diferencia (las mujeres se resisten a aceptar que existe desigualdad, se escudan en la crisis o juegan el juego perverso de sacar sus «armas de mujer»).

Todas estas razones son las que nos permiten afirmar que parece optimista pensar que los datos cuantitativos van a cambiar, sin más esfuerzo, sólo con el paso del tiempo, las relaciones cualitativas y justifican la pertinencia de monográficos como el que tiene el lector en sus manos.

Excepcional en su contenido, extraordinariamente culto y magníficamente documentado es el artículo de Juan Bravo Bravo «Así en la cocina como en la fábrica», en el cual se recorre, en cinco etapas, el estudio de la cocina doméstica contemporánea, su definición, desarrollo y crisis, como elemento capaz de sintetizar las aportaciones de las mujeres arquitectas y diseñadoras a la historia de esta disciplina a la vez que ilustra la evolución del rol de género asignado a las mujeres dentro y fuera de la familia.

El primer apartado, Diseño en femenino. Estudio de un caso: la cocina doméstica, revela el papel de la mujer en el diseño, fructífero y enriquecedor por lo comprehensivo de su mirada. El segundo epígrafe, Mujer y Bauhaus: Benita OTTE y la cocina de la Haus am Horn, Weimar, 1923, da buena cuenta de la fortuna crítica de la solución presentada en esta muestra, que lo es de un cierto compromiso entre la opción de cocina-laboratorio y la de cocinacomedor, compromiso que se optimiza en las propuestas para la exposición del Werkbund de 1927 en Stuttgart, adonde, paralelamente a la Weissenhofsiedlung, Lilly Reich dirigió el programa de equipamiento doméstico recogido en Die Wohnung (El Apartamento), dentro del cual el tema de la cocina fue responsabilidad de Hilde Zimmermann y Erna Meyer.

El ecuador de la aportación se dedica a Grete SCHÜTTE-LIHOTZKY y la definición del tipo de cocina contemporánea, la que se dio en llamar Cocina de Frankfurt y que fue el estándar en las viviendas sociales, basada en la eficacia entendida como optimización productiva (de tiempos y movimientos) y en la asunción, por razones económicas, del tipo cocina-laboratorio matizada con una comunicación directa, a través de una amplia corredera, con el comedor. Se trata de una cocina compacta e integrada dispuesta en L, con armarios de base y de pared. Los inferiores definen un plano horizontal de trabajo liso y 
continuo, y uno vertical rematado en zócalo que se interrumpe puntualmente para poder trabajar sentado. Mide menos de $6,50 \mathrm{~m}^{2}$ y todas sus dimensiones moduladas apuntan a la fabricación industrial seriada.

Todos estos avances dirigidos a aligerar la carga de trabajo no cuestionan en absoluto que dichas faenas las desempeña la mujer, por lo que es del todo pertinente el cuarto apartado Propuestas de cocina colectivizada iúnica alternativa auténticamente feminista?, opción que el capitalismo no permitió pero la Rusia posterior a 1917 sí. Se trataba de liberar a las mujeres de las tareas domésticas para incorporarlas a las productivas. La solución transitoria que representa el bloque Narkomfin, adonde la familia aún guarda un núcleo de privacidad, deriva en la radicalización de las propuestas que disuelven al individuo en el grupo y cuya ocupación inhumana por varias familias provocó la reacción popular en contra de estas residencias.

Cierra el artículo una reflexión sobre la Difusión y crisis del tipo tras la Segunda Guerra Mundial, en el que la industria estadounidense introdujo una masiva mecanización mientras la «cocina sueca» trataba de suavizar el funcionalismo, humanizándolo. Hoy, que ya no aceptamos más una vida en la que las distintas actividades que realizamos hayan de tener un único e inamovible espacio asignado, que asistimos a nuevas formas de convivencia, que aspiramos a compartir responsabilidades en las tareas domésticas y familiares, la cocina se nos presenta a los arquitectos como una oportunidad y un reto para el diseño, como un espacio para compartir la vida, el trabajo y el placer, que espera nuestro esfuerzo y nuestro talento para interpretar nuestros anhelos y nuestro legítimo derecho de igualdad plena.

María Melgarejo Belenguer, en «De armarios y otras cosas de casas...» nos ofrece una reflexión a propósito de la capacidad de transformación que encierran las cosas pequeñas. A través de un breve discurso histórico, sitúa, en el siglo XVII holandés, el comienzo de una tradición pictórica, la de género, que gusta de representar ambientes íntimos y domésticos adonde las mujeres protagonizan una vida ordenada, sencilla, limpia y apacible rodeadas de sus niños y de sus enseres. La vivienda burguesa del siglo XIX reflejará en su estructura, a su vez, la de las relaciones familiares.

Habrá que esperar al siglo XX y a sus vanguardias de entreguerras para asistir a un doble acontecimiento que cambiará para siempre la idea de arquitectura y el papel de los arquitectos. Por un lado, el convencimiento de que el tema esencial de arquitectura, que merece todo el esfuerzo y todo el talento, para cambiar la vida es la casa. Por otro, la incorporación de las mujeres profesionales al reto de repensar la vivienda y hacerlo desde el compromiso social.

Feminismo/s 17, junio 2011, pp. 9-22 
Dos arquitectas protagonizan el relato, ambas bajo la alargada sombra de sus compañeros: Charlotte Perriand (y Le Corbusier) y Lilly Reich (y Mies van der Rohe). La primera, entregada al diseño de los casiers (armarios), unidad de medida para el diseño del mobiliario y, con él, de la vivienda que lo alberga. La segunda, trabajando la concepción del espacio doméstico como un espacio de habitación, de luz, de transparencia, de fluidez, cuya mínima organización se confía precisamente al mobiliario, el cual, en su calidad de móvil, puede cambiar de disposición con la vida a la que sirve y acompaña.

En una impecable composición simétrica, tres mujeres comparecen, desde sus experiencias y disciplinas próximas al mundo de la arquitectura sin ser arquitectas, precedidas de una suerte de introducción sobre el contexto en el que se desarrollan su vida y su labor y sucedidas por una especie de conclusión final, en la aportación de Andrés Martínez Medina «Higiene, vivienda y ciudad: Cifras, imágenes y palabras femeninas».

En Mujeres en la Historia: la responsabilidad por capacitación, el autor explicita la relación entre democracias más o menos maduras, adonde la libertad, la igualdad y fraternidad (hoy, más políticamente correctos pero también menos comprometidos, diríamos solidaridad) son derechos constitucionales, y la posibilidad efectiva, real, de que las mujeres sean reconocidas por sus méritos, los cuales se deben a su valía personal pero también a un contexto que les ha permitido la formación y, con ella, la independencia económica.

El primer caso se trata en Las enfermedades en el ámbito de la higiene o el poder de las cifras y narra el aporte de la enfermera Florence Nightingale a la definición de una tipología arquitectónica, la sanitaria, basada en los principios de higiene (limpieza, orden, ventilación, iluminación) y en el propio método científico sobre el que esta mujer cimenta los estudios profesionales de la enfermería: observación, reflexión, destreza práctica, en suma, formación y experiencia. Sin duda, sus conocimientos matemáticos fueron decisivos.

La sección central del artículo está dedicada a Las viviendas en el ámbito de lo doméstico o el poder de la imagen y en ella se plantea una idea muy sugerente inspirada en las relaciones de ida y vuelta que se establecen entre las casas que se construyen en América por F. Ll. Wright (las Prairie Houses) primero, Mies después y, como síntesis, las Case Study Houses, y las experiencias en vivienda social que se impulsan en la Europa de entreguerras. Esa hermosa idea consiste en relacionar los nuevos modos de habitar, permeables a la naturaleza, fluidos, transparentes, adonde se han disuelto los límites interior-exterior, con los nuevos roles que desempeña la mujer en su definición, protagonista tanto en el diseño (Catherine Ostertag y Ray Eames) como en su difusión y divulgación masivas (Aline B. Louchheim y Esther McCoy). 
El tríptico se completa con la crítica, pionera y aguda, de una periodista, Jane Jacobs, a la ciudad funcional en el epígrafe titulado La insegura convivencia en las ciudades o el poder de la palabra, la cual reivindica la calle como el espacio público de relación, es decir, de vida urbana, por excelencia. Asimismo reclama redirigir la atención a lo real, a la vida, a lo común y ordinario que hoy llamamos cotidiano. Se anticipó y fundamentó las críticas al Movimiento Moderno tanto desde América (Venturi y la arquitectura como comunicación) como desde Europa (Rossi y la reinserción de la arquitectura en el discurso histórico de la ciudad).

Cierra el artículo Una reflexión a propósito de las protagonistas, sus armas $y$ sus contextos adonde se apuesta por el entendimiento de la arquitectura y de la ciudad desde la interdisciplinaridad y por sociedades que, garantizando la igualdad de derechos, no obstaculicen la libertad del individuo. Sociedades en las que convencer signifique vencer con razonamientos: con números, con imágenes, con palabras. Con argumentos.

Carlos Luis Marcos Alba nos ofrece las claves profundas y rigurosas del sistemático e incansable mal trato que Le Corbusier (LC) infligió a Eileen Gray utilizando para ello el acoso incesante a su famosa y hermosa casa en Cap Martin, Roquebrune, en su interesantísimo artículo «Crítica de género. E. 1027: Eileen Gray vs. Le Corbusier en Cap Martin». El discurso se articula en tres partes: la primera de ellas, el Contexto de la obra, nos sitúa, en su tiempo y en sus circunstancias profesionales y vitales, a los tres protagonistas de la historia: Badovici, arquitecto, crítico, editor y admirador y divulgador de la obra de LC, pareja sentimental de Eileen Gray en el momento del encargo. Para ella, interiorista, esta obra adquiere connotaciones especialísimas que se traducen en la cuidadosa elección del lugar como primer acto de proyecto, un lugar íntimo y reservado para disfrutar del amor y del mar.

La sección central Le Corbusier y la E.1027: una atracción fatal narra las vicisitudes en las relaciones de estas tres personas: desde la explícita admiración que siente LC por la casa (1926-29), cuyos amigos le invitan a visitar, hasta la ruptura de la amistad con su autora por los murales que, en 1938, LC pinta al fresco en sus paredes. Para entonces, el romance está roto, pero el inmueble pertenece a Badovici (a pesar de haberlo financiado ella) quien, obviamente, consiente (y quizá propicia) la «colonización pictórica», tanto más flagrante cuanto el lenguaje utilizado, figurativo, contrasta con la delicada abstracción de la casa.

En 1949 LC incluso se permite criticar la E.1027, amenazando a su propietario con hacer pública la polémica. Es el año de la ruptura definitiva y del proyecto de las casas denominadas Rob y Roq que LC diseña, precisamente, 
arriba de la ladera adonde asienta la casa de Gray. Este proyecto no pasa del papel, sin embargo, a escasos 20 metros, LC construye en 1952 su Cabanon (cabañita), que Beatriz Colomina llama «caseta de perro guardián». Además, en 1957, LC también proyecta y construye, en el mismo paraje, la Unité de Camping.

Así pues, LC practica un doble acoso a la vivienda: por un lado, como el hierro sobre el ganado, la marca con sus pinturas al fresco (una de las cuales, para mayor agravio, sobre otra anterior de Gray); por otro, la cerca con dos obras que, desde su posición dominante, se enseñorean del lugar y dan al traste con la tan preciada y buscada intimidad. No es de extrañar que algunas interpretaciones de los hechos hablen de auténtica violación.

La obsesión de LC prosigue haciendo comprar la casa a una amiga suya, Mme. Schelbert, cuando Badovici muere. Ello le permite, además, pasar largas temporadas en la casa al final de su vida.

Los hechos son terribles y hablan por sí solos, pero una pregunta es pertinente: ¿por qué? A ella responde, con claridad meridiana, Carlos L. Marcos en el epígrafe final de su aportación Crítica de género: la arquitectura de Eileen Gray en la E.1027: porque la casa es una crítica, no lacerante pero sí contundente, a los principios corbuserianos. Veámoslo.

La casa se levanta sobre pilotis que no lo son tanto cuanto pilastras y machones: su sintaxis es muraria. La cubierta-jardín no es habitable ya que ello sería incompatible con la ansiada intimidad. La planta no es una planta libre, es decir, el producto de la disociación de la estructura portante y los cerramientos y divisiones, sino que es el resultado de la wrigthiana «ruptura de la caja» y de las circulaciones en torno a unidades funcionales.

A Eileen Gray no le interesa la máquina de habitar, no cree en ella: aspira a la obra de arte total y se esmera, con acierto, en concertar espacios, mobiliario y enseres. La fachada tampoco es libre, sino consecuencia cabal de la planta; las ventanas son una respuesta al paisaje y a la habitación y por eso las hay horizontales, pero también rasgadas hasta el suelo; el paseo arquitectónico, máxima expresión del predominio de la cultura de la imagen y su movimiento, se sustituye por la interpenetración interior-exterior. Frente a la arquitectura internacional, la casa nace como vinculación y diálogo con el lugar y reinterpreta la tradición (en este caso, mediterránea) a la que la modernidad ha dado la espalda.

Dice Carlos L. Marcos que si en esta historia hay crítica de género, ésta es la que Eileen Gray hizo sobre la ortodoxia del movimiento moderno con su propia obra. Sin duda. Pero parece asimismo incontestable que el machaqueo que sufrió, perpetrado por LC, consentido por Badovici y con la complicidad 
de la historiografía de la modernidad, tienen todo que ver con el hecho de que fuera mujer. Y libre, además.

Yolanda Agudo e Inés Sánchez toman de María Antonia García de León la expresión del «síndrome de la abeja reina» para referirse al que presentan algunas mujeres que llegan al poder y se instalan en la élite distanciándose del resto y adoptando modelos masculinos, individualistas y agresivos, en su práctica profesional, con el fin de legitimar su propio statu quo. Un ejemplo paradigmático nos lo sirve Laura Muñoz Pérez en su artículo «Singularidad, naturalismo y movimiento. La aportación de Zaha Hadid al contexto arquitectónico actual», a propósito de esta arquitecta instalada, en efecto y por derecho propio, entre las estrellas más rutilantes del firmamento arquitectónico. Una prueba de ello es que es la única mujer galardonada con el Premio Pritzker (2004), el Nobel de los arquitectos.

La autora nos describe, con amor y con pormenor, una selección de obras de Zaha Hadid ordenadas cronológicamente: la Estación de bomberos de Vitra, en Weil am Rhein, 1990-1994, adonde destaca el efecto de movimiento congelado; el Aparcamiento e intercambiador Terminus Hoenheim-Nord, en Estrasburgo, 1998-2001, premio Mies van der Rohe de la Unión Europea 2003, caracterizado por la fuerza rompedora de la diagonal; las Cuatro estaciones, funicular Nordpark, puente (2004-2007) y pista de saltos de esquí del monte Bergisel (1999-2002), en Innsbruck, una lengua de hielo que el vidrio remeda; la Fábrica y salón de exposiciones para la BMW, en Leipzig, 2001-2005, cuya fuerza centrípeta irradia el entorno; el Centro de la Ciencia Phaeno de Wolfsburg, 2000-2005, en el que las energías telúricas reaparecen bajo la forma de volcánicos conos y el Pabellón-puente de la Expo 2008 de Zaragoza, una suerte de artefacto reptante por cuyas entrañas discurren los fluidos a modo de gran vaso comunicante.

La tesis de Laura Muñoz es clara y se explicita con honradez: el discurso de Zaha Hadid no es en absoluto de género. La arquitecta juega, en un mundo tradicional y mayoritariamente de hombres, tan bien o mejor que ellos, el juego de los varones, para lo cual la complicidad del ordenador le es vital. Acomete con energía y desinhibición cuanto programa se le plantea en cualquier parte del mundo y derrocha eso que Llàtzer Moix llama «incontinencia expresiva». Es cierto. Pero no lo es menos que lo que ha logrado, la fama, merece, por su condición de mujer, un especial reconocimiento: el que la autora reivindica precisamente por alejarse de todo aquello que pudiera sonar a lo propio de las féminas. Es un punto de vista...

Finalmente, "Compartir la vida», de José Laborda Yneva, es una breve reseña del proyecto editorial La ciudad compartida (CSCAE, 1998), 
materializado en dos libros que matizan el título con el aporte de un subtítulo diferencial: Conocimiento, afecto y uso, de la socióloga María Ángeles Durán, y El género de la arquitectura, del arquitecto Carlos Hernández Pezzi. Dicho proyecto recoge las experiencias tanto del Programa de Igualdad de Oportunidades para las Mujeres (UE y CSCAE, 1992) como de los cursos Urbanismo y mujer celebrados en Andalucía y Castilla La Mancha en 1993 y 1994.

José Laborda aporta una revisión crítica tanto de los dos textos, publicados hace trece años, como de su primera reseña a los mismos (de hace doce), revisión que parece ahondar en las diferencias (a la vista de los dos volúmenes por separado, irreconciliables) entre ambos. Elogia la actitud de Durán quien, teniendo tanto para decir, prefiere sin embargo escuchar, dando buena prueba de la facilidad y disposición de las mujeres para ponernos en el lugar del otro. Pezzi, por su parte, se afana en definir y reparar agravios de lo masculino sobre lo femenino en la ciudad que sigue ignorando que su único fin es ayudar a compartir la vida, es decir, a convivir. 


\title{
¿QUÉ CIUDAD ...? \\ ACERCA DE LA NECESIDAD DE REFORMULAR LA PREGUNTA $^{1}$
}

\author{
JAVIER RUIZ SÁNCHEZ \\ Universidad Politécnica de Madrid
}

Recibido 09/02/2011

Aceptado 20/05/2011

\section{Resumen}

El presente artículo pretende cuestionar una cierta tendencia a la crítica del urbanismo funcionalista llevada a cabo desde una perspectiva funcionalista. Mucha de la crítica así realizada sólo conduce a una práctica urbanística consistente en sustituir un programa por otro. Se reivindica la necesidad de ir más allá, de un cambio real, no sólo nominal, del punto de vista. Se reivindica la ciudad compleja, en su imperfección y dinamismo, frente a cualquier proyección de un proyecto ideal sobre el territorio urbano. La ciudad justa e igualitaria será compleja o no será.

Palabras clave: Urbanismo, complejidad urbana, ciudad funcionalista.

1. El presente artículo desarrolla en extensión las ideas apuntadas en el coloquio La integración del principio de igualdad y la perspectiva de género en la normativa urbanística, llevado a cabo en Valladolid el 17 de septiembre de 2008 con motivo de la presentación de la Ley de Medidas sobre Urbanismo y Suelo de Castilla y León.

Feminismo/s 17, junio 2011, pp. 23-43 


\begin{abstract}
This paper tries to question a certain trend to criticize functionalism in urban planning from a similar functional adapted concepts or points of view. Much of this criticism just leads us to an urban practice which merely introduces changes in the program, worse if only in the domestic scale. It is necessary to look further, looking for a real change, not just in the use of terms. The answer must be the complex city, even if not perfect and difficult to face in its dynamics, avoiding the easier simple answer: to try to project some kind of utopia. The just and equal city will be complex or just won't be.
\end{abstract}

Keywords: Urban planning, urban complexity; functional city. 
A city is a place where there is no need to wait for next week to get the answer to a question, to taste the food of any country, to find new voices to listen to and familiar ones to listen to again.

Margaret Mead

The only thing that makes life possible is permanent, intolerable uncertainty: not knowing what comes next

Ursula K. Le Guin: The Left Hand of Darkness, 1969

Cito de memoria, de algo leído y quizá también escuchado hace casi treinta años, por lo que sólo soy capaz de esbozar aproximadamente la idea. Fue en una entrevista realizada al director de cine suizo Alain Tanner en la revista $\mathrm{Pa}$ peles de cine Casablanca con motivo del estreno en 1981 de Les Années lumièrel Light Years Away, y quizá también en un coloquio con el propio director en la cafetería del cine Alphaville, en Madrid. Repasando algunas de las películas más significativas de su trayectoria, y hablando a propósito del lenguaje y la censura política, Tanner recordaba un detalle referido a La salamandre, de 1971, coescrita con John Berger. En esta película hay entre todos los planos al menos uno mítico, un plano fijo en el que la protagonista, Rosemonde, obrera en una industria cárnica, elabora mecánicamente salchichas u otro embutido, con gesto de absoluto desinterés ante la máquina de la que va extrayendo la carne picada. Mientras elabora las primeras piezas, el público tiende a sonreir, sin duda debido a la inequívoca connotación sexual de la acción, pero cuando, contaba Tanner, en el primer montaje aguantaba el plano a lo largo de un número importante de salchichas la sonrisa se tornaba en profundo desasosiego; ello hasta tal punto que el censor de la época, en su informe, obligó a limitar el número máximo de salchichas embutidas a una cifra concreta. Para Tanner aquello era la prueba definitiva de la inteligencia del censor, que había entendido perfectamente el contenido político del plano.

Como es bien conocido y ha sido bien debatido, el joven Marx, en los Manuscritos económico-filosóficos de 1844, desarrollaba la teoría del trabajo 
alienado, la producción por el obrero de un objeto que, una vez transformado en mercancía, se volvía ajeno al productor, dejaba de pertenecerle en absoluto. Pero al mismo tiempo, esta mercancía no pertenecería tampoco al comprador, al consumidor. Ambos procesos, el de producción y el de consumo dentro del marco capitalista, son procesos al margen de la realización vital de la persona: en el momento en que tanto el trabajo como el consumo (esto último queda sólo apenas intuido en los incompletos Manuscritos ...) se ponen exclusivamente al servicio de los procesos de circulación de capital, ambas acciones contribuyen no sólo a perpetuar papeles de dominación, sino en último término a caracterizar las relaciones entre las personas, simplificadas y reducidas a meros actos mercantiles.

La historia social del siglo XX es un solo aparente paso del predominio de la sociedad del trabajo al de la sociedad del consumo, dado lo inseparable de los mismos. Pero, gracias a la hipertrofia de los canales y medios de transporte en toda la extensión de la superficie planetaria, la imagen de la ciudad contemporánea es la imagen del espacio del consumo, oculto o enmascarado el espacio de la producción. Pero el siglo XX, en particular su segunda mitad, es también el siglo de la conversión del espacio urbano en sobre todo espacio mercantil, objeto de mercado, objeto de producción capitalista a través de la progresiva acumulación de valor. En este proceso, el llamado espacio doméstico cobra una importancia central, el mismo espacio doméstico que Dolores Hayden cita y discute («el lugar de la mujer es el hogar») como uno de los principios básicos del diseño arquitectónico y urbano del pasado siglo ${ }^{2}$. No pretendo en este artículo detenerme sino tangencialmente en una de las tesis básicas del clásico artículo de Hayden y muchas otras autoras ${ }^{3}$, sobre cómo una parte importante del trabajo humano, fundamentalmente el que bajo el epígrafe general de trabajo doméstico oculta no sólo el mantenimiento del espacio familiar sino una carga muy significativa de trabajo que acaba siendo no remunerado, recae sobre todo sobre las mujeres, situación indiscutible sobre la que cabe no obstante una visión más compleja que debería introducir no pocos matices de clase $\mathrm{u}$ otros. El objetivo de este artículo es desarrollar las consecuencias que dicha situación acarrea no al espacio doméstico, lo que es igualmente indiscutible, sino a la compleja relación entre dicho espacio y el

2. Dolores HAYDEN: «What would a non-sexist city be like? Speculations on housing, urban design and human work», en Ekistics, vol. 50, (1985), p. 310.

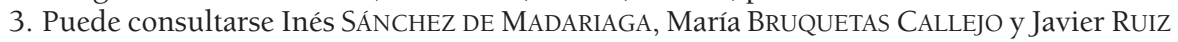
SÁNCHEZ: Ciudades para las personas. Género y urbanismo: estado de la cuestión, Instituto de la Mujer, Ministerio de Trabajo y Asuntos Sociales, Madrid 2004. 
espacio público, resultante de la discutible progresiva introducción de funciones y significados sobre aquél a costa de éste.

La primera discusión, el primer punto de debate y la pregunta a que se refiere el título, es sobre el tipo de ciudad que queremos. Esto, «the kind of city we want», es el título de un, para mí, importante artículo de la antropóloga Margaret Mead ${ }^{4}$. En este artículo, la autora de Coming of age in Samoa lleva a cabo una demoledora crítica a las bases del diseño urbano más ortodoxo, en una de las revistas más importantes de teoría del mismo. Hay que recordar que la misma Mead se había aproximado a la planificación urbana de la mano del propio Constantinos Doxiadis, el padre de la llamada Ekística o «ciencia de los asentamientos humanos» y uno de los planificadores teóricos y prácticos más importantes de los años cincuenta-setenta del pasado siglo. Es muy interesante el relato de Hashim Sarkis de la relación de debate interdisciplinar establecida en torno a Doxiadis y la reivindicación de esta necesaria visión compleja, integradora de puntos de vista de diferentes personas, para abordar tanto el conocimiento como la acción sobre la ciudad ${ }^{5}$. En el artículo publicado por Mead en la revista de Doxiadis, desde el primer párrafo la antropóloga es crítica con el planificador anfitrión. Mead inicia la construcción de la crítica a partir de algo aparentemente secundario, si no banal, el significado del cerramiento, el muro perimetral de la ciudad mediterránea frente a la inexistente o insignificante línea que delimita las propiedades en el suburbio norteamericano. Es un tema de seguridad, y es un tema de imagen urbana, pero sobre todo estamos ante un tema de establecimiento de reglas de juego entre los papeles del espacio a uno u otro lado de la línea-valla-muro del que la forma urbana es más que una consecuencia. La cita de Mead que abre este artículo no es, en absoluto, una frase obvia. Reivindica sutilmente algo que explicita en «The kind of ...»: que la ciudad no es, pero tampoco debe de ser, solamente el teatro de relaciones seguras entre sus habitantes. Aquí la idea de seguridad trasciende y pretende ir más allá de la idea de protección frente a más o menos seguras o intuidas amenazas. Mead alaba la idílica vida de las pequeñas y manejables poblaciones mediterráneas, donde todos se conocen y la vida discurre en un ambiente plácido de relaciones seguras y predecibles, para a continuación hacernos ver lo que sí es realmente obvio: que la ciudad no es eso, y que eso, además de terriblemente aburrido, no es ni siquiera deseable. No obstante, sin embargo, el modelo urbano, muchos modelos

4. Margaret MEAD: «The kind of city we want». Ekistics vol. 35, (1973), p. 209.

5. Hashim SARKIS: «Dances with Margaret Mead: Planning Beirut since 1958», en Peter ROWE y Hashim SARKIS (eds.): Projecting Beirut. Episodes in the Construction and Reconstruction of a Modern City, Preste, Munich (1998). 
urbanos basados en la idea de comunidad, proponen el espacio de desarrollo de ese tipo de ciudad. Para Mead el estar completamente rodeados de gente perfectamente predecible en sus comportamientos, de la que se sabe todo de su presente y su pasado, puede ser más una situación de la que huir y escapar que un sueño a conquistar.

A continuación la autora se despacha consecuentemente con el relato planteado por la arquitectura y el urbanismo modernos de la célula familiar como unidad. La discusión no es sólo sobre el modelo de familia, que naturalmente no es único y puede adoptar muchas formas y composiciones. Esto es interesante desde el punto de vista del arquitecto diseñador de viviendas, que progresivamente va postulando la superación del programa doméstico estandarizado hacia, bien nuevos modelos o bien soluciones flexibles. Ahí queda para quien le pueda interesar, no es un tema menor pero para algunos de nosotros sí secundario, un tema otro que puede ser abordado y resuelto de manera no complicada (iquién dijo que sólo nos preguntamos aquello que podemos contestar, que sólo nos planteamos los problemas que podemos resolver?). El problema es que las células no son (nunca lo han sido) estancas. ¿Qué pasa con los niños y adolescentes, por ejemplo? ¿No son las relaciones que se establecen entre individuos de distintas familias relaciones tanto o más importantes que las relaciones familiares? Hay un acuerdo sobre lo complejo del modelo presente de familia, pero poco sobre cómo se construye el modelo de espacio residencial casi exclusivamente a partir de dicho modelo. Como apunta literalmente Mead, la mejor manera de que un niño no crezca es mantenerlo dentro del recinto seguro de la familia o su entorno inmediato. Sólo el niño muy pequeño y el anciano dependiente, salvo otras circunstancias excepcionales, justificarían la introducción de más espacio libre en el ámbito privado.

La ciudad es la convivencia de lo familiar y lo extraño, de la seguridad y la incertidumbre. No obstante, sabemos diseñar las respuestas a los extremos opuestos, porque es lo que somos capaces de definir desde la perspectiva funcional triunfante, pero no sabemos diseñar los espacios de la convivencia entre ellos. Sabemos diseñar, y producir, una ciudad en la que las relaciones entre individuos se reduzcan al mínimo, una ciudad basada en relaciones fácilmente nominalizables y trasladables a un programa urbano: una ciudad de espacio doméstico optimizado, de espacios de trabajo, ocio o consumo igualmente perfeccionados, con los mejores y más sofisticados espacios de transporte, sólo muy parcialmente sustituidos por un espacio social virtual cuyas relaciones con el espacio real están siendo peligrosamente ignoradas. Es la adaptación y desarrollo del modelo Carta de Atenas. Por otra parte también 
sabemos diseñar y producir el espacio de la comunidad segura en su conjunto, reproducir (o creer que se reproducen) la forma y el espacio de la comunidad idílica, de espacio compartido bajo el supuesto de la primacía de la seguridad, el conocimiento y la previsibilidad. En ambos casos la estructura chirría en los bordes: en los bordes físicos de las comunidades basadas en la ignorancia y consecuente exclusión del extraño, transformadas en gated communities; en las acciones cuya complejidad escapa de los procesos de nominalización y adscripción a un espacio funcionalmente adecuado y acaban incomodando el buen gobierno del sistema.

No creo, frente a lo que defienden otros autores, que no produzcamos la ciudad que queremos. Otra cosa es que queramos la ciudad que se nos ha enseñado a querer, y no siempre con perversas intenciones latentes. La ciudad heredada es una proyección permanente de un deseo utópico. La mayor parte, la práctica totalidad de estos deseos utópicos son profundamente estáticos: cómo queremos vivir, cómo queremos que sea nuestra ciudad; nunca nos planteamos cómo tiene que ser nuestra ciudad para que la podamos cambiar, para que cambie de acuerdo con nosotros, con nuestras relaciones, nuestros deseos, nuestra movilidad. En la mayor parta de las situaciones cada cambio de paradigma supone un cambio de perspectiva utópica, de utopía de referencia. Muchos discursos de emancipación, de clase, de género, ejemplifican esto ${ }^{6}$. Las utopías funcionalistas, por bienintencionadas que sean, no son sino ejemplos de una necesaria simplificación, lo que implica, de una u otra manera, en mayor o menor medida, homogeneización. La sustitución de los modelos utópicos más conservadores por modelos utópicos de base socialista, ecologista, feminista, sólo aportan la sustitución de unas premisas funcionalistas por otras, pero no afectan para nada al propio modelo de planificación funcionalista, no suponen sino sustitución de un funcionalismo por otro. La profesora Daphne Spain señala la inequívoca tendencia a relacionar estructuras espaciales y relaciones sociales tanto por parte de analistas del espacio (geógrafos o sociólogos) como de planificadores, y alerta acertadamente sobre los riesgos de la visión estática de esta tendencia, que ignora los necesarios procesos evolutivos, tanto de la sociedad como de los propios espacios. Si el funcionalismo está conceptualmente unido a la univocidad, cualquier visión metodológicamente anclada en el mismo tenderá a reproducir errores. De nuevo Mead, en el artículo citado, recuerda el fracaso de la mayor parte de las comunidades planificadas simplemente en el momento en que alcanza la

6. Fundamental como ejemplificador W.H.G. ArmytAgE: Heavens Below. Utopian Experiments in England 1560-1960, Routledge and Kegan Paul, Londres 1961.

Feminismo/s 17, junio 2011, pp. 23-43 
madurez la segunda generación, todo lo más la tercera, en el momento que los hijos crecen y las demandas espaciales cambian. No puede ser de otra manera. Cualquier funcionalismo supone una apuesta por un modo u otro de optimización espacial. Las estructuras espaciales así diseñadas son raramente adaptables, son muy rígidas, de manera que la mayor parte de los éxitos de algunas actuaciones ejemplares son efímeros. En algún momento hemos postulado la necesidad, casi obligatoriedad de plantear estructuras evolucionables, trasladando un concepto biológico a la interpretación, análisis y posterior proyecto o planificación de acciones urbanas ${ }^{7}$.

La renuncia a los óptimos a favor de la evolucionabilidad (más que adaptabilidad, que tendría más que ver con la posibilidad de los espacios de albergar nuevas o diferentes funciones, mientras que lo que se propone con la evolucionabilidad es la capacidad de transformarse estos espacios mismos) tiene además consecuencias reales sobre temas que a veces se despachan con no poca simplicidad: apropiación, participación, construcción colectiva. El tema de la participación se convierte aquí en un tema muy importante. La mayor parte de los procesos participativos lo que plantean es dar poder a través de la voz, de la capacidad más o menos intensa y efectiva de decisión sobre la ciudad que se quiere. Como resultado de los procesos participativos, incluso los mejor orientados, no cabe duda de que pueden darse resultados a corto plazo muy satisfactorios; a medio y largo plazo caben las dudas. La mayor parte de las actuaciones que se presentan como ejemplares apenas tienen rodaje, y la historia de la planificación urbana está llena de proyectos significativos que han sufrido un envejecimiento prematuro. Desde nuestro punto de vista es mucho más interesante que el poder de decidir la ciudad que se quiere, el poder de transformar la ciudad que se tiene.

Marshall Berman, en el fundamental All that is Solid Melts into Air: The Experience of Modernity, dedica la mayor parte de un apartado (significativamente titulado «a shout in the street / un grito en la calle»), dentro del capítulo sobre la experiencia moderna de la ciudad de Nueva York, a la figura de Jane Jacobs, y el papel seminal tanto de su activismo urbano como de su texto Death and Life of Great American Cities. Berman por primera vez apunta la figura de Jacobs y su libro como «the first fully articulated woman's view of the city since Jane Addams». Pero tenemos que discrepar o al menos matizar parcialmente temas que apunta Berman en los párrafos posteriores a

7. Javier RUIZ SÁNCHEZ: «Evolucionabilidad urbana (urban evolvability): necesidad de nuevas perspectivas en planificación y diseño en el marco de la regeneración urbana», Comunicación técnica, Actas del $10^{\circ}$ Congreso Nacional de Medioambiente CONAMA, Madrid (2010). 
esta afirmación. Mientras que para Berman la importancia de Jacobs radica en el origen de su análisis y crítica desde la experiencia doméstica de primera mano, desde nuestro punto de vista esta experiencia traspasa el ámbito de lo doméstico. De hecho, poco o nada dice Jacobs de lo que sucede de puertas adentro. El escenario fundamental de Jacobs es el espacio público de la vida cotidiana, el espacio público del entorno próximo de la vivienda, incluso, y esto es más que interesante, la sutil relación que se establece en la transición público-privada o privado-pública como espacio comunicativo. Se ha hablado mucho sobre la reivindicación que hace Jacobs de la acera neoyorkina como espacio de profusión de acontecimientos. En ningún caso se trata, nada más lejos, de una guía de diseño. No existe una acera perfecta, una calle perfecta, existen calles donde pueden suceder y acaban sucediendo los acontecimientos que dan lugar a una vida social satisfactoria. No es necesariamente más segura una calle en la que se restringe el paso a los extraños. Es más segura una calle «con ojos». Los ojos de Jacobs no son los ojos vigilantes de los tenderos conocidos y conocedores, como a menudo se cita en una lectura simplificada de Death and ... ya que estos no son vigilantes conscientes ni por voluntad expresa; están, en el más amplio sentido que se le pueda dar a esta idea. La seguridad no se establece a través de mecanismos exclusivos de vigilancia, sino a través sobre todo de acontecimientos que son más que lo que aparentan ser: personas entrando y saliendo de portales y tiendas, transeúntes de paso (no necesariamente amenazadores extraños), vecinos simplemente estando, haciendo uso del espacio público pero sin ninguna pretensión utilitaria concreta: $y$ a esto sumadas las funciones que son más que funciones, como el sencillo aparato expendedor de periódicos a la salida de un drugstore que sirve a Christopher Alexander como pretexto para describir la complejidad de una aparentemente convencional, anodina esquina urbana transitada en una ciudad norteamericana cualquiera, en un punto, eso sí, especialmente rico en actividad.

Porque es de complejidad de lo que estamos hablando. Densidad de acontecimientos, evolucionabilidad, espacio comunicativo dinámico, son ideas que apuntan la necesidad de considerar la ciudad compleja como la única respuesta urbana. La mayor parte de los espacios urbanos unánime o mayoritariamente considerados de éxito, lo que quiere decir considerando grupos y voces diversos, por edad, género, clase, cultura, etcétera, son espacios maduros, esto es, espacios que el tiempo ha modelado de acuerdo con la sociedad que los habita. Queremos ir más allá: incluso espacios maduros fallidos, porque la sociedad que los ha conformado no ha tenido en cuenta la propia complejidad social o porque la represión de la misma así se ha manifestado en 
el espacio, pueden en muchas veces ser más susceptibles de generar complejidad. Muchos proyectos de vivienda realizados y construidos aplicando conocimiento derivado de la perspectiva de género resultan más exitosos cuando se insertan en una trama urbana madura y compleja, y apenas anecdóticos si simplemente son una anomalía dentro de un moderno y banal desarrollo urbano. El discurso de género no es un discurso de igualdad, sino de trabajo sobre la diferencia; y trabajo sobre la diferencia entendida tanto como valor como, como proceso. La ciudad compleja es una ciudad en evolución abierta a futuros posibles, la incertidumbre como valor. En este contexto, un discurso desde mi punto de vista equivocadamente vinculado al discurso de género como es el discurso-relato de la seguridad debe ser más que matizado. La violencia criminal, el delito visible, no es más que una parte, si bien la más perceptible de la violencia como fenómeno vinculado a las relaciones de poder explícito e implícito. En no pocas ocasiones la seguridad tiene más que ver con otro instrumento de dominio, mucho más sutil: el miedo. Es muy interesante cómo en la recopilación de ensayos sobre arte realizado por mujeres de Lucy Lippard, From the Center, la autora indica y señala de forma expresa el miedo como el instrumento de dominio que es, y apunta como su contrario, como el instrumento de superación de la dominación, el conocimiento, vinculado a la experiencia; no la seguridad, sino el conocimiento, y éste no como certeza, sino como indagación. Y es también de interés, por la posibilidad de traslación a nuestro contexto urbanístico de no pocas ideas, el capítulo «Points of view / Puntos de vista» del libro de Lippard dedicado a representantes femeninas que exploran en el tema del paisaje como objeto artístico, no sólo su representación. Es interesante cómo muchas artistas introducen el tiempo como objeto de conocimiento inseparable del conocimiento del espacio; cómo para muchas de estas artistas son los temas del fragmento, la relación, el movimiento, básico para la aprensión del objeto artístico, que emerge como una resultante a través de un proceso de desentrañamiento complejo. Para la mujer, más que para el hombre, el espacio no es unívoco, pero tampoco aprehensible a través de una única o simple acción. Ante la complejidad y la incertidumbre, incuestionables, del espacio, sean urbano o no, caben dos posturas. Una de ellas es considerar dicha complejidad y la incertidumbre vinculada a la misma como más que un problema, como una situación a extinguir. Aquí sólo cabe la fuerza bruta, la tabla rasa, la imposición de un nuevo orden espacial simplificado, la imposición de una utopía. Esta imposición espacial necesita ser acompañada de la imposición consiguiente de un sistema de regulación, represor, orientador de los deseos y las actividades humanas para acomodarlas a esta escena trágica efectivamente 
construida a partir de ejercicios de renovación urbana radical o simples, en el más peyorativo sentido de la palabra, nuevos desarrollos urbanos o incluso nuevas ciudades. Donde muchos, en teóricos (y a veces llevados a la práctica de una u otra manera) ejercicios que postulan la ciudad del futuro, limpia, sostenible, homogénea, igualitaria, ven la utopía a conquistar, otros vemos el infierno en la tierra. La otra postura ante la complejidad y la incertidumbre es el cambio de punto, de vista: la aceptación (no resignación) de ambas como un valor («una bendición», decía Ramón Folch en su casi siempre atinado Diccionario de Socioecología) y la decisión consiguiente de modificar nuestras formas de conocimiento y nuestros principios de acción.

El discurso de género o es un discurso de la complejidad o no es sino la sustitución de la perspectiva funcionalista, de un funcionalismo por otro más amable. La mayor parte de los trabajos circunscritos a la transformación del espacio en la escala doméstica no son sino ejemplos de esta sustitución. Sin negar la validez en sí que tiene producir mejores viviendas ( ¡casi nada!) se me debe permitir afirmar que ahí no está el problema, al menos no el más importante ni significativo. Peter Sloterdijk se despacha en el tercer tomo (Espumas. Esferología plural) de su Esferas sobre el significado último del apartamento individual como el más indivisible átomo, la unidad elemental en la construcción del espacio antrópico. Del individuo a la familia, de la familia al vecindario, la construcción del espacio moderno en no pocos casos, consiste en la definición del escalón superior como un modelo de agrupación basado en la yuxtaposición de unidades al que se añade un espacio selectivo de relaciones. Una parte importante de la ciudad contemporánea se está construyendo a base de un modelo de unidad urbana muy concreto y, desde nuestro punto de vista, absolutamente antiurbano. En no pocos casos utilizando como pretexto la seguridad, identificando la incertidumbre inherente al espacio público con el miedo, cuando realmente ante lo que estamos es ante el desprecio del espacio complejo como un espacio de difícil dominación, y consiguiente difícil mercantilización, nos encontramos ante la profusión de modelos de vecindarios cerrados. Estos vecindarios, como se ha apuntado más arriba, no necesariamente adoptan una única forma. En casi todos los ensanches españoles recientes (nada que ver con las formas urbanas reconocidas como ensanches y asociadas al modo de producción de espacio urbano de la segunda mitad del siglo XX) nos encontramos ante manzanas completas cerradas, introvertidas; en otras ocasiones son superestructuras urbanas, prototipos que a veces son presentados como ciudades verticales, nada que ver con una ciudad; en otros casos son urbanizaciones cerradas, evolución de la forma de la ciudad jardín en cualquiera de sus variantes, pero acotadas con precisión y valladas con 
cerramientos casi infranqueables. Desde una perspectiva topológica estamos ante lo mismo bajo estas distintas formas en lo aparente, independientemente de si el lenguaje es historicista, pintoresco o high tech: esferas familiares elementales (bajo la forma de apartamento o falsa vivienda unifamiliar) que forman parte de un conjunto de diseño unitario e incluyen un conjunto de servicios compartidos que permiten reducir la necesidad de intercambio con el espacio público, piscinas, juegos infantiles, espacios de práctica deportiva, zonas verdes y equipamientos diversos al servicio exclusivo del conjunto. La exclusividad está garantizada por la reducción al mínimo del espacio de contacto con el exterior, a través de mínimos e hipervigilados accesos. Es muy probable que sea la ciudad que queremos o que una mayoría desea, la ciudad segura, el espacio doméstico y su entorno con la mayor cantidad de incertidumbre eliminada. ¿Ante qué estamos realmente? Transformada una parte significativa de la ciudad espacio de trabajo en ciudad como espacio de consumo, alejados los espacios de actividad económica y empleo en polígonos y parques temáticos, estamos ante un equivalente extrañamiento, una equivalente alienación, en los mismos términos del Marx de los Manuskripte entre el consumidor y el objeto. La vivienda actual es casi siempre un objeto que su habitante sólo parcialmente puede elegir, en el simplificado marco de elección del sistema de consumo capitalista, y apenas transformar. Porque estas unidades urbanas contemporáneas son auténticos artefactos con una capacidad de evolución prácticamente nula. ¿Es posible, en estos momentos, concebir un sistema de producción espacial en que la mayor parte de los ciudadanos construya ex novo o amplíe o adapte su vivienda o una existente? No estoy hablando de una reforma interior del programa, reforma de acabados interiores; estoy hablando del contenido comunicativo del propio espacio privado con el espacio público, de la transformación de las características de la vivienda como tipo, esto es, de sus valores de inserción en el sistema urbano. Por otra parte, el paisaje apropiable alternativo a este paisaje contemporáneo no es para nada un ejercicio teórico; al contrario, no es un paisaje que nos resulte para nada ajeno: basta con pasear por cualquier núcleo urbano tradicional, posicionado o no como centro urbano dentro del sistema de la ciudad región contemporánea; un paisaje de parcelas menudas, sobre las que se levantan edificios de épocas diversas, muchas veces (prácticamente todas) carentes de interés arquitectónico individual, pequeños establecimientos comerciales (no necesariamente comercio tradicional pero también éste, rentable en un espacio que ha ido adquiriendo densidad de manera simultánea a cómo ha ido transformándose de manera consiguiente el comercio, y también el equipamiento), incluso espacio de actividad económica, incluso productiva, para 
nada incompatible salvo situaciones muy específicas con la residencia. Son espacios maduros, complejos, apropiables, evolucionables. También son casi siempre espacios bien valorados, si los procedimientos de valoración atienden a la potenciación de valores relacionados con una difícil forma de definir calidad de vida. Pido perdón por una referencia concreta a mi propia actividad. Durante más de quince años he impartido docencia de diseño y planificación urbanos en una escuela de arquitectura. Interrogados los alumnos sobre qué lugar concreto de su ciudad, de cualquier ciudad, elegirían para vivir, una amplia mayoría opta por localizaciones en imperfectos centros urbanos de origen preindustrial, lo más moderno un ensanche decimonónico o un reducto de ciudad jardín clásica no alejada o contigua al centro. Sus proyectos, en cambio, tienden a reproducir fielmente las tendencias de moda del couché arquitectónico, basada en el gran artefacto. ¿Dónde viven los arquitectos autores de las anónimas periferias que nos rodean? Los que pueden elegir residen en espacios que son casi siempre las antípodas de lo que diseñan. Se desea, consciente o inconscientemente, la complejidad; se diseña la simplicidad. Debo negar que la simplificación sea la única forma posible de hacer ciudad en la actualidad, si bien en ningún caso lidiar con la complejidad es (no debe serlo) tarea fácil ${ }^{8}$.

Porque las consecuencias sobre la calle son necesariamente fatales en el modelo arriba expuesto y generalizado. Privada de otro contenido, se convierte en un mero canal de comunicación. El consiguiente modelo urbano y regional va más allá. Parques temáticos monofuncionales conectados umbilicalmente a una hipertrofiada red de comunicaciones proyectada y construida para el comportamiento óptimo de esa otra esfera elemental que es el automóvil privado. De nuevo Sloterdijk, en Esferas II. Globos, Macrosferología, subraya más allá el significado de estas compartimentaciones del territorio. Desde las murallas mesopotámicas, estamos ante «experimentos morfológicos de la posibilidad de edificar un gran mundo como mundo propio e interior autoincubante». Esos mundos propios reproducen los valores del sistema socio-político-económico hegemónico en cada momento histórico: hoy día nada más que expresión de relaciones simplemente convertibles en relaciones

8. Una cierta indagación propia sobre una cierta tendencia, excepcional en cualquier caso, de introducir complejidad en algunas actuaciones emblemáticas recientes, desde una perspectiva formal, puede consultarse en Javier RUIZ SÁNCHEZ: «Transformación y evolución recientes en la forma del espacio urbano residencial», en Ciudad y Territorio - Estudios Territoriales. XLI (161-162) (2009); una limitada y modesta aproximación al problema desde la práctica profesional en Javier RUIZ SÁNCHEZ: «Proyectar la complejidad urbana: Móstoles Sur, indagaciones desde la práctica del planeamiento residencial», en Urban, 9. Varia urbanistica. Proyecto residencial en la región urbana de Madrid. (2004). 
mercantiles. El propio Sloterdijk, de nuevo, relaciona expresamente los procesos de alienación del trabajador con la respuesta egoísta e individualista del mismo, trasladable en la modernidad reciente a la residencia, el ocio, y el consumo, que casi pueden ser leídos como uno9. Estamos ante la imposición de la utopía como dominio y domesticación, la alienación del trabajo y del consumo (incluida aquí la residencia) como instrumento fundamental de dicha imposición.

No sorprende que la crisis capitalista presente adquiera una componente espacial como ninguna precedente. Como ilustración, más allá de la posible representación del conflicto social, sobre la posible representación en imágenes de El Capital trata uno de los últimos proyectos cinematográficos, quizá el más monumental de todos ellos, del alemán Alexander Kluge, Nachrichten aus der ideologischen Antike (Noticias de la antigüedad ideológica) ${ }^{10}$. El pre-texto: en octubre de 1927 Serguei M. Eisenstein acababa de terminar el montaje de Октябрь/Oktiabr (Octubre), película que le dejaría agotado y con problemas de visión ${ }^{11}$. A propósito escribía en su diario su intención de llevar al cine El Capital «con guión de Karl Marx» como «única salida posible» en el estado al que había llevado las posibilidades del lenguaje cinematográfico ${ }^{12}$. Los meses sucesivos el diario de Eisenstein se llena de anotaciones sobre las posibilidades del proyecto: la aplicación del método dialéctico al montaje, una posible extrapolación de los hallazgos literarios del Ulysses de James Joyce al cine, varias ideas sobre planos y secuencias concretas, sobre todo sobre la puesta en escena de la producción... Las últimas anotaciones parecen escépticas, hablan del riesgo de banalización por exceso de simplificación, y hablan de la contradicción que implica la necesidad de ilustrar con técnicas de superproducción cinematográfica este tema específico. La fatiga frustra el proyecto, y las nuevas circunstancias llevan a Eisenstein a un nuevo campo de investigación, concretamente el campo del sonoro. Ochenta años después, Alexander Kluge se plantea una indagación sobre la facticidad del proyecto de Eisenstein, pregunta que da lugar a la monumental película-ensayo Nachrichten...

9. Peter SloteRdijK: Die Verachtung der Massen (Versuch über Kulturkämpfe in der modernen Gesellschaft), Suhrkamp, Frankfurt (2000) [version castellana El desprecio de las masas. Ensayo sobre las luchas culturales de la sociedad moderna, Pre-textos, Valencia 2002].

10. Alexander KLUGE Nachrichten aus der ideologischen Antike. Marx - Eisenstein - Das Kapital.

11. El final del rodaje coincidió con la doctrina oficial de eliminación de la imagen de Trotski de cualquier documento, lo que supuso un sobreesfuerzo de trucaje y montaje para hacerlo desaparecer de cada plano o secuencia.

12. Los entrecomillados son parte de los extractos del diario de Eisenstein sobre el tema. 
Marx y Eisenstein, como también Joyce y Brecht, sirven de hilo conductor a las nueve horas y media de la heterogénea película-collage de Kluge. En un fragmento, Kluge conversa con Hans Magnus Enzensberger sobre el proyecto Marx-Eisenstein y su posible actualización. Se indica que se trata de dos momentos que coinciden aproximadamente, además, con dos de las más importantes crisis del sistema capitalista, la del crack de 1929 y la más reciente, apenas comenzada en 2007 . Un comentario es que la posible representación fílmica de la crisis capitalista debería ser, en cualquier caso, más fácil en la actualidad que en el final de los años veinte, simplemente porque la componente inmobiliaria, y por tanto espacial, es inseparable de lo que está aconteciendo ahora, de manera que el escenario del conflicto es en realidad omnipresente. Parece más fácil ilustrar el sistema de relaciones del capital en una ciudad contemporánea que, en cierto modo, es producto directo de este sistema. Una posible línea de análisis de relaciones espaciales la marca el cortometraje de ocho minutos de Tom Tykwer Der Mensch im Ding que forma parte del conjunto. En éste, un fragmento de acera y calzada en una calle de Berlín, la entrada de un edificio de viviendas, las ropas y complementos de una mujer que camina, cuya imagen es congelada, son analizados en su perspectiva económica espacial como elementos individualizados y en su conjunto como sistema. La cámara «vuela» falsamente -pues la técnica digital ha procesado y convertido el plano en un escenario virtual tridimensionalde objeto en objeto, del bolso de la mujer al chicle pegado en el suelo, del portero automático al registro de suministro de gas en la acera, y nos narra sus historias individuales y razón de su ser en aquellos precisos tiempo y espacio. En este breve corto, el director de Lola rennt (Corre Lola, corre, 1998), va más allá en la experimentación sobre las posibilidades ensayísticas acerca del aspecto relacional del espacio, algo ya esbozado previamente desde una perspectiva más accesible para el público en el cortometraje True (2004), más conocido como fragmento «Faubourg Saint-Denis» en la colectiva Paris, je t'aime (2006), en este caso explorando la relación entre el espacio urbano y los sentimientos personales.

La palabra utopía recorre de forma permanente los 570 minutos de la película de Kluge. «Die Utopie wird immer besser, während wir auf sie warten» (la utopía sigue perfeccionándose mientras más la esperamos), afirma el propio escritor y cineasta, mostrando una confianza inequívoca en un proyecto pendiente. Sin embargo, desde cierta perspectiva, nunca hemos puesto en marcha, realizado de manera plena, un proyecto utópico como ahora. La paradoja es que para que ello se haya producido se tiene que haber llevado a cabo, de hecho, la alianza entre el proyecto urbano de la arquitectura moderna y el 
sistema económico capitalista, en las antípodas del proyecto utópico socialista, de cuyo eje forma parte el segmento Marx - Kluge. El urbanismo moderno se ha internacionalizado incluso aún más que la arquitectura moderna que lo conforma, el estilo internacional acuñado por Henry-Russell Hitchcock y Philip Johnson en la exposición seminal del MoMA de Nueva York de 1932. Las periferias, los nuevos suburbios, las nuevas ciudades de casi cualquier país del mundo planificadas y urbanizadas durante la segunda mitad del siglo XX son prácticamente intercambiables.

No puede ser casualidad que el fragmento cinematográfico de Tom Tykwer en el macrofilm de Kluge, el análisis de la esquina del expendedor automático de prensa de Christopher Alexander en «A City is not a Tree» y las indagaciones de Jane Jacobs coincidan en algo tan importante. Sus escenarios son aceras, aceras cualesquiera, de barrios normales, ya sea en Berlín, Berkeley o Nueva York, respectivamente, pero podrían estar en cualquier otra ciudad. ¿Por qué la acera, y por qué ello es tan importante y significativo desde la perspectiva de género? Como hemos descrito antes, el proyecto urbano moderno tiende a reprimir los espacios que no puede asignar de manera unívoca a funciones específicas, a construir un árbol donde se debería construir una red, en los propios términos del artículo de Alexander. La acción de abandonar el espacio doméstico, pisar la acera, tiene un significado y un sentido que van más allá de un simple paso. Nos podemos encontrar en un espacio de libertad, con múltiples posibilidades, abierto a posibles decisiones, incluso el simple paseo sin rumbo a la manera del flâneur Franz Hessel o su amigo Walter Benjamin. La acera es la conquista del niño y luego del adolescente que descubren el mundo sin la tutela y vigilancia de sus mayores. El niño que juega en la calle conquista metros a medida que adquiere conocimiento y experiencia, este conocimiento se liga de hecho a la conquista del espacio urbano: desparecer del campo visual de la ventana desde la que vigila la madre (siempre la madre), doblar la esquina y burlar la vigilancia de tenderos y vecinos, cruzar la calle y conquistar manzanas próximas. No creo estar describiendo nada ajeno a la experiencia infantil de nadie que me esté leyendo. Desde la perspectiva adulta, pisar la calle puede suponer el comienzo de una acción mecánica e inconscientemente dirigida, hacia el trabajo, hacia el comercio o el ocio, hacia el colegio o el médico, o el comienzo de una experiencia urbana. ¿Qué grados de elección tenemos? ¿Tengo las mismas posibilidades de elegir dónde compro el periódico si vivo en el centro de Buenos Aires o en un country club cerrado en medio de la pampa? Decidido mi destino, ¿tengo uno, varios o muchos caminos posibles? ¿Puedo elegir modo de transporte, 
variar el itinerario, programar o no paradas intermedias, improvisar? ¿Puedo complicar mi actividad tanto como yo quiera?

Rosemonde en La salamandre confeccionando salchichas de manera mecánica realiza una acción tan alienante como el conjunto de acciones que muchas mujeres llevan a cabo en su cadena de tareas diaria. Con el agravante de que esta cadena de tareas es más repetitiva, implica más desplazamientos en número y distancia, y abarca más tiempo en el caso de las mujeres, precisamente por esa asunción extra de tareas no reconocidas ni valoradas cuando no directamente invisibles. El objetivo debe ser entonces la conquista de la complejidad urbana en la proximidad, en cualquier escala pero sobre todo en la proximidad. Y esta conquista tiene un doble objeto: por una parte facilitar dicha cadena de tareas; sobre esto hay no poca literatura escrita y cierta experiencia práctica; pero por otra parte, y esto es menos reconocido, porque la propia ciudad compleja debe, en último término, favorecer la consecución progresiva de justicia en la distribución de actividad. No se trata de que la ciudad vaya a hacer la sociedad más justa; se trata de que la ciudad posibilite que ello suceda. Y, de verdad, la mayor parte de la ciudad que producimos ahora no está haciendo ni va a hacer más que suavizar o maquillar situaciones indeseadas o indeseables, eso en el mejor de los casos. Porque sí es cierto que el diseño del espacio urbano puede ser un instrumento de control, como es sabido de Bentham a Foucault, o directamente modelador de conductas.

Mucha literatura reciente habla de la ciudad justa ${ }^{13}$. La ciudad no puede, en su forma, estructura, distribución de funciones, garantizar por sí misma la equidad, diversidad o democracia que apunta como objetivos, por ejemplo, Susan Fainstein en The Just City. Pero sí es cierto que mucho del espacio urbano construido en el siglo XX es un espacio donde la consecución de estos valores está penalizada si no imposibilitada. Es muy significativa la experiencia de la abortada reforma del Nieuwmarkt en el centro de Amsterdam que recuerda Fainstein. Porque el objetivo de la reforma de este espacio, como de mucho espacios centrales europeos, era la construcción de un espacio de excelencia desde la perspectiva mercantil-funcionalista. Discrepo en un tema: el objetivo de la contestación no fue la preservación del patrimonio, no el mantenimiento de la ciudad existente. El objetivo implícito era el mantenimiento de la complejidad de la ciudad existente, de la posibilidad de transformarse de acuerdo con muchas decisiones, no una única, de evolucionar en un proceso continuo soportado en la memoria colectiva del barrio. El mercado de hoy no

13. David Harvey como pionero, más recientemente autores como Edward Soja o Susan Fainstein, ésta última trasladando de manera explícita al contexto urbano conceptos de la Teoría de la justicia de Rawls.

Feminismo/s 17, junio 2011, pp. 23-43 
es el mismo de hace treinta años, no son las mismas tiendas ni bares, se han hecho obras en el espacio público y los bordes del canal, se han sustituido pocos edificios, reformado más. Pero, para todos, no cabe ninguna duda de que, sigue siendo el mismo barrio, y es muy posible que para muchos vecinos, comerciantes, visitantes, sea un mejor barrio. No pretendo aquí abrir un complejo debate sobre el posible proceso de gentrificación llevado a cabo. Ni es sencillo, ni está consensuado, no todo proceso de aumento de rentas y reequilibrio social consiguiente tiene que ser censurable de manera sistemática.

La segunda cita que abre este escrito no procede de un texto técnico, ni recoge una opinión autorizada en el plano científico, como si eso supusiese para alguien autoridad efectiva. La fuente es literaria, y de la que para muchos es la literatura más prescindible, la ciencia ficción más popular. No voy a detenerme aquí sobre la vinculación y la importancia de la ciencia ficción anticipatoria con el urbanismo, pero ninguna historia del urbanismo puede estar completa sin recurrir a analizar aportaciones, cuando no influencia directa de la literatura (sobre todo) de este género ${ }^{14}$. He tenido la oportunidad de destacar la importancia de la obra de Ursula K. Le Guin como análisis e indagación sobre las relaciones entre las sociedades y sus espacios, en particular de conjunto de novelas del ciclo Hainish o Ekumen. En este conjunto, Le Guin ${ }^{15}$, describe mundos en los que los seres humanos han evolucionado de manera diferente, en lo biológico y en lo social, a partir del tronco común. Ello permite plantearse múltiples preguntas sobre las complejas relaciones entre la psicología y la biología humanas y la sociedad y la política, dentro de un marco histórico, en evolución. La mano izquierda de la oscuridad es especialmente pertinente en el contexto de este artículo puesto que introduce el tema de la sexualidad como construcción, al presentar una sociedad de individuos cuyo sexo sólo sufre diferenciación un corto periodo de tiempo al mes con propósitos exclusivamente reproductivos, prolongado en caso de concepción mientras dure el periodo en que los hijos son dependientes. De esta manera, la mayor parte de los habitantes del planeta han experimentado de manera consecutiva tanto la paternidad como la maternidad, y no establecen ningún tipo de relación distinta con los hijos según se haya producido de una u otra manera. Sobre esta novela cabe hablar mucho a propósito de las consecuencias

14. Sin ánimo de avanzar sobre este tema pero a simple modo de ejemplo, la ciudad jardín, de la que surge mucho de lo que nos rodea, no puede entenderse sin influencias explícitas literarias de anticipación utópica o distópica. El propio Howard titula significativamente la primera edición del libro del que nace todo esto To-morrow ...

15. La K. corresponde al apellido paterno. Ursula K. Le Guin es hija de Alfred Kroeber, uno de los padres de la escuela antropológica norteamericana. 
de la desaparición efectiva de cualquier construcción sexista, pero aquí sólo haremos un breve apunte sobre las consecuencias espaciales. En un planeta, Gethen, también conocido como Invierno por la dureza de su climatología, que hace absolutamente hostil el exterior. Los habitantes de Gethen enfatizan la importancia del individuo como unidad social, de manera que la única barrera física de tipo espacial infranqueable o sujeta a inviolabilidad inmutable es la propia piel de la persona. El resto del territorio es construcción mítica, social, convencional, pero es, sobre todo, mutable. En los distintos países de Gethen se han desarrollado posibilidades diferentes, que van de la aparente no diferenciación política y espacial, donde cada individuo se relaciona como igual con el resto, dando lugar a un superorganismo vigilante, hasta la superespecialización que se traduce en un sistema fuertemente jerarquizado y regulado. La perfecta homogeneidad se convierte en tan peligrosa como la más absoluta diversificación cuando de lo que estamos hablando es de un sistema social. En ambos casos, el riesgo es el de la simplificación.

La pregunta ¿qué ciudad? tiende a querer una respuesta, en forma de modelos, reglas, manuales. Tiende a pensar que es posible crear buenas comunidades a través del diseño urbano ${ }^{16}$. Podemos repasar la historia del urbanismo moderno como un permanente ejercicio de proyección del poder hegemónico, pero es muy cierto que mucho de lo realizado está cargado de buenas intenciones. La propia historia de la disciplina tal y como la conocemos es fruto del intento de corrección de la ciudad industrial; llevamos doscientos años corrigiendo desmanes. Pero sí hay una lección que parece que todavía no hemos aprendido: que en los propios defectos de la ciudad está el germen del cambio, pero que también tanto lo defectuoso como la corrección pertinente tienen mucho de relativo. El riesgo es crear artefactos inertes, inmutables, perfectos. El riesgo es proyectar la utopía, más aún cuando nuestra fuerza transformadora nos lo permite, el paso casi inmediato del papel al territorio. El crítico y arquitecto Vittorio Magnago Lampugnani hablaba hace unos años de la ciudad normal. La pregunta no debe ser qué ciudad si lo que esperamos es una respuesta formal, sino cómo se nos permite ser en ella; tener libertad para complicarnos la vida es la base de la libertad para poder simplificárnosla.

16. El caso de Edward J. Blakely y Mary Gail Snyder en Fortress America: un impecable análisis deslucido por un último capítulo de recomendaciones más que discutible.

Feminismo/s 17, junio 2011, pp. 23-43 


\section{Referencias bibliográficas}

AleXAnder, Christopher. «A City is not a Tree», en Architectural Forum, 122-1 1965.

Armytage, W.H.G. Heavens Below. Utopian Experiments in England 1560-1960, Routledge and Kegan Paul, Londres. 1961.

Berman, Marshall: All that is Solid Melts into Air: The Experience of Modernity, Simon and Schuster, Nueva York 1982.

Blakely, Edward J. y SNYDER, Mary Gail. Fortress America. Gated Communities in the United States. Brookings Institution Press and The Lincoln institute for Land Policy, Cambridge Mass. 1997.

DeCAmpo, Marcelo y VEGA, Felipe. «A años luz», en Papeles de Cine Casablanca, 7-8. 1981.

FAinstein, Susan S. The Just City, Cornell University Press, Ithaca 2010.

FAINSTEIN, Susan S. «Planning in a Different Voice», en Planning Theory, 7-8 1992.

HAYDEN, Dolores. "What would a non-sexist city be like? Speculations on housing, urban design and human work», en Ekistics, 52. 1985.

JacoBs, Jane. Death and Life of Great American Cities, The Random House, Nueva York 1961.

KLUGE, Alexander. Nachrichten aus der ideologischen Antike. Marx - Eisenstein - Das Kapital, filmedition suhrkamp, fes1, Suhrkamp Verlag, Frankfurt am Main 2008. 3 DVDs, 570 minutos.

LAmpugnani, Vittorio Magnazo. «La Ciudad Normal», en El País, 30 de diciembre de 2000.

LE Guin, Ursula K. The Left Hand of Darkness, 1969.

LIPPARD, Lucy. From the Center: Feminist Essays on Women's Art, E.P. Dutton, Nueva York 1976.

MEAD, Margaret. «The kind of city we want», Ekistics vol. 35, (1973), p. 209.

RUIZ SÁNCHEZ, Javier. «Evolucionabilidad urbana (urban evolvability): necesidad de nuevas perspectivas en planificación y diseño en el marco de la regeneración urbana», Comunicación técnica, Actas del $10^{\circ}$ Congreso Nacional de Medioambiente CONAMA, Madrid. 2010.

RUIZ SÁNCHEZ, Javier. «Transformación y evolución recientes en la forma del espacio urbano residencial», en Ciudad y Territorio - Estudios Territoriales. XLI, (2009), pp. 161-162.

RUIz SÁNCHEZ, Javier. «Proyectar la complejidad urbana: Móstoles Sur, indagaciones desde la práctica del planeamiento residencial», en Urban, 9. Varia urbanistica. Proyecto residencial en la región urbana de Madrid. 2004.

SÁnCHez de Madariaga, Inés, BRUQuetas CAllejo, María y Ruiz SánCHEZ, Javier. Ciudades para las personas. Género y urbanismo: estado de la cuestión, Instituto de la Mujer, Ministerio de Trabajo y Asuntos Sociales, Madrid. 2004. 
SARKIS, Hashim. «Dances with Margaret Mead: Planning Beirut since 1958», en ROWE, Peter y SARKIS, Hashim (eds.): Projecting Beirut. Episodes in the Construction and Reconstruction of a Modern City, Preste, Munich 1998.

SloterdijK, Peter. Die Verachtung der Massen (Versuch über Kulturkämpfe in der modernen Gesellschaft), Suhrkamp, Frankfurt 2000 [version castellana El desprecio de las masas. Ensayo sobre las luchas culturales de la sociedad moderna, Pre-textos, Valencia 2002].

SloterdiJK, Peter. Sphären II (Makrosphärologie). Globen, Suhrkamp, Frankfurt 1999 [version castellana Esferas II. Globos. Macrosferología, Siruela, Madrid 2004].

Sloterdijk, Peter. Sphären III (Plurale Sphärologie). Schäume, Suhrkamp, Frankfurt 2004 [version castellana Esferas III. Espumas. Esferología plural, Siruela, Madrid 2006].

SoJA, Edward W. Seeking Spatial Justice. University of Minnesota Press, Minneapolis 2010.

Sorkin, Michael (ed.). Variations on a Theme Park. The New American City and the End of Public Space. Hill and Wang, Nueva York 1992.

SPAIN, Daphne. Gendered Spaces. University of North Carolina Press, Chapell Hill 1992. 



\title{
HAY UNA CIUDAD BAJO LA CIUDAD. EL PROYECTO DE CONSERVACIÓN TEMPORAL DE LOS RESTOS MEDIEVALES DEL JARDÍN DE SAN ESTEBAN (MURCIA)
}

\author{
Pilar VALLALTA MarTíneZ \\ Restauradora. Murcia \\ FranCisCo J. SÁNCHEZ MEDRANO \\ Dr. Arquitecto. Universidad Católica San Antonio de Murcia
}

Recibido 09/02/2011

Aceptado 20/05/2011

\section{Resumen}

El yacimiento arqueológico del jardín de San Esteban de Murcia ha acaparado la atención social durante muchos meses. Las obras de un aparcamiento subterráneo han dejado paso a una incoación del expediente de BIC y a la necesidad de un mantenimiento de las estructuras islámicas descubiertas. Los restos, que superan los diez mil metros cuadrados de extensión, deberán integrarse en una propuesta de intervención urbana pendiente de convocar. Un equipo plural de técnicos, con decisiva presencia femenina, se adjudicó el Proyecto de Conservación Temporal, cuyas líneas principales se describen, comentando algunas de las dificultades derivadas de la propia composición de dicho conjunto.

Palabras clave: Yacimiento Arqueológico, Restauración, Equipo Femenino, Conservación, Consolidación, Protección, Futuro. 


\begin{abstract}
The archaeological site of the garden of San Esteban de Murcia has dominated social care for many months. The works of underground parking have given way to a record opening of BIC and the need for maintenance of Islamic structures discovered. The remains, which exceed ten thousand square meters, must be integrated into an urban intervention proposal pending call. A team of technicians plural, with decisive presence of women, won the Temporary Conservation Project, whose main lines are described, discussing some of the difficulties arising from the very composition of this set.
\end{abstract}

Keywords: Archaeological Site, Restoration, Women’s Team, Conservation, Consolidation, Protection, Future. 


\section{Puesta en situación: los antecedentes próximos}

El 1 de junio de 2005 el Ayuntamiento convocaba la construcción, mediante concesión de obra pública, de un aparcamiento en el subsuelo del Jardín de San Esteban de Murcia capital. La elección del lugar, en el centro neurálgico administrativo y comercial de la ciudad, históricamente un antiguo arrabal adosado al recinto amurallado, no estuvo exento de una gran contestación, en la que confluían ingredientes políticos, urbanísticos, culturales y económicos.

El recinto se comenzó a desfondar en el mes de abril de 2009, llevando en paralelo los trabajos de una excavación arqueológica, que, fuera de la práctica habitual se desarrolló de forma simultánea en toda la extensión de la parcela. La propuesta que los técnicos y especialistas manejaban era el traslado a cota cero, sobre la futura plaza-jardín, de las estructuras más relevantes que pudieran ser descubiertas.

En el mes de diciembre de 2009, tras varias semanas de movilizaciones ciudadanas, se paralizaron los trabajos y la Administración Regional reconsideró la decisión de autorizar la construcción del aparcamiento subterráneo, con el fin de conservar las estructuras de época islámica aparecidas en la propia cota de excavación.

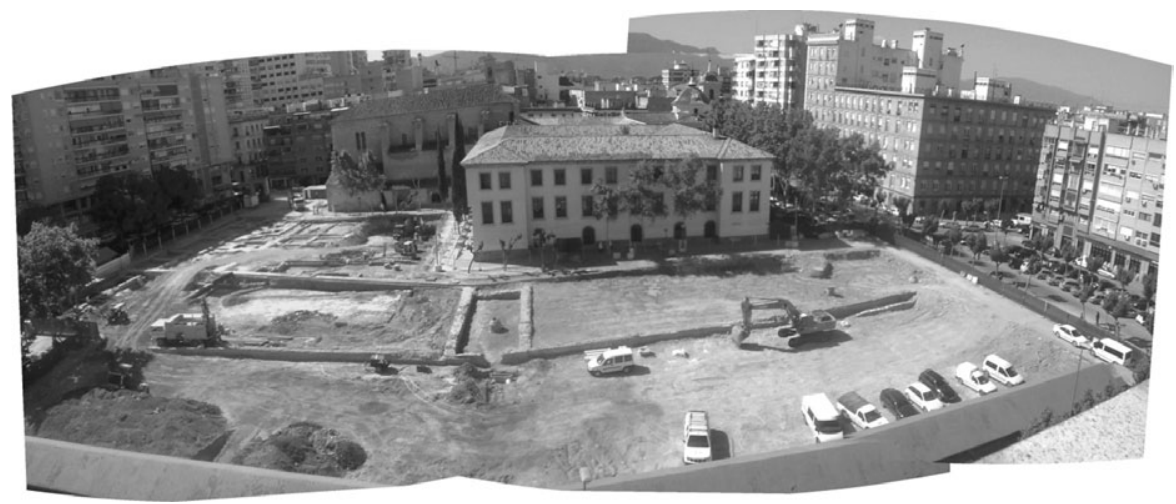

Fig. 1. Vista panorámica de los inicios de la excavación, mayo 2009 (Fuente: autores).

Feminismo/s 17, junio 2011, pp. 45-64 

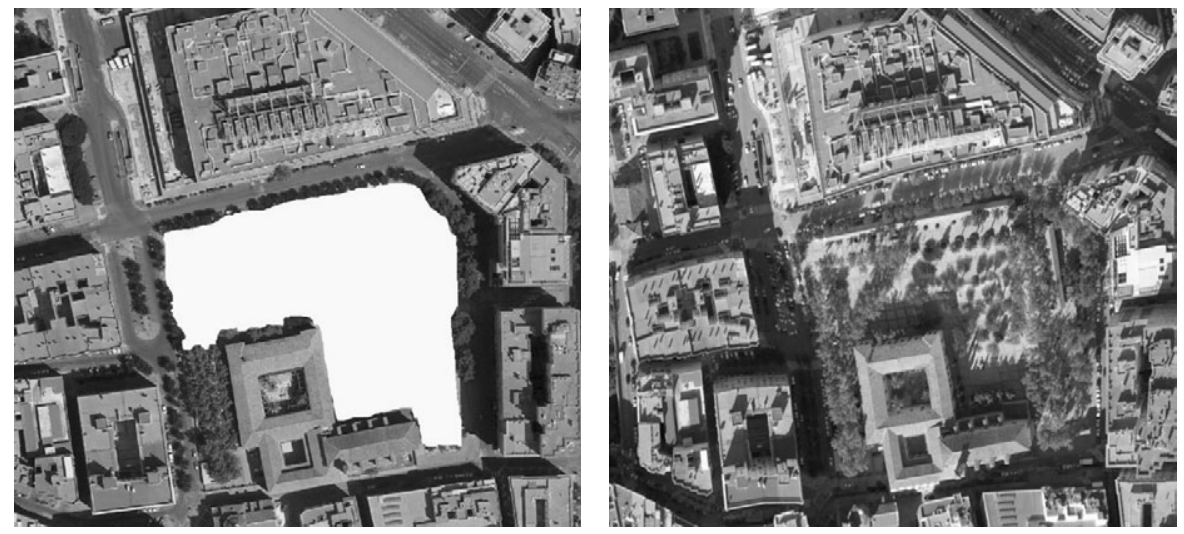

Figs. 2. y 3. Fotografía aérea del jardín de San Esteban (Fuente: Cartomur y autores).

El yacimiento ocupa todo el espacio ajardinado que rodeaba la Iglesia y Palacio de San Esteban, primer colegio jesuita y actual sede de la Presidencia de la Comunidad Autónoma. Está situado entre las calles Jerónimo de Roda, Portillo de San Antonio, y Burruezo frente un gran centro comercial (El Corte Inglés). En total ocupa 10.143,28 m2 con planta en forma de «L», y corresponde parte del arrabal de la Arrixaca'.

Al iniciarse la incoación de B.I.C y a la espera del concurso de ideas sobre la musealización del yacimiento y el tratamiento del espacio urbano circundante, el Ayuntamiento de Murcia lanzó una convocatoria pública para establecer una conservación temporal de los restos.

En el mes de enero de 2010 fue adjudicado el concurso de Redacción del Proyecto para la adopción de medidas de conservación y protección preventiva temporal del Yacimiento Arqueológico del jardín de San Esteban a la empresa Constructora Villegas bajo la dirección de una Restauradora y Arqueóloga: Pilar Vallalta, con un equipo de mayoritaria presencia femenina.

\section{Perspectivas asonantes: femenino plural}

Restauración, arquitectura, arqueología, historia son disciplinas que se enuncian en género femenino. Hace tiempo que las aulas universitarias están

1. El primer Concejo de poblamiento cristiano tras la reconquista se asentó en este barrio situado al norte de la ciudad, desplazando a la primitiva ocupación musulmana. TORRES FONTES, Juan: Crónica Concejil. En Batiburrillo Murciano. Academia de Alfonso X el Sabio. Murcia, 1998. 
estadísticamente tomadas por mujeres; luego, en la cotidianeidad profesional, a medida que se asciende en ámbitos de mando, disminuye esta presencia hasta resultar singular. Patrones de comportamiento, que dependen en gran medida de experiencias pasadas, y que limitan la capacidad para generar proyecciones hacia el futuro, o de impulsar visiones creativas desde «otra» perspectiva.

En el equipo multidisciplinar creado para concursar había mayoría femenina (una arqueóloga, tres responsables técnicos de empresa constructora y una restauradora), en unión de dos arquitectos y un aparejador; aunque quizás lo más inhabitual es que la coordinación recaía en una mujer.

Es difícil distinguir en la preparación del proyecto si ha habido más complicación en estar conducido por una experta, o que ésta no fuera arquitecta, poniendo de manifiesto lo arduo de superar la asignación de roles de género, pero en paralelo con el hándicap de desplazar de las tareas de máxima responsabilidad a profesiones ungidas por la regulación administrativa.

Estamos en una sociedad compleja, plural, con creciente preocupación por la cultura y el patrimonio, donde un movimiento ciudadano puede hacer reconsiderar posturas y decisiones, y la infalibilidad no se presupone. Lo que vale para el posicionamiento de la mujer frente al mundo masculino, y también para reconsiderar el peso y contribución de los variados agentes que intervienen en hacer ciudad desde la perspectiva profesional o la especialidad.

\section{Desmontando el pasado: destapando muñecas rusas}

En algún momento la técnica podrá deparar exámenes estratigráficos con mínimas medidas intrusivas. Hoy, en comparación con la ciencia médica, sólo sabemos intervenir con cirugía mayor y biopsias claramente invasivas.

Para conocer la realidad del s. XVIII hay que desmontar los restos del s. XIX, y así sucesivamente... ¿hasta qué período?

Cuando decimos que hay una ciudad bajo la ciudad, en realidad queremos decir que hay muchas otras ciudades: bajo el jardín de los setenta, la casa de huérfanos de la postguerra, el ambicioso frenopático de finales del XIX, el moreral sedero, el huerto jesuítico, el arrabal cristiano, el arrabal islámico, y todo en callada convivencia de ocho siglos. Hay que buscar los orígenes, y se sigue profundizando, aunque queden debates pendientes entre arqueología/ historia/arquitectura.

Todo el espacio ha sido desfondado una media de cuatro metros de profundidad y los laterales están construidos por taludes con una inclinación en algunos casos de $70^{\circ}$ a $80^{\circ}$, casi verticales, al norte y sur parcialmente protegidos por un mortero proyectado. El talud del oeste está realizado formando 

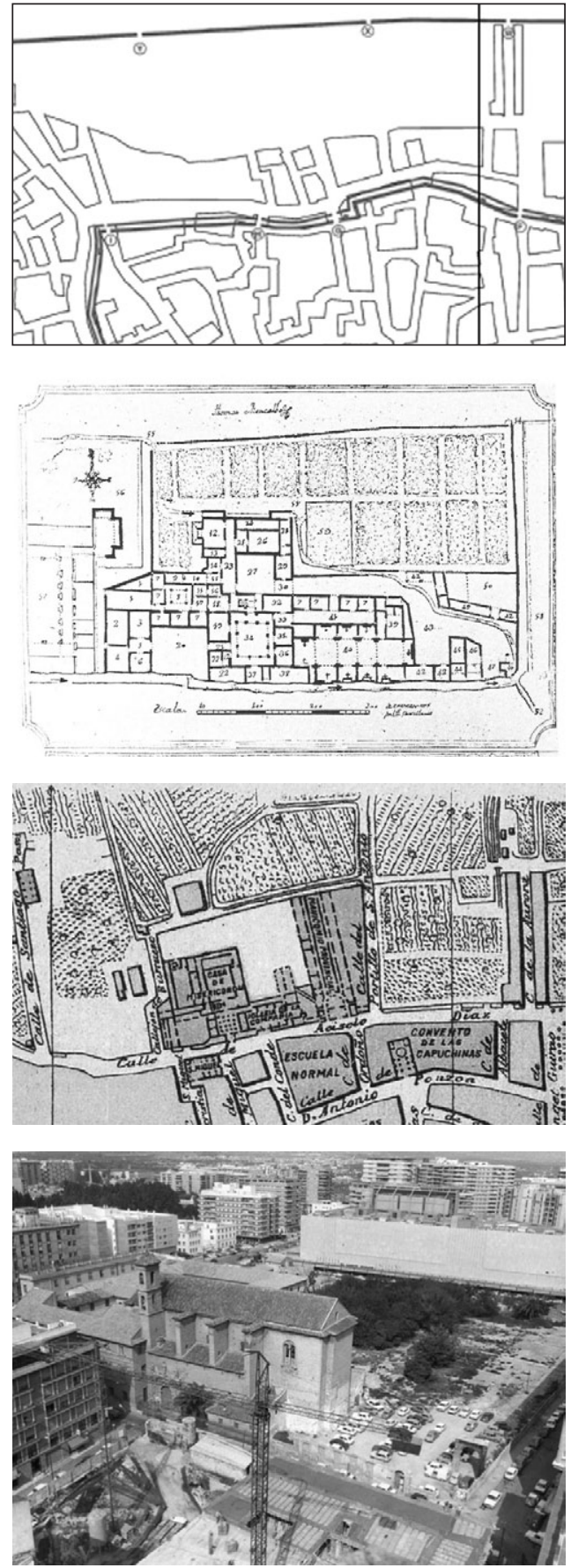

Fig. 4. Plano del arrabal de la Arrixaca.

Fig. 5. Colegio Jesuita h. 1714.

Fig. 6. Plano de García Faria 1896.

Fig. 7. Foto de la zona 1975.

Feminismo/s 17, junio 2011, pp. 45-64 


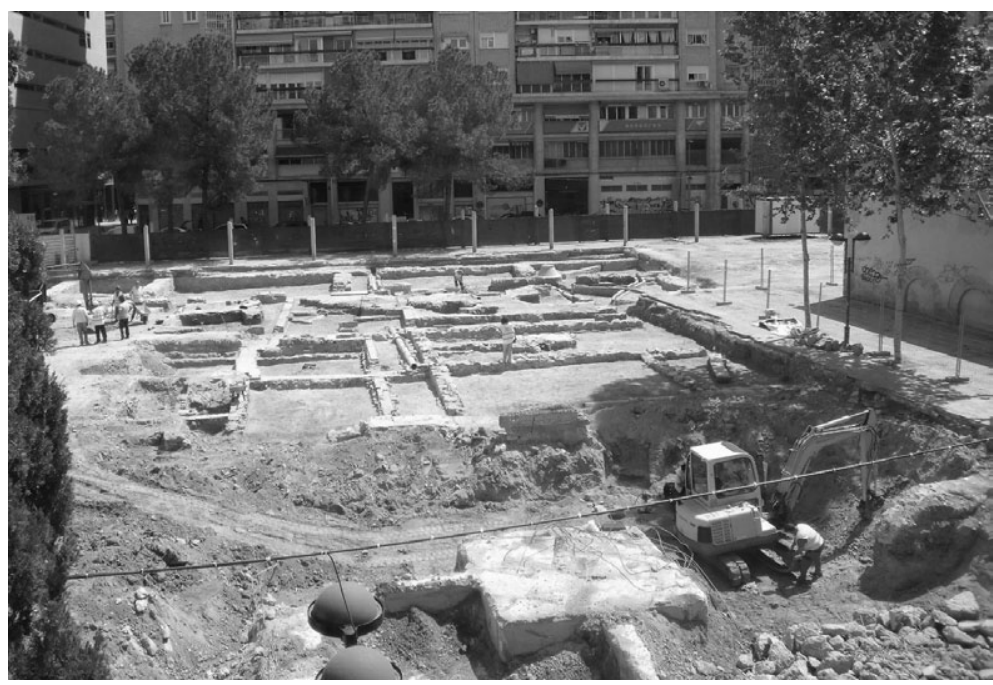

Fig. 8. Vista de los restos, junio 2009 (Fuente: autores).

escalones de 1,0 m. de altura. El talud este consta de dos grandes escalones de 2,0 m. de altura cada uno. La topografía del yacimiento es totalmente horizontal sin desniveles. Hay una zona de terrera en el ángulo suroeste y una rampa de acceso de vehículos y personal en el ángulo noreste.

Desde el comienzo de la excavación se han documentado diversas fases de uso y ocupación que van desde la actualidad hasta el siglo XIII donde aparecen restos de un barrio mudéjar-andalusí. Todo el yacimiento es una parte del barrio del arrabal norte de la Arrixaca que estaba densamente poblado en los siglos XII y XIII. La gran mayoría de las casas excavadas hasta la fecha representan el momento cronológico del siglo XIII. La trama urbana general es muy abigarrada con edificios de muy diversos tamaños que abarcan desde el principio del siglo XII, el siglo XIII y principios del XIV. El barrio se organiza en calles y azucaques de unas anchuras que van desde 3,0 m. a 1,20 m. La gran mayoría de edificaciones se agrupan en manzanas de 4 ó 5 casas. Las viviendas se componen de patios con arriates a los que se asoman el zaguán, letrinas y salas con alcobas laterales. En otra zona se observan edificaciones más grandes con un diseño totalmente ortogonal con grandes arriates que dan a una gran calle con dirección este-oeste y otra que la cruza en dirección norte-sur.

Las estructuras están formadas por variados materiales constructivos. En la mayoría de los casos estos materiales están mezclados entre sí, lo que 


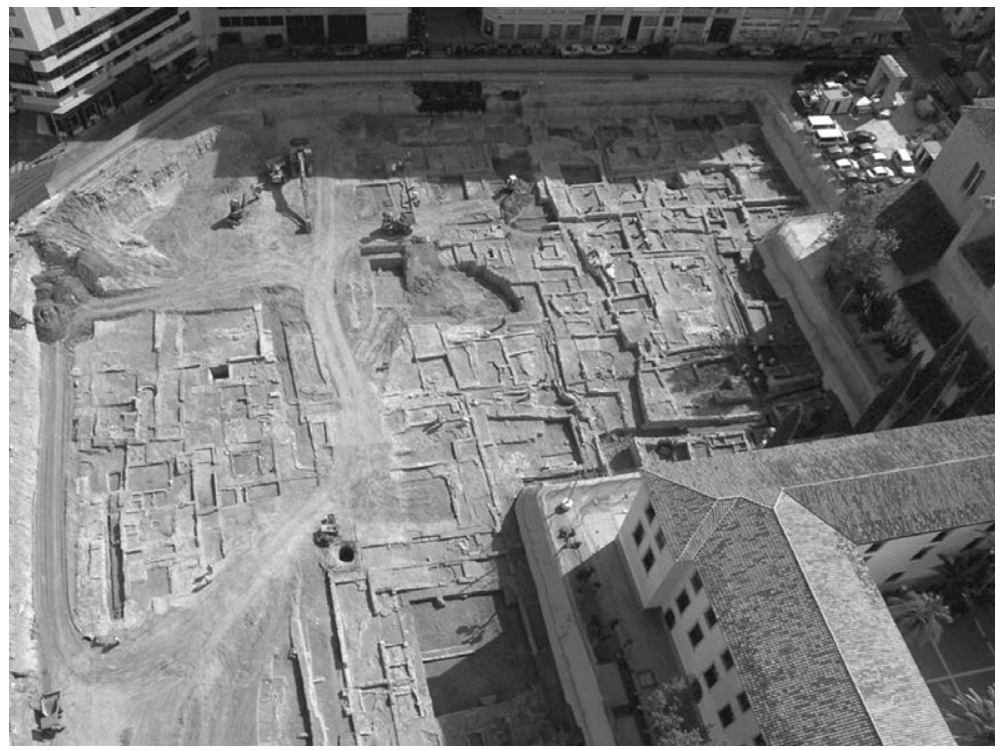

Fig. 9. Vista aérea de la excavación, septiembre 2009 (Fuente: Ana Pujante).

describe un sistema constructivo pobre y de reformas continuas, cambiando suelos y reforzando muros por otros de mejor material y factura en siglos posteriores.

Los muros están formados por combinaciones de ladrillos, tapial y hormigón de cal encofrados. Los muros elementos creados con estas mezclas no suelen ir trabados entre los diversos materiales para configurarles solidez, por lo que se deterioraban fácilmente y pasaban por continuas reparaciones, incluso durante su uso. Esto también les confiere una gran fragilidad ante la exposición ambiental sin una adecuada protección.

\section{Factor asombro: el valor del tamaño}

Más de diez mil metros cuadrados, la extensión de casi dos campos de fútbol. ¿Cuánto ha pesado en la valoración el tamaño de lo excavado frente a la categoría de los restos? Estamos ante el trazado de un discreto arrabal medieval, pero ¡con tanta contemplación simultánea!

Podemos observar: Muros de tapia de tierra estabilizada, de tapial calicastrado, de tapia de hormigón de cal y de fábrica de piezas cerámicas; Pavimentos de cal, cerámicos y de piedra; Estructuras de tierra, Cimentaciones; Cortes estratigráficos y paredes de cuadrículas arqueológicas; Anillos de pozos, sistemas de saneamiento de ladrillos y de hormigón de cal. 
Según Xavier Sust ${ }^{2}$, para merecer alguna de las «estrellas Michelin» la arquitectura debe, además de estar calificada como «curiosidad» y pertenecer «a la antigüedad», ostentar grandiosidad en sus dimensiones. Así que, si los expertos no lo remedian (haciendo una pedagogía complicada con la masa social que ha rescatado los restos de las palas mecánicas), tenemos un yacimiento que asegura una considerable puntuación de cara a participar de ese difuso campo denominado turismo cultural.

Se habla de mantener el yacimiento «abierto», de promover un centro de interpretación de la ciudad medieval, de no perder el carácter de plaza-jardín para no macizar uno de los escasos vacíos del casco urbano.

Cualquiera de las opciones sobre las que se trabaje precisará de una extraordinaria sensibilidad, ya que el propio tamaño de elemento a musealizar (a componer dentro de una propuesta), será forzosamente limitador de la cohabitación entre pasado y actualidad ${ }^{3}$.

\section{De patologías y deterioros: toma de pulso}

Centrándonos sobre aspectos técnicos, en el estado de conservación del yacimiento se han definido tres tipos de niveles de deterioro que afectan al conjunto de estructuras arquitectónicas, y que en orden creciente son: Alteración, degradación y ruina.

La alteración indica una modificación del estado normal de la superficie sin ser una reducción de materia. Este problema se aprecia en los muros de hormigones de cal y estructuras de alta consistencia por el tipo de materiales con los que se fabricaron. Las pequeñas fisuras en muros de tierra y la pérdida de junteado sobre pavimentos y muros cerámicos que no conllevan una pérdida de volumen, se considera asimismo alteración.

Las lluvias intensas han provocado el lavado continuo de estructuras de tierra y la pérdida de morteros de cal disgregados. Las coronaciones de los muros de tabiquería han perdido el junteado de mortero, los ladrillos están sueltos y en un gran número están rotos o fragmentados. Las filas superiores han perdido adhesión por deterioro de los morteros de agarre. El lavado de las estructuras de tierra y el embalsado del agua de lluvia han cubierto el yacimiento de barro, tapando suelos y pavimentos.

2. SUST, Xavier: Las estrellas de la arquitectura. Tusquets Editor. Barcelona, 1975.

3. La cohabitación es la función propia, material y anímica, psicológica y social, de toda arquitectura. ARNAU AMO, Joaquín: 72 voces para un Diccionario de Arquitectura Teórica. Celeste Ediciones S.A. Madrid, 2000. 
La degradación implica una reducción de materia. Hay numerosos pavimentos de morteros de cal con grandes lagunas. Las pérdidas de consistencia de las fábricas de ladrillos con caída de éstos en sus coronaciones. Hay grandes fisuras y oquedades en los muros de tierra, que se generan al secarse y perder la humedad interna.

Este nivel de degradación está generalizado en todo el yacimiento ya que este está a la intemperie durante muchos meses.

La ruina se considera al deterioro muy grave, con grandes pérdidas de elementos constructivos. En el yacimiento se observaron descalces de muros, lagunas en las partes bajas de muros de tierra, severas pérdidas de verticalidad en muros de ladrillos y muros de hormigón. Peligro de derrumbe con apuntalamientos puntuales. Caídas de elementos de sillarejo y tabiquería. Estancamiento de agua de lluvia por ausencia de filtración del terreno.

En todo el yacimiento podemos apreciar degradaciones y ruinas acontecidas en los mismos siglos XIII y XII, es decir a causa del propio uso de las edificaciones, que durante décadas se fueron reutilizando, reparando y reformando hasta su abandono.

La gran heterogeneidad de materiales formando parte de un mismo elemento crea una alteración diferencial. La tierra no se conserva de la misma manera que la cerámica, ni ésta igual que los morteros de cal. Los factores de degradación no atacan de la misma forma a los materiales, y estos se comportan de forma diferente ante ellos. También se localizan materiales de construcción de escasa calidad.

El nivel de Ruina se aprecia por la acción de catástrofes naturales, como grandes riadas o inundaciones ${ }^{4}$, y por la acción del hombre: abandonos, creación de fosos como suministro de materiales.

Los factores de alteración de los elementos constructivos del yacimiento son de carácter intrínseco y extrínseco. Los factores intrínsecos están determinados por la propia composición y fabricación de los materiales y su colocación en el yacimiento. Los factores extrínsecos son climáticos, químicos, físicos y antropológicos.

\subsection{Factores intrínsecos}

5.1.1. Fabricación de los materiales: Es uno de los factores más generalizados en la degradación de un yacimiento o una estructura. Es el deterioro

4. Frutos BaEza, José: Bosquejo histórico de Murcia y su Concejo. Academia Alfonso X el Sabio. Murcia, 1988 ( $1^{a}$ ed. 1934) y Estrella SeVILla, Emilio: Murcia: ciudad, territorio, cultura y agua. Murcia, 2005. 
propio de los elementos constructivos por defecto en su fabricación. Muchos procesos destructivos están causados por la mala calidad de los materiales componentes, la falta de profesionalidad en la construcción y los suelos en los que se asentó.

Los muros de las casas del yacimiento están fabricados con ladrillos de muy mala calidad, y con materiales poco duraderos como tapiales o encofrados de arcillas y tierras. Las fábricas y muros tuvieron que ser conservados desde el inicio de su construcción con continuos trabajos de reparación.

5.1.2. Las reutilizaciones de estructuras: como base para alzar otras posteriores o las utilizaciones de espacios grandes para crear otros más pequeños.

5.1.3. Asentamientos del terreno: el propio suelo no era apropiado para muchas de las construcciones, teniendo que reforzar las cimentaciones para poder edificar y para reparar los continuos hundimientos del terreno.

\subsection{Factores extrínsecos}

5.2.1. Factores térmicos: Conocemos la climatología de la Ciudad de Murcia, típicamente extrema en temperatura. Las variaciones térmicas anuales van desde los 6 grados de mínima a los 35 o 40 de máxima, teniendo muchos días del año por encima de los 20 grados a mediodía.

Las avenidas o riadas han sido un elemento clásico de derribo y configuración de la ciudad de Murcia: a finales del s. XIV era obligatorio reedificar antes de 30 días las casas demolidas en el Barrio de San Miguel (parroquia a la que pertenecía el arrabal), so pena de perder los solares (en gran medida ocupados por casas de mancebía).

El agua absorbida por la gran porosidad de los materiales, expande éstos en momentos de baja temperatura en invierno y por la noche. Durante los meses de calor esta agua acumulada en el interior de los muros se extrae de forma rápida en la superficie, produciendo fracturas, descomposición, debilitamiento y pulverización. Esta alteración se ve favorecida por la existencia de sales solubles en el agua.

5.2.2. Factores hidráulicos: son muy diversos. Las propiedades mecánicas y solventes del agua de lluvia son significativas. Tiene gran capacidad de penetración en los materiales arcillosos y cerámicos, tanto por capilaridad como por condensación. Asimismo altera el estado de las cimentaciones, que en el caso de este yacimiento son de muy mala calidad, ya que están asentadas en terrenos arcillosos, de limos y avenidas del río. 
Además las precipitaciones que se producen en Murcia son de forma discontinua, de manera intensa y torrencial, lo que supone un gran problema de conservación para estructuras frágiles o debilitadas.

Entendemos también como factor hidráulico de alteración, la humedad ambiental. El vapor de agua contenido en el aire es muy abundante en la zona, teniendo alto grado de humedad relativa. La humedad por capilaridad transporta las sales solubles del suelo hacia los muros y suelos. Estas sales se alojan en las estructuras de forma estable mientras la humedad continúe sin oscilaciones. Si la humedad se reduce por el secado de las estructuras se cristalizan y comienzan a degradarlas.

La acción conjunta de los factores hidráulicos y térmicos, aceleran la alteración química y física de todos los materiales del yacimiento. La saturación completa de las estructuras con el agua de lluvia será eliminada por la acción del sol y aumento de temperaturas. El proceso de secado se iniciará de forma incontrolada, provocando agrietamientos y desprendimientos de materia.

5.2.3. Factor eólico: El viento tiene un gran poder erosivo por las partículas sólidas que transportada. La gran extensión del yacimiento y no estar encajado entre medianeras de edificios, hace que el viento tenga espacio para actuar.

El debilitamiento y disgregación de las arcillas, tierras y morteros secos por la acción del sol y las altas temperaturas, resultan el estado ideal para que la acción del viento: erosionando coronaciones y esquinas de muros, suelos de morteros de cal, etc., y acelerando los procesos de secado de las estructuras, aumentando la proliferación de fisuras y resquebrajamientos de las estructuras de tapial y de calicastrado y la degradación de los ladrillos cerámicos.

5.2.4. Factores químicos: actúan sobre los restos arquitectónicos creando procesos de alteración, siendo los más importantes los componentes del aire: el oxígeno ataca los metales que están presenten en pequeñas partículas en las arcillas, creando alteraciones cromáticas, y fracturas. El vapor de agua es un excelente solvente de ciertas partículas que componen los morteros o las cerámicas.

Las sales solubles del suelo se introducen en las estructuras por la humedad por capilaridad. Sales que son nocivas para el mantenimiento del yacimiento y para la aplicación de los tratamientos de conservación que se utilizan.

5.2.5. La contaminación atmosférica: está causada por gases y partículas sólidas. Los productos derivados de la combustión, los compuestos de azufre y los aerosoles salinos actúan alterando el color y la forma de las fábricas excavadas. Con la exposición prolongada de las estructuras de cal y de cerámica 
a la contaminación, aparecen capas sólidas como costra negra y superficies carbonatadas.

5.2.6. Contaminación biológica: producida por la aparición de mohos y hongos tras una gran lluvia y humedad prolongada. El moho crea manchas verdosas y ocres muy difíciles de eliminar. Crecimiento de plantas de pequeño y gran porte y la acción destructora de las raíces sobre las estructuras.

5.2.7. Alteraciones antropogénicas: Siendo un yacimiento en proceso de excavación, podemos considerar alteración por la acción humana: la propia excavación, y el método utilizado: la excavación en extensión. Esta forma de trabajo, muy importante para la apreciación global del yacimiento, es muy perjudicial para la conservación, ya que grandes zonas excavadas están a la intemperie durante muchos meses.

5.2.8. Ausencia de conservación: No ha habido un equipo de restauración que tratara los materiales aparecidos para su conservación.

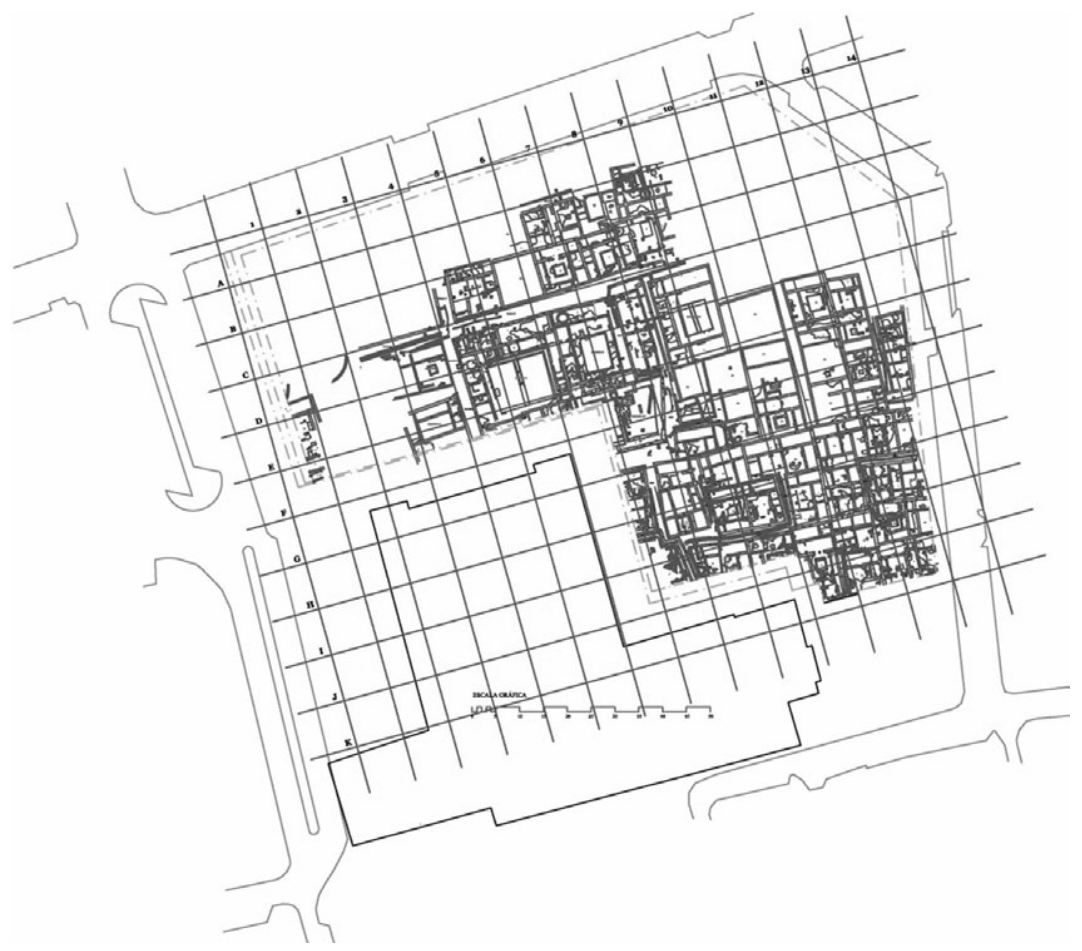

Fig. 10. Planta del Yacimiento (Fuente: autores).

Feminismo/s 17, junio 2011, pp. 45-64 


\section{Conservación temporal: cuidados de mantenimiento hasta el quirófano}

La propuesta del proyecto ha seguido las prescripciones técnicas dadas por el Servicio de Conservación y Restauración de la Dirección General de Bellas Artes y Bienes Culturales. Estas instrucciones marcaban una doble protección con lámina de geotextil y cubrición total con gravas y zahorras de forma general en el yacimiento. Sistema que debe servir de protección durante un tiempo que puede alargarse en torno a tres años.

\subsection{La protección}

Todo especialista en conservación y restauración de elementos arquitectónicos arqueológicos, sabe que el peor factor de alteración es el período que pasan estas estructuras al aire libre. Los materiales que las forman se degradan por la acción del agua, del sol, por los cambios de humedad, de temperatura y la acción erosiva del viento. Si se cubre totalmente el yacimiento se eliminan la mayoría de estas acciones negativas.

A efectos de poder contar con un espectro completo de metodologías de conservación, dada la extensión de la zona de actuación y la multitud de opiniones contrapuestas expresadas por toda clase de personas (especialistas o no en la materia), se diseñaron tres formas de protección:

6.1.1 Protección completa: Cubrición total y completa de estructuras con tierra. Las estructuras se protegen con láminas de geotextil y sobre ellas se arroja zahorra o gravas de diversas granulometrías, de forma ordenada por niveles horizontales hasta llegar a cotas máximas superiores en $20 \mathrm{~cm}$ del muro más alto del yacimiento. Esta cubrición total puede realizarse con inclinación con el fin de generar un sistema de evacuación de agua de todo el yacimiento. Este sistema de protección se debe contemplar, cuando el yacimiento no va a ser utilizado durante más de dos años.: cuando no va a tener actividad, ni para seguir con las excavaciones, ni para realizar otro tipo de trabajos. Así se crea una protección total de estructuras evitando la acción de todos los factores de alteración.

El sistema precisa una fumigación de la superficie para evitar la proliferación de plantas. Se prevé el mantenimiento de labores de limpieza superficial, comprobación de los sistemas de drenaje y refuerzo periódico de fumigado.

6.1.2. Cubrición al 50\%: Protección con geotextil de todos los elementos. Cubrición de las estructuras horizontales con zahorra y gravas, sin llegar a nivel de coronación de muros. Es imprescindible para reducir la acción de los factores de degradación la protección completa de los elementos más débiles, 
ladrillo, muros de tierra, pavimentos de cal, etc. Por ello se plantea una protección que crea una semicubrición. Los muros más compactos y resistentes se dejan al aire, pero se protegen con lámina de geotextil.

Este sistema conlleva un mantenimiento mensual de revisión de zonas semicubiertas con fumigación del yacimiento y eliminación de aguas localizadas en los espacios cerrados entre muros. Cada tres meses de debe revisar las láminas de geotextil que quedan a la intemperie, porque se degradan con la acción del sol. Cada seis meses se debe limpiar todo el yacimiento de hojas o de basuras que se arrojen desde el exterior.

6.1.3. Cubrición de elementos horizontales: La protección se desarrolla en las superficies horizontales para cubrir todos los elementos arqueológicos de suelos, pavimentos de cal, piedra y ladrillo. Se protege con lámina de geotextil previamente, y sobre ellos se deposita gravas de grano medio. Se deben gestionar sistemas de drenaje naturales en cada espacio entre muros o provocar la salida de agua de forma artificial con bombas de extracción o canales de evacuación.

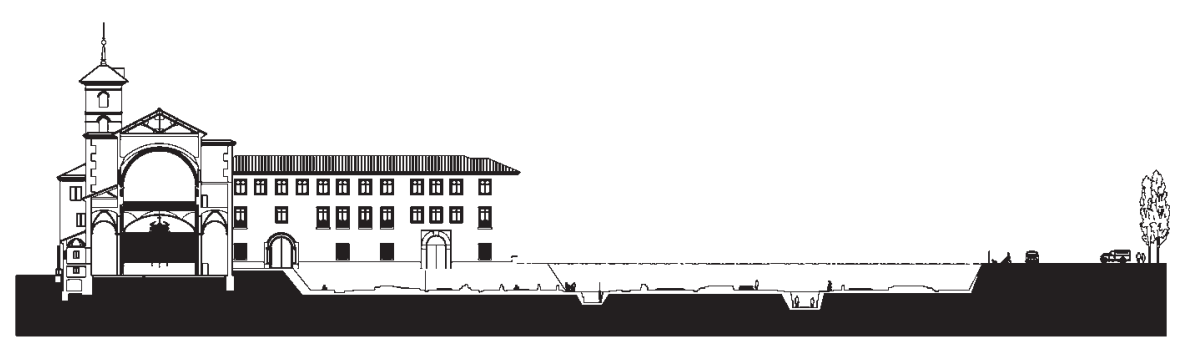

Fig. 11. Sección del Yacimiento (Fuente: autores).

\subsection{Sectores y zonas del yacimiento}

El yacimiento tiene una gran extensión y presenta diversos momentos cronológicos y constructivos superpuestos y descontextualizados. Tras un estudio de las diferencias de cotas, y a efectos de diseñar criterios de protección, se ha dividido en cuatro sectores:

Sector 1: zona del yacimiento con un nivel de profundidad de excavación alto, que tiene muros de un máximo de 2,00 $\mathrm{m}$ de altura, respecto de los pavimentos y fondos de sondeos realizados.

Sector 2: zona del yacimiento con un nivel de profundidad de excavación alto, que tiene muros de un máximo de 1,30 $\mathrm{m}$ de altura, respecto de pavimentos o desfondes realizados a su alrededor. 
Sector 3: zona del yacimiento con un nivel de profundidad de excavación medio, que tiene muros de un máximo de 0,60 $\mathrm{m}$ de altura, respecto de pavimentos a su alrededor.

Sector 4: zona del yacimiento con un nivel de profundidad de excavación bajo, que tiene muros o estructuras con un máximo de $0,40 \mathrm{~m}$ de altura.

Por motivos de accesibilidad y actuación en los trabajos de restauración, el yacimiento lo dividimos en tres grandes zonas. Estas zonas se adaptan a los sectores de nivel de cotas antes descritos y se tratarán con tres modelos diferentes de protección y cubrición. Al mismo tiempo estas zonas adaptan metodología de trabajo y la cronología de actuación.

La zona 1 tiene 2.188,68 $\mathrm{m} 2$ de superficie y agrupa zona la arqueológica con mayor número de edificaciones. Esta zona cubre dos sectores del yacimiento según su nivel de profundidad de excavación, el sector 1 y el 2.

La zona 2 tiene 2.310,94 $\mathrm{m} 2$ de superficie y agrupa las grandes estructuras de edificación, con los sectores de profundidad de excavación 3 y parte del 2.

La zona 3 ocupar 5.204,03 m2 de extensión. Esta zona abarca todo el sector 4, la rampa de acceso de camiones y la terrera sureste, con una profundidad de excavación de $0,40 \mathrm{~m}$.

\subsection{La consolidación}

Para las pruebas de Restauración y Consolidación se han estudiado los siguientes consolidantes:

Silicato de etilo: Silicato tetraetilo hidrolizado disuelto en disolventes orgánicos como etanol, nafta, y dibutil dilaurate. Es un producto específico para consolidación de elementos silíceos, cerámicos y arcillosos. La aplicación para su correcto uso está condicionada a la ausencia de humedad e inexistencia de sales solubles. El protocolo de actuación es en tres capas como mínimo, diluidas en white spirit o etanol a proporciones adaptadas a cada elemento.

Silicato de litio: Producto que se basa en la reacción que precipita el sílice como elemento consolidante, pertenece a la familia de los vidrios solubles. Sus principales cualidades son el poder consolidante, la inocuidad del diluyente que es agua destilada y que se aplica con humedad en superficie. Su punto flaco es la interacción con sales solubles presentes en los paramentos o elementos a consolidar. El protocolo de actuación es: Humedecer las superficies o aprovechar la que provoca un día de lluvia. Aplicar el consolidante en dos manos al 50 o $70 \%$ según la porosidad. Previamente a la aplicación es imprescindible eliminar las sales solubles con desalaciones, ya que el producto precipita al contacto con ellas produciendo manchas blanquecinas. 
Agua de cal: Para consolidación de elementos o estructuras constituidos por tapiales, fábricas de adobes, y en general morteros realizados a base de cal, se empleará agua de cal. El óxido y el hidróxido de calcio o magnesio es un producto natural y que constituye la base de todas las construcciones antiguas. Para la consolidación de estructuras se utiliza el agua de apagar la cal viva. Es aconsejable la utilización de cales de mínimo de 6 meses de apagado, empleándose de 10 años para la restauración de elementos arquitectónicos específicos.

Resinas acrílicas en emulsión acuosa. Acril A33: Esta resina se aplicará en proporciones muy reducidas en el agua de cal. La proporción indicada para las muestras es 11 de agua con 1 de resina, reduciendo la cantidad de resina hasta 15 de agua y 1 de resina. Se utilizará en la consolidación de muros de tierra y ladrillos totalmente degradados y pulverulentos.

Entre las cuatro propuestas nos decantamos por el agua de cal para una consolidación temporal, ya que aun no están definidos los sistemas a emplear a largo plazo. Será necesario que un equipo de restauración haga seguimiento de las patologías que puedan degradar las estructuras no cubiertas, aplicando de forma regular tratamientos de conservación y consolidación junto a labores de limpieza y de fumigación.

\section{Lucha por la visibilidad: los debates pendientes}

En una suerte de paralelismo no buscado la supervivencia del yacimiento en su propia cota ha dependido de la visibilidad del mismo; y en la fase actual, hasta su definitiva reconsideración, se ha preferido una intervención que siga mostrando parcialmente cubiertas las estructuras. Ésta no es la fórmula más segura para la conservación de los restos, pero sí actúa como recordatorio de que hay un problema pendiente.

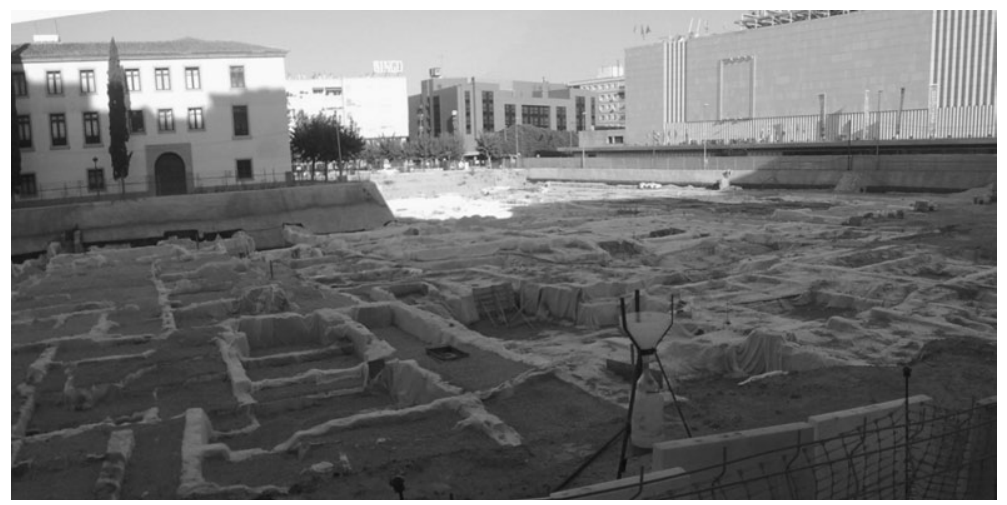

Fig. 12. El Yacimiento después de la intervención de conservación temporal. 


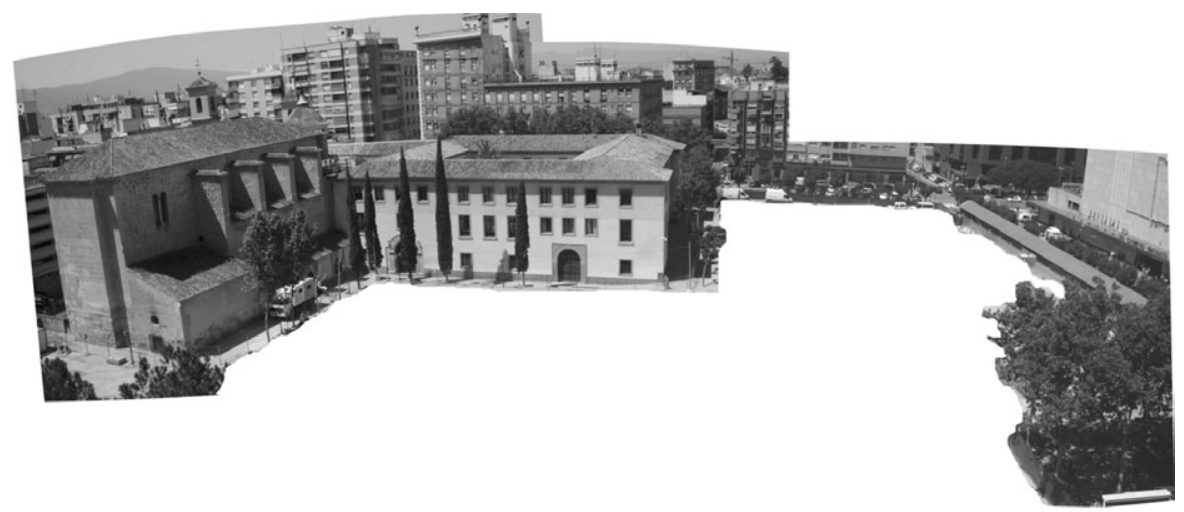

Fig. 13. El espacio «en blanco» pendiente de integración (Fuente: montaje autores).

De una forma mimética la lucha de la mujer por alcanzar el puesto que le corresponde o la responsabilidad para la que se ha capacitado necesita de visibilidad: de promoción, respeto e imagen. En un mundo subordinado a las impresiones visuales, como casi única fuente informativa, hay necesidad de mostrarse y exponerse con tanta fuerza como peso en una argumentación técnica o científica. A partir de ahí, y siendo conscientes de la potencial carga de rechazo, estaremos más preparados para debatir los fondos de las cuestiones que nos preocupan.

\section{Bajando el telón del primer acto}

Aún nos sorprende que bajo nuestras seguras pisadas ya hubiera precedentes. Recorta exclusividad, relativiza la posición de los miembros de una sociedad que tanto ha primado el individualismo; devuelve a una perspectiva gregaria y recurrente.

Hay que hacer cabida emocional para incorporar la pertenencia a una fragmentación histórica de la que no podremos evadirnos. Y también nos aporta recursos, bagajes y secuencias, para promocionar un presente y futuro con escasez de referentes válidos.

En la portada de la iglesia de San Esteban, en la hornacina de la derecha, hay una figura de mujer con la palma del martirio, que pisa con el pie derecho una cabeza con cinta en la frente, abajo una leyenda premonitoria: Sapientes pietate superavit ( $\mathrm{A}$ los sabios les supera la piedad»).

En el caso que nos ocupa se están escribiendo sólo los capítulos iniciales. Quedan muchos temas pendientes, incluyendo que, tras la recuperación de la 


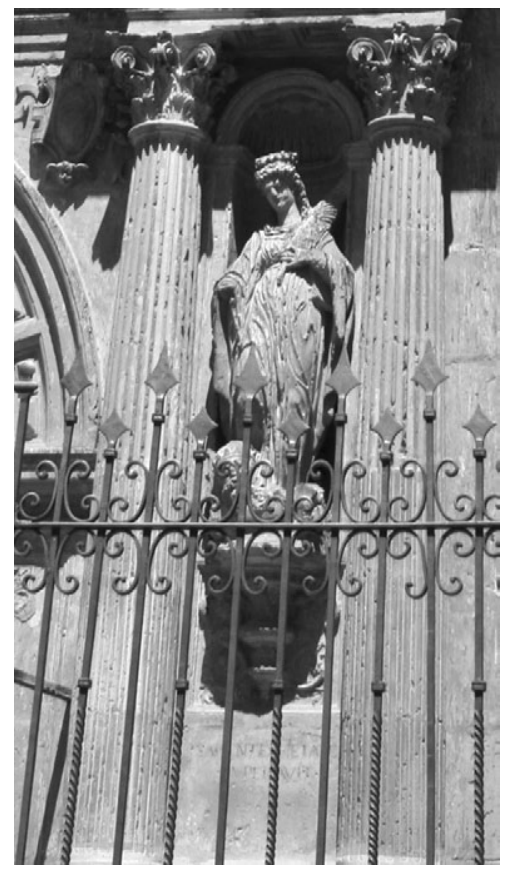

Fig. 14. Detalle de la portada de San Esteban: La piedad superando a los sabios (Fuente: autores).

estabilidad social, y con la ampliación de conocimientos que estas primeras intervenciones aporten, se vuelvan a exponer y dirimir argumentaciones en beneficio de la polis.

\section{Referencias bibliográficas}

ARnau Amo, Joaquín: 72 voces para un Diccionario de Arquitectura Teórica. Celeste Ediciones S.A. Madrid, 2000.

AA VV: Ciudades históricas: conservación y desarrollo. Fundación Argentaria - Visor. Madrid, 2000.

Estrella SeVIlLA, Emilio: Murcia: ciudad, territorio, cultura y agua. Murcia, 2005

Frutos BAezA, José: Bosquejo histórico de Murcia y su Concejo. Academia Alfonso X el Sabio. Murcia, 1988 ( $1^{\text {a }}$ ed. 1934).

GARATE ROJAS, I. Artes de la Cal. Instituto español de arquitectura. MRRP Universidad de Alcalá, 2002.

LIPOVETSKY, G. y otros: La cultura de la conservación. Fundación cultural Banesto. Madrid, 1993. 
Sust, Xavier: Las estrellas de la arquitectura. Tusquets Editor. Barcelona, 1975.

VAllalta MartíneZ, Pilar. «Tratamiento de consolidación y restauración de la

Muralla Púnica de Cartagena» en XVII Jornadas de patrimonio histórico de la Región de Murcia. 2006.

TORRES FonTES, Juan: «Crónica Concejil». En Batiburrillo Murciano. Academia de Alfonso X el Sabio. Murcia, 1998. 


\title{
LA VISIÓN DE GÉNERO Y EL ESPACIO INTELIGENTE
}

\author{
Carlos Hernández PeZzi \\ Universidad de Málaga
}

Recibido 09/02/2011

Aceptado 20/05/2011

\section{Resumen}

El ensayo traza una concepción, $1^{\circ}$ del espacio europeo como un espacio de derechos y deberes, $2^{\circ}$ del espacio físico y virtual como recipiente accesible y poroso y $3^{\circ}$ del espacio inteligente como superación de las tres brechas digitales, del conocimiento, el uso, y el acceso. La influencia recíproca de nuevos modelos sociales y de la web 3.0, a través de las redes sociales que transforman el modelo físico de la ciudad. Se busca un espacio público entendido como resultado de esas tres primeras concepciones y del espacio inteligente como aquel que además de igualitario es accesible sin brechas, como fundamento y objetivo de la ciudad interactiva. La ciudad digital como resultado de la interacción de espacios públicos y privados inteligentes, no discriminatorios para un nuevo modelo social de plena ocupación del espacio real y virtual por las mujeres.

Palabras clave: Género, espacio europeo inteligente, modelos y redes sociales, web 3.0, brechas de conocimiento.

Feminismo/s 17, junio 2011, pp. 65-89 


\begin{abstract}
Of «the vision of gender and the intelligent space» test trace a conception, 1 of the European space as an area of rights and duties, $2^{\circ}$ of the physical and virtual space as accessible and porous container and 3rd grade of intelligent space as overcoming the three digital gaps of knowledge, the use and access. The reciprocal influence of new social models and web 3.0, through the social networks that transformed the physical model of the city. You are looking for a public space as a result of these first three conceptions and the intelligent space as one who in addition to equal is accessible without gaps, as rationale and objective of the interactive city. The digital city as a result of the interaction of public and private spaces intelligent, non-discriminatory for a new social model for full occupation of the real and virtual space for women.
\end{abstract}

Keywords: Gender, intelligent, notions of space, social models, social models of networks, web 3.0, gaps of knowledge. 


\section{Europa y las ciudades}

La visión de género ha ido ocupando los espacios del conocimiento, de la ciencia, la tecnología y las ciencias sociales. El espacio urbano y el espacio íntimo, o privado, se han revisado a la luz de lo que sabemos sobre el uso y la percepción de esa construcción multidimensional cuya percepción y relación con el tiempo cambia constantemente. Arquitectura y planeamiento urbanístico se han venido realizando bajo una nueva concepción, que se ha ampliado a documentos presupuestarios y estudios económico-financieros que han ido sumando posiciones de racionalización de los paradigmas de igualdad en al acceso y uso de la ciudad.

Este Ensayo pretende establecer un proceso fluido de concepción, $1^{\circ}$ del espacio europeo como un espacio de derechos y deberes, $2^{\circ}$ del espacio físico $\mathrm{y}$ virtual como recipiente accesible y poroso y $3^{\circ}$ del espacio inteligente como el resultado de la superación de las tres brechas digitales, del conocimiento, el uso, y el acceso, abiertos sin distinciones. La consecuencia es un espacio público ${ }^{1}$ entendido como resultado de esas tres primeras concepciones y del

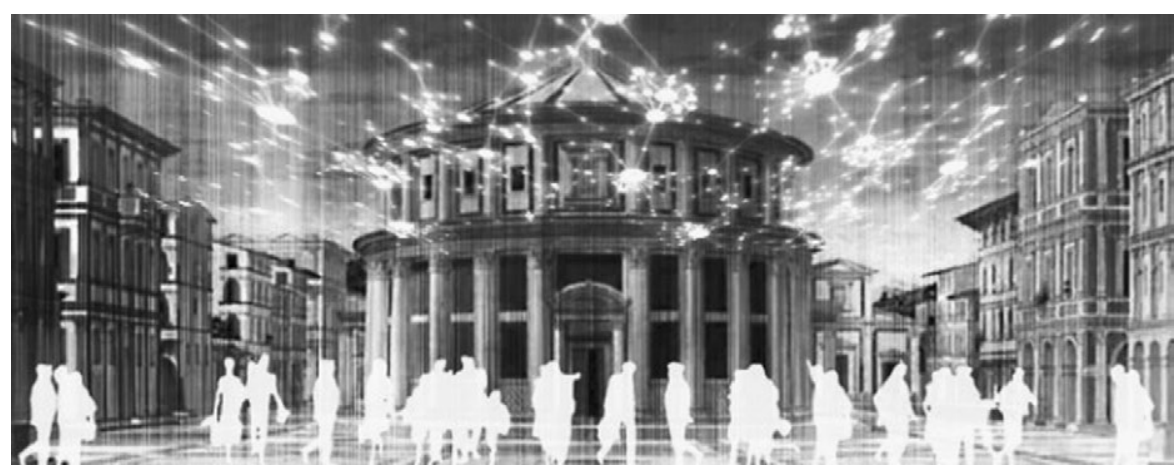

La imagen es una re-elaboración de Francesco Cingolani de la «Città ideale, Galleria nazionale delle Marche, Urbino de Pietro della Francesca».

1. INNERARITY, Daniel. «El nuevo espacio público». Espasa. Madrid. 2006.

Feminismo/s 17, junio 2011, pp. 65-89 
espacio inteligente como aquel que además de igualitario es accesible sin brechas, que debe entenderse como fundamento y objetivo de la ciudad digital. La ciudad digital como resultado de la interacción de espacios públicos y privados inteligentes y, por eso, no discriminatorios para un nuevo modelo social.

A la progresiva difusión de la Carta Europea de las Mujeres en la Ciudad, le han seguido en España la Ley Orgánica 3/2007², y el RDL 2/2008. Sin embargo, la percepción general es que la visión parcial, de alguna manera limitada, de la estructura de conocimiento de la ocupación del espacio urbano, viene legitimándose por una noción cuantitativa de los standards y requisitos urbanísticos obligatorios, más que por el resultado de la aproximación sugestiva o persuasiva de las políticas públicas de identidad igualitaria del espacio como entidad al alcance de todos los seres humanos. Contribuyen a ello ciertas visiones bienintencionadas, pero poco científicas, que reivindican legítimamente aspectos sectoriales del uso de los equipamientos, movilidades o servicios urbanos como requisitos puntuales de igualación formal sin trascender el apriorismo planificador de la separación entre el espacio público y el privado. Dicotomía acentuada por la consagración de las células de la telépólis, caracterizada unilateralmente como el espacio nuclear de la relación digital con la ciudad contemporánea. La sublimación europea de esa idea de ciudad ha sucumbido de la mano de la arruinada Estrategia de Lisboa, política que ha sido incapaz de frenar la falta de bienestar que la «sociedad del bienestar» ya no garantiza sino como un 'estado social europeo dual' de inclusión y exclusión. La defensa del «estado de bienestar europeo», sugiere que los recortes a éste en materia de reforma laboral, económico-financiera y de servicios deban, por efecto de la crisis, mantener ese esquema dual ineficiente en cuestiones básicas de acceso, empleo o uso efectivo de la ciudad.

$\mathrm{Si}$, hasta ahora, la introducción de la perspectiva de género en los instrumentos de planeamiento y planificación representaba un plus de calidad relativamente utilizado, ahora la situación cambia y se hace preceptiva. Pero la igualdad efectiva de hombres y mujeres en las políticas de suelo, en derechos urbanos peligra en el momento en que las políticas mundializadas mediante medidas anti-crisis se han centrado en el socorro del capitalismo financiero y en la precarización o acoso del «estado de bienestar» o su recorte, como si el cambio hacia un «nuevo modelo productivo» pudiera hacerse desde las mismas bases culturales y sociales anteriores a la crisis. Es discutible que las

2. Ley Orgánica 3/2007 de 22 de marzo, para la Igualdad efectiva de mujeres y hombres, art. 31.3, y el Real Decreto Legislativo 2/2008, de 20 de junio, por el que se aprueba el texto refundido de la Ley de Suelo, arts. 2.2 y 10.1 
conquistas sociales estuvieran ya equitativamente repartidas y/o garantizadas para todos los inmigrantes o nativos del modelo social europeo y para la mayoría de las mujeres. En los márgenes de la ciudad europea se encontraban ya, tras cuarenta años de experiencia, numerosas bolsas de exclusión y pobreza especialmente de los jóvenes-, bajo tensiones étnicas, religiosas o económicas, que estaban poniendo en riesgo la cohesión social anterior, siempre también bajo la discriminación de las mujeres. Desigualdad que la ciudad genérica no ha conseguido reducir o enmascarar. Los suburbios y las áreas metropolitanas se salen, así pues, del discurso políticamente correcto de la ciudad europea, como emblema a identificar y reproducir, y del espacio público europeo definido como perfil categórico por su acceso y disfrute democrático.

La precipitación de la crisis y las medidas anti-crisis ha procurado el olvido de que el «estado de bienestar» entendido como «isla» en la globalización tenía ya necesidad de reformas urgentes e inaplazables, especialmente en la ciudad y en lo que hace a la plena incorporación de las mujeres al modelo productivo. El mundo ha cambiado mucho en el período final de siglo para mantener intocado un modelo que hacía agua por el desarrollo insostenible, la tendencia al envejecimiento, la ampliación a la Unión Europea de 27 miembros, las adhesiones de Turquía y otros países y el empuje irreversible de los movimientos migratorios y las economías emergentes. Europa está afronta la ineludible reforma del modelo productivo disimulando la imprescindible reforma del modelo social y del modelo urbano que esta profunda crisis lleva indisolublemente aparejada, plagada de nuevas desigualdades endógenas.

Las economías europeas salen de la crisis sin revisar - para bien o para mal -sus modelos sociales y urbanos, pese a que estos dan muestras de creciente agotamiento. Las ciudades neoliberales son como marcas que, bajo la máscara del bienestar, esconden formas nuevas de la desigualdad e injusticia, disfrazando los efectos de la exclusión de grandes sectores de mujeres y jóvenes e inmigrantes del pleno derecho a la ciudad.

Igual que ocurre con la energía, las incongruencias del modelo europeo, -la falta de cohesión social post-Lisboa-, muestran el fracaso ratificado por el desapego de los ciudadanos e implican, además, una demora en la construcción del espacio digital de redes y conocimiento que no se ha producido. Además, el doble discurso estatal y transversal europeo se salta a menudo el discurso sobre la ciudad. El énfasis en la vivienda y la poca influencia relativa de todo aquel espacio que no es público o privado enteramente, sino un espacio de mezcla, por ser comunitario, colectivo o de transición, han dejado el protagonismo a la dualidad vivienda-estado que tiene al hogar digital como el nodo de una red de espacios interconectados sin continuidad espacial en la 
realidad física de la ciudad. Esta red de espacios accesibles solo a partes de la ciudadanía puede ser abierta o cerrada, pero en sí misma constituye un espacio de relación física que está vinculado a las redes sociales de convivencia y cohesión que fundamentan un tejido urbano sano, saludable, o si se quiere, sostenible. La lentitud en europea de las estrategias informacionales y comunicacionales ha ralentizado la imparable maduración de la ciudad digital de redes y capas.

\section{La ciudad digital}

La progresiva implantación de las redes de telecomunicación y las redes sociales ha ido demostrando cómo la riqueza de contactos virtuales podía superar en complejidad, dinamismo y poder de comunicación a los de los espacios convencionalmente destinados a esa función en el espacio real. Esta implantación/suplantación espacial ha traído consigo la doble superchería de que $1^{\circ}$, la ciudad digital ya era una realidad física y que $2^{\circ}$, ya vivíamos en ella con igualdad de derechos y accesos. Por el contrario, la persistencia de las desigualdades de acceso, las brechas digitales y las censuras o zonas limitadas en la red, han dimensionado también de forma desigual el espacio digital, como espacio comunitario de alto nivel de calidad.

La muerte de William Mitchell en 2010 nos privó de uno de los principales teóricos de la ciudad digital real virtual conformada por el espacio público digital, entendido éste como ámbito de soberanía ciudadana. En la Milla Digital de Zaragoza y entre la wikiplaza de Sevilla y la red global, la conexión y interdependencia entre ciudades reales y virtuales, anticipa un cambio de atributos y escenarios e implica una transferencia de conocimiento sobre el espacio y sus nuevas dimensiones. Se anticipa así la nueva concepción del espacio igualitario como espacio público, o «espacio común múltiple» de la ciudad del futuro. Ya no imaginamos las urbes emergentes sin la hibridación de conexiones, sin la complejidad espacial de lo real y lo virtual entrelazados y sin la afloración de redes de información, tareas y personas interconectadas en un territorio público de acceso con la mera limitación de preservar de la intimidad y privacidad de la nueva ciudadanía. La ciudadanía emergente, por otro lado, tiene nuevos protagonistas suprapersonales, considerados también como «individualidades colectivas», en la medida en que están personalizadas, perfiladas e identificadas individualmente, pero también trenzadas, abiertas y agrupadas según sus propias pautas de cooperación, solidaridad e intercambio. Sin pausa estamos abriendo constantemente las puertas a una nueva ciudad con componentes tomados de metáforas tecnológicas de las redes globales e iluminando la realidad urbana con nuevas luces. El espacio digital y lo 


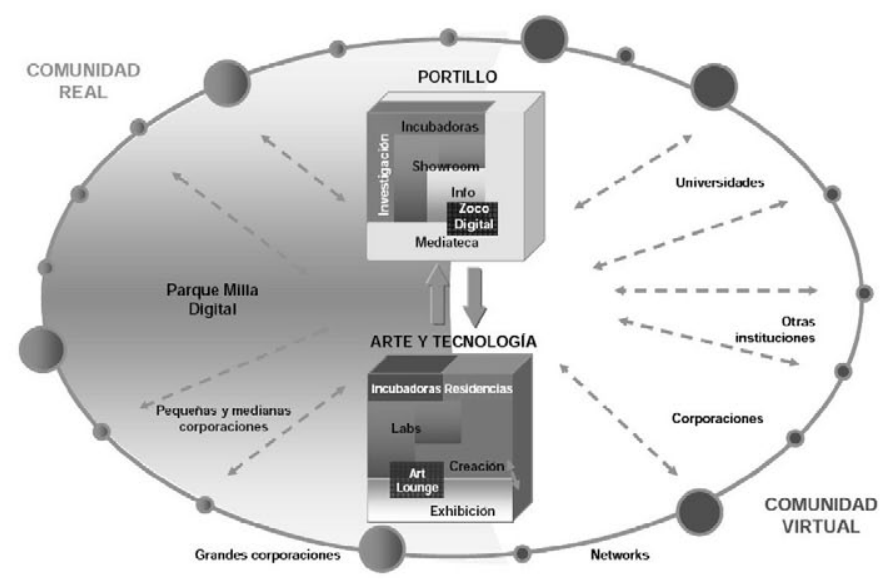

Ayuntamiento de Zaragoza Milla Digital

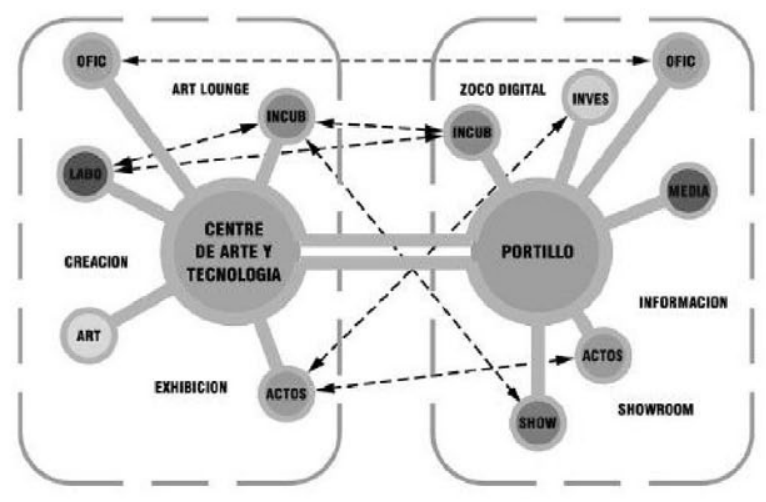

Ayuntamiento de Zaragoza Milla Digital

que se anticipa de la web $3.0^{3}$ se ha abierto como el territorio expandido, aún inexplorado del todo, que abarca los territorios de unas dimensiones casi ilimitadas entre lo real y lo virtual. La visión de género se extiende a medida que se vuelven también más y más interactivos, interdependientes y accesibles,

3. SABAdell ARTiga, Lluís. Web 3.0 y la trasformación del espacio (físico) en la web de Ecosistema Urbano. 22 de Junio de 2010. Lluis Artiga es artista y comisario especialiado en Arte y Naturaleza. Director de Post-Oil Cities y de Hibrids 2.0 aplica el concepto de Web 3.0 a los talleres expandidos on-line.

Feminismo/s 17, junio 2011, pp. 65-89 


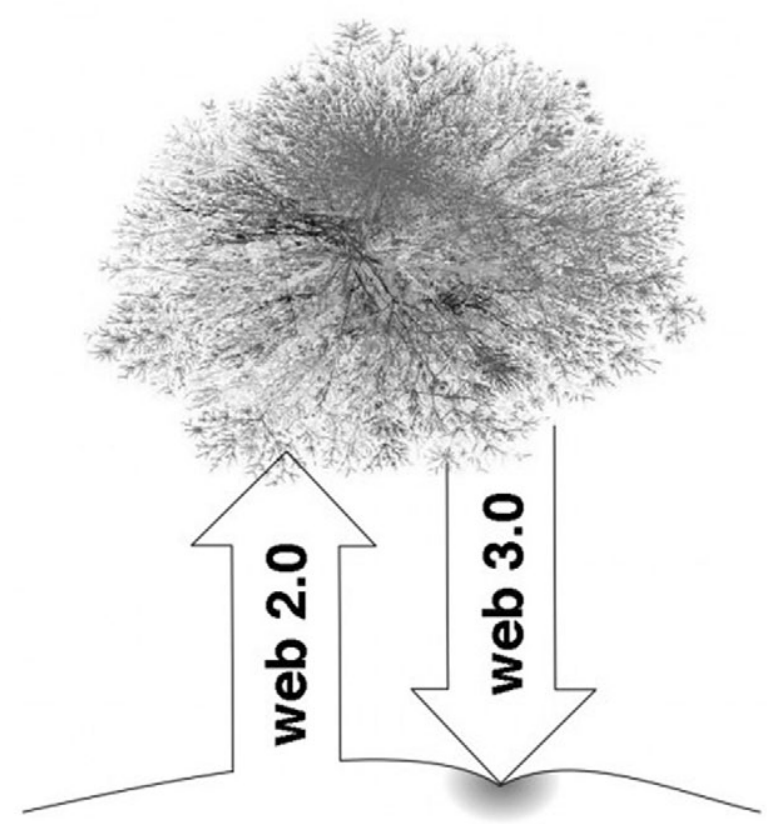

Web 3.0 y la trasformación del espacio (físico) por Ecosistema Urbano. 22 de Junio de 2010. Lluís Sabadell Artiga: artista y comisario especialiado en Arte y Naturaleza. Director de Post-Oil Cities y de Hibrids 2.0 aplica el concepto de Web 3.0 a los talleres expandidos on-line.

dotándose de una flexibilidad que no tiene hasta ahora la concepción, la construcción social del espacio, o su diseño en la práctica arquitectónica y urbana, por muy correcta que sea. De hecho, la perspectiva de género ha abierto nuevas posibilidades de acercamiento a la realidad global de los nuevos sujetos sociales, en la medida en que la incorporación plena de la mujer al sistema productivo es una incorporación plena a un nuevo modelo de ciudad. Podemos afirmar, sin lugar a dudas, que el cambio el modelo productivo que empieza a emerger en 2010, desde la crisis global, producirá un nuevo modelo social y, en consecuencia un nuevo modelo de ciudad, por la acumulación de factores de innovación disruptiva que la crisis ha congregado. Innovación que rompe los moldes y costuras de la idea de ciudad neo-liberal amable y cuidadora; idea fracasada tanto para tanto para la esfera de la «ética del cuidado» (aunque se discuta desde el feminismo) como frente a la esfera del poder. El estallido de la burbuja inmobiliaria y sus secuelas urbanas de espacios inhóspitos, inaccesibles o degradados crecen sobre la ruina hipotecaria y el desempleo. Un modelo de interculturalidad y de carácter intergeneracional es, por 
eso, la única esperanza para el cambio social del nuevo modelo productivo. No sólo de las condiciones de creación y reparto de la riqueza, de sus formas de acumulación, sino de la conformación del proyecto de un nuevo espacio público más justo y cualificado, ocupado por nuevos sujetos sociales.

La repercusión de este proceso social sobre las ciudades es clave, pues en las ciudades es dónde más fuertemente se ha producido el proceso de decadencia de la ciudad neoliberal que está en el horizonte conservador, como si nada hubiera pasado. En ese sistema, lo que el urbanista David Harvey ha denominado «acumulación por desposesión $»^{4}$ se ha venido ejecutando en las ciudades. En España y algún otro sitio más, la desposesión de las nuevas clases medias y los grupos emergentes se ha producido gracias a la acumulación de activos - vía inmobiliaria - por unos pocos, bajo el engaño a los consumidores y el consentimiento social de las sucesivas burbujas en los precios de la vivienda y en el trasvase de rentas del suelo a las sociedades de la Bolsa (y al bolsillo de muchos especuladores). En tanto algunos patriarcas han considerado las políticas de igualdad como adornos superfluos, la ciudad neoliberal ha propiciado el expolio de las hipotecas y se ha construido a imagen y semejanza del modelo social caducado: coches, unifamiliares y burbujas, en medio de un estado de embriaguez y melancolía un consumo que se espera recuperar en cuanto salgamos de la crisis. La ciudad genérica basada en ese modelo de apropiación (pretendidamente global) del espacio público y del espacio digital, se ha construido sobre la desposesión forzada, vía hipotecaria, del espacio individual; y sobre la brecha digital en el espacio de las telecomunicaciones. Es un hecho contrastado que la «acumulación por desposesión» afecta más a las mujeres, víctimas frecuentes de su propia insolidación como sujetos de ciudadanía de pleno derecho, a la vista de violencia urbana (mal denominada «violencia doméstica») contra las mujeres. Frente a una ciudad más «femenina», paradójicamente, se procura una orientación desde la visión de género de las mujeres, que debería alumbrar el nuevo modelo post-crisis y facilitar empatías e hibridación entre las redes sociales y las redes urbanas, desbordando la mera perspectiva de género, con la plena ocupación social del espacio real y digital por las mujeres ahora protagonistas frente a los actores ejecutivos de la especulación financiera.

4. HaRVEY, David. «El nuevo imperialismo: acumulación por desposesión», en Pantich, Leo y Colin Leys (ed.): El Nuevo desafí Imperial: Buenos Aires: Merlin Press - Clacso. 2004, pp. 99-129. 


\section{Espacio inteligente}

Pero volvamos a la noción del género como atributo particular de la condición inteligente del espacio. Entendemos esos condicionantes de inteligencia dentro de la competencia digital, el poder de control y autonomía del sujeto al alcance de los sistemas abiertos que caracterizan el uso del espacio como contenedor cultural de emancipación. En numerosas ciencias como la sociología, la psicología o la antropología, el género es una construcción simbólica que alude al conjunto de atributos socioculturales asignados a las personas a partir del sexo biológico que convierten la diferencia sexual en una desigualdad social entre hombres y mujeres. El feminismo post-igualitario, sin embargo, discute estas visiones de identidad y diferencia como esencias universales, una de las muchas caras del problema. Según Juan Freire, en un artículo en su blog, de 2009,

Hay dos perspectivas para aproximarse al tema de la identidad digital y de Internet. Una es creer que la presencia virtual significa un peligro para la seguridad personal y, por tanto, convenir en que si un individuo no construye su identidad digital, una tercera persona puede suplantarla y pueden ocurrir hechos indeseables. La otra perspectiva es entender la construcción de la identidad en la red como una oportunidad de aprendizaje tanto personal como profesional dentro de la cultura informacional donde vivimos inmersos.

Además de esto, la identidad puede ser múltiple y suprapersonal en el espacio inteligente. Si ya las posturas de la visión de género sobre la identidad y la diferencia abren posibilidades a una reinterpretación de los problemas de la igualdad, las dicotomías entre lo analógico y lo digital y la posibilidad de multiplicar las identidades digitales abren perspectivas inéditas al aprendizaje uso y accesibilidad al espacio de la red, de la ciudad virtual y de los espacios públicos del mundo global de las redes.

Estas consideraciones sobre igualdad y diversidad, sobre identidad múltiple y multiplicación de diferencias de acceso también dejan flancos abiertos a la relación desjerarquizada entre la visión de género y el espacio. Se abre así una vía ambigua entre el espacio especialmente interactivo, múltiple y complejo (el espacio público) de las redes y el espacio privado, dando por hecho que ambos necesitan una componente singular de conocimiento cualificado, para ser apropiables libre y democráticamente, sin limitaciones; lo que sugiere la triple apuesta del sujeto por superar las brechas de desigualdad en la competencia, el control y la autonomía, así como en el uso.

El diccionario de la Real Academia Española de la lengua define la Inteligencia (del latín intellegentřa), entre otras acepciones como la «Capacidad para entender o comprender» y como la «Capacidad para resolver problemas». 


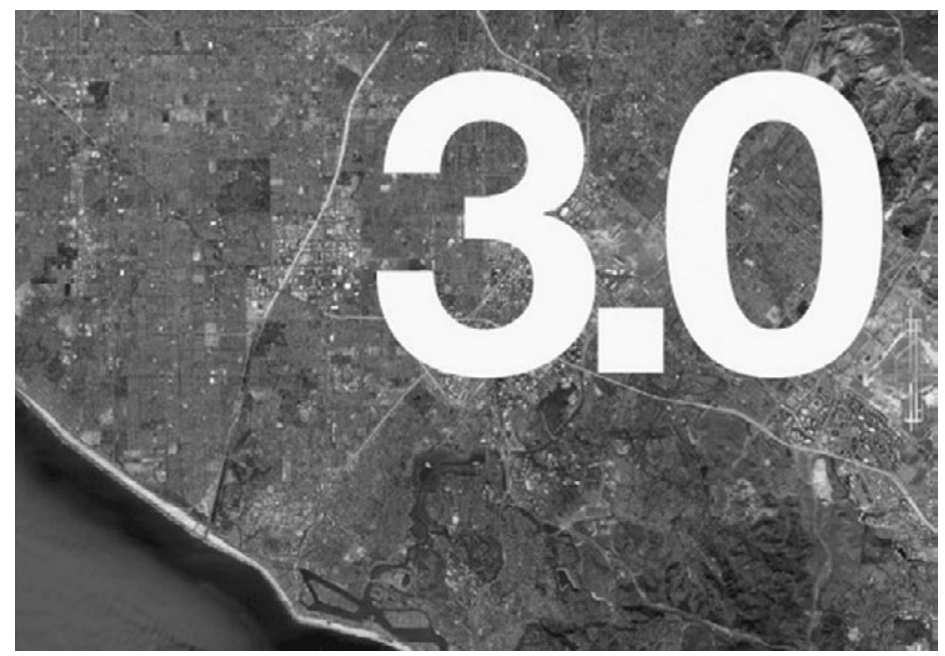

Web 3.0 y la trasformación del espacio (físico) por Ecosistema Urbano - Martes, 22 de Junio de 2010.

La inteligencia parece estar ligada a otras funciones mentales como la percepción, o capacidad de recibir dicha información, o la memoria, o capacidad de almacenarla. Nos encontramos, pues, con acepciones que encajan perfectamente con la filosofía del espacio-tiempo que está representada por la ontología, la epistemología y la naturaleza del espacio y del tiempo, tomados como variables de construcción de la ciudad; que tanto auge han tenido en el conocimiento del impacto de género sobre esta. Tanto en la comprensión, percepción o memoria, la ciudad es el lugar donde el espacio tiende a interferirse con el tiempo en conflictos de toda naturaleza. Sobre todo con el tiempo simultáneo, o con su percepción simultánea.

La aplicación científica al espacio del atributo de la inteligencia tiene un recorrido más difícil. Si la noción de ciudad es difícil de definir y precisar hoy en el conocimiento y la ciencia, la noción de espacio tiene acepciones ilimitadas de las que vamos a repasar someramente sólo dos, las que se refieren a Informática y Matemáticas, que se ajustan al objetivo de este trabajo. En informática, una breve relación de tipologías tomada de Wikipedia ${ }^{5}$, suministra

5. Wikipedia define la web 2.0 como «término asociado a un fenómeno social, basado en la interacción que se logra a partir de diferentes aplicaciones web, que facilitan el compartir información, la interoperatividad, el diseño centrado en el usuario y la colaboración en la World Wide Web.» La web 3.0 se caracteriza como un paso de cambio tecnológico (3D, 
un inventario de analogías razonables para establecer vínculos entre denominaciones de la realidad virtual y la realidad física: Espacios de color; Función de espacio constructivo Espacio duro, como variante del carácter «espacio»; Espacio afín (dotado de una aplicación). Son definiciones semejantes a las del espacio urbano: Espacio de usuario, un espacio de aplicación; Espacio de intercambio de zona (un fichero o partición); Espacio de puntuación entendido como vacío. De la codificación de caracteres pasamos al entramado de redes como un conjunto de decisiones, de complejidad y orden. Situaciones de compromiso espacio-tiempo o tiempo-memoria, comprimidas o ampliadas por la velocidad de ejecución de que disponga el usuario, de si lo comparte o lo aplica a usuarios afines.

Nociones como el espacio de usuario, o el de intercambio, o el espacio duro, sirven en esta ligera enumeración como sencillas trasposiciones de los espacios elementales de la ciudad. El conocimiento informático atribuye elementos de reflexión a la trasposición de nociones del espacio informático al espacio real. Como sostiene el arquitecto sevillano José Pérez de Lama, empezamos a vislumbrar un nuevo modelo de metáfora informática que lleve a «plantear una arquitectura que comparta las cuatro libertades del software libre: que pueda ser usada por todos; que el código fuente pueda ser leído por todos; que pueda ser modificada por sus usuarios / habitantes, y que las modificaciones puedan a volver ser distribuidas». Una metáfora arriesgada, porque el uso, lectura, reforma y distribución, seguridad, confianza o manipulación han tenido históricamente connotaciones desiguales desde el punto de vista del género.

En matemáticas y geometría el inventario de analogías es interminable. La multiplicación científica de trabajos sobre la materia, no permite entrar en complejidades científicas. El catálogo de conceptos es aplicable a la arquitectura de la ciudad, si observamos las nociones de espacios duales, separables, uniformes, etc. Un breve repaso da cuenta de su múltiple caracterización, de sus interferencias con los espacios, dimensiones y topologías de la realidad urbana: dual, vectorial, normado, multidimensional, euclídeo, compacto, para-compacto, espacio localmente anillado; espacio sobrio, espacio tangente, espacio escalado, separable, muestral, universal, uniforme..., particionado, funcional, completo, recubridor,... Aunque si nos fijamos atentamente, el espacio geométrico frente al informacional es un espacio de recintos ante el que plantear siempre el conflicto de los «dilemas de ingreso».

semántica,...), pero se piensa que, como la anterior, también dará lugar seguramente a un cambio social y una transformación física del espacio y la realidad física. 
Haremos de este sobrevuelo de definiciones un atisbo de metáfora para no caer en ninguna impostura intelectual de las denunciadas por Sokal ${ }^{6}$ y Bricmont. Desde el punto de vista epistemológico, hay que dar saltos controlados para no caer al vacío retórico, cotejando estas acepciones espaciales de la construcción del espacio social por excelencia, el espacio público; y del uso público de Internet, que se viene demandando como tal espacio público. A las redes sociales como Facebook y a las nuevas intervenciones urbanas aisladas se las está calificando ya de «islas de conocimiento»o «islas de experiencia», - en la medida en que puedan limitar el uso social de sólo algunas porciones de territorios amigables -, en lugar de abrirse a los espacios de «confines porosos» ${ }^{7}$. Confines fluidos y continuos, que son una obsesión de las ciencias sociales de la posmodernidad. Posición distinta a la de Peter Sloterdijk ${ }^{8}$ en su Trilogía Esferas. A pesar de lo que dice Rüdiger Safranski, sobre Sloterdijk, nuestra perplejidad ante el argumento aflora ante la perspectiva de que no podamos combatir un destino tan metafísico como el del enclaustradamente geométrico.

«convoca los sentidos, las sensaciones y el entendimiento para conseguir claridad sobre lo cercano. ¿Lo cercano? Lo cercano es aquello que la filosofía pasa a menudo por alto: el espacio vivido y vivenciado. Vivimos «en» espacios, esferas, atmósferas; la experiencia del espacio es la experiencia primaria del existir». ${ }^{9}$

Ya que si la experiencia de vivir transcurre en las atmósferas de la ciudad, en los microcosmos urbanos y efectivamente, en aquellos en los que lo vivenciado es lo próximo, la red rompe el límite entre lo cercano y lo global. La desenvoltura de la filosofía de Sloterdijk abre una panoplia de mundos indetectados como tales, como la compacidad del aire acondicionado, la crisis ambiental definida la espuma que encierra a los individuos en lo «redondo». En su primer volumen, el filósofo alemán habla de burbujas, en el segundo de globos y en el tercero de espumas, en una suerte de esferología plural que abarca lo redondo, aclarando que el «tercer volumen se ocupa de la catástrofe moderna del mundo redondo». Pero la preocupación geométrica por la forma, por la morfología y por la ciudad aparece cuando cita, a Hans Blumenberg, Salidas

6. SoKAL, Alan. «Más allá de las imposturas intelectuales. Ciencia, filosofía y cultura». Paidós. Transiciones. Barcelona 2009. Págs. 44-45 y siguientes.

7. En expresión de Sheila Benhabib, citada por GALLI, Carlo. «La humanidad Multicultural». Katz Editores. Madrid, 2010, pp. 22, 44 y 64.

8. SlOteRDiJK, Peter. «Esferas I, II y III» «Esferas I», «Esferas II» y «Esferas III». Editados por Ediciones Siruela S.A. Madrid, 2003, 2004 y 2006, respectivamente.

9. SAFranski, Rüdiger en el Prólogo a SLOTERdijK, Peter. «Esferas I». Madrid, 2003, pp. 13 y 14 .

Feminismo/s 17, junio 2011, pp. 65-89 
de la caverna "La ciudad es la repetición de la caverna con otros medios» ${ }^{10}$ y localizando una metafísica universal de la polis que abarca una historia de la forma «del mundo poliesférico que vivimos hoy no es ya el globo sino la espu$m a »-$ concluye $-{ }^{11}$. En ese sentido, el concepto de «techo de cristal» se habría transformado en el de «esfera de cristal», o burbuja, de la que sólo se sale si se rompe una o se pincha la otra.

Esta noción proveniente del discurso de las geometrías ${ }^{12}$ es cara a los matemáticos y atractiva para los arquitectos, pero muy excluyente si consideramos la esfera como la metáfora para definir la sociedad global y la ciudad digital, como islas y la noción de la arquitectura y el urbanismo de la «Foam City». Al fin y al cabo la posmodernidad digital en arquitectura, - por ejemplo, en Zaha Hadid -, se asocia con formas bulbosas, placentas. El espacio celular de los telepolitas urbanos se encaja en una suerte de cavernas telemáticas en las que los eremitas digitales se dedican a la meditación electrónica y a su comunicación con el mundo a través del cosmos global y esférico, lo que excluye el contacto del común de los sentidos con la vida de lo real y sus avatares. Las complejidades urbanas en el espacio contemporáneo no parecen encontrarse en esa visión de recintos aislados. La Web. 3, por el contrario se aventura en otra transformación física y dimensional de la ciudad. Sin una forma preconcebida, la ciudad-red es una metáfora sociológica. La aproximación a la geometría de Sloterdijk (tras la de Jacques Derrida a propósito de Hussserl en «Introducción a 'El origen de la geometría de Husserl ${ }^{13}$ ) se muestra excluyente, como acredita la cita del alemán al recordar la inscripción en la entrada de su Academia de la frase atribuida a Platón «que decía: manténgase alejado de este lugar quien no sea geómetra». Como casi todas las multi-dimensiones de los espacios geométricos excluyen atributos de percepción porosa y de flujos, su condición sería restrictiva o restringida. Los espacios estáticos, esenciales o universales están en decadencia, en tanto otros entran en clara sintonía o sincronía en el tiempo con los problemas que apunta el espacio inteligente de la era digital (y el espacio público de la ciudad digital). Por ejemplo el espacio abierto, aunque asume el riesgo de la identidad digital no acreditada o camuflada, es más atractivo a la creatividad y la innovación. En este sentido,

10. SlOterdijK, Peter. «Esferas I». Madrid, 2004. Página 219.

11. SLOTERDiJK, Peter (Esferas I, página 73).

12. FERNÁNDEZ, Isabel. Por primera vez, por una matemática española, Isabel Fernández, se ha presentado a nivel del Congreso Internacional de Matemáticos de Hyderabad (India 2010) un trabajo sobre las superficies de geometría variable de las pompas de jabón.

13. DERRIDA, Jacques. «Intoducción a 'El origen de la geometría de Husserl». Ediciones Manantial. Buenos Aires 2000. pp. 12, 108, 176 y 188. 
siguiendo a Husserl, la web 3.0 podría ser un ejemplo paradigmático de una «forma en formación». La simulación de un paisaje topológico, que puede hacerse en el espacio virtual casi con más realismo que en la ciudad misma, pre-configura el campo de batalla de los dilemas de ingreso, de la igualdad, la diferencia o el acceso al espacio físico. Por eso, conocer los límites de la capacidad de apropiación del espacio digital es necesario para tener la libertad de saltárselos o mantenerlos en la hipótesis auto-protectora. Tal vez como ocurre en la experiencia urbana, el anticipo o el vector de la ruta es tan importante como el itinerario a recorrer, es una apuesta más que sólo un derecho a la igualdad; resulta más inteligente ofrecer libertad segura a quienes quieren navegar en la red sin naufragar en ella.

En la nueva percepción de la ciudad el espacio con perspectiva de género se identifica como recipiente de alta calidad frente al espacio indiferente o genérico, en la medida en que la noción de inteligencia se encuentre asociada a la apropiación y soberanía del usuario sobre el espacio en su conjunto, público o privado, y a su inseparable relación con el cuerpo y con el tiempo, con los que mantiene una declinación común. Las nuevas identidades de las mujeres para ser libres requieren de ropajes diferentes -algunos los llamarían máscaras- y otros como la opaca frontera del «burka», nos llevarían abrir un frente no deseado en este contexto

El nuevo modelo social está unido a la recuperación de una noción participativa y accesible de la nueva ciudad, que puede ser la ciudad P2P (intercambio de archivos) que augura Juan Freire ${ }^{14}$ o la ciudad por capas, pero ya no parece que vaya a ser la versión física literal de la La ciudad-red de Manuel Castells; al menos si no se establecen nuevos cauces de accesibilidad, ocupación y soberanía del espacio público y consecuentemente del espacio digital por la ciudadanía, así como otra noción de los ciclos vitales y temporales globales. Eso no ocurre, porque siguen existiendo brechas de género (menos del $22 \%$ de ganancia anual y menos del $16 \%$ en salario/hora en las empresas), de participación proactiva (siempre inferior al $40 \%$ en el gobierno local de las ciudades) y de formación del capital humano (12, \% de catedráticas en las Universidades españolas y grandes diferencias en las universidades europeas y entre éstas y las asiáticas), y desigualdades en el tránsito de la formación a la producción. En uso de la ciudad la inercia de la denominada «ley» del 35/65\%

14. Freire, Juan. Ver en la web «Ciudades innovadoras y sostenibles». http://nomada.tumblr.com/post/1003243471/la-gestion-de-la-identidad-digital-unanueva habilidadhttp://dig.csail.mit.edu/breadcrumbs/node/215. 
que afecta a las diferencias entre mujeres y hombres respecto a vivienda movilidad, empleo y rentas. ${ }^{15}$

\section{El urbanismo de las redes}

La utopía neo-liberal de la ciudad competitiva y del marketing urbano ha acabado por sumirnos en la crisis más grande de la historia. Esa ciudad no se construía con ladrillos sino con hipotecas, con trasvases de rentas y con diferencias de acceso a la red. El urbanismo de la red y la era digital son, pues, inseparables de un concepto de apropiación en el que los espacios no se consiguen por hipoteca o expropiación, sino por flexibilización de los accesos, gratuidad y participación equilibrada. Es lo que se han denominado espacios porosos. En las Telépólis, el espacio de redes ha trascendido los límites de la casa y ha puesto el espacio individual de más de 500 millones de personas en las redes, Facebook, entre otras. La ciudad real de la especulación inmobiliaria ha cedido sitio a la ciudad virtual. Los nuevos modelos sociales más igualitarios desde la perspectiva de género están prefigurándose antes en los modelos urbanos alternativos, en los nuevos movimientos sociales urbanos, en los modelos avanzados de participación y en la interactividad de las redes urbanas de Zaragoza, Sevilla, Barcelona o Córdoba o Toronto, - por citar biodiversidad de modelos -, mucho más que en el modelo uniforme del pensamiento único de la ciudad competitiva, descabalgado por la crisis y el estallido de la burbuja. Y paradójicamente esos modelos osmóticos son reales, se parecen más a los de las redes sociales que a las utopías caducadas del tardo-capitalismo, puestas en la picota por su falta de democracia urbana.

La democracia deliberativa en lo local, donde funciona, está aproximándose a la formulación de ciudad como república accesible global; no como república de hogar digital independiente, como alardea muy equívocamente, la multinacional del espacio privado Ikea. Esta fórmula deliberativa converge con la democracia representativa y permite emplear nuevos métodos frente a la «ciudad indiferente», la del despilfarro, que alimenta el abuso del poder local y las prácticas corruptas de la democracia inmobiliaria. La ciudad digital se convierte en un procedimiento, que afecta a la sustancia de las cosas, a su estructura. De forma creciente, los debates urbanos se convierten así, gracias a este procedimiento participativo, en foros deliberativos que tocan la raíz misma del acceso a la democracia urbana, mediante resortes de redes antes impensables. De esta forma, lo que la democracia representativa no alcanza a reconocer, por las inercias perversas de un sistema que convierte en

15. Fuentes: Datos de varios organismos y Ministerio de Igualdad del Gobierno de España. 


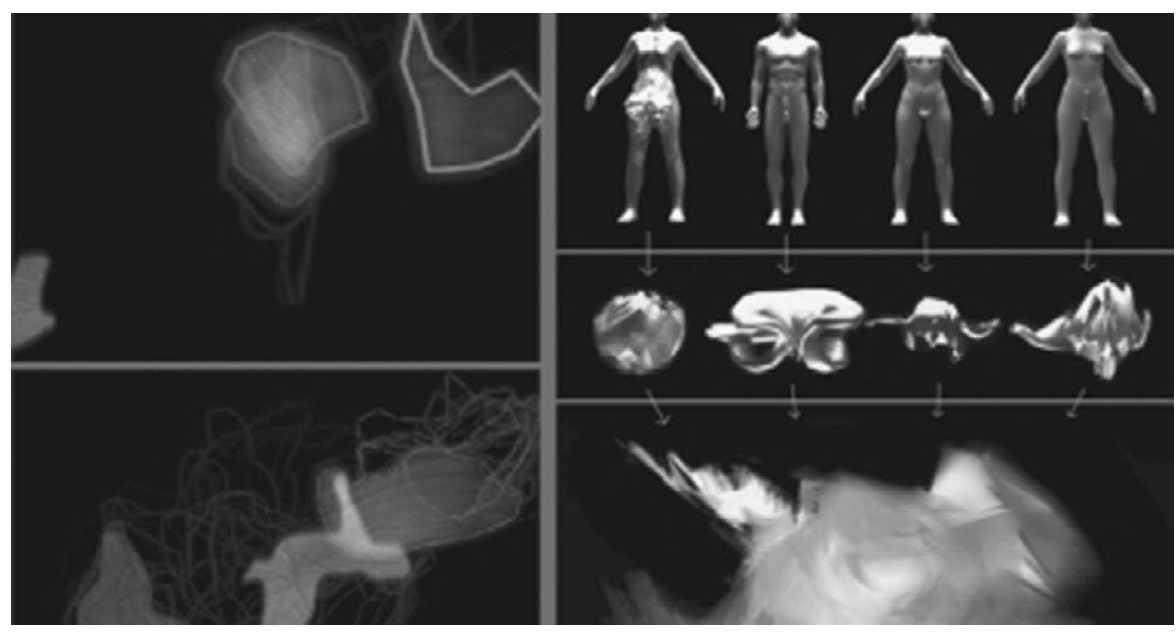

Cuerpos en red ETP: European Teleplateaus.

DESORIENTACIONES - Telemática abstracta, presencia amorfa y proximidad sin identidad - Producida por el grupo ETP-Madrid.

AMORFOGÉNESIS - Arquitectura colectiva y espacios digitales en 3D generativos no cartesianos - Producida por el grupo ETP-Praga en colaboración con Jaime del Val.

clientelares los movimientos sociales urbanos, lo alcanzan parcialmente las redes con un modelo de barrio, de vecindad, de ciudadanía. Nuevos mecanismos se alzan con un alto nivel de interactividad, que luego afecta en directo a la política y al gobierno local en lo que se puede llamar apropiadamente ciudad interactiva. ¿Puede esta ciudad de interactividad digital permanente convertir alguno de sus paradigmas en realidades urbanas? Tal vez, siguiendo la estela de esa sentencia por el cual se asegura que «la naturaleza imita al arte», la ciudad se convierta en espejo de las redes sociales; y sus colectivos más dinámicos en agentes públicos de una democracia interactiva, que combina a la vez el gobierno participativo y la deliberación en red con la representación democrática clásica.

Esta visión tendría algunas repercusiones en la construcción de la ciudad, de forma que se perderían paulatinamente las nociones centro-periferia, inclusión-exclusión, barrio-ciudad, entre otras y aparecerían nuevas convergencias colectivas a favor de una inter-territorialidad común, más representativa y global de la ciudad en su conjunto. Una visión así establecería las bases del interés general muy por encima de las particularidades desmembradas en que la óptica neoconservadora traduce los tejidos sociales, dejando siempre pospuesta la igualdad plena de hombres y mujeres en el uso del espacio. 
Frente a la extensión sobrepujada del city-marketing, ${ }^{16}$ como valor de valores refundidos en una marca, la asimilación consecuente del discurso de igualdad de género es un indicador de valor que puede hacerse visible y parametrizarse con relativa eficiencia, como ha sucedido con el reconocimiento de buenas prácticas en esta materia a Gijón y otras ciudades.

La ciudad digital debería ser el horizonte de una ciudad igualitaria de redes interconectadas, que tuviera en cuenta los grandes cambios del principio de siglo. Los cambios de los consumidores a los prosumidores (prosumers) aflorarán seres urbanos productores y consumidores de energía e información a la vez, distintos de los del siglo XX. Los cambios en la esfera de lo virtual, luego pasarán a la realidad material en forma de espacios mucho más fluidos, accesibles y soberanos de los actuales. Es fácil avanzar que el paso de las mujeres consumidoras, que ejercen hoy el poder de decisión sobre el mayor porcentaje de renta familiar de gasto evolucionará hacia mujeres prosumers productoras y consumidoras de bienes y servicios, información y conocimiento; cambio que se reflejará pronto en una apropiación de los espacios necesarios para adoptar el nuevo rol.

\section{La ciudad interactiva}

En esa ciudad «la visión de género y el espacio inteligente» estarán íntimamente hibridados de forma que sean coherentes con los nuevos papeles, no sólo porque el género ha invadido positivamente el escenario de las nuevas tecnologías, sino porque "género y TICs» son realidades de tipo igualitario que van acabando paulatinamente fragmentación del espacio urbano, en función de la identidad y de la condición digital, caracterizando definitivamente el espacio público como catalizador de cohesión social y colectividades locales, es decir, aunando individualidad colectiva y personalidades grupales, desde lo inter-generacional y lo intercultural como bases de una nueva mutación de los objetivos del género entendido como atributo del espacio inteligente, compartido y cooperante de la ciudad de nuestro tiempo.

La sensibilización por el enfoque de género en la construcción del espacio físico y la construcción del espacio social ha hecho que los espacios de la ciudad se vayan estudiando de otra manera. La identidad digital, las redes sociales y el uso de las nuevas tecnologías nos permitirán caracterizar el espacio público como el lugar de libre expresión por excelencia. De hecho el lugar es como el sitio digital, suele enterrar arqueologías narrativas durante tiempos

16. Puig, Toni. «Marca Ciudad. Cómo rediseñarla para asegurar un futuro espléndido para todos». Paidós. Barcelona. 2009. pp. 253, 271.

Feminismo/s 17, junio 2011, pp. 65-89 


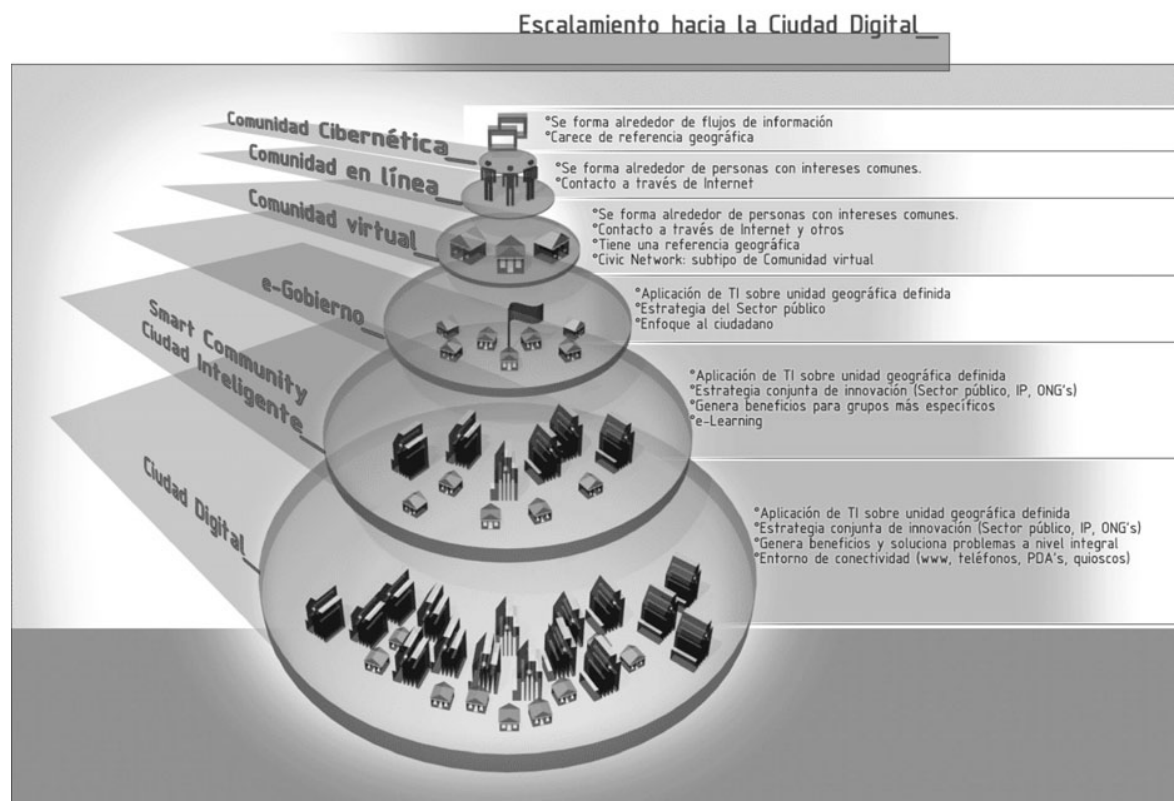

Infotec Conacyt-Fideicomiso México 2004. CIUDADES DIGITALES. Página 9. www.cibersociedad.net/public/documents/45_epi6.pdf

ilimitados. Como recuerda J. Pérez de Lama ${ }^{17}$ a propósito de la «wikiplaza» si los lugares hablan de nosotros es posible que como consecuencia volvamos a interesarnos por las características (calidades) físicas de nuestro entorno. Por muy contingente que sea el ius publicum europaeum que alberga entidades suprapersonales, en una Europa entendida como espacio público por antonomasia, los de más calidad serán los que contengan capacidades de memoria y percepción y no en los de consumo, mediocres o degradados, o desgarrados.

Por eso la vinculación de espacio público con identidad digital, depende de reglas de juego limpio a la hora de compartir y acceder a las redes, con seguridad, confianza y nuevas posibilidades de entretejer lazos de conocimiento. No otra cosa es el objetivo perseguido por la universalidad de la red, pero los riesgos son evidentes. Sin un espacio comunitario de calidad no hay un espacio público utilizable y la red ha de favorecer una transparencia que produzca confianza, si no quiere que se transmuten las identidades digitales

17. PÉREZ De Lama, José. http://www.hackitectura.net/.

Feminismo/s 17, junio 2011, pp. 65-89 


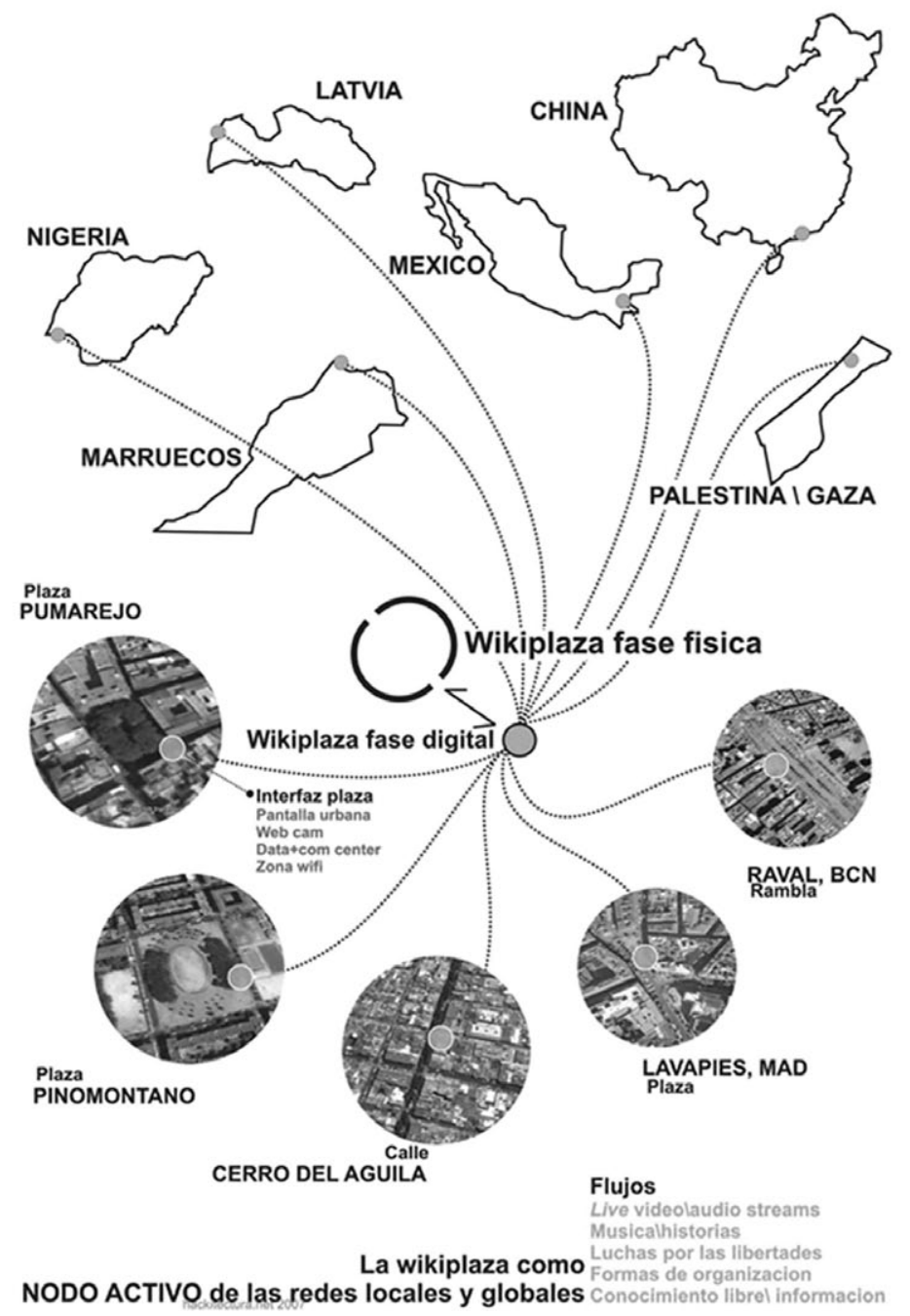

Wikiplaza

PÉREZ DE LAMA, José. http://www.hackitectura.net/

en máscaras utilitaristas y los escenarios públicos en artificios teatralizados o temáticos. El concepto de «vecino», «usuario» o «amigo» extrapolado de la sociedad a las redes, tal como ha sido transformado o manipulado por estas y así devuelto a la red, permite tanto crear o romper fronteras de comunicación. Tiene un carácter ambivalente que articula redes de metáforas y simulaciones, 
lo que lleva también a la impostación del simulacro de la realidad y al espectáculo de una comunicación tergiversada según los papeles que ejerzan sus protagonistas. El proyecto de espacio público digital implica nuevas relaciones de construcción social del espacio y del sujeto en relación con este. ${ }^{18}$ La ciudad interactiva requiere un nuevo tipo de sujeto urbano, pero las redes sociales no deben jugar a los SIMs. Se trata de que las relaciones entre el Yo y el Otro sean relaciones de cercanía/lejanía que permitan interactuar sin suplantar las identidades digitales de los sitios y las personas, acrecentando las posibilidades de conocimiento e interrelación y comunicación local o a distancia en las redes urbanas a través de confines porosos, no difuminados, o simulados por un falso universalismo de la esencia de la igualdad o de la diferencia unívocos, como intentos de ontologías del ser contemporáneo ya caducados en su versión universalista.

En la ciudad interactiva, la visión de género ha de ocupar democráticamente la igualdad en el desarrollo local sostenible y el urbanismo mediante la construcción social de un espacio inteligente que propicie la ocupación plena del espacio público de las ciudades y de las redes por parte de las mujeres. Espacios que cuenten con los atributos de igualdad en el uso, acceso, razón, belleza y vida, entre otros (protección, seguridad,...). ${ }^{19}$ Por extensión podríamos ampliarlos a aquellos de la ciudad que cumplen similares requisitos. Mediante las redes, y el urbanismo 3.0 la ciudad digital se ha de volver más participativa y democrática y la ciudad real más entretejida y solidaria, en suma, una ciudad interactiva de espacios físicos y virtuales inteligentes.

\section{Valores e indicadores}

Pero no nos dejemos llevar de discursos seráficos porque no estamos ante una tendencia asentada, ni mucho menos. No es muy consolador pasar del «techo de cristal» a la «esfera de cristal». Tampoco poner la esperanza en la transformación física del urbanismo realmente existente. No es fácil el cambio, ni está a la vuelta de la esquina de la salida de la crisis. El urbanismo actual

18. Según datos contrastados de la OIT, la mujer está ocupando progresivamente el espacio de la red en todo el mundo hasta entrar en condiciones de igualdad en los países desarrollados (50\%) y acercándose, por pura necesidad, al $45 \%$ en los países pobres, está construyendo el espacio igualitario, pero falta transmitir la condición que ya no es de dualidad sino de porosidad y atributo del espacio inteligente.

19. Por definición adversa, caracterizamos los espacios de uso limitado, con acceso precario o restringido, irracionales, feos y/o inhabitables, como aquellos resultantes del consumo o de la mediocridad, que tanto han crecido al amparo de la burbuja inmobiliaria y la mercantilización del espacio.

Feminismo/s 17, junio 2011, pp. 65-89 
construye burbujas. El futuro, en cambio, se construye con formas complejas. Los urbanistas hacemos todavía geometría bidimensional, poco asimilable a la lámina de las superficies alabeadas de las pompas y las burbujas y poco entretejida con las redes y las nuevas redes sociales. En este sentido, la construcción de la web 3.0 es una «forma en formación», la ciudad es una forma en contradicción, entre muchas razones porque la geometría es variable en la red y anárquica en la ciudad.

El discurso avanzado en esta materia por Freire y Gutiérrez-Rubí, ${ }^{20}$ entre otros, aporta información sobre las orientaciones de los procesos que obligan a cambiar el discurso de los urbanistas en la web 2.0. A la vez, introducen la perentoria necesidad de innovar en los foros universitarios y científicos en materia de visión de género, revisando valores, y mejorando los mecanismos de establecer indicadores de evaluación. En plena adaptación a su creciente aceptación social, ambas cuestiones están en proceso de cambio urgente y de puesta al día desde el punto de vista de la construcción del nuevo espacio urbano inteligente que se desarrollará tras la crisis; un discurso muy desconectado de las sinergias que hay que provocar tras pinchar las burbujas y revisar las nociones de acceso e igualdad reconociendo el nuevo escenario. Basta con enunciar los problemas de la nueva visión sobre el cuerpo, la noción de los sujetos como «nativos» e «inmigrantes» digitales y sus consecuencias aplicadas a niñas y mujeres o el revolucionario proceso de aprendizaje de las nuevas tecnologías y las redes, que hace aprender, - de forma inversa a como ha sucedido históricamente -, a las madres de las hijas, y a las abuelas de las nietas y de las madres. El síndrome de Ulises, la inmigración digital y el aprendizaje inverso empiezan a ser obligado patrimonio también de las mujeres Por eso hay que elaborar un discurso basado en la investigación científica del cambio de marco y un diálogo estable sobre la formación de la forma en la ciudad y en la red bajo los parámetros nuevos.

También la formación social en perspectiva de género tiene sus altibajos en cuanto trata con la red. Si Castells ponía en tela de juicio la noción de ciclos vitales y temporales en su clásico "La ciudad-red», cuestión que ahora habría que elucidar con un nuevo discurso del cuerpo y del espacio-tiempo. Los ciclos son la raíz de la vida. La web 3.0 se constituye mediante procesos participativos abiertos en redes cercano/lejano y apuntan a ciclos cotidianos o globales. A estos efectos, la ciudad no debería construirse en recintos estancos. La curva no es la forma contemporánea estereotipada de la ciudad o

20. Freire, Juan. Gutiérrez-Rubí, Antoni. Prólogo de Pisani, Francis «2010-2020. 32 Tendencias de cambio» Septiembre 2010. http: //www.gutierrez-rubi.es/wp-content/ uploads/2010/09/32Tendencias de cambio.pdf 


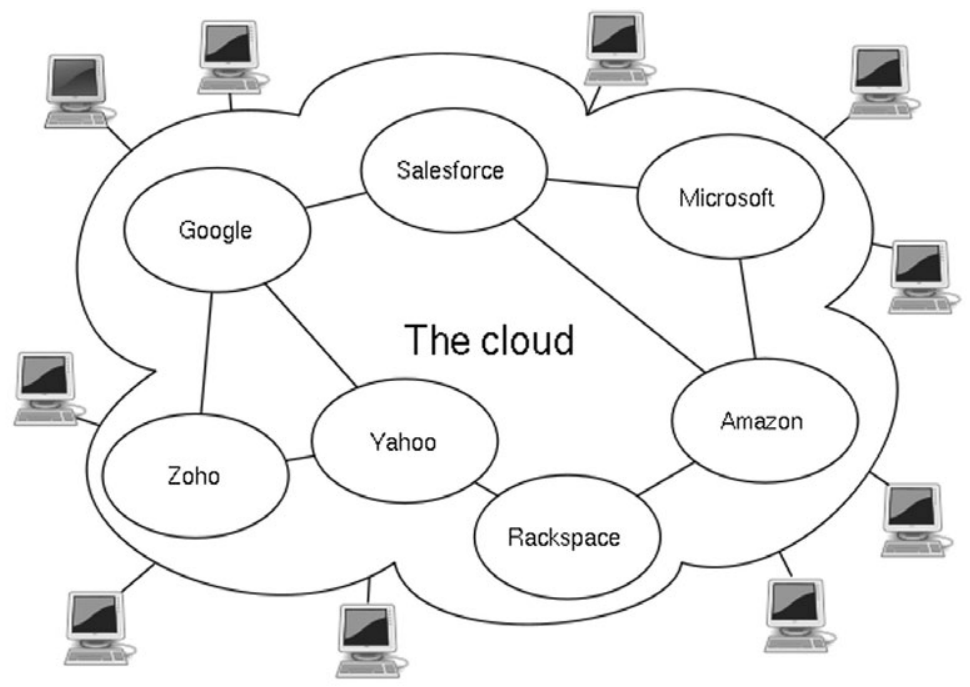

Wikimedia Commons Wikipedia

de la arquitectura... como la esfera no lo es de la red. Las multi-dimensiones son la componente esencial del proyecto de la red y de las ciudades cuando aseguran modelizaciones de proyectos compartidos. El alabeo de la realidad abarca superficies geométricas impuras y, como tales, utiliza verdades contrapuestas, contingentes, precarias. Ese es el desgarramiento de la modernidad que afecta al tiempo que vivimos. Pero no se puede negar que las metáforas de la red -como la visión informática de «cloud computing $»^{21}-$, por ejemplo,

21. Wikipedia. En este tipo de computación todo lo que puede ofrecer un sistema informático se ofrece como servicio, ${ }^{1}$ de modo que los usuarios puedan acceder a los servicios disponibles «en la nube de Internet» ${ }^{2} \sin$ conocimientos (o, al menos sin ser expertos) en la gestión de los recursos que usan. ${ }^{3}$ Según el IEEE Computer Society, es un paradigma en el que la información se almacena de manera permanente en servidores en Internet y se envía a cachés temporales de cliente, lo que incluye equipos de escritorio, centros de ocio, portátiles, etc. Esto se debe a que, pese a que las capacidades de los PC han mejorado sustancialmente, gran parte de su potencia se desaprovecha, al ser máquinas de propósito general. Cloud computing es un nuevo modelo de prestación de servicios de negocio y tecnología, que permite al usuario acceder a un catálogo de servicios estandarizados y responder a las necesidades de su negocio, de forma flexible y adaptativa, en caso de demandas no previsibles o de picos de trabajo, pagando únicamente por el consumo efectuado. El concepto de la computación en la nube empezó en proveedores de servicio de Internet a gran escala, como Google, Amazon AWS y otros que construyeron su propia infraestructura.

Feminismo/s 17, junio 2011, pp. 65-89 
coinciden con la aspiración a abrir sucesivos «confines porosos» de espacios de certeza por muy contingentes o fragmentarios que sean. Las geometrías como conjunto de verdades fragmentarias lo son, en la red y en la ciudad, tanto como en la arquitectura, pero no pueden poner límites a la humanidad que se reconoce en un nuevo imaginario colectivo, ni convertirse en fines en sí mismos, en el espacio ciudadano abierto.

El cambio de paradigmas urbanos se asentará sobre la inteligencia que se demuestra en los valores de igualdad y democracia urbana, pero bajar de las nubes informacionales a las ciudades reales requerirá de una vuelta de tuerca a los discursos sobre el género y sobre la ciudad, para que converjan e interactúen en la dirección adecuada a los cambios que vienen.

\section{Referencias Bibliográficas}

Agrest, Diana. Conway, Patricia. KAnes Wisman, Leslie. Editors. «The sex of architecture». N.Y. Harry N. Abrams, Inc. 1996.

BETSKY, Aaron. «Building sex. Men, women, architecture, and the construction of sexuality». USA, 1995.

BOYER, M. Christine. «City of collective memory». London, The MIT Press. 1996.

ColominA, Beatriz. «Cybercities». New York, Princeton Architectural Press. 1996.

ColominA, Beatriz. «Sexuality \& Space». Princeton Papers on Architecture. Princeton University School of Architecture, New Jersey. 1992.

Colomina, Beatriz. Editor «Privacy and publicity. Modern Architecture as mass media». The MIT Press. London, 1996.

DERRIDA, Jacques. «Intoducción a 'El origen de la geometría de Husserl». Buenos Aires, Ediciones Manantial.pp. 12, 108, 176 y 188. 2.000.

GALLI, Carlo. «La humanidad Multicultural». Madrid, Katz Editores Págs 22, 44 y 64. 2010.

HANKS, William F: «Referential practice». Chicago University Press. Chicago, 1990.

HARVEY, David. «El nuevo imperialismo: acumulación por desposesión» (2004); Pantich, Leo y Colin Leys (ed.) «El Nuevo desafí Imperia»l: 99-129. Buenos Aires: Merlin Press - Clacso. 2004.

HAYDEN, Dolores: «La felicidad entre cuatro paredes». (I'll buy that dream) Arquitectura y vivienda, nº 12, Págs. 34-37. 1987.

De entre todos ellos emergió una arquitectura: un sistema de recursos distribuidos horizontalmente, introducidos como servicios virtuales de TI escalados masivamente y manejados como recursos configurados y mancomunados de manera continua. Este modelo de arquitectura fue inmortalizado por George Gilder en su artículo de octubre 2006 en la revista Wired titulado Las fábricas de información. 
INNERARITY, Daniel. «El nuevo espacio público». Madrid, Espasa. 2006.

PUIG, Toni. «Marca Ciudad. Cómo rediseñarla para asegurar un futuro espléndido para todos». Barcelona. Paidós. pp. 253, 271. 2009.

RÜELI, Katerina y otras. «Designing Practices. Architecture, gender and interdisciplinarity». Black dog Publishing Ld, 1996.

SlOterdiJK, Peter. «Esferas I, II y III».«Esferas I», «Esferas II» y «Esferas III». Madrid, Ediciones Siruela S.A. 2003, 2004 y 2006, respectivamente.

SOKAL, Alan. «Más allá de las imposturas intelectuales. Ciencia, filosofía y cultura». Barcelona, Paidós. Transiciones. Págs 44, 45 y siguientes. 2009.

STEVE, Pile. «The body and the city». Routledge. London and New York, 1996.

Feminismo/s 17, junio 2011, pp. 65-89 



\title{
ESTUDIANTES DE ARQUITECTURA: ¿UN ÁMBITO DE IGUALDAD?
}

\author{
PilAR CHÍAS NAVARRO \\ Universidad de Alcalá
}

Recibido 09/02/2011

Aceptado 20/05/2011

\section{Resumen}

La presencia de la mujer en los estudios relacionados con la Arquitectura en España -Arquitectura Superior y Arquitectura Técnica, actualmente Ingeniería de la Edificación- hace años que es equiparable en número, e incluso superior, a la de los hombres. Pero a diferencia de lo que afecta al ámbito profesional, hasta ahora no había ningún estudio que permitiera efectuar una valoración cualitativa de su actividad académica, ni un análisis comparativo de los rendimientos respectivos de mujeres y hombres. El presente artículo presenta el panorama actual del alumnado en las citadas titulaciones, y expone sobre la base de parámetros objetivos las principales características y conclusiones que se pueden extraer sobre los futuros profesionales de la Arquitectura en nuestro país.

Palabras clave: Mujeres, Universidad, Estudiantes, Escuelas Superiores de Arquitectura, España 


\begin{abstract}
It is a long time since women study the universitary careers that are related to architecture. In Spain, these careers are Architecture and Technical Architecture -actually named Building Engineering. Although the women's rate rises by 50 percent -or is even superior-, there was any search yet about the qualitative evaluation of their academic activities, that looked for the comparative academic results between women and men. The present article is based on objective features and depicts the main characterisics and conclusions that can be extracted, in order to be applied to the professional behaviour of the future architects and builders.
\end{abstract}

Keywords: Women, University, Students, Technical Schools of Architecture, Spain 


\section{Introducción}

La consideración de la variable 'género' ya no puede obviarse en ningún estudio riguroso, y cada vez son más frecuentes y valiosas las aportaciones que destacan el papel de la mujer en la construcción del mundo en sentido amplio ${ }^{1}$.

El ámbito más concreto de la construcción material de lugares para habitar está siendo objeto de difusión y debate desde hace quince años en el foro «La mujer construye» ${ }^{2}$, creado y dirigido por las arquitectas Ana Estirado y Cristina García-Rosales. Desde 1995 vienen desarrollando numerosos proyectos, exposiciones, jornadas y publicaciones dirigidas a poner en valor el trabajo de la mujer en el mundo de la construcción, tanto como participante anónima -sin contar como mano de obra en ningún cómputo del PIB ${ }^{3}$ - o como arquitecta de fama.

Tradicionalmente ha sido éste un campo que hasta fechas recientes estaba reservado a los hombres, aceptándose socialmente este hecho como un acuerdo o código no escrito que contribuía a perpetuar la exclusión ${ }^{4}$, ocultando la callada labor que realizaban las mujeres en el tercer mundo o en el ámbito rural.

Sin embargo, dentro de este espacio de revisión ${ }^{5}$ son muy escasos los estudios que abordan el ámbito del alumnado universitario ${ }^{6}$, y en particular del alumnado de las Escuelas Técnicas, persistiendo aún un vacío en las

1. RAMOS, $\mathrm{M}^{\mathrm{a}}$ Dolores. «Historia de las mujeres, saber de las mujeres: la interpretación de las fuentes en el marco de la tradición feminista», Feminismo/s 1 (2003), pp. 1-32.

2. <http://lamujerconstruye.org/ARTICULOS>, consultado el 10-01-2011.

3. Amelia Valcárcel, cit. en CoLLADO, Concepción. «Mujeres, poder y derecho», Feminismo/s 8 (2006), p. 15.

4. Fontana, José. La historia de los hombres. Barcelona, Crítica, 2001.

5. PAPí, Natalia. «Un nuevo paradigma para el análisis de las relaciones sociales: el enfoque de género», Feminismo/s 1 (2003), pp. 135-148.

6. CHÍAs, Pilar. «Proyectos de mujeres arquitectas en las obras para la Universidades». En 1er Encuentro en la Arquitectura. La mujer construye, Alcalá de Henares (30 junio-4 julio 1997). <http://www.lamujerconstruye.org/ENCUENTROS/es/iencuentro.htm>, consultado el 10-01-2011. 


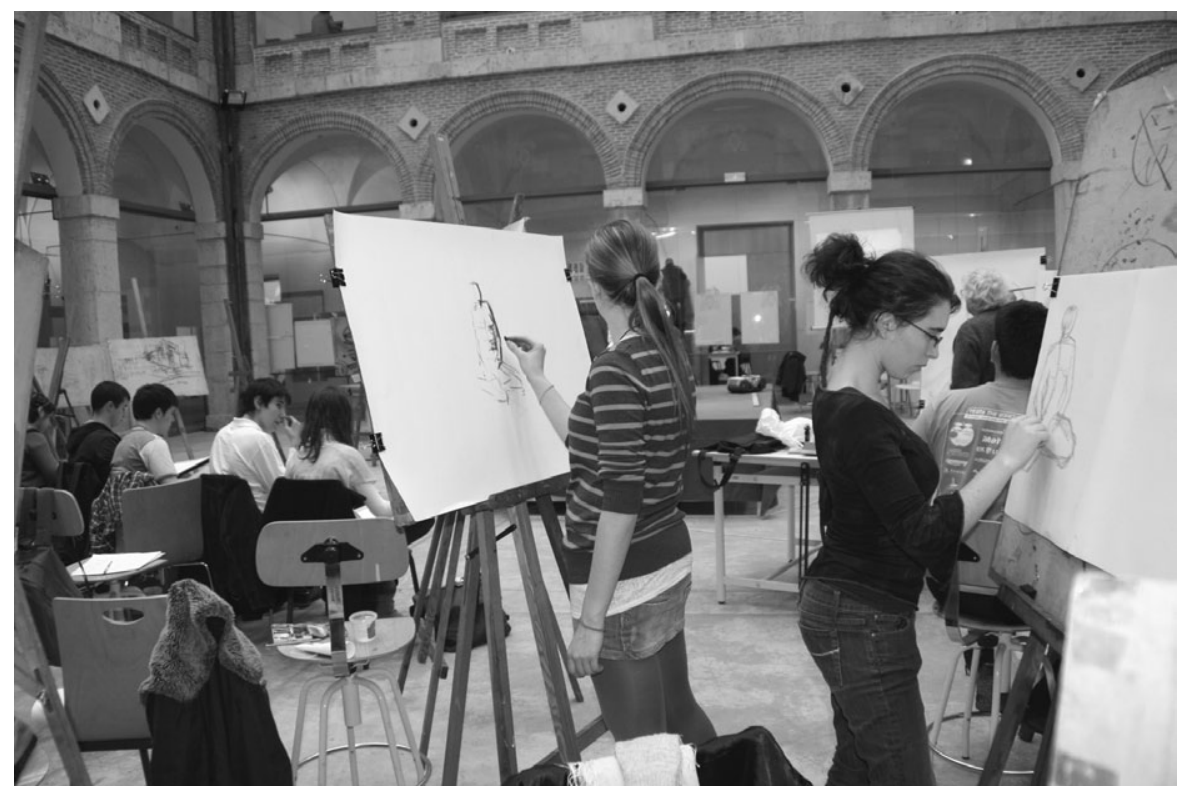

Figura 1: Mujeres estudiantes de Arquitectura en la Universidad de Alcalá (Foto: Juan Prado Osorio).

investigaciones sobre la realidad académica de la mujer en las carreras universitarias relacionadas con la arquitectura.

El objetivo del presente artículo es analizar esta realidad, y valorar en qué medida este contexto que ha sido durante años mayoritariamente de hombres, lo sigue siendo, y en qué medida se continúan o no perpetuando viejos prejuicios sobre la calidad y proyección del trabajo de las alumnas en relación con el de sus compañeros.

La presencia femenina en las aulas de arquitectura ha cambiado mucho desde los años 30, época en la que estudiaba la pionera Matilde Ucelay, cuando no había arquitectas en España y la carrera se prolongaba durante siete años $^{7}$. También ha cambiado mucho la práctica profesional desde aquel 15 de julio de 1936 en que consiguió el título. Pero ochenta años más tarde aún se perciben en algunos ámbitos académicos ciertas falsas creencias sobre la calidad y proyección social del trabajo de las alumnas en relación con el de sus compañeros.

7. LA MUJER CONSTRUYE, «Homenaje a Matilde Ucelay», <http://www.lamujerconstruye. org/actividades/es/articuloslmc/homenajematildeucelay.htm>, consultado el 10-01-2011. 
En este sentido, y coincidiendo con Gerda Lerner, se puede afirmar que el espacio académico de la arquitectura sigue «mirando con un solo ojo» ${ }^{8}$ y manteniendo, en consecuencia, una perspectiva limitada que conduce a que en él persistan opiniones que se alejan considerable e injustamente de la realidad.

Afortunadamente, el acceso creciente de la mujer a cargos de responsabilidad académica permite que seamos espectadoras de primera fila en este proceso y que podamos aportar un punto de vista basado en parámetros objetivos sobre una realidad social que se impone y que ya es evidente en el ejercicio de la profesión.

A lo largo del presente artículo se abordará este periodo formativo desde un punto de vista que no sólo constate los aspectos cuantitativos -relacionados con el número de alumnas matriculadas y egresadas en cada titulación en relación con el número de alumnos hombres-, sino que valore desde un punto de vista cualitativo sus actividades y resultados.

Sobre la base de datos objetivos recabados desde las Direcciones de las Escuelas de Arquitectura y de Arquitectura Técnica de la Universidad de Alcalá -UAH en adelante-, que se ha comprobado que son equivalentes a los de la mayoría de Escuelas del territorio nacional, se desterrará definitivamente la errónea y extendida creencia de la supuesta superioridad de los resultados académicos de los alumnos de Arquitectura y Arquitectura Técnica frente a los de sus compañeras.

\section{La presencia de la mujer en los estudios universitarios relacionados con la arquitectura}

\subsection{El marco académico actual}

Los estudios universitarios que en España tienen relación con el mundo profesional de la arquitectura, se estructuraban antes de la entrada en vigor del 'Plan Bolonia' en torno a dos carreras: Arquitectura Superior y Arquitectura Técnica. Hasta hace un par de años la primera tenía una duración de cinco años, y la segunda, de tres.

Actualmente existen en España treinta y una Escuelas de Arquitectura Superior y veintisiete centros homologados de Arquitectura Técnica, lo cual da una idea de la potencia que hasta ahora han tenido estos estudios en el marco académico de nuestro país. En concreto, en la Universidad de Alcalá se

8. LERNER, Gerda. La creación del patriarcado. Barcelona, Crítica, 1990, p. 20.

Feminismo/s 17, junio 2011, pp. 91-103 


\begin{tabular}{|l|l|l|}
\hline $\begin{array}{l}\text { NOMBRE, DURACIÓN DE LOS } \\
\text { ESTUDIOS Y N } \\
\text { TOTALES DE CRÉDITOS } \\
\text { PLAN BOLONIA }\end{array}$ & $\begin{array}{l}\text { NOMBRE, DURACIÓN Y N } \\
\text { DE CRÉDITOS ECTS DE } \\
\text { LOS ESTUDIOS DE GRADO } \\
\text { ACTUALES }\end{array}$ & $\begin{array}{l}\text { ESTUDIOS } \\
\text { DE MÁSTER } \\
\text { ACTUALES }\end{array}$ \\
\hline $\begin{array}{l}\text { Arquitectura Superior, } \\
5 \text { años, } \\
\mathrm{n}^{\circ} \text { créditos variable entre } 375 \text { y } \\
450\end{array}$ & $\begin{array}{l}\text { Grado en Fundamentos de la } \\
\text { Arquitectura y el Urbanismo, } \\
10 \text { semestres, } \\
300 \text { créditos ECTS }\end{array}$ & $\begin{array}{l}\text { Máster en } \\
\text { Arquitectura, } \\
2 \text { semestres, } \\
60 \text { créditos }\end{array}$ \\
\hline $\begin{array}{l}\text { Arquitectura Técnica, } \\
3 \text { años, } \\
180 \text { créditos }\end{array}$ & $\begin{array}{l}\text { Grado en Ingeniería de la } \\
\text { Edificación, } \\
8 \text { semestres, } \\
240 \text { créditos ECTS }\end{array}$ & \\
\hline
\end{tabular}

Tabla 1. Resumen de los estudios de Arquitectura y Arquitectura Técnica en la UAH, antes y después de la implantación de Bolonia.

imparten ambas titulaciones en las correspondientes Escuelas, basadas en los criterios de excelencia académica que ha promovido el equipo rectoral.

La Escuela Universitaria de Arquitectura Técnica de la UAH ha cumplido este curso dieciséis años desde su creación en 1995; por su parte, la Escuela Técnica Superior de Arquitectura inició su andadura en el curso 2000-2001. Como puede apreciarse, son dos centros relativamente recientes que cuentan con una plantilla de profesorado también joven y entusiasta.

El 'Plan Bolonia' supuso introducir importantes cambios en los planes de estudios con la intención de lograr la máxima compatibilidad, movilidad y reconocimiento de créditos en el marco de la Unión Europea; y todo ello sobre la base de dotar de la máxima autonomía a cada Universidad para que diseñara sus estudios de acuerdo con sus propias cualidades diferenciales.

Este planteamiento fue seguido con éxito en la Universidad de Alcalá en la transformación de los estudios de Arquitectura Técnica en los del Grado en Ingeniería de la Edificación, de modo que en el presente curso 2010/2011 ya va a culminar el proceso de adaptación con los primeros graduados.

En el caso particular de Arquitectura Superior, la adaptación ha requerido considerar además la Directiva Europea propia que ha obligado a unificar en todo el ámbito nacional una serie de aspectos relacionados con el número de créditos totales de la carrera, y con los mínimos a asignar a cada uno de los bloques de materias o asignaturas propedéuticas, técnicas y proyectuales. La implantación del Grado en Arquitectura en la UAH -actualmente en el primer curso- también está arrojando unos resultados magníficos, acordes con el nivel de exigencia y de excelencia que está alentando la Universidad en todas sus titulaciones. 
La equivalencia entre los estudios anteriores y posteriores al 'espíritu de Bolonia', se resume en la Tabla 1.

Como puede apreciarse, la inversión de tiempo que requiere completar los estudios es considerable, y, en el caso de Arquitectura Superior, supone invertir un mínimo de seis años para obtener las competencias profesionales. Estas duras condiciones de partida exigen una dedicación muy intensa a los estudios, lo que implica estar en posesión de unas cualidades personales muy concretas.

\subsection{El perfil del alumnado}

El perfil del alumno que accede a los estudios de Arquitectura y Arquitectura Técnica es bastante homogéneo, y no admite distinciones entre las alumnas y los alumnos a la hora de valorar sus cualidades. Todos ellos comparten una gran capacidad de trabajo -que está acreditada en las elevadas notas de corte que son necesarias para acceder a los estudios, especialmente en Arquitectura Superior-, una gran capacidad de iniciativa, una cierta predisposición a trabajar en equipo -que se potencia a lo largo de la carrera-, y una inicial y poco realista vocación por la arquitectura, ya que con el tiempo van descubriendo que aquélla tenía un gran componente idealista que no responde, en muchos casos, a la realidad de la práctica profesional ${ }^{9}$. Sin embargo, este descubrimiento no llega a menguar su entusiasmo, por lo que la tasa de abandonos en ambas carreras en la UAH es muy baja.

Si consideramos la incorporación de las mujeres a estos estudios, las Tablas 2 y 3 permiten apreciar la evolución de la matriculación en los últimos diez años en ambas titulaciones. Aunque los datos se refieren a la Universidad de Alcalá, como se ha apuntado más arriba se puede afirmar que la tendencia es compartida por todas las Universidades españolas que ofrecen estos estudios.

Un primer análisis de los datos arroja luz sobre la proporción que existe de mujeres y hombres que están cursando ambas titulaciones, y permite apreciar unas tendencias claras.

La primera conclusión que se puede extraer es que el porcentaje de mujeres respecto al total de matriculados en Arquitectura se ha mantenido a un ritmo creciente, marcando una tendencia que se consolida y que desde un

9. CAStaño, Enrique et al. «Repercusiones en los alumnos de primer curso de la implantación del Espacio Europeo de Educación Superior». Revista Complutense de Educación vol. 18, nº 1 (2007), pp. 199-216. 


\begin{tabular}{|c|c|c|c|c|c|}
\hline Titulación & $\begin{array}{l}\text { Curso } \\
\text { Académico }\end{array}$ & $\begin{array}{l}\text { Total } \\
\text { matriculados }\end{array}$ & \begin{tabular}{|l|} 
Total \\
hombres \\
matriculados \\
\end{tabular} & $\begin{array}{l}\text { Total mujeres } \\
\text { matriculadas }\end{array}$ & $\begin{array}{l}\text { \% mujeres } \\
\text { respecto } \\
\text { al total } \\
\end{array}$ \\
\hline \multirow{11}{*}{$\begin{array}{l}\text { Arquitectura } \\
\text { Superior }\end{array}$} & \begin{tabular}{|l|}
$2000-2001$ \\
${\text { (sólo } 1^{\text {er }}}$ \\
curso)
\end{tabular} & 145 & 71 & 74 & 51,03 \\
\hline & 2001-2002 & 218 & 107 & 111 & 50,92 \\
\hline & $2002-2003$ & 287 & 136 & 151 & 52,61 \\
\hline & 2003-2004 & 356 & 177 & 179 & 50,28 \\
\hline & 2004-2005 & 409 & 198 & 211 & 51,59 \\
\hline & $2005-2006$ & 489 & 230 & 259 & 52,97 \\
\hline & 2006-2007 & 557 & 262 & 295 & 52,96 \\
\hline & 2007-2008 & 620 & 291 & 329 & 53,06 \\
\hline & 2008-2009 & 665 & 310 & 355 & 53,38 \\
\hline & $2009-2010$ & 702 & 321 & 381 & 54,27 \\
\hline & $\begin{array}{l}2010-2011 \\
\text { (incluye } 1^{\circ} \\
\text { de Grado) }\end{array}$ & 747 & 343 & 404 & 54,48 \\
\hline
\end{tabular}

Tabla 2. Evolución de la matriculación entre los años 2000 y 2011 en las titulaciones relacionadas con la arquitectura (datos UAH).

\begin{tabular}{|l|l|c|c|c|c|}
\hline \multirow{3}{*}{ Titulación } & $\begin{array}{l}\text { Curso } \\
\text { Académico }\end{array}$ & $\begin{array}{l}\text { Total } \\
\text { matriculados }\end{array}$ & $\begin{array}{l}\text { Total } \\
\text { hombres } \\
\text { matriculados }\end{array}$ & $\begin{array}{l}\text { Total mujeres } \\
\text { matriculadas }\end{array}$ & $\begin{array}{l}\text { \% mujeres } \\
\text { respecto } \\
\text { al total }\end{array}$ \\
\hline \multirow{5}{*}{$\begin{array}{l}\text { Arquitectura } \\
\text { Técnica }\end{array}$} & $2000-2001$ & 323 & 197 & 126 & 39,01 \\
\cline { 2 - 7 } & $2001-2002$ & 356 & 235 & 121 & 33,99 \\
\cline { 2 - 7 } & $2002-2003$ & 360 & 245 & 115 & 31,94 \\
\cline { 2 - 7 } & $2004-2004$ & 338 & 224 & 114 & 33,73 \\
\cline { 2 - 7 } & $2005-2006$ & 346 & 222 & 124 & 35,84 \\
\cline { 2 - 7 } & $2006-2007$ & 373 & 229 & 127 & 35,67 \\
\cline { 2 - 7 } & $2007-2008$ & 393 & 240 & 153 & 37,27 \\
\hline $\begin{array}{l}\text { Ingeniería de la } \\
\text { Edificación } \\
\text { (excluyendo } \\
\text { matriculados } \\
\text { en Arquitectura } \\
\text { Tecnica) }\end{array}$ & $2009-2010$ & 2482 & 232 & 150 & 39,27 \\
\cline { 2 - 7 } & $2010-2011$ & 229 & 156 & 90 & 36,59 \\
\hline
\end{tabular}

Tabla 3. Evolución de la matriculación entre los años 2000 y 2011 en las titulaciones relacionadas con Arquitectura Técnica y con el Grado en Ingeniería de la Edificación (datos UAH). 
mínimo del 50,28\% en el curso 2003-2004, ha alcanzado en el actual año académico el 54,48\%.

En cambio, en Arquitectura Técnica se aprecia una caída y posterior recuperación de la matrícula femenina, que se ha visto ligeramente reducida en el nuevo Grado en Ingeniería de la Edificación, que ha sufrido un descenso que nos retrotrae a los datos de 2004-2005.

Si se comparan los datos en las dos titulaciones, se observa una diferencia: el porcentaje de mujeres respecto al total de estudiantes matriculados en Arquitectura es un 15-16\% superior al de mujeres respecto al total en Arquitectura Técnica. Este porcentaje es superior al 18\% durante el presente curso.

El diferente enfoque que proporciona cada formación académica, refleja que la mayor presencia en el tajo y en las tareas de ejecución de obra que contemplan los planes de estudios de Arquitectura Técnica y de Ingeniería de la Edificación, ha llevado a que la crisis en el sector de la construcción de los últimos dos años haya tenido mayor repercusión en la matrícula en estas carreras universitarias, y que se refleje particularmente ese descenso en el alumnado femenino.

En cambio, el enfoque más amplio y creativo de los estudios de Arquitectura Superior ha supuesto que la crisis no sólo no haya repercutido en las matrículas, sino que la proporción de mujeres estudiantes siga aumentando.

Queda pendiente para ser abordado en un futuro próximo, conocer los datos sobre la dedicación parcial a los estudios ${ }^{10}$ que permite Bolonia, para saber si existe algún tipo de carga social sobre el alumnado femenino que le obligue a optar por dilatar en el tiempo los estudios, y que resulte relevante en términos de género.

\subsection{El entorno de trabajo}

Ya se ha comentado que en estas carreras el trabajo en equipo y la defensa pública de los proyectos resultan dos componentes formativos esenciales.

En el liderazgo de los equipos, se aprecia una clara ventaja del alumnado femenino en la primera mitad de los estudios, que se ve compensada en la segunda parte.

En cambio, en la defensa de los trabajos, realizados individualmente o en equipo, la tendencia arriba apuntada se invierte, de modo que son los

10. Los planes de estudios que se han redactado bajo los conceptos de Bolonia permiten al alumnado relizar cada curso a tiempo completo o a tiempo parcial, lo que supone contemplar dos velocidades en las modalidades de matriculación y alargar la duración de los estudios. 
alumnos los más dispuestos a hablar en público en los primeros cursos, compensándose de nuevo la participación femenina en la segunda mitad de los estudios.

Se ha apuntado que una de las posibles causas de ello sea la franja de edades -que varía entre los dieciocho años del ingreso y los veintidos ${ }^{11} \mathrm{o}$ veinticinco ${ }^{12}$ años de media que corresponden a la graduación- y el grado de madurez alcanzado en cada etapa.

Aparte de estas observaciones, en el día a día del alumnado no se detecta ningún tipo de división del trabajo o de asimetría en las relaciones entre mujeres y hombres, que podría llevar en fases ulteriores del desarrollo profesional a un reparto de poder y de autoridad ${ }^{13}$.

\section{$2.4 \mathrm{El}$ perfil del egresado}

Los datos anteriores nos han permitido valorar los aspectos más puramente cuantitativos que afectan al conjunto del alumnado femenino y masculino en las carreras de referencia.

Pero uno de los índices de calidad del trabajo que desarrollan es la valoración que reciben los Proyectos Fin de Carrera. Éstos consisten en el desarrollo, la presentación y defensa de «un proyecto integral de arquitectura de naturaleza profesional en el que se sinteticen todas las competencias adquiridas en la carrera, desarrollado hasta el punto de demostrar suficiencia para determinar la completa ejecución de las obras de edificación sobre las que verse, con cumplimiento de la reglamentación técnica y administrativa aplicable. $\gg^{14}$

Por otra parte, los Proyectos son juzgados por un tribunal en el que se incluyen profesionales externos de reconocido prestigio, y las dos propuestas para premios extraordinarios se elevan anualmente al Consejo de Gobierno para su concesión. Por otra parte, para optar al premio extraordinario, la calificación del Proyecto Fin de Carrera ha de ser igual o superior al Sobresaliente (Tabla 3).

11. En el caso de Arquitectura e Ingeniería de la Edificación.

12. En el caso de Arquitectura Superior.

13. PAPÍ, Op. cit., p. 140.

14. Orden Ministerial ECI/3856/2007, de 27 de diciembre, y Reglamento del Proyecto Fin de Carrera de la Escuela Técnica Superior de Arquitectura y Geodesia (UAH): <http:// www2.uah.es/arquitectura/documentos/Reglamento\%20del\%20PFC\%202010.pdf>, consultado el 24-01-2011.

Normativa del Trabajo Final de Carrera de Arquitectura Técnica: <http://www.uah es/arquitectura_tecnica/estudios/documentos/Normativa_TFC_2007Modif_sept.pdf>, consultado el 24-01-2011. 


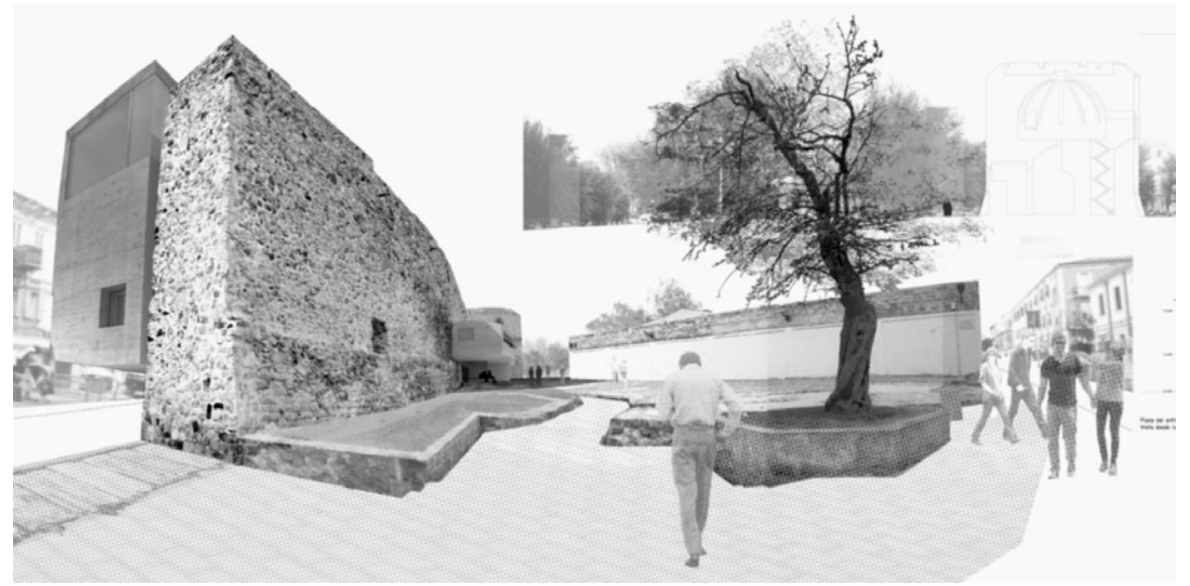

Figura 2. Alba Castillón Caro, Proyecto de Museo de la Ciudad en Alghero (Proyecto Fin de Carrera, 2010).

\begin{tabular}{|l|c|c|c|c|}
\hline $\begin{array}{l}\text { Curso } \\
\text { Académico }\end{array}$ & \multicolumn{2}{|l|}{$\begin{array}{l}\text { Propuesta de Premios } \\
\text { extraordinarios } \\
\text { Titulación de Arquitecto }\end{array}$} & \multicolumn{2}{l|}{$\begin{array}{l}\text { Propuesta de Premios } \\
\text { extraordinarios } \\
\text { Titulación de Arquitecto Técnico }\end{array}$} \\
\hline & Hombres & Mujeres & Hombres & Mujeres \\
\hline $2005-2006$ & 1 & 1 & - & 1 \\
\hline $2006-2007$ & 1 & 1 & - & 1 \\
\hline $2007-2008$ & 1 & - & 1 & - \\
\hline $2008-2009$ & - & 2 & 1 & - \\
\hline $2009-2010$ & 2 & - & - & 1 \\
\hline
\end{tabular}

Tabla 3. Resumen de las propuestas para premios extraordinarios de los últimos cinco años.

Se puede apreciar que la calidad de los trabajos de mujeres y hombres es perfectamente equiparable tanto en el caso de Arquitectura Superior, como en el de Arquitectura Técnica.

\section{Conclusiones}

De acuerdo con lo anteriormente expuesto, se puede afirmar lo siguiente:

1. En la última década se ha producido un aumento prácticamente constante en el porcentaje de mujeres que estudian carreras relacionadas con la Arquitectura, respecto al de hombres; en el caso concreto de Arquitectura Superior, aquél es claramente superior. 
2. La tendencia se consolida en ambas titulaciones, a la espera de conclusiones sobre el Grado en Ingeniería de la Edificación, de implantación aún muy reciente, por lo que los datos aún no son significativos.

3. Esta importante presencia femenina en términos cuantitativos también lo es en términos cualitativos, como ha quedado sancionado por las valoraciones de los profesores externos de prestigio que forman parte habitual de los tribunales -especialmente en el Proyecto Fin de Carrera.

4. No se aprecian diferencias en el comportamiento académico entre el grupo de mujeres y el de hombres, puesto que las posibles facilidades -de comunicación, de liderazgo, etc.- que aparecen esporádicamente en los primeros cursos, se equilibran y desaparecen en torno al tercer año de carrera. Este aspecto es especialmente relevante porque constituye el fundamento de las futuras relaciones profesionales, y evita reproducir situaciones antiguas en la división del trabajo entre mujeres y hombres ${ }^{15}$.

Ante la situación descrita, sólo cabe felicitarse puesto que se ha puesto de manifiesto que no existe ninguna asimetría entre los estudiantes de ambos sexos dentro del marco cultural, espacial y temporal en el que se inscribe el presente estudio.

El siguiente paso será comprobar en qué medida esta situación de igualdad que se da en el ámbito académico se reproduce o no en otros contextos como el de los equipos de jóvenes profesionales de la arquitectura, puesto que la desigualdad continúa siendo manifiesta en nuestro país en la mayoría de los ámbitos laborales ${ }^{16}$, y de ello el ámbito académico e investigador de las mujeres docentes no está ni mucho menos excluído. Afortunadamente la realidad se impone y, como dice Amelia Valcárcel, «la idea de igualdad es pertinaz, incluso cabezota $»^{17}$. Como ella, creo firmemente que cada vez es más difícil ponerle fronteras.

\section{Agradecimientos}

Manifiesto mi agradecimiento al Vicerrector de Estudiantes y Deportes de la UAH, profesor Carmelo García Pérez, y al Director de la Escuela Universitaria de Arquitectura Técnica, profesor Andrés García Bodega, que me han proporcionado los datos necesarios para realizar el estudio.

15. PAPÍ, Op. cit., pp. 144-147.

16. Véanse algunos datos recientes en MORAGA, $\mathrm{M}^{\mathrm{a}}$ Ángeles. «La igualdad entre mujeres y hombres en la Constitución Española de 1978». Feminismo/s 8 (2006), p. 53.

17. VAlCÁrCel, Amelia. «Las filosofías políticas en presencia del feminismo», en Celia Amorós (ed.): Feminismo y Filosofía, Madrid, Síntesis, 2000, p. 116. 


\section{Referencias bibliográficas}

BONILla, Teresa y PinTADO, Patricia. «Construyendo con la comunidad», <http:// www.lamujerconstruye.org/actividades/es/otrosarticulos/construyendo_comunidad.htm>, consultado el 10-01-2011.

CASTAÑO, Enrique et al. «Repercusiones en los alumnos de primer curso de la implantación del Espacio Europeo de Educación Superior». Revista Complutense de Educación vol. 18, nº 1 (2007), pp. 199-216.

CHíAs, Pilar. «Proyectos de mujeres arquitectas en las obras para la Universidades». En 1er Encuentro en la Arquitectura. La mujer construye, Alcalá de Henares (30 junio-4 julio 1997). <http://www.lamujerconstruye.org/ENCUENTROS/es/iencuentro.htm>, consultado el 10-01-2011.

Collado, Concepción. «Mujeres, poder y derecho», Feminismo/s 8 (2006), pp. 15-34.

FONTANA, José. La historia de los hombres. Barcelona, Crítica, 2001.

LA MUJER CONSTRUYE, <http://lamujerconstruye.org/ARTICULOS>, consultado el 10-01-2011.

LA MUJER CONSTRUYE, «Homenaje a Matilde Ucelay», <http://www.lamujerconstruye.org/actividades/es/articuloslmc/homenajematildeucelay.htm>, consultado el 10-01-2011.

LERNER, Gerda. La creación del patriarcado. Barcelona, Crítica, 1990.

MiQueO, Consuelo et al. «Del análisis crítico a la autoridad femenina en la Ciencia», Feminismo/s 1 (2003), pp. 195-215.

MoraGA, Ma Ángeles. «La igualdad entre mujeres y hombres en la Constitución Española de 1978». Feminismo/s 8 (2006), pp. 53-69.

PAPÍ, Natalia. «Un nuevo paradigma para el análisis de las relaciones sociales: el enfoque de género», Feminismo/s 1 (2003), pp. 135-148.

RAMOS, $\mathrm{M}^{\mathrm{a}}$ Dolores. «Historia de las mujeres, saber de las mujeres: la interpretación de las fuentes en el marco de la tradición feminista», Feminismo/s 1 (2003), pp. 1-32.

SEGURA GRAíño, Rosario. «Aspectos sociológicos del desarrollo profesional de las mujeres: las arquitectas». <http://www.lamujerconstruye.org/actividades/es/ otrosarticulos/asp_sociologicos.htm>, consultado el 25-01-2011.

VALCÁRCEL, Amelia. «Las filosofías políticas en presencia del feminismo», en Celia Amorós (ed.): Feminismo y Filosofía, Madrid, Síntesis, 2000, pp. 115-133. 



\title{
¿QUÉ APORTA LA PERSPECTIVA DE GÉNERO AL URBANISMO?
}

\author{
Zaida MuXí Martínez, Roser Casanovas, Adriana \\ Ciocoletto, Marta Fonseca y Blanca GutiÉrRez VAldivia \\ Universidad Politécnica de Cataluña
}

Recibido 09/02/2011

Aceptado 20/05/2011

\section{Resumen}

¿Qué significa un urbanismo con perspectiva de género? ¿Cómo hacer planificación urbanística y proyectos urbanos que tengan en cuenta la perspectiva de género? El objetivo del urbanismo deberia ser poder vivir en barrios inclusivos que tengan en cuenta la diversidad real que caracteriza a los espacios urbanos, y así hacer posible que el derecho a la ciudad sea un derecho humano para todas las personas. Pensar el espacio urbano para todas y para todos es hacerlo desde la diferencia pero no desde la desigualdad: una diferencia entre mujeres y hombres, entre clases, entre orígenes, culturas, religiones, etc. posicionando en igualdad de condiciones todas las demandas, sin decisiones a priori, que excluyan la experiencia de las personas como fuente fundamental de conocimiento en las deciciones urbanas.

Palabras claves: Planificación urbanística. Proyecto urbano. Perspectiva de género. Participación urbana. 


\begin{abstract}
What is the meaning of gender urban perspective? How can we make urban planning and urban projects that have gender mainstreaming? The main objective of urban planning should be the fact of being able to enjoy inclusive cities that take into account the diverse population that inhabits them, thus making the city a human right for all. To think about urban space for all is to do it from the difference between people but not from the inequality, the difference between women and men, between classes, origins, culture, religions etc, placing in equal condition all the demands without excluding the experiences of people and without taking any decision by ourselves, consider this experiences as the fundamental source for urban planning decisions.
\end{abstract}

Keywords: Urban Panning. Urban project. Gender perspective. Urban participation. 
¿Qué significa un urbanismo con perspectiva de género? ¿Cómo hacer planificación urbanística y proyectos urbanos que tengan en cuenta la perspectiva de género? Habitar es mucho más que la sumatoria de la residencia, el trabajo, las tareas del hogar, el ocio, el transporte, la educación, la cultura, los deportes y la sanidad. Habitar es poder desarrollar las diferentes esferas de la vida en igualdad de oportunidades, con intensidad e integridad. Por ello consideramos necesario pensar y, sobre todo, repensar las ciudades y los barrios guiados por esta idea. Poner en primer plano la vida y las necesidades de las personas es una tarea compleja, no exenta de complicaciones.

Por lo tanto, ¿qué significa repensar un barrio con perspectiva de género? ¿Significa trabajarla sólo para las mujeres, es decir, en oposición a la de los hombres? No; se trata de pensar un barrio y una ciudad con todos sus detalles y a través de todas las escalas desde la complejidad y la diversidad, sin dar prioridades exclusivas a consideraciones económicas alejadas de las personas. Se trata de construir, o reconstruir, barrios que no perpetúen las diferencias y las desigualdades de género, clase, raza o edad. Se trata de ponerse las gafas lila ${ }^{1}$ y volver a estudiar, analizar y registrar la realidad para conseguir entornos urbanos más adecuados.

El objetivo del urbanismo deberia ser poder disfrutar de ciudades inclusivas que tengan en cuenta la diversidad real que caracteriza a los espacios urbanos, y así poder hacer posible que el derecho a la ciudad sea un derecho humano para todas las personas. ¿Qué quiere decir hoy el derecho a la ciudad? ¿Es todavía vigente denominar de manera universal los sujetos de derecho? ¿Puede existir el sujeto universal como homogeneizador de las necesidades, derechos y voluntades? ¿Es aceptable que el sujeto universal, enmascarado en el masculino, englobe de manera genérica hombres y mujeres? Los espacios físicos condicionan el derecho a la ciudad, entendida según el artículo I de la Carta Europea de Salvaguarda de los Derechos Humanos en la Ciudad como espacio colectivo que pertenece a todos los habitantes, los cuales tienen derecho a encontrar las condiciones para su realización política, social y ecológica, asumiendo deberes de solidaridad.

1. LiENAS, Gemma; El diari lila de la Carlota. Barcelona: Editorial Empuries, 2001.

Feminismo/s 17, junio 2011, pp. 105-129 
La universalidad esconde el sujeto real de derecho, que es quien ha conformado con sus necesidades la falsa neutralidad. Según Cristina Carrasco ${ }^{2}$ el universalismo es una forma de enmascarar que el sujeto de los derechos de ciudadanía es masculino. El problema de fondo es que la ciudadanía, y por lo tanto el derecho a la ciudad y las prioridades en la definición de esta, se ha construido tomando como referencia el mundo público, la participación en el mercado y los espacios asignados a los hombres. El espacio doméstico-femenino no está incluido en la categoría de ciudadanía. Pero, como dice Anna Bofill:

La gestión de la vida cotidiana no se produce solamente en el interior de las paredes que conforman la vivienda. Es también un conjunto de actividades, comportamientos, sensaciones y experiencias que se producen en el espacio público, en el espacio hasta ahora considerado masculino. ${ }^{3}$

Hay que reconocer la importante aportación a la economía y la sociedad de las tareas de atención y cuidados, tanto físicos como psíquicos, tradicionalmente asignadas a las mujeres, contribuciones que no han sido reconocidas. El urbanismo y la planificación tienen que considerar las necesidades derivadas de estas tareas como puntos imprescindibles para diseñar una ciudad inclusiva.

Hay que prescindir de falsas mitificaciones que quieren construir un pasado idílico de personas iguales y asumir la complejidad de la realidad que vivimos a comienzos del siglo XXI. Como dice Saskia Sassen, la ciudadanía no siempre aporta cumplidos e iguales derechos a todas las personas. A pesar del reconocimiento formal de la igualdad, miembros de grupos oprimidos por razones de etnia, religión, género u orientación sexual se enfrentan de forma cotidiana a diferentes formas de exclusión que los imposibilitan de la plena participación en la vida pública.

\section{Aplicar la perspectiva de género en el urbanismo}

La perspectiva de género aplicada al urbanismo significa poner en igualdad de condiciones las exigencias derivadas del mundo productivo y las derivadas del mundo reproductivo, es decir, las necesidades cotidianas de atención a las personas. Los dos mundos tienen que situarse en el mismo nivel de importancia en las decisiones para evitar ampliar o mantener las diferencias.

2. Carrasco, Cristina i Serrano, Mònica; Compte satèl $\bullet$ lit de la producció domèstica(CSPD) de les llars de Catalunya 2001, col•lecció Estudi 1, Institut Català de les Dones, Generalitat de Catalunya, octubre del 2006.

3. Bofill LeVI, Anna; Planejament urbanístic, espais urbans i espais interiors des de la perspectiva de les dones. Quaderns de l'Institut / 6. Barcelona, Generalitat de Catalunya, Institut Catalá de les Dones, Departament de Política Territorial i Obres Públiques, 2005, p. 30. 
Cuando analizamos la ciudad como un todo, en una escala lejana, obtenemos datos de distribución de los equipamientos, de transportes, de conectividad y accesibilidad, así como las posibilidades de relación entre áreas, etc. Estos datos siempre se tienen que confirmar desde la proximidad. La cuantificación numérica y las proporciones según las necesidades de equipamientos y áreas verdes, son un primer peldaño en la planificación y la organización territorial. Aun así, una vez hemos cumplido y demostrado que numéricamente se resuelven todas las necesidades, tenemos que acercarnos y entender cada uno de estos elementos dentro del funcionamiento de las redes cotidianas. La creación de sectores de suelo, de polígonos no cualificados que esperan la construcción de los equipamientos u otros servicios no son mecanismos suficientes para garantizar el desarrollo de la vida cotidiana de las personas.

Los equipamientos se tienen que entretejer con los recorridos de cada día, es decir no se tienen que colocar en los límites de las áreas urbanizadas puesto que genereran calles sin vida y con falta de seguridad. Con la expulsión de los equipamientos a las afueras de nuestras ciudades perdemos uno de las máximas ventajas de la mezcla y la proximidad: conseguir que los recorridos representen tiempos útiles. Es decir, poder utilizar el tiempo eficientemente si los diversos itinerarios cotidianos nos permiten satisfacer las necesidades cotidianas. En cambio, el uso del tiempo no es eficiente cuando cada recorrido es exclusivo para una función.

En la ciudad lo mejor que puede pasar es la «promiscuidad» de funciones, es decir, hacer una planificación que nos permita la mezcla de usos, no sólo en parcelas contiguas sino en las mismas parcelas. La ciudad tiene que ser cono una cebolla con miles de hojas iguales y diferentes a la vez: iguales en relevancia e impresindibilidad y diferentes en los usos, en los usuarios y usuarias y en los tiempos de utilización, de este modo garantizaremos, como diria Jane Jacobs $^{4}$ una danza urbana constante.

La perspectiva de género aplicada al urbanismo se entiende desde la experiencia y, por lo tanto, la escala próxima, pero esto no excluye la lectura analítica de la estructura general, que nos permitirá hacer recomendaciones en otros momentos de la planificación, más generales y lejanos, como puede ser un plan general.

No tenemos que olvidar que muchas decisiones quedan hipotecadas en esta etapa de la planificación donde las personas son, en el mejor de los casos, datos estadísticos incompletos porque no tenemos suficientes datos

4. JACOBS, Jane; Muerte y Vida de las grandes ciudades. Barcelona: Ed.62, 1967.

Feminismo/s 17, junio 2011, pp. 105-129 
segregados o porque estas se basan en áreas censales que distorsionan la distribución territorial de las personas y, por lo tanto, de las necesidades.

La planificación urbana tendría que enfocarse de forma que nos permita hacer un constante trabajo transversal, transescalar e interdisciplinario. Transversal entre las personas profesionales que trabajan y entre las áreas del mismo ayuntamiento, otras instituciones y también poblaciones implicadas, es decir, transversalidad vertical y horizontal.

Transescalar significa trabajar verificando las propuestas siempre desde la proximidad. Los departamentos de urbanismo y vivienda deciden las formas, esto significa un gran poder y una gran responsabilidad; a pesar de esto hay que tener en cuenta que el conocimiento urbano es compartido pero diferente en las diferentes áreas de trabajo y conocimiento.

En la sociedad actual, los roles de género tienden a difuminarse y las tareas asignadas tradicionalmente a las mujeres dejan de ser exclusividad suya. Sin embargo, en el proyecto urbano, las decisiones sobre las viviendas y los equipamientos (horarios, características, localización, etc.) se siguen pensando desde la división de roles, como si existiera una persona que tuviera un horario liberado para dedicarlo a la atención a las persones dependientes o para el cuidado del hogar.

La Ley orgánica 3/2007, llamada ley de igualdad, ha sido redactada para hacer posible el derecho a la igualdad real entre mujeres y hombres, el cual ya se proclama en el artículo 14 de la Constitución española y es un principio jurídico universal reconocido en varios textos internacionales sobre derechos humanos, y así se recoge en el preámbulo de dicha ley:

El pleno reconocimiento de la igualdad formal ante la ley, a pesar de haber comportado, sin duda, un paso decisivo, ha resultado insuficiente. La violencia de género, la discriminación salarial, la discriminación en las pensiones de viudedad, el hecho que haya más desocupación femenina, la todavía escasa presencia de las mujeres en lugares de responsabilidad política, social, cultural y económica, o los problemas de conciliación entre la vida personal, laboral y familiar, demuestran que la igualdad plena, efectiva, entre mujeres y hombres, la «perfecta igualdad que no admite poder ni privilegio para unos ni incapacitadada para otros», en palabras escritas por John Stuart Mijo hace casi 140 años, hoy todavía es una tarea pendiente que necesita nuevos instrumentos jurídicos.

Como la Ley busca la prevención, entiende que la construcción del medio que habitamos no es neutral, por eso hace referencia al impacto de género de diferentes actuaciones de relevancia económica, social, cultural y artística. Con anterioridad a esta Ley, en las disposiciones adicionales del Decreto legislativo 1/2005, de 26 de julio, que aprueba el Texto refundido de la ley de 
urbanismo ${ }^{5}$ la disposición decimocuarta lleva como título «Incorporación de la perspectiva de género», y dice:

El Departamento de Política territorial y obras públicas tiene que incorporar la perspectiva de género en el desarrollo de esta Ley para garantizar la promoción de la representación paritaria en la composición de los órganos urbanísticos colegiados y de la evaluación del impacto de la acción urbanística en función del género.

La ley de igualdad también determina en su articulado una serie de cuestiones que pueden ser de gran utilidad para confirmar la pertinencia de llevar a cabo un urbanismo que incorpore la perspectiva de género como herramienta esencial. Lo encontramos en el artículo 20, Adecuación de las estadísticas y estudios; en artículo 22, Acciones de planificación equitativa de los tiempos y, especialmente, el artículo 31, Políticas urbanas, de ordenación territorial y vivienda. En resumen:

1. Las políticas y los planes de las administraciones públicas en materia de acceso a la vivienda tienen que incluir medidas destinadas a hacer efectivo el principio de igualdad entre mujeres y hombres. Del mismo modo, las políticas urbanas y de ordenación del territorio tienen que tener en consideración las necesidades de los diferentes grupos sociales y de los varios tipos de estructuras familiares, y favorecer el acceso en condiciones de igualdad a los diferentes servicios e infraestructuras urbanas.

2. El Gobierno, en el ámbito de sus competencias, tiene que fomentar el acceso a la vivienda de las mujeres en situación de necesidad o en riesgo de exclusión, y de las que hayan sido víctimas de la violencia de género, especialmente cuando, en los dos casos, tengan hijos menores exclusivamente a su cargo.

3. Las administraciones públicas tienen que tener en cuenta en el diseño de la ciudad, en las políticas urbanas, en la definición y ejecución del planeamiento urbanístico, la perspectiva de género, utilizando para hacerlo, especialmente, mecanismos e instrumentos que fomenten y favorezcan la participación ciudadana y la transparencia.

\section{Recomendaciones para la aplicación de la perspectiva de género}

Las recomendaciones se basan en la convicción de la necesaria incorporación de la perspectiva de género en el conocimiento de los mecanismos de la planificación y los proyectos de urbanización así como en la observación de las características físicas y sociales para lograr el cumplimiento efectivo de la Ley orgánica 3/2007 según la cual:

5. Texto refundido de la Ley de Urbanismo y de su Reglamento aprobado por el Decreto 305/2006, de 18 de julio. 
La prevención de estas conductas discriminatorias y en la previsión de políticas activas para hacer efectivo el principio de igualdad. Esta opción implica necesariamente una proyección del principio de igualdad sobre los diversos ámbitos del ordenamiento de la realidad social, cultural y artística en que se pueda generar o perpetuar la desigualdad. De aquí la consideración de la dimensión transversal de la igualdad, señal de identidad del moderno derecho antidiscriminatorio, como principio fundamental de este texto.

La Ley se refiere a la generalidad de las políticas públicas en España, tanto estatales como autonómicas y locales:

Artículo 15. Transversalidad del principio de igualdad de trato entre mujeres y homes.el principio de igualdad de trato y oportunidades entre mujeres y hombres tiene que informar,con carácter transversal, la actuación de todos los poderes públicos. Las administraciones públicas lo tienen que integrar, de manera activa, en la adopción y ejecución de las disposiciones normativas, en la definición y presupuestos de políticas públicas en todos los ámbitos y en el desarrollo del conjunto de todas las actividades.

\subsection{Un análisis diferenciado e integrado}

La legislación urbanística divide la problemática del territorio según escalas, segregando problemas y necesidades que tendrían que plantearse en conjunto. Es imprescindible intervenir en esta división puesto que las relaciones y actividades cotidianas no se encuentran segregadas en la vida de las personas, especialmente en la vida de las mujeres, en quienes recae todavía de manera mayoritaria la responsabilidad de hacer encajar esferas y tiempos diferentes. Según la encuesta demogràfica del 2007, en Cataluña ${ }^{6}$ el 47\% de las mujeres asume la práctica totalidad de los trabajos no remunerados del hogar mientras que el porcentaje de hombres que se responsabilizan de casi todos los trabajos domésticos es sólo del 8,8\%. Los porcentajes de no participación en el cuidado de los hijos en el hogar son más altos en hombres $(23,9 \%)$ que en mujeres $(9,4 \%)$. La atención compartida de las criaturas es la situación más frecuente, de forma que en torno el 43,5\% de los hombres y de las mujeres dicen repartir el trabajo de cuidar los niños y niñas con al menos otra persona del hogar. Un 38,6\% de las mujeres asume en su práctica totalidad el cuidado de las criaturas, lo cual indica que conviven con personas que no participan o que tienen una mínima participación en los trabajos de atención a los pequeños de la casa, incluyendo también las situaciones de familias monoparentales, que representan el 19\% de los núcleos con hijos. En el 85\% de los núcleos monoparentales la persona progenitora presente es la madre.

6. <http://www.idescat.cat/cat/idescat/serveis/premsa/ed2007ds.pdf> Consultado el 07-02-2011. 
La segregación de decisiones según la escala de trabajo ha generado una falta de coherencia en muchos territorios que se manifiesta especialmente en los barrios y en sus entornos, en la falta de redes de proximidad para el desarrollo de la vida cotidiana.

Por eso, la aplicación de la perspectiva de género en los proyectos urbanos necesita como punto de partida una nueva forma de análisis, diferente a las empleadas habitualmente. Este análisis tiene que introducir de una forma exhaustiva criterios físicos y sociales en todas las escalas y fases del planeamiento de manera transversal. No se puede entender y estudiar un territorio o un entorno específico sin entender y estudiar las personas que viven, sus especificidades y sus necesidades diversas.

Aunque estudiamos el detalle no se pueden dejar de atender las consecuencias que repercuten en el entorno próximo y más amplio, y a la inversa, el planeamiento general tiene que atender a la particularidad de cada calle y de cada línea que se dibuja. Por lo tanto, es necesario un análisis diferenciado de cada circunstancia o problema a resolver en cada proyecto, pero es fundamental que estén integrados, es decir, que cada variable esté entretejida con el resto.

El cambio fundamental que propone la aplicación de la perspectiva de género en la construcción de las ciudades y los pueblos es priorizar los seres humanos concretos y sus necesidades en todos los niveles de planeamiento, teniendo como objetivo principal hacer barrios y ciudades con redes adecuadas para la vida cotidiana de todas las personas que conviven en un territorio.

\subsection{Variables de análisis de la realidad}

El entorno cotidiano es un complejo tejido de variables. Para poder facilitar el estudio de esta red las hemos dividido en seis ${ }^{7}$. Los espacios públicos o de relación, los equipamientos, la movilidad y la vivienda son las variables que definen el apoyo físico sobre el cual se desarrolla la red cotidiana. La participación y la seguridad son conceptos que influirán a su vez en la definición física. Las seis variables, no pueden entenderse si no como temas a trabajar necesariamente de manera transversal.

7. MuXí MARTINEZ, Zaida y COL.LECTIU PUNT 6; Recomanacions per la implementació de polítiques de gènere al urbanisme. Entidad financiadora: Institut Català de les Dones, expediente U-62/06. Convenio de colaboración con la Universitat Politècnica de Catalunya grupo de investigación I-00868. 2006-2007. <www.punt6.net> Consultado el 07-02-2011. 
Espacios públicos de relación

Los espacios de relación pensados para la equidad de género favorecen la autonomía y la socialización de las personas puesto que han sido pensados priorizando en su diseño y trazado las necesidades de mujeres y hombres.

Para conseguirlo son imprescindibles estos elementos: aceras anchas y activas que favorezcan la realización de diferentes actividades, con diferenciación de materiales, colores y texturas en los cambios de nivel; alcorques al mismo nivel de la acera; barandillas y rampas en las zonas con pendiente; pasos de peatones muy diferenciados y con semáforos que tengan en cuenta los tiempos lentos; bancos con sombras que generen zonas de descanso en los recorridos urbanos y en las áreas de estancia; espacios intermetdios de relación entre los interiores y exteriores; señalización que facilite la orientación, la identificación y la apropiación. Se tienen que trabajar los espacios de relación de manera inclusiva, pensando en todas las edades y condiciones de las personas que lo usarán, incorporando espacios específicamente pensados para grupos concretos de usuarios y usuarias.

El reconocimiento de la importante tarea de las mujeres en la sociedad tiene que hacerse visible en el espacio público y uno de los mecanismos más inmediatos para conseguirlo es denominarlos en femenino, es decir, dar a los

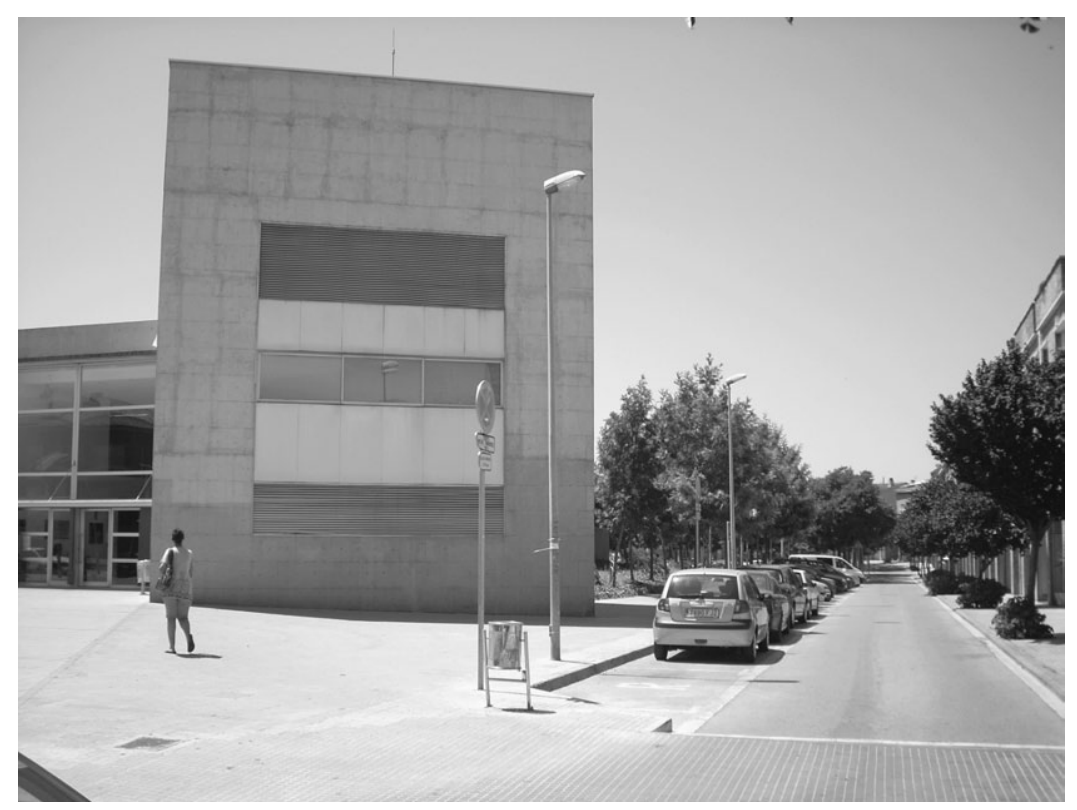

Feminismo/s 17, junio 2011, pp. 105-129 


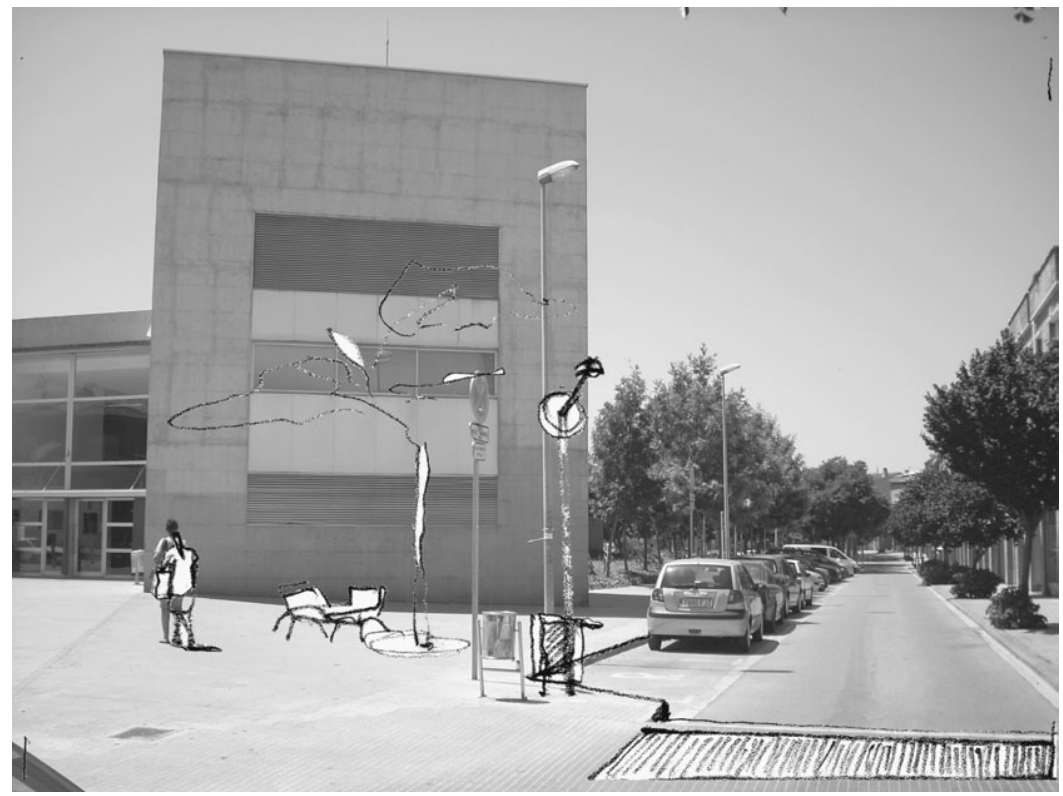

parques, plazas y calles nombres de mujeres y explicar cuál fue su aportación a la sociedad. Tal como señala el Manual práctico para una señalización urbana igualitaria ${ }^{8}$ de la Federación Española de Municipios y Provincias, se tienen que trabajar las señalizaciones urbanas para hacer visible la igualdad de hombres y mujeres en el derecho a la ciudad y a sus espacios públicos. La carencia de figuras femeninas en las señales es una dimensión más que nos revela que, bajo la apariencia de universalidad en la concepción de la ciudad, hay un orden androcéntrico que se reproduce con la falsa neutralidad.

\section{Equipamientos y servicios}

La oferta de equipamientos se amplia cuando la sociedad en la que se inscriben reconoce, asume y valora el trabajo derivado de los roles de género. El espacio de los equipamientos necesita entretejerse al espacio público de la ciudad con la máxima permeabilidad y flexibilizando su utilización para maximizar la utilización de los espacios. Su distribución en el territorio en relación a los usos y a las redes de movilidad garantiza la calidad de vida, porque

8. www.femp.es/.../Manual\%20práctico\%20para\%20una\%20señalización\%20igualitaria.pdf. Consultado el 09-02-2011. 

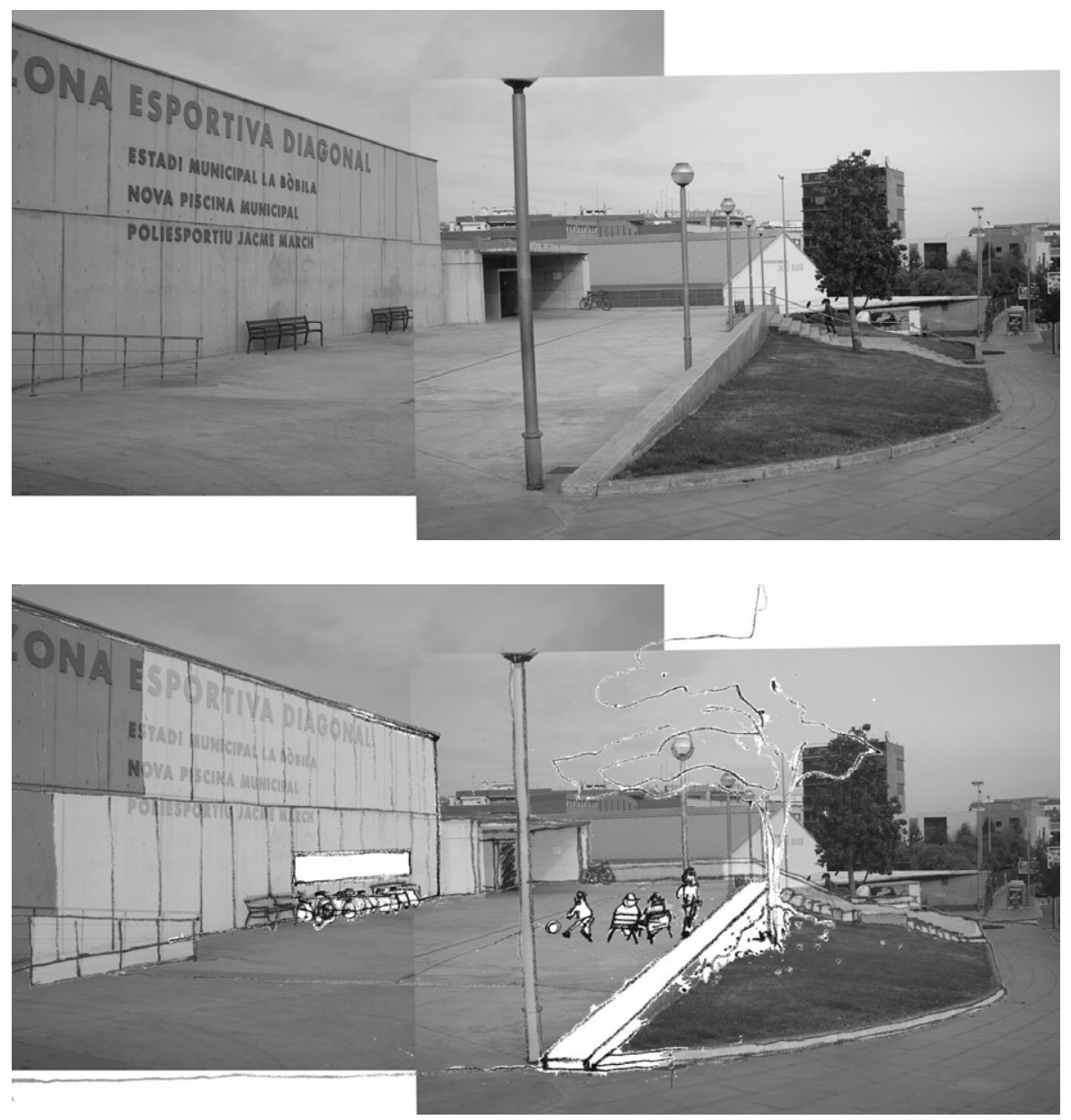

los convierte en estrategias para fomentar redes sociales, generar intercambio de servicios y posibilitar diferentes tiempos de uso acercando su funcionamiento a la complejidad de la vida cotidiana.

Movilidad

La oferta de medios de transporte y las características de los espacios soportes de la movilidad determinan formas y calidades de vida. La movilidad ha de ofrecer la máxima cantidad de variedad de opciones privilegiando los recorridos peatonales que se apoyan en un tejido urbano funcionalmente variado. 

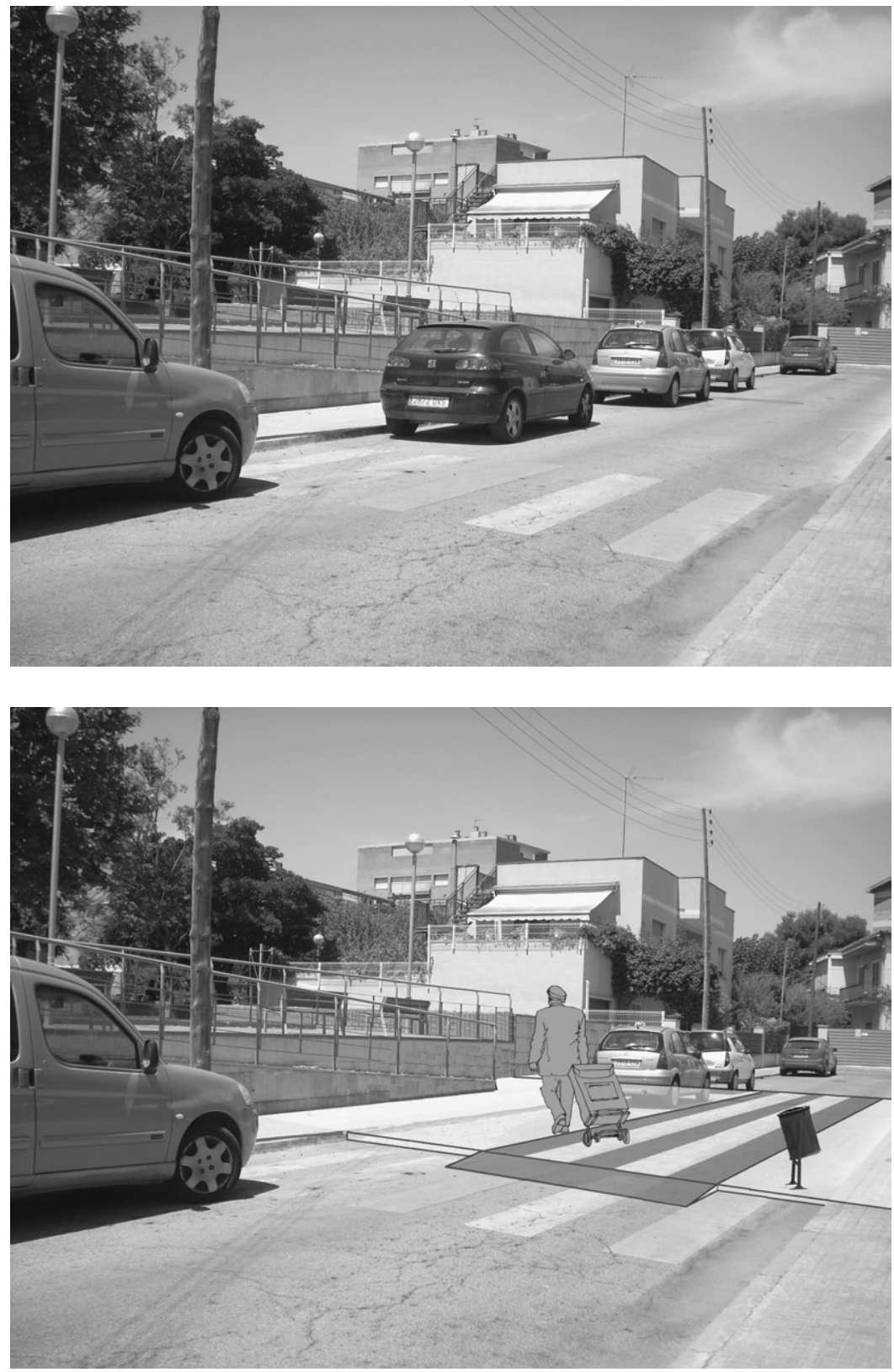

Los transportes públicos tienen que dar respuesta a la variedad de horarios del mundo reproductivo que genera recorridos no lineales ni uniformes. 
Se debe pensar la movilidad respondiendo a la diversidad y a la seguridad en todos sus aspectos, para facilitar la planificación de todas las actividades de la vida cotidiana y haciendo posible la igualdad de oportunidades en el acceso a la ciudad.

Vivienda

El espacio representa los valores sociales que lo han creado, por ello las viviendas han de reconocer las tareas de cuidado del hogar y las personas dándoles un espacio. Las tareas del hogar han de ser compartidas, no se deberían esconder no dejar la responsabilidad de las mismas en una sola persona.

Es necesario aprovechar los edificios de viviendas para generar espacios de relación entre vecinos, haciendo un uso compartido de servicios y construyendo espacios de tránsito entre lo privado y lo público. Es importante que en las plantas bajas se ofrezcan actividades variadas en relación directa con el espacio público favoreciendo la seguridad del mismo.

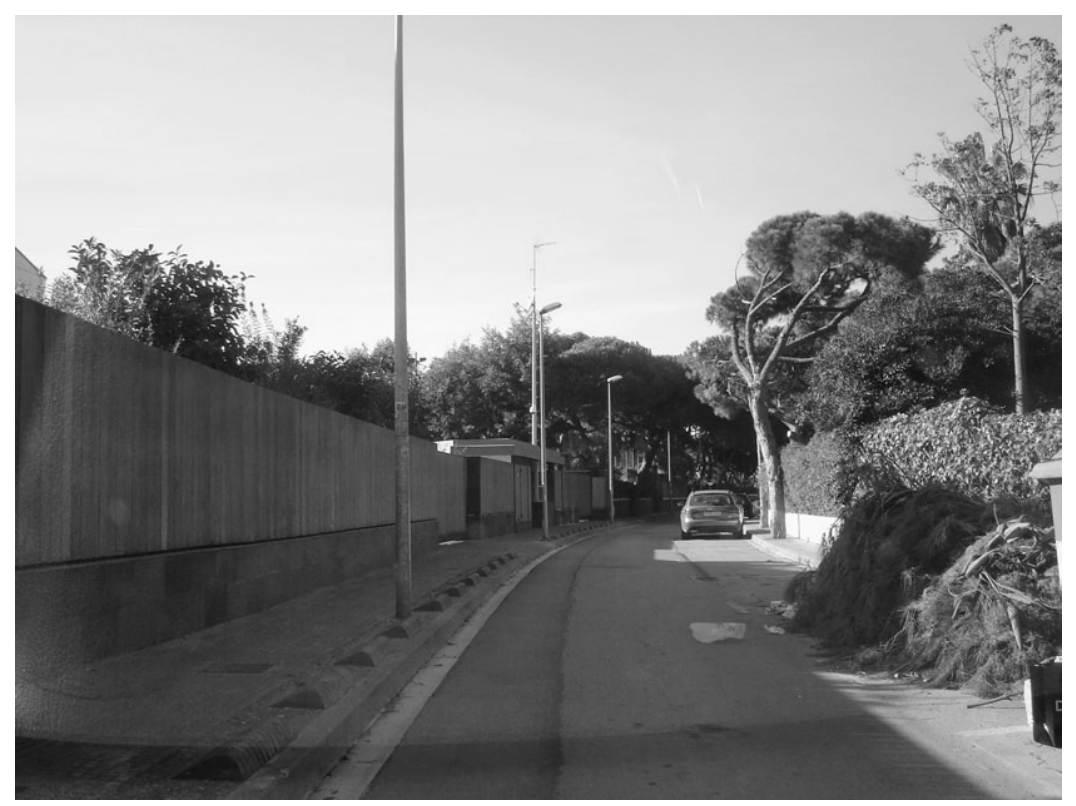

Feminismo/s 17, junio 2011, pp. 105-129 


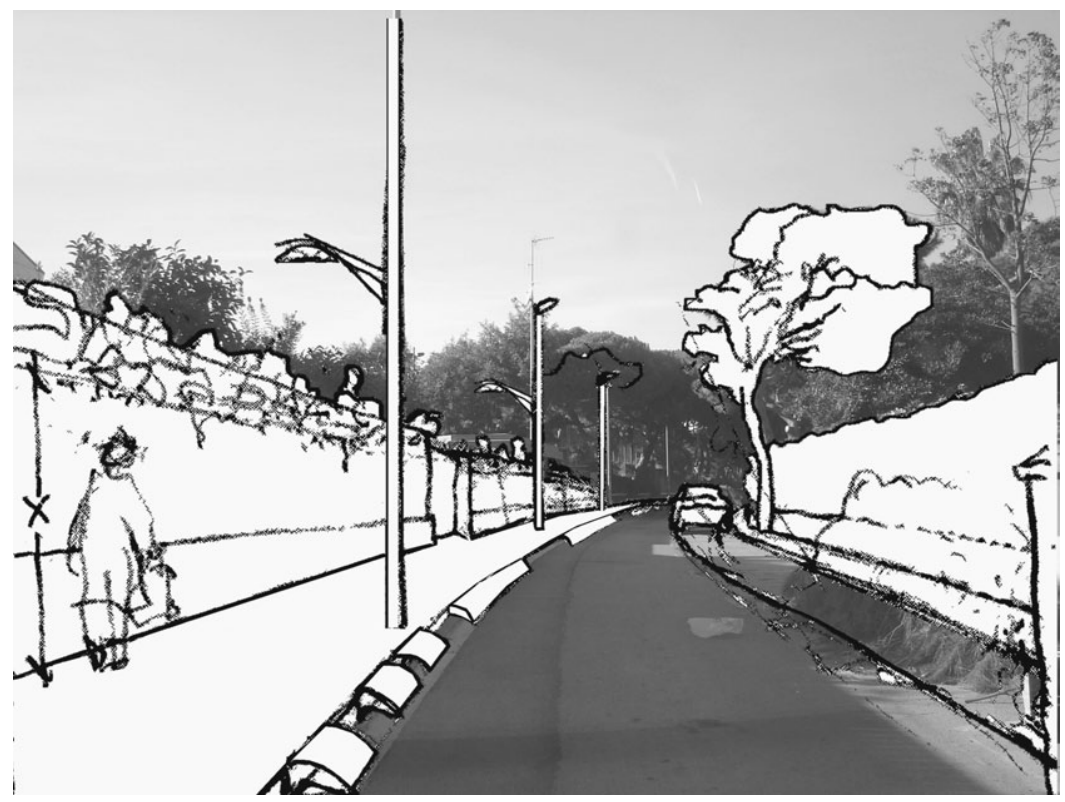

Seguridad

La percepción de seguridad está vinculada a la capacidad de las mujeres de apropiarse del espacio adquiriendo autonomía. Entre los factores espaciales que colaboran en la percepción de seguridad están la visibilidad, la claridad y alternativa de recorridos, la variedad de usos y actividades y la presencia de gente diversa. Para favorecer el sentimiento de pertenencia y seguridad en los espacios públicos se tiene que cuidar especialmente la iluminación de los espacios para peatones y se han de evitar muretes, vallas y escaleras que generen rincones de difícil accesibilidad y escondidos. (Figuras 5 a y 5b)

Todos los estudios sobre seguridad realizados, tanto a nivel local como mundial, nos hablan de una percepción de miedo más importante por parte de las mujeres que de los hombres. Según estudios hechos en Gran Bretaña, la sensación de inseguridad que sufren las mujeres hace que muchas eviten salir por la noche, que modifiquen su recurrido a pie por la ciudad:

(...) estadísticamente las mujeres son generalmente más pequeñas y menos fuertes que los hombres. Las mujeres son las acompañantes de gente mayor o criaturas dependientes el que hace que sus movimientos estén más restringidos (...) las mujeres tienen menos acceso al vehículo privado, y en general cargan con las compras (...) Las circunstancias que hacen que las mujeres tengan miedo a los espacios público en orden de importancia estadística son: la poca luz, la oscuridad, los jóvenes, los hombres sólo, las drogas 

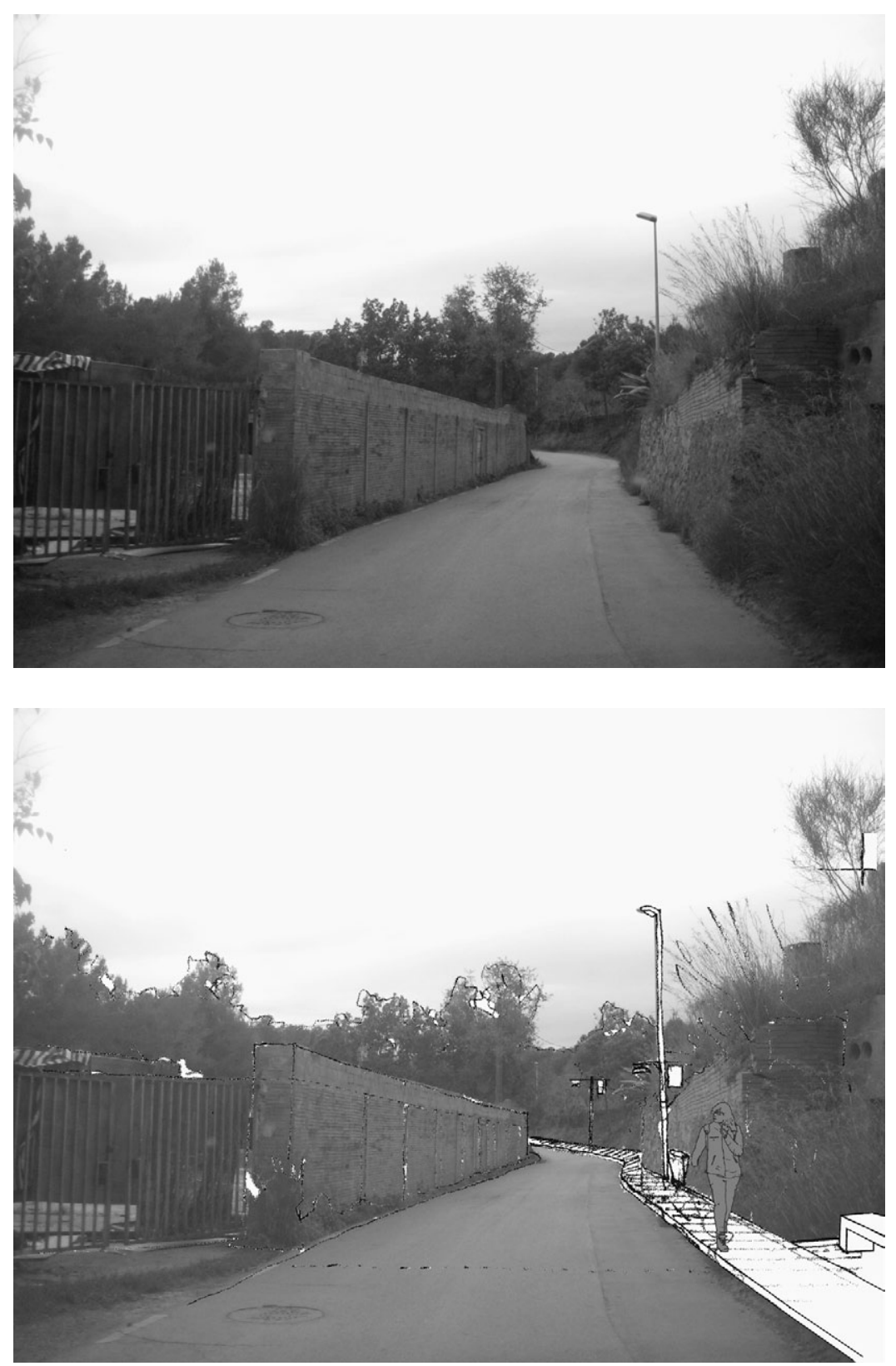

Feminismo/s 17, junio 2011, pp. 105-129 
y el alcohol, el vandalismo, el encontrarse perdida, los perros, y los medios de comunicación $(. . .)^{9}$

\section{Participación}

La participación es imprescindible para comprender y visibilzar lo que ocurre en un espacio, para poner sobre el papel todo el conocimiento que acumula una comunidad sobre su propio territorio y concretamente, la experiencia de las mujeres en su vida cotidiana. Entendemos la participación como un proceso interdisciplinar y transversal, que es necesario que esté presente y sea vinculante desde la diagnosis de la planificación urbanística a la evaluación de la misma.

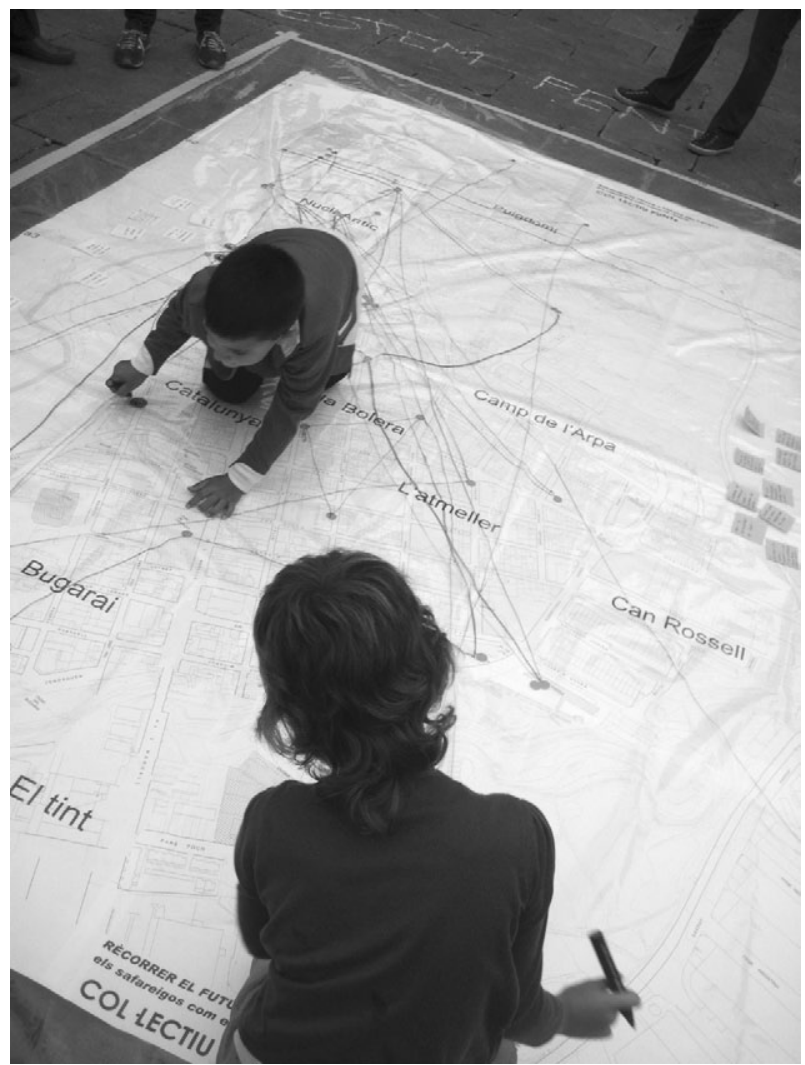

9. Women's Design Service in collaboration with Anne Thorne Architect's Partnership. What to Do About Women's safety in Parks. From A to Y. London: Women's Design Services, 2007, pp. 7, 18-19. 


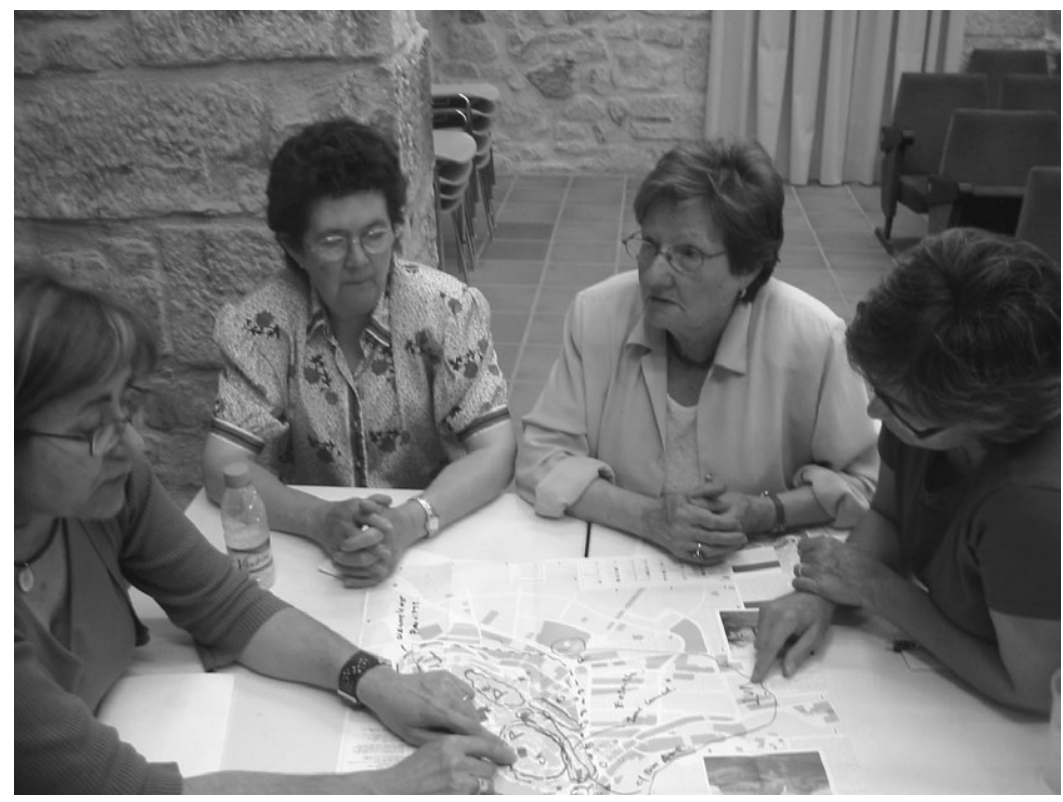

3. Participación desde la experiencia: La experiencia de las mujeres como conocimiento urbano

Entendemos que cualquier intervención en el territorio se tiene que hacer con la participación de las personas que viven, que además serán usuarios y usuarias del espacio resultante. La participación de la ciudadanía en las cuestiones urbanas significa la implicación y la corresponsabilidad en el devenir del entorno que habitan y aumenta el sentimiento de pertenencia al lugar.

La experiencia de las mujeres en la ciudad no ha sido tenida en cuenta como conocimiento dentro de la planificación y el proyecto urbano. El rol del género femenino ha abocado históricamente a las mujeres, y todavía hoy en día a una mayoría, a la realización casi exclusiva de las tareas derivadas del cuidado y atención de los hogares y las personas. Las tareas derivadas del trabajo reproductivo han provocado que las mujeres utilizaran los barrios y las ciudades de forma diferente a la establecida puesto que para los planificadores este conocimiento ha sido invisible o inexistente.

Hoy en día, por ejemplo en Cataluña, las mujeres siguen realizando un $70 \%$ de los trabajos derivados del hogar y la familia, a pesar de que la incorporación al mercado laboral remunerado ha llegado a cotas similares a las masculinas. Estas actividades han dado a la mujer un conocimiento diferencial, 
un conocimiento no tenido en cuenta hasta hoy. Esto lo hemos podido comprobar en los resultados de más de 80 talleres La experiencia de la mujeres en el entorno cotidiano ${ }^{10}$ realizados en los últimos 6 años.

Para poder conocer las experiencias múltiples de las mujeres -múltiples en cada una de ellas y múltiples en la diversidad del grupo- es necesario extraer esta experiencia como dato, como por ejemplo, realizando talleres de participación con los diferentes grupos femeninos que habitan el territorio sobre el cual se trabajará.

Cómo exponen Susan Fainstein y Lisa Servon:

Para la mayor parte de la historia de la planificación urbana las diferencias de género han sido invisibles. (...). La utilización del género como categoría de análisis nos permite deshacer los supuestos que han marcado la teoría y la práctica. Como resultado podemos cuestionar y modificar estos supuestos y alterar la manera que teoría, decisiones y políticas se hacen, para alcanzar y considerar un amplio rango de conocimiento. Para lo cual es necesario hacer diferentes grupos de preguntas, ampliando el rango de métodos que usamos y revaluando el tipo de información que incluimos en el análisis. ${ }^{11}$

No hay duda que los procesos de participación son un paso adelante imprescindible en la democratización de la sociedad. Y es dentro de estos procesos que se tiene que trabajar especialmente con las mujeres. Esta exclusividad está justificada al reconocer la situación de invisibilidad vivida por ellas que les ha traído una falta de seguridad en el autoconocimiento, y, por lo tanto, se hace difícil la participación en igualdad de condiciones cuando el grupo es mixto. Es por este motivo que, a pesar de que en etapas más avanzadas del proceso se reúnen grupos mixtos, es necesario el trabajo en exclusividad sólo con mujeres para generar la confianza necesaria en su conocimiento sobre el hecho urbano.

Si los habitantes de un determinado lugar tienen un saber difícilmente alcanzable exclusivamente desde la observación exterior y los planos, este se hace todavía más evidente cuando son las mujeres quienes participan. Sus experiencias reúnen las de otros grupos, debido precisamente a que son y han sido ellas las encargadas de las personas que necesitan atenciones especiales.

En términos generales un proceso de participación comporta el aprendizaje, la sensibilización y la toma de conciencia crítica para cuestionar el

10. El taller La experiencia de la mujeres en el entorno cotidiano, dinamizado por las autoras de este artículo, forma parte de las Herramientas de participación que el Institut Catalá de les Dones ofrece a las asociaciones y entidades de mujeres en Cataluña desde al año 2005.

11. Fainstein, Susan y Servon, Lisa (ed); Gender and Planning: A Reader. Journal of the American Planning Association, 2007, pp. 1 y 4. 
modelo imperante tanto por parte de la ciudadanía como de técnicos, técnicas, políticos y políticas. Un proceso de participación tiene que tener objetivos estratégicos, transversales y a largo plazo.

\section{Metodologías de análisis urbano desde una perspectiva de género}

Diversos autores y autoras han discutido intensamente durante años sobre la existencia de una metodología propia feminista, sobre si las investigaciones y trabajos que se enmarcan dentro de la teoría feminista utilizan una metodología particular o no. En este artículo no se quiere entrar en este debate, sin embargo, lo que parece evidente es la existencia de unas características específicas cuando se trabaja aplicando la perspectiva de género.

La primera de estas características sería el uso del género como categoría analítica básica, que traspasa el planteamiento teórico del trabajo y se introduce en el diseño metodológico del mismo. Usar la categoría de género obliga a adaptar la metodología de manera que sea capaz de recoger la diversidad de experiencias y necesidades de la población.

La filósofa Sandra Harding, citada por Prats ${ }^{12}$, ha sido una de las autoras que ha tomado parte en estas discusiones, y aunque defiende que no existe un método propio feminista, reconoce las características metodológicas de la investigación sobre género. Por ejemplo, el hecho de que los problemas se plantean desde la perspectiva de la experiencia de las mujeres o el hecho de que se tenga en cuenta el contexto social en el que se realiza la investigación.

Tener en cuenta la experiencia y realidad particular de las mujeres es importante por ejemplo cuando se realizan trabajos participativos, donde para que sea posible la participación en igualdad de condiciones, además de atender las diferentes disponibilidades horarias, tienen que existir facilidades para las personas responsables del cuidado y atención de las personasdependientes.

Otra particularidad de aplicar metodología con perspectiva de género tiene que ver con que la finalidad última de los trabajos va dirigida a influir en el cambio de las relaciones de género. Esta implicación política de los trabajos tiene una repercusión directa en la manera en la que se utiliza la metodología y los resultados que se quieren obtener de ella. Este posicionamiento políticoteórico desde la fase inicial del trabajo, hace que en ocasiones estos trabajos sean tildados de sesgados y poco rigurosos. Estos calificativos podrían entenderse si realmente la ciencia y la praxis pudieran desarrollarse de manera completamente autónoma con respecto las determinaciones sociales, y sin

12. Prats FerRet, María; Geografía feminista i metodología: Reflexió sobre un procès d'aprentatge paral-lel Cuadernos de Geografía no 64, Valencia 1998, pp. 313-323. 
presencia de valores preconcebidos. Aunque, como diversas investigaciones históricas y sociológicas han demostrado, los valores prácticos socialmente dominantes (morales o de otro tipo) acaban repercutiendo en los métodos y los contenidos de la ciencia, bien contribuyendo a seleccionar los objetivos epistémicos que predominan en una determinada fase de la actividad científica, bien suplantando a éstos en el proceso de resolución de los debates científicos. ${ }^{13}$

Por último, otra especifidad del uso de la perspectiva de género está relacionada con la visibilización de la vida cotidiana, independientemente de la escala de aplicación del trabajo. El concepto de vida cotidiana hace referencia a las actividades desarrolladas por las personas en su día a día, indistintamente de la esfera a la que pertenezcan pública y/o privada. Por esto, para evidenciar la complejidad de las prácticas llevadas a cabo en la cotidianeidad, es necesario utilizar una metodología que no invisibilice la realidad cotidiana de parte de la población.

En los trabajamos que hemos desarrollado se han empleado estos puntos como base y además se ha empleado la estrategia de la triangulación múltiple: multidisciplinareidad y diversidad de métodos y datos para desarrollar el trabajo. La diversidad de disciplinas aporta al trabajo variedad de enfoques y puntos de vista. La utilización de distintas técnicas pertenecientes a diversas metodologías (cualitativa, cuantitativa, análisis bibliográfico) aporta al trabajo representatividad y al mismo tiempo información detallada.

A continuación se detallan las metodologías utilizadas generalmente y la manera en la que se aplican.

Primero se hace una aproximación cuantitativa al área de estudio. Se extraen datos estadísticos de diferentes fuentes y posteriormente se analizan. Estos datos son muy útiles para hacer un marco general de la situación, o para trabajar con una escala municipal o metropolitana, sin embargo, cuando se intenta hacer un estudio más pormenorizado, a una escala de barrio o de sección censal, son recurrentes las incoherencias y las deficiencias de los datos, siendo necesario que estos datos vayan acompañados de otro tipo de técnicas que verifiquen y contrasten la información.

A pesar de esto, esta aproximación cuantitativa al área de estudio, ofrece la posibilidad de contextualizar la zona y es un buen punto de partida para poder implementar el resto de técnicas de investigación.

13. RODRIgUeZ AlCAZAR, Javier; Esencialismo y neutralidad científicas en el libro Ciencia, Tecnología y Sociedad. Contribuciones para una cultura de la paz. Ed. Rodríguez Alcázar, Medina Doménech y Sánchez Cazorla, Ed. 1997, pp. 49-84. 
La utilización de herramientas cualitativas en los análisis urbanos nos permite incorporar datos no cuantificables dentro de los datos estadísticos y trabajar a una escala de detalle para la que no existen datos. Para desarrollar la parte cualitativa de la investigación se emplean diferentes técnicas que intentan dar respuesta a una serie de cuestiones básicas: quién usa o quién vive, con quién, por qué, y cómo. ${ }^{14}$ La primera es la observación participante. Esta técnica permite la verificación de los datos cuantitativos así como obtener información primaria de fenómenos difícilmente cuantificables en estadísticas. Está compuesta por una serie de técnicas de obtención y análisis de datos y permite aproximarse a la realidad social intentando observarla de modo directo, entero y en su complejidad, sin artificios ni simplificaciones y en el momento en que sucede el fenómeno que se quiere estudiar. Posibilita una visión total de la realidad, teniendo en cuenta el contexto y sin fragmentar lo real. Ningún fenómeno social puede ser entendido fuera de sus referencias espacio-temporales y de su contexto. ${ }^{15}$

La observación consta de un análisis secuencial en distintos espacios para cada uno de los contextos seleccionados a diferentes horas del día (mañana, tarde, noche) y en días distintos (laborable, sábado, festivo)

Para recoger la información de las observaciones se utilizan una serie de fichas (Col-lectiu punt $6^{16}$ ) que clasifican la información según dos dimensiones (física y social) lo que facilita su posterior análisis. La utilización de las fichas de recogida de datos, sistematiza la información lo que permite comparar diferentes contextos espaciales y temporales.

Durante las observaciones se hacen entrevistas espontáneas a personas usuarias de los espacios públicos. Estas entrevistas no son estructuradas y se pretende obtener información de primera mano acerca de las percepciones que tienen las personas de los espacios.

Por último, se realizan entrevistas en profundidad que aportan información adicional a la conseguida mediante las observaciones y las entrevistas espontáneas, además de corroborar las dinámicas observadas

Durante la realización del trabajo de campo se toman fotografías y se realizan diagramas y dibujos para complementar la información obtenida y como medio para depurarla.

14. RAINERO, Liliana y RODIGOU, Maite; Indicadores urbanos de género. Instrumentos para la gobernabilidad urbana. Córdoba Argentina CICSA, 2001.

15. VAlLes, Miguel; Técnicas cualitativas de investigación social. Reflexión metodológica y práctica profesional. Madrid Editorial Síntesis, 1999.

16. MuXí MARTínEZ, Zaida y COL·LECTIU PUNT 6; 2006-2007. 


\section{Conclusiones}

Por todo lo expuesto entendemos que una sociedad que aspire a estar formada por seres humanos en igualdad, sin factores discriminatorios por sexo, clase, capacidades físicas, raza o edad, tiene que planificar sus ciudades -incluyendo todas las escalas y todos los ámbitos- desde la visibilidad y la igualdad en importancia de las dos esferas en las cuales se han dividido los trabajos de las personas tradicionalmente. Es imprescindible reconocer que la manera como se construyen las ciudades no es neutral. Afectará de diferente manera a las personas si no se han tenido en cuenta las heterogéneas necesidades de la población, poniendo en primer plano los requerimientos del trabajo reproductivo. Por eso, pensar el espacio urbano para todos y para todas es hacerlo desde la diferencia pero no desde la desigualdad: una diferencia entre hombres y mujeres, entre clases, entre orígenes, culturas, religiones, etc. posicionando en igualdad de condiciones todas las demandas, sin decisiones a priori, que excluyan la experiencia de las personas como fuente fundamental de conocimiento en las deciciones urbanas.

\section{Referencias bibliográficas}

AAVV; La Carta Europea de la Mujer en la Ciudad, Bruselas (Bèlgica). Experiència seleccionada en el Concurso de Buenas Prácticas patrocinado por Dubai en 1996.

AAVV; Urbanisme i gènere. Una visió necessària per a tothom. Barcelona, DIBA, Xarxa de Municipis, 2006.

AAVV; Manual práctico para una señalización urbana igualitaria. Sexismo en la señalización. FEMP, Federación Española de Municipios y Provincia Ministerio de Igualdad.

BOFILL LEVI, Anna; Guia per al planejament urbanístic i l'ordenació urbanística amb la incorporació de criteris de gènere. Col•lecció Eines $n^{\circ} 11$. Barcelona, Generalitat de Catalunya, Institut Catalá de les Dones, Departament de Política Territorial i Obres Públiques, 2008.

Bofill LeVI, Anna; Planejament urbanístic, espais urbans i espais interiors des de la perspectiva de les dones. Quaderns de l'Institut / 6. Barcelona, Generalitat de Catalunya, Institut Catalá de les Dones, Departament de Política Territorial i Obres Públiques, 2005.

BоотH, Christine; «La participación de las mujeres en la planificación y el desarrollo urbanístico», en las jornadas del País Vascó organizado por la Diputación Foral de Bizkaia, gabinete del Diputado General. 2005. 
Carrasco, Cristina i Serrano, Mònica; Compte satèl $\bullet$ lit de la producció domèstica (CSPD) de les llars de Catalunya 2001, col•lecció Estudi 1, Institut Català de les Dones, Generalitat de Catalunya, octubre del 2006.

CRUELls, Eva y PARICIO, Anna; La ciutat possible i desitjada per les dones: recercaper un diseny i planifi cació urbanística des d'una perspectiva de gènere. Investigación para la Diputación de Barcelona, Barcelona, 2007.

FAinstein, Susan y Servon, Lisa (ed); Gender and Planning: A Reader. Journal of the AmericanPlanning Association, 2007.

GREED, Clara; «Genero y planificación del territorio. ¿Un mismo tema?» en el Fórum internacional de planificación del territorio desde una perpectiva de género, organizado por la Fundació Aurèlia Campany, 17 de noviembre de 1997.

JACOBS, Jane; Muerte y Vida de las grandes ciudades. Barcelona: Ed. 62, 1967.

LIENAS, Gemma; El diari lila de la Carlota. Barcelona: Editorial Empuries, 2001.

Miralles-Guasch, Carme; Dones, mobilitat, temps i ciutats, col-lecció Quaderns de l'Institut 14, perspectives des del feminisme, Institut Català de les Dones, Barcelona, juny 2010.

MuXí MARTINEZ, Zaida y COL.LECTIU PUNT 6; Recomanacions per la implementació de expediente U-62/06. Convenio de colaboración con la Universitat Politècnica de Catalunya grupo de investigación I-00868. 2006-2007.<www. punt6.net>.

Muxí MARTíneZ, Zaida; de «Barris per a viure» en Nous Horintzons. Els barris invisibles $n^{\circ} 195$, editada per la Fundació Nous Horitzons, Barcelona, 2009.

MUXí MARTíNEZ, Zaida; de «Infraestructures socials i de proximitat, equipaments per a la vida quotidiana» en la revista Quaderns d'Acció Social i Ciutadania. Revista d’informació, anàlisi i investigació socials. Generalitat de Catalunya. Departament d'Acció Social i Ciutadania, n³. Barcelona (2008) pp. 60-62.

Muxí Martínez, Zaida; de «Ciudad Pròxima. Urbanismo sin Género.» a la Revista Ingeniería y Territorio $n^{\circ} 75,2006$. Revista del Colegio de Ingenieros de Caminos, Canales y Puertos, Barcelona.

Muxí MARTíneZ, Zaida; «Decir la ciudad desde la experiencia» en la revista Arquitectos, Construcción de la ciudad, $n^{\circ} 2$, 2006. Revista de información del Consejo Superior de los Colegios de Arquitectos de España. Madrid.

Muxí MARTíneZ, Zaida; de «El espacio no es neutro: reflexiones en torno al derecho a la vivienda y la ciudad desde una perspectiva de género» en Boletín Derecho por el derecho a la vivienda y contra los desalojos. Diciembre 2008 - enero 2009.

MuXí MARTínEZ, Zaida; Urbanisme i Génere. El paper de les Dones en la configuració de la ciutat. De Dossier en Femení del programa municipal de la Dona de l'ajuntament de l'Hospitalet, Hospitalet del Llobregat, 2008. 
Muxí MartíneZ, Zaida; «Ciutat Próxima. Una crítica feminista a la ciutat global» en el llibre Sota les Llambordes, la platja, de José Miguel G.Cortés, editen H. Associació per a les Arts Contemporánies y Eumo editorial, Vic, Barcelona.

PRATS FERRET, María; Geografía feminista i metodología: Reflexió sobre un procès d'aprentatge paral.lel Cuadernos de Geografia no 64, pag 313-323, Valencia 1998.

RAINERO, Liliana y RODIGOU, Maite; Indicadores urbanos de género. Instrumentos para la gobernabilidad urbana. Córdoba Argentina CICSA, 2001.

RODRIGUEZ AlCAZAR, Javier; Esencialismo y neutralidad científicas en el libro Ciencia, Tecnología y Sociedad. Contribuciones para una cultura de la paz (ed: Rodríguez Alcázar, Medina Doménech y Sánchez Cazorla) pp. 49-84, 1997.

SÁNCHEZ DE MADARIAGA, Inés; Urbanismo con prespectiva de género, Ed. Junta de Andalucía, Instituto Andaluz de la Mujer.

SOLSONA, Glòria; Introducció a la perspectiva de gènere en els procesos de participacióciutadana. Diputació de Barcelona, Barcelona, 2007.

VAlles, Miguel; Técnicas cualitativas de investigación social. Reflexión metodológica y práctica profesional. Madrid Editorial Síntesis, 1999.

VelázQuez, Isabela, Gea 21; Instrumentos, métodos y técnicas para la participación. Presentación Flor de Maig 2005.

WOMEN'S DESIGN SERVICE en colaboración con ANNE THORNE ARCHITECT'S PARTNETSHIP; What to Do About Women's safety in Parks. From A to Y. London: Women's Design Services, 2007.

Pàginas webs:

www.punt6.net

www.diba.cat/dretshumans

www.gencat.cat/icdona/

www.wds.org.uk/

www.habitat.aq.upm.es/boletin/n7

www.generourban.org

www.lamujerconstruye.org

www.redmujer.org.ar

www.mujeresyciudades.org 



\title{
LA LEY DE BARRIOS EN CATALUÑA: \\ LA PERSPECTIVA DE GÉNERO COMO HERRAMIENTA DE PLANIFICACIÓN
}

\author{
ZAida MuXí Martínez y AdRiana CiOCOletTo \\ Universidad Politécnica de Cataluña
}

Recibido 09/02/2011

Aceptado 20/05/2011

\section{Resumen}

La Ley catalana 2 / 2004, de mejora de barrios, áreas urbanas y villas que requieren atención especial, ha sido una herramienta que permite comenzar a desarrollar un urbanismo con perspectiva de género. El punto 6 de la ley se refiere a la aplicación de la igualdad de oportunidades en el uso del espacio público y los equipamientos en la renovación urbana. Un análisis comparativo de una selección de las propuestas presentadas hasta la fecha, y un análisis in situ de los proyectos ya terminados permitirá obtener la evolución de la aplicación de la perspectiva de género en la planificación urbana. En resumen, esta investigación podría ser la oportunidad para revisar lo que se ha hecho y cómo, dando como resultado nuevas recomendaciones para las intervenciones junto a la aplicación de la perspectiva de género en la planificación urbana.

Palabras claves: Renovación Urbana. Perspectiva de género. Barrios. Vida cotidiana. Urbanismo Catalán. 


\begin{abstract}
The Catalonian Law 2 / 2004, improvement for districts, urban areas and villages that require special attention, has been a leading tool to start developing an urban planning with a gender perspective. The point 6 of the law is about the promotion of equal opportunities in the use of public facilities and public spaces by the means of urban renovation. A comparative analysis of a selection of the proposals submitted so far, and an on-site analysis of the projects already completed will permit to draw the evolution of the application of gender perspective on urban planning. Summing up, this research could be the opportunity to review what has been done and how, giving as result new recommendations for next interventions to be applying the gender perspective in urban planning.
\end{abstract}

Keywords: Urban renewall. Gender perspective. Neighbourhoods. Everyday life. Catalonian urbanism. 


\section{Introducción}

El siguiente artículo es parte del resultado del trabajo de investigación Recomendaciones para la aplicación de políticas de género en el urbanismo ${ }^{1}$, dentro del cual se realizaron estudios de casos, análisis bibliográfico y observación de la realidad para elaborar un documento de recomendaciones sobre el tema.

La ley 2/2004 del 4 de junio, es una ley autonómica aprobada por la Generalitat de Cataluña que tiene por objetivo intervenir en las mejoras de barrios, áreas urbanas y villas que requieren atención especial. La idea de esta ley, dotada económicamente en cada legislatura, es que cada ciudad determine los barrios que necesitan ser mejorados con el fin de evitar su progresiva guetización. La ley establece una serie de parámetros y criterios sociales, económicos, y físicos que se comparan localmente, permitiendo detectar estos barrios y justificar los proyectos que se presentan para optar a la subvención del 50\% del gasto total, que se cubre por el gobierno autonómico y que se han de desarrollar en cuatro años. Según la Ley, el barrio elegido ha de pertenecer a alguno de los tres tipos de tejido urbano determinados como áreas prioritarias de financiación: Áreas viejas y núcleos antiguos, Polígonos de viviendas y Áreas de urbanización marginal.

Los proyectos presentados deben incluir actuaciones en ocho campos, que serán verificados con un sistema de indicadores que se revisan y mejoran en cada convocatoria. Los puntos o campos de actuación propuestos por la ley son:

1. Mejora del espacio público y dotación de espacios verdes.

2. Rehabilitación y equipamientos de los elementos colectivos de los edificios

3. Provisión de equipamientos para el uso colectivo

4. Incorporación de las tecnologías de la información en los edificios

1. MuXí MarTineZ, Zaida (investigadora principal) Recomanacions per la implementació de polítiques de gènere al urbanisme. Entidad financiadora: Institut Català de les Dones, expediente U-62/06. Convenio de colaboración con la Universitat Politècnica de Catalunya grupo de investigación I-00868. 2006-2007. 
5. Fomento de la sostenibilidad del desarrollo urbano

6. Equidad de género en el uso del espacio urbano y de los equipamientos

7. Desarrollo de programas que comporten una mejora social, urbanística y económica del barrio

8. La accesibilidad y la supresión de barreras arquitectónicas

Una de las aportaciones más innovadoras de esta Ley es la incorporación de la perspectiva de género en una ley de rehabilitación urbana. El campo 6 establece la «equidad de género en el uso del espacio urbano y los equipamientos» como uno de los campos financiables que deben estar contemplados dentro de los proyectos de reforma urbana presentados por los ayuntamientos catalanes.

Para determinar si un área es de atención especial se utilizan cuatro series de parámetros o criterios que demuestran que está afectada por procesos de regresión urbanística y déficit de equipamientos y servicios; que sufre problemas demográficos; que hay problemas económicos, sociales o medioambientales y que sufren un déficit social y urbano. Quedando demostrados los criterios comparativamente con la ciudad en la que se halla, es decir, que no son parámetros absolutos sino relativos a cada situación urbana en particular.

La forma de presentación de los proyectos, incluye dos partes principales: una memoria diagnosis de la situación urbanística y estado de ejecución del planeamiento vigente y otra de la situación socioeconómica.

Para la redacción de los proyectos se cuenta con un manual orientativo para la redacción y elaboración de las propuestas según los 8 campos, que se revisa cada año mejorando y actualizando la información. La retroalimentación del conocimiento, de la teoría a la práctica, es otra de las características singulares de la gestión de la Ley con lo cual se está configurando un bagaje abierto y compartido de conocimiento.

Como en toda ley no es menor el contexto político en que es redactada, y en este caso merece que sea explicado. En el año 2004 el Gobierno autonómico es una coalición entre tres fuerzas políticas progresistas y en el cual el Instituto Catalán de las Mujeres (Institut Català de les Dones - ICD) depende directamente de la presidencia. Esta situación en el organigrama político generó una transversalidad de la cuestión de género en todas las políticas públicas. La transversalidad es una herramienta fundamental, imprescindible, para actuar con perspectiva de género, ya que significa entre otras cosas que no se considere a las mujeres como una minoría y un problema, sino como parte imprescindible y constitutiva de la sociedad y que para ello es necesario un redireccionamiento de los sistemas de pensamiento y actuación vigente que se 
basan en una neutralidad abstracta que corresponde a la experiencia y el pensamiento exclusivamente masculino. Por ello el hecho que el ICD dependiera de presidencia les permitió a las cuatro directoras ser parte activa del gobierno en todos los ámbitos, interviniendo y aportando desde la perspectiva de las mujeres saberes y conocimientos. En estas intervenciones está incluida la Ley de Barrios que aquí analizamos.

\subsection{Aplicación de la perspectiva de género en el proyecto urbano}

Es necesaria una mirada próxima y compleja sobre el espacio urbano, es decir, un planeamiento sin simplificación, en el que se hagan lecturas y análisis en diferentes escalas. Se trata de considerar las necesidades del mundo reproductivo de igual manera que las necesidades del mundo productivo. Se trata de equiparar las dos esferas poniéndolas en igualdad de valoración. El no tener en cuenta, como hasta ahora, las necesidades derivadas de las tareas asignadas al género femenino genera una descompensación de oportunidades y obligaciones que penaliza especialmente a las mujeres y a las personas dependientes como son las criaturas, las personas mayores o con falta de autonomía.

Para revertir esta situación es fundamental incorporar la participación de las mujeres en los procesos de reconocimiento, conocimiento y mejora de barrios, de manera que esta participación nos permita extraer de sus experiencias, derivadas del rol asignado cultural y tradicionalmente, un conocimiento directo de las realidades urbanas. Las mujeres somos las principales usuarias, disfrutadoras y sufridoras del espacio público y los equipamientos y en general en al cuidado de otros y otras.

La multiplicidad de actividades que llevamos a cabo y de las que somos responsables nos lleva a realizar recorridos de máximo aprovechamiento. Las mujeres realizamos una gestión del tiempo de máxima eficacia y para que esto sea posible se necesitan espacios urbanos complejos, que combinen usos (compras-escuelas-actividades cívicas y administrativas, etc.) al mismo tiempo que estén conectados con otras áreas de la ciudad por servicios de transporte público eficientes y variados.

El espacio público es el espacio conector de actividades dónde de forma individual o colectiva desarrollamos nuestra vida cotidiana y establecemos vínculos sociales y culturales. Por esto, desde una visión de género, el espacio público no es entendido como un espacio meramente funcional sino, como un espacio de experiencias vitales y por esto debe garantizar la igualdad de oportunidades y la equidad de usos. En este sentido, se deben procurar los usos mixtos que le den actividad, una movilidad sostenible que valore la proximidad y que priorice los desplazamientos peatonales, una accesibilidad 
sin discriminación, una percepción positiva de seguridad y una relación activa y entretejida con equipamientos, comercios y edificios en general. Como espacio de la memoria e identidad social, debe ser referente de las mujeres, reconociendo su protagonismo en la historia del barrio, pueblo o ciudad que en general es inexistente en los nomencladores de calles actuales.

Para equilibrar las responsabilidades, organizar las tareas reproductivas asignadas a cada género y proporcionar igualdad de oportunidades a mujeres y hombres, los equipamientos han de incorporar el «concepto de infraestructuras para la vida cotidiana» aportando nuevos espacios de actividades o equipamientos conforme la sociedad evoluciona. Una reflexión en torno a las experiencias diversas que se dan en la ciudad contemporánea, amplia el listado de necesidades, verifica que el espacio físico de los equipamientos debe proponer ámbitos para intercambiar, compartir, apoyar, integrar... y plantear «el tiempo de uso» como determinante para favorecer el acceso y la participación.

\subsection{Análisis de casos dentro de la ley}

En el contexto de esta ley nos interesa analizar qué ha significado, qué significa y puede significar el campo 6, equidad de género en el uso del espacio urbano y de los equipamientos, en los planteamientos de reformas urbanas, y de manera más amplia que significa la perspectiva de género aplicada al proyecto urbano.

Como hemos dicho el punto 6 es una aportación innovadora, que generó y genera no pocas dudas. Por ello a partir de las experiencias cada año se revisa y mejora el Manual para la elaboración de los proyectos de intervención integral en los barrios y áreas urbanas de atención especial y para la elaboración del informe de evaluación final que es una herramienta de gran ayuda dada la dificultad que presentan los ayuntamientos para realizar propuestas en este punto en concreto.

En las diferentes convocatorias se puede observar cómo han evolucionado las propuestas, cómo algunos equipos técnicos han adquirido nuevos conocimientos y han incorporado el género como herramienta de análisis y proyecto. Aún queda mucho por andar, pero los ejemplos que aquí analizaremos enseñan diferentes maneras de abordar un proyecto urbano con perspectiva de género.

En los primeros años de la convocatoria, la mayoría de actuaciones quedó acotada a las siguientes propuestas:

1. Actividades sociales: Talleres y campañas de concientización sobre el tema género. Mujeres inmigrantes e integración. 
2. Equipamientos para realizar las actividades anteriores.

3. Seguridad. Se refiere en su mayoría a mejorar la iluminación en zonas oscuras del espacio público.

La ampliación de los conocimientos y las mejoras en la aplicación de criterios de género en los proyectos han sido y son posibles gracias al soporte que las distintas administraciones (Generalitat, Diputación de Barcelona y Ayuntamientos) han dado a los trabajos de investigación de técnicas y técnicos, a la organización de jornadas, a la publicación de bibliografías y a la realización de cursos de formación técnica y ciudadana.

No es posible hoy día, febrero 2011, realizar una evaluación completa de los resultados de aplicación de estos criterios ya que de los 148 proyectos financiados por la Ley de barrios son pocos los que han finalizado de manera completa sus proyectos. Si bien en muchos de los barrios de la primera y segunda convocatoria se puede ya analizar provisionalmente la aplicación de la ley como por ejemplo, el Barrio de Santa Caterina en Barcelona y Can Anglada en Terrassa. También podemos comprobar que dentro de las últimas propuestas presentadas se intenta trabajar con mayor transversalidad aplicando los criterios de género en forma integral dentro del proyecto de reforma urbana.

Proponemos un análisis de tres casos desde la perspectiva de género en los que buscamos verificar si la aplicación del campo 6 mejora el espacio público y los equipamientos para la igualdad de género, y en un análisis transversal comprobar si las actuaciones en otros campos también se realizan desde la perspectiva de género. Los casos que hemos seleccionado para analizar plantean, de manera diferente a otros proyectos, la incorporación de la participación social como herramienta en el desarrollo del proyecto urbano.

\section{Estudio de casos}

\subsection{Barrio Collblanc / Torrassa, L'Hospitalet de Llobregat - (2004-2008)}

El barrio de Collblanc-Torrassa pertenece a la tipología de centro histórico, con alta densidad residencial de las décadas de los 50 s y 60s. Además de la falta de calidad de muchos de los edificios, la estrechez de las calles dificulta la movilidad interna y condiciona la calidad de los espacios públicos.

El «Proyecto equidad de género», impulsado por el Programa Municipal para la Mujer, es una propuesta que se ha planteado desde el área de políticas sociales con la intención que este programa sea la herramienta que permita la inclusión de los temas sociales y la perspectiva de género en los proyectos urbanos. Por ello se trabajó en fortalecer el tejido social a través del intercambio 
y el conocimiento mútuo. Uno de los primeros objetivos esenciales fue la creación de una asociación de mujeres del barrio, que a diferencia de otros barrios aquí no existía previamente.

La propuesta engloba seis programas de actuación:

- Coha: Servicio de intermediación para compartir vivienda

- Apropar (acercar): Participación social de mujeres inmigrantes

- Bellugant-nos (movernos): Actividad física y convivencia intercultural

- Participa: Potenciar la creación de una asociación de mujeres en el barrio

- Xarxa de dones (red de mujeres): Participación de mujeres del barrio en el proceso de planificación desde la perspectiva de género

- Estudi de mobilitat (estudio de movilidad): Movilidad adaptada a las necesidades de la vida cotidiana

Como característica del tejido social, el barrio está compuesto por aproximadamente un 30\% de su población de origen extracomunitario, consolidada en los últimos 6 años. Esto provoca en muchos casos problemas de convivencia en el uso de los espacios públicos, fundamentalmente por el desconocimiento y el temor al otro.

La percepción de la seguridad de las mujeres esta muy influida por este fenómeno. El centro de atención e información para la mujer, dentro del cual se encuentra el Proyecto de equidad de género, trabaja para promover el conocimiento entre las diferentes culturas y mejorar la convivencia.

A partir de este programa y con la asociación de mujeres formada, se ha realizado un informe sobre la percepción y demandas de mejoras de los espacios públicos, que se ha presentado al ayuntamiento para su consideración, del que destacan:

Mejora de los espacios públicos:

- Plantar árboles, situar bancos bajo la sombra de árboles y mejorar las zonas verdes existentes (Pl. Guernica)

- Percepción de inseguridad (Parc de la Marquesa)

- Limpieza en el barrio: ampliar la limpieza a todas las calles, no sólo a las principales.

Valoración de espacios para la práctica deportiva:

- Actualmente son insuficientes, debido cantidad de población y a la extensión territorial del distrito. 
- Abrir las instalaciones escolares para toda la población fuera del horario escolar, sin perder de vista la posibilidad, a más largo término, de construir instalaciones deportivas apropiadas.

- Proveer de servicio de guarderías o ludotecas en los equipamientos deportivos, para facilitar el acceso a la práctica deportiva de las mujeres con criaturas.

Local más adecuado para el grupo de mujeres: contar con un espacio céntrico y visible a los ojos de la ciudadanía, abierto al exterior, con la ventilación y la luz que actualmente no disponen.

El estudio de movilidad posiblemente sea el más próximo al proyecto urbanístico concreto. Realizado por el IERMB (Institut d'Estudis Regionals i Metropolitans de Barcelona) dirigido por Carme Miralles-Guash, con la colaboración de las investigadoras Gemma Solé Masó y Angel Cebollada Frontera. El trabajo, además del estudio sobre usos y percepción del espacio público y estrategias de movilidad, formula once propuestas de actuación, entre ellas:

- Garantizar la seguridad del espacio público con la presencia de la gente en la calle

- Políticas de prevención para evitar focos de inseguridad.

- En el diseño de los espacios públicos evitar zonas escondidas fuera de la vista de las personas y espacios generadores de inseguridad.

- Adaptar y ampliar los servicios públicos a las necesidades de la población actual.

- Elaborar el Plan de Movilidad Urbana con la máxima participación ciudadana.

- Mejorar la seguridad en estaciones de metro y vagones.

- Ampliar aceras, colocar barandillas en las calles y garantizar la iluminación y visibilidad.

Algunos aspectos como resultados de los criterios anteriores se pueden ver en el diseño de las calles que forman parte de la red de equipamientos y comercios donde se prioriza la movilidad peatonal y en la reforma del Parc de La Marquesa, donde se han instalado juegos para distintas edades y la instalación de un nuevo equipamiento cultural, en el centro del mismo, que le da vida al parque a distintas horas.

Dentro del proyecto de equidad de género se realizaron talleres participativos con mujeres del barrio para describir sus cotidianeidades y aportar conocimiento sobre el mismo desde la experiencia de las mujeres. Como derivado de esas sesiones se publicó el dossier Urbanismo y género, el papel de 

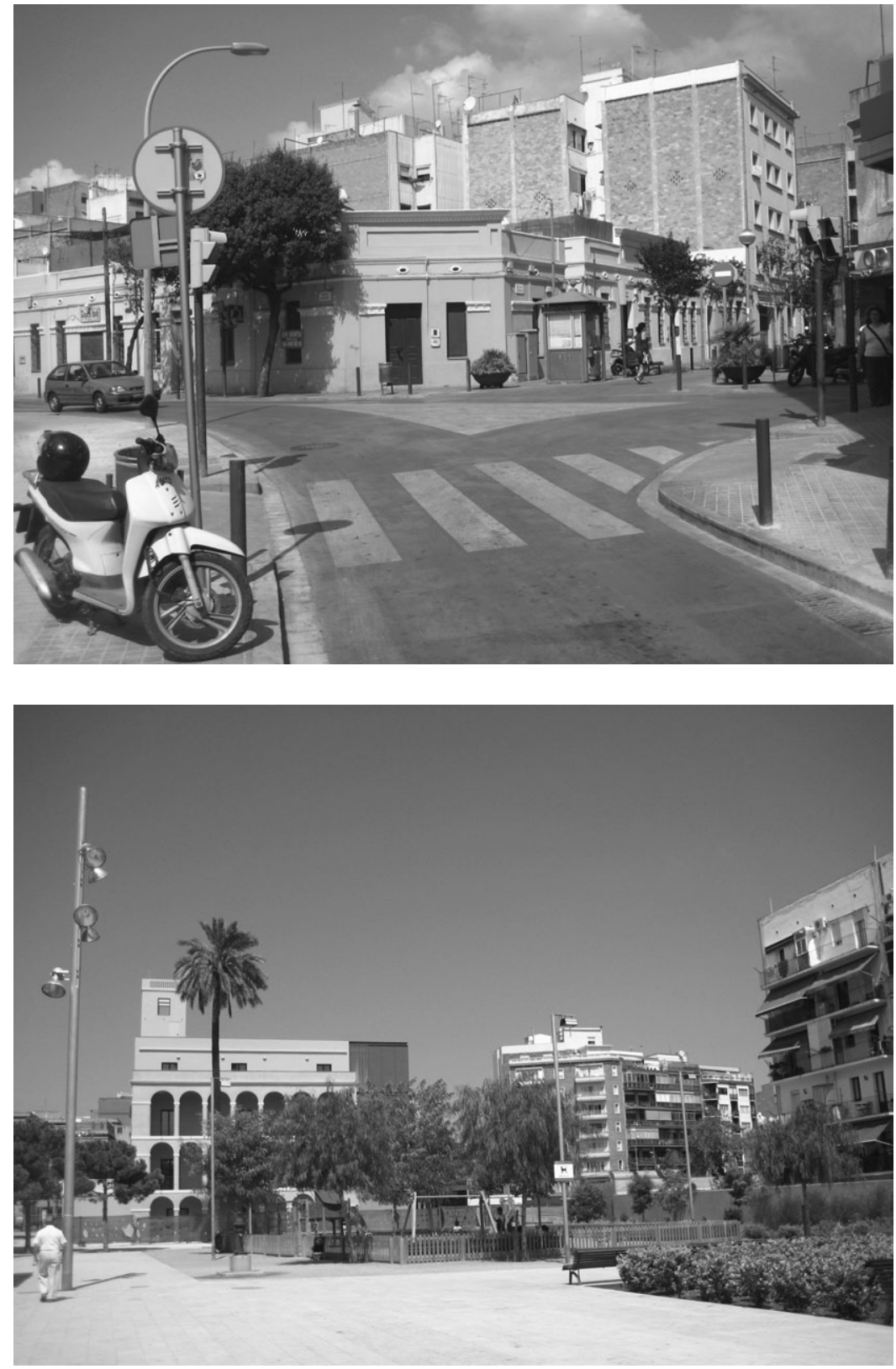

Feminismo/s 17, junio 2011, pp. 131-153 
las mujeres en la configuración de la ciudad² que tenía como objetivo acercar la reflexión urbana a todas las mujeres, ofreciendo una herramienta para la visibilización, información y capacitación técnica desde la perspectiva de género en el espacio urbano.

\subsection{Barrio de l'Erm, Manlleu - (2004-2008)}

La trama ortogonal con una sección de calle de gran amplitud y poca circulación vehicular es una de las características del barrio del Erm, en el municipio de Manlleu. A pesar de la gran amplitud de la calle, la distribución de aceras y calzada es desproporcionada, privilegiando el espacio vehicular. Otra característica del barrio, es la baja densidad y la sectorización de las tipologías edificatorias, las viviendas sociales en altura con espacios intermedios abandonados y viviendas unifamiliares en hilera. El barrio se encuentra rodeado por calles de mayor envergadura y de mucha afluencia vehicular que genera una frontera física con el resto de la ciudad.

La propuesta urbanística propone invertir radicalmente la relación de las calles-aceras favoreciendo el caminar y otros usos de los espacios públicos compartidos como el descanso y el encuentro, fomentando la vida en la calle.

La memoria del proyecto propone una visión de género integral y transversal que entrecruza cuatro temas principales: vivienda, equipamientos, espacio público y desarrollo socioeconómico.

La actuación en el barrio del Erm parte de la premisa de ser un laboratorio capaz de dar pautas para próximas rehabilitaciones del municipio, desde el comienzo se ha querido crear un proyecto muy conciente y enriquecedor, contando para ello con un equipo técnico experto en espacio público.

Para realizar la mejora del barrio se cuenta con la tutoría de equipos técnicos de la Diputación de Barcelona como soporte para los proyectos de la ley de barrios. Entre los materiales de difusión, información y formación de la Diputación de Barcelona se encuentra la Guía para el desarrollo de los proyectos de intervención integral en la que aparecen detalladamente los criterios de género a considerar en la realización de los proyectos arquitectónicos y urbanísticos.

Para una gestión más ágil, independiente y directa del proyecto urbanístico y del Plan de convivencia se ha creado el Instituto de desarrollo del Erm. De esta manera el proyecto de ejecución es el resultado del trabajo de un

2. MuXí MARTíneZ, Zaida en colaboración con COL·LECTIU PUNT 6; Urbanisme i Génere. El paper de les Dones en la configuració de la ciutat. De Dossier en Femení del programa municipal de la Dona de l'ajuntament de l'Hospitalet, Hospitalet del Llobregat, 2008. 
conjunto de expertos que suman sus experiencias y opiniones a las de las personas del barrio en un proceso de trabajo transversal.

De la propuesta urbanística destaca la visión integral de la remodelación en relación con el resto del municipio apostando claramente por los espacios públicos para la vida cotidiana de las personas definido en el documento «Estudio para la definición de criterios de urbanización en los procesos de renovación urbana».

El proyecto pone énfasis en las relaciones entre las calles y los edificios tanto públicos como de viviendas, haciendo un estudio y propuesta muy detallada de las tipologías de las calles del barrio. Se da mucha importancia a una clara diferenciación de las calles a través del carácter particular del diseño para identificarlas y que faciliten la orientación dentro del barrio.

\section{Los criterios de género específicamente detallados son:}

- En referencia a los espacios públicos la mejora de la movilidad, la accesibilidad y la permeabilidad. Prioridad peatonal y diseño de las aceras como espacio de encuentro. Rincones abiertos y sin obstáculos. Vegetación y mobiliario urbano que permita identificar las calles y que de esta manera ayude a reconocerlas y mejore la orientación de las personas. Espacios públicos con sol y sombra para distintos usos.

- En relación a las plantas bajas y los portales generar relaciones directas entre el espacio público y el espacio privado estudiando las secciones de calles y patios.

- Para mejorar la seguridad se propone eliminar barreras visuales y una iluminación estratégica diferenciando la de las calles y aceras, al tiempo que se potencia la actividad y la apropiación de la calle con el diseño del mobiliario.

Dentro de los proyectos ya ejecutados se encuentra una primera actuación en el colegio público Puig-Agut donde se ha eliminado el cerramiento perimetral formado por un muro y reemplazado por una reja. Esto ha permitido establecer una relación abierta entre el patio y el entorno como una manera de comenzar a concretar los criterios de permeabilidad, visibilidad y relación, ya que se ubica frente al mercado municipal del barrio.

Otro de los proyectos materializados dentro de los proyectos de espacios singulares, es la Plaza de San Antonio de Padua. La plaza ubicada entre dos bloques lineales de vivienda conformaba un patio con un gran desnivel hacia las calles por las cuales se accedía, generando escaleras y muretes que junto a la gran arboleda interior dificultaban uno de los objetivos generales de la 

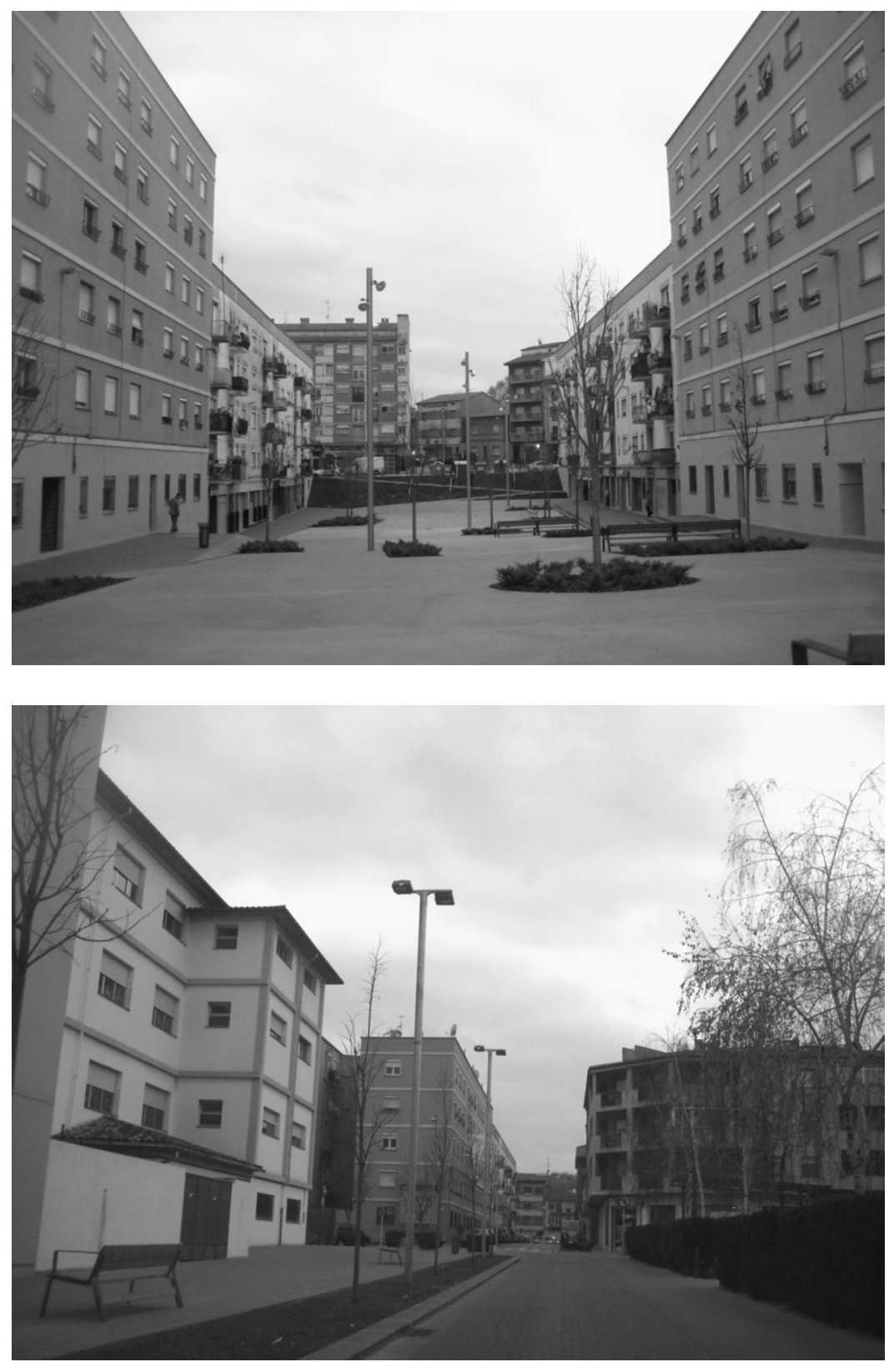

Feminismo/s 17, junio 2011, pp. 131-153 
remodelación que era la permeabilidad de los espacios públicos. Actualmente debido a la reforma, la plaza es un espacio con mucha visibilidad que facilita la accesibilidad al barrio y ha generado un espacio de relación más inclusivo ya que en general era utilizado mayormente por grupos de hombres.

Dentro de los proyectos generales está el cambio de secciones de calle las cuales algunas ya están ejecutadas favoreciendo la prioridad peatonal y el ensanchamiento de aceras con mobiliario e iluminación.

El programa social, «plan de convivencia», actúa paralelamente a la dinámica del proyecto urbano y está compuesto por cinco mesas de trabajo, fundamentalmente de educación, inclusión y participación ciudadana. Las mesas trabajan de forma interdisciplinaria y tienen la capacidad de interceder en las definiciones de los proyectos urbanísticos. Además, se mantiene constante diálogo con las personas del barrio sobre la evolución del proceso, que de esta manera está en constante replanteo y evaluación.

Uno de los trabajos realizados en el plan de convivencia es el sociograma del barrio que recoge la relación entre equipamientos, espacios públicos y usuarios. Esta información es una herramienta esencial para actuar en el espacio físico concretamente a través del conocimiento detallado de personas y dinámicas sociales.

\subsection{Barrio El Congost, Granollers - (2006-2010)}

El barrio del Congost en el municipio de Granollers provincia de Barcelona, se consolida en la década de los años 60 del siglo pasado con la llegada de la inmigración de otras zonas de España. Para dar respuesta a estas nuevas familias, se construyen masivamente viviendas públicas, muchas de ellas con una muy baja calidad constructiva y de habitabilidad. En la actualidad estas viviendas más deficientes están siendo habitadas por las nuevas familias inmigrantes, principalmente magrebíes y subsaharianas.

Otra de las características del barrio es su situación entre la margen del Río Congost y el trazado del ferrocarril, dificultando la relación y movilidad hacia los barrios vecinos. A esto se le agrega un gran déficit urbanístico por la falta o el mal estado de equipamientos y espacios públicos.

Dentro de los objetivos principales del proyecto de reforma se encuentra mejorar la accesibilidad general, los espacios públicos de relación y los equipamientos colectivos conjuntamente con programas sociales que favorezcan la inclusión, la convivencia y la igualdad de oportunidades. Además, se prevén programas de dinamización comercial para el fortalecimiento económico del barrio. 
En el caso del municipio de Granollers existe la regiduría de igualdad que es la encargada de llevar adelante el Plan para la igualdad de oportunidades. En el barrio del Congost, el plan es la herramienta utilizada para realizar diversas actividades para promover la participación del colectivo de mujeres, con el objetivo de que participen activamente en las mejoras urbanas en el marco de la aplicación del campo 6 de la ley de barrios.

Las actuaciones realizadas en orden cronológico fueron las siguientes:

- Diagnosis de género (datos segregados por sexo, edad y origen, elaboración de información cualitativa).

- Mesa de trabajo transversal: Presentación de informe impacto de género a todas las áreas implicadas en el proyecto de reforma del ayuntamiento.

- Formación de la comisión intercultural de mujeres del barrio del Congost: Grupos de discusión para detectar las necesidades de las mujeres del barrio (paralelamente al programa «Buen vecindario») y definir la estrategia y difusión del proceso de participación.

- Taller participativo «Las mujeres hacemos piña»: Organización de un encuentro para plantear problemáticas urbanísticas del barrio desde una perspectiva de género. Plenario y presentación de resultados ante el alcalde y la regiduría de igualdad.

- Devolución política (6 meses más tarde), con actuaciones en el territorio siguiendo criterios resultantes del taller participativo.

Para conocer la realidad multicultural de las mujeres del barrio fue necesario construir datos estadísticos por sexo, ya que como en la mayoría de los censos no estaban desglosados. Se trabajó con indicadores demográficos, socioeconómicos y de situación familiar. Esta informacion se completó con datos cualitativos obtenidos de entrevistas con distintos colectivos de mujeres ya agrupadas por nacionalidades (españolas, latinoamericanas, magrebies y subsaharianas), representantes de la escuela barrial y con personal técnico del ayuntamiento. Esta informacion permitió realizar un análisis previo con perspectiva de género.

Una primera aportación de las necesidades de las mujeres en relación a su experiencia cotidiana en el barrio surge del trabajo social realizado, por un lado los grupos de discusión interculturales, que crea la «Comisión intercultural de las mujeres del Congost» y por otro una primer experiencia de «Banco de tiempo».

La comisión trabajó conjuntamente con la regiduría en el plan de igualdad, estableciendo los criterios para realizar el taller participativo con el conjunto de mujeres del Congost. 


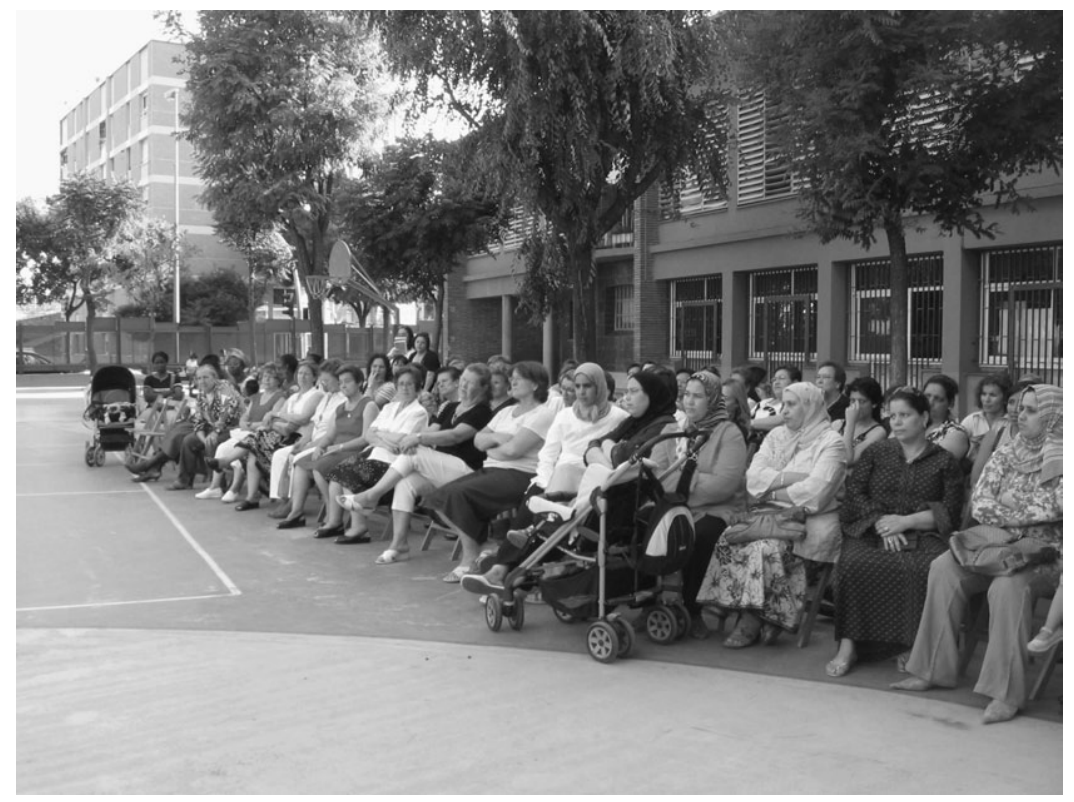

El primer encuentro «Las mujeres hacemos piña», consistió en una jornada intensiva donde asistieron un total de 99 mujeres acompañadas por 87 niñas y niños, para quienes se había previsto actividades y personal a cargo facilitando la participación de las madres. Del total de mujeres, 53\% pertenecían a Cataluña y resto de España, 23\% el Magreb, 17\% África Subsahariana y $7 \%$ Americana. ${ }^{3}$

El taller, dinamizado por el col-lectiu punt 6 , se centró en la problemática del urbanismo desde una perspectiva de género. El objetivo principal del taller fue ser capaces de nombrar, enumerar y argumentar la estructura de la vida cotidiana de las personas, hasta ahora infravalorada en el urbanismo como trabajo reproductivo ó como parte de un grupo minoritario de la población.

Como criterio de trabajo se visibilizó y reivindicó la experiencia de las mujeres como expertas cuando se habla de vida cotidiana en el entorno urbano, y en la necesidad de incluir este conocimiento empírico en el centro de

3. POLEO, Natàlia y SOLSONA, Glòria (2009) «La llei de barris: una oportunitat per avançar en la transversalitat de gènere i la participació de les dones. El cas del barri del Congost de Granollers» Col-lecció Grana número 26: Ciutats i Persones. Polítiques de gènere i participació ciutadana al món local Barcelona, Institut de Ciències Polítiques i Socials. 
las decisiones, de los procesos de diseño y de la planificación de las ciudades y del territorio.

De manera de poder profundizar en el análisis y sistematizar la información se realizaron grupos de discusión dinamizados que trabajaron en cuatro talleres temáticos: espacios públicos, seguridad, movilidad, y equipamientos públicos además de un taller-recorrido fotográfico de reconocimiento y valoración del barrio.

Algunos de los resultados elaborados con una lectura transversal entre sí reflejan la siguiente problemática:

- La plaza de la Libertad y su entorno fueron los espacios detectados como más problemáticos. La plaza por su diseño poco accesible y sobretodo los muros que segregan sectores y facilita la apropiación de algunos grupos de la población (hombres jóvenes) en detrimento de otros (mujeres e infantes). A las calles del entorno les falta mantenimiento, limpieza, iluminación adecuada, mobiliario y los árboles están deteriorados por incivismo.

- La percepción de inseguridad, además de lo comentado en el caso de la Plaza de la Libertad existe por la apropiación de los espacios públicos por grupos que se dedican a algunas actividades ilegales, edificios con viviendas vacías, el paso debajo del tren peligroso (túnel) al cual le falta iluminación y visibilidad.

- Los problemas de accesibilidad y movilidad son generalidades en todo el barrio con aceras y calles en mal estado; falta de rampas; paso de peatones no respetado; exceso de velocidad; falta transporte público hacia algunas zonas de concentración de trabajo; falta de carriles para bicicletas; falta de información en las paradas de autobuses. Esta problemática es más percibida en el entorno del colegio debido al uso de muchas familias del barrio.

- Los equipamientos reclamados fueron un pabellón deportivo, que existe pero está cerrado y en mal estado; la falta de espacio para que la juventud juegue al básquet $u$ otros deportes y la falta de una guardería municipal.

Actualmente entre las obras de mejora realizadas se encuentran:

- La mejora general de los espacios públicos atendiendo a los criterios de iluminación, visibilidad y accesibilidad destacando el entorno a la plaza de la libertad, acceso al colegio, a la estación de tren de cercanías y al túnel bajos las vías. 


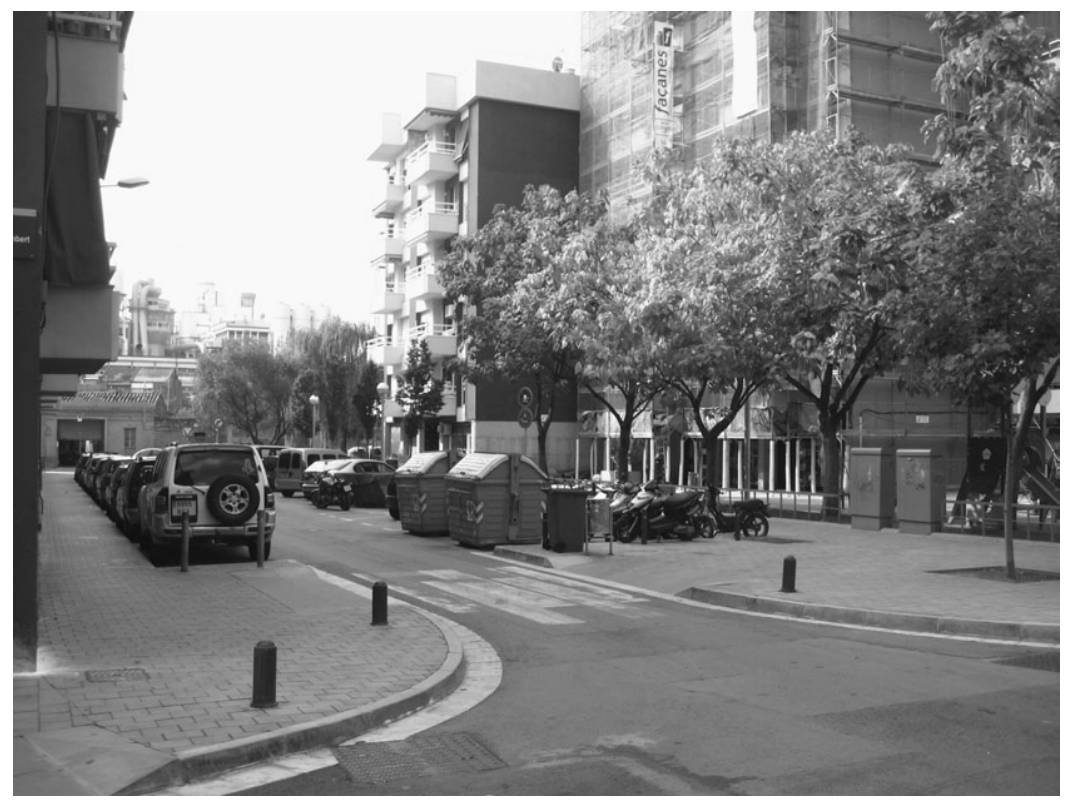

- La reforma de la Plaza de la Libertad atendiendo a los criterios de visibilidad y accesibilidad habiendo eliminado muretes y elementos que sectorizaban el uso de la plaza. Actualmente es un espacio compartido entre distintos colectivos del barrio principalmente para actividades de juegos infantiles de distintas edades y el descanso.

- La rehabilitación del equipamiento polideportivo además de revitalizar su uso anterior será un equipamiento con actividades sociales y culturales donde se mezclarán los distintos colectivos del barrio.

- La nueva guardería municipal ubicada frente al colegio completa la red de equipamientos reclamados por las mujeres.

- La reforma de la plaza de la Iglesia, abrió un nuevo espacio en relación al colegio y la guardería municipales además de mejorar la llegada a estos dos equipamientos desde otras zonas del barrio.

\section{Conclusiones sobre los proyectos analizados}

En los tres ejemplos estudiados aparece una combinación indispensable de programas de cohesión social paralelamente, aunque comenzado con anterioridad, al proyecto urbanístico. 

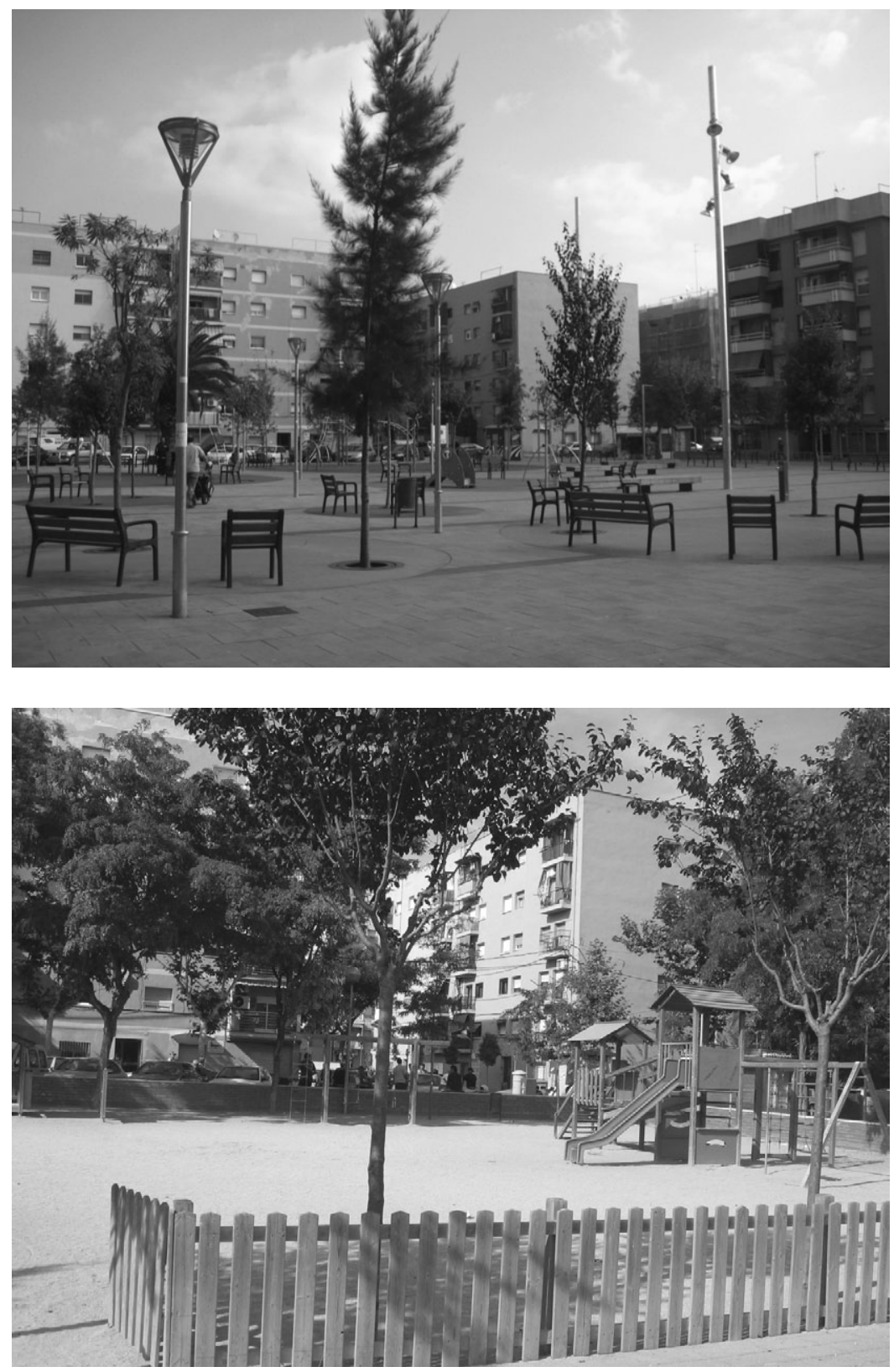

Feminismo/s 17, junio 2011, pp. 131-153 
Los programas sociales han avanzado formando o reforzando el tejido social que luego ha participado en la modificación de su propio entorno cotidiano. Debemos tener en cuenta que si bien todas las personas tenemos un conocimiento empírico de los espacios públicos, es necesario enseñar a participar y a valorar la experiencia cotidiana como conocimiento de una realidad determinada. La falta de visión integral entre los aspectos sociales y espaciales o urbanos, si es que se pueden separar, empobrecen los proyectos y les quita legitimidad.

En cuanto al campo 6 específicamente nos encontramos con un abanico muy diverso de metodologías para integrar a las mujeres de los barrios en la vida cívica y participativa, y, especialmente, para reforzar las redes de conocimiento y solidaridad entre ellas, asi como desvelar el valor de su experiencia como saber urbano.

Si bien las ejemplos analizados en mayor o menor medida integran a las mujeres en aspectos más directos del proyecto urbano, en un análisis más general de los barrios presentados hasta la convocatoria del año 2009, en su mayoría han entendido la participación de las mujeres y la perspectiva de género aplicados al proyecto urbano como cuestiones de integración social, de incorporar actividades lúdicas y formativas de «mujeres» (cursos de cocina, tejidos...) y de, en el mejor de los casos, construir un equipamiento para este fin. Actualmente, en la última convocatoria de la ley del año 2010, comienzan a aparecer propuestas más integrales como la transversalidad de género en el diseño, la ejecución y la evaluación de las actuaciones contenidas en los proyectos.

De lo analizado podemos extraer las siguientes consideraciones necesarias en relación al diseño de los espacios públicos, los equipamientos y la perspectiva de género:

- Realizar estudios detallados de las tipologías de calles que permiten realizar propuestas específicas no genéricas. En estos análisis es fundamental analizar las relaciones de permeabilidad que permiten las plantas bajas tanto en su diseño como por los usos que propone. Dar prioridad a las personas que van a pie, teniendo en cuenta que la unidad de trabajo es la barrial y que esta actuación tiene que reforzar la estructura interna. El espacio público se tiene que entender como espacio de relación, de encuentro.

- Integrar los equipamientos públicos a los espacios públicos de uso cotidiano. Permitir, por ejemplo, la permeabilidad visual de los patios de escuelas colabora en la seguridad en la calle, mejor rejas que muros 
ciegos. Generar ensanchamientos de acera en los accesos a los equipamientos públicos para generar espacios intermedios.

- Integrar los espacios con poca utilización o estancos a las redes de recorridos más utilizados. Reducir escaleras, desniveles y muretes que impidan la continuidad tanto de los peatones como de las visuales, garantizando todas las movilidades con la accesibilidad adecuada, con el uso intensivo y variado de los espacios públicos se consigue una percepción de seguridad.

- Integrar actividades diversas en los recorridos cotidianos de manera que el tiempo de los trayectos de desplazamiento sean utilitarios y seguros.

- Proyectar los equipamientos públicos teniendo máximas consideraciones a su permeabilidad visual y espacial con los espacios públicos circundantes.

- Hacer visibles las huellas que las actividades y las historias de las mujeres han dejado en la ciudad. Ya sea con la recuperación de espacios que antaño hubieran sido utilizados por las mujeres, como en muchos pueblos son los antiguos lavaderos, y también designar calles, plazas y equipamientos con nombres de mujeres.

En cuanto a la manera de analizar los barrios es imprescindible realizar estudios cualitativos con los que se obtiene información más detallada y sensible. Por ejemplo, formar grupos de trabajo integrado por vecinas del barrio capaces de evaluar el espacio público y los equipamientos de la red de usos cotidianos. Es fundamental incoporar estudios de la movilidad cotidiana que permitan saber como se utiliza el espacio público como conector de las diferentes actividades que las personas realizan.

Es importante tener en cuenta los datos estadísticos segregados por sexo además de edades y origenes e incoporar cuales son las cuestiones derivadas de la percepción de inseguridad que condicionan el libre movimiento de las mujeres por el barrio.

Incorporar la participación de las personas del barrio en las diferentes etapas del proyecto. El diagnóstico y diseño participativo son herramientas que pueden emplearse para conocer las dinámicas sociales del espacio público y para establecer criterios de diseño con las usuarias y usuarios. El programa de necesidades de los proyectos debería basarse en procesos de participación directa.

Incluirr la visión de los más pequeños, ya que junto a sus cuidadoras o cuidadores son de los que más utilizan el espacio público y necesitan consideraciones particulares y específicas. 
En relación a la gestión-coordinación, debe ser transversal y ágil, con un conocimiento directo del territorio en el que se trabaja para conocer las dinámicas sociales y la situación espacial existente. Muchas veces ni los conocimientos estadísticos, censales ni las planimetrías reflejan la complejidad de la realidad, especialmente los roles y usos diferenciados del espacio de los hombres y las mujeres.

El equipo técnico debe estar integrado por profesionales de diferentes disciplinas los cuales deben ser capaces de trabajar desde una perspectiva de género. Es indispensable el intercambio de conocimientos e información entre las diferentes áreas de actuación y que se articulen en una organización flexible que permita modificar rumbos o incorporar variaciones derivadas de la experiencia cotidiana en el lugar.

La evaluación del proyecto por parte del equipo técnico debe ser constante y también participada para construir un proceso vivo y no una fórmula cerrada.

La ley de barrios ha permitido la visibilización diferenciada de las necesidades de las mujeres en la ciudad y en los barrios. Aún falta para incorporar la cotidianeidad y las necesidades de la reproducción en igualdad de condiciones a aquellas derivadas de la producción, pero sin duda se ha iniciado un camino en el proyecto urbano que mejorará y cambiará las prioridades y proyectos urbanos futuros.

\section{Referencias bibliográficas}

AAVV;» La Carta Europea de la Mujer en la Ciudad, Bruselas» (Bèlgica). Experiència seleccionada en el Concurso de Buenas Prácticas patrocinado por Dubai en 1996.

AAVV; Urbanisme i gènere. Una visió necessària per a tothom. Barcelona, DIBA, Xarxa de Municipis, 2006.

BOFILl LeVI, Anna; Guia per al planejament urbanístic i l'ordenació urbanística amb la incorporació de criteris de gènere». Col•lecció Eines no 11 . Barcelona, Generalitat de Catalunya, Institut Catalá de les Dones, Departament de Política Territorial i Obres Públiques, 2008.

Bofill LeVI, Anna; Planejament urbanistic, espais urbans i espais interiors desde la perspectiva de les dones. Quaderns de l'Institut / 6. Barcelona, Generalitat de Catalunya, Institut Catalá de les Dones, Departament de Política Territorial i Obres Públiques, 2005.

Bоотн, Christine; «La participación de las mujeres en la planificación y el desarrollo urbanístico», en las jornadas del País Vasco organizado por la Diputación Foral de Bizkaia, gabinete del Diputado General. 
FAinstein, Susan y SERVON, Lisa (ed.); «Gender and Planning: A Reader. Journal of the American Planning Association, 2007.

GREED, Clara; «Genero y planificación del territorio. ¿Un mismo tema?» en el Fórum internacional de planificación del territorio desde una perpectiva de género, organizado por la Fundació Aurèlia Campany, 17 de noviembre de 1997.

Miralles-Guasch, Carme; Dones, mobilitat, temps i ciutats, col-lecció Quaderns de l'Institut 14, perspectives des del feminisme, Institut Català de les Dones, Barcelona, 2010.

MuXí MARTINEZ, Zaida (investigadora principal) Recomanacions per la implementació de polítiques de gènere al urbanisme. Entidad financiadora: Institut Català de les Dones, expediente U-62/06. Convenio de colaboración con la Universitat Politècnica de Catalunya grupo de investigación I-00868. 2006-2007.

MuXí MARTíNEZ, Zaida; «Barris per a viure» en Nous Horintzons. Els barris invisibles, $n^{\circ} 195$, editada per la Fundació Nous Horitzons, Barcelona, 2009.

MuXí MARTíNEZ, Zaida; «Infraestructures socials i de proximitat, equipaments per a la vida quotidiana» en la revista Quaderns d'Acció Social i Ciutadania. Revista d’informació, anàlisi i investigació socials, n³. Generalitat de Catalunya. Departament d'Acció Social i Ciutadania. Barcelona, (2008), pp. 60-62.

Muxí MartíneZ, Zaida; "Ciudad Pròxima. Urbanismo sin Género.» Revista Ingeniería y Territorio $\mathrm{n}^{\circ}$ 75, 2006. Revista del Colegio de Ingenieros de Caminos, Canales y Puertos, Barcelona.

Muxí MARTíneZ, Zaida; «Decir la ciudad desde la experiencia» Arquitectos, Construcción de la ciudad, n² 2, 2006. Revista de información del Consejo Superior de los Colegios de Arquitectos de España. Madrid.

MuXí MARTínEZ, Zaida; «El espacio no es neutro: reflexiones en torno al derecho a la vivienda y la ciudad desde una perspectiva de género» en Boletín Derecho a la vivienda y a la ciudad en América Latina, n 5. Editat per COHRE, 2008.

Muxí Martínez, Zaida; Urbanisme i Génere. El paper de les Dones en la confi-guració de la ciutat. De Dossier en Femení del programa municipal de la Dona del'ajuntament de l'Hospitalet, Hospitalet del Llobregat, 2008.

Muxí MARTíneZ, Zaida; «Ciutat Próxima. Una crítica feminista a la ciutat global» Sota les Llambordes, la platja, de José Miguel G.Cortés, editen H. Associació per a les Arts Contemporánies y Eumo editorial, Vic, Barcelona. 2008.

POLEO, Natàlia y SOLSONA, Glòria La llei de barris: una oportunitat per avançar en la transversalitat de gènere i la participació de les dones. El cas del barri del Congost de Granollers Col-lecció Grana número 26: Ciutats i Persones. Polítiques de gènere i participació ciutadana al món local. Barcelona, Institut de Ciències Polítiques i Socials.Barcelona, 2009.

SÁNCHEZ DE MADARIAGA, Inés; Urbanismo con prespectiva de género, Ed. Junta de Andalucía, Instituto Andaluz de la Mujer. (1998). 



\title{
CONSTRUYENDO UN LUGAR EN LA PROFESIÓN: TRAYECTORIAS DE LAS ARQUITECTAS ESPAÑOLAS
}

\author{
YOLANDA AGUDO ARROYO \\ Universidad Nacional de Educación a Distancia \\ INÉS SÁNCHEZ DE MADARIAGA \\ Escuela de Arquitectura de Madrid
}

Recibido 09/02/2011

Aceptado 20/05/2011

\section{Resumen}

Este artículo resume los resultados de una investigación empírica sobre la situación de las mujeres en la arquitectura española, a través del análisis de 21 entrevistas en profundidad a arquitectas de distintas generaciones - de 25 a 40 años, de 40 a 60, más de 60- y sectores de actividad -profesión liberal, administración pública, docencia universitaria, asalariadas. Esta muestra por edad es representativa de la experiencia de las mujeres en la arquitectura española porque menos de 10 mujeres se titularon como arquitectas antes de 1960. La información cualitativa obtenida de las entrevistas se pone en referencia con los datos estadísticos disponibles y con otros análisis cuantitativos ya existentes en la literatura. Se analizan así las pautas de acceso a la universidad y la experiencia en las aulas; la transición de la etapa formativa al empleo y los primeros pasos en el éste; la experiencia en el ejercicio de la profesión; el desarrollo profesional, en particular la asignación diferencial de roles profesionales, los problemas de invisibilidad y sobreesfuerzo, la promoción desigual, y la negación de la diferencia.

Palabras clave: mujeres arquitectas, formación, trayectoria, integración profesional, diferencias de género, España. 


\begin{abstract}
This article summarizes the results of an empirical research on the situation of women in Spanish architecture through the analysis of 21 in-depth interviews of women of different generations -from 25 to 40 years, 40 to 60, and over 60- and sectors of activity -private practice, public sector, university teaching, salaried personnel. This sample by age is highly representative of the experience of women in Spanish architecture because less than 10 women became architects before 1960. The qualitative information obtained is put in parallel with existing statistical information and other quantitative analyses already available in the literature. Themes covered include: patterns of access to the university and experience while students; transition from education to employment and early professional experiences; professional development, particularly, differential job assignments and roles, the problems of invisibility and excess of workload, unequal promotion and denial of difference.
\end{abstract}

Keywords: women architects, education, professional careers, gender differences, Spain 


\section{Introducción}

Este artículo recoge los principales resultados de una investigación empírica cualitativa sobre las carreras profesionales de las mujeres arquitectas españolas. Esta investigación se ha realizado en el marco más amplio de un proyecto sobre las mujeres en la arquitectura española que también cubre aspectos cuantitativos, a partir de los datos estadísticos disponibles, e históricos, a través de la investigación en archivos sobre la trayectoria de la primera arquitecta de nuestro país, Matilde Ucelay. ${ }^{1}$

El objetivo de esta parte empírica y cualitativa de la investigación es arrojar luz sobre la situación profesional de las mujeres en la arquitectura española, tanto en lo que se refiere a su integración horizontal, o cuantitativa, como a su integración vertical, o cualitativa, en la profesión. Para ello se han estudiado las trayectorias de tres generaciones de arquitectas.

El análisis se ha hecho a través de la exploración de las trayectorias y experiencias profesionales de arquitectas con edades comprendidas entre los 40 y 60 años (la segunda generación de arquitectas objeto de nuestro estudio), con el fin de identificar los obstáculos específicos del «techo de cristal» y/o el «suelo pegajoso» en la Arquitectura. La información obtenida de las entrevistas a las arquitectas en este segmento de edad resulta especialmente valiosa a la hora de conocer las claves de las trayectorias de mujeres profesionales en algunos casos con carreras bien consolidadas, que ocasionalmente han alcanzado el reconocimiento en sus respectivas áreas de actividad. En otros casos, sin embargo, se ha producido un práctico abandono de la profesión.

Por otro lado, se han analizado las pautas de integración profesional horizontal mediante el análisis de la experiencia laboral de una generación más joven (la tercera generación analizada): la de las arquitectas con edades

1. Proyecto de investigación CSO2008-05308-E/SOCI titulado Mujeres en la arquitectura española. De Matilde Ucelay a la primera promoción universitaria en paridad, Plan Nacional de I+D+i, Ministerio de Ciencia e Innovación. Investigadora principal Inés Sánchez de Madariaga. Sobre la trayectoria de Ucelay, véase SÁNCHEZ DE MADARIAGA, I. «Amigos del alma. Matilde Ucelay y Félix Candela. La incautación del Colegio de Madrid y la represión de los arquitectos durante el franquismo», en del Cueto Ruiz-Funes, J.-I. (ed.) Félix Candela 1910-2010, IVAM-SECC, Madrid, 2010, pp. 121-138. 
comprendidas entre los 25 y 40 años, que todavía se encuentran en período de acceso al empleo, las más jóvenes, o de consolidación profesional, las más mayores, y que, cuantitativamente, representan un porcentaje significativo del total de los arquitectos de su edad, a diferencia de las de la generación precedente.

Respecto a la otra generación de referencia, la de las primeras mujeres arquitectas en España, el objetivo ha sido el análisis de los discursos y testimonios de tituladas durante el período de 1940-1975, una masa crítica de mujeres que cuentan ahora con más de 60 años, y que representan un porcentaje muy pequeño entre los arquitectos de su edad.

En conjunto, la exploración de las condiciones de trabajo en estudios, empresas, Administración Pública y docencia universitaria, donde estas mujeres desarrollan la profesión, ha permitido alcanzar una visión amplia de las pautas de integración profesional de las distintas generaciones de arquitectas españolas, así como la identificación de los obstáculos a esa integración.

El trabajo empírico ha consistido en entrevistas en profundidad a arquitectas que reconstruyen la propia historia vital, personal y profesional. El diseño de la muestra ha sido abierto, orientado en función del criterio de saturación establecido por la redundancia de la información. Se han realizado un total de 21 entrevistas en profundidad, todas ellas grabadas y transcritas, que alcanzan una representación cualitativa de la población objeto de estudio mediante un criterio estructural de diferencia de casos y trayectorias ${ }^{2}$. La selección atendió, por un lado, a la edad-generación de referencia-y, por otro, al sector de la actividad donde las arquitectas desempeñan su profesión, contando con la debida heterogeneidad en cada uno de los colectivos entrevistados. Una vez establecidos los perfiles y tipologías de referencia y transcritas las entrevistas, se procedió al análisis en profundidad de las actitudes, opiniones y estrategias de acción desarrolladas por las distintas generaciones de arquitectas que constituyen estos colectivos, recogiendo pautas típicas de sus trayectorias en función de la edad, el sector profesional, el origen social y la motivación laboral, social o personal que ha entrañado la elección de la profesión. Los discursos recogidos revelan las distintas representaciones que las arquitectas españolas tienen hoy en día de sí mismas como mujeres profesionales.

2. Las entrevistas se han realizado entre el mes de diciembre del año 2009 y el mes abril del año 2010. La codificación de los relatos de entrevista de este artículo obedece a la siguiente correspondencia de actividad: As-Asalariada, U-Universidad, PL-Profesión Liberal y AAPP-Administración pública. Sobre el método de análisis empleado, AGUDO, Yolanda, 2008. 


\section{La formación: acceso a la universidad}

La incorporación de las mujeres a la arquitectura en España ha sido tardía y lenta en comparación con otros países europeos. La primera mujer arquitecta española, Matilde Ucelay, se tituló en 1936 en la Escuela de Madrid. Por entonces la universidad española, que sólo había abierto sus puertas a las mujeres en 1912, era un espacio netamente masculino. Pocas mujeres estudiaron en España antes de la guerra civil, y menos aún en las que entonces se denominaban escuelas especiales, como eran las escuelas de arquitectura y de ingeniería en la época. De hecho, junto a Ucelay, sólo otras tres mujeres estudiaban arquitectura en España antes de la guerra, todas ellas en Madrid: Lali Úrcola, que no terminó la carrera al casarse con un compañero, Cristina Gonzalo, titulada en 1940, y Rita Fernández-Queimadelos, en 1941.

En las dos décadas siguientes, sólo otras cinco mujeres estudiaron arquitectura: en 1945 se tituló Cruz López Muller, en 1949 Juana Ontañón, en 1956 Margarita Mendizábal, en 1957 María Eugenia Pérez Clemente, y, en 1958, Elena Arregui, todas ellas en Madrid. ${ }^{3}$ En estas dos décadas, la ideología dominante del Estado franquista, impulsada por la Sección Femenina de Falange y convertida en legislación abiertamente discriminatoria, alejó a las mujeres de los estudios y del mercado laboral, empujándolas a permanecer en sus casas, o, en todo caso, en ocupaciones de servicio y cuidado. En términos generales, en estos años las mujeres no estudiaban, ni tenían más expectativa que la de casarse, de modo que, salvo excepciones en mujeres procedentes de los reducidos ambientes más liberales de la época, las que estudiaron fueron pocas. Durante los años 60, con el desarrollismo, el número de universitarias se incrementó notablemente, pero las cifras siguieron siendo muy bajas. ${ }^{4}$ Las mujeres tituladas en arquitectura en la década de 1960, ahora ya también en la Escuela de Barcelona, donde la primera mujer se tituló en 1964, ronda la cuarentena.

...mi hermano sí estudió ingeniero de minas porque mis padres tenían clarísimo que el chico tenía que estudiar, entonces se pensaba que las mujeres se tenían que casar (AAPP, 64 años)

3. Datos extraídos de los listados de arquitectos españoles publicados anualmente por el COAM y la Hermandad de Arquitectos.

4. A las mujeres que por entonces accedían a la educación se las instruía en su mayoría como enfermeras, matronas o maestras, para que pudieran desempeñar labores de cuidado acordes a su condición femenina, como ampliación del trabajo doméstico. Según datos del Instituto Nacional de Estadística, en 1960-61 había 13.778 mujeres universitarias, cifra que se multiplica por cuatro, hasta alcanzar las 55.066, en el curso 1970-71. 
Esta situación cambió con la supresión progresiva de la legislación discriminatoria, la transformación de las mentalidades, y la llegada de la democracia a finales de la década de 1970, que favorecieron el acceso de las mujeres al empleo y a la vida pública del país, ejerciendo profesiones antes vedadas para ellas. ${ }^{5}$ A partir de la década de 1980 el crecimiento del número de mujeres estudiando en la universidad ha sido constante, de manera que las mujeres son hoy el $60 \%$ del alumnado universitario. En arquitectura, las mujeres han pasado de un escaso 15\% en 1980 a superar, por primera vez en 2007, el 50\% del alumnado matriculado en primer curso.

No disponemos de estadísticas fiables del acceso de mujeres a las escuelas españolas de arquitectura en las décadas centrales del siglo XX, ni tampoco se pueden componer a partir de documentos oficiales, porque las fichas de matrícula en la Escuela de Madrid, la más grande, y en la que estudiaron en esas décadas más mujeres, no se conservan. Sin embargo, nos podemos acercar a estos datos a partir de los listados de arquitectos españoles publicados anualmente por el Colegio de Madrid y por la Hermandad de Arquitectos. Como ya hemos indicado, estos datos nos permiten apreciar cómo el número de arquitectas se incrementa poco a poco desde 1940 hasta 1975, pero no es hasta finales de la década de 1970 cuando la proporción aumenta de manera significativa. Las primeras generaciones de arquitectas españolas fueron extremadamente reducidas y, en general, procedían de un origen social privilegiado.

También, dado el escaso número de Escuelas existentes en esos años Madrid, Barcelona y Sevilla- es posible realizar una «reconstrucción» a partir de testimonios personales de mujeres que ahora tienen más de 60 años, que confirman lo que nos indican los listados de arquitectos publicados por el Colegio de Madrid: en ninguno de los cursos de la década de 1960 llegaron a la decena el número de mujeres estudiantes.

...las chicas éramos poquísimas... te encuentras con un curso de 200, entonces era cuando comenzamos, creo que éramos 7 y ahí acabamos en el orden de $5 .$. yo, como toda la gente de aquella época, pues nuestras familias estaban, había muchas que tenían muchísimo dinero, pero claro éramos una clase media...es que cuando yo estudiaba no había ni una sola ... solamente eran»señoras de» (AAPP, 64 años)

En esos años el sistema educativo actuaba como un mecanismo reproductor del capital cultural de origen, como indica la teoría de la reproducción de Bourdieu y Passeron, que corrobora la contribución del sistema educativo a la

5. Para más detalle puede consultarse VV.AA. (1999): Españolas en la transición... 
reproducción del orden social ${ }^{6}$. De acuerdo a esta teoría, el bagaje cultural y social de origen determina, en cierto modo, las estrategias de conservación o acrecentamiento a partir de la formación superior. No obstante, a medida que pasan los años, la Universidad pierde el carácter «elitista» característico de otros tiempos y este mecanismo pierde fuerza en las siguientes generaciones, en que las posibilidades de acceso al sistema educativo se han democratizado en relación a épocas anteriores. Las mujeres de la segunda generación de arquitectas cuentan, en su mayoría, con padres universitarios y de un origen social medio o alto, pero es precisamente en esta generación donde empieza a darse una movilidad social clara. En cuanto a las más jóvenes, se observa todavía la hegemonía del modelo mencionado, pero el proceso de movilidad ascendente se hace más evidente en una generación con un origen social heterogéneo.

A propósito de lo anterior, resulta relevante distinguir cuáles son los motivos que llevan a las mujeres a estudiar Arquitectura, una formación considerada propiamente masculina por tradición. La motivación es, para muchas, sobre todo para las más jóvenes, el gusto y/o la vocación, más cuando el entorno familiar no aparece como determinante.

...empezó más la cosa por una vocación de capacidades o vocaciones intelectuales que por la emulación de un rol familiar o, ni siquiera, por conocer arquitectos (PL, 33 años)

Esta elección se distancia de la influencia de estereotipos de género. No obstante, algunos prejuicios de género permanecen vigentes en formulaciones que hacen evidente la proyección estereotipada de los padres sobre las hijas, de tal manera que disponen expectativas diferentes por razón de género ${ }^{7}$. En ocasiones sucede que es la propia vocación frustrada de los padres la que determina esta elección, rompiendo de nuevo con los estereotipos conformados en torno a la elección de carreras por género.

... a mi padre le hubiera encantado ser arquitecto... A mí también me encantaba dibujar y tal... me gustaba un toque más creativo, se me daban bien las ciencias (AS, 33 años)

Entre las arquitectas españolas es común encontrar familiares próximos relacionados con la profesión, aunque en las más jóvenes es cada vez menos habitual:

6. Bourdieu, P. y PASSERON, J.C. La reproducción. Elementos para una teoría del sistema de enseñanza, Madrid, Editorial Popular, 2001, pp. 96 y ss.

7. Véase FERRER, M.P. y SÁNCHEZ VILLENA, I. Toma de decisión vocacional no sesgada por razón de género. Madrid, CIDE, Ministerio de Educación y Ciencia, 1995. 
...vivíamos mucho la profesión... tengo un abuelo que es arquitecto... y desde luego mi madre que también es arquitecto porque su padre era arquitecto; yo me metí en arquitectura sin pensarlo, siempre me había gustado dibujar... yo creo que sobre todo por la formación humanística, historia del arte, todo eso es lo que me había gustado en el colegio... más que la parte científica... (PL, 41 años)

Destaca la omisión de justificación sostenida en el futuro profesional y es más usual que se recurra al apoyo familiar para cobijar la elección:

...mis padres me apoyaron (AS, 37 años)

Ello puede deberse a la aceptación implícita de la ausencia de apoyo social, configurado por la naturalización de los roles de género. También las previsiones de oportunidades sobre el éxito académico (habilidades con el dibujo y materias de ciencias) se explicitan en los discursos de las arquitectas, más que aquellas relacionadas con la inserción profesional. Las más jóvenes destacan a menudo el afán de superación y de hacer algo, irreflexivamente, de elevada valoración social:

...hice arquitectura, hubiera hecho Bellas Artes, pero también con ese afán de superación que nuestros padres nos inculcaban pues apostamos a más alto... (U, 39 años)

Con independencia de sus expectativas, la llegada a la Universidad de las arquitectas no se ha desarrollado, ni mucho menos, con normalidad. Lejos de caracterizarse por ser un proceso natural, estas mujeres han carecido del apoyo social y/o familiar al aferrarse a una elección alejada de prejuicios y estereotipos sociales conformados en torno a lo que tradicionalmente se consideran atributos masculinos y femeninos:

...(apoyo) no en absoluto, mi padre estaba horrorizado, él quería que yo fuera abogada (U, 38 años)

Pese al carácter igualitario formal del acceso a la educación, muchas barreras (burlas y bromas provocadas por compañeros y profesores) han dificultado el paso de las arquitectas por la Escuela, más si cabe entre las pioneras del área:

... me metí en la Escuela de Arquitectura y ahí fue el, el tortazo mayor que yo me llevé... éramos muy pocas y entonces al llegar a la Escuela era como un poco exótico... y bastante mala educación... tenías que aguantar bromitas... Y los profesores, sobre todo al principio... un poco despectivos... algunos ramalazos machistas... de mis compañeros... (PL, 65 años)

A las entrevistadas les cuesta mucho admitir la discriminación sufrida, por su naturalización. En un primer momento niegan cualquier desventaja con respecto a sus compañeros en la Escuela, si bien, a medida que avanza su 
discurso, emergen evidencias machistas en sus experiencias, más aún cuando se hace referencia a la actividad profesional:

... éramos muy pocas, todas teníamos nombre y apellido, todos nos conocían... bastante bien, porque la verdad... los tíos eran bastante amables... no hubo ningún problema de acosos ni de nada...claro... había tomaduras de pelo... con el profesorado depende, depende... te sacaban al encerado a explicar un proyecto, te ponían a caldo... y los chicos se divertían mucho. Luego los chicos... pues a esa se le ha hecho una carrera en las medias y tú que lo estabas oyendo y bueno, ahora me toca subir a mí, pero bueno, todo eso era simpático (AAPP, 64 años)

A medida que pasan los años se va normalizando cuantitativamente el acceso, y el escenario para las mujeres de las siguientes generaciones es diferente. En el curso 1978-79, momento de la transición a la democracia, el porcentaje de mujeres estudiantes en la Escuela de Madrid, según datos de la UPM, ronda el 15\% (357 mujeres frente a 2.221 varones). En estos años empiezan a estudiar Arquitectura las mujeres que hoy se encuentran en su madurez profesional, con edades comprendidas entre los 45 y los 55 años:

... había más chicos que chicas... pero ya no era la excepción, ni muchísimo menos (U, PL 52 años)

...notabas que éramos menos, pero no te dabas cuenta hasta qué punto éramos una minoría (U, AAPP, 46 años)

A partir de ese momento, el número de mujeres estudiando no ha dejado de crecer de forma estable y sostenida, y tres décadas más tarde, el porcentaje femenino supera por primera vez el 50\% del total del alumnado en el primer año de carrera, porcentaje que sube hasta el 57\% en la Escuela de Madrid ${ }^{8}$. En términos cualitativos, tal y como ocurría con las de la generación anterior, las de edad media tampoco perciben con nitidez la desigualdad por género que se da en su entorno formativo: niegan discriminación alguna, si bien matizan después su argumentación reseñando situaciones (discriminatorias) específicas.

...yo no noté ningún... bueno, hombre, en algún caso... (PL, 41 años)

Otras aluden al ambiente universitario como algo desagradable, aunque sin reconocer de forma explícita la discriminación sufrida por ser mujeres:

8. En las últimas tres décadas se han titulado la inmensa mayoría de las arquitectas españolas, lo que implica todavía una media de edad de las arquitectas muy inferior a la de los arquitectos y una concentración de ellas en los grupos de menor edad, sobre todo en el segmento de los 25 a 35 años. En realidad pocas arquitectas hay hoy en España con edades superiores a los 55 . 
...y yo, durante los años de la universidad, nunca me sentí a gusto... con los compañeros no he tenido ningún problema pero el ambiente no era agradable, no, no, yo no me sentí muy integrada en la universidad... (U, AAPP, 46 años)

Aún se divisan escenarios parecidos entre las más jóvenes, quienes perciben una igualdad cuantitativa que no se corresponde aún, en su generación, con las estadísticas. Estas mujeres reconocen que sus compañeros de estudio llevan la voz cantante, y, en términos generales, ven que el trato -sobre todo por parte de los profesores, mayoría masculina- es distinto según el sexo del alumnado:

...en mi generación éramos mitad y mitad, más menos... los profesores no, bueno, a lo mejor hay algún profesor que tiene más tendencia por los tíos, que sabes, pero... en general no, en toda mi trayectoria de educación vamos, no he tenido, no he sentido en ningún momento machismo, pero luego es eso, cuando ya te pones a trabajar, en ciertos momentos pues sí, pues sí que se nota... cuando dices jostras!... ahí sí hay bastante machismo (AS, 33 años)

\section{De la formación al empleo}

Las situaciones discriminatorias son visibles cuando el discurso se dirige al ámbito profesional. Las arquitectas españolas no lo han tenido fácil, han enfrentado grandes obstáculos para integrarse y mantenerse en la profesión. A base de mucho esfuerzo, han conseguido, y no siempre, ganarse el respeto ante situaciones discriminatorias. La falta de integración se hace evidente cuando relatan su experiencia a través de sucesos anecdóticos, representativos del trato en un entorno profesional masculinizado, donde las mujeres son todavía poco «tomadas en serio» y experimentan situaciones de verdadera injusticia.

...ahí empieza una experiencia curiosa para una mujer porque quizás nosotros en la profesión hemos tenido más problemas con las empresas, con el trato con las empresas constructoras, con los oficios y demás... hemos tenido que tragar sapos gordísimos, injusticias, estrés (AAPP, 64 años)

Con el paso de los años, en la siguiente generación, aunque hay más mujeres, sus trayectorias siguen chocando con grandes dificultades. ${ }^{9}$ Algunas incluso

9. Los resultados de la encuesta sobre el estado de la profesión realizada en 2009 indican diferencias de género en la percepción de cómo se ha producido la incorporación de las arquitectas en los tramos de edad más jóvenes. Sus compañeros masculinos consideran esta incorporación como «fácil» con una media de 7.8. Las opiniones de ellas variaban entre calificar esta entrada como «lenta» o «con limitaciones». Informe arquitectos 2009. Encuesta sobre el estado de la profesión, Consejo Superior de los Colegios de Arquitectos de España, dirigido y coordinado por Emilio Luque. 
abandonan la profesión, dada la dificultad que encuentran para desarrollar una carrera profesional con normalidad:

... y como era tan irregular también decidí meterme en otra cosa (PL, 46 años).

Estas situaciones obedecen al desempeño de una actividad alejada del rol femenino tradicional, por parte de un colectivo que manifiesta claramente el predominio de los varones en la profesión ${ }^{10}$. La situación de las mujeres arquitectas en la carrera académica, de la que existe abundante información estadística, es un indicador claro de lo que sucede en otros campos de la actividad profesional. ${ }^{11}$ La presencia de las mujeres en el profesorado de las escuelas de arquitectura españolas presenta la típica conformación de tijera que describe normalmente la presencia de mujeres en la carrera académica, así como una muy baja representación en los órganos y cargos de gestión y gobierno. Como ocurre en las profesiones con escasa integración vertical de las mujeres, el alumnado cuenta con pocos referentes femeninos en las esferas académicas más poderosas:

...mis referentes sí, eran masculinos ( $U$, 39 años);

...profesoras no había prácticamente... mujeres así...como modelos, no había (U, AAPP, 46 años)

Las mujeres de la primera y segunda generación han abierto caminos en la práctica profesional de la Arquitectura en nuestro país y, algunas de ellas, pocas hay que decir, empiezan a alcanzar puestos de responsabilidad y reconocimiento en sus distintos campos de actividad. Ellas han tenido que trabajar duramente en ambientes altamente masculinizados, paternalistas unas veces, hostiles otras, ejerciendo con humildad en círculos donde han sido acosadas, incluso en algún caso sexualmente, e ignoradas pese a su profesionalidad.

10. En 2008, el $71 \%$ de las personas colegiadas en España eran varones y el 29\% mujeres (datos ofrecidos por el Consejo Superior de los Colegios de Arquitectos de España).

11. Sobre la presencia de las mujeres en las escuelas de arquitectura españolas, véanse SÁNCHEZ DE MADARIAGA, Inés: «El papel de las mujeres en la arquitectura y el urbanismo, de Matilde Ucelay a la primera generación universitaria en paridad», en Leboreiro, Marian (ed.), La arquitectura y el urbanismo desde la perspectiva de las arquitectas, Ministerio de Vivienda- ETSAM, Madrid, 2008, pp. 69-77, y SÁNCHEZ DE MADARIAGA, Inés, "Women in architecture. The Spanish case», Urban Research and practice, Vol.3, 2, 2010, pp. 203-218. Los datos ofrecidos en 2009 por el estudio del Consejo Superior de los Colegios de Arquitectos Arquitectura y Género. Situación y perspectiva de las mujeres arquitectas en el ejercicio profesional, de Patricia Molina y Begoña Laquidáin, están parcialmente extraídos del primero de estos dos artículos, aunque sin cita explícita, y, en una ocasión, atribuidos erróneamente a una publicación del Ministerio de Educación en la que tales datos no aparecen.

Feminismo/s 17, junio 2011, pp. 155-181 
...verdaderamente las mujeres en arquitectura estamos con la cabeza gacha... estamos muy machacadas (U, PL 52 años)

Al respecto, el sistema de auto percepciones observado esboza un horizonte que identifica la profesión a partir de características asociadas tradicionalmente a lo masculino (endiosamiento, creación, mitología, dinero, poder, reputación, reconocimiento, ego, narcisismo, soberbia, individualismo y egocentrismo), frente a lo femenino y más accesible a las mujeres (lo doméstico y el cuidado).

...los arquitectos son personas muy, que se creen, que están un poco endiosadas, hay como un mito de que son creadores, se ven como artistas... manejan dinero, tienen acceso al poder... la reputación del arquitecto... el reconocimiento profesional... tienen el ego muy subido... hay una gran mistificación, todo es contrario a los valores convencionalmente femeninos ( $\mathrm{U}$, AAPP, 46 años);

\section{El ejercicio de la profesión}

Las arquitectas españolas se concentran, en mayor proporción que sus compañeros de profesión, en las categorías de asalariados/colaboradores, funcionarios de la administración o docentes no funcionarios ${ }^{12}$, lo cual refleja una segregación horizontal clara. El ejercicio libre -el sector de actividad más valorado- es mayoritariamente masculino, aun cuando el ideal de estudio independiente es el que las arquitectas tienen en mente cuando deciden formarse en la Escuela. Si bien, una vez en activo, este ideal presenta para ellas una opción poco accesible por su inestabilidad y limitado desenvolvimiento, dado el contexto en el que se inscribe todavía la profesión, donde los arquitectos varones ofrecen «mayor seguridad»y una confianza que se cuestiona cuando se trata de mujeres.

...yo tenía la profesión liberal en la cabeza (AS, 47 años)

...en las estructuras pequeñas el problema es que no consiguen encargos y entonces están haciendo chalets y reformas y poco más, porque no consiguen introducirse al mercado ... entonces lo que tienen los estudios pequeñitos, estos de mujeres, es una inestabilidad tremenda... que lo que tienen es muy de andar por casa ¿no?, femenino, doméstico (U, AAPP, 46 años)

...de hecho, una vez un cliente no quiso que nosotras hiciésemos el proyecto porque éramos mujeres (AS, 44 años)

Las arquitectas que atienden al ideal de ejercicio libre subrayan un sinfín de dificultades cuando hacen referencia a su experiencia profesional. Otras se

12. Las Encuestas sobre el Estado de la Profesión sólo recogen a la población colegiada. Al respecto, cabe mencionar que el funcionariado tiende a no colegiarse. 
deshacen del mismo dada la dureza del ejercicio en el estudio y en la construcción, enfrentando nuevos retos, muchas veces con desilusión.

... hay muchos aspectos que yo creo que es que los aprendes a fuerza de poquito a poco, de batacazos y mucha valentía y mucho, y también mucha humildad, una mezcla (U, PL 52 años)

...creía que lo que acababa siendo un arquitecto o una arquitecta era una persona que dirigía su estudio y hacía los planos de unas edificaciones y después se ponía el casco y se iba a la obra... Convencerme a mí misma de que no tenía que ser la arquitecta que pensaba, es decir esa era una idea que tenías desde el desconocimiento y desde, así, de la idealización, pero era tan arraigada que a mí lo que más me ha costado ha sido deshacerme de esa idea (U, 39 años)

Cuando permanecen, muchas veces lo consiguen gracias a los concursos ${ }^{13}$ y a redes sociales informales. Los concursos permiten a las arquitectas desarrollar trabajos importantes, de magnitud, por el mayor anonimato que caracteriza el procedimiento.

...en los concursos eres un lema y no hay sexismo posible (PL, U, 63 años)

...hemos tenido desde cosas privadas, así pequeñas, más bien cosas menores, reformas y eso, no de edificación, casi nada y luego últimamente trabajamos para cosas de la administración... ganamos un concurso... hay veces que son concursos que para nosotros sí que son inabarcables frente a otros estudios (PL, 50 años)

También es frecuente encontrar parejas sentimentales en estudios donde las mujeres suelen aparecer en un segundo plano y es el socio varón quien se colegia y asume el rol de representación legal, actuando como interlocutor en los entornos formales e informales del ejercicio, invisibilizando el trabajo y la coparticipación de sus compañeras.

...están contadas... las de renombre... casi todas tienen pareja arquitecto y el

famoso es él... quien lleva la voz cantante es él(AS, 44 años)

... si vas al lado de un hombre desapareces (AS, 47 años)

En muchos de estos casos las arquitectas desarrollan su actividad a la sombra de sus maridos y/o socios, relegadas e invisibles ante el cliente, asumiendo

13. Los concursos son bastante más importantes para las arquitectas que para los arquitectos (el $34.8 \%$ de las arquitectas tienen estas opinión frente al 25.5\% de los arquitectos) (Datos presentados por Luque, E. (2009), «Exposición de los resultados de la encuesta sobre el estado de la profesión y estudios previos», Congreso de Arquitectos de España, Valencia, 2 de julio (datos obtenidos a partir de la ENCUESTA SOBRE EL ESTADO DE LA PROFESIÓN» Consejo Superior de los Colegios de Arquitectos de España. Fundación Caja de Arquitectos. 
el trabajo en el interior del estudio con poco protagonismo y, en ocasiones, incluso anuladas como profesionales. Estas mujeres se sienten «cubiertas» por una estructura donde el dominio es masculino, y sólo ante situaciones de discriminación explícita perciben la desigualdad de la que son víctimas:

...en ese tema, ahí sí que jugaba mi marido porque un poco el que tenía los contactos de los trabajos era más él... yo no buscaba el trabajo... era una especie de relación de socio capitalista a socio industrial, yo hacía el trabajo, llevaba la responsabilidad y me encargaba del estudio pero no localizaba el cliente... una experiencia tenebrosa... sobre todo la obra porque el trabajo de estudios y tal, yo me bandeaba sin problemas, primero porque estaba muy cubierta porque estaba en una estructura en la que te integrabas...la conciencia de que las cosas, las cosas eran desiguales, yo digamos que, que la primera, la primera vez que me encontré de frente con ellas fue cuando me divorcié... (PL, U, 63 años)

Paradójicamente esta situación sombría se percibe de forma conformista como positiva, en la medida en que «evita problemas» aún sin dejar de ocasionar insatisfacción ante un desarrollo profesional coartado por «compartir» el ejercicio profesional.

...como yo siempre he estado trabajando con..., en el fondo no he tenido tanto problema en eso porque... nos complementamos... Ahora me estoy replanteando un poco, me apetece hacer cosas por mí misma, sola, porque al final como estás con el otro, no has hecho todo lo que podías ¿sabes? (PL, 41 años)

Frente al ejercicio libre, la distribución de arquitectas por ámbitos de la profesión muestra una alta proporción de mujeres entre el funcionariado. El acceso al empleo público ofrece estabilidad y es menos discriminatorio por sus procedimientos de selección, del «logro» frente a la «adscripción» ${ }^{14}$. La estabilidad se refleja, sobre todo, en la formalización de horarios, por ello, cuando la perspectiva biográfica del tiempo de trabajo es distinta en cada uno de los sexos, la figura del funcionariado se ajusta a las demandas laborales femeninas, dada la situación en que se encuentran las mujeres en el sistema de las relaciones de género tradicional, donde las labores del cuidado se asocian sistemáticamente con ellas ${ }^{15}$. El sistema de oposición explica la feminización del sector

14. Véase DURÁN, M ${ }^{a}$.A. El trabajo de la mujer en España. Un estudio sociológico. Madrid, Editorial Tecnos, 1972, pp. 150 y ss.

15. Véase CALLEJO, Javier. «Temporalidades y tiempo de trabajo: vivencias de trabajadores y trabajadoras» en PRIETO, C. (ed.). Trabajo, género y tiempo social. Madrid, Editorial Complutense, 2001, pp. 142-172. 
público $^{16}$, si bien, la situación cambia cuando se hace referencia a la ocupación de puestos directivos, todavía mayoritariamente masculinos, donde no es la oposición, sino la designación, el criterio que confiere la selección y la promoción.

...en la administración hay muchas arquitectas, lo que pasa es que al final los cargos que sean decisorios es raro que sean de mujeres (PL, 41 años)

\section{El desarrollo profesional}

El modelo cultural masculino permanece prácticamente sin erosionar en la Arquitectura ${ }^{17}$, donde existe una discriminación sutil pero real en el desempeño de las mujeres. Las tituladas en Arquitectura no llegan en su totalidad a practicar la profesión, y las que lo hacen soportan peores condiciones que sus compañeros de profesión. A continuación se presentan algunas de las causas fundamentales que dificultan el desarrollo profesional de estas mujeres.

\subsection{Asignación diferencial de roles en el sistema de las relaciones de género}

Las arquitectas españolas ejercen su profesión en un contexto social donde los roles de género atienden a una construcción cultural tradicional de la estructura ocupacional ${ }^{18}$. La influencia de los estereotipos de género en la estructura diferencial de la profesión se refleja en el reparto de roles a partir de patrones culturales sexuados que definen las distintas ocupaciones como femeninas o masculinas. Esta configuración se nutre de profundas creencias y actitudes negativas en torno a las capacidades femeninas, que condicionan el acceso a determinadas actividades ${ }^{19}$. Como concreción de estos roles, en la profesión de la Arquitectura se distinguen tareas propias de mujeres y otras que son propias de varones ${ }^{20}$ :

16. Actualmente, en el conjunto nacional hay un 52.61\% de mujeres, respecto al total, al servicio de las administraciones públicas (Ministerio de Administraciones Públicas: Boletín estadístico del personal al servicio de las administraciones Públicas).

17. GARCía DE CORTÁZAR, M y GARCíA DE LEÓN, M. «Las mujeres ingenieras en España, Un caso de desigualdad en el sistema de enseñanza y en el mercado de trabajo». Revista de Educación, 305, (1994), pp. 297-319.

18. Gómez Bueno, C. «Producción de identidades de género diferenciales» en Identidades de género y feminización del éxito académico. Madrid, Ministerio de Educación, Cultura y Deporte, CIDE, 2001, pp. 19-115.

19. Mosteiro, $M^{a} J$., CAjIDE, J. y Porto, A.M ${ }^{a}$. «Modelos y factores que influyen en el desarrollo de la carrera de las mujeres» en RADL PHILIPP, R. (Ed). Cuestiones actuales de la Sociología del Género. Madrid, CIS, 2001, pp. 301-315.

20. Véase BROWNE, K. Trabajos distintos. Una aproximación evolucionista a las mujeres en el trabajo, Barcelona, Crítica, 2000. Traducción castellana de A. J. Desmonts. Este autor 
...el problema es que las elecciones aquí, al final, son en función del sexo y de la presión de la sociedad que impone sobre el sexo de las personas (AS, 44 años)

La feminización ideológica de las ocupaciones reproduce el rol tradicional femenino de la atención personal, mientras que la «mística de las profesiones» se relaciona con el rol de la objetividad, la impersonalidad y la competitividad asociada a la «mística de lo masculino» ${ }^{21}$. El ejercicio de las arquitectas se dirige con frecuencia a actividades que reproducen simbólicamente la función hogareña de la ayuda y tareas relacionadas con el entorno interior, aun cuando ello conlleve acatar mayor carga de trabajo y responsabilidades no reconocidas desde el exterior.

...yo asumo mi cuota particular, porque entre otras cosas, yo no me he trabajado más la componente exterior de mi trabajo porque no me ha interesado ... eso requiere una inversión de tiempo y energía de tal calibre que no es posible hacer otra cosa... yo por lo menos primo más el estar en mi interior, más que no estar en el exterior...cuando tú trabajas en un equipo con hombres ...llevando el grueso del trabajo, pero alguno de los hombres se permiten decir «he hecho esto» ....apropiándose de la representación exterior (PL, U, 63 años)

... encasillan un poco en cuanto a funciones pero bueno, quizás es que se nos da mejor, no lo sé, pero a las mujeres siempre te ponen más en partes, todo lo que puede ser de decoración de interiores... en general, en temas de detalles

aplica la teoría evolucionista al comportamiento humano para indicar que la estructura social patriarcal puede ser el efecto de las diferencias sexuales, en lugar de la causa. Con un argumento esencialista, Browne defiende que los factores sociales que determinan las diferencias sexuales no están exentos de la contribución biológica a esa diferenciación, afirmando que en el mercado de trabajo (en la división sexual del trabajo), más allá de los prejuicios sociales y de la discriminación sexual directa basada en falsos supuestos sobre las capacidades relativas de ambos sexos, operan diferencias sexuales de orden biológico que afectan a la personalidad y al temperamento. Este autor cree que tales diferencias son el resultado de las diferentes estrategias reproductivas que han seguido los dos sexos en la trayectoria de la evolución humana. No apunta a la biología como única causante de la brecha de género, y reconoce la influencia de actitudes sociales en cuanto a la diferencia, pero destaca el papel de la biología en la diferencia de los sexos al defender que hay «una naturaleza del varón y otra de la hembra». Respecto a la primera señala que «la teoría evolucionista predice que los hombres presentarán mayor afán de prestigio, competitividad y disposición de correr riesgos que las mujeres». En cuanto a la segunda, especifica que «las mujeres presentarán una mayor inclinación a la crianza». No obstante, reconoce que las anteriores no son generalizaciones ciertas para todos los individuos, pues hay mujeres competitivas, perseverantes y agresivas asî como hombres «más interesados por perder el tiempo con los hijos que por ascender en las jerarquías».

21. Martín Moreno, J. y Miguel, A. de. Sociología de las profesiones. Madrid, CiS, 1982, p. 110. 
de fachadas y tal, en general son hombres... al final tener un estudio es una cosa desgraciadamente extremadamente violenta (AS, 33 años)

La distribución tradicional de atributos por sexo relaciona la lucha, el trabajo instrumental y de riesgo con los varones, mientras que el trabajo rutinario, delicado y menos competitivo se reserva sistemáticamente a las arquitectas. En la Arquitectura triunfa el modelo masculino por su competitividad en un mundo donde se valoran el poder y la autoridad, mientras que las arquitectas tienden a refugiarse en tareas «menos serias», distintas a las de la construcción y más relacionadas con el diseño y el arte.

... lo que se llama construir es durísimo para una chica... Ella suele estar más en los trabajos de diseño y él más en la calle porque es que hay mucha violencia, mucha discusión, es duro ¿sabes?, porque al final se maneja mucho dinero en obra (PL, 41 años)

Tal distribución hace que las arquitectas desempeñen de forma sistemática roles menos valorados en una sociedad donde se priorizan los valores típicamente masculinos relacionados con la instrumentalidad, la competitividad y motivación por el logro profesional, frente a los relacionales, afectivos y de expresividad tradicionalmente femeninos. El menor reconocimiento no se relaciona necesariamente con un menor esfuerzo pero sí con la racionalidad frente a la agresividad. En este sentido, ante una negociación del tipo que sea, las arquitectas recurren al diálogo en mayor medida que los arquitectos, quienes actúan con mayor agresividad y enfrentamiento.

...siempre me he encontrado que los hombres no escuchan, no escuchan las voces de las mujeres... si un hombre le tiene que poner, que decir a otro que no tiene razón casi llegan a las manos, no hay diálogo fácil... A nosotras no nos cuesta ningún trabajo tener un debate de ideas entre nosotras, las mujeres (AAPP, 64años)

Por otro lado, entre las arquitectas se hace constante referencia a la maternidad, uno de los mayores obstáculos a la integración profesional de estas mujeres. Con la incorporación a la actividad profesional, no ha perdido sentido la identidad femenina con la ideología familiar tradicional. La doble jornada de trabajo a la que traslada la naturalización de los roles de género, supone una objeción al nuevo rol social y económico femenino. La reproducción de estos roles en ocasiones va más allá de lo simbólico, siendo supuesta elección de las mujeres en un contexto social que se resiste a evolucionar de acuerdo a esta 
nueva situación ${ }^{22}$ : una elección considerada innata haciendo de la necesidad virtud.

Yo no me he dado cuenta de que era mujer hasta que he tenido los niños, antes me parecía que era exactamente igual todo... tener unas anclas por ahí que no te dejan moverte (PL, 41 años)

...es que es una cuestión que somos nosotras, en mi caso he sido yo. En el reparto que se ha planteado, es que cuando tienes un bebé, yo creo que te apetece... me ha apetecido y digo, bueno, tú vas a tener que trabajar más lo que yo no voy a poder estar trabajando... en el fondo yo creo que muchas elegimos ser nosotras...te apetece más, la madre, le apetece más bueno, se lo pide el cuerpo, no sé cómo decirlo (U, 39 años)

Constantemente se plantea la necesidad de decidir entre la vida familiar o la profesional. Cuando optan por ambas, tienen que hacer verdaderos malabarismos para compaginar responsabilidades, sin saber bien si identificarse como malas profesionales o malas madres, con un sentimiento de culpa añadido a la presión social que genera cualquiera de las decisiones.

... ellas fueron solas al colegio... era necesidad... pues solas... pero claro jugándome la historia... (con un sentimiento de) de culpa tremendo, tremendo... yo me moría, me moría porque pobrecitas mías, se van a sentir abandonadas, pero joe... (PL, 65 años)

....no tengo, pareja sí que tengo... eso sí, lo que, la presión social y que siempre te llega (AS, 37 años)

La decisión de renunciar a la carrera laboral cuando se forma una familia lleva, en ocasiones, al abandono de la profesión pese a la formación de estas mujeres, relegando su identidad profesional y la participación en el mercado laboral al rol maternal23.

...se juntó con que tuve mi primer hijo y ya compaginarlo con eso... luego tuve mi segundo hijo... y ya estaba bastante más complicado todo... decidí dejarlo... (PL, 46 años)

\subsection{Invisibilidad versus sobreesfuerzo ante el modelo masculino de la profesión}

Los códigos masculinos son dominantes en la cultura de la Arquitectura, limitando el desarrollo profesional de las mujeres. Una cultura organizada,

22. VARella, R. «Las políticas de igualdad en el ámbito del trabajo: una propuesta de construcción teórica desde el género» en Cuestiones actuales de la Sociología del Género, Madrid, CIS, 2001, pp. 105-125.

23. Véase INSTITUTO DE LA MUEJR. Las mujeres jóvenes y el trabajo, Madrid, Ministerio de Trabajo y Asuntos Sociales, 2006, pp. 116 y ss. 
diseñada en términos masculinos, pese a la mayor presencia de mujeres, a la que siguen sin acostumbrarse colegas, compañeros, constructores y clientes.

...esos ámbitos son más de hombres... te cuesta mucho...que te tomen en serio... me ha costado mucho...que me escucharan ( $U$, 38 años)

...fue duro porque no estaban acostumbrados ... ya no tanto a que hicieran el proyecto sino que además llevaran la dirección de obra... no nos miraban a la cara... se subían todos a la cubierta para no tener que hablar con nosotras, bueno, unas cosas, cosas inauditas (AS, 44 años)

...la situación casi de herencia de valores culturales, yo creo que cuando un cliente o una administración piensa en una obra, piensa en que la persona que va a defender su dinero necesita tener una capacidad agresiva... obras... es un campo de batalla (PL, 33 años)

A menudo se cuestiona su capacidad con prejuicios sexistas enraizados que actúan mediante sutiles mecanismos de invisibilización. La propia cultura organizativa hace que, muchas veces, las arquitectas adopten modos de hacer propios del modelo masculino, ante la falta reconocimiento profesional. El hecho de «ejercer como un tío» se aleja de los roles tradicionalmente asignados a mujeres. Con ello se percibe cierto proceso de aculturación en la transformación de la cultura femenina de origen, en otra dominante amoldada al modelo masculino, cuando las arquitectas adoptan formas de comportamiento «propias» de hombres: "puñetazo en la mesa», «trato con mano dura», «comer y tomar copas», «decir tacos», «imponer su voluntad», «ser un sargento» o «tener mucho genio» como hacen los compañeros de profesión.

... un trato que tienen que tener mucha mano dura, mucha mano dura y al mismo tiempo el saber hacerlo y no caer en la blandenguería... saber ponerles en su sitio y al mismo tiempo exigir, el, el oficio de la construcción es muy malo... muy duro... (PL, 65 años)

Otras mujeres, sin embargo, detestan este modo de hacer cuando se utiliza para «acercarse al caballo ganador», rechazando asimismo la actitud impositiva habitual del arquitecto «de dar órdenes de forma tajante». Pese a su empeño en la consecución de la organización consensuada del trabajo, a veces tienen que adoptar el modelo dominante para despertar reacciones, aun cuando estas reacciones confluyan en «desobediencia», desembocando de nuevo en invisibilidad y falta de reconocimiento. Ante situaciones de este tipo, se recurre a la profesionalidad y la distancia (presentados éstos como valores propios de los varones) con la intención de encontrar el respecto y de no ser tomadas «por imbécil». Sin embargo, pese a esa aculturación asumida de los valores masculinos, como negación de los femeninos, tampoco es fácil formar parte de este ámbito profesional, coto cerrado a las mujeres. 
...yo lo de dar una orden, yo no tengo alma así de... tú lo que haces generalmente es organizar el trabajo, repartes... cuando empieza a haber un poco de discrepancia, empiezas a explicarle, no, mira... llega un momento en que tienes que decir, no mira, así... esto se hace así, no es porque lo digo yo, pero así... pues bueno, puedes encontrarte cómo reaccionan, no haciéndolo (AS, 47 años)

Las vivencias discriminatorias son comunes a todas las generaciones de arquitectas que constantemente tienen que poner en marcha estrategias de supervivencia diversas en su ejercicio profesional, con un sobreesfuerzo mayor al que tienen que hacer los varones para obtener reconocimiento. Ellas tienen que «salvar resistencias», «ser el doble de buenas para montar un estudio», en definitiva, «currárselo más» que los varones para conseguir credibilidad y oportunidades, reafirmándose continuamente ante situaciones que describen como «inauditas» y «de mucho desgaste» que, con «persistencia y grandes esfuerzos» logran ir sobrellevando.

... tienes que ahí intentar dar la talla porque estás en el punto de mira, mucho más que si fueras un hombre (AS, 37 años)

...cosas inauditas, trabajando muchísimo... no aceptar ni un fallo... muy exigente... lo he pasado francamente mal... fue pánico, horrible... estoy ya un poco quemada (AS, 44 años)

...tienes que hacer el triple de esfuerzo que a lo menor un tío que es mucho menos serio pero llega ahí y pone a todos firmes ¿sabes?, con su sola violencia personal (PL, 41 años)

El sobreesfuerzo de las mujeres traducido en logros no es positivo para sus compañeros de profesión y llegan a percibirlo como «amenaza». Ante ello, algunas arquitectas adoptan «la docilidad» como supervivencia con el objetivo de no «levantar demasiadas suspicacias» hasta lograr la confianza del entorno, a base de un buen trabajo que lime las desconfianzas y extermine prejuicios en torno a su trabajo:

...para ponerte delante de esta gente, al final, lo que tienes es como que, por decir, hacerte la tonta, o como dejar un poco de lado cosas que tú harías, o iniciativas que tú tomarías ya, a lo mejor ser un poco más dócil... el problema... una primera desconfianza ¿vale?, que luego se solventa cuando ven que eres capaz y muy trabajadora (U, PL, 31 años)

Algunas viven la dureza de la situación como algo relativamente positivo, en el sentido de la riqueza que conlleva la superación de retos cuando, a base de hacer de la necesidad virtud, se asume la cultura del trabajo y del esfuerzo como propia de las mujeres. Sin embargo, las consecuencias de este sobreesfuerzo no siempre son positivas y desenlazan directamente en abandono de 
la profesión, tras el desánimo que genera la «perversidad» de un entorno tan «retrógrado»y «despectivo» con las mujeres.

...el género te marca evidentemente unas pautas pero no son insuperables, a lo mejor ese esfuerzo te da más riqueza, que no lo veo como algo negativo (AAPP, 64 años);

... la cultura del trabajo, del esfuerzo si quieres, la tenemos como más inculcada (U, PL, 31 años)

\subsection{La promoción en la profesión: ¿techo de cristal y/o suelo pegajoso?}

...la cabeza visible suele ser varón... el jefe sigue siendo hombre (AAPP, 60 años)

El incremento en el acceso de mujeres a la profesión en los últimos años no se refleja en el protagonismo que ellas asumen en procesos de toma de decisión o en la cumbre del control de recursos e información. Como consecuencia de la división de roles de género, las mujeres ocupan escalones modestos de una jerarquía ocupacional ${ }^{24}$ donde existe fuerte correspondencia entre la clasificación social de la situación de empleo y la clasificación social de los géneros ${ }^{25}$. El éxito profesional medido en términos de promoción es más favorable a los varones que a las mujeres dado que la tradición, la costumbre o el supuesto carácter masculino, más que los méritos propios, conceden el poder en un mercado de trabajo donde las mujeres acusan una promoción laboral lenta. Uno de estos obstáculos es el propio paternalismo protector hacia la «más débil»:

...en el fondo a mí siempre se me han puesto las cosas bastante fáciles en el estudio, en plan de que yo empecé como becaria... el problema es que yo no sé hasta qué punto se sienten como un poco invadidos o ¿sabes?, ante chicas jóvenes, capaces, preparadas...es como que te perciben un poco como una amenaza (U, PL, 31 años)

Las mujeres han reunido un gran capital en formación y profesionalidad, sin embargo, se retraen ante el liderazgo por mecanismos sociales conformados por sus colegas cuando se sienten amenazados, protegiéndose mediante la obstaculización y cuestionamiento de la profesionalidad femenina. Esta situación provoca la sobrecualificación de las arquitectas que realizan tareas de menor cualificación que la que les corresponde, obedeciendo a un modelo profesional menos competitivo y más participativo que el de los varones,

24. Martín Moreno, J. y Miguel, A. de. Op. Cit., p. 77.

25. En Prieto, C. «Los estudios sobre mujer, trabajo y empleo: caminos recorridos, caminos por recorrer» en Política y Sociedad, $\mathrm{n}^{\circ}$ 32, Madrid, Universidad Complutense de Madrid, 1999, pp. 141-149. 
quienes se desenvuelven mejor en el poder ${ }^{26}$. Aún más difícil es el reconocimiento cuando la mujer es cosificada como objeto sexual o como algo menor y, además, patrimonial.

...en el momento que te ven como una relación sexual o de pareja, les cuesta mucho trabajo asumir que el reconocimiento social sea mayor en la mujer que en el hombre (AAPP, 64 años)

...el jefe... a lo mejor porque siempre suele tener mujeres a su cargo nos llama mis niñas... (AS, 44 años)

El metafórico techo de cristal es casi infranqueable y permanece lleno de obstáculos propios del «star system» en el que arquitecto y varón son una misma cosa. Otro componente se relaciona con la persistencia de valores sociales establecidos en torno al rol del cuidado y la maternidad que suponen una ventaja para los profesionales (responsables del sustento familiar) y una desventaja para sus compañeras de profesión en las respectivas trayectorias ${ }^{27}$. La maternidad frena la incorporación y el desarrollo profesional femenino hasta puestos de alta responsabilidad, mientras ellos incluyen la trayectoria vital en la laboral de manera lineal ${ }^{28}$.

...es muy difícil para una mujer porque es, la dedicación es enorme, enorme, entonces generalmente las mujeres tenemos hijos... los hombres no, en España, por lo menos por ahora... Los hombres, vamos, como si tienen churros, la que se ocupa es la madre (PL, 41 años)

Las que han logrado ascender a base de sobreesfuerzo profesional no siempre adquieren el mismo respeto que se otorga a un hombre, en la misma posición, sintiéndose «ignoradas», «boicoteas» y sufriendo «situaciones de verdadero desgaste».

...tuve subordinados... muchos hombres y muchos mayores, y entre ellos, pues muchos no llevaban para nada bien tener una jefa que fuera mujer... incómodos... cuando tenían un hombre en mi puesto, pues estaban encantados, y estando yo, pues no les gustaba nada seguir instrucciones... la técnica

26. Véase García de León, M.A. Herederas y Heridas. Sobre las élites profesionales femeninas. Madrid, Ediciones Cátedra, 2002, pp. 253 y ss.

27. OSCA, A. y MARTÍNEZ-PÉREZ, $M^{a} D$. «Avance profesional y género: variables personales, familiares y organizacionales» en Revista de Psicología Social, 17(2), Fundación Infancia y Aprendizaje, 2002, pp. 193-205.

28. Véase LisbonA, A. y TOPA, G. «Trabajando en la diversidad: inserción y desarrollo profesional de la mujer» en PALACí, FJ. y MoRiano, J.A. (Coord.): El nuevo mercado laboral. Estrategias de inserción y desarrollo profesional, Madrid, Universidad Nacional de Educación a Distancia, 2003, pp. 229-259 y CALLEJo, J. «Temporalidades y tiempo de trabajo: vivencias de trabajadores y trabajadoras» en PRIETO, C. (ed.): Trabajo, género y tiempo social, Madrid, Editorial Complutense, 2007, pp. 142-172. 
del escaqueo, sobre todo... el no hacer las cosas, el boicotearlas, el no informar, el intentar puentear (U, AAPP, 46 años)

Otras llegan al poder exhibiendo lo que se conoce como el «síndrome de la abeja reina ${ }^{29}$, viviendo su condición de élite desde la distancia, frente a posturas solidarias con su propio género. Estas mujeres adoptan el modelo masculino en su práctica laboral, a través de un proceso de aculturación que les lleva a actuar de forma individualista y agresiva para legitimarse en la esfera del poder.

...también a las tías, porque anda que no hay tías machistas ahora, y las ha habido ¿eh?, no hay peor machista que una mujer ¡eh!... mujeres que estén más o menos frustradas... una venganza inconsciente, contra el macho opresor y despreciativo... mujeres que funcionan como hombres (AAPP, 64 años)

Cuando las propias mujeres - de forma consciente o inconsciente- aceptan la versión misógina de la realidad laboral, forzadas por la situación en la que viven su profesión, se da una falsa conciencia que contribuye a mantener el estatus quo. Esta postura impide un curso ascendente en sus trayectorias, dado el efecto del suelo pegajoso traducido en conformismo o pasividad ante una situación de desventaja que les viene socialmente dada.

...somos más machistas que ellos... nos auto limitamos, yo creo que ese es un poco el problema (AS, 44 años)

...la dirección, bueno... no ha habido ni oportunidad, ni ganas... todo en esta vida es cuestión de voluntad... puedo asegurarte que no tengo el menor interés (U, PL 51 años)

En estos casos, las arquitectas apelan a la voluntad para justificar su limitada promoción a puestos directivos «ocultando la naturalización de las identidades de género tradicionales sobre las que dichas distinciones y desigualdades aún se recrean y reconstruyen ${ }^{30}$.

\subsection{Negación de la evidencia/ diferencia}

La invisibilidad ante la hostilidad de un entorno masculino hace que muchas arquitectas hablen en términos de normalidad, negando cualquier situación de desigualdad por género. Estas mujeres, en cierto modo, aceptan la versión machista o misógina de la realidad laboral cuando, frente a discursos igualitarios, hablan del «paternalismo», «situaciones únicas»y «atípicas» que contradicen la realidad cuantitativa del acceso femenino a la profesión. La

29. GARCía de LeÓn, M.A. Op. cit., p. 200

30. Callejo, J., Gómez, C. y Casado, E. Op. Cit., p. 36

Feminismo/s 17, junio 2011, pp. 155-181 
adopción de un discurso políticamente correcto, efecto de la deseabilidad social, impide que reconozcan experiencias discriminatorias como tales.

...he tenido siempre la suerte de que mis jefes no han sido machistas y de hecho, el problema que tuve con el señor este que me tuve que ir del trabajo no creo que fue por ser yo mujer sino porque él me veía como una amenaza... no me ha tocado directamente (AS, 37 años)

En términos generales, las arquitectas españolas se ven a sí mismas de manera neutra cuando hacen referencia a ellas mismas como «arquitectos» en lugar de «arquitectas», huyendo de su identificación como mujeres y alejándose, asimismo, de reflexiones y planteamientos relacionados con cuestiones de género en términos profesionales. Su discurso es una muestra más de espejismo de la igualdad que oculta situaciones discriminatorias y hace difícil detectar los obstáculos que impiden su desarrollo profesional. Ello dificulta, además, que se organicen como colectivo dentro de la profesión, con el fin de identificar y mejorar su situación, mostrando cierta resistencia a un modo de actuación reflexivo.

...el problema es que tradicionalmente ha habido menos mujeres y ahora que en realidad hay bastantes... son bastantes chicas, son mujeres que se han incorporado con el mal sabor de boca de ser mujeres, entonces lo último que se les ocurre es plantear un tema de género (PL, 33 años)

Otra forma de ocultar la discriminación es mediante el recurso a argumentaciones relacionadas con la situación económica de crisis que vive el sistema económico actual o mediante un discurso que habla de la "pérdida de valor» de la profesión en los últimos tiempos; excusas que muestran, una vez más, la invisibilidad y afán de silenciamiento de la situación discriminatoria de la que son presa estas mujeres. Además, los condicionantes sociales y culturales arraigados en la sociedad en general, y en la profesión de la arquitectura en particular, perpetúan actuaciones machistas engalanadas con explicitaciones (como chistes o comentarios armados de engañosa y silenciadora consistencia) que contribuyen a que la situación se mantenga en el tiempo. Parecería que está socialmente mejor visto hacer un chiste machista que defender públicamente los derechos de las mujeres.

...chistes por parte de los tíos... y a mí eso me cabrea profundamente (AAPP, 64 años)

Buscando la parte "positiva» ante la presión que se vive en estos entornos, por la importancia económica de las negociaciones, algunas arquitectas actúan de manera poco racional «explotando» las «armas femeninas», con la indumentaria y «el encanto femenino», originando la «cosificación de las mujeres» en 
situaciones donde se une la debilidad con la «feminidad»y con la «coquetería» pero no con las cualidades técnicas:

... era otro trato. Tanto es así que eso, que cuando yo tenía que ir a algún sitio, yo prefería ir yo, y yo me arreglaba, me ponía tal, porque sabía que conseguía más con las armas adecuadas que otra persona. Nunca he tenido problemas... (PL, 65 años)

\section{El futuro}

El hecho de que las arquitectas que ahora se encuentran en la cima de su trayectoria profesional, con carreras consolidadas, hayan ido soslayando situaciones difíciles no impide que las más jóvenes que ahora empiezan su andadura lo tengan también difícil. La gran afluencia de mujeres al campo de la Arquitectura, tanto académico como profesional, ha roto en cierta medida con el modelo de actividad exclusivamente masculino que caracterizaba tradicionalmente al ámbito de referencia. En términos cuantitativos podría decirse que el modelo social tradicional de las relaciones de género comienza a resquebrajarse, sin embargo, el reto que ahora se presenta es la adaptación cualitativa a estas nuevas situaciones cuantitativas, impedida por pautas de conductas que alimentan círculos de poder masculino en la profesión. Los próximos años serán importantes para observar la evolución cuando las cohortes de las arquitectas sean tantas como las de los arquitectos, alcanzando las edades a las que normalmente se produce la integración vertical.

Desde el optimismo, se recurre al argumento temporal para presumir un cambio sustancial en el futuro próximo de esta situación de desventaja que sufren las arquitectas en relación a sus compañeros de profesión. Este argumento es cuestionable ante la panorámica descrita en este artículo donde, con matices, los avances y retrocesos se constatan en la incoherencia observada en términos cuantitativos y cualitativos. El diagnóstico presentado pretende contribuir a paliar deficiencias y carencias detectadas, frente a la intención de olvido, frente a la ocultación a menudo inconsciente e involuntaria de las diferencias que, de forma más o menos explícita, siguen existiendo. Una intención que parece predominar en el sector profesional de la Arquitectura, filtrado por una mirada dominante parcial y por la casi inexistente reflexión desde el género. 


\section{Referencias bibliográficas}

Agudo, Yolanda. Diferencias de género en el alumnado egresado de la universidad y su inserción laboral: acceso/ éxito académico de mujeres y hombres e itinerarios laborales en el acceso al empleo. Estudio de la UNED. Tesis Doctoral. Inédita, 2008.

AlBerT, C. La demanda de educación superior en España: 1977-1994. Madrid, CIDE, Ministerio de Educación y Ciencia, 1998.

BOURDiEU, P. y PASSERON, J.C. La reproducción. Elementos para una teoría del sistema de enseñanza, Madrid, Editorial Popular, 2001.

BROWNE, K. Trabajos distintos. Una aproximación evolucionista a las mujeres en el trabajo, Barcelona, Crítica, 2000. Traducción castellana de A. J. Desmonts.

CALlejo, J. «Temporalidades y tiempo de trabajo: vivencias de trabajadores y trabajadoras» en PRIETO, C. (ed.): Trabajo, género y tiempo social, Madrid, Editorial Complutense, 2007, pp. 142-172.

Callejo, J., Gómez, C. y CaSAdo, E. El techo de cristal en el sistema educativo español, Madrid, Ediciones UNED, 2004.

DURÁN, Mª.A. El trabajo de la mujer en España. Un estudio sociológico. Madrid, Editorial Tecnos, 1972.

FERRER, M.P. y SÁNCHEz VillenA, I. Toma de decisión vocacional no sesgada por razón de género. Madrid, CIDE, Ministerio de Educación y Ciencia, 1995.

FLECHA, Consuelo. «Un espacio de libertad para las mujeres: su acceso a los estudios universitarios» en Mujer y Ciencia. Jaén, Universidad de Jaén, 1999, pp. 23-42.

GARCÍA DE CORTÁZAR, Marisa. Educación superior y empleo en España. Madrid, Ministerio de Trabajo, 1987, pp. 19 y ss.

García de Cortázar, Marisa, Arranz, Fátima, Del Val, Consuelo, Agudo, Yolanda, Viedma, Antonio, Justo, Cristina y Pardo, Pilar. Mujeres y hombres en la ciencia española. Una investigación empírica. Madrid, Instituto de la Mujer, 2006.

GARCÍA DE CORTÁZAR, M y GARCíA DE LEÓN, M. «Las mujeres ingenieras en España, Un caso de desigualdad en el sistema de enseñanza y en el mercado de trabajo». Revista de Educación, 305, 1994, pp. 297-319.

GARCÍA DE LEÓn, María Antonia y GARCíA de CORTÁzAR, Marisa: Las académicas. Profesorado universitario y género. Madrid, Instituto de la Mujer, 2001.

GARCÍA DE LEÓN, M.A. Herederas y Heridas. Sobre las élites profesionales femeninas. Madrid, Ediciones Cátedra, 2002.

Gómez Bueno, C. «Producción de identidades de género diferenciales» en Identidades de género y feminización del éxito académico. Madrid, Ministerio de Educación, Cultura y Deporte, CIDE, 2001, pp. 19-115. 
INSTITUTO DE LA MUJER. Las mujeres jóvenes y el trabajo, Madrid, Ministerio de Trabajo y Asuntos Sociales, 2006, pp. 116 y ss.

LisBona, A. y TOPA, G. «Trabajando en la diversidad: inserción y desarrollo profesional de la mujer» en PALACí, FJ. y MORIANO, J.A. (Coord.): El nuevo mercado laboral. Estrategias de inserción y desarrollo profesional, Madrid, UNED, 2003, pp. 229-259.

Martín Moreno, J. y Miguel, A. de. Sociología de las profesiones. Madrid, CIS, 1982.

MedinA, E. «Educación, Universidad y Mercado de Trabajo» en LeRENA, C. (ed.) Educación y Sociología en España. Madrid, Akal Universitaria, 1987.

Mosteiro, $\mathrm{M}^{\mathrm{a}} \mathrm{J}$., CAJIDE, J. y PORTO, A.Mª . «Modelos y factores que influyen en el desarrollo de la carrera de las mujeres» en RADL PHILIPP, R. (Ed). Cuestiones actuales de la Sociología del Género. Madrid, CIS, 2001, pp. 301-315.

OSCA, A. y MARTínEZ-PÉREZ, MªD. «Avance profesional y género: variables personales, familiares y organizacionales» en Revista de Psicología Social, 17(2), Fundación Infancia y Aprendizaje, 2002, pp. 193-205.

PRIETO, C. «Los estudios sobre mujer, trabajo y empleo: caminos recorridos, caminos por recorrer» en Política y Sociedad, $\mathrm{n}^{\circ} 32$, Madrid, Universidad Complutense de Madrid, 1999, pp. 141-149.

SÁNCHEZ DE MADARIAGA, Inés. «El papel de las mujeres en la arquitectura y el urbanismo, de Matilde Ucelay a la primera generación universitaria en paridad», en Leboreiro, Marian (ed.), La arquitectura y el urbanismo desde la perspectiva de las arquitectas, Ministerio de Vivienda- ETSAM, Madrid, 2008, pp. 69-77.

SÁnCHEZ DE MADARIAGA, Inés: «Amigos del alma. Matilde Ucelay y Félix Candela. La incautación del Colegio de Madrid y la represión de los arquitectos durante el franquismo», en del Cueto Ruiz-Funes, J.-I. (ed.) Félix Candela 1910-2010, IVAM-SECC, Madrid, 2010, pp. 121-138.

SÁnCHEZ dE MAdARIAGA, Inés, «Women in architecture. The Spanish case», Urban Research and practice, Vol.3, 2, 2010, pp. 203-218.

VAL, Consuelo del y GutiÉRrez, Jesús. Prácticas para la comprensión de la Realidad Social. Madrid, McGraw-Hill, 2005.

VARELla, R. «Las políticas de igualdad en el ámbito del trabajo: una propuesta de construcción teórica desde el género» en Cuestiones actuales de la Sociología del Género. Madrid, CIS, 2001, pp. 105-125.

VV.AA. Españolas en la transición. De excluidas a protagonistas (1973-1982). Madrid, Biblioteca Nueva 1999. 



\title{
ASÍ EN LA COCINA COMO EN LA FÁBRICA
}

\author{
JUAN BRAVO BRAVO \\ Universitat Politècnica de València
}

Recibido 09/02/2011

Aceptado 20/05/2011

\section{Resumen}

Estudio de un caso: definición, desarrollo y crisis del tipo de cocina doméstica contemporáneo en Europa. Se recurre a interpretaciones de género, actualmente muy fructíferas en el ámbito de la Historia del Diseño. La cocina de la Haus am Horn en la Exposición Bauhaus de Weimar, 1923. La Cocina de Frankfurt diseñada por Grete Schütte-Lihotzky, 1927. Propuestas de comunas y cocinas colectivas. Identificación de sus debilidades para dar respuesta a las actuales características de la sociedad del bienestar y planteamiento de su capacidad para contribuir al incompleto proceso de igualdad de género, estimulando la sociabilidad y corresponsabilidad del grupo familiar en las tareas domésticas.

Palabras clave: Historia del diseño; espacio doméstico; tipologías de cocina; estudios de género

\begin{abstract}
Case study: definition, development and crisis of contemporary home kitchen in Europe. The paper draws on gender interpretations currently successful in History of Design. The Haus am Horn kitchen in the Exhibition Bauhaus, Weimar, 1923. The Frankfurt Kitchen designed by Grete Schütte-Lihotzky in 1927. Proposals for communes and collective kitchens. Identifying weaknesses in response to the current characteristics of the welfare society. Approach to their capacity to contribute to the incompleteness of gender equality process by encouraging the sociability and responsibility in household chores.
\end{abstract}

Keywords: History of Design; domestic space; kitchen types; gender studies 



\section{Diseño en femenino. Estudio de un caso: la cocina doméstica}

No ha sido hasta las últimas décadas, con la proliferación de las enseñanzas de diseño en sus diferentes variantes, cuando la Historia del Diseño ha ido configurándose como una disciplina autónoma. Sus orígenes se remontan a los años treinta del siglo $\mathrm{xx}^{1} \mathrm{e}$ inicialmente se nutrió de métodos e interpretaciones procedentes de la historia del arte en general y de la arquitectura y de las artes decorativas en particular, disciplinas con las que se entronca, si bien, progresivamente ha ido enriqueciéndose con aportaciones procedentes de otras ciencias como la antropología, la sociología o la arqueología, que han ido aportándole nuevas e ilustrativas perspectivas desde las que contemplar su objeto de estudio. De esta manera, a los estudios iniciales relativos a las relaciones entre forma, función y producción, y centrados en la labor pionera de una serie de arquitectos y artistas heroicos, se ha ido añadiendo un conjunto cada vez más numeroso de obras dedicadas a estudiar el fenómeno del diseño desde nuevos aspectos como, por ejemplo, el desarrollo de la profesión; sus relaciones con el contexto socio-político; los vínculos entre diseño, publicidad y consumo; o el papel de la mujer en el diseño.

Probablemente ha sido la última de esas nuevas miradas anteriormente mencionadas la que se ha revelado como una de las más fructíferas, al constituirse en una especie de reflejo de la totalidad puesto que, a su vez, ha ramificado sus aportaciones en diferentes direcciones: desde la recuperación de las primeras mujeres diseñadoras; pasando por el análisis del rol de consumidora, tradicionalmente asignado a las mujeres en las sociedades capitalistas, y su responsabilidad en la definición de algunas características de la identidad femenina; hasta una crítica específica a algunas aportaciones del Movimiento Moderno al poner de relieve cómo éste, al entronizar la máquina, resalta aspectos vinculados con la ciencia, la tecnología o la producción industrial -habitualmente identificados con el universo masculino-, para relegar a un

1. Fue en esa década cuando apareció la primera literatura específica: Herbert READ: Art and industry, the principles of industrial design. Londres: Faber\&Faber, 1934; ó Nikolaus PEVSNER: Pioneers of the modern movement, from William Morris to Walter Gropius. Londres: Faber\&Faber, 1936. 
segundo plano aquellos otros -tradicionalmente relacionados con lo femenino-, como son la esfera de lo doméstico, lo privado o lo decorativo. ${ }^{2}$

El presente texto pretende conjugar, en cierta manera, varias de esas opciones a través del estudio de un caso concreto: el proceso de definición, difusión y crisis de la cocina doméstica moderna. Con este propósito, empieza por repasar la aparición y el desarrollo del tipo de cocina contemporánea, resaltando la significativa aportación de arquitectas y diseñadoras pioneras en la definición de muchas de cuyas características todavía permanecen vigentes en la actualidad. En segundo lugar, se señala el mayoritario rol de usuarias y consumidoras habitualmente asignado a la mujer en la consolidación del nuevo espacio así definido, para plantearse la manera en que esos nuevos diseños de cocina han contribuido a la progresiva emancipación de la mujer cuestionándose su validez actual y en qué direcciones deberían evolucionar para impulsar el todavía incompleto proceso de igualdad de género en las sociedades post-industriales contemporáneas.

\section{Mujer y Bauhaus: Benita OTTE y la cocina de la Haus am Horn, Weimar,} 1923

Como en tantos otros aspectos relativos al diseño industrial, los orígenes de la cocina moderna pueden rastrearse también en el trabajo de la Bauhaus, la escuela vanguardista y democrática por excelencia.

Es conocido cómo la Primera Guerra Mundial contribuyó a la modernización de determinados aspectos sociales, facilitando el acceso de buen número de mujeres a las instituciones de enseñanza así como que muchas otras alcanzaran una cierta independencia económica como resultado de ocupar aquellos puestos laborales que sus compatriotas masculinos habían dejado vacantes tras su incorporación a los frentes de batalla. Una vez finalizada la Guerra, la constitución de la República de Weimar garantizó, por primera vez, el derecho de las mujeres a estudiar y a votar, reconociéndoles una igualdad de derechos que, de la misma manera, fue explícitamente recogida en el primer programa de la Staatliches Bauhaus de 1919. Sin embargo, la

2. Para ampliar estas cuestiones relativas a la historiografía del diseño, véase Judy ATTFIELD: «Form/female follows Function/male: Feminist Critiques of Design», pp. 199-225, en John A. WALKer: Design history and the history of design. Chicago: Pluto Press, 1989 y, en español, Isabel CAMPí: «Algunas reflexiones sobre la historia del diseño de productos», pp. 219-241, en La idea y la materia, V. I: El diseño de producto en sus orígenes. Barcelona: Gustavo Gili, 2007. 
desmovilización obligó a un retroceso en muchos de estos aspectos. ${ }^{3}$ En ese mismo sentido, investigaciones recientes están poniendo de relieve cómo pese a que, en teoría, aquellos alumnos que superaban el curso inicial o Vorkurs tenían libertad para elegir el taller donde querían completar su formación, de forma más o menos implícita, se obstaculizó la incorporación de la mujer a los talleres mecánicos -tradicionalmente considerados como masculinos-, para orientarla principalmente hacia aquellos otros de carácter artesanal -habitualmente relacionados con lo femenino- como eran el textil, el de cerámica o el de encuadernación. ${ }^{4}$ Aún así, el sistema había dejado de ser impermeable a la incorporación femenina por lo que, entre los diseñadores más activos y reconocidos, se encuentran algunas mujeres cuya obra posee incuestionable calidad, como son los casos de Marianne Brandt, Gunta Stölzl o Anni Albers, por citar sólo algunos ejemplos relevantes. En esa misma línea, cuando con ocasión de los primeros egresados de la Escuela, en 1923, se organizaron una serie de actos destinados a justificar la subvención que ésta recibía del estado de Turingia, uno de los logros que recibió un reconocimiento más unánime había sido también diseñado por una mujer.

Con el doble objetivo de satisfacer a las autoridades estatales y de difundir las actividades de la Escuela entre arquitectos, artistas y críticos alemanes y extranjeros que habían sido convenientemente convocados, se programaron diferentes conferencias, conciertos, obras de teatro y exposiciones. La más ambiciosa de éstas últimas consistió en la construcción de una vivienda unifamiliar, la Haus am Horn, inicialmente denominada Casa Modelo y, más tarde, Casa Experimental. El proyecto de la misma se debió al joven profesor de pintura Georg Muche y fue democráticamente elegido por los alumnos de la Escuela entre las diferentes opciones presentadas. La ejecución de la obra fue dirigida por el estudio de Walter Gropius, que había aceptado deportivamente el rechazo de su propia propuesta, mientras que en su equipamiento participaron todos los talleres de la escuela aportando prototipos de sus diseños.

3. Sobre los cambios sociales y los nuevos roles de género en la República de Weimar, puede verse Eric D. Weitz: La Alemania de Weimar. Presagio y tragedia. Madrid: Turner, 2009, especialmente el capítulo titulado «Cuerpos y sexo», pp. 345-383.

4. Véase, por ejemplo, Magdalena Drosde: Bauhaus 1919-1933. Colonia: Taschen, 1991, en particular: «Mujeres en la Bauhaus», p.40; Anja BAUMHOFF: «Las mujeres en la Bauhaus: un mito de la emancipación», pp. 96-107, en Jeannine FIEDLER y Peter FEIERABEND (eds.): Bauhaus. Madrid: Könemann, 2000; ó, también, Mercedes VAlDiviESO: «Retrato de grupo con una dama: el papel de la mujer en la Bauhaus», pp. 246-255, en Anna CALVERA y Miquel MALlol (eds.): Historiar desde la periferia: historia e historias del diseño. Barcelona: Universitat de Barcelona, 2001. 
Se trata de una vivienda aislada de una sola planta cuadrada $(12,70 \mathrm{x}$ $12,70 \mathrm{~m}$ ), lo que arroja una superficie construida de unos $160 \mathrm{~m}^{2}$, a los que hay que sumar otros $60 \mathrm{~m}^{2}$ adicionales en sótano, donde se encuentran diferentes dependencias de servicio, tales como la lavandería, la caldera de calefacción o un almacén. En el centro se sitúa la pieza colectiva más importante de la vivienda: la sala de estar, de planta también cuadrada (5,94 x 5,94 m) con una altura $(4,10 \mathrm{~m})$ superior en más de metro y medio a la del resto de la casa, para poder abrirse así a la iluminación y ventilación directa mediante una serie de ventanas altas que orlan su perímetro. Alrededor de esta pieza central se organizan -de acuerdo con criterios funcionales o de orientaciónel resto de estancias de la vivienda, reduciendo al mínimo los espacios de distribución, según un esquema tipológico similar al de las viviendas-patio romanas, planificadas alrededor de un patio descubierto -el atrio-, cuyo lugar está aquí ocupado por ese mencionado salón, cubierto a mayor altura.

Tanto la vivienda como su equipamiento fueron objeto de críticas poco favorables desde diferentes frentes. Aquéllos situados en posiciones antivanguardistas, declaradamente contrarias a la Escuela, la tacharon de mal gusto, censurando su ascetismo exterior, la ausencia de cuarto de servicio o rechazando la evidente inspiración técnica y mecánica de buena parte su equipamiento. Por su parte, desde más favorables posturas de vanguardia -casos de Adolf Behne o Ernst May, por ejemplo-, se criticó que estuviera destinada a un tipo de usuario socialmente minoritario, bien distinto de aquel que constituía el verdadero problema social del momento -la vivienda mínima-, consagrando tanto una forma de vida familiar patriarcal como unos estándares superficiales muy alejados de los convenientes para ese caso. Desde el punto de vista formal criticaron también el excesivo estatismo y rigidez geométrica de su proyecto arquitectónico así como la evidente deuda de su mobiliario con los diseños de Rietveld. ${ }^{5}$

La cocina, sin embargo, suscitó opiniones casi unánimemente favorables, para alcanzar posteriormente su reconocimiento como prototipo europeo de cocina moderna. Su proyecto se debía a Ernst Gebhardt y Benita Otte quien, como la mayoría de las estudiantes de la Bauhaus, estaba adscrita al taller textil y no al de mobiliario. Había sido diseñada aplicando criterios de

\footnotetext{
5. La vivienda que, en 1996, fue declarada por la UNESCO monumento de la humanidad, puede visitarse en la actualidad tras su conveniente restauración. Una minuciosa descripción de la misma, así como de las vicisitudes que rodearon su construcción y primera exhibición, puede encontrarse en Mercedes VALDIVIESO: «La aportación de la Bauhaus a la innovación del espacio doméstico: la «Casa Modelo» Haus am Horn (1923)», <http:// www.ub.edu/gracmon/capapers/mercedesvaldivieso.pdf>, consultado el 05-12-2010.
} 


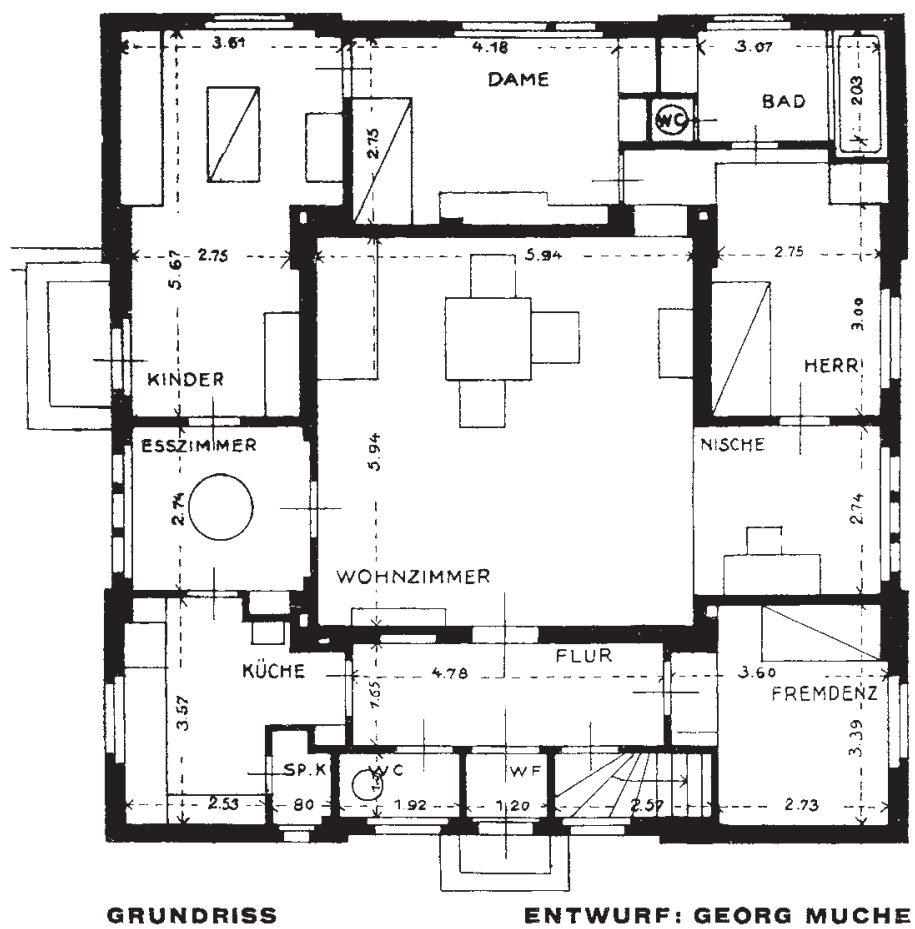

Georg Muche: Casa Modelo Exposición Bauhaus, Weimar, 1923. Planta general.

racionalización del espacio para facilitar el trabajo de un ama de casa que carecía de servicio doméstico.

La cocina habitual en esos años estaba comúnmente equipada mediante una serie de aparadores para el almacenamiento de alimentos y menaje junto a alguna que otra mesa donde realizar las tareas de limpieza y preparación, todo ello dispuesto en yuxtaposición a los tres elementos funcionales fundamentales: la cocina, el fregadero y, en su caso, la nevera. Por el contrario, en esta ocasión se avanza claramente hacia un tipo de cocina compacta e integrada, compuesta por dos clases distintas de armarios -murales y de base-, que se disponen adosados a las paredes según una configuración en L, para definir una superficie de trabajo continua y sin juntas al mismo nivel que el fregadero y los fogones. Pese a que su altura era adecuada para trabajar de pie, se liberó parte del espacio inferior para las piernas y donde integrar un taburete que permitía sentarse para realizar determinadas tareas con mayor comodidad. Sobre dicha superficie de trabajo se abrió una amplia ventana basculante para procurar un adecuado nivel de iluminación y ventilación 


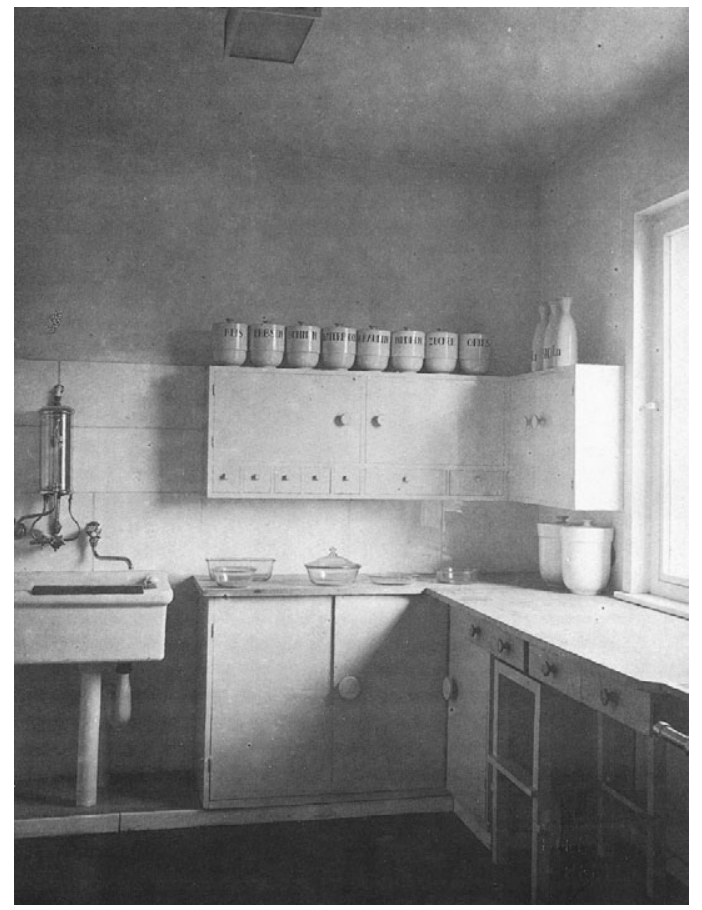

Benita Otte y Ernst GebHardt: Cocina de la Casa Modelo, Weimar, 1923. Vista.

natural sin interferir las actividades que se realicen sobre ella. Para facilitar las tareas de limpieza y mantenimiento, los armarios de base carecen de patas que han sido sustituidas por un zócalo continuo, al tiempo que las paredes se han revestido parcialmente mediante piezas cerámicas vidriadas. En palabras de Sigfried Giedion, quien también se contaba entre los visitantes invitados por Walter Gropius:

Su punto de partida era el centro de almacenaje; un sencillo fregadero y una alacena quedaban situados junto a la pared larga, con la alacena dividida ya en dos elementos, el armario de base y el armario de pared. El espacio de la ventana es plenamente utilizado y recuerda las cocinas americanas Craftsman de 1910. Una amplia superficie de trabajo discurre por debajo de la ventana oscilante y al nivel de la misma se extiende la parte superior de la cocina de gas, alargada a su vez por una superficie como la que aparecería en las cocinas americanas alrededor de los años treinta. ${ }^{6}$

6. Sigfried Giedion: La mecanización toma el mando. Barcelona: Gustavo Gili, 1978, p. 529. El autor se centra fundamentalmente en las aportaciones estadounidenses, alguna de las cuales será comentada más adelante. 
Por otro lado, cabe señalar también que en el debate arquitectónico de la época se estaba discutiendo sobre las ventajas e inconvenientes entre una cocinalaboratorio, exclusivamente dedicada a las tareas culinarias, y una cocinacomedor, destinada no solo a la manipulación de los alimentos sino también a su ingesta. La primera tenía como ventaja la facilidad para aislar el resto de la vivienda de las molestias derivadas de la cocina: humos, olores, suciedad, etc. y como inconveniente el alargamiento de los recorridos de servicio y una mayor dificultad para atender a los niños mientras uno se ocupaba en las tareas domésticas.

En el caso de la Haus am Horn se ensayó una opción de cierto compromiso dado que, por un lado, se trata de una estancia de trabajo en exclusiva pero, por otro, se encuentra adyacente al comedor y únicamente separada de éste por una puerta que permite aislarla o comunicarla a conveniencia. Además, dicha puerta se encuentra enfilada con la correspondiente al cuarto infantil -destinado a dormitorio y juegos- que se abre, simétricamente a la cocina, al otro lado del comedor. Esta solución permite vigilarlos al tiempo que los mantiene alejados de los riesgos inherentes a la inevitable presencia en la cocina de fuego y agua. $^{7}$

El prototipo de cocina diseñado por Benita Otte para la Bauhaus tuvo continuidad pocos años después cuando, aprovechando el breve alivio para la economía alemana que supuso el Plan Dawes, entre la hiperinflación de 1923 y las consecuencias de la gran depresión de 1929, el Werkbund organizó en 1927 la exposición de Stuttgart. Como es conocido, el acontecimiento principal estuvo constituido por la construcción de la Weissenhofsiedlung, bajo la dirección de Mies van der Rohe y con participación de algunos de los arquitectos de vanguardia más relevantes de la época, tanto alemanes como extranjeros. Pero, en paralelo, se celebró también una segunda exposición dedicada al equipamiento doméstico bajo el título de Die Wohnung (El apartamento), dirigida por Lilly Reich, ${ }^{8}$ en la que la organización de la cocina constituía

7. Según Mercedes VALDivieso: op. cit., n. 29, esa posición del cuarto infantil se tomó a última hora, dado que en los planos iniciales, fechados a principios de 1923, éste se encontraba situado en la esquina orientada a sur, ocupada en la solución final por el baño y el dormitorio masculino.

8. A partir de esta exposición, Lilly Reich empezaría una fructífera colaboración con Mies van der Rohe que se prologaría hasta el exilio de éste en EUA en 1938. Durante ese período participaron en la Exposición de Barcelona de 1929 y en la de Berlín de 1931. En 1932, un año antes del cierre de la Escuela, Reich llegó a dirigir el taller de interiorismo y diseño textil de la Bauhaus, en sustitución de Gunta Stölzl. Sobre su vida y obra puede verse, en español, Carmen ESPEGEl AlONSO: Heroínas del espacio: mujeres arquitectos en el movimiento moderno. Buenos Aires: Atlántida, Nobuko, 2007, pp. 134-163. 
cocina diseñada por Erna Meyer, asesora de la exposición Weissenhof de 1927.

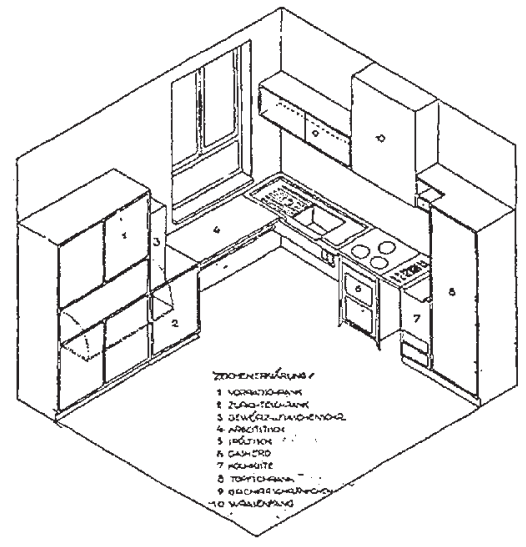

cocina de J.J. P. Oud para la exposición. Weissenhof, 1927.

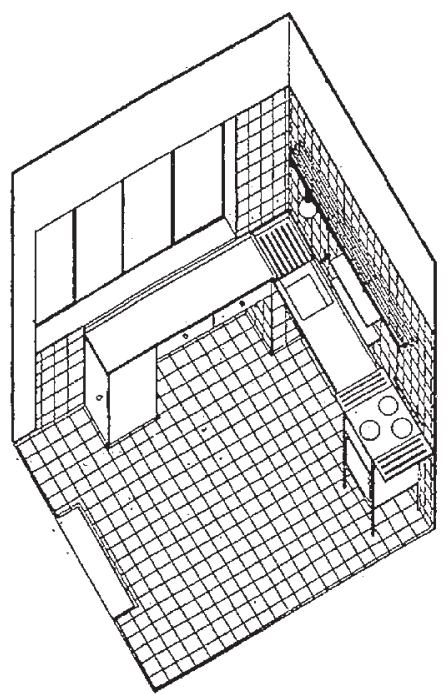

Jacobus J. P. OUD: Vivienda unifamiliar, Weissenhofsiedlung, Stuttgart, 1927. Planta y vista.

uno de sus temas más significativos. Las encargadas del mismo fueron Hilde Zimmermann y Erna Meyer quien también se había ocupado en asesorar a los arquitectos participantes en todos aquellos requisitos que debían cumplir las cocinas de las viviendas por ellos proyectadas para la Weissenhof. No en vano se trataba de la autora de Der neue Haushalt (El nuevo hogar), texto de gran influencia publicado por vez primera en 1926 y continuamente reeditado hasta 1941. Entre otras características, esta diseñadora fue la primera en incorporar criterios de ergonomía en el proyecto de cocinas para dimensionar, por ejemplo, la altura correcta para trabajar de pie o qué tipo de tareas podían realizarse desde un asiento.

En opinión de Erna Meyer, el mejor diseño de cocina entre todos los participantes en la Weissenhof correspondió a las viviendas construidas por el arquitecto holandés Johanes J. P. Oud. Éste insistió en una cocina integrada y compacta dispuesta en L, con la superficie de trabajo perfectamente iluminada y ventilada bajo una amplia ventana y liberando parte del espacio inferior para las piernas -lo que permite sentarse para trabajar con mayor comodidad-; los armarios murales han sido sustituidos, en esta ocasión, por meros estantes y 
una barra donde tener a mano parte del menaje y de los accesorios necesarios para las diferentes tareas. Sin embargo, la aportación más interesante de Oud fue quizás la apertura de una ventana interior con carpintería corredera que comunicaba la cocina con el salón-comedor adyacente, estableciendo de esta forma no solo un vínculo directo -a modo de pasaplatos- para facilitar el servicio de la mesa, sino también una comunicación visual y auditiva que suaviza el aislamiento de la cocina -y de la cocinera- como espacio exclusivamente de trabajo.

\section{Grete Schütte-Lihotzky y la definición del tipo de cocina contemporánea}

A diferencia de los ejemplos anteriores, que permanecieron como experiencias aisladas, el caso que tuvo una mayor repercusión, hasta el punto de configurarse como tipo de referencia, es el conocido como Frankfurter Küche o Cocina de Frankfurt. Este modelo se asumió como estándar en la ambiciosa operación de construcción de viviendas sociales que, de manera similar a otras ciudades europeas tales como Berlín, Rótterdam o Viena por ejemplo, se acometió en dicha ciudad durante el período de entreguerras. Cuando, en 1924, el liberal Ludwig Landmann accedió a la alcaldía de Frankfurt, nombró al arquitecto Ernst May al frente del Departamento de Construcciones de la ciudad, estructura administrativa de nueva creación que unificaba diferentes departamentos relacionados con la construcción y promoción de viviendas, lo que le proporcionó un amplio margen de acción para enfrentarse con éxito a ese acuciante problema de carestía de viviendas, común a numerosas ciudades europeas tras la Primera Guerra Mundial.

Ernst May convocó a su alrededor a un nutrido grupo de colaboradores, alemanes y extranjeros, procedentes de diferentes disciplinas. Entre ellos se encontraban, por ejemplo, el arquitecto Eugen Kaufmann, responsable del departamento de estandarización; los diseñadores Hans Leistikow, gráfico, y Ferdinand Kramer, de mobiliario -que había seguido un año de formación en Bauhaus-; o la arquitecta austriaca Grete Schütte-Lihotzky, ${ }^{9}$ que se hizo cargo

9. Margarete SCHÜTTE-LinotZKY (1897-2000) fue la primera arquitecta austriaca y una de las primeras de Europa. Formada en Viena entre 1915-19 con Oskar Strnad, Heinrich Tessenow o Josef Hoffmann, colaboró con Adolf Loos antes de integrarse en el equipo de Ernst May en Frankfurt, dedicando toda su vida a la arquitectura desde posiciones política y socialmente comprometidas. Dicho compromiso le condujo al exilio — junto a May y otros miembros de su equipo- primero en la URSS, donde trabajó entre 1930 y 1937 como profesional y docente, y más tarde en Turquía entre 1938-40. Como integrante de la resistencia antifascista volvió a Viena durante la Guerra donde fue apresada por los nazis y, aunque pudo escapar de la pena de muerte, pasó en prisión desde 1941 hasta el final de la contienda en 1945. Sobre su vida y obra puede verse Angela 
de la investigación y planificación para el equipamiento de las nuevas cocinas. El modelo desarrollado por Schütte-Lihotzky fue instalado en más de 10.000 viviendas construidas en Frankfurt entre 1924-1930 alcanzando también cierta resonancia internacional, de modo que, por ejemplo, el ministro de trabajo francés Louis Loucheur proyectó para su país 260.000 viviendas sociales equipadas con este diseño de cocina. ${ }^{10}$ En palabras de la propia Grete SchütteLihotzky, las responsabilidades que hubo de asumir fueron las siguientes:

En primer lugar, mi trabajo consistió en considerar los principios básicos envueltos en el planteamiento y construcción de viviendas, con vistas a racionalizar la organización doméstica. ¿Dónde vivir, cocinar, comer y dormir? Esas son las cuatro funciones básicas que toda vivienda debe cubrir. La función básica, que influye en el diseño de manera decisiva, es cocinar y comer. Mi primera propuesta, construir un salón y combinar una cocina y comedor, fue rechazada bajo el argumento del coste [...] Así que nos decidimos por una sola unidad, compuesta de una cocina compacta e integrada, separada del salón-comedor mediante una amplia puerta corredera. Consideramos la cocina como una especie de laboratorio que, a causa del mucho tiempo que pasamos en ella, tiene que ser «hogareña». El tiempo necesario para ejecutar las diferentes funciones fue medido usando un cronómetro, como en el sistema de Taylor, con el objetivo de alcanzar la óptima y ergonómica organización del espacio. ${ }^{11}$

Dos son los aspectos destacables en la cita anterior. En primer lugar la revelación que la propia arquitecta hace de alguna de las referencias metodológicas que influyeron en su tarea al citar el sistema de Taylor. Remite a los esfuerzos que, durante la década de 1910, Christine Frederick (casada con Frederic W. Taylor) había estado realizando para trasladar al espacio doméstico las teorías sobre optimización productiva -de tiempos y movimientos- que, junto a su esposo, estaba desarrollando y aplicando con tanto éxito a diferentes cadenas de montaje estadounidenses de producción industrial. En The New Housekeeping (La nueva gestión doméstica), publicado en 1913, Christine Frederick analiza científicamente una cocina sin servicio doméstico e incluye unos

OEDEKOVEN-GERISCHER et al. (eds.): Frauen im Design: Berufsbilder und Lebenswege seit 1900. Women in Design: Careers and Life Histories since 1900 (2 v.) Stuttgart: Design Center Stuttgart, 1989, pp. 148-173 y, en español, Carmen EsPEGEl AlONSO: Op. cit., pp. 165-195.

10. Rita Mielke: La cocina. Historia, cultura, diseño. Berlín: Feierabend, 2004, p. 19

11. Grete SCHÜTTE-LihotZKY: Erinnerungen (Memorias). Viena: manuscrito inédito, 198090. Citado en la web del Museo Austriaco de Artes Aplicadas y Arte Contemporáneo (MAT) que, desde 1989-90 expone una réplica de la cocina realizada por el arquitecto Gerhard Lindner en colaboración con la propia Grete. Véase <http://www.mak.at/e/ sammlung/studien/studiens_frakue_e.html>, consultada el 06-12-2010 (traducción propia de la versión en inglés). 

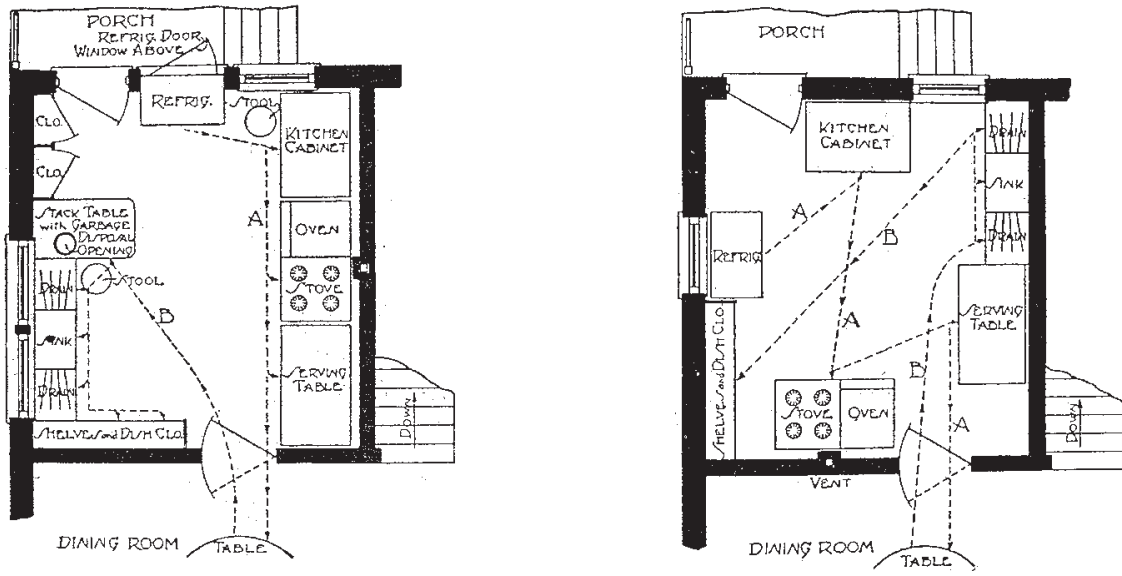

Christine FredericK: The New Housekeeping, 1913. Diagramas de cocina ineficaz y eficaz.

diagramas comparativos entre los movimientos realizados por el ama de casa durante su proceso de trabajo en lo que la autora denomina «cocina ineficaz» y en una cocina donde se ha racionalizado la disposición de sus diferentes elementos y calificada, por tanto, de «eficaz». Otro de sus textos, Scientific Management in the Home (Gestión cientifica del hogar), fue traducido con gran éxito al alemán en 1922 y está, sin duda, en la base del libro de Erna Meyer Der neue Haushalt (El nuevo hogar) de 1926, anteriormente citado como obra de referencia a la hora de materializar ejemplos como los de Johannes J. P. Oud en la Weissenhof de Stuttgart de 1927, así como de sus contemporáneos berlineses de Bruno Taut.

La aportación estadounidense tiene raíces incluso anteriores, en la obra de las hermanas Catherine Beecher y Harriet Beecher-Stowe que, ya en 1869, habían publicado The American Woman's Home (El hogar de la mujer americana), texto que incluye unos bocetos de cocina donde es posible detectar el embrión de algunas características que desarrollarán los tipos europeos de entreguerras. ${ }^{12} \mathrm{Si}$ la arquitecta austriaca remite a la cocina del vagón-restaurante de los ferrocarriles como modelo de eficacia en el que inspirarse, las

12. Se trataba de una edición revisada y ampliada de un texto anterior de 1841, suscrito por Catherine en solitario y titulado Treatise on Domestic Economy (Tratado de Economía Doméstica) que había alcanzado una importante difusión y repercusión. 
estadounidenses se refieren a las pequeñas y compactas cocinas colectivas presentes en los buques de vapor de su época. ${ }^{13}$ En el levantamiento interior propuesto por Catherine Beecher se observa su temprano rechazo a una yuxtaposición de mesas y aparadores independientes para preferir en su lugar la definición de un banco de trabajo continuo -enrasado con el fregadero-, adosado a la pared y bien iluminado bajo las ventanas que en ella se abren. El espacio inferior de dicha superficie de trabajo se ocupa por contenedores para menaje y alimentos mientras que en la parte superior, entre las ventanas, se disponen unas simples estanterías y ganchos que permiten acercar todo tipo de accesorios al alcance de la mano. Por lo que respecta a su organización en planta, es posible observar cómo la autora identifica los tres vértices de lo que hoy se denomina el triángulo funcional de una cocina: el almacenamiento y conservación de alimentos (ocupado en la actualidad por el frigorífico); la limpieza y preparación (fregadero); y el cocinado-servicio (fuego). Debido a su temprana fecha no aparece todavía un dispositivo de conservación en frío sino unos contenedores para alimentos a granel (harina, aceite, azúcar,...); como tampoco cuenta con una instalación de fontanería, sino con un rudimentario sistema autónomo de agua corriente ideado por ella misma; a la vez que los fogones se apartan a un compartimento distinto, separado por puertas deslizantes, para reducir los numerosos inconvenientes producidos por un fuego todavía a partir de combustible sólido.

Volviendo a Frankfurt, cabe señalar en segundo lugar cómo en el texto anteriormente citado Grete Schütte-Lihotzky reconoce que se planteó esa disyuntiva entre una cocina-laboratorio -dedicada exclusivamente a tareas domésticas- y una cocina-comedor -más favorable a las relaciones familiares-, confesando cómo, pese a sus propias preferencias iniciales, motivos económicos decantaron finalmente la decisión hacia la opción más especializada. Sin embargo, como en el diseño de Benita Otte para la Casa Modelo, también en este caso se optó por suavizar dicha especialización comunicando directamente la estancia con el comedor adyacente «mediante una amplia puerta corredera», para mejorar la relación entre ambos espacios. Pero no es esta la única coincidencia con Bauhaus. La Cocina de Frankfurt es también un claro ejemplo de cocina integrada y compacta dispuesta en L que segrega los contenedores en dos tipos: de base y de pared. Mediante los inferiores define una superficie de trabajo continuo y sin juntas -enrasada con el fregadero y los fogones-, así como perfectamente iluminada y ventilada a través de la ventana

13. Cabe recordar que las primeras patentes de Pullman para vagón-restaurante de ferrocarril datan, precisamente, de 1869 por lo que Catherine Beecher no podía tener todavía esa experiencia. 

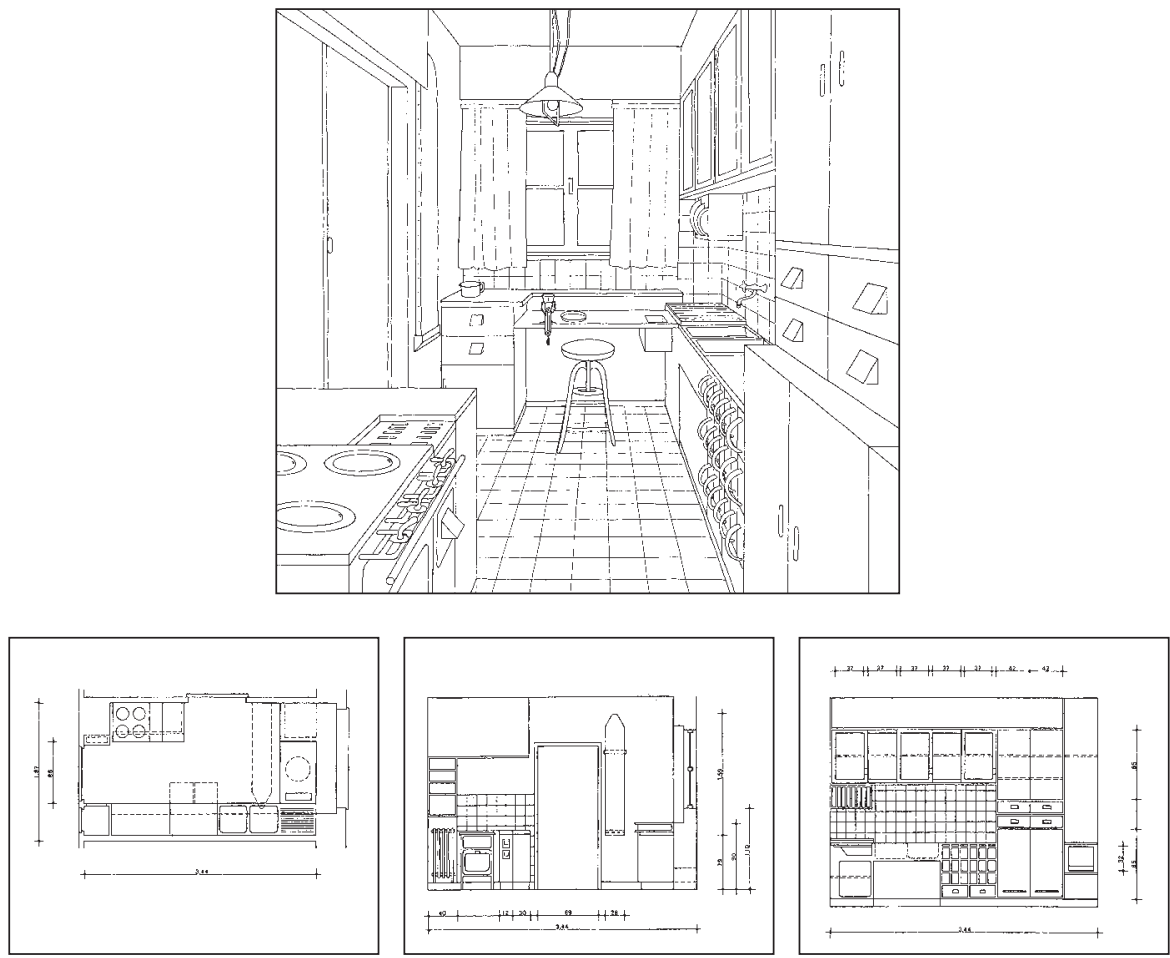

Grete SCHÜTtE-Linotzky: Cocina de Frankfurt, 1927. Vista general y planimetría.

de la estancia. Análogamente, los paramentos se revisten de aplacados cerámicos y los armarios de base carecen de patas para descansar sobre un zócalo continuo que facilita las labores de limpieza y mantenimiento. También aquí, por último, se libera parte del espacio inferior de la superficie de trabajo dejando hueco para las piernas, lo que permite sentarse para realizar parte de las tareas sacando un taburete que, cuando no se sutiliza, encaja en dicho espacio.

Sin embargo, frente al ejemplo de la Haus am Horn, incorpora nuevas aportaciones entre las que cabe destacar, en primer lugar, su ajustada superficie -inferior a los $6,50 \mathrm{~m}^{2}$ - manteniendo e incluso incrementando sus funciones, para lo que Schütte-Lihotzky se inspiró en las reducidas y compactas cocinas instaladas en los barcos y trenes de la época. En segundo lugar, sus dimensiones fueron sometidas a una estricta modulación, condición necesaria para posibilitar su estandarización y fabricación industrial masiva. Así se conseguía un ahorro económico considerable, al tiempo que se incluía su 
coste junto al de construcción de la vivienda como fórmula para hacer asequible su financiación. En palabras de la propia arquitecta:

\begin{abstract}
La cocina resultaba tan compacta que no permitía recurrir al mobiliario-tipo habitual en la época, que necesitaba mucho más espacio. La economía consecuencia del reducido tamaño de la cocina resultaba significativa, sin embargo, la Cocina de Frankfurt proporcionaba la doble ventaja de simplificar el trabajo de sus usuarios. Únicamente recurriendo a tales argumentos fue posible obtener el permiso de las autoridades municipales de Frankfurt para la instalación de las cocinas, con todas sus aplicaciones destinadas a la simplificación de tareas [...] Los costos de la unidad completa se sumaban al presupuesto de construcción y se incluían en el alquiler, una solución aceptable para los inquilinos porque ya no necesitaban amueblar la cocina. Sobre este principio financiero fue posible la producción masiva de la Cocina de Frankfurt, ahorrando a miles de mujeres gran cantidad de tiempo y esfuerzo en beneficio de sus familias y de su propia salud. ${ }^{14}$
\end{abstract}

Además, se estudiaron minuciosamente todas las actividades a ejecutar, integrando nuevos accesorios tales como: una tabla de planchar abatible que se recogía sobre la propia pared; un canal de residuos junto a la superficie de trabajo que podía vaciarse al exterior a través de un colector vertical; un contenedor de columna para escobas, cubos y productos de limpieza; una despensa que incorporaba los vertedores Haarer de aluminio para conservar alimentos a granel, ${ }^{15}$ excepto en el caso de la harina, almacenada en un contenedor especial fabricado en madera de roble cuyo ácido tánico impide que se agusane; un escurreplatos sobre el fregadero para evitar secar la vajilla; un radiador para el necesario confort térmico; una luminaria corredera que permite concentrar la luz allí donde más falta haga en cada momento; etc. Asimismo, la posición de cada uno de estos elementos fue estudiada en relación a todos los demás para ahorrar todo esfuerzo innecesario al tiempo que se procura la máxima comodidad de trabajo.

Una cocina tan austera y racionalizada resultaba tan innovadora frente a los tipos acostumbrados en la época que, en 1928, Paul Wolff filmó una película muda promocional, de 7,53 minutos de duración, ${ }^{16}$ con el objetivo de facilitar su difusión y aceptación social. Para ilustrar la enorme simplificación de tareas que procuraba el nuevo diseño, la película muestra una comparación

14. Grete SchütTE-LiHotzKy: Op. cit.

15. Patentados por el ingeniero Otto Haarer en 1923, reunían las ventajas de un cajón y de una lata con un resultado higiénico y muy práctico.

16. Véase <http://www.vam.ac.uk/vastatic/microsites/1331_modernism/highlights_18_v02. html>, consultada el 06-12-2010, trabajo incluido en la exposición Modernism: Designing a new world 1914-1939, celebrada en el Victoria \& Albert Museum de Londres entre el 6 de abril y el 23 de julio de 2006. 
entre el trabajo de un ama de casa en la cocina de Frankfurt con su equivalente en una cocina convencional de esos años. De esa manera destaca la funcionalidad de muchas de las nuevas soluciones anteriormente apuntadas para terminar con unos diagramas comparativos en planta donde se señala la diferencia entre la distancia recorrida por el ama de casa en la cocina tradicional durante la realización de sus tareas habituales -unos 90 metros-, frente a su equivalente en la Cocina de Frankfurt -de tan solo 8 metros-, como demostración científica definitiva de la mayor eficacia del diseño de esta última.

Las revisiones críticas a la propuesta de Grete Schütte-Lihotzky aparecerán desde fechas muy tempranas precisamente a partir de esa discusión entre ambas alternativas, cocina-laboratorio y cocina-comedor, que permanecerá en el debate arquitectónico contemporáneo a finales de los años veinte y principios de los treinta. Aunque, como ya se ha visto, la solución de Frankfurt se impondrá de manera mayoritaria por motivos económicos, es

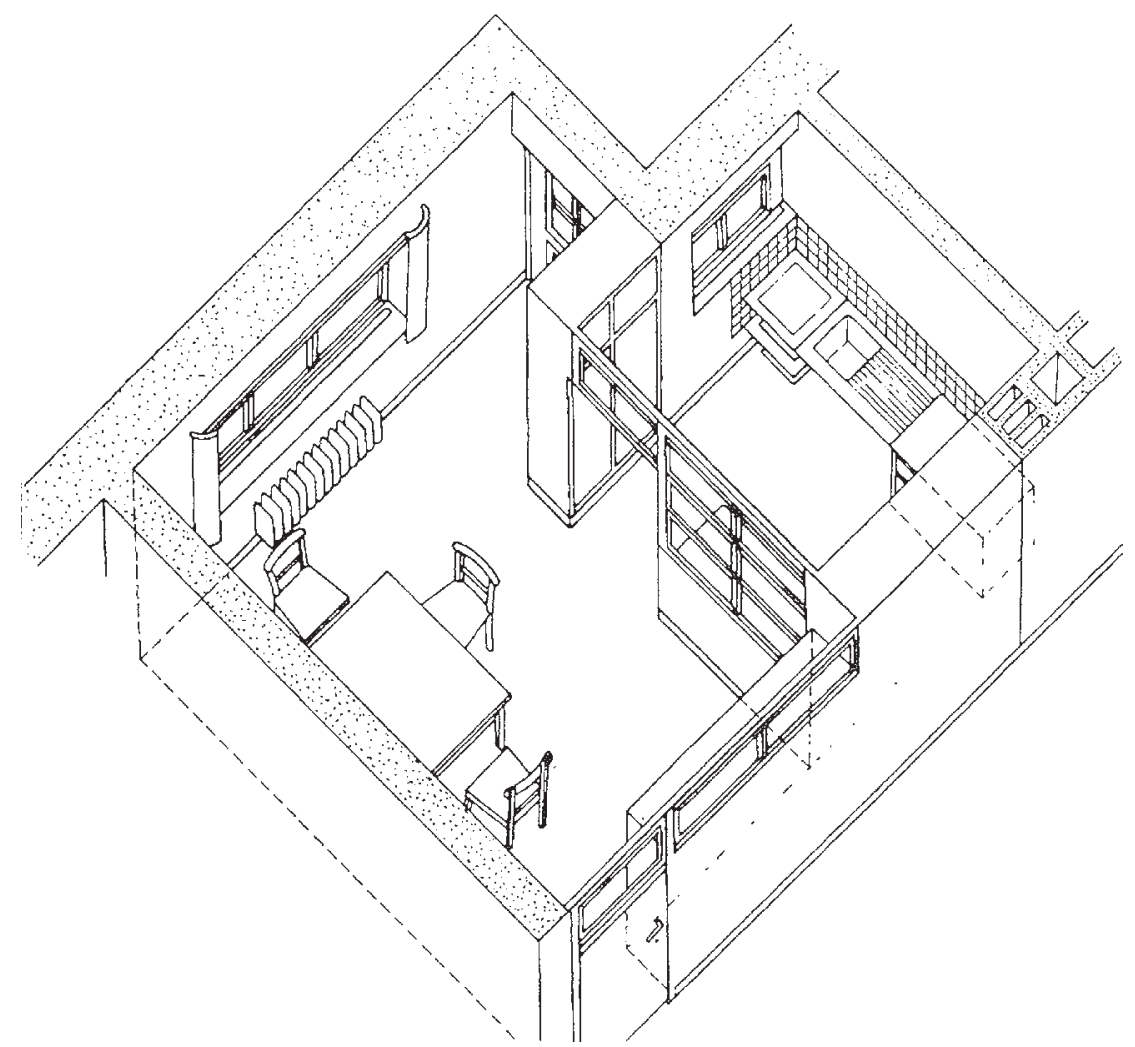

Robert VolHoelzer, Walther SCHMidt y Hanna Löw: Cocina de Munich, 1928-29. 


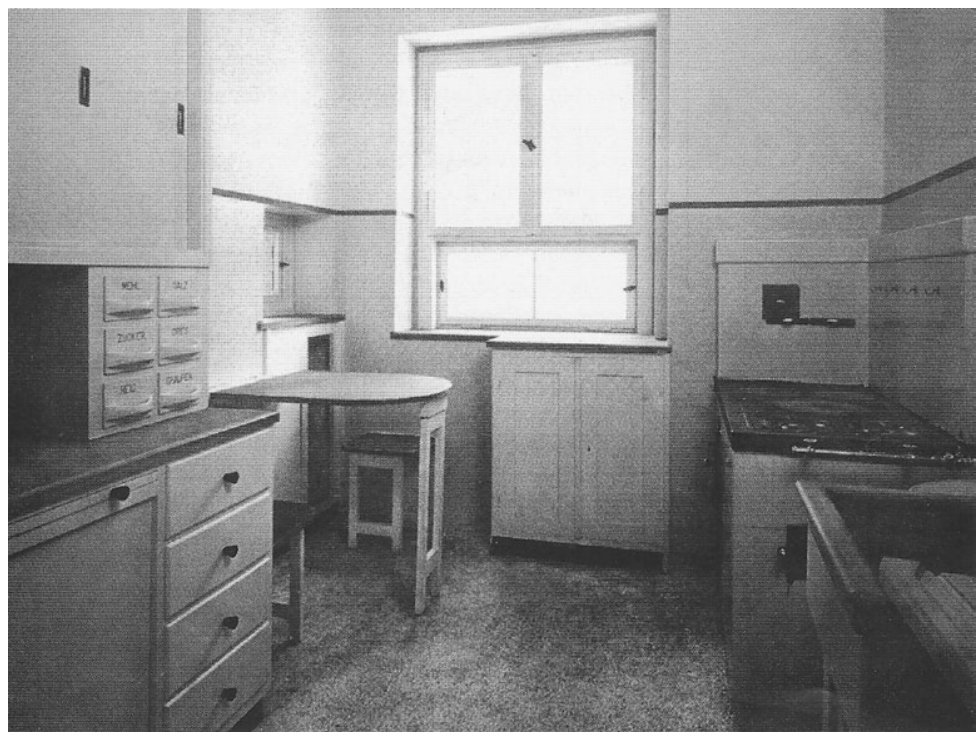

Bruno TAUT: Vivienda social, Onkel Toms Hütte, Berlín, 1927-32. Vista de una cocina.

posible encontrar otras propuestas interesantes que ensayarán diferentes grados de permeabilidad entre esa cocina especializada en las tareas domésticas y el comedor adjunto donde tienen lugar las actividades familiares colectivas. Tales son los casos, por ejemplo, de la conocida como Cocina de Munich, ${ }^{17}$ que se encuentra en las construcciones de Robert Vorhoelzer y Walther Schmidt -con el asesoramiento de la arquitecta Hanna Löw- en 1928; o de las cocinas instaladas en las viviendas de Onkel Toms Hütte por Bruno Taut (Berlín, 1927). ${ }^{18}$ En el ejemplo de Munich se establece una comunicación visual entre cocina y salón-comedor mediante una puerta y una amplia vidriera que mitiga el aislamiento de quien realiza las tareas domésticas. Bruno Taut, por su parte, ensaya también diferentes soluciones para comunicar cocina y comedor tanto para facilitar el servicio de comedor como para comunicar acústica y visualmente ambos espacios, al tiempo que incorpora -aunque sea plegable o de mínimas dimensiones- una mesa o una barra donde realizar pequeñas colaciones o bien, donde mantener la atención sobre las tareas infantiles sin abandonar las ocupaciones domésticas.

17. Véase Otl AICHER: La cocina para cocinar. El final de una doctrina arquitectónica. Barcelona: Gustavo Gili, 2004, p. 20.

18. Véase Rita MielKe: op. cit., p. 20. 


\section{Propuestas de cocina colectivizada ¿única alternativa auténticamente feminista?}

No cabe duda de que todos los ejemplos reseñados supusieron importantes avances en las determinaciones de la cocina contemporánea como espacio principal de una nueva vivienda que, merced a la incorporación de innovaciones fundamentales en los ámbitos constructivo, funcional y formal, permitió una notable reducción presupuestaria. De esta manera se posibilitó, por primera vez, el acceso a una vivienda digna de amplios sectores de la población que, hasta esas fechas, habían permanecido excluidos de tal derecho. Al mismo tiempo, gracias a la incorporación de estándares mínimos de confort: generalizando instalaciones de fontanería y saneamiento o de abastecimiento energético; renovando el equipamiento doméstico - no sólo de cocinas y baños-; ensayando nuevas tipologías de vivienda más adecuadas a los usuarios a los que estaban destinadas; racionalizando la organización de las tareas domésticas; garantizando condiciones higiénicas de soleamiento y ventilación; etc. contribuyeron a simplificar las tareas domésticas de innumerables amas de casa, de manera que facilitaron su integración en un mercado laboral industrial generalmente siempre favorable a la incorporación de mano de obra barata y de escasa especialización.

Bien es cierto que todos los ejemplos mencionados apenas se cuestionaban el rol social de la mujer a quien continuaban atribuyendo, prácticamente en exclusiva, la responsabilidad en las tareas domésticas y en el cuidado de los niños. Catherine Beecher, por ejemplo, concibió su obra como libro de texto para «escuelas femeninas», así como parte de la obra de Christine Frederick fue publicada en forma de curso por correspondencia para que las amas de casa estadounidenses mejoraran su rendimiento en la realización de las tareas diarias. Por su parte, la distribución de la Haus am Horn consagraba los roles sociales de género, incluyendo dormitorios separados para el matrimonio de manera que el femenino comunicaba directamente con el cuarto infantil mientras que el masculino se encontraba en otra de las alas y directamente relacionado con el pequeño despacho abierto al salón central. Igualmente, es una mujer la única e indudable protagonista de esa breve película anteriormente reseñada que demuestra las ventajas de la Cocina de Frankfurt, ilustrando su funcionamiento.

Todas estas razones permiten argumentar cómo ese indudable protagonismo de numerosas mujeres -puesto en evidencia a lo largo del presente texto-, en la definición y desarrollo del tipo de cocina contemporánea apenas puede explicarse sin atribuirlo a una «concesión» de sus colegas masculinos que únicamente buscaron su colaboración para el diseño de aquellos espacios 
o equipamientos tradicionalmente considerados como femeninos, en los que les reconocían superior competencia. Tales fueron los casos de Benita Otte para la Bauhaus en 1923, de Grete Schütte-Lihotzky con Ernst May en Frankfurt o de Erna Meyer en la Weissenhof de Stuttgart de 1927. Sin embargo, resulta asimismo innegable que la contribución de estas brillantes profesionales pioneras en la transformación de la cocina doméstica, en sentido de su racionalidad, mecanización y modernización, permitió abrir las primeras grietas que aceleraron la salida de la mujer de ese mismo espacio interior -privado- en el que había permanecido recluida durante tanto tiempo, facilitando su gradual incorporación al espacio exterior -público-, impulsando así un imparable proceso de conquista de su progresiva igualdad social.

Sin embargo, en paralelo al desarrollo explicado con anterioridad, se planteó una alternativa diferente que sí se cuestionó e intentó transformar radicalmente el papel social de la mujer, liberándola de las tareas domésticas. Se trata de las numerosas iniciativas tendentes a eliminar las cocinas en las viviendas particulares para sustituirlas por la gestión comunitaria y centralizada de la manutención familiar, así como de otras pesadas tareas domésticas tales como la lavandería o, incluso, la limpieza. La idea no era nueva dado que, sin necesidad de remontarse a casos singulares de la Antigüedad clásica, ${ }^{19}$ los teóricos del socialismo utópico ya habían planteado, durante la Ilustración, la creación de comunas autogestionadas en régimen cooperativo. Los Falansterios de Charles Fourier (1772-1837), por ejemplo, eran comunidades compuestas de residencias y servicios colectivos donde las viviendas carecían por completo de cocina puesto que la manutención general se encontraba centralizada en una cantina. Es conocido cómo la idea de Fourier fue llevada a la práctica, entre otros, por el industrial Jean-Baptiste Godin (1817-1888), fabricante de hornos y fogones, quien en 1865 construyó una versión industrial y reducida, denominada Familisterio, constituida por un conjunto de viviendas servidas desde una cocina comunitaria.

Poco después, hacia finales del siglo XIX e inspirándose en el movimiento de las Ciudades-Jardín impulsado por Ebenezer Howard (1850-1920), se construyeron en Inglaterra diferentes colonias como el complejo Meadow Way Green (Letchworth, 1914) cuyos inquilinos se encargaban colectivamente de la planificación del menú semanal y del abastecimiento de alimentos, mientras que unas cocineras a sueldo se responsabilizaban de las tareas culinarias, de acuerdo con un sistema que permaneció vigente hasta $1970 .{ }^{20}$ Aunque

19. ARISTÓFANES: Asambleístas, 392 a. n. e.

20. Véase Rita MiElKE: op. cit., p. 21. Sobre la ideología colectivista del movimiento de Ciudad Jardín puede verse también, por ejemplo, Raymond Unwin: La práctica del 
tales iniciativas fueron objeto de constantes críticas por parte de la burguesía, que las interpretaba como una firme amenaza a la familia y al matrimonio como pilares de la sociedad, con anterioridad a la Primera Guerra Mundial, la iniciativa fue imitada en otros lugares de Europa como Copenhague, Berlín o Viena, llegando a tener numerosos defensores y adeptos incluso en Estados Unidos, ${ }^{21}$ antes de descartarse finalmente en aras de la consolidación del sistema capitalista:

Algunas feministas y teóricas del pensamiento doméstico progresista predijeron la centralización de las principales tareas domésticas a través del establecimiento de servicios comunitarios. Basándose en el precedente de los trenes, barcos y hoteles de lujo, los reformadores vieron la posibilidad de realizar las tareas domésticas a escala industrial. Sin embargo, después de la Primera Guerra Mundial, se reafirmó como norma norteamericana el modelo privado de llevar la casa. Muchos líderes políticos y empresariales querían evitar que las mujeres compitieran con los hombres por salarios, sobre todo con los veteranos de guerra que volvían a casa. La propiedad de la vivienda privada se vio como una forma de asegurar que los trabajadores estuvieran contentos, cargados de hipotecas y por tanto a prueba de huelgas, mientras que al mismo tiempo se incrementaría la base de consumidores para los bienes producidos en serie. ${ }^{22}$

Sin embargo, el lugar donde esta iniciativa tuvo una mayor repercusión fue, evidentemente, en Rusia durante los años de fervor revolucionario posteriores a octubre de 1917. En esos primeros momentos, las comunas se organizaron de manera casi espontánea a partir de los repartos de viviendas burguesas:

La mudanza masiva de obreros a las casas de la burguesía transcurría paralelamente al proceso de surgimiento natural de las comunas domésticas [...] Al recibir gratuitamente una vivienda en usufructo, los obreros creaban en los edificios órganos de autoadministración, los cuales no sólo administraban la explotación del edificio, sino que también organizaban tales instituciones comunales domésticas como comedores-cocinas comunes, jardines de infancia, casas-cuna, rincones rojos, bibliotecas y salas de lectura, lavanderías, etc. La manutención de estas instituciones, así como la limpieza y la reparación de las instituciones de uso común, eran realizadas por los mismos moradores, sin remuneración. ${ }^{23}$

Urbanismo. Una introducción al arte de proyectar ciudades y barrios. Barcelona: Gustavo Gili, 1984, pp. 281-283.

21. Sobre las experiencias colectivistas en EUA, véase el magnífico trabajo de Dolores HAYDEN: The Grand Domestic Revolution. Cambridge: MIT Press, 1982.

22. Ellen LUPTON y J. ABBOtT MilleR: El cuarto de baño, la cocina y la estética de los desperdicios. Procesos de eliminación. Madrid: Ayuntamiento de Madrid, 1992, p. 12.

23. Selim Omárovich JAN-MAGOMÉDOv: Las cien mejores obras del vanguardismo soviético (ed. bilingüe). Moscú: URSS, 2004, p. 107. 
Estas uniones voluntarias de consumo estaban regidas por un Estatuto que reglamentaba la vida en la comuna, velaba por el mantenimiento, socializaba la alimentación y el cuidado de los niños y, ocasionalmente, alcanzaba hasta la gestión de los recursos financieros. De esa manera se contribuía a la liberación de la mujer de las tareas domésticas tradicionales con el objetivo de incorporarlas a la vida social y, sobre todo, al sistema productivo, llevando a la práctica las ideas enunciadas por el propio Lenin: «Crearemos instituciones modelos, cantinas, guarderías que libren a la mujer de las preocupaciones domésticas...». ${ }^{24}$

En una segunda etapa, a partir de 1925, aparecieron los primeros proyectos de instalaciones colectivizadas ocupando edificaciones específicas de nueva planta: cocinas industriales, viviendas comunales, clubes obreros, etc. Según Jan-Magomédov: «el camino principal en la solución del problema social de liberar a la mujer de la carga doméstica se veía en el máximo desarrollo de la red de alimentación social, próxima no sólo al sitio de trabajo, sino también a la vivienda.». En esa dirección, la primera cocina industrial de Rusia se abrió ese año en la ciudad de Ivánovo-Voznesiensk, núcleo industrial textil situado en el centro de la Rusia europea, convirtiéndose en el prototipo de la nueva tipología edificatoria. ${ }^{25}$

Por su parte, el ejemplo más conocido de vivienda comunal es posiblemente el Edificio de viviendas en el Bulevar Novinski (Narkomfin), levantado en Muscú por Moisei Guínzburg e Ignaty Milinis entre 1928-30. Inicialmente se proyectó como un conjunto de cuatro bloques: vivienda, servicios comunes (sala deportiva y cocina-comedor), jardín de infancia independiente y patio de servicios (equipado con lavandería industrial y garaje). Finalmente sin embargo, sólo se ejecutó el de viviendas y, parcialmente, el de servicios donde se encuentra la cocina -que distribuía la alimentación por las distintas viviendas- y un jardín de infancia. El bloque de vivienda tiene seis plantas elevadas sobre pilotis y distribuidas por dos corredores -en planta segunda y sexta-, de manera que el ubicado en planta segunda comunica directamente con el bloque comunal de servicios. Las viviendas corresponden a los tipos desarrollados por el Departamento de Estandarización del Stroikom de la RSFR. ${ }^{26}$

24. LENIN en la cuarta conferencia de los trabajadores moscovitas sin partido, 1919, cit. en Anatole KopP: Arquitectura y urbanismo soviéticos de los años veinte. Barcelona: Lumen, 1974 , p. 133.

25. V. Selim O. JAN-MAGOMÉDOv: op. cit., p. 137-138.

26. Comité para la edificación de la República socialista federativa soviética de Rusia, del que formaban parte M. Barsch, V. Vladímirov, A. Pasternak y G. Sum-Shik, bajo la dirección de M. Guínzburg. 

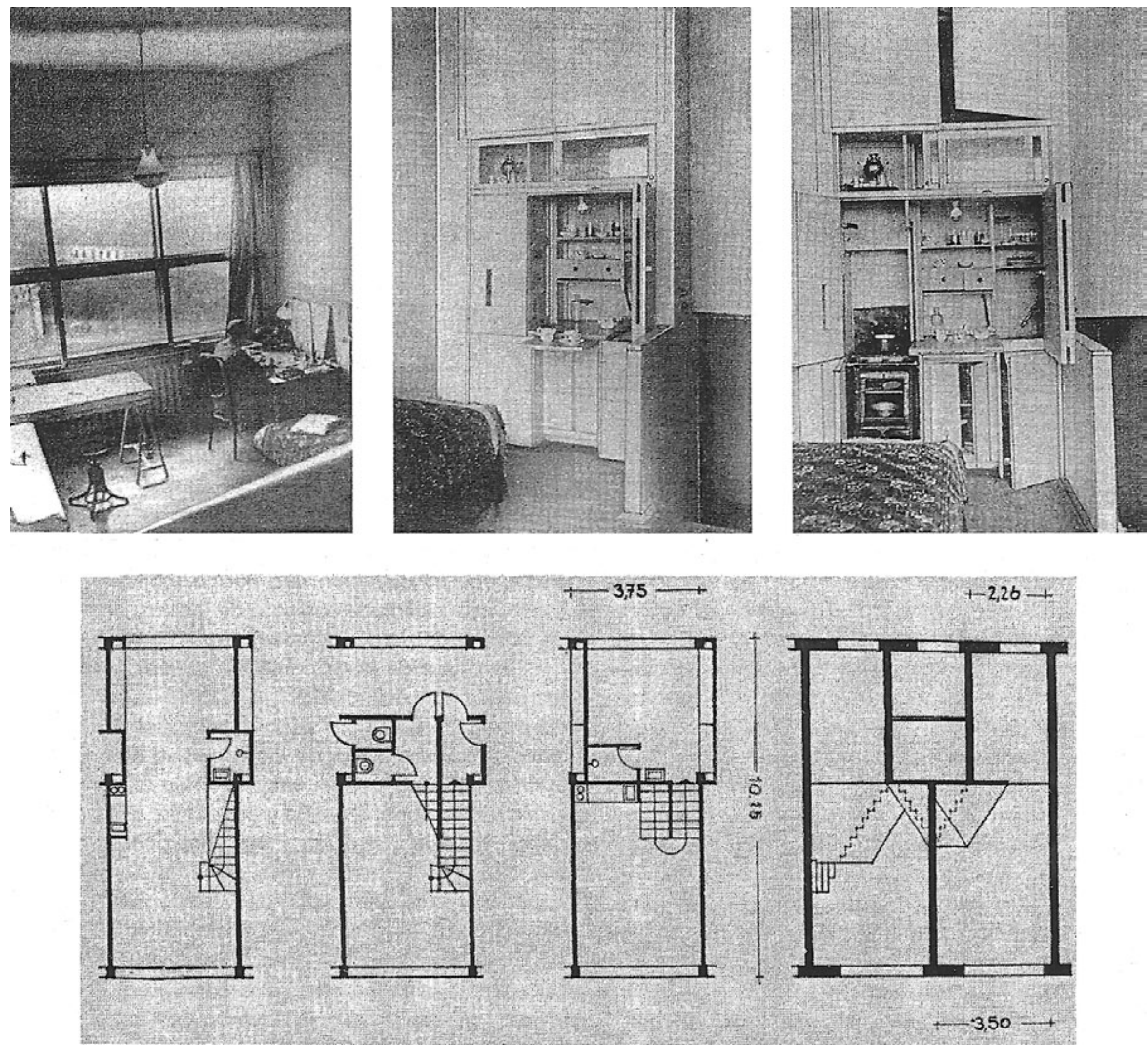

Moisei GuínZBurg e Ignaty MiLINIS: Vivienda comunal (Narkomfin), Moscú, 1928-30. Planta vivienda tipo y equipamiento de una cocina.

Se trata de viviendas transitorias, esto es, donde además de las instalaciones comunales de uso colectivo, cada familia cuenta todavía con un apartamento propio, si bien, de superficie reducida. Se idearon tres variantes de 27,30 y 31 $\mathrm{m}^{2}$, cada uno de los cuales consta de recibidor con escalera que -bien hacia arriba, bien hacia abajo- conduce hasta el espacio principal de 3,5 m (3,2 m) de altura. Junto a la ventana se sitúa un equipo básico de cocina -hornilla, fregadero,...-, que puede cerrarse mediante unas puertas correderas. En la parte posterior de menor altura, 2,25 $\mathrm{m}(2,15 \mathrm{~m})$, aparece un dormitorio y un baño con bañera, ducha o, simplemente lavabo. Cada unidad constituye un apartamento de un dormitorio o dormitorio y medio, destinado a una familia de tres o cuatro miembros. 
El Lissitzky, junto con sus estudiantes del VJUTEIN, ${ }^{27}$ diseñó prototipos de mobiliario parcialmente empotrado para estas unidades, distinguiendo zona de trabajo, zona de comedor y zona de dormitorio; por su parte, S. Lisagor desarrolló diferentes instalaciones empotradas (guardarropas, anaqueles, cocina-armario,...) que llegaron a producirse para el equipamiento de varios tipos experimentales construidos en el bulevar Gogol de Moscú. ${ }^{28}$

Todas estas interesantes investigaciones perecerían, sin embargo, en breve plazo víctimas, en parte, de sus propios excesos tras cubrir en pocos años el tramo que separa unos planteamientos razonables de una utopía colectivista deshumanizadora. La puesta en marcha del Primer Plan Quinquenal, a partir de 1929, exigía abundante mano de obra de manera que, a principios de los treinta, se volvió indispensable la incorporación masiva de la mujer al proceso productivo lo que, inmediatamente, agudizó el problema de la vivienda a la vez que aceleró la transformación de los modos de vida. En ese contexto cabe entender, por ejemplo, la propuesta de N. Kuzmín que, en 1928-29, planteó un Combinado habitacional-Poblado para los mineros de la región hullera de Anzherka-Sudzhenka, calculado para más de cinco mil personas organizadas por grupos de edad que podían relacionarse entre sí pero cuyos dormitorios estaban separados. El proyecto reglamentaba todos los aspectos de la vida de los mineros, incluyendo un "gráfico de vida» que contemplaba todas las etapas de la vida de un comunero desde su nacimiento hasta su muerte.

Todo está colectivizado, empezando por el cosido de los botones y el arreglo de la ropa (la esposa no tiene tiempo para eso), y culminando con la limpieza de las habitaciones. Los trabajadores se levantan después de dormir y salen de sus dormitorios. Las camas se pliegan. Un personal especializado realiza la limpieza de las habitaciones... El área de los dormitorios se calculó partiendo del gráfico de movimiento y del mobiliario de las habitaciones. El mobiliario era el siguiente: camas plegables de pared, mesita de noche y armario para las batas. El gráfico de movimiento era: el obrero se levanta (al llamado de la radio que regula la vida de la comunidad), guarda la cama, se dirige a su armario, se pone la bata y el calzado y sale al cuarto de gimnasia donde puede hacer ejercicios, tomar una ducha, lavarse y vestir la ropa limpia preparada con antelación por el personal especializado. ${ }^{29}$

27. Acrónimo de «Instituto Superior del Arte y de la Técnica», nueva denominación entre 1927-30 de los VJUTEMAS, «Talleres de Enseñanza Superior del Arte y de la Técnica» (1920-27), escuela vanguardista soviética radicada en Moscú, con interesantes paralelismos con la Bauhaus alemana.

28. V. Selim O. JAN-MAGÓMEDOV: op. cit., p. 321-324.

29. N. KuzMín: «Problema de la organización científica del modo de vida», en AM (Arquitectura Moderna), n. ${ }^{\circ}$ 3, 1930, pp. 16-17, cit. en Selim O. JAN-MAGÓMEDOv: op. cit., p. 332. 
El proyecto fue defendido por Kuzmín en 1929 ante los propios mineros, quienes le dieron su aprobación lo que llevó a la empresa minera responsable a firmar un contrato con el arquitecto para preparar la construcción del complejo. Sin embargo, después del decreto del Comité Central del Partido Comunista, de 1930, «Sobre la reorganización del modo de vida», los trabajos fueron definitivamente suspendidos.

De esta manera, esos planteamientos razonables denominados transitorios -como el comentado Narkomfin-, donde las viviendas todavía eran completas y la colectivización preservaba una cierta intimidad del grupo familiar, evolucionaron hacia una progresiva reducción del espacio de uso individual, considerando como colectivas funciones originalmente concebidas como familiares, hasta alcanzar excesos casi cuartelarios -como el de Kuzmín-, donde desaparecía el grupo familiar y el individuo se disolvía en el grupo al estar obligados todos sus usuarios a realizar, a la vez, las mismas actividades durante todo el día y durante toda su vida. En palabras de Anatole Kopp:

No deja de ser verdad que en el campo de la vivienda los errores se pagan caros y que si se hubiera dado prioridad a las soluciones del Stroikom, esas viviendas serían hoy usadas por los solteros, los ancianos y los matrimonios de un solo hijo, que constituyen una parte importante de la población. ${ }^{30}$

A todo ello cabe añadir que durante la década de los treinta, como consecuencia del aludido decreto y de la agudización de la carestía de viviendas, numerosas de esas células mínimas, originalmente planificadas y dimensionadas para grupos de tres o cuatro miembros, fueron ocupadas por varias familias lo que las hizo verdaderamente más incómodas que las viviendas convencionales, donde cada familia mantenía cierta independencia al ocupar un dormitorio. Circunstancias que derivaron en una clara reacción popular en contra de ese tipo de residencias.

\section{Difusión y crisis del tipo tras la Segunda Guerra Mundial}

Al mismo tiempo, el tipo establecido por Grete Schütte-Lihotzky inició en occidente su desarrollo hacia la producción industrializada, de la mano de emprendedoras empresas que empezaron a experimentar con nuevos tipos de contenedores cada vez más especializados o con nuevos materiales sintéticos mejor adaptados a los exigentes requisitos de su función específica. Comenzaba así una carrera pronto interrumpida por el estallido de la Segunda Guerra Mundial que reclamaría para la causa bélica la práctica exclusividad de los esfuerzos financieros e industriales.

30. A. KopP: op. cit., p. 170-171.

Feminismo/s 17, junio 2011, pp. 183-211 
Durante los años de la contienda, la Cocina de Frankfurt continuaría su periplo por Estados Unidos y Suecia, territorios periféricos del conflicto bélico. Los diseñadores estadounidenses del período aerodinámico aportaron la mecanización de algunos elementos de la nueva cocina, siendo responsables de la incorporación a la misma de numerosas innovaciones tecnológicas, al definir las características de muchos dispositivos progresivamente convertidos en imprescindibles merced al impulso de poderosas estrategias de mercado. ${ }^{31}$ Los del país nórdico, por su parte, aportaron la humanización característica del diseño escandinavo, suavizando ese funcionalismo tan austero que había tenido su origen en los países centroeuropeos. Ello permitió que, a principios de los cincuenta, cuando los años más duros de posguerra estaban quedando definitivamente atrás, el modelo de cocina compacta e integrada fuera adoptado de manera mayoritaria -bajo la denominación de «cocina sueca»-, aprovechando el masivo proceso de reconstrucción de los hogares europeos e incorporando numerosos electrodomésticos nuevos, buena parte de los cuales habían definido su moderno y flamante diseño prototípico de la mano de los profesionales estadounidenses del Streamlining.

En ese contexto, por ejemplo, la empresa alemana Poggenpohl lanzó al mercado su primera cocina integrada en 1950, con una distribución modular y flexible de contenedores murales y de base que permitían equipar la estancia de pared a pared, solución que a lo largo de la década fue adaptándose para integrar no solo el fregadero, sino también los electrodomésticos que no dejarán de ir apareciendo y evolucionando con el tiempo: fogones eléctricos, frigorífico, horno, lavadora, lavavajillas, microondas, etc. La capacidad combinatoria del equipamiento y de los contenedores de la cocina vino a consagrarse de manera definitiva en 1957, gracias a la publicación de las primeras normas DIN relativas a este espacio.

A partir de esos momentos, la cocina doméstica quedaría sometida a los vaivenes de un consumo regido por las reglas de la publicidad y del mercado, de modo que, una vez en este punto, cabe preguntarse por la vigencia del tipo cuya evolución ha sido descrita, en unas condiciones que tanto difieren de aquéllas para las que tuvo lugar su definición. En la actual sociedad del bienestar, la incorporación de la mujer a la vida pública es ya un hecho incuestionable que, hoy por hoy, ha desplazado el debate social más hacia la corresponsabilidad en las tareas domésticas, desde la limpieza, la compra o la

31. Sobre la mecanización del espacio doméstico por parte de la industria estadounidense y su influencia en la definición de la identidad femenina, puede verse Ellen LUPTON: Mechanical Brides. Women and Machines from Home to Office. Nueva York: Cooper-Hewitt National Museum of Design-Smithsonian Institution-Princeton University Press, 1993. 
cocina hasta la atención infantil. Por otro lado, aún subsistiendo el problema de la vivienda, tiene también un cariz bien distinto. Pese a las dificultades ciertas que determinados sectores sociales tienen para acceder a la misma, como consecuencia en buena medida de su elevado precio derivado de las condiciones de mercado, el derecho a la vivienda está asumido por la legislación de la mayoría de los países occidentales. Del mismo modo, su construcción ha sido sometida a normativas que regulan desde sus dimensiones hasta sus condiciones de habitabilidad o calidad constructiva, especificando, entre otras características, los mínimos de ventilación, iluminación, aislamiento o equipamiento. Como resultado, el mayor problema actual radica, probablemente, en que lo estricto y sobreabundante de tales regulaciones convierte, en numerosas ocasiones, en norma incuestionable los mínimos que ellas establecen. Por último, tampoco el acceso a una alimentación de subsistencia suele representar hoy día un problema grave para la mayoría de la población en el denominado primer mundo, por apuntar únicamente algunos de los principales agentes que, en su momento, actuaron como impulsores de los cambios relatados.

Reunirse a comer en las poblaciones del mundo contemporáneo suele ser un acto cargado de elevado contenido social. Compartir un almuerzo o una cena con amigos, compañeros de trabajo o, incluso con clientes o colegas de negocio o profesión, acostumbra ser pretexto habitual no tanto para alimentar el cuerpo sino para fomentar y cultivar las relaciones personales en un ambiente agradable y distendido. Tal dimensión social no debería corresponder únicamente a la función de comer. Por el contrario, también la de cocinar, junto con el resto de tareas que ello conlleva -aprovisionamiento, mantenimiento, preparación, limpieza,...-, debería tener un contenido social análogo. Como señala Otl Aicher, tanto comer como cocinar son actividades mucho más agradables cuando se llevan a cabo en compañía:

Cocinar es una actividad de varios. En la cocina, el ser humano es un ser social. La cocina es una función de la naturaleza social del hombre. Sólo se cocina con ganas cuando se va a disfrutar de la cocina con otros. Y se cocina con más ganas si se cocina en compañía.

Por muy sociales que hayan sido las preocupaciones de los arquitectos que concibieron la Cocina de Frankfurt, forzar a alguien a cocinar donde sólo cabe una persona, es parecido a una condena. ${ }^{32}$

Cabría aventurar por tanto para terminar que, respecto a su futuro como espacio doméstico, la cocina no solo debería ser el lugar donde compartir buena

32. Otl Aicher: Op. cit., p. 43.

Feminismo/s 17, junio 2011, pp. 183-211 
parte de esas tareas que giran alrededor de la función de cocinar sino también, deseablemente, las relativas a la de comer. Con ello se amplificaría otro de sus papeles fundamentales al definirse como un lugar central en la vivienda para la socialización y educación de las nuevas generaciones donde, de manera natural, éstas puedan aprender el valor y la satisfacción de responsabilizarse y compartir las diferentes tareas domésticas. He ahí, probablemente, uno de los mayores retos que se presenta a los jóvenes profesionales de la arquitectura y el diseño a la hora de interpretar las características de las sociedades postindustriales donde desarrollarán su trabajo. Para ellos quizás resulte positivo recordar, por último, el mito moderno de la fusión entre arte y vida, según el cual la arquitectura -y, por ende el diseño- no solo reflejan una imagen del mundo en el que desarrollan su actividad sino que, mediante ésta, son también capaces de incidir en la transformación de la sociedad, de sus grados y valores internos, al dar forma a sus funciones.

\section{Referencias bibliográficas:}

AICHER, Otl: La cocina para cocinar. El final de una doctrina arquitectónica. Barcelona: Gustavo Gili, 2004 (ed. orig.: Munich, 1982).

AtTFIELD, Judy: «Form/female follows Function/male: Feminist Critiques of Design», pp. 199-225, en John A. WALKER: Design history and the history of design. Chicago: Pluto Press, 1989.

BAUMHOFF, Anja: «Las mujeres en la Bauhaus: un mito de la emancipación», pp. 96-107, en Jeannine Fiedler y Peter FeIERABend (eds.): Bauhaus. Madrid: Könemann, 2000 (ed. orig.: Colonia, 1999).

CAMPí I VALLS, Isabel: «Algunas reflexiones sobre la historia del diseño de productos», pp. 219-241, en La idea y la materia, V. I: El diseño de producto en sus orígenes. Barcelona: Gustavo Gili, 2007.

DROSDE, Magdalena: Bauhaus, 1919-1933. Colonia: Taschen, 1991.

ESPEGEL Alonso, Carmen: Heroinas del espacio: mujeres arquitectos en el movimiento moderno. Buenos Aires: Atlántida, Nobuko, 2007.

GIEDION, Sigfried: La mecanización toma el mando. Barcelona: Gustavo Gili, 1978 (ed. orig.: Nueva York, 1948).

HAYDEN, Dolores: The Grand Domestic Revolution. Cambridge: MIT Press, 1982

JAN-MAGOMÉDOV, Selim Omárovich: Las cien mejores obras del vanguardismo arquitectónico soviético (ed. bilingüe). Moscú: URSS, 2004.

KopP, Anatole: Arquitectura y urbanismo soviéticos de los años veinte. Barcelona: Lumen, 1974 (ed. orig.: París, 1967).

LuPTON, Ellen: Mechanical Brides. Women and Machines from Home to Office. Nueva York: Cooper-Hewitt National Museum of Design-Smithsonian Institution-Princeton University Press, 1993. 
J. AbBott Miller: El cuarto de baño, la cocina y la estética de los desperdicios. Procesos de eliminación. Madrid: Ayuntamiento de Madrid, 1992 (ed. orig.: Nueva York, 1992).

Mielke, Rita: La cocina. Historia, cultura, diseño. Berlín: Feierabend, 2004.

OEDEKOVEN-GERISCHER, Angela et al. (eds.): Frauen im Design: Berufsbilder und Lebenswege seit 1900. Women in Design: Careers and Life Histories since 1900 (2 v.) Stuttgart: Design Center Stuttgart, 1989.

SCHÜTTE-LihotZKY, Grete: Erinnerungen (Memorias). Viena: manuscrito inédito, 1980-90. Citado en la web del Museo Austriaco de Artes Aplicadas y Arte Contemporáneo (MAT), <http://www.mak.at/e/sammlung/studien/studiens_ frakue_e.html>, consultada el 06-12-2010.

VALDIVIESO, Mercedes: «Retrato de grupo con una dama: el papel de la mujer en la Bauhaus», pp. 246-255, en Anna CALvera y Miquel MAllol (eds.): Historiar desde la periferia: historia e historias del diseño. Barcelona: Universitat de Barcelona, 2001.

- «La aportación de la Bauhaus a la innovación del espacio doméstico: la «Casa Modelo» Haus am Horn (1923)», <http://www.ub.edu/gracmon/capapers/ mercedesvaldivieso.pdf $>$, consultado el 05-12-2010.

WeITZ, Eric D.: La Alemania de Weimar. Presagio y tragedia. Madrid: Turner, 2009 (Ed. orig.: Princeton University Press, 2007).

WOLF, Paul: Frankfurter Küche, película promocional de 7'53" incluida en la exposición Modernism: Designing a new world 1914-1939, celebrada en el Victoria \& Albert Museum de Londres entre el 6-04 y el 23-07-2006, consultado el 06-12-2010, <http://www.vam.ac.uk/vastatic/microsites/1331_modernism/ highlights_18_v02.html>. 



\title{
DE ARMARIOS Y OTRAS COSAS DE CASAS...
}

\author{
María Melgarejo Belenguer \\ Universidad Politécnica de Valencia
}

Recibido 09/02/2011

Aceptado 20/05/2011

\section{Resumen}

Al inicio del siglo XX, durante sus tres primeras décadas, en la arquitectura se produjo un cambio radical y absoluto que no tuvo precedentes, como reflejo de la sociedad. Una ruptura con el pasado y una voluntad decidida de renovación y transformación que arrasó con todo lo conocido y que inició la lucha por la vida moderna

Se estudia en este texto la aportación de dos mujeres: Charlotte Perriand, y Lilly Reich, a la renovación de la arquitectura.

Ambas por su origen y formación, anclada aún en el siglo XIX, conocían bien las restricciones de ese ámbito privado, la casa, al que habían sido relegadas. Sabían qué era necesario en el hogar y cómo organizarlo y lo aplicaron para iniciar la renovación desde el interior de la arquitectura.

Palabras clave: Diseño de interiores, arquitectura, mujeres diseñadoras, la casa moderna.

\begin{abstract}
At the beginning of the twentieth century, during its first three decades, in architecture there was a change radical and all that was unprecedented, reflecting the society. One break with the past and will determination of renewal and transformation that swept all know nand who started the fight for modern life. We study in this paper the contribution of two women: Charlotte Perriand, and Lilly Reich, a renewal of architecture.

Both share origin and training, were still anchored in the XIX century, were aware of the restrictions of this area private house, which had been closed. They Known what was needed at home and how to organize it, and applied to start the renovation from the inside of the architecture.
\end{abstract}

Keywords: Interior Design, Architecture, women designers, Modernism House. 

La imagen de Peter de Höoch, nos muestra, en un primer plano, a dos mujeres frente a un armario, guardando la ropa de la casa, recién lavada, de forma ordenada; en el plano siguiente una niña juega entretenida ajena al quehacer de las mayores.

Esta pintura es un ejemplo bastante característico, de lo que el teórico francés Quatremère de Quincy calificó como "pintura de género», para describir únicamente la pintura de escenas domésticas y de la vida cotidiana. ${ }^{1}$

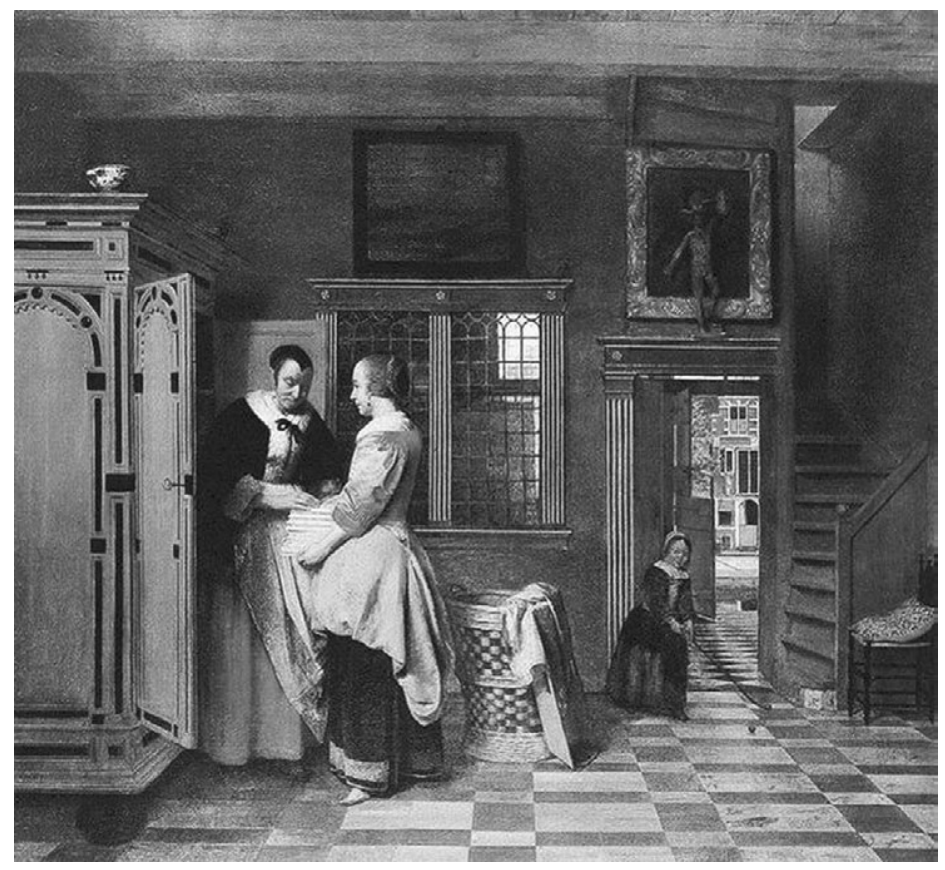

Peter de Höoch. El armario de la ropa blanca. 1663.

(http://www.centroarte.com)

1. Vegara, Alejandro. Vermeer y el interior holandés. Madrid, Museo Nacional del Prado, 2003.

Feminismo/s 17, junio 2011, pp. 213-228 
A partir de 1658, en Holanda, Pieter de Höoch realizó principalmente escenas de interior, con personajes en su mayoría femeninos. En las pinturas con mujeres trabajando, como la que es objeto de análisis, de Hooch idealizó la vida doméstica, de la época. La pintura holandesa del siglo XVII, se centró en la temática de la vida del hogar, donde la mujer era la figura protagonista, y asumía el papel doméstico que correspondía al ideal de la época: las virtudes simples, la correcta administración del hogar, la maternidad y la buena educación de los niños. En el hecho de que las figuras de mujeres predominen en la pintura de interior doméstico, desde 1650, en autores como Pieter de Hooch y Johannes Vermeer se puede encontrar el reflejo de una sociedad que confinaba en el ámbito doméstico a la mujer.

El concepto de vida interior que se estaba desarrollando en ese momento, separaba la vida de la calle, de la vida familiar, apareciendo una incipiente diferenciación de espacios. La casa era el ámbito femenino, el ámbito privado, frente al masculino, que era el público, la calle, el café, el club. La casa se estructuraba reproduciendo estos dos ámbitos, dividiendo los espacios en privados y públicos, en estancias femeninas y masculinas.

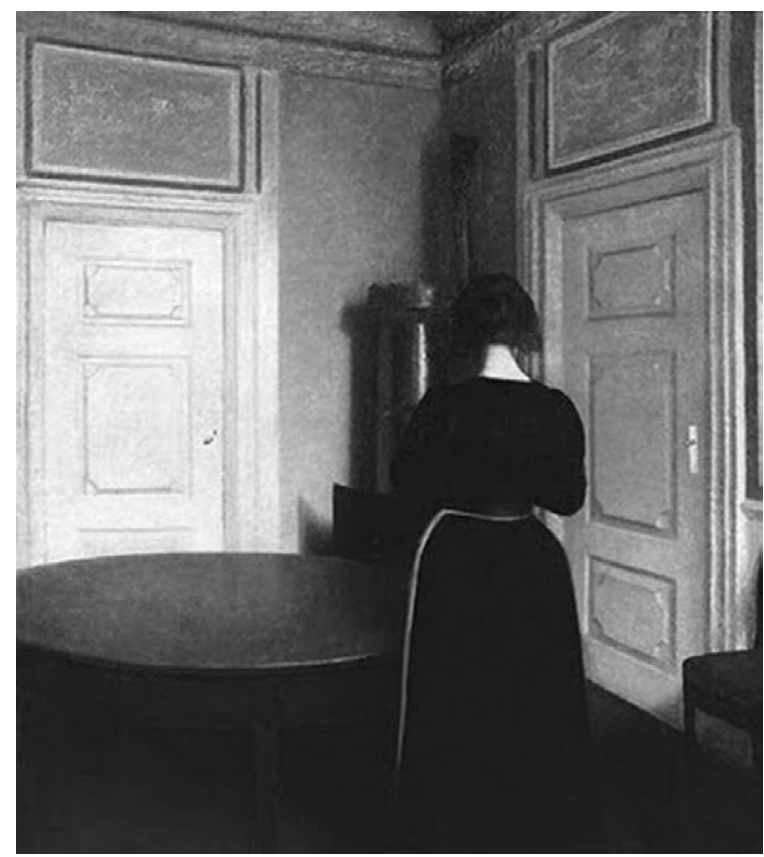

Vilhelm Hammershøi. Muchacha joven cosiendo. 1887. (http://www.uv.es/capelo/Hammershoi.html) 
La correlación entre estructura espacial y estructura social se hará más explícita en el siglo XIX, donde se diferenciarán las posiciones en el espacio de la vivienda según la estructura jerárquica de las relaciones familiares.

Como señala Richard Sennet, en La conciencia del ojo, el hogar era el refugio moral en el que estaban reducidas las mujeres, mientras que a los hombres se les permitía salir a la calle» ${ }^{2}$. El autor hace referencia a un artículo titulado «Una o dos nociones más acerca del bienestar doméstico», que fue publicado en el Appleton's Journal en 1879, en el que un escritor proclamaba:

...Para una mujer el hogar representa la vida militar; para un hombre, la vida del reposo...Ella no dispone de otra esfera en la cual realizar sus actividades...la mujer, por las propias necesidades de su existencia, tiene que tener una idea muy diferente, de la que tiene un hombre. ${ }^{3}$

La mujer en el siglo XIX, tenía la responsabilidad moral y material del hogar. Las tareas domésticas eran su forma de expresión. Su cometido era cuidar del hogar y procurar en él, la vida en familia.

En el periodo comprendido entre los años veinte y la primera década de los años treinta, del siglo XX, se hizo necesaria una ruptura con el pasado y surgió una voluntad decidida de renovación y de transformación, que arrasó con todo lo conocido y que inició la lucha por la vida moderna. En la arquitectura se produjo un cambio radical y absoluto que no tuvo precedentes.

Desde 1921, aproximadamente, el arquitecto Le Corbusier inició sus investigaciones para encontrar una solución al problema de la casa moderna.

Le Corbusier, pronunció una serie de conferencias en Buenos Aires en 1929. En la décima, la que llevaba por título «La aventura del mobiliario», comentó ante una asociación llamada «Los Amigos de las Artes»:

... No se enfocará con eficacia la renovación de la planta de la casa moderna, sino después de haber puesto al desnudo la cuestión del mobiliario. Aquí está el nudo gordiano. Hay que cortarlo, de lo contrario, toda persecución de vida moderna es vana. ${ }^{4}$

En dicha conferencia se declaró obsesionado por la anomalía del mobiliario. También mencionó a Madame Charlotte Perriand, de la que se refirió como «nuestra asociada para el acondicionamiento de los interiores de las casas» 5 . Para acometer la renovación de la casa, Le Corbusier, eligió una mujer.

Por iniciativa de Charlotte Perriand, en el Salon d'Automne de 1929, una exposición que se celebraba anualmente desde 1903 en París, el taller de Le

2. SENNET, Richard. La conciencia del ojo. Barcelona, Versal, 1991.

3. Ibídem, p. 47

4. Le Corbusier. Precisiones. Barcelona, Poseidón, 1979, p. 128.

5. Ibídem, p. 135. 

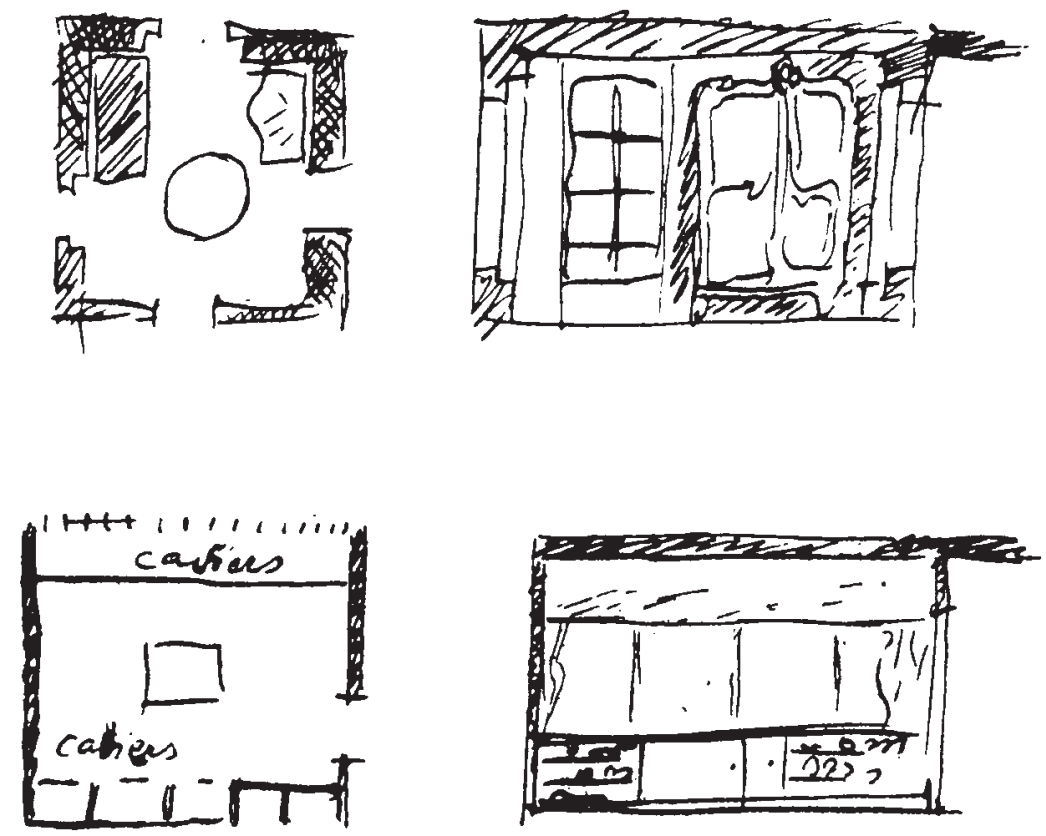

Le Corbusier, dibujos comparados. Dibujo de un plano de amueblamiento y la sección de un dormitorio tradicional con el gran armario normando. Dibujo en plano y en sección de un dispositivo moderno: ventanas, tabiques y casiers. (Le Corbusier: Precisiones. Barcelona, Poseidón, 1979)

Corbusier, construyó un prototipo de vivienda moderna. Por primera vez, el proyecto de arquitectura se iniciaba a partir de la organización y dimensionado del espacio interior y con un nuevo concepto de mobiliario, que adquiriría una nueva denominación Equipamiento.

Charlotte Perriand nació en 1903, su formación había sido en el más puro estilo «Artes Decorativas», la enseñanza que había recibido de los decoradores Maurice Dufrène y de Henri Rapin, conocía muy bien los patrones heredados del siglo XIX, había sido educada en ellos, como ella mismo explicaría en su autobiografía. ${ }^{6}$

Perriand trabajó en el taller de la rue Sèvres, desde su incorporación, a finales de 1927, en el equipamiento para viviendas, al mismo tiempo que desarrollaba el estudio de los casiers, los elementos que iban a resolver el problema del almacenaje, y a sustituir los antiguos «armarios normandos», aquellos grandes muebles.

6. Perriand, Charlotte. Une vie de creation, París, Odile Jacob, 1998. 


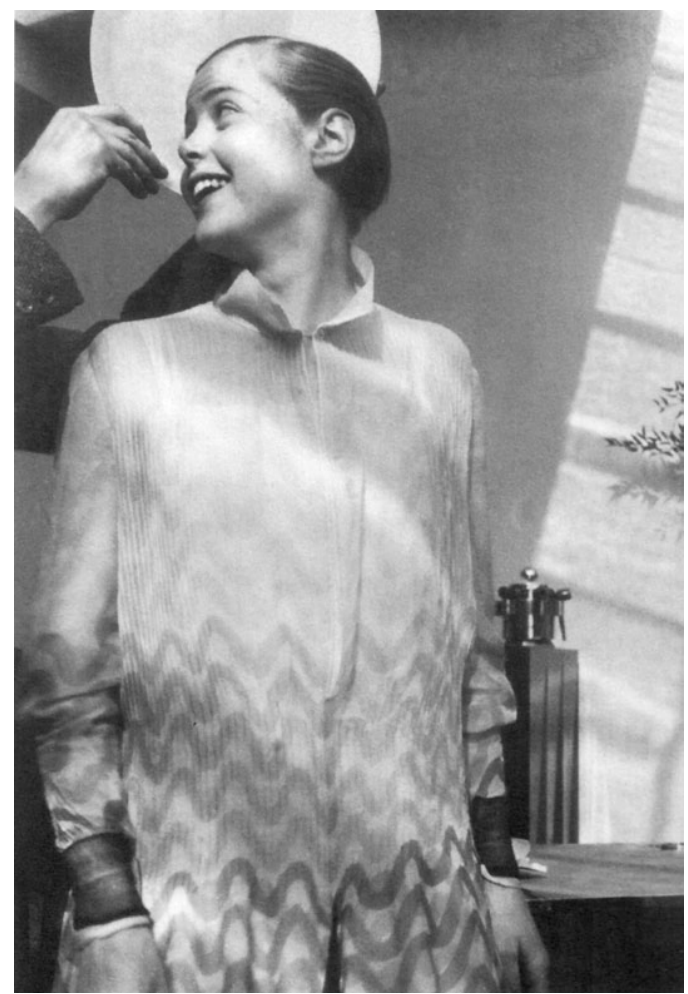

Charlotte Perriand en 1928.

(PERRIAND, Charlotte: Una vie de création. París, Odile Jacob, 1998)

Ella, por su educación, sabía qué era necesario en el hogar y cuánto ocupaba, había sido preparada como todas las mujeres en el siglo XIX, para saber crear un hogar bello y organizado. El almacenaje era definido por Perriand como factor de orden y armonía, estaba convencida de que al lograr resolver este problema, conseguirían la transformación en la vivienda. Para ello, llevó a cabo un proceso exhaustivo de dimensionado de todos los objetos de la vida cotidiana, una camisa plegada, un sombrero, o unos libros... todo fue medido y clasificado.

Todo, hasta el más mínimo detalle, se encontraba registrado en sus «tablas de dimensionado», lo que le permitió establecer unas superficies mínimas, para cada función de la vida doméstica.

De sus conclusiones, obtuvo las necesidades de espacio para las actividades más habituales, del modo de vida previsible, del número de ocupantes y de la relación entre ellos. 


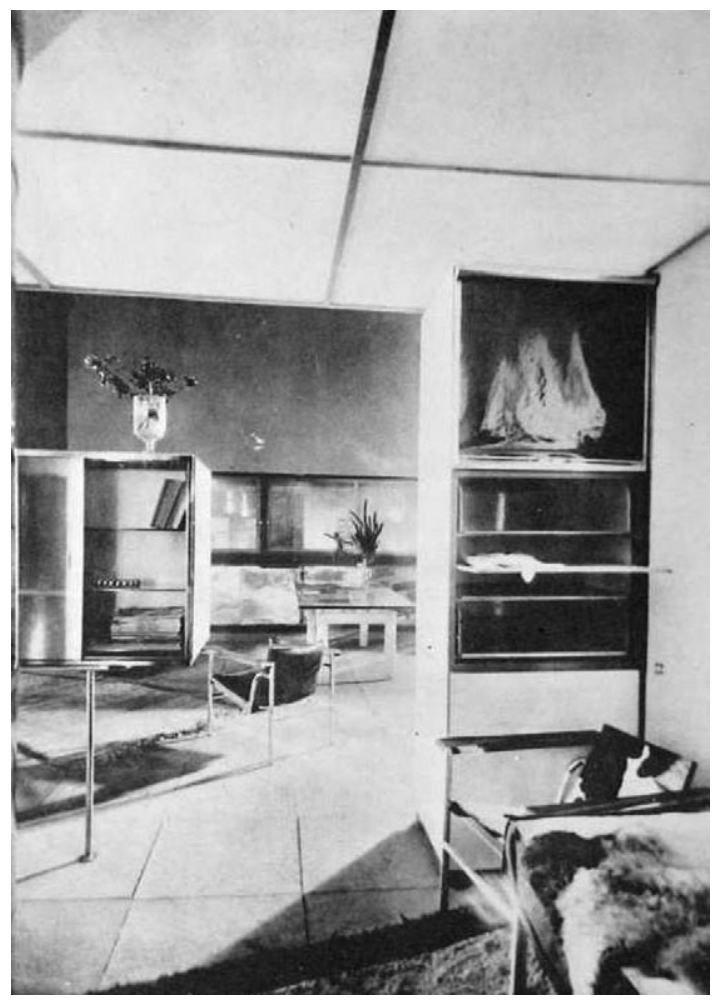

Le Corbusier, Pierre Jeanneret y Charlotte Perriand. Vivienda en el Salon d' automne París. 1929.

(Revista Architecture Vivante 1929)

Y surgió nuevo concepto de organización del espacio interior, sin compartimentaciones estancas, tan sólo por los nuevos elementos de almacenaje, los llamados casiers, a cuyo diseño y producción en serie, Perriand dedicó varios años.

Ya no había muros, el espacio era abierto y flexible, esta nueva configuración llevaba implícita un cambio en el modo de vida, una nueva mentalidad, una redefinición de la estructura jerárquica de los habitantes de la casa, que años más tarde daría lugar a la integración de la cocina abierta, al estar como parte del cambio del papel de la mujer en el hogar. Una muestra de ello fue el mueble - cocina - diseñado para el apartamento de Le Corbusier hacia 1931 y posteriormente adaptado al que diseñó para la Unité d'Habitation de Marseille. La cocina fue diseñada por Perrriand, estaba separada del comedor y de la sala de estar, por una puerta, frente a la que colocó un cuerpo de casiers que 


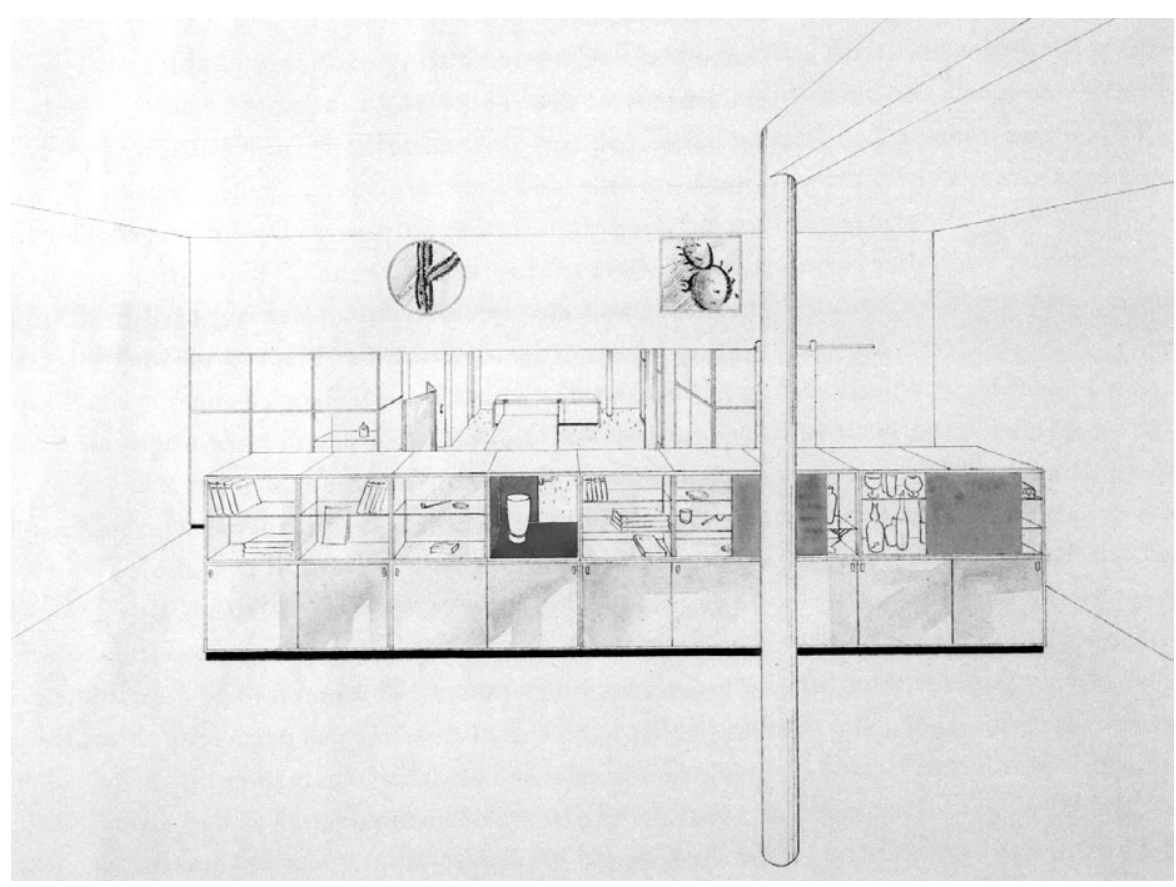

Charlotte Perriand. Vivienda para Julian Martinez de Hoz. 1930

(BARSAC, Jacques: Charlotte Perriand: Un art d'habiter. París, Norma, 2005)

se interrumpía para dejar el espacio libre a la altura de la vista y de las manos, lo que simplificaba aspectos funcionales, como pasar los platos o permitir una mayor comunicación mientras se trabajaba, con el comedor. Está solución ya había sido empleada para la cocina del Salon d' Automne de 1929.

Con sus estudios, Charlotte Perriand resolvía el problema de la vivienda moderna, aquella que Le Corbusier anhelaba, la casa -máquina, exacta y precisa.

Estos principios también fueron aplicados por Perriand al diseñar, en solitario, una vivienda en 1930, para Julián Martinez de Hoz, aunque no fue construida.

Una forma de hacer, que demostraba: «tener una idea muy diferente del hogar de la que tiene un hombre». ${ }^{7}$ La idea de proyectar para una nueva manera de vivir, comenzaba a estar presente en todos los autores del momento. Adolf Behne, crítico, historiador del arte, escritor sobre arte y arquitectura,

7. SENNET, Op. cit., pág. 47. 
vinculado a la Asociación Deutscher Werkbund, insistía en esa idea, y decía que: «La arquitectura no es otra cosa que organizar el espacio de manera que la vida pueda desarrollarse lo mejor posible ${ }^{8}$. La verdadera transformación de la arquitectura sólo podría hacerse cambiando gradualmente los valores de la sociedad y para ello, era necesario renovar el núcleo básico de la misma: la casa.

Desde otra posición, el arquitecto Mies van der Rohe era consciente de esa necesidad. En una carta a la revista Die Form, en 1927, afirmaba que:

La forma como meta desemboca siempre en formalismo.

Un esfuerzo que se orienta hacia el exterior no al interior.

Sólo un interior vivo puede tener un exterior vivo.

Sólo la intensidad vital puede tener intensidad formal

La verdadera forma, presupone una vida verdadera, pero ninguna vida pasada ni tampoco imaginada. ${ }^{9}$

1927 fue el año que podría considerarse como el punto de partida de la verdadera renovación en la arquitectura. Se inició con la exposición La vivienda de la Asociación Deutscher Werkbund, en Stuttgart, y la construcción de un conjunto de viviendas, la colonia Weissenhof. La exposición quería dar respuesta a la pregunta "Wie wohnung» ¿cómo vivir? El arquitecto Mies van der Rohe fue el director de la misma, y en ella inició su colaboración con Lilly Reich.

Lilly Reich nació en 1885, fue estudiante en 1910, en Berlín, de Else Oppler - Legband, en la Fachschule für Dekorationskunst, una diseñadora de vestuario, desde 1904, que había estudiado con los diseñadores y arquitectos, Maximiliano Dasio en Munich, Henry van de Velde en Berlín y Peter Behrens en Nuremberg.

Reich también había estudiado en 1908, en los Wiener Werkstätte, los Talleres Vieneses, como Oppler - Legband, había sido también estudiante de Henry van de Velde, quien alcanzó su prestigio a mediados de 1890 y que en 1904, fue nombrado profesor de la recientemente inaugurada escuela de Artes y Oficios en Weimar, y estuvo también vinculado a la Deutscher Werkbund, de la que Oppler - Legband fue co-fundadora.

Lilly Reich, al igual que Charlotte Perriand, había tenido una educación anclada en el siglo XIX y su formación procedía de las Artes Decorativas. Ambas pertenecían a una minoría selecta de mujeres, que había podido estudiar.

8. Según indica Adolf Behne en Neues Wohnen-Neues Bauen. Citado en Fritz Neumeyer, Mies Van der Rohe, La palabra sin artificio, Reflexiones sobre arquitectura, 1922-1968, Madrid, Croquis, 1995. pág. 278.

9. Íbidem, Fritz Neumeyer, Mies Van der Rohe, pág. 470. 


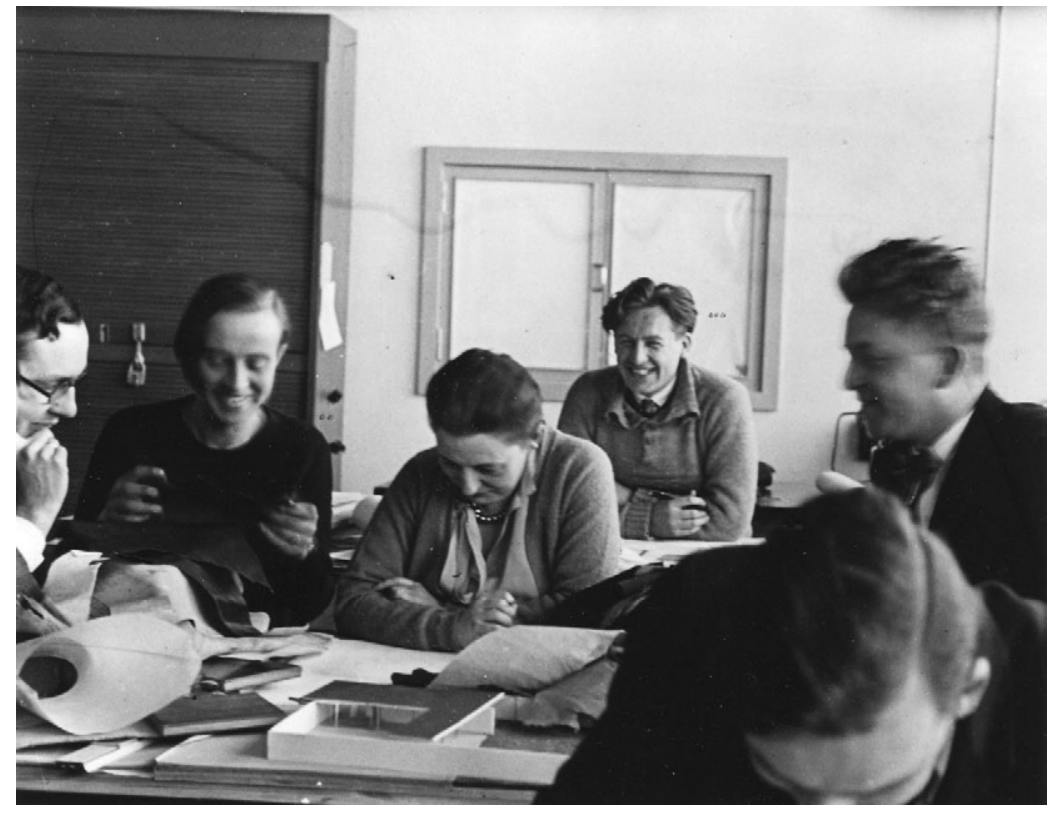

Lilly Reich en 1930.

(Lilly Reich en 1930. Archivo Bauhaus)

1927, fue también el año en el que se consolidó la relación profesional de Mies y Reich, Para amueblar alguno de los apartamentos del bloque construido por Mies van der Rohe en la Weissenhoff, en Stuttgart, en 1927, eligió a Lilly Reich. El concepto de espacio interior de Lilly Reich ya se podía intuir allí; los espacios eran austeros pero agradables. Los elementos elegidos se reducían a lo esencial.

Mies y Reich realizaron juntas, algunos proyectos que marcarían su trayectoria posterior. Entre ellos: el Café Samt und Seide, Café de terciopelo y seda, para la feria Die mode der dame, Moda de mujer, que tuvo lugar en Berlín, entre septiembre y octubre de 1927 y dos instalaciones que realizaron al mismo tiempo en Stuttgart, para la exposición de la Werkbund, la Glass Room, la Sala del Cristal, para la Asociación Alemana de Fabricantes de cristal y el stand contiguo, para la Deutsche Linoleum Werke, Los Fabricantes Alemanes de Linóleo.

Con estos trabajos, Mies y Reich mostraron que la configuración espacial se podía conseguir con otros materiales, que no era necesario definir el espacio con elementos arquitectónicos. Un concepto abstracto para paredes, suelos y techos que se encontraría años más tarde, en los proyectos para la casa 


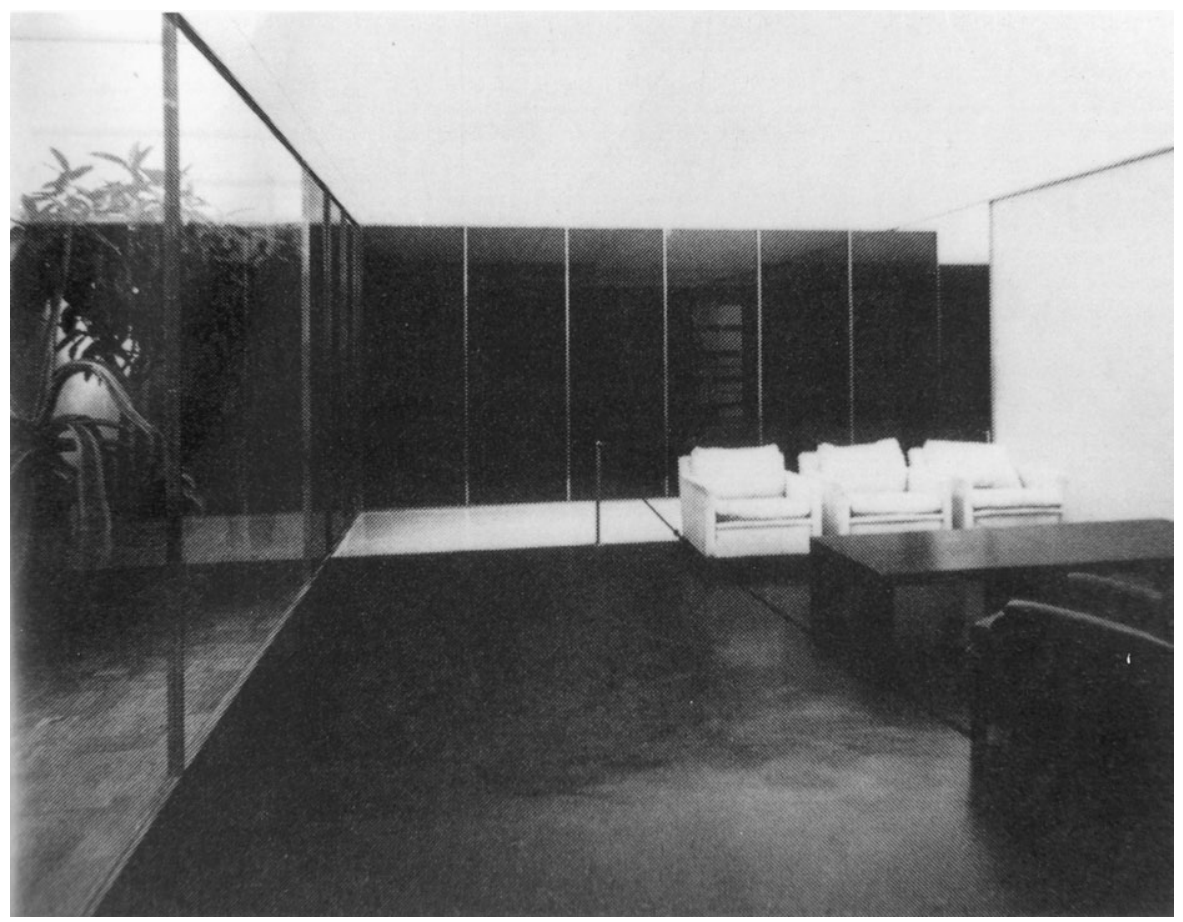

Exposición de la Werkbund. 1927. Glass Room, la Sala del Cristal.

(MCQUAID, Matilda: Lilly Reich, Designer and Architect. Nueva York, The Museum of Modern Art, 1996)

Tugendhat en Brno de 1928-29 y para el pabellón representativo de Alemania en la Exposición Internacional de Barcelona, de 1929.

El conocimiento y la sensibilidad de Reich por los materiales, era una cualidad, sabía sentir su naturaleza y cómo utilizarlos según sus leyes, esto hizo que utilizara pieles poco usuales, también elementos aparentemente secundarios, como alfombras y cortinas de diversos tejidos y colores arriesgados, que adquirieron un papel principal en la configuración del espacio.

Las telas, sus propiedades, sus colores, eran muy importantes para Reich. El trabajo con las telas fue una constante en toda su carrera. Desde sus primeros años, dedicada al diseño de moda, tenía un buen conocimiento de este material. Gracias a ella la tela se volvió a utilizar, pero pasó de ser un material de decoración a ser un material con el que se podía construir el espacio. Con el tiempo, Mies fue concediendo mayor importancia a estos aspectos del diseño para configurar sus espacios. 
A través de estos proyectos Mies Van der Rohe y Lilly Reich, consolidaron una nueva relación espacio - mobiliario. Crearon piezas pensadas para cada uno de los espacios en los que iban a estar situadas. El mobiliario fue cuidadosamente realizado conjuntamente por Mies y Reich en ambos proyectos. Con el mobiliario, se construía, se determinaba la configuración del espacio, por ello su colocación era exacta y precisa. Pequeños conjuntos de muebles se situaban sobre un plano horizontal, recortado sobre una superficie continua, una alfombra.

El trabajo de Mies y Reich, redefinió el concepto de espacio interior, como un espacio por el que se podía circular libremente. El espacio se convirtió en una cualidad esencial en sus proyectos.

Esta colaboración entre Mies van de Rohe y Lilly Reich en el diseño y acondicionamiento de mueble y de espacios interiores, se puso de manifiesto claramente durante la realización de las viviendas de la Exposición de Berlín, en 1931, La vivienda de nuestro tiempo. O también en los proyectos de las casas - patio, en los años treinta. Allí Lilly Reich pudo construir su primera vivienda, en solitario y contigua a una de Mies Van der Rohe, ambas

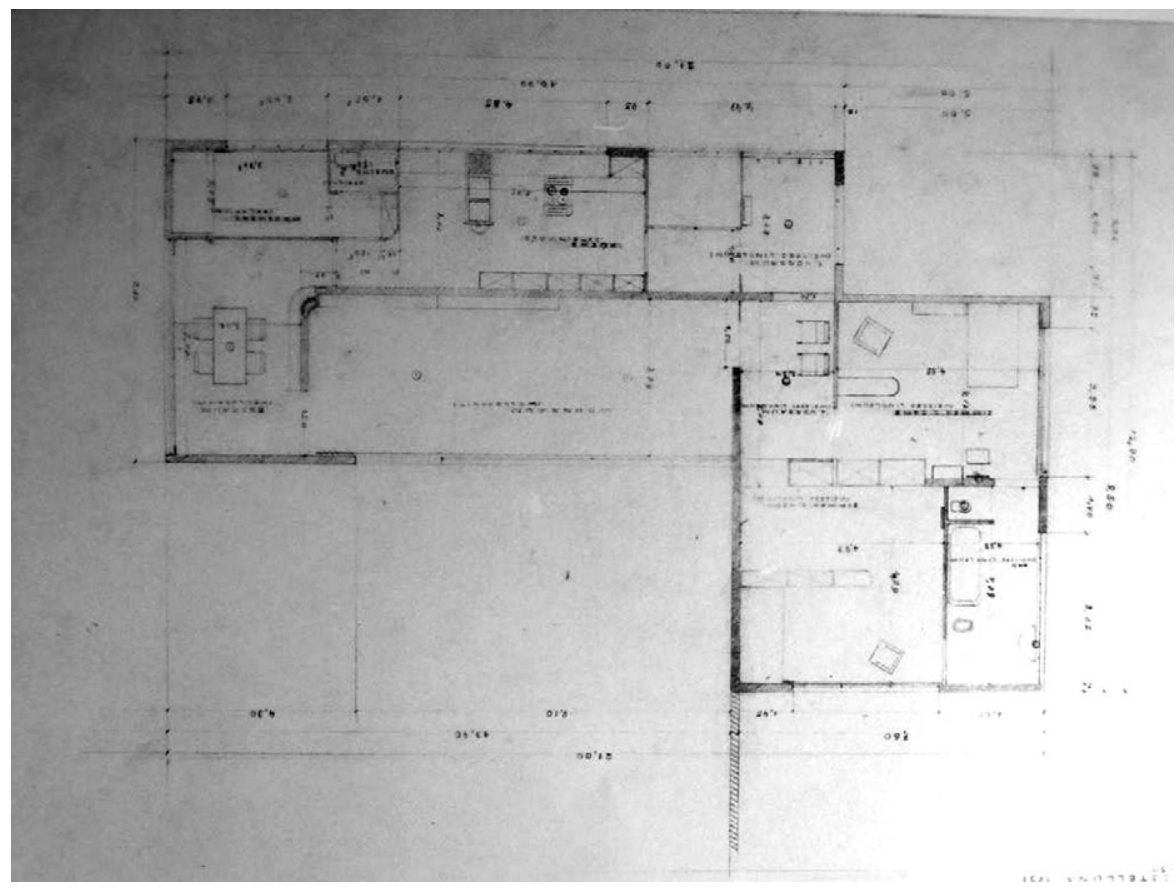

Planta Lilly Reich, croquis vivienda en planta baja. Exposición de Berlín 1931.

(Colecciones Garland de los archivos de Mies van der Rohe) 
situadas en la planta baja de la nave, halle 2, del recinto ferial de Berlín en la Reichskanzlerplatz.

El mobiliario estaba compuesto, tan solo, por lo imprescindible: librería, mesas y sillas que fueron diseñados especialmente por Reich para esta vivienda, y producidos como modelos LR.

La ausencia de compartimentación permitía que la luz llegara hasta el interior de la casa, las paredes blancas reflejaban esta luz aumentando la sensación de amplitud en el espacio. En los espacios de la casa que construyó Reich, para la exposición de Berlín, se podía apreciar la cualidad del vacío, que era entendido como ausencia de formas y objetos innecesarios. Así, se conseguía la reducción a lo esencial. También para la Exposición de Berlín, Lilly Reich proyectó el interior de dos apartamentos contiguos en la última planta de un bloque residencial, la Boarding-Haus. La primera, era una vivienda para una persona sola y la segunda una vivienda, para una pareja sin hijos. Unos programas habitacionales, poco convencionales para la época. En ellas puso en práctica la nueva organización del espacio interior. Los bocetos de Reich, para estas viviendas, muestran hasta cuatro tipos de estudios sobre variaciones de división espacial. Ensayó mediante la disposición de armarios y la colocación del mobiliario, con estos elementos construía los espacios.

El baño era el único elemento arquitectónico fijo, lo que permitía libertad en la distribución del resto del interior de las viviendas.

Aunque el conjunto del bloque de la Boarding-Haus, estaba concebido para la utilización de los servicios comunes, por lo que no era necesario incorporar cocina en las viviendas, Reich diseñó para este apartamento, un bloque compacto, exento que servía de almacenaje y cocina, y que además era

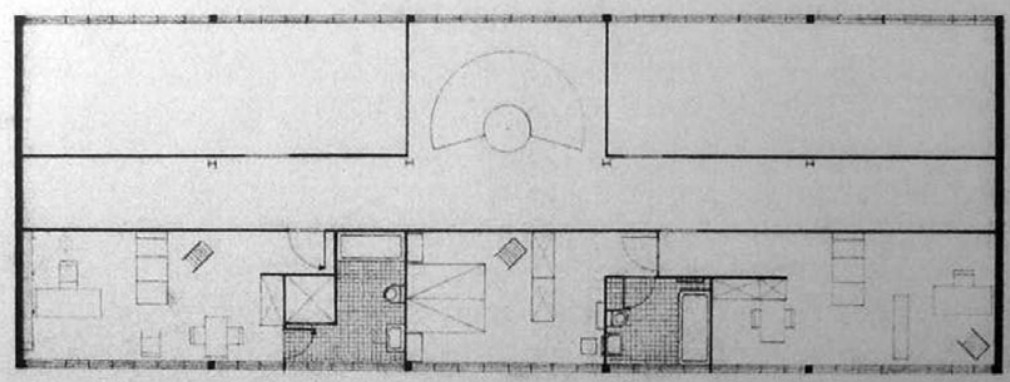

Lilly Reich planta viviendas contiguas de la Boarding-Haus.

(Colecciones Garland de los archivos de Mies van der Rohe) 

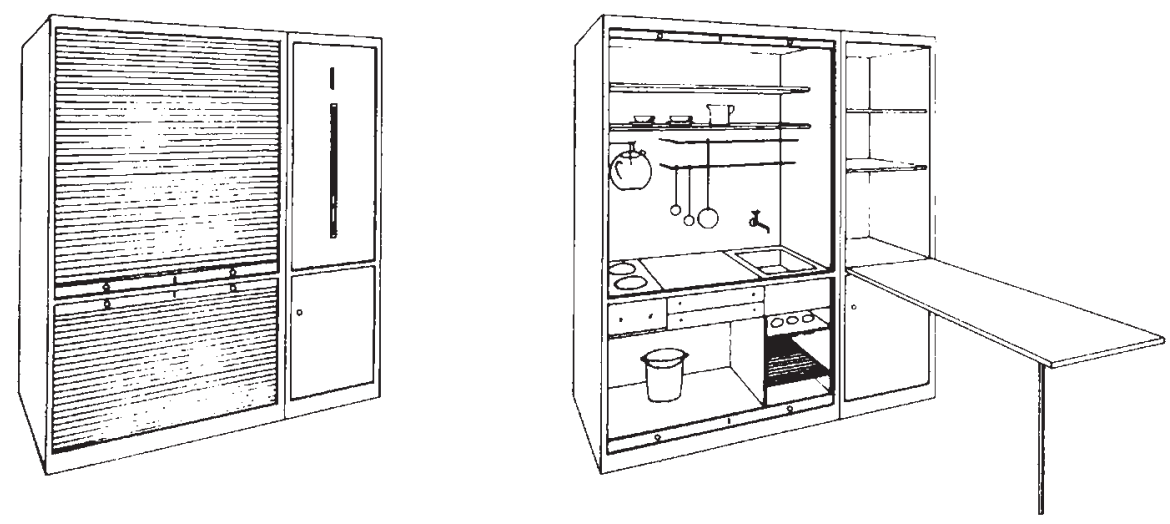

Lilly Reich. Bloque compacto armario cocina.

(MCQuAID, Matilda: Lilly Reich, Designer and Architect. Nueva York, The Museum of Modern Art, 1996)

el único elemento de compartimentación en el espacio, separando la sala de estar, del núcleo de baño.

La actividad de cocinar fue estudiada y organizada, con rigor, por Reich, para conseguir la máxima eficacia en el menor espacio posible. También estudió la función de almacenaje, pues el mueble permitía guardar los utensilios de cocina que se clasificaron por tamaño y se colgaron para optimizar la capacidad y hacer más fácil su acceso, además se podía extraer una tabla, para planchar y también guardar otros objetos. El espacio en Reich se definía mediante el mobiliario, con su colocación y su cualidad, forma y material, que eran estudiados minuciosamente al detalle.

Quedan en el archivo de Mies van der Rohe, entremezclados con sus dibujos, los que realizó Lilly Reich en solitario, con sello Atelier Reich. Entre ellos, se encuentran los estudios para el amueblamiento del apartamento para un soltero de Mies; llama la atención la precisión y el detalle del diseño de un armario, al igual que Charlotte Perriand, todo estaba medido y ordenado, muestra de la importancia concedida por su autora a esta pieza de la casa.

La mujer, desde su ámbito, la casa, al que había sido confinada, había tomado las riendas de la transformación para lograr el diseño de la casa para la nueva vida.

Charlotte Perriand, y Lilly Reich, fueron dos de esas mujeres que por su origen y formación conocían bien las restricciones de ese ámbito privado, e iniciaron la renovación desde el interior de la arquitectura, desde un elemento mínimo de la casa, el armario, que pasó de ser el símbolo de las tareas 


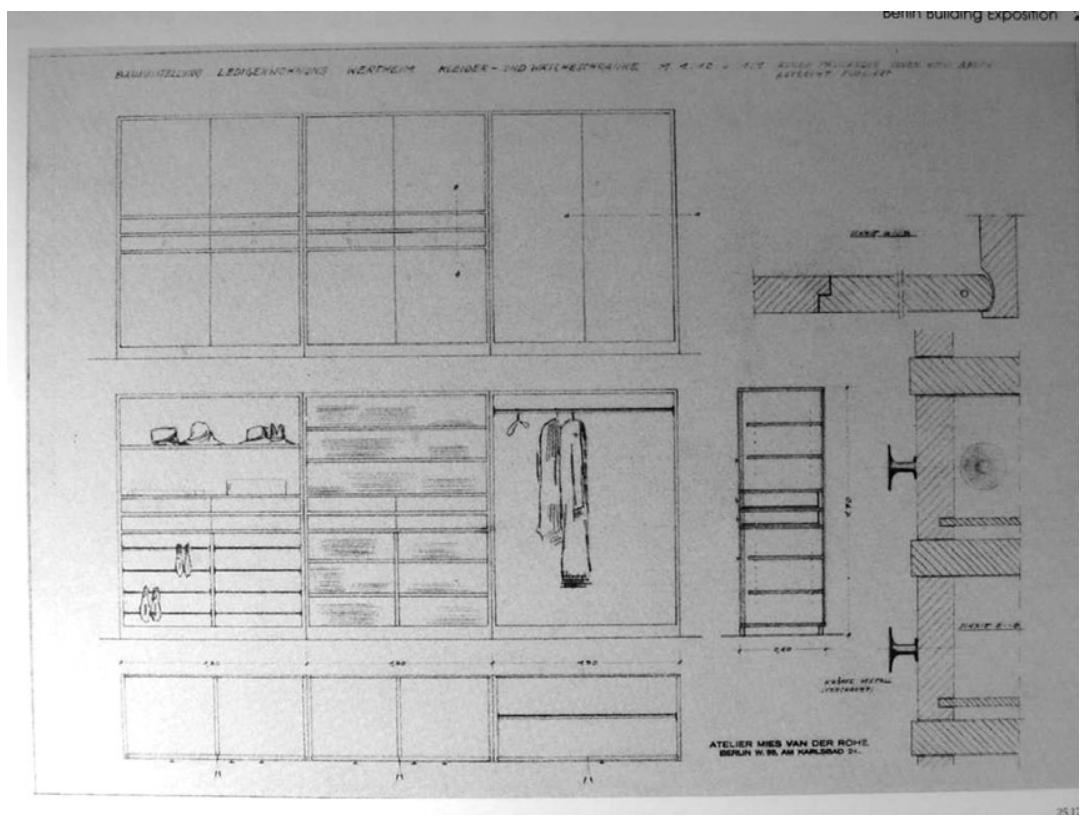

Lilly Reich. Croquis armario apartamento para un soltero. Exposición de Berlín 1931. (Colecciones Garland de los archivos de Mies van der Rohe)

domésticas de la mujer al elemento utilizado por la mujer para transformar la estructura de la vivienda y desde ahí poder plantear un nuevo tipo de relaciones espaciales y con ellas un cambio en la relación entre los habitantes.

Quizá todo comenzara con el diseño de un armario...

\section{Referencias Bibliográficas}

LE Corbusier: Precisiones. Barcelona, Poseidón, 1979.

MCQUAID, Matilda: Lilly Reich, Designer and Architect, Nueva York: The Museum of Modern Art, 1996.

MIES VAN DER ROHE, archivos, colecciones Garland.

NEUMEYER, Fritz: Mies van der Rohe: La palabra sin artificio. Reflexiones sobre arquitectura, 1922-1968. Madrid, Croquis, 1995.

PERriand, Charlotte: Una vie de création. París, Odile Jacob, 1998.

RÜEGG Arthur: Perriand Charlotte: Livre de Bord. 1928-1933. Basilea, Birkhäuser, 2004.

SENNET, Richard. La conciencia del ojo. Barcelona, Versal, 1991.

Vegara, Alejandro. Vermeer y el interior holandés. Madrid, Museo Nacional del Prado, 2003. 


\title{
HIGIENE, VIVIENDA Y CIUDAD: CIFRAS, IMÁGENES Y PALABRAS FEMENINAS
}

\author{
ANDRÉS MARTÍNEZ MEDinA \\ Universidad de Alicante
}

Recibido 09/02/2011

Aceptado 20/05/2011

\section{Resumen}

¿Qué forma final tenía el proyecto de la Modernidad, iniciado en el siglo XVIII? No es relevante. Aquí se desgrana la trayectoria de mujeres que desde sus profesiones influyeron decisivamente en la arquitectura. Se constata que estas aportaciones se realizaron desde países con Democracia donde se favorecía la libertad individual, la educación y la independencia económica; es decir: donde la responsabilidad se depositaba en función de la capacitación. Tres ámbitos de estudio: la higiene, la vivienda y la ciudad a lo largo de los siglos XIX y XX. La primera protagonista es la fundadora de la Enfermería que sienta los principios de la higiene a partir de la experiencia traducida a cifras. La segunda es una serie de diseñadoras y editoras que se interesaron por los nuevos modos de vivir que se ensayaron en USA a mitad de siglo XX, apostando por las imágenes. La tercera es una periodista que reflexionó en torno al urbanismo que se estaba dando en dicho periodo, sintetizando su pensamiento en un libro. Una reflexión entorno al poder de las cifras, las imágenes y las palabras.

Palabras clave: Arquitectas, Ciudad, Vivienda, Higiene, Democracia 


\begin{abstract}
What form had the Modernity initiated from the eighteenth century? It isn't relevant. In this article I analyze the path of women who had a decisive influence on architecture from their professions. It is noted that these contributions were made in countries where Democracy favoured individual freedom, formation and economic independence, that is: where responsibility is placed on the training function. The three areas of study are: health, housing and city throughout the nineteenth and twentieth centuries. The first protagonist is the founder of nursing that sets out the principles of hygiene from experience translated to numbers. The second one is a series of designers and publishers were interested in new ways of living that were tested in the U.S. mid-twentieth century resting the pictures. The third one is a reporter who reflected the urban environment that was taking place in this period, synthesizing her though in a book. It's a reflection about the numbers, the pictures and the words.
\end{abstract}

Keywords: Women Architects, Cities, Houses, Hygiene, Democracy 


\section{Mujeres en la Historia: la responsabilidad por capacitación}

El primero de enero de 2011 tomaba posesión Dilma Rosseff como Presidenta de Brasil. Relacionar los méritos de las mujeres que han ocupado cargos de responsabilidad en la toma de decisiones que afectan a amplios segmentos sociales $-\mathrm{y}$ los cuales no procedan por razón hereditaria-, o han desarrollado tareas creativas, no es el objeto de este trabajo, ya que todas y todos tenemos en mente una amplia lista al respecto. Sin embargo, sí pretendemos constatar que este listado se incrementó desde que se redactaron en 1776 la Constitución de Derechos de Virginia y en 1791 la Declaración de los Derechos de la Mujer y la Ciudadana, esta última, obra de M. O. de Gouges. Resulta más interesante comprobar cómo este aumento corre en paralelo a la implantación de la Democracia como forma de gobierno de las sociedades, de manera que se intuyen relaciones entre los sistemas políticos que fomentan la libertad individual y el incremento de las mujeres en tareas reservadas a los hombres. Esta presencia se extiende a casi todas las disciplinas y trabajos.

La democracia ha traído, desde su reinvención a finales del siglo XVIII, más libertad. Este es un proceso vivo, un camino del que desconocemos el final, cuyo recorrido hasta la fecha constata que su despliegue ha concatenado la consecución de derechos para los seres como personas no del todo previstos en un principio. De algún modo, paulatinamente, se ha alcanzado un cierto orden $\sin$ plan $^{1}$ y, este proceso, que se retroalimenta sin fin, ha permitido que las mujeres alcancen la misma legitimidad que los hombres y que, desde entonces, otra mirada y otro modo de hacer se instaure en las propias sociedades. Especialmente en las occidentales, donde el grado de evolución de las democracias está muy elaborado. Claro que no sólo de libertad vive la democracia, la primera también se alimenta de otros dos pilares casi incuestionables: la posibilidad de la independencia económica de las personas (sean del género que sean) y de la posibilidad de acceso a una educación que forme

1. Esta expresión reproduce parte del título del libro de INFANTINO, Lorenzo. El orden sin plan. Las razones del individualismo metodológico [1998]. Madrid, Unión Editorial, 2000, en el cual se mantiene la tesis según la cual el ente «sociedad» tiende a autorregularse y su acción no se puede separar de la acción de sus individuos. 


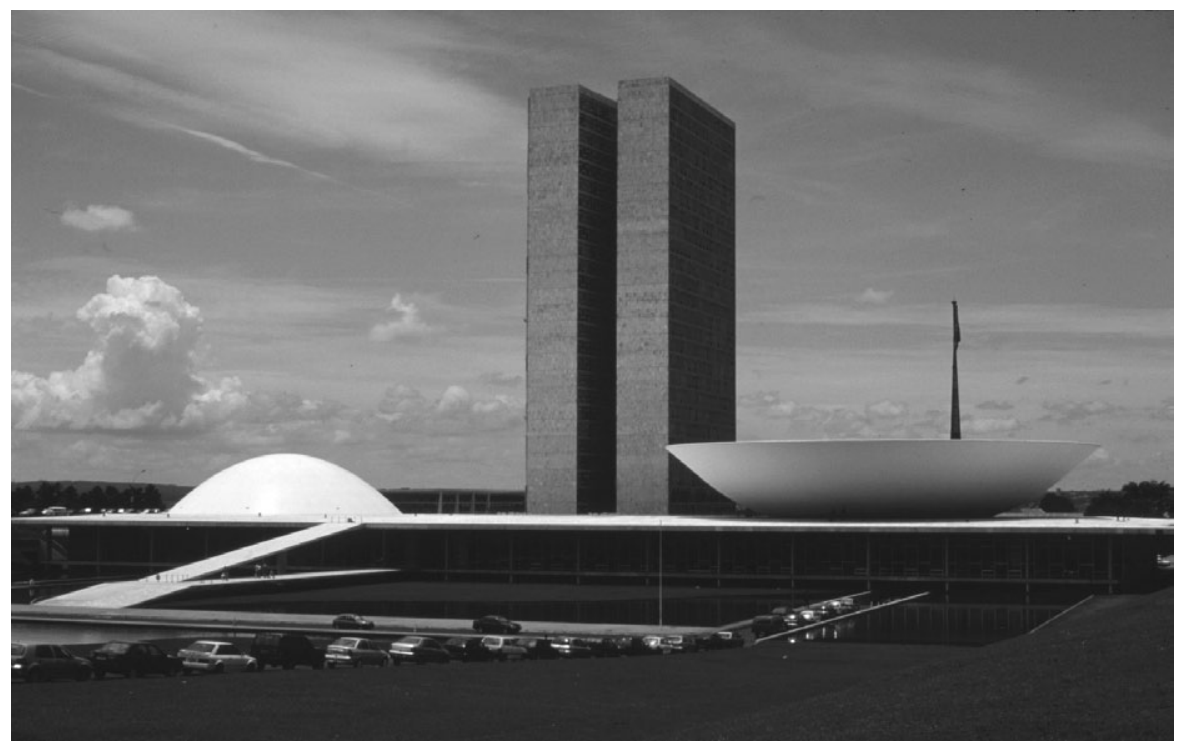

Plaza de los Tres Poderes y Congreso Nacional. Brasilia. Oscar Niemeyer (1957-58).

a las personas para poder desarrollar todas sus capacidades en plenitud. A nuestro juicio, no existe libertad sin independencia económica y sin criterio formado libre y ampliamente.

Si hemos comenzado por la Presidenta de un país donde se cruzan razas, religiones, lenguas y muchas otras excusas que hasta hoy han sido motivo de discriminación o exclusión, lo es tanto por estos hechos cuantitativos como por el cualitativo y simbólico de que la ceremonia tuviera lugar en el edificio del Congreso de la ciudad de Brasilia (1957-59); el primero obra de O. Niemeyer y la segunda obra de L. Costa y el mismo O. Niemeyer. Ambos conjuntos, enlazados en la plaza de los Tres Poderes, han representado, en algún momento, un ejemplo de la culminación del «proyecto moderno», donde una nueva arquitectura desencadenaría una nueva ciudad que, con toda probabilidad, desembocaría en una nueva sociedad Dudamos que el futuro se pueda dirigir como si nos encaminásemos hacia una utopía, siquiera de bases científicas, ni que la modernidad tenga un modelo predefinido de arquitectura y de ciudad. Ambas se definen en cada tiempo para cada espacio y grado de desarrollo político y económico y al fin social, porque la arquitectura, como la ciudad, son construcciones sociales, como principio y como fin. 
Lejos de iniciar un debate sobre si la modernidad finalizó y a esta le sucedió la posmodernidad o sobre si el proyecto de la modernidad fue bien interpretado en el ámbito de la arquitectura y el urbanismo (si es que había tal proyecto en su inicio), nos resulta más sugerente rastrear el camino de una serie de mujeres que, trabajando al lado de la arquitectura, contribuyó a mejorarla desde los ámbitos de sus específicas profesiones. No creemos que sea casualidad que las protagonistas elegidas se desenvuelvan -no sin cierta dificultad- en países con una democracia bastante desarrollada, con un sistema económico liberal, con un amplio grado de libertad de prensa, con un sistema educativo que, poco a poco, alcanzaba a capas sociales más amplias y donde era posible su independencia económica, la que garantizaba su libertad de acción. Este periplo, que barre los cien años que van desde mediados del siglo XIX a mediados del XX, se detiene en tres disciplinas: la higiene (o la enfermería), la vivienda (o lo doméstico) y la ciudad (o la convivencia). Dos de estos ámbitos resultan cruciales en las cuestiones de género, como señala Zaida Muxí: «la escenificación y puesta en práctica de roles tiene dos espacios: la casa y la ciudad $»^{2}$. Todas estas aportaciones han ayudado a dignificar el ámbito donde vivimos, en la salud y en la enfermedad, en la vivienda y en la ciudad. Es decir, forman parte del proceso de modernización de nuestra sociedad. Si la modernidad la identificamos con una mejora de las condiciones de vida, incluiría, necesariamente, el respeto y consideración entre todos los seres humanos.

\section{Las enfermedades en el ámbito de la higiene o el poder de las cifras}

Vida es sinónimo de salud. Salud es ausencia de enfermedad o a la inversa: las enfermedades son la carencia de una completa salud. Salud y enfermedad puede que sean opuestos, pero no contrarios. Algunas enfermedades mantienen una cierta vecindad con la muerte: algo de muerte tiene la enfermedad. Y la muerte vuelve iguales a todos los seres humanos, quizás porque dejan de serlo. Las enfermedades tienen la misma antigüedad que la propia vida: se tiene conocimiento de la existencia de enfermedades desde los albores de la Humanidad y, para curarlas -entre otros menesteres-, surgieron brujos, hechiceras y chamanes ${ }^{3}$. Ellos y ellas intentaban reponer las fuerzas (físicas) y el ánimo (espiritual) que las enfermedades habían mermado en el cuerpo,

2. Muxí, Zaida: «Decir la ciudad desde la experiencia». Arquitectos, nº 2, (2006), Madrid, pp. 53-58.

3. Todavía, a comienzos del siglo XX, los nativos de Nigeria con quienes trataba la misionera Mary Slessor (1848-1915), natural de Escocia, la llamaban «la bruja blanca» por su fama de sanadora. 


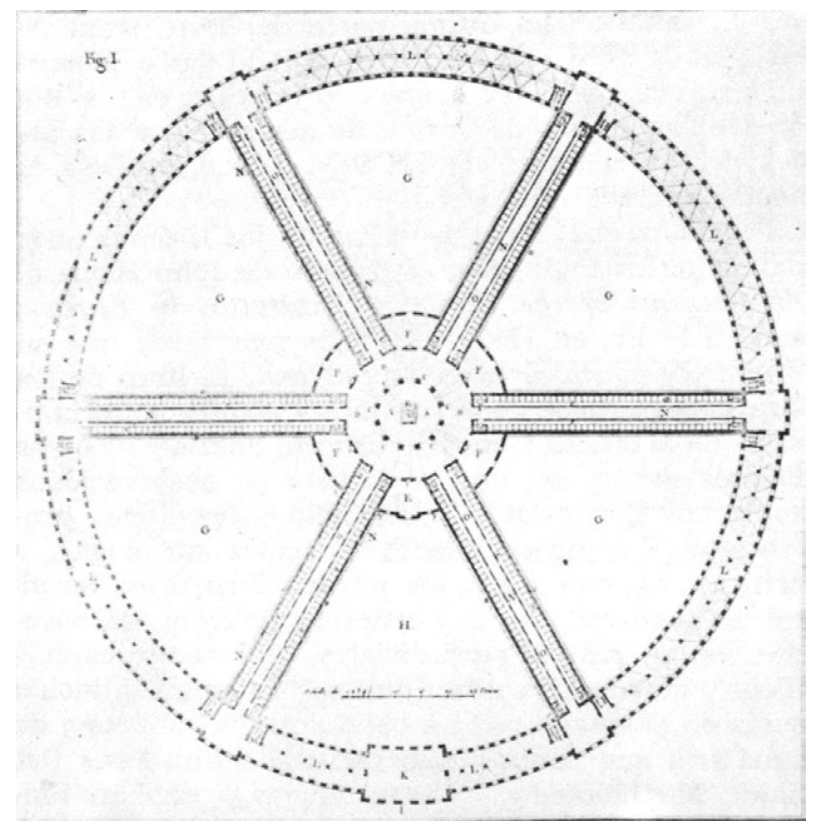

Planta hospital Hôtel-Dieu en París. Antoine Petit (1774).

en la cabeza o en el corazón. No sería de extrañar que una de las primeras arquitecturas fueran primitivos hospitales: cabañas donde alojar a los enfermos para separarlos de los sanos.

El trayecto que nos sitúa a finales del siglo XVIII, en plena efervescencia intelectual en la que se fraguan las dos grandes revoluciones sociales citadas que instauran los derechos del hombre (y de la mujer) no es relevante para la higiene. Sí lo es que en aquellos años de derroche de racionalidad, los mismos criterios que emanaban de la ciencia se pretendían aplicar para resolver los problemas formales y funcionales de la arquitectura. Cuestiones de tipología: encontrar los mejores encajes de las formas -conocidas o experimentables-a las funciones o viceversa: acoplar de modo óptimo el contenido al contenedor. Uno de los debates que reunía a profesionales de la arquitectura y de la medicina era el del diseño de hospitales. Ambas disciplinas - una menos científica que la otra- estaban siendo sometidas a profundos cambios, muchos de ellos de base empírica.

A lo largo del setecientos fueron formulados dos tipos arquitectónicos para solucionar funcionalmente los hospitales. Por un lado estaba el modelo radial con salas partiendo desde su centro (donde se encontraba la capilla), el 


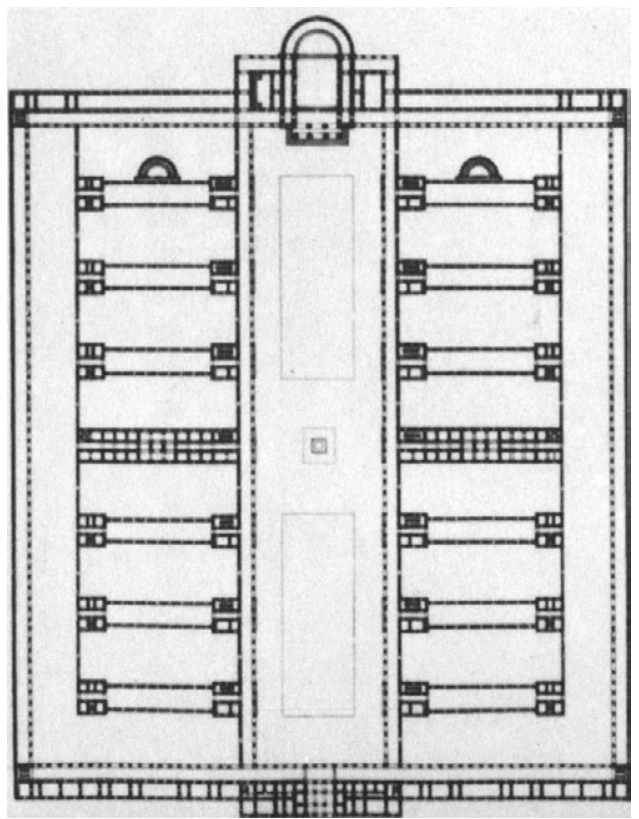

Planta hospital en La Roquette, París. J.R. Tenon y B. Poyet (1788).

cual permitía «más camas en una misma superficie» ${ }^{4}$; estaría representado por el proyecto del Hôtel-Dieu (1774) en París. Por otro lado estaba el modelo de pabellones dispuestos perpendicularmente a ambos lados de un patio alargado (con la capilla situada al final del eje); estaría representado por el proyecto de un hospital en La Roquette (1788), también en París, que venía avalado por científicos, cirujanos y arquitectos. En esos años ya se pensaba que la falta de ventilación de las salas se encontraba relacionada con las muertes de los ingresados en dichas instituciones.

El debate no quedó zanjado y los hospitales existentes tendían a colmatar sus espacios libres y a densificarse en altura, sin que las intuitivas ventajas higiénicas de ambos modelos pudieran surtir efecto. A mediados del siglo XIX, el Hospital Militar de Netley (1856-63) de Londres presentaba unas condiciones infrahumanas y unos altos índices de mortandad. Florence Nightingale (1810-1910) hizo de este centro sanitario -al que no consideraba tal- su objeto de lucha: «quería que fuera demolido, tan rápido como había

4. Pevsner, Nikolaus. Historia de las Tipologías Arquitectónicas [1976]. Barcelona, ed. Gustavo Gili, 1979, p. 173. 


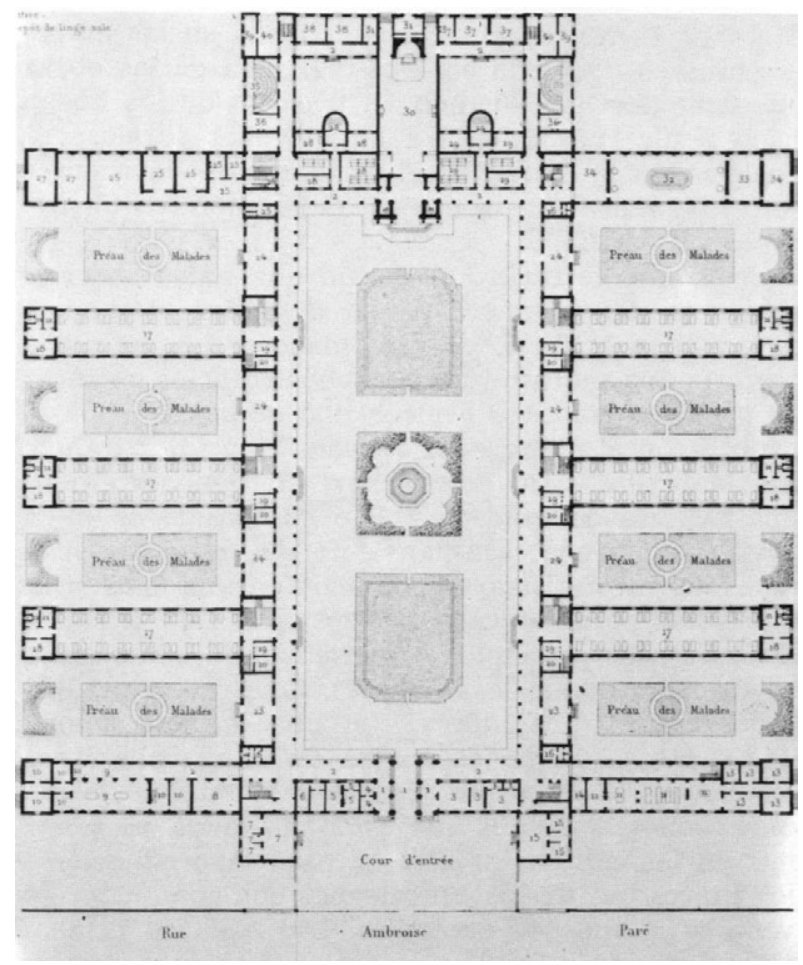

Planta hospital Lariboisière, París. M.P. Gautier (1839-1854).

sido construido y que fuera reemplazado por otro edificio según el tipo de proyecto de Lariboisière» ${ }^{5}$ (1839-54) de París que seguía el modelo pabellonario. Nightingale argumentaba razones de índole científica basadas en «la experiencia, la observación y la reflexión $»^{6}$. Señalaba que en los hospitales de pabellones «las salas estaban especialmente diseñadas para recibir la luz y el aire fresco, al tiempo que permitían que los 'efluvios malignos' o 'miasmas' pudieran disiparse entre los largos y estrechos bloques» ${ }^{7}$.

Florence Nightingale, nacida en Florencia en el seno de una rica familia británica, ya desde pequeña se había sentido atraída por el cuidado de

5. PEVSNER, Nikolaus. Op. cit., p. 184.

6. AtTEWELL, Alex. «Florence Nightingale (1820-1910)». Perspectivas: revista trimestral de educación Comparada, vol. XXVIII, n 1, 1998, París, pp. 173-189; también disponible en: <http://www.ibe.unesco.org/publications/Thin-kersPdf/nightins.PDF> pp. 1-13 (2011.02.01).

7. AtTEWell, Alex. Op. cit., p. 5. 
enfermos (y también por la enseñanza), si bien se formaría primero en matemáticas, aunque a ambos conocimientos se opusieron sus padres. A mediados del siglo XIX la enfermería no era considerada una profesión adecuada para una mujer de su posición, era propia de mujeres pobres. Aún así, a los 24 años comenzó a visitar centros asistenciales, aunque el estudio de los sistemas hospitalarios se fraguó entre 1849 y 1853 en distintos viajes que le llevarían de Europa a Alejandría, formándose como enfermera en Dusseldorf y en Saint Germain cerca de París ${ }^{8}$. A su regreso a Londres en 1853, Nightingale se convirtió en la directora de un sanatorio para damas de la alta sociedad londinense.

Su fama de profesional rigurosa -observadora y organizadora- la llevaría a estar al frente de las instalaciones sanitarias en Üsküdar por la Guerra de Crimea (1854-56). Las condiciones antihigiénicas de los hospitales de campaña eran tales que existía una probabilidad siete veces mayor de morir en estas instalaciones de cualquier enfermedad que de morir en el campo de batalla. Allí aplicó lo que consideró principios de la higiene (o leyes de la salud) para combatir las epidemias de cólera y disentería, basados en la limpieza, la ventilación, la iluminación, el empleo de agua potable y una alimentación sana (de frutas y productos frescos). Recolectó datos que, más tarde, se volverían estadísticos. Las matemáticas se volvieron «sanadoras» cuando Nightingale usó las cifras. Sus cálculos demostraron que una mejora en los medios higiniestas empleados disminuía el número de muertes (redujo la tasa de mortalidad en porcentajes considerables). Estas informaciones serían herramientas para mejorar los hospitales urbanos.

Al volver a Londres en 1856, Nightingale descubrió que, en época de paz, los soldados de entre 20 y 35 años tenían una tasa de mortalidad que doblaba a la de los civiles. Usando sus datos ilustró la necesidad de una reforma sanitaria en todos los hospitales, comenzando por los militares. Fue una experta estadística y una pionera de la epidemiología, coincidiendo con el descubrimiento de los gérmenes de Louis Pasteur (1858). En 1860 abrió la primera Escuela de Enfermería en Londres, logrando transformar la mala fama de esta dedicación en una carrera responsable y respetable para las mujeres. Aunque pasó el resto de su vida postrada, la enfermedad no la detuvo en hacer campaña para mejorar los estándares de salud. Publicó 200 libros entre los que destacan: Notas sobre los hospitales (1959), Notas sobre enfermería (1860) y Notas sobre enfermería para las clases trabajadoras (1861); estos últimos específicos

8. Ibíd., p. 174.

Feminismo/s 17, junio 2011, pp. 229-257 
para la enseñanza de la enfermería y traducidos a varios idiomas. Su método se resume en sus propias palabras de 1882:

«La observación indica cómo está el paciente; la reflexión indica qué hay que hacer; la destreza práctica indica cómo hay que hacerlo. La formación y la experiencia son necesarias para saber cómo observar y qué observar; cómo pensar y qué pensar»".

Florence Nightingale se convertiría en la fundadora de la actual Enfermería, sentando las bases científicas de la higiene y profesionalizando la formación del personal desde una perspectiva laica. No fue un caso aislado en el panorama del diecinueve, sino que ayudó a consolidar la gran corriente higienista que atravesó el siglo y puso en contacto a diferentes disciplinas para que colaborasen entre ellas -allí donde se necesitaban- desde presupuestos científicos y racionales. De alguna manera, la primera de las enfermeras de la era Contemporánea nos igualó a todas las personas ante la enfermedad y la muerte, al sistematizar experimentalmente los requerimientos que habían de reunir los espacios sanitarios para mejorar la salud y definiendo la higiene, que ya entraría a formar parte de las ciencias médicas al tiempo que estas se revolucionaban con los descubrimientos del micromundo. Obviamente, el papel desempeñado por Nightingale es difícil de imaginar sino se suman, a su posición adinerada (que le permitía la independencia económica) y personalidad (de fuertes convicciones procedentes de la experiencia), las condiciones de una sociedad liberal que, poco a poco, avanzaba en la consecución de derechos individuales basados en la valía y cualificación profesional. Los números, aunque estadísticos, tuvieron razón y repercutieron en los espacios y organizaciones de las arquiecturas hospitalarias.

\section{Las viviendas en el ámbito de lo doméstico o el poder de la imagen}

El hábitat. La vivienda. La casa. Probablemente el primer hogar cubierto hecho con las manos humanas fue una cabaña: una tienda móvil o una choza fija. Casa deriva del mismo término latino y significa choza, cabaña. Estas primitivas arquitecturas, como las actuales, tenían un exterior, que protegía, y un interior, que cobijaba y acogía la familia. Un exterior acorazado y un interior doméstico. «Mi casa es mi castillo» escribiría en 1919 Alvar Aalto sobre el porche de la casa de sus padres ${ }^{10}$. «La casa es una máquina de habitar»

9. Florence Nightingale citada en: AtTEWELl, Alex. Op. cit., p. 9.

10. Zabalbeascoa, Anatxu; RodríGuez Marcos, Javier. Vidas construidas, biografías de arquitectos. Barcelona, ed. Gustavo Gili, 1998, p. 221. 
afirmaría cuatro años después Le Corbusier ${ }^{11}$. La mayoría de los antropólogos coinciden en que la choza se ancló al terreno con el descubrimiento y dominio de la agricultura, una actividad que transcurre a ras de suelo. El hábitat se hizo casa en el campo, vinculándose a la tierra. Quizás por ello, frente al sentido de verticalidad inherente a la casa que apunta el filósofo G. Bachelard ${ }^{12}$, cabría -en origen- la visión de la casa como un ser horizontal, posada y reposada, vinculada con su entorno inmediato: el jardín, el huerto, el campo... junto a una naturaleza domesticada. Y doméstico deriva de domus -casa-, es lo que se domina desde la casa o queda bajo su ámbito. Cuando las casas estaban encerradas tras los muros, se abrían a un patio interior -que miraba al cielo- donde habitaba una menuda fracción de naturaleza, como lugar de descanso -jardín- o como fuente de alimento -huerto-. Cuando se derribaron los muros, el espacio del hogar se expandió a su alrededor para conquistar su entorno. Nadie mejor que el arquitecto Wright supo pulverizar los ciegos muros e invertir estos términos en el ámbito de lo doméstico: lo vertical vuelto horizontal y el interior vuelto exterior atrayendo la naturaleza, intentando devolver el equilibrio primitivo.

La publicación de las Prairie House de F. Lloyd Wright (1867-1959) en los primeros años del siglo XX en revistas de $"$ Casas» ${ }^{13}$ para la clase media-alta estadounidense revolucionó el ámbito de lo doméstico en lo material, no en lo social ${ }^{14}$. El éxito de estas viviendas unifamiliares aisladas, cuyos programas se desplegaban mayoritariamente en planta baja, emplazadas en suburbios

11. LE CORBUSIER. Hacia una arquitectura [1923]. Barcelona, ediciones Apóstrofe, 1998, p: XXXI.

12. BACHelard, Gaston. La poética del espacio [1957]. México, ed. Fondo de Cultura Económica, 2010, p. 48: «La casa es imaginada como un ser vertical», «La casa es imaginada como un ser concentrado» y «...se puede oponer la irracionalidad del tejado a la irracionalidad del sótano».

13. FRAMPTON, Kenneth. Historia crítica de la arquitectura moderna [1980]. Barcelona, ed. Gustavo Gili, 1998, p: 60. El nombre de Wright llegó hasta el extremo que la revista Ladies' Home Journal le encargó entre 1900 y 1901 que proyectara viviendas-tipo para esta "clase media» americana a fin de difundirla entre sus lectoras.

14. WATSON, Peter. Historia intelectual del siglo XX [2000]. Barcelona, ed. Crítica, 2007, pp: 233-236, cita a los sociólogos Robert y Helen Lynd que realizaron un estudio modélico en una ciudad «media» que definía la sociedad americana hacia la década de 1920 y que denominaron Middletown (en la actualidad Muncie, Indiana). Allí constataron que, a diferencia de Europa donde se consideraba que existían tres clases sociales (alta, media y baja), en USA sólo se detectaban dos clases: la empresarial y la trabajadora. Descubrieron también que los cambios en las conductas sociales eran más rápidos en relación a lo material que a lo social: «Los cuartos de baño y la electricidad han invadido los hogares de de la ciudad de forma más rápida que las innovaciones relativas a la vida marital o al trato de padres e hijos. El automóvil ha cambiado las ocupaciones del tiempo libre...». El estudio completo se recogió en los libros: Middletown: A Study in 


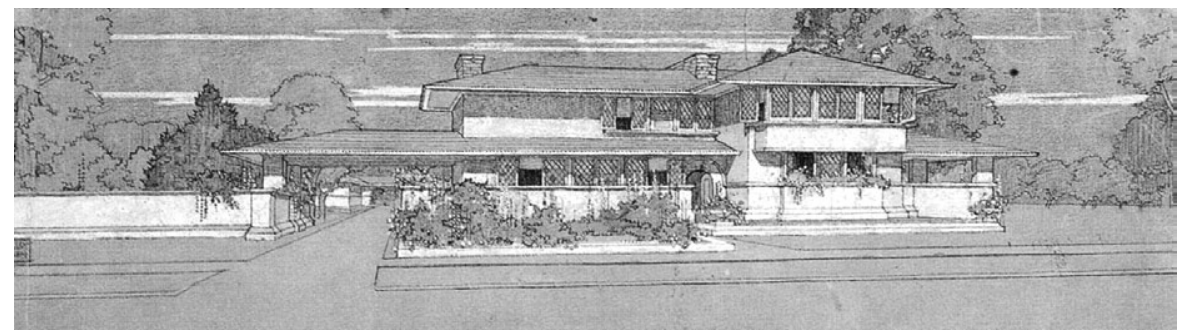

Perspectiva de casa para el Ladies' Home Journal. F. Ll. Wright (1901).

jardín de las metrópolis americanas se debía, entre otras razones, a la estrecha relación que establecían sus interiores con el jardín circundante (para su disfrute estético), el cálido tratamiento de los espacios que basculaban alrededor de una o varias chimeneas, la tranquilidad que transpiraban sus interiores y la funcionalidad de sus distribuciones (que, en muchos casos, incluían el acceso en coche); un buen ejemplo de todo ello se resume en la casa A. Coonley en Riverside (1907-09). Uno de los aspectos significativos del trabajo de Wright fue que contaba con mujeres en su equipo de técnicos (como la ceramista Catherine Ostertag), más sensibles en la creación de atmósferas íntimas y a la vez abiertas, así como el hecho de que solía prestar más atención a las esposas de sus clientes que a ellos mismos, ya que las consideraba las auténticas usuarias y conocedoras de los ámbitos domésticos de las viviendas.

$\mathrm{Su}$ idea sobre la arquitectura, bastante peculiar y receptiva a múltiples influencias, debió ampliarse con las aportaciones de sus colaboradoras y sus clientas que lo defendían ${ }^{15}$. Wright no imaginó la trascendencia e influencia que acarrearía para toda la arquitectura europea (de vanguardia o no) del momento y posterior, tras la exposición de su obra en Berlín y su publicación por E. Wasmuth en 1910. El poder de la impresión de estas arquitecturas mediante planos y fotografías se revelaba en la capacidad de convicción de las imágenes por lo que evocaban, evidenciando que una imagen valía más que mil palabras. Seguramente uno de los arquitectos europeos contemporáneos más receptivos a su sentido de fluidez espacial y su prolongación en la naturaleza sería el alemán Ludwing Mies van der Rohe (1886-1969), si bien las interpretaciones de este quedaban bajo la órbita de las rupturistas vanguardias del viejo continente y sus propuestas, además de radicalmente geométricas y

Contemporary American Culture (1929) y Middletown in Transition (1937). Y las «casas» pertenecen a lo material.

15. Zabalbescoa, Anatxu; Rodríguez Marcos, Javier. Vidas construidas... Op. cit., p. 128. 


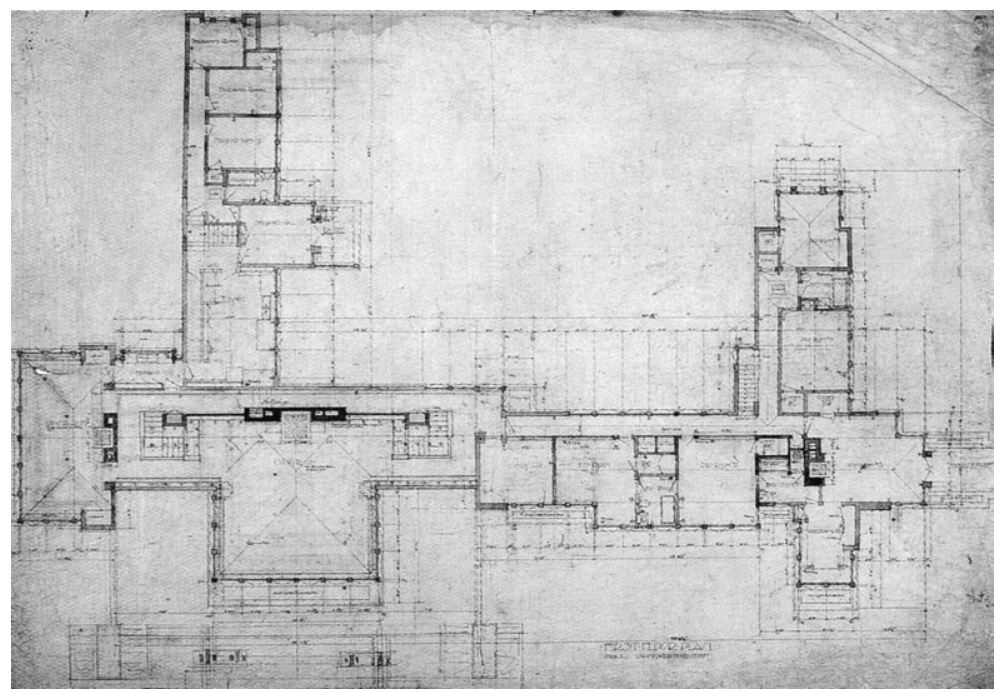

Planta casa A. Coonley, Riverside (Illinois). F. Ll. Wright (1907-09).

tendendes a la disolución de la materia, establecían un diálogo con el entorno natural sobre el que o no se intervenía o se hacía lo mínimo. La cena de bienvenida de Mies a USA fue presidida por Wright (Mies fue el único de los maestros europeos recibidos por el patriarca), con lo que, si bien entre sus arquitecturas $-\mathrm{y}$ entre ellos- hubieron diferencias, también son patentes las deudas y el parentesco. Y además: «Mies influyó tanto en los Estados Unidos como los Estados Unidos influyeron en él ${ }^{16}$, incluida la arquitectura.

Entre la visita de Wright al viejo mundo (1909) y la emigración de Mies al nuevo continente (1937), tiene lugar una de las más significativas aportaciones de la arquitectura contemporánea al campo de la vivienda y al universo de lo doméstico, bajo la órbita de los principios científicos de la vanguardia de la Nueva Objetividad. La vivienda en Europa no tenía el mismo tipo de planteamiento que al otro lado del Atlántico; aquí los problemas de falta de viviendas, su nivel de equipamiento e instalaciones, sus condiciones de salubridad e higiene, su superficie habitable, su calidad constructiva y su precio (en alquiler o en propiedad), provocó que los experimentos vivaran más hacia lo social y lo urbano que hacia las lúdicas relaciones del interior con el exterior, propios de una sociedad más opulenta, con mayor nivel de riqueza tanto en lo material como en lo temporal (una incipiente sociedad del ocio). En Europa se

16. Íbid., p. 192. 
derivó más hacia la agrupación colectiva mientras que en USA la cuestión era de individualidad. En las numerosas investigaciones teóricas (exposiciones, publicaciones, congresos...) y prácticas (casas, edificios, barrios...) también participaron arquitectas y diseñadoras. Entre ellas destacarían Eileen Gray (1878-1976), Margarete Schütte-Lihotzky (1897-2000), Hana CucherováZáveska (1902-1944) y Lilly Reich (1885-1947) -esta última compañera profesional y sentimental de Mies-, cuyas trayectorias han sido exhaustivamente estudiadas por Carmen Spegel ${ }^{17}$.

Aquí nos interesa el poder de los medios gráficos, de la prensa más especializada, que contribuyó a divulgar una cierta manera de entender la arquitectura de viviendas en USA que tuvo su continuidad con la labor del editor John Enteza y el programa Case Study House (CSH), desarrollado a lo largo de dos décadas (1945-1966) en el condado de Los Angeles (California) y que divulgó a través de la revista ArtsEAArchitectura. Este programa se considera «one of American's most significant contributions to architecture at midcentury ${ }^{18}$ y fue "Conceived as low-cost, experimental modern prototypes» ${ }^{19}$, cuyas estructuras, mayoritariamente, «incluían también elementos modulares estandarizados y estaban concebidas como prototipos para la fabricación en serie $»^{20}$. Este sumatorio de experiencias piloto está considerado, por muchos, una continuación a los grandes avances realizados en el campo de la vivienda mínima en dos frentes. Por un lado, el concurso nacional Designs for Postwar Living de 1943 patrocinado por industriales americanos y la propia revista Arts $\mathcal{E}$ Architecture ${ }^{21}$. Por otro, los logros en el entorno de la Nueva Objetividad en la Alemania de la república de Weimar entre 1924 y 1929, de los cuales, quizás, el barrio más internacional fue el experimental de la Exposición del Werkbund celebrado en Sttutgart en 1927 del que fue comisario Mies van der Rohe. Mucho de aquello que Wright y Mies tenían en común parece conjugarse en los resultados del programa CSH: jardín, espacio fluido, relación exterior-interior, modulación precisa, estructura metálica y posibilidad

17. EsPegel Alonso, Carmen. Mujeres arquitectos en el movimiento moderno. Heroínas del espacio. Valencia, Ediciones Generales de la Construcción, 2006.

18. Smith, Elizabeth A.T.; ShUlman, Julius; Goessel, Peter (ed.). The complete CSH program, 1945-1966. [1984] Cologna, ed. Taschen, 2009, p. 8.

19. Smith, Elizabeth A.T.; Shulman, Julius; GoEssel, Peter (ed.). Op. cit., p. 7.

20. Sмiтh, Elizabeth A.T. Case Study Houses, 1945-1966. El impulso californiano. Colonia, ed. Taschen, 2006, p. 23.

21. Coll Barreu, Juan. Construcción de los paisajes inventados. Los Ángeles doméstico 19001960. Barcelona, ed. Fundación Caja de Arquitectos, 2004, pp. 211-215. En 1943 se trataba del «diseño de una casa pequeña, modesta y moderna», apropiada para el fin de la guerra»; los ganadores: Saarinen y Lundquist propusieron dos módulos PAC-A y PAC-B que se complementaban y compartían un sofisticado sistema de climatización. 


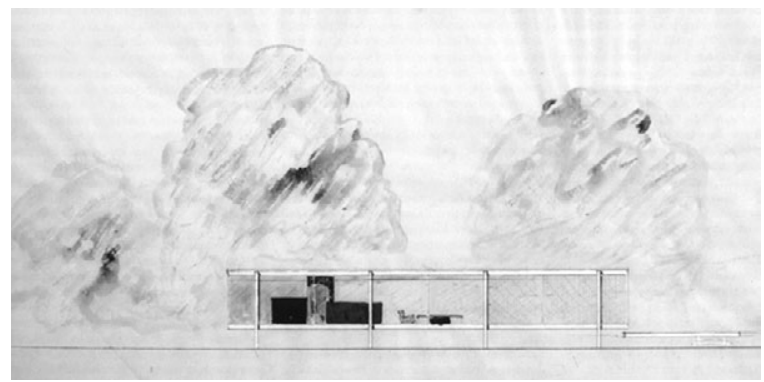

Alzado casa Farnsworth, Plano (Illinois). Mies van der Rohe (1946-51).

de estandarización de elementos para su prefabricación, entre otros, eso sí, desprendidos ya de contenido ideológico alguno. Y entre la concreción individual de las casas de Wright y la vocación de abstracción general de Mies, el programa CSH optó por la obra de autor de posibles patentes universales, como la casa 50x50 y su más ilustre antecedente: la casa Farnsworth en Plano (1946-51).

A igual que en este barrio de Sttutgart (y en toda la producción de viviendas sociales del periodo de entreguerras), los nuevos materiales y el equipamiento doméstico (que incluía sanitarios, elementos de cocina, armarios, mobiliario, luminarias) jugaban un papel determinante en la definición de la nueva vivienda - una vivienda mínima-, salvo que ahora, tras finalizar la II GM, el desarrollo de la tecnología aplicada a las máquinas del quehacer y bienestar domésticos había alcanzado una sofisticación sin precedentes. Todo había pasado a ser eléctrico y por tanto el hogar devenía electrodoméstico y automatizado, algo que la televisión ${ }^{22}$ (la primera ventana al mundo, más allá del jardín, desde el interior de las viviendas) se encargaba de divulgar en anuncios publicitarios y teleseries de ficción. Estas casas, respecto de aquellas de principios de siglo, habían reducido sus superficies, se completaban con un geométrico jardín de menor dimensión, el living se unía espacialmente al comedor y a la cocina, incluían un garaje de dos plazas y resultaban más

22. Resulta muy interesante efectuar un estudio de la relación de los modos de vivir los ámbitos domésticos y los medios de difusión de imágenes animadas, particularmente el cine y la televisión (cuyas emisiones comienzan la BBC en 1936 -en GB- y la CBS y la NBC en 1939 -USA-). También resultan instructivas las relaciones que entre Rayos $\mathrm{X}$, Mies y casas con amplias superficies de cristal que se apunta COLOMinA, Beatriz: «Visiones Borrosas. La arquitectura de la vigilancia» en ACCA (ed.). Foro Crítica. Arquitectura y Naturaleza. Alicante, ed. CTAA, 2009, p. 17: «formaron la base de la arquitectura cotidiana de mediados del siglo en los EEUU, cuando la casa transparente se convirtió en un fenómeno de masas». 


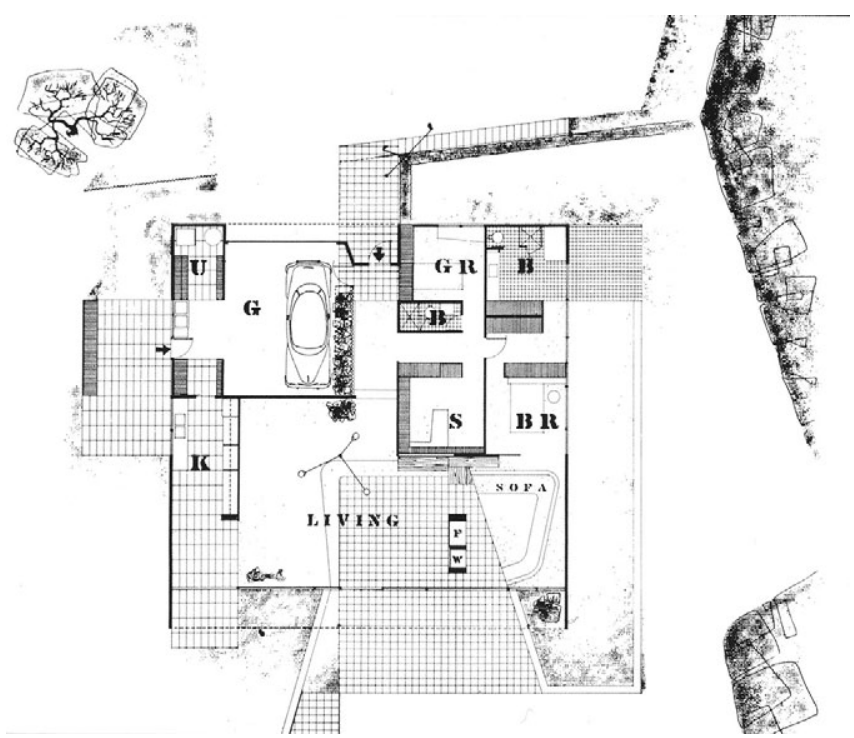

Planta casa CSH-9 (J. Enteza), Los Angeles (California). Ch. Eames y E. Saarinen (1945-49).

económicas por su estandarizada modulación. Se había definido así el que debía ser el programa de vivienda para los nuevos tiempos: «como modelo de casas pequeñas, realistas, abiertas al paisaje, higiénicas, prefabricadas, racionalistas, avanzadas ${ }^{23}$. La casa -casi siempre de una planta- se había vuelto más compacta y asequible a un mayor número de ciudadanos, sin renunciar a los tres principios que Wright había experimentado: el calor del hogar, la fluidez interior y el contacto con el jardín que, ahora, se había vuelto más un lugar de ocio, relax y diversión (incluyendo a veces piscinas), frente a aquel más estético y paisajista (con charcas y estanques).

El editor John Enteza, promotor del programa, seleccionó personalmente a los profesionales. Entre los más conocidos estaban C. Eames, R. Neutra, P. Koening y E. Saarinen; su propia casa (la CSH de 1945-49) sería proyectada por el primero y el último de la lista. No había arquitectas, pero Charles Eames trabajaba a dúo con su segunda esposa (m. 1941), la diseñadora Bernise Kaiser (1912-1988), más conocida por Ray Eames-, quien había colaborado con él y Saarinen a producir el mobiliario para la exposición «Diseño orgánico para muebles del hogar» del MoMA en 1940, con evidentes tendencias

23. Coll Barreu, Juan. Op. cit., p. 213. 
hacia la ergonomía que emana del cuerpo humano y la funcionalidad interior del espacio doméstico. En el programa también estaba Eero Saarinen, que se casaría (m. 1953) con Aline B. Louchheim (1914-1971), historiadora, editora de arte y crítica del New York Times.

De un lado, Ray se implicó de lleno en el diseño de la que sería su Casa Eames (1945-49), concebida para la «coexistencia ininterrumpida del trabajo y del ocio ${ }^{24}$, introduciendo el juego y el azar como criterios de diseño trasladados desde el ámbito de su propia vida personal y profesional. Ambos deseaban preservar los eucaliptos e integrar la casa en el paisaje porque querían «disfrutar del prado» ${ }^{25}$. Aline, sin embargo, desvinculada de este programa residencial, sería quien «gestionaba todas las relaciones públicas y diseñaba estrategias $»^{26}$ para promocionar la firma Eero Saarinen \& Associates, incluso entre los medios impresos más populares como la revista Time Magazine. Ambas mujeres, diseñadora y editora, se involucraron en contribuir a difundir el nuevo estilo de vida de la mujer, el cual conseguía liberar tiempo de sus obligaciones domésticas y familiares para dedicarlo a sus auténticas aspiraciones. Un tiempo que se arañaba gracias a los adelantos electrodomésticos y que permitía vislumbrar un nuevo modo de vida con más tiempo libre para el ocio o para el trabajo personal de cada mujer. Un genuino modo de vida que se sobrealimentaba por la publicidad televisiva y las proyecciones en cinemascope.

El efecto de este programa iría más allá de las intenciones de su promotor de la mano de su colaboradora Esther McCoy (1904-1989), editora y crítica ${ }^{27}$, especializada en la arquitectura californiana del siglo XX. Faltaban aún cuatro años para que el programa finalizase y ella recopiló una ingente cantidad de material que publicó en 1962 con el título de: Case Study Houses: 1945-1962, divulgando un particular estilo de vida expansivo y optimista, confiado en el equilibrio entre una tecnología y una naturaleza domesticadas. Su convicción de que la arquitectura californiana, en particular la de la viviendas, tenía un futuro bien cimentado en un pasado que enhebraba tradición y modernidad, ya había sido anticipado en su libro de 1960 titulado: Five California Architects; un título que sería tomado prestado una década después para titular un libro-catálogo con similares fines propagandísticos -no ajenos a la moda del

24. SмIтн, Elizabeth A.T. Op. cit., p. 23.

25. Ray Eames citada en: Koening, Gloria. Charles \& Ray Eames, 1907-78, 1912-88. Pioneros de la modernidad a mediados del siglo XX. Colonia, ed. Taschen, 2005.

26. SERRANO, Pierluigi. Eero Saarinen, 1910-1961. Un expresionista estructural. Colonia, ed. Taschen, 2005, p. 14.

27. La lista de revistas profesionales en las que colaboraba es bastante extensa; entre las más importantes citaremos: Arts \& Architecture, Architectural Forum, Architectural Record, Progressive Architecture, L'Architectura y Lotus. 
consumo de imágenes-, siendo entonces otros arquitectos los protagonistas: los Five Architects (además, situados geográficamente, en la otra costa -en la Este-, aunque lo exhibido volviera a ser lo mismo: viviendas y más viviendas).

El papel jugado por la mujer en la definición de este nuevo modo de vivir resulta significativo, máxime cuando tradicionalmente la casa ha presentado dos caras. Una exterior que entiende la casa como volumen, como posesión material y, por tanto, ligada al hombre. Otra interior, que entiende la casa como espacio, como expresión emocional y, por tanto, ligado a la mujer. Como apunta C. Espegel: «relacionar antropológicamente la casa con la construcción, y por lo tanto con el varón, en oposición al hogar, la habitación y la mujer, es un hecho histórico» ${ }^{28}$. Quizás por ello, aunque el hecho de que el interior doméstico se vuelva exterior fuese una invención básica de los arquitectos, en la consolidación del concepto de este nuevo modo de vivir -junto a una naturaleza más dominada y que proporcionaba más tiempo libre gracias a la tecnología- participaron las múltiples colaboradoras tanto en sugerencias al diseño (Catherine Ostertag y Ray Eames) como en su divulgación en imágenes fundamentalmente impresas (Aline B. Louchheim y Esther McCoy). Quizás este proceso que diluye los límites entre el interior doméstico y el exterior también pueda leerse como una muestra de la progresiva equiparación social entre la mujer y el hombre que encuentran un espacio que compartir con un mayor tiempo individual. Es obvio que en este proceso de reequilibrio -el exterior y el interior, el hombre y la mujer- jugaron un papel relevante los medios gráficos, pero más crucial aún se revelaron los medios audiovisuales - la pantalla grande y la caja tonta- como difusores de imágenes, modos de vida y roles sociales. Con toda probabilidad porque las personas somos más visuales de lo que pensamos y porque las imágenes transmiten más que meras formas.

\section{La insegura convivencia en las ciudades o el poder de la palabra}

¿La casa o la ciudad?, ¿qué fue primero? No es una pregunta que tenga una respuesta inmediata. La casa apareció para la seguridad de la vida, con su decidida vinculación a la tierra. La ciudad surgió para extender esta protección a la sociedad y garantizar la convivencia. Los poblados no resultan sólo de la agrupación de un número mínimo de viviendas. Para que resulte una ciudad es necesaria la aparición de acciones mercantiles que dinamicen las actividades de intercambio. Es consustancial la creación de una red de asentamientos en el territorio que interactúan, entre los cuales tienen lugar las

28. SPegel, Carmen. Op. cit, p. 29. 
acciones de intercambio de todo tipo de bienes. Aunque Jane Jacobs (19162006) sostuviera que «la agricultura y las técnicas de cultivo surgieron desde las ciudades ${ }^{29}$, a partir de una ficción recreada desde las investigaciones del arqueólogo británico James Mellaart en Catalhöyück (Turquía), la interpretación más aceptada es la contraria: que la agricultura fue antes que el comercio, que la casa y el poblado fueron antes que las ciudades. La original, pero ficticia, Nueva Obsidiana de Jacobs «no supone un gran desafío al <dogma de la primacía agrícola $>»^{30}$.

Sea como fuere hay un rasgo que caracteriza a las ciudades desde su nacimiento. Es la aparición de espacios públicos bien delimitados donde, como mínimo, tienen lugar las reuniones de los mercaderes (que no sólo se reúnen allí, también lo hacen en las calles que confluyen). Se trata de la plaza del mercado que todos conocen, incluso quienes no son ciudadanos del lugar. Una plaza pública que identifica a los habitantes con la ciudad. Probablemente la construcción de las ciudades arrancó muchas casas del campo y las alejó del entorno natural para configurar la obra más grande de los humanos: la ciudad. Un ser artificial que se desarrolla con las mismas pulsiones de los seres vivos que lo habitan. Ciudad y civilización tienen la misma raíz latina y el mismo género, no así la raíz sajona town que carece de género. La vita en la civitas dio origen a la civilitas, con sus registros y sus escrituras. Ciudades que tienen en su germen el fin de proteger a sus ciudadanos y garantizar la convivencia de la sociedad que albergan. Inevitablemente la distancia de sus habitantes y sus arquitecturas al medio natural de su entorno se hace mayor en la medida que la propia urbe se desarrolla, crece y se extiende. Ciudad y naturaleza parecen dos entidades contrapuestas, donde la primera niega la segunda aunque, en realidad, se sustenta sobre ella.

Por extraño que parezca, algunos periodistas - con sus obras críticas, reflexivas o propositivas- han tenido más repercusión sobre las disciplinas de la arquitectura y del urbanismo del que ni ellos mismos, ni nadie, habrían podido imaginar. Seguramente de medicina son muy pocos los que se atrevan a opinar sin ser profesionales de dicha ciencia, pero no sucede otro tanto con la arquitectura y la ciudad: a todos nos afecta y todos podemos aportar nuestro particular punto de vista. De hecho, un tema como lo urbano, con sus múltiples dimensiones, presenta entre sus especificidades el cambio continuo y el

29. JACOBS, Jane. La economía de las ciudades [1969]. Madrid, ed. Península, 1972 (original: The Economy of Cities. New York, ed. Random House, 1969).

30. MORRIS, A.E.J. Historia de la forma urbana. Desde sus orígenes hasta la revolución Industrial [1979]. Barcelona, ed. Gustavo Gili, 2006, p. 453. Este autor dedica el apéndice «D» a la teoría de Nueva Obsidiana de J. Jacobs. 


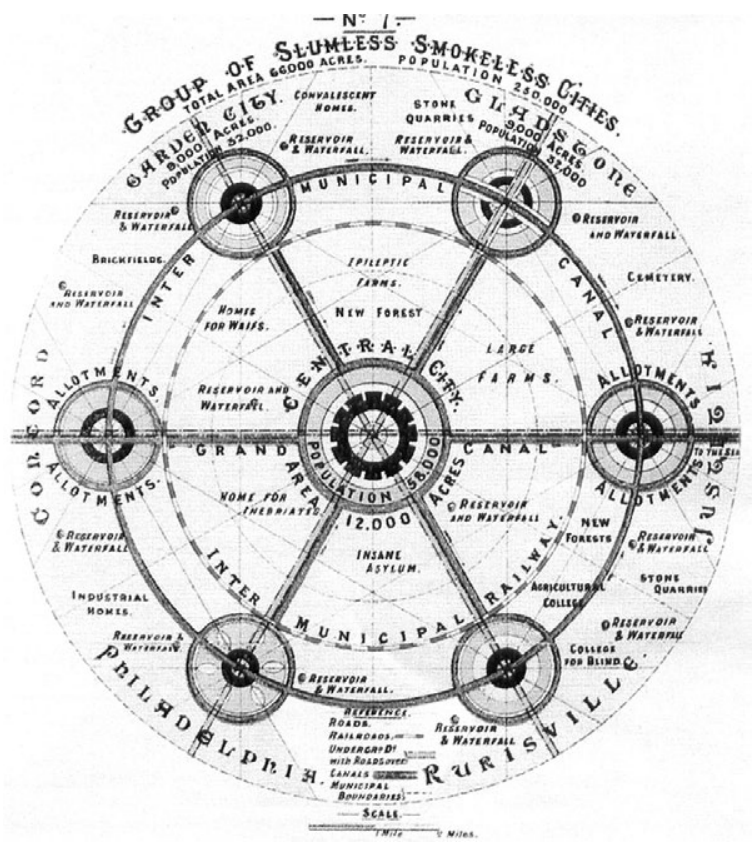

Diagrama de la ciudad jardín de Ebenezer Howard (1904).

ser objeto de estudio desde distintas perspectivas y disciplinas. Lo específicamente urbano no sólo es arquitectónico, también es público, social, económico, político, cultural, legal, paisajístico, inmobiliario y mucho más, y casi todo ello es noticia: tras la política son las cuestiones de la ciudad las que más llenan las páginas de los medios de difusión impresos o digitales. Algunas de las opiniones elaboradas por expertos de cualquiera de estas materias, o por un buen observador, se convierten en punto de arranque para otras disciplinas.

En el caso del urbanismo y la arquitectura, el libro escrito por el periodista británico Ebenezer Howard (1850-1928) supuso una revolución que daría lugar a un modo distinto de entender la convivencia en las ciudades. Fue redactado después de haber vivido en USA y haber observado con detenimiento la organización de las ciudades de aquel país y, sobre todo, las viviendas que las configuraban ${ }^{31}$. Tras su libro, Tomorrow. A Paceful Path towards

31. Para una sucinta biografía y análisis de su obra pede consultarse: BAYLEY, Stephen. La ciudad Jardín [1977]. Madrid, Adir Editores, 1982, pp: 38-43. Se señala que Howard permaneció en USA entre 1871 y 1876 trabajando como granjero y periodista. Estas 
Reform $^{32}$ (1898), surgieron las ciudades-jardín que hicieron posible que empezara a tomar cuerpo la idea de que las ciudades y la naturaleza domesticada ( «lo verde») no eran enemigas y que, por tanto, era posible un modelo de expansión (o dispersión) de las ciudades donde se estableciese un equilibrio entre lo urbano y lo rural. La influencia de sus razonamientos ${ }^{33}$ (a partir de las teorías de los tres imanes que confluían en la posibilidad de construir una ciudad que reunía las ventajas del ajetreo urbano y de la paz del campo) y de sus esquemas gráficos fueron tales que, desde entonces, casi nadie, de dentro o de fuera de las disciplinas en torno a las ciudades, cuestiona la necesidad de hacer prevalecer la presencia de la naturaleza (con el grado de artificiosidad que se requiera en cada caso) en un diálogo constante con cualquier asentamiento urbano.

A mediados del siglo XX, tanto el desarrollo desmedido de las metrópolis como la aplicación sin escrúpulos ni rigor disciplinario de los principios de la ciudad funcional -de la Carta de Atenas (1934) emanada de los CIAM- estaban dando resultados urbanos bastante desastrosos como balance general. Ciudades con los cascos históricos abandonados, barrios periféricos sin enlazar con la ciudad matriz, arquitecturas repetitivamente especulativas, carencia de equipamientos e infraestructuras básicas y, en todas ellas, la generación de espacios públicos urbanos sin ningún tipo de cualificación e incapacitados para generar identidad urbana y social. Una de las más inmediatas consecuencias de esta ciudad fragmentada y desestructurada -que no sólo se debía a las malas prácticas urbanísticas sino también a la carencia de políticas económicas y educacionales que ayudasen a cohesionar las vecindades y perfilasen un futuro de bienestar-, donde las calles y las plazas se habían diluido en un continuo espacio público indiferenciado, en una tierra de nadie salpicada por edificaciones anodinamente repetidas y de baja calidad constructiva y estética, fue el incremento de la inseguridad ciudadana simultáneo a la pérdida de la capacidad de representación de los lugares destinados al tránsito y el encuentro de los ciudadanos.

En medio de este panorama urbano surge la voz aguda de Jane Jacobs, divulgadora científica -periodista- y teórica del urbanismo, que con su libro

influencias son evidentes hasta en los términos empleados: «Central Park», «Avenues» y la numeración de las vías.

32. Este libro tuvo una edición posterior cuyo título refería directamente el modelo de ciudad dispersa: Howard, Ebenezer. Garden Cities of Tomorrow [1902]. London, ed. Faber and Faber, 1944.

33. Las propuestas de este intelectual iban más allá de lo urbano y descendieron hasta las viviendas «donde las tareas domésticas eran compartidas por una cooperativa de inquilinos» y a donde terminaría por mudarse a vivir. Véase: MuXí, Zaida. Op. cit, p. 55. 


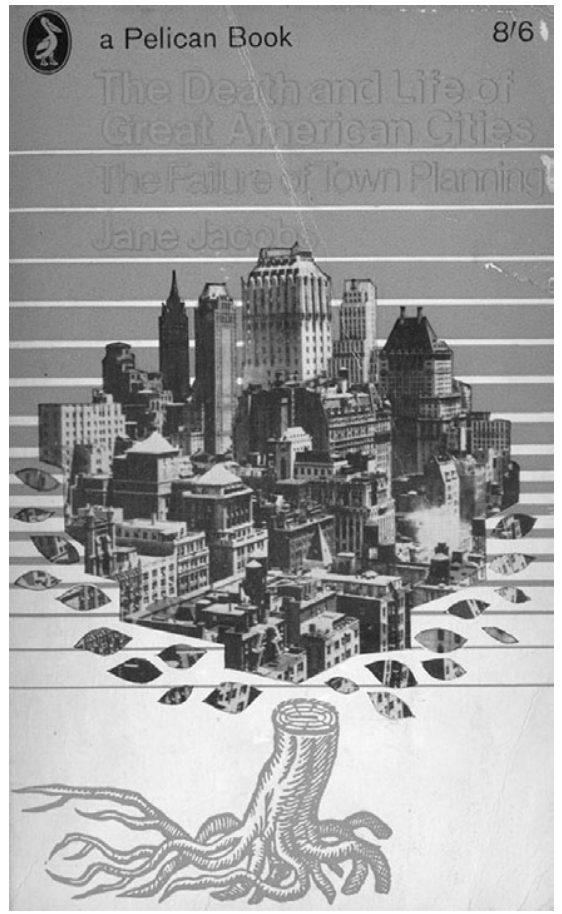

Portada del libro de J. Jacobs: Muerte y Vida de las grandes ciudades americanas (1961).

Muerte y vida de las grandes ciudades americanas ${ }^{34}$, de 1961, describió los desaciertos de la aplicación de modelos esquemáticos ideales a la planificación urbana del momento. En su discurso no deja lugar a dudas y sustituye los conceptos teóricos por las experiencias de la realidad:

$\mathrm{Al}$ exponer unos principios diferentes, me referiré esencialmente a cosas y temas perfectamente comunes y ordinarias $»^{35}$ que reafirma con decidida voluntad: «En una palabra, me referiré siempre a cosas reales, a ciudades reales y a la vida real de las ciudades $»^{36}$. Enumera los fracasos más sonados con clarividente sencillez: «los barrios de viviendas baratas se han convertido en los peores centros de delincuencia, vandalismo y desesperanza social, mucho

34. JACOBS, Jane. Muerte y vida de las grandes ciudades americanas [1961]. Madrid, ed. Península, 1973. Original: The Death and life of Great American Cities. New York, ed. Random House Inc., 1961; también disponible, parcialmente, en: <http:// abitat. aq.upm.es/boletin/n7/ajjac.html> (2010-06-23).

35. JACOBS, Jane. Muerte y vida... Op. cit.

36. Íbid. 
peores que los viejos barrios bajos que intentábamos eliminar; los proyectos de construcción de grupos de viviendas de renta media -auténticas maravillas de monotonía y regimentalización- sellaron a cal y canto las perspectivas de una vida ciudadana llena de vitalidad y dinamismo; los barrios residenciales de lujo (...) son hoy escaparates de una insípida vulgaridad; y no hablemos de los centros culturales (...) o los centros cívico-recreativos cuidadosamente evitados por todo el mundo (...); amén de los centros comerciales imitación sin lustre de lo supermercados suburbiales y de todos esos paseos que no vienen de ningún sitio y no van a ninguna parte (...); y esas autopistas que destripan las grandes ciudades» ${ }^{37}$. Concluyendo: «Esto no es reordenar las ciudades. Esto es, simplemente, saquearlas ${ }^{38}$.

Jane Jacobs, en tono irónico y guerrero, atacaba por igual a Howard y a Le Corbusier (1887-1965); al último achacaba la gran «plaga de monotonía» que observaba a su alrededor ${ }^{39}$. Identificaba las causas de la violencia en lo cotidiano de la vida urbana a una confluencia de factores entre planificación, seguridad ciudadana, calidad de vida y grado de abandono de los espacios urbanizados. Insistía en la necesidad de recuperar el contacto vecinal diario, el cual tenía lugar en las calles y en sus aceras, no en lugares indefinidos ni imprecisos: «Las calles y sus aceras son los principales lugares públicos de una ciudad, sus órganos más vitales. ¿Qué es lo primero que nos viene a la mente al pensar en una ciudad? Sus calles. Cuando las calles de una ciudad ofrecen interés, la ciudad entera ofrece interés; cuando presentan un aspecto triste, toda la ciudad parece triste ${ }^{40}$. Se anticipó, en parte, a los situacionistas como el antropólogo Marc Augé (1935), al identificar en las ciudades lo que ella llamaba «vacíos fronterizos» (ferrocarriles, autopistas, parques extensos) de dudoso beneficio ${ }^{41}$.

Su crítica radical al urbanismo imperante en los años 60 y su preocupación por redefinir el espacio público que se había vuelto un no-lugar inseguro, influyó decisivamente en toda la generación de técnicos involucrados en el planeamiento y la gestión urbanística. Se adelantó a toda la crítica que después se formalizaría en contra de la arquitectura del movimiento moderno y del urbanismo funcionalista, iniciada por Robert Charles Venturi (1925) y Denise Scott Brown (1931) en USA y por Aldo Rosi (1931-1997) en Europa; todos ellos serían autores de una serie de libros que reclamaban la capacidad

\footnotetext{
37. Íbid.

38. Íbid.

39. WATSOn, Peter. Op. cit., p. 559.

40. JACOBS, Jane. Muerte y vida... Op. cit.

41. WATSON, Peter. Op. cit., p. 560.
} 


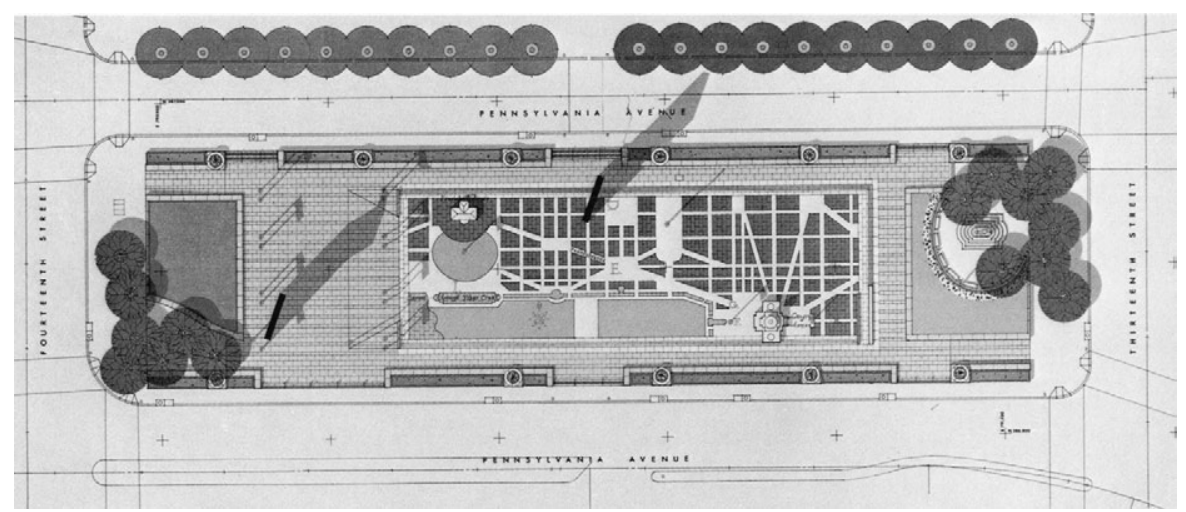

Planta de la Western Plaza, Washington DC. Venturi, Rauch y Scott (1977).

de comunicación de la arquitectura, la recuperación de un sentido consciente del pasado y la redefinición de los entornos urbanos próximos (la plaza, el jardín, el parque, la calle, la avenida, el bulevar...). Un ejemplo de la recuperación de los espacios urbanos públicos, por parte de los profesionales citados, sería la Westem Plaza en Washington D.C. (1977). Las palabras de Jacobs tuvieron como sucesoras palabras más eruditas en nuevos libros en 1966, cuya repercusión sigue resonando en las aulas de las universidades.

Sin embargo, mientras Jacobs fue aguda en su diagnosis de los problemas, a partir de la observación de la pérdida de la buena convivencia civil como consecuencia del avance de la delincuencia y la inseguridad (lo que hacía que las ciudades perdiesen su razón de ser y proliferasen los suburbios residenciales vigilados), no fue tan acertada en sus propuestas de organización y restructuración urbana. Sus cuatro principios urbanísticos (multifuncionalidad de los distritos, redimensión de las manzanas, estratificación por edades y aumento de densidades) ${ }^{42}$ constituían herramientas genéricas, poco concretas. De hecho, el problema de la convivencia urbana, de la proximidad de las relaciones, de la cercanía vecinal, era socavada por el aumento de la delincuencia, pero esta no se solucionaba sólo actuando sobre la morfología urbana y las tipologías edilicias: las soluciones requerían la convergencia de múltiples esfuerzos y políticas de los que no estaba exenta la arquitectura que definía calles que desembocaban en plazas y se abría a jardines... Sin embargo, sus ideas de autoorganización espontánea vecinal serían aplicadas con posterioridad al nuevo concepto de sistemas emergentes. Fueran cuales

42. Íbid., p. 560. 


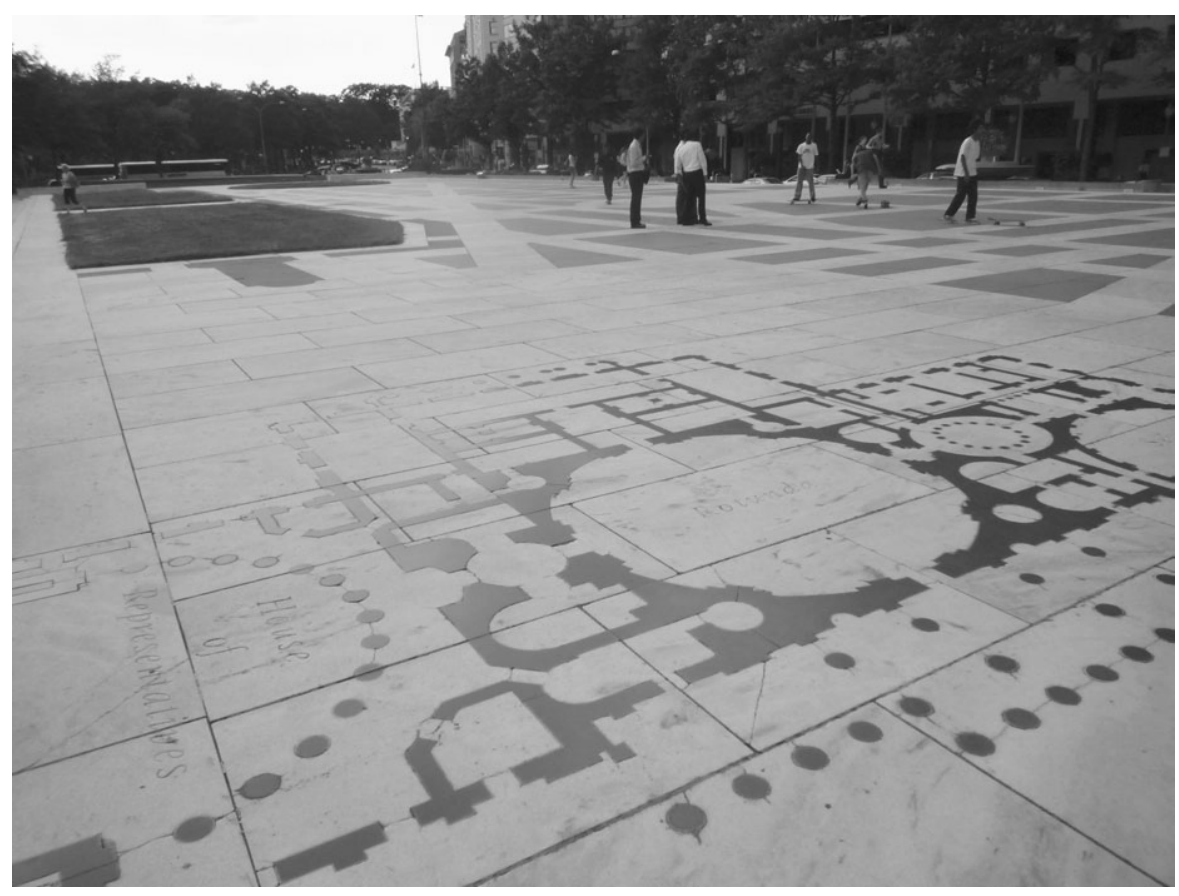

Vista de la Western Plaza, Washington DC. Venturi, Rauch y Scott (1980).

fueran sus propuestas concretas y la eficacia de las mismas, lo cierto es que el libro de Jacobs alertando del peligro de desintegración de las ciudades por falta de convivencia, fueron palabras que no cayeron en el vacío. Las palabras escritas se revelaron poderosas.

\section{Una reflexión a propósito de las protagonistas, sus armas y sus contextos}

Es obvio. Las protagonistas de este artículo no se han elegido de modo casual. No. Tampoco lo son los lugares donde vivieron y desarrollaron sus trabajos, si bien una cosa liga a la otra, aquí no hay elección. Ninguna de ellas es arquitecta, pero todas se involucraron con la arquitectura y la ciudad, los ámbitos donde se definen los roles del género. Sus esfuerzos fueron decisivos desde sus respectivas disciplinas para influir en la higiene, la vivienda y la ciudad. Florence Nightingale, británica, en el campo de la enfermería. Catherine Ostertag, Ray Kaiser, Aline B. Louchheim y Esther McCoy en el campo de lo doméstico. Y Jane Jacobs en el campo de la conveviencia. Por supuesto que 
hay más protagonistas que, comprometidas con su profesión, contribuyeron a construir una sociedad mejor y un mundo más amable, donde las personas se valoran por lo que son capaces de hacer, no por lo que se les presupone que pueden hacer o no hacer. No es extraño que todas estas protagonistas habiten países con larga tradición democrática, donde se apuesta por la libertad individual (la cual se han conquistado, no ha sido un regalo de nadie ni de nada), donde se ha favorecido la independencia económica de las personas y donde se ha implantado un sistema educativo que alcanza a más amplias capas sociales, al cual no son ajenos los medios de comunicación ${ }^{43}$ y su libertad de opinión, es decir: donde se ha fomentado una mayor libertad de prensa (y de palabra y de imágenes) y donde la competencia se fomenta como diálogo (no como imposición de criterios). Es todo un conjunto. Nada es separable. No había un destino escrito anticipado: este se ha fraguado poco a poco.

$\mathrm{El}$ artículo no pretende resolver las contradicciones de las personas. Tampoco las propias de las disciplinas de la arquitectura y la ciudad. A veces resulta incompatible defender un determinado tipo de arquitectura (y de espacio doméstico vinculado a la naturaleza domesticada y próxima) con una ciudad que no esté diseminada o dispersa. En algún momento lo hemos avanzado: ciudad y naturaleza son dos entidades contrapuestas, pero una necesita de la otra. No se trata de una dependencia mutua y correspondida, a diferencia de la relación que se establece entre arquitectura, ciudad y sociedad: nos resulta muy difícil imaginarlas cada una por separado. Sólo se pretende poner de relieve dos cuestiones. La primera es que las influencias y avances en una materia no siempre proceden del interior, apostando por la interdisciplinaridad e interacción del conocimiento entre disciplinas próximas o, en apariencia, lejanas, por lo que han sido posibles las aportaciones de mujeres a materias en las que, en su época, difícilmente ostentaban responsabilidad profesional directa. En su momento las mujeres no eran enfermeras formadas, arquitectas o urbanistas y, sin embago, desde territorios afines influyeron decisivamente aportando sus experiencias y puntos de vista. La segunda es que el protagonismo alcanzado por mujeres siempre ha resultado más posible en aquellos países que dificultaban menos sus ansias por hacerse valer como profesionales

43. WATSON, Peter. Op. cit., p. 241, señala que: «El historiador J.H. Plumb (1911-2001) ha señalado que uno de los logros no reconocidos del siglo XX ha sido la formación cultural de un vasto número de personas. Esto ha sido posible gracias a las escuelas y universidades subvencionadas por el gobierno, pero también a los nuevos medios de comunicación, muchos d elos cuales tuvieron su incio en los años veinte». Y se refiere explícitamente a las revistas de difusión masiva, la radio, el cine, la televisión e internet. 
de una determinada materia, en lugar de tiranizar a las personas considerándolas por igual, de bien o de mal; es decir: permitía vías para la realización profesional aunque esta no estuviera exenta de dificultades.

En nuestro caso, Florence Nightingale se valio de su perseverancia y sus dotes de observación de las condiciones espaciales y materiales que rodeaban la vida de los enfermos. Estos datos los transformó en cifras que reflejó en tablas que resultarían estadísticas y le dieron las pistas de cómo mejorar las instalaciones hospitalarias con lo que ella denominó las leyes de la salud o la higiene. Los números le dieron la confirmación de sus deducciones experimentales. En segundo lugar, Catherine Ostertag y Ray Eames colaboraron a diseñar viviendas que apostaban por abrir el interior de la vivienda horizontal al exterior ajardinado, disolviendo los límites de lo doméstico para ganar espacio para sus ocupaciones y tecnificando las tareas domésticas que liberaban tiempo para sus aspiraciones. Esta tarea del proyecto fue compartida con los hombres, como no podía ser de otro modo. Mientras que Aline B. Louchheim y Esther McCoy se hicieron cargo de divulgar y difundir este singular modo de vida californiano -no exento de contradicciones-, para el que resultaron decisivas las aportaciones de los medios de comunicación audiovisuales como el cine y la televisión. Por último, Jane Jacobs, tras su estudio y análisis de las ciudades americanas, constató la degradación de la convivencia en las mismas a consecuencia de la creciente delincuencia que achacó a la deficiente planificación vigente. Sus palabras, más que sus propuestas, sirvieron para que la comunidad de expertos empezase a mirar la ciudad de otro modo y fuese capaz de ir encontrando soluciones parciales a la complejidad del problema urbano. Tanto en la higiene, en la vivienda como en la ciudad, siempre está presente la Naturaleza. «Naturaleza se escribe con 'N' mayúscula» que diría Wright para quien «La Naturaleza es todo lo que llegaremos a conocer del cuerpo de Dios» ${ }^{44}$.

Así pues, números, imágenes y palabras se convirtieron en armas para hacer valer las ideas de mujeres profesionales en los ámbitos de la higiene, la vivienda y la ciudad, demostrando su validez, sino universal, sí, al menos, particular para su momento y los problemas allí planteados. Números, imágenes y palabras que son armas del diálogo y del convencimiento y que podemos usar mujeres y hombres por igual. Compartimos, pues, la visión del historiador Herbet Butterfield (1900-1979), según la cual no hay necesidad de emitir juicios morales, por lo que no pretendemos juzgar el pasado desde

44. Frank Lloyd Wright citado por: BROOKS PFEIFFER, Bruce. Frank Lloyd Wright [1991]. Cologne, ed. Taschen, 2007, p. 28. 
el presente, porque las grandes luchas del pasado no se han dado entre un bando de «buenos»y otro de «malos» $»^{45}$. A lo sumo que aspiramos es a haber contribuido a la construcción con más detalle de nuestra historia, porque el pasado sucede, pero la Historia se construye.

\section{Referencias bibliográficas}

Attewell, Alex. «Florence Nightingale (1820-1910)». Perspectivas: revista trimestral de educación Comparada, vol. XXVIII, nº 1, (1998), París, pp. 173-189.

BACHELARD, Gaston. La poética del espacio [1957]. México, ed. Fondo de Cultura Económica, 2010.

BAYLEY, Stephen. La ciudad Jardín [1977]. Madrid, Adir Editores, 1982.

BROOKS PFEIFFER, Bruce. Frank Lloyd Wright [1991]. Cologne, ed. Taschen, 2007, p. 28.

Coll Barreu, Juan. Construcción de los paisajes inventados. Los Angeles doméstico 1900-1960. Barcelona, ed. Fundación Caja de Arquitectos, 2004.

ColominA, Beatriz: «Visiones Borrosas. La arquitectura de la vigilancia» en ACCA (ed.). Foro Crítica. Arquitectura y Naturaleza. Alicante, ed. CTAA, 2009.

ESPEGEL AlONSO, Carmen. Mujeres arquitectos en el movimiento moderno. Heroinas del espacio. Valencia, Ediciones Generales de la Construcción, 2006.

FRAMPTON, Kenneth. Historia crítica de la arquitectura moderna [1980]. Barcelona, ed. Gustavo Gili, 1998.

HOwARD, Ebenezer. Garden Cities of Tomorrow [1902]. London, ed. Faber and Faber, 1944.

INFANTINO, Lorenzo. El orden sin plan. Las razones del individualismo metodológico [1998]. Madrid, Unión Editorial, 2000.

JACOBS, Jane. Muerte y vida de las grandes ciudades americanas [1961]. Madrid, ed. Península, 1973; también disponible, parcialmente, en <http:// abitat.aq.upm. es/boletin/n7/ajjac.html> (2010-06-23).

KoENING, Gloria. Charles \& Ray Eames, 1907-78, 1912-88. Pioneros de la modernidad a mediados del siglo XX. Colonia, ed. Taschen, 2005.

LE CORBUSIER. Hacia una arquitectura [1923]. Barcelona, ediciones Apóstrofe, 1998, p: XXXI.

MORRIS, A.E.J. Historia de la forma urbana. Desde sus orígenes hasta la revolución Industrial [1979]. Barcelona, ed. Gustavo Gili, 2006.

MuXí, Zaida: «Decir la ciudad desde la experiencia». Arquitectos, n 2, (2006), Madrid, pp. 53-58.

PeVSNER, Nikolaus. Historia de las Tipologías Arquitectónicas [1976]. Barcelona, ed. Gustavo Gili, 1979.

45. WATSON, Peter. Op. cit., p. 278.

Feminismo/s 17, junio 2011, pp. 229-257 
SERrano, Pierluigi. Eero Saarinen, 1910-1961. Un expresionista estructural. Colonia, ed. Taschen, 2005.

Smith, Elizabeth A.T. Case Study Houses, 1945-1966. El impulso californiano. Colonia, ed. Taschen, 2006.

Smith, Elizabeth A.T; Shulman, Julius; Goessel, Peter (ed.). The complete CSH program, 1945-1966 [1984]. Cologna, ed. Taschen, 2009.

Watson, Peter. Historia intelectual del siglo XX [2000]. Barcelona, ed. Crítica, 2007.

Zabalbeascoa, Anatxu; Rodríguez Marcos, Javier. Vidas construidas, biografías de arquitectos. Barcelona, ed. Gustavo Gili, 1998. 



\title{
CRÍTICA DE GÉNERO. E. 1027: EILEEN GRAY VS. LE CORBUSIER EN CAP MARTIN
}

\author{
CARlos L. Marcos \\ Universidad de Alicante
}

Recibido: 09/02/2011

Aceptado: 20/05/2011

\section{Resumen}

La villa E.1027 ha permanecido durante años en un segundo plano en las historiografías del Movimiento Moderno a pesar de su sofisticada modernidad y su sabio entendimiento del lugar; tal vez por su crítica sutil a los principios de la modernidad instaurados en los años 20 e impuestos durante las décadas siguientes. Este ominoso olvido ha incluido también a una mujer, Eileen Gray, a quien corresponde la mayor parte de su autoría. Le Corbusier no fue ajeno ni a lo uno ni a lo otro. El artículo analiza el comportamiento del maestro en su obsesión y posterior ocupación de la Maison en bord de mer y su entorno próximo, tratando de desvelar las causas que probablemente animaron a su profanación; y finaliza con la crítica de género que premonitoriamente Gray desplegó en la E.1027 respecto del canon corbusierano ya en 1926.

Palabras Clave: Crítica, ocupación, género, Gray, Le Corbusier, E. 1027 


\begin{abstract}
The villa E.1027 has remained silenced for years in the historiography of modern architecture despite its sophisticated modernity and its wise understanding of the locus; perhaps due to its subtle criticism over the modern principles established during the 20 's and imposed over the following decades. This ominous oblivion has also included a woman, Eileen Gray, responsible for most of its authorship. Le Corbusier was not alien to either of them. This article analyzes the master's behaviour regarding his $o b-$ session and subsequent occupation of the Maison en bord de mer and its surroundings, trying to uncover the causes that probably encouraged their desecration. It ends up summarizing Gray's gender criticism presciently unfolded in E.1027 regarding corbusieran canon as early as 1926 .
\end{abstract}

Keywords: Criticism, occupation, gender, Gray, Le Corbusier, E. 1027 
Le Corbusier's «shack» [Cabanon] has been lovingly kept as a small museum, looked after the Commune of Roquebrune and visited by students and admirers of a glorious moment of modern architecture. A few yards away one of the purest examples of the same period is slowly dying.

Peter Adam (1989) ${ }^{1}$.

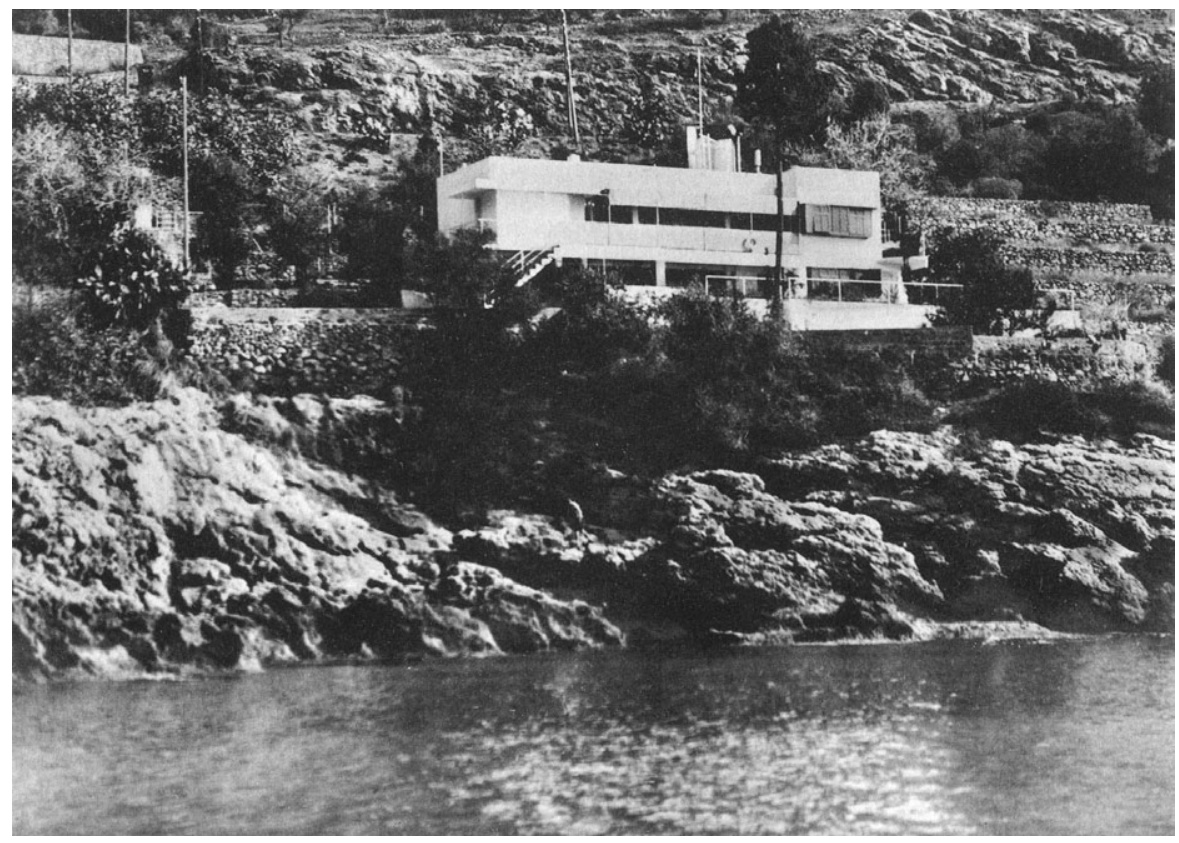

Fig. 1. E.1027 vista desde el mar.

(foto publicada en L'Architecture Vivant, 1929)

1. ADAM, Peter, 1989, «Eileen Gray and Le Corbusier», 9H, 8, p. 150-153. Afortunadamente hoy la vivienda ha sido restaurada.

Feminismo/s 17, junio 2011, pp. 259-295 
Durante la década prodigiosa del Movimiento Moderno en arquitectura, entre 1926 y 1929, Eileen Gray proyectó y construyó una villa, la E. 1027 ó Maison en bord de mer, para sí y para Jean Badovici en Cap Martin, Roquebrune. En 1952 Le Corbusier construyó una pequeña cabaña, el cabanon, a escasos 20 metros ladera arriba y hacia el este de la villa diseñada por su rival en una posición dominante sobre ella. Está sería solamente una de las muchas acciones encaminadas a la ocupación, apropiación, manipulación, alteración o desfiguración que Le Corbusier ejercería sobre una obra de arquitectura; una obra que desde luego no le dejó indiferente. Una extraña mezcla entre admiración, envidia, desprecio o machismo -acaso un poco de todo ello-, marcaría la historia de una de las obras más sofisticadas de la arquitectura del período de entreguerras, pero ¿por qué?

Analicemos primero los actos para intentar desvelar las causas. Esta peque$\tilde{n} a$ historia ya ha sido narrada de diversas formas y con distintas intensidades en otros textos ${ }^{3}$, pero en estas líneas intentaremos analizar el comportamiento de Le Corbusier en lo referente a la E.1027 y la propia vivienda como arquitectura crítica, en muchos aspectos con un incipiente canon capitaneado por el propio arquitecto, así como las causas que pudieron llevar a éste a terminar con una actitud hostil hacia la casa, como objeto, y hacia sus propietarios y diseñadores, como sujetos.

\section{Contexto de la obra}

Jean Badovici era arquitecto, crítico y editor de la influyente revista LArchitecture Vivant. Como tal, fue también uno de los protagonistas en difundir las obras y escritos de algunos de los arquitectos de la modernidad en los diez años durante los que se publicaron los 21 números de la revista. Entre ellos, Le Corbusier ocuparía un lugar muy destacado; algo que conviene tener presente en el contexto que nos ocupa. La influencia que ejercía Le Corbusier sobre él era, desde el principio, la de una autoridad en la materia.

2. La participación de Jean Badovici en el diseño de la vivienda es imprecisa y forma parte del misterio o la ocultación que por parte de la historiografía o de la crítica de arquitectura ha envuelto este baluarte de la modernidad. En principio, y como quedará justificado en el texto, parece claro que el mayor protagonismo se deba a Eileen Gray aunque Badovici también debió participar al menos en el asesoramiento de los aspectos más técnicos, a tenor de sus respectivas formaciones.

3. Ver p. ej., «E. 1027: The Nonheroic Modernism of Eileen Gray» de Caroline Constant, «Líneas de Batalla: E. 1027» de Beatriz Colomina, «Eileen Gray and Le Corbusier» de Peter Adam o «Occupying E.1027: Reconsidering Le Corbusier's «Gift» to Eileen Gray» de Jasmine Rault, al margen de biografías como las del propio Adam o la exhaustiva y estupenda monografía sobre la E.1027, Aires Modernos, de Carmen Espegel. 
Badovici animó a Eileen Gray a dedicarse a la arquitectura -más allá de su actividad como interiorista por la que era reconocida en el París de los años 20- entablando con ella una doble relación profesional y personal desde 1924 que duró varios años y que desembocaría en el encargo de la E. 1027. Como bien apunta Espegel ${ }^{4}$, la actitud de Badovici no fue desinteresada ya que vio en ella a una diseñadora de gran talento y con los recursos económicos suficientes como para materializar sus propias ideas.

Para entender todas las claves de esta historia de atracción, odio y deseo, en la que se entremezclan las relaciones personales y la atracción por un objeto, la Maison en bord de mer, resulta imprescindible considerar la génesis del proyecto y el valor afectivo que Eileen Gray otorgaba a dicho objeto. No se trataba de un encargo cualquiera para un cliente sin más. Era la primera oportunidad de construir una obra de arquitectura con arreglo a las convicciones más íntimas y los anhelos de diseño de una morada que lo sería para ella misma y para su amante ${ }^{5}$, con quien compartía buena parte de sus ideales concernientes a la arquitectura. Gray y Badovici se enrolan en la aventura de proyectar y construir una residencia en colaboración siendo con ello clientes y autores al mismo tiempo. La intensidad e intimidad de su propia relación y de ambos para con el proyecto da nombre a la propia vivienda ${ }^{6}$. Sólo así puede entenderse, entre otras cosas, que siendo el propio Badovici arquitecto y editor amigo de buena parte de los arquitectos de mayor prestigio en aquel momento y estando comprometido con la vanguardia arquitectónica, decidiera sin embargo, realizar el encargo a una interiorista sin apenas experiencia en el campo de la arquitectura ${ }^{7}$. A no ser que, razones sentimentales aparte,

4. ESPEGEL, Carmen. Heroínas del espacio. Mujeres arquitectos en el Movimiento Moderno. Ed. Generales de la Construcción. Valencia, 2006, p. 105. Quiero agradecer públicamente los comentarios y sugerencias recibidas por parte de Carmen Espegel para la redacción final de éste artículo; sin duda sus acertados consejos y su conocimiento sobre la materia han contribuido a mejorarlo.

5. Respecto de la bisexualidad de Eileen Gray, Espegel escribe «Su anhelo de independencia era demasiado fuerte como para conformarse con un mero intercambio familiar dependiente de obligaciones matrimoniales. Durante toda su vida evitó el matrimonio o cualquier otro tipo de relación duradera. Tuvo algunas relaciones íntimas tanto con hombres como con mujeres [...]» (ESPEGEL, Carmen, 2006, Op. cit., p. 97).

6. El código E. 1027 responde a un mensaje cifrado: E por Eileen, 10 por la «J» de Jean, 2 por la «B» de Badovici, y 7 por la «G» de Gray, como es bien conocido y recogido en toda la bibliografía sobre la vivienda.

7. Además del proyecto teórico con el que Gray se inició en la arquitectura a partir del modelo de la Villa Moissi (diseñada por Loos y expuesta en el Salon d'Automne de 1923, exposición en la que participaba también Gray), y su colaboración en la decoración de la renovación de algunas viviendas en Vézelay junto con Badovici precisamente en 1926 (el año en el que se proyecta la E.1027) el único proyecto arquitectónico de Gray anterior a 


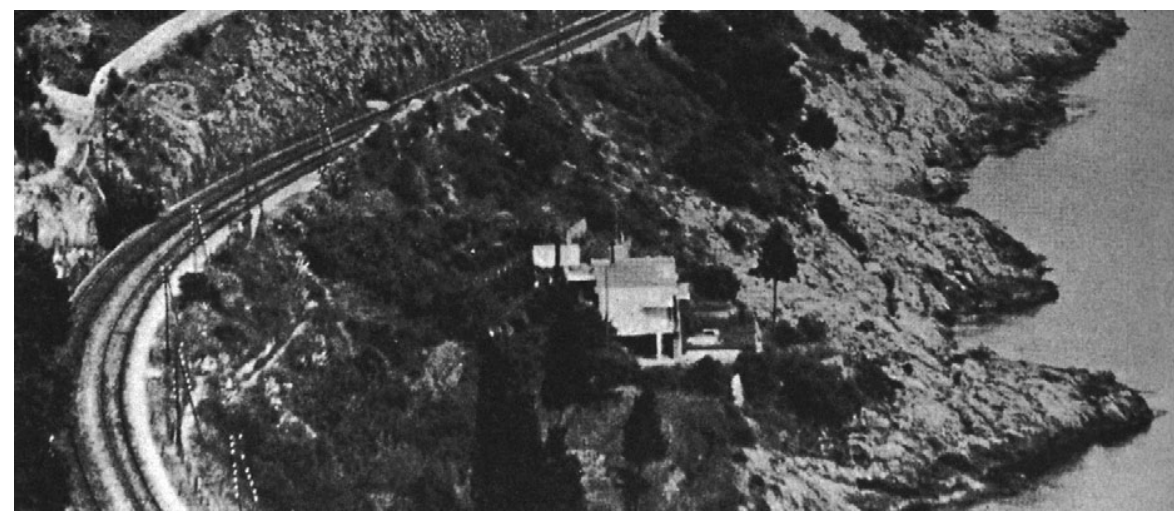

Fig. 2. E.1027 en el entorno aislada por dos límites:. (Detalle de foto de la época publicada en Aires modernos, Carmen Espegel)

quisiera ejercer sobre ella una actitud paternalista y de control sobre lo proyectado que habría sido imposible de practicar en otro caso.

Así, a finales de 1926 Eileen Gray recibe el encargo de buscar un lugar para proyectar y construir la E.1027. Esta es otra de las características que añaden un valor afectivo a la morada: su ubicación ha sido cuidadosamente escogida por la arquitecto, un rincón del paraíso de la riviera francesa, en las proximidades de Montecarlo. Este es el primer acto de apropiación del lugar; no es aventurado decir que es la primera decisión de proyecto. A diferencia de lo que sucede en un encargo convencional en el que el cliente posee una parcela y contacta con el arquitecto para que haga un proyecto para él y ese lugar, aquí es el propio arquitecto quien elige cuidadosamente el lugar. Apenas accesible, a escasos metros del mediterráneo, en una lengua de terreno aislada por la doble condición de límite entre el litoral y la vía férrea ladera arriba (Fig. 2), una parcela abancalada se asoma hacia el mediodía para conquistar el horizonte marino. La intención de aislamiento es clara; su vinculación con el mar intencional e inevitable.

\section{Le Corbusier y la E. 1027: una atracción fatal}

Le Corbusier mantenía una relación fluida con Badovici, quien había publicado algunas de sus viviendas y sus escritos en la revista L'Architecture Vivant.

la maison en bord de mer es su proyecto no construido de Casa para un Ingeniero, también desarrollado en ese mismo año. (CONSTANT, Caroline. "The Nonheroic Modernism of Eileen Gray», Journal of the Society of Architectural Historians, Vol. 53, Nº 3 (Sep. 1994), pp. 265-279). 
Eileen Gray conoció a Le Corbusier por mediación de Badovici; estaba al tanto de su arquitectura y sus escritos a través de la revista, las exposiciones parisinas y la publicación de L'Esprit Noveau. De hecho, los interiores de las viviendas que reformaría en Vézelay junto a Badovici incluían un repertorio formal y de detalles similares a los de los proyectos de Le Corbusier, como la casa Citrohan, aunque es probable que buena parte de dicha influencia fuera más una imposición por parte de Badovici, como bien señala Constant ${ }^{8}$ :

Unlike her House for an Engineer, in which Gray explored variations on Le Corbusier's spatial formulas, each of Vézelay interiors incorporated formal devices borrowed directly from his Maison Citrohan: a double height living room overlooked by a mezzanine, accessed by a narrow ship's stair and lined with pipe railings. Badovici may have mandated such adherence to Corbusieran forms to fulfil his avant-garde objectives.

Como interiorista, el trabajo de Eileen Gray tenía el suficiente vigor, personalidad y originalidad como para no depender de las imitaciones. Desde el momento en que tuvo ocasión de proyectar arquitectura, su libre interpretación de los preceptos corbusieranos estuvo patente. La tan escasa como exquisita arquitectura de Gray $^{9}$ es, de hecho, una obra compleja en la que los límites entre arquitectura, interiorismo y mobiliario se diluyen, y en la que varias de las distintas corrientes dentro del Movimiento Moderno quedan sabiamente integradas.

Por otro lado, Le Corbusier fue uno más del elenco de personajes de la cultura que frecuentaron la E. 1027 por invitación de Badovici y Gray, quienes gustaban de recibir a personas de la cultura en su Villa de la costa azul ${ }^{10}$.

Gray, Badovici y Le Corbusier fueron tres arquitectos unidos por un destino que acabaría confluyendo en un objeto arquitectónico: la Maison en bord de mer. Puede que un repaso de los hechos que enhebran la relación de los

8. Constant, Caroline. Op. cit., p. 269.

9. Rykwert, el primer crítico que se hace eco del valor de su arquitectura años después, se refiere en estos términos a la obra arquitectónica de Eileen Gray: «For an architectural oeuvre two houses, a few interiors and some unexecuted projects might seem excessively modest. In the particular case of Eileen Gray the modest quantity is in sharp contrast to extraordinary quality: quality high enough to set her among the masters of the modern movement however condensed her accomplishment.» (RYKWERT, Joseph. «Eileen Gray: two Houses and an Interior, 1926-1933», Perspecta, Vol. 13/14 (1971), pp. 67-73).

10. «Entre los numerosos invitados que visitan la casa se encuentran Christian Zervos, Fernand Lèger, Claude Roger-Marx, y Rex Martienssen. Picasso parece haber conocido la casa por medio de Le Corbusier, como cita Stanislaus von Moos en «Mariage des Contours», Oppositions 19/20, Invierno/primavera 1980.» (EPEGEL, Carmen. Aires modernos. E. 1027: maison en bord de mer Eileen Gray y Jean Badovici 1926-1929. Madrid, Ed. Mairea Libros, 2010. n.p.p. V, p. 8). 
tres para con la villa, ordenados cronológicamente, alumbre las causas por las que Le Corbusier pasó de la admiración al rechazo y de éste al deseo del objeto en sí.

Tenemos evidencia de la alta estima en que Le Corbusier tenía inicialmente a la E. 1027 por una carta ${ }^{11}$ fechada en abril de 1938 que dirigió a la propia Eileen Gray después de pasar unos días en la villa:

Me produce una gran alegría comunicarte lo mucho que esos pocos días pasados en vuestra casa me han hecho apreciar el espíritu particular que dicta toda la organización, interna como externa, y que da a los muebles -al equipo- una forma tan digna, tan encantadora, tan llena de espíritu. ${ }^{12}$

En el tono elogioso de la carta Le Corbusier apunta ya a algunas características que hacen de la E. 1027 una obra singular dentro de la modernidad: la integración entre el diseño interior y el exterior, así como la combinación del mobiliario y el equipamiento ${ }^{13}$ en un conjunto coherente a todas las escalas. Refiriéndose a esa misma carta Colomina añade: «En 1938, el mismo año en el que fue a pintar el mural Graffite à Cap-Martin, Le Corbusier había escrito una carta a Eileen Gray, en la que no solamente reconoce la única autoría de ella, sino también cuánto le gusta la casa». Algo que, en lo referente a la autoría, resulta bastante evidente a la vista de los interiores diseñados por Gray con anterioridad así como su propia vivienda estival realizada unos pocos años después en Castellar, a pocos kilómetros de Cap Martin, Tempe à Pailla ${ }^{14}$.

11. Citada por AdAm, Peter. Eileen Gray, Architect/designer: A Biography (Rev. Ed.). Londres, Ed. Thames and Hudson, 2000 (1987), pp. 309-310 y referida en varios textos sobre la E.1027. (La traducción al español es la que aparece en la monografía sobre la E.1027 de Carmen Espegel).

12. Esta carta, que iba acompañada por una pequeña acuarela del maestro, produjo una gran satisfacción personal en Eileen por lo que tenía de reconocimiento por parte de uno de los arquitectos de mayor prestigio y proyección internacional del momento, a quien ella había admirado. (ADAM, Peter, 1989, «Eileen Gray and Le Corbusier», Op.cit, p. 150).

13. La casa estaba equipada con una serie de instalaciones que conviene tener presentes en contexto temporal -1926-1929- en el que se proyecta y edifica la vivienda: frigorífico eléctrico, depósito de agua con filtro Pasteur-Chamberland, calefacción y, por supuesto, los entonces ya habituales de fontanería, electricidad y sanitarios, etc. (EsPegel, Carmen, Aires Modernos, Op. cit.).

14. Esa ambivalencia en la sexualidad y la relación de Gray y Badovici queda subrayada por el hecho de que el terreno en el que se edificó la segunda y última obra construida de Eileen Gray, su vivienda estival Tempe à Pailla, lo adquirió ella misma ya durante la construcción de la E.1027 (RAULT, Jasmine. «Occupying E.1027. Reconsidering Le Corbusier's «Gift» to Eileen Gray, Space and Culture, Vol. 8, 2 (May 2005), pp. 160-179). 
Así, la «casa llena de sentido arquitectónico» ${ }^{15}$, como Le Corbusier se refería a ella, pronto pasaría a ser un objeto de polémica. Cuando en 1938 Le Corbusier comenzó a pintar los murales en la vivienda la relación entre Gray y Le Corbusier se quebró. La intromisión de la mano de Le Corbusier en su diseño contó con la desaprobación de Gray desde el principio y, al parecer, no volvió a pisar la vivienda desde aquél momento. Si bien, rota su relación sentimental con Badovici desde hacía años y estando la propiedad a nombre de éste, no podía hacer nada para evitar que Le Corbusier «regalara» los murales a su propietario pintándolos, eso sí, sobre las paredes de una vivienda que no había diseñado él; una vivienda cuya construcción, para más desdicha, había financiado la propia Gray ${ }^{16}$, y cuya severa estética en clave de abstracción geométrica tenía bastante poco que ver con el figurativismo de dichos murales.

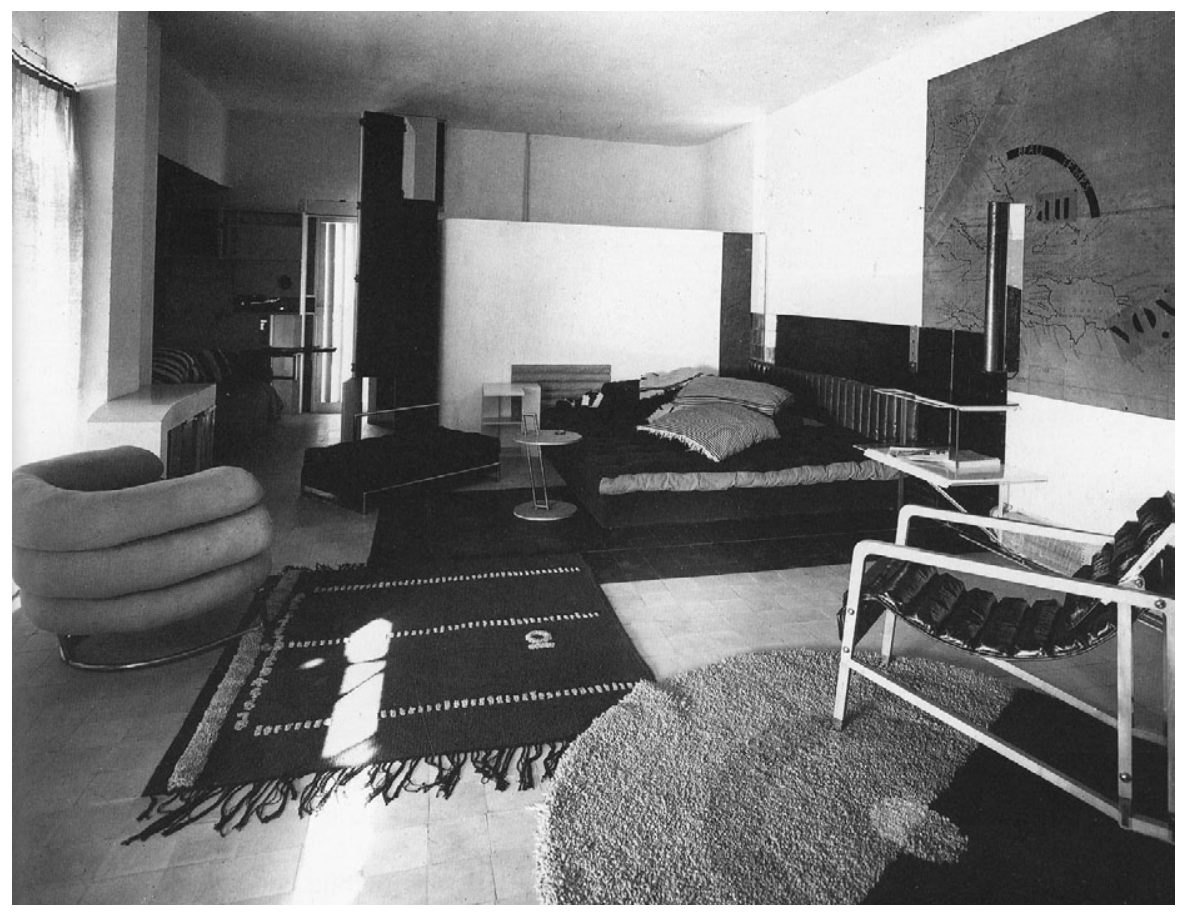

Fig. 3. Estar de la E.1027.

(foto publicada en Eileen Gray, Architect/designer: A Biography, Peter Adam)

15. AdAM, Peter, 1989, «Eileen Gray and Le Corbusier», Op. cit., p.150.

16. Tal y como lo describe Adam, «In 1956 Jean Badovici died, he had not made a will. The house, built and paid for by Eileen, was in his name.» (ADAM, Peter. Eileen Gray, Architect/designer: A Biography Op. cit., p. 152). 
Si analizamos el acto mismo de pintar los frescos sin apasionamientos, es decir el origen de la afrenta de Le Corbusier, si hay en ello un ultraje al menos tanta culpa debe atribuírsele a Badovici. En realidad, nadie pinta un fresco en una pared que no es suya dentro de un recinto privado a no ser que reciba permiso para hacerlo, o incluso sea alentado a ello; algo que parte de la historiografía reciente, quizás por sus propios prejuicios, parece olvidar. Badovici, ya contaba con un mural que el propio Le Corbusier había realizado en 1935 en su vivienda de Vézelay, como respuesta a otro mural ejecutado por Leger en la misma vivienda el año anterior. Poco después y antes de que Le Corbusier comenzara con la colonización pictórica de algunos de los muros de la E.1027, en 1937, Badovici ${ }^{17}$ escribía en estos términos sobre los trabajos murales realizados por Leger y Le Corbusier: «assembled before the courtyard wall [...] an idea ocurred to us all: THAT OF THE DESTRUCTION OF WALLS BY PAINTING, crowning, above all, the architecture to come». Sin embargo, aún pensando así sobre el papel de los frescos en los muros respecto de la obra de arquitectura, no tuvo ningún reparo en que Le Corbusier colonizara algunas de las paredes de la E.1027 con su imaginería emparentada con la estética del Picasso de la época.

La afrenta de Le Corbusier radicaba inicialmente en dos cuestiones: por un lado la más grave, consistente en la ejecución de uno de sus murales sobre un fresco de Gray en la entrada de la casa, y, por otro, en el hecho de que aún conociendo el papel de Eileen Gray en la autoría de la E.1027 no le pidiera, al menos, su parecer al respecto, como colega de profesión. Para eso tendría que haberla considerado como tal, cosa que resulta mucho suponer a tenor de su comportamiento. Así lo describe Adam ${ }^{18}$ :

Eileen had never bee asked for permission. When she found out she fell into a deep depression and rage. She considered it an act of vandalism. A fellow architect simply defaced her pure conception. After that she could never bring herself to stay in the house.

Pero la actitud un tanto ambigua de Badovici para con el oscuro objeto de deseo del maestro suizo no es únicamente un acto cobarde sino que también tiene otro tipo de motivaciones. Después de todo, Le Corbusier, por aquel entonces, no era sólo un arquitecto mundialmente reconocido; su actividad como pintor tampoco pasaba precisamente desapercibida. Los murales tendrían un valor nada desdeñable que iría incrementándose con el paso del tiempo.

17. BADOVICI, Jean, «Peinture Murale ou Peinture Spatiale.», L'Architecture d'Adjourd'hui, 8, no, 3 1937, (Cit. por Constant, Caroline, Op. cit., p. 278.).

18. AdAm, Peter. Eileen Gray, Architect/designer: A Biography, Op. cit., p. 151. 
Así, el editor y amigo de Le Corbusier no sólo consentiría que éste le regalara los frescos sino que muy probablemente lo animó a hacerlo, como bien apunta Constant ${ }^{19}$ a propósito de una carta fechada en 1941 del propio Badovici redactada poco después de un bombardeo sufrido en la zona:

As with the Vézelay murals, Badovici not only sanctioned but encouraged Le Corbusier's pictorial intervention at E.1027. His eagerness to comply with Corbusian polemics may have led Badovici to ignore the incongruities between this pictorial dissolution of the wall and Gray's more constructive integration of architecture and the decorative arts. However contrary to Gray's architectural intentions, the Roquebrune murals brought Badovici a considerable pleasure, as he recounted to Le Corbusier after surveying the limited damage his house sustained under the Italian bombardment: «Your frescoes more luminous and beautiful than ever. Intact $»^{20}$.

Así, es fácil entender que, después de todo, Le Corbusier también sintiera, en cierto sentido, menospreciado su trabajo, dado que la polémica que duraría durante el resto de sus días, estaba en bastante medida generada por el propio Badovici y él no había recibido pago alguno por unos frescos a pesar de que, sin duda, tendrían un gran valor. Desde el punto de vista de Le Corbusier, él sólo había pintado unos frescos como regalo a su editor. Esta consideración de los murales como regalo queda bien acreditada en más de una ocasión. A ello se refiere Colomina ${ }^{21}$ en estos términos:

Como todos los colonizadores, Le Corbusier no pensó en ello como invasión, sino como regalo. Es sintomático que, recapitulando el trabajo de su vida cinco años antes de morir, escriba sobre Argel y Cap-Martin en los siguientes términos: «Desde 1930, L-C dedicó doce años a un estudio ininterrumpido de Argel y su futuro. (...) Durante dichos años, preparó sin ningún coste siete grandes propuestas (siete enormes estudios)». Y más adelante escribe, «1938-1939. Ocho pinturas murales realizadas sin ningún coste en la casa de Badovici y Helen Gray en Cap-Martin». No charge for the discharge. Eileen Gray se sintió traicionada: le habían desfigurado hasta el nombre. Y renombrar es, después de todo, el primer acto de la colonización.

En efecto, Le Corbusier siempre consideró los frescos como un regalo pero, como bien sabía él mismo, en arquitectura todos los gestos adquieren significación. En el marco referencial del lugar, el espacio y el tiempo de la E.1027 su

19. Constant, Caroline, Op. cit., Ibidem..

20. BADOVICI, Jean, carta a Le Corbusier, fechada el 2 de julio de 1941, Fundación Le Corbusier (Cit. por Constant, Caroline, Op. cit., p. 278.).

21. Colomina, Beatriz. «Líneas de Batalla: E. 1027», Pasajes, $2^{\circ}$ semestre 2001, Univ. de Buenos Aires. Centro de Estudios Amancio Williams., pp. 47-55, (publicado en versión inglesa «Battle Lines: E.1027», en AGREST, Diana, ABRAMS, Harry (ed.), The Sex of Architecture, 1996, pp. 54-55). 
actividad adquiría una fuerza simbólica que, en contraste con la pureza y sencillez geométrica que animaban el diseño original, se veía incluso potenciada. Los frescos colonizaban los muros y paredes de la villa tanto como el propio Le Corbusier colonizaba y hacía en parte suya la E.1027. Es frente a esa apropiación a la que responde Gray con mayor disgusto. Pero no en menor medida por la arrogancia que demostraría Le Corbusier en lo concerniente a este asunto. Haciendo gala de su proverbial chovinismo alimentaría la polémica algún tiempo después cuando, con motivo de la edición de su Obra Completa en 1946, en las imágenes en las que aparecían los frescos de la E.1027 ni siquiera se mencionaba el nombre de Eileen Gray ${ }^{22}$. Proceder que repetiría dos años después en L'Architecture d'Aujourd'hui en un número especial dedicado a su obra. Los comentarios publicados ${ }^{23}$ un tanto despectivos hacia el valor de los muros seleccionados para ser animados con su pincel consiguieron enfurecer más aún a Gray.

En 1949, en una carta de Le Corbusier a Badovici, el primero hace una crítica bastante más explícita a propósito de la arquitectura de la E.1027, concretamente respecto del biombo que ralentiza el acceso a la gran sala de la vivienda y que actúa como límite del vestíbulo una vez en el interior de la villa: «Os aconsejo desmontar de la sala ese cacharro de contrachapado que no es más que un pseudo e ilusorio compañero del de la zona de ducha. Vuestra pieza se transformará y la entrada será totalmente distinta $»^{24}$. El límite al que se refiere, cuidadosamente diseñado como el resto de la villa, además de servir de gabanero y sombrerero crea un ámbito de privacidad añadida al entrar en el interior de la vivienda aunque la escala de la totalidad de la sala se percibe, no obstante, gracias a que dicho biombo -a caballo entre una pieza de mobiliario y un tabique bajo- no llega a tocar el techo.

Por otro lado, este elemento forma parte del ritual de entrada a la vivienda, enormemente elaborado en el diseño original, que se vincula a las propias inscripciones que Gray repartió por distintas estancias de la casa haciendo referencia explícita no tanto a su función como a la manera de utilizar cada uno de los elementos que integraban el diseño de la misma. Concretamente a la inscripción «Entrez Lentement» (entrar lentamente) que acompaña el

22. CONSTANT, Caroline, Op. cit., Ibidem.

23. «The walls chosen to receive nine large paintings were the most colourless and insignificant. In this way the beautiful walls have remained and the indifferent ones have become interesting... This villa that I animated with my paintings was very beautiful, white on the interior, and it could have managed without my talents.» LE CORBUSIER, «Unité», L'Architecture d'Adjourd'hui, 19, (número monográfico dedicado a Le Corbusier), 1948.

24. Espegel, Carmen, Heroínas del espacio, Op. Cit., n.p.p. 13, p. 128. 
elaborado rito de ingreso bajo la marquesina de entrada matizado por otra «sense interdit» (dirección prohibida); el biombo (épine-paravent) simplemente alarga dicho ritual un poco más. Al mismo tiempo, dicho biombo sirve para dividir la circulación en el interior de la sala separando el ambiente de la sala principal del pequeño comedor. Por último, en el recorrido de ingreso el biombo dirige finalmente la mirada del visitante hacia el mar que la sinuosa entrada a la vivienda se ha encargado de esconder para provocar un efecto sorpresa hacia las espléndidas vistas, una vez alcanzado el interior de la misma.

Sin embargo, de todas las consideraciones que se pueden hacer a propósito de la ocupación de la vivienda por parte de Le Corbusier relacionadas con la realización de los frescos, sin duda la más dolorosa debió ser la ejecución del fresco de la entrada sobre otro que la propia Eileen Gray había ejecutado en el mismo paramento. Aquí cobran todo el sentido las apreciaciones de Adam quien compara la ejecución de los polémicos frescos con una auténtica «violación» ${ }^{25}$. El desprecio olímpico por lo diseñado por Gray es aquí manifiesto. Siendo discutible la acción de Le Corbusier sobre las paredes neutras de la E.1027 -si es que acaso hay alguna pared que pueda serlo- mucho más lo es la ejecución de un fresco sobre otro. A este fresco de la entrada se refiere Espege ${ }^{26}$ en los siguientes términos:

Ya en el interior del zaguán surge la elección entre la puerta principal y la entrada de servicio. En su frente, la pared que oculta la escalera de caracol «gran muro desnudo aunque neto y claro, [que] sugerirá la idea de resistencia», está pintada con un fresco con motivos geométricos que incluye dos inscripciones [...] (se desconoce el trazado de dicho fresco ya que en 1939 Le Corbusier realizó otro sobre este mural, en el que únicamente mantuvo las dos inscripciones del original de Eileen Gray: Sense Interdit y Entrez Lentement).

25. AdAm, Peter, Eileen Gray, Architect/designer: A Biography, Op. cit.,p. 311. De hecho las comparaciones con la actitud de Le Corbusier con un acto de violencia sexual han producido una serie de textos algo más recientemente pretendiendo adentrarse en implicaciones psicoanalíticas que poco tienen que ver con la crítica de arquitectura y que -quizás por sus prejuicios ideológicos- caricaturizan la actitud de Le Corbusier y la polémica en torno a los frescos, perdiendo con ello la debida objetividad crítica. En ninguno de ellos se menciona el valor indiscutible de los frescos o el hecho de que fuera el propio Badovici quien consintiera e incluso alentará al propio Le Corbusier a pintarlos y, lo más llamativo, la destrucción del fresco original de carácter geométrico que Eileen Gray pintó en la entrada de la E.1027 -el acto más reprobable de todos ellos- tampoco se denuncia.

26. Espegel, Carmen, Aires modernos, Op. Cit., p. 28 y n.p.p. 4, Ibidem. El entrecomillado corresponde al texto del número monográfico de L'Architecture Vivante de otoñoinvierno de 1929, E.1027: Maison en bord de mer y el texto entre paréntesis a la nota a pie de página del texto de Carmen Espegel. 
La coherencia formal que alumbra todo el diseño de la E.1027 desde los menores detalles, pasando por el mobiliario y las artes decorativas hasta la escala de la propia arquitectura se veía drásticamente alterada ante la rotundidad formal de los frescos y su estética figurativista. Además de los diseños en alfombras, cortinas y demás elementos cuidadosamente diseñados e incluso tejidos por la propia Gray en clave inequívoca de abstracción geométrica, se ha conservado el collage que preside la pared norte de la gran sala en el que se integran elementos funcionales, el mobiliario y el propio collage en una partitura polifónica: «Affixed to the wall by a light fixture and holding shelves, this collage exemplified an important principle for Gray: the inseparability of painting and architecture -a view shared with the early adherents of De Stijl $\gg^{27}$. En efecto, a pesar de que el diseño de Gray resulta difícil de catalogar, las afinidades con la arquitectura neoplasticista parecen incluso más claras que los preceptos funcionalistas de Le Corbusier. Podemos imaginar que el fresco destruido por Le Corbusier estuviera animado de la misma estética.

Le Corbusier probablemente veía en su regalo un equivalente -salvando las distancias- de la intervención de Miguel Ángel con sus frescos en la Capilla Sixtina por los que hoy es conocida mundialmente dicha obra de arquitectura, pero es evidente que Eileen Gray no percibía la actuación de Le Corbusier en los mismos términos. Lo que sin duda empezaba a preocupar más a Le Corbusier a estas alturas de la polémica era la posible destrucción de sus frescos que -además de tener un gran valor objetivo- para él tenían un valor afectivo mucho mayor. El tema del desnudo femenino le había atraído desde al menos 1927 y como él mismo confesaría tenía una cierta predisposición a «desnudar» las figuras femeninas para comprender mejor cuál era su constitución formal ${ }^{28}$. Durante años estuvo haciendo y rehaciendo unos estudios para unos desnudos que había empezado en Argel $^{29}$. La belleza ${ }^{30}$ de

27. Constant, Caroline, Op. cit.,p. 271..

28. ZAKNIC, Ivan, «Le Corbusier Sans Fin», Journal of Architectural Education, Vol. 42, 3 (Spring 1989), pp. 49-59.

29. «Nuestras andanzas por las calles laterales nos llevaron al final del día a la calle Kataroudji, donde él [Le Corbusier] quedó fascinado por la belleza de dos jóvenes muchachas, una española y la otra argelina. Ellas nos condujeron por una escalera estrecha a su cuarto: allí dibujó algunos desnudos en -para mis sorpresa- un bloc escolar de dibujo con lápices de colores. Los bocetos de la joven española, tanto acostada sola en la cama como agrupada bellamente con la argelina, eran bellos y realistas, pero él dijo que no eran buenos y se negó a mostrarlos», Carta de Jean de Maisonseul a Samir Rafi, fechada el 5 de enero de 1968 (cit. por ColominA, Beatriz., Op. cit. p. 48).

30. Quizás no sólo fue la belleza de las dos mujeres sino algo más relacionado con algún tipo de experiencia sexual que le dejó marcado de por vida. Parece evidente que las dos 
las dos figuras obsesionó a Le Corbusier durante años quien estuvo dibujando y redibujando estudios a partir de ellas que con el tiempo acabaría uniendo a su interpretación personal del cuadro de Delacroix, Femmes d'Alger Dans leur appartement, tal y como lo recoge Colomina ${ }^{31}$ : «Pero pronto ambos proyectos se solaparon: Le Corbusier modificó los gestos de las figuras de Delacroix, haciéndolos coincidir gradualmente con las figuras de sus propios bocetos. Le Corbusier afirmó que habría llamado a esta composición final Las Femmes de la Casbah». Sin embargo, la versión final no llegó a ver la luz hasta que, según Colomina, Le Corbusier realizara uno de los murales en la E.1027, el conocido como Sous les pilotis o Graffite à Cap-Martin ${ }^{32}$ a partir de dichos bocetos. La reelaboración a lo largo de años de esos dibujos da buena cuenta
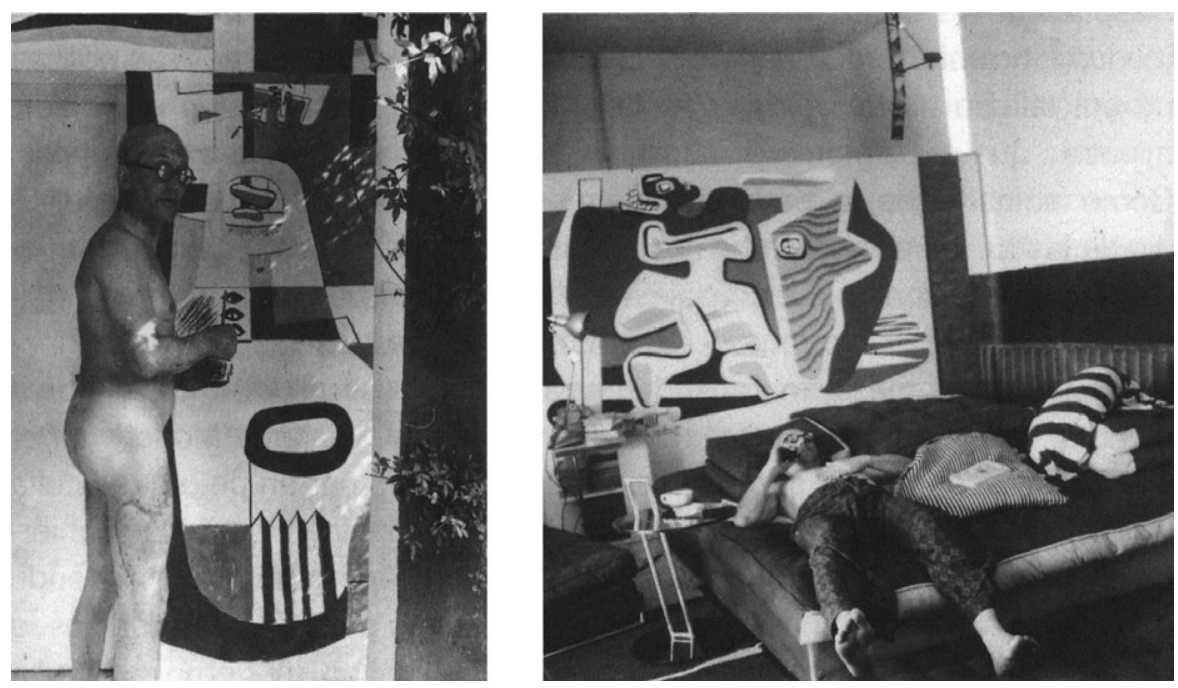

Figs. 4 y 4 bis. Dos murales de Le Corbusier en la E.1027.

(fotos publicadas en Aires modernos, Carmen Espegel)

mujeres desconocidas debieron ofrecer algo más que posar desnudas para Le Corbusier y Maisoneul si se observan las poses -algunas de ellas abiertamente sexuales- de los dibujos de Le Corbusier (Ver el catálogo Le Corbusier Secret de la Ahrenberg Collection), aunque la discreción del relato sea parca al respecto.

31. Colomina, Beatriz. «Líneas de Batalla: E. 1027», Op. cit. p. 49.

32. Respecto de este mural pintado en el exterior en la terraza cubierta bajo la gran sala de la vivienda al que también se refería su autor como Trois Femmes, según el testimonio de Mme. Schelbert, Le Corbusier «explicó a sus amigos que 'Badou' [Badovici] estaba representado a la derecha, su amiga Eileen Gray a la izquierda, y el contorno de la cabeza y el pelo de la figura sentada en el centro, decía, era 'el hijo deseado y nunca nacido'» cit. por ColominA, Beatriz. Op. cit. Ibidem. 
del valor afectivo y la importancia que Le Corbusier atribuía a los frescos de la E.1027 como parte de esa larga investigación pictórica sobre la que llevaba años trabajando.

Por otro lado, si se observa el contenido geometrismo del diseño de Gray es evidente que, desde un punto de vista exclusivamente estético, el figurativismo -aun siendo de carácter abstractivo-, el tratamiento cromático y la potencia formal de los frescos poco o nada tienen que ver con la pureza y sencillez formal de la E.1027. El propio Badovici llegaría a amenazar a Le Corbusier con destruirlos para restaurar el sentido del diseño original alterado por la intervención del maestro suizo. La correspondencia de la época entre Badovici y Le Corbusier demuestra cómo sus relaciones se habían deteriorado notablemente a propósito de los polémicos frescos. Como ha apuntado Caroline Constant en su magnífico artículo, ya le había costado bastante conseguir fotos de los mismos para su publicación, que Badovici le facilitó más bien a regañadientes cuidando de recortar las imágenes para evitar que mostraran su contexto en el espacio arquitectónico. Le Corbusier volvió a pedirle a Badovici más fotografías de los frescos que también incluyeran el contexto espacial de la vivienda, fotos que no acababan de llegar. Una ansiedad creciente a la vista del cariz que debieron tomar los acontecimientos -quizás ante la sospecha de que los murales que tanto apreciaba su autor fueran finalmente eliminados para restaurar el diseño original de la vivienda- fue apoderándose de Le Corbusier. Ante las presiones de Gray para que Badovici conminara a Le Corbusier a deshacer lo hecho, finalmente Badovici escribió en una carta fechada el 30 de diciembre de $1949^{33}$ que el biógrafo de Eileen Gray, Peter Adam, sugiere que pudo dictar ella misma:

What a narrow prison you have built for me over a number of years, particularly this year through your vanity. On the contrary, my attitude toward you has been nothing but joyful and full of happy trust -seven volumes of the heroic era of LArchitecture Vivante. My hut [baraque] served [you] as a testing ground by sacrificing the profound direction of an attitude that formally banished painting. As purely functional architecture, that was its strength for such a long time: 1925. And you have denied its absolute character with such harshness in your writings, disseminating them through your world-wide authority. You lack of generosity toward me. A correction from you seems necessary, if not, I will be forced to do it myself, thus to re-establish the original spirit of the house by the sea.

La contestación a la carta de Badovici no se hizo esperar, iestá fechada al día siguiente! Además de la ironía malintencionada con la que contestaba a

33. Cit. por Constant, Caroline, Op. cit., pp. 278-279. 
las insinuaciones de Badovici ${ }^{34}$ era bastante consciente de que, como sugiere Adam, la carta debió ser idea de Gray porque, además, Le Corbusier amenazaba con hacer público el debate en el plano de la arquitectura con un comportamiento arrogante e impropio de su condición, incluyendo también en ella la vivienda que Gray se había construido para sí en Castellar, Tempe à Pailla, sin ninguna colaboración de Badovici, por lo que resulta inequívoca la estructura profunda del mensaje así como el destinatario real de su contenido:

Quieres un juicio mío basado en mi autoridad mundial para mostrar -si entiendo correctamente tus pensamientos más íntimos-, para demostrar 'la calidad de la arquitectura pura y funcional' que has puesto de manifiesto en la casa de Cap-Martin y que ha sido destruida por mis intervenciones pictóricas. OK, envíame algunos documentos fotográficos de esa manipulación de puro funcionalismo... Envíame también algunos documentos de [la casa de] Castellar, ese submarino del funcionalismo; entonces yo expondré a la luz de todo el mundo este debate.

Todo lo anterior ha tratado de contextualizar la polémica con el nivel de detalle suficiente como para entender los hechos y las motivaciones que se triangulan en torno a los tres arquitectos. Sorprendentemente, la ocupación de Le Corbusier no fue únicamente pictórica. Incluyó también varios episodios de manipulación e intervenciones en el plano arquitectónico que quizás resulten tan interesantes como reveladoras a propósito de la fijación que vinculó fatalmente a Le Corbusier con la E.1027 y con el privilegiado lugar en el que se asentaba. Sobre todo si se comparan con la elegancia de la Maison en bord de mer.

La primera intervención arquitectónica que Le Corbusier planeó en las inmediaciones de la E.1027 data precisamente de 1949 -el año de la ruptura-; sus primeros croquis para Robert Rebutato son de septiembre de ese año. Se trata de dos propuestas para colonizar la ladera de la montaña que baja hacia el mar con unas agrupaciones modulares de viviendas diseñadas a partir de la métrica del modulor a las que denominó Rob y Roq. Su justificación para promover agrupaciones de viviendas incluso en ese entorno tan especial se debía, como explicaría él mismo, a su intención de evitar la proliferación de las «ineficientes viviendas unifamiliares» ${ }^{35}$. A diferencia de la sabia ocupación del lugar que caracteriza a la E.1027 sutilmente girada respecto de los bancales

34. «Perhaps I misunderstand the underlying sense of your thoughts, as, even though you have lived in Paris for thirty years, you have not yet been able to make others comprehend your writing» LE CORBUSIER, carta a Badovici fechada el 1 de enero de 1950. Fundación Le Corbusier. (El fragmento en español está extraído del texto de Colomina, Beatriz., Op.cit., p. 51).

35. ZAKNIC, Ivan, op. cit., p. 56.

Feminismo/s 17, junio 2011, pp. 259-295 
existentes para optimizar la orientación y que «utiliza las terrazas-bancadas como parte integrante de la arquitectura de la casa aunque no se mimetiza con ellas ni en construcción, material o geometría ${ }^{36}$, en los proyectos de Rob y Roq los módulos se disponen linealmente en perpendicular a la línea de máxima pendiente del terreno. A causa de ello, el desnivel se maximiza debiendo recurrir a la solución inelegante de los pilotis de altura variable en contacto con el terreno bajo el primer forjado, además de acomodarse mucho peor a la orografía abrupta del lugar. La imagen más característica del proyecto se debe al motivo recurrente en la obra de Le Corbusier de las bóvedas a la catalana que aparece ya en algunas de sus primeras propuestas como las casas Monol de 1919 pero, sobre todo, entroncaba con su reciente mirada hacia la arquitectura vernácula como en su proyecto para una explotación agrícola en Cherchell (norte de África) de 1942, su proyecto en Sainte-Baume en los terrenos de su amigo Edouard Trouin ya en 1948 o las Maisons Jaoul terminadas en 1955 en Paris. Frampton se refiere al abandono de la estética moderna y a la sintaxis basada en la lógica del hormigón armado en sus proyectos posteriores a la segunda guerra mundial como una búsqueda de vincular su obra con la arquitectura vernacular:

Sin embargo, la 'a-racionalidad' de Le Corbusier iba más allá de la aplicación anacrónica, aunque expeditiva, de la bóveda a la catalana o la fábrica de ladrillo vista y el hormigón aplicado directamente en el encofrado de madera [...] La ventana arquetípica ya no era la fenêtre en longueur a través de la cual se miraba, sino una inserción enmarcada y con paneles a la que se miraba.

La solución constructiva de la cubierta a la catalana proyectada para las propuestas de Rob y Roq de Le Corbusier en Cap-Martin contrasta con la delicada cubierta plana de hormigón con vigas de canto invertidas y la doble piel diseñada por Gray y Badovici ${ }^{37}$ : «El forjado superior se ha construido con vigas invertidas, se ha podido colocar por encima un segundo forjado ligero de material cerámico con huecos que [...] constituyen un aislamiento perfecto para todas las temperies». Por otro lado, la sinceridad constructiva brutalista que caracterizaba la arquitectura de Le Corbusier en la posguerra con las huellas de los encofrados en el hormigón ya era anticipada en la E.1027 de 1926: «Esta disposición permite eliminar la escayola demasiado frágil para el techo

36. EsPegel, Carmen, Aires Modernos, Op. cit., p. 78.

37. GraY, Eileen, BADOviCI, Jean. «De l'Eclecticisme au doute». Londres, Da Capo Press, inc. \& Trewin Copplestone Publishing Ltd., vol. 1928-1929, 1975, y planchas pp.1738 y pp. 27-59, reproducción correspondientes a la monografía E.1027: Maison en bord de mer publicada en L'Architecture Vivante, número Otoño-invierno, (1929), Ed. Albert Morance, Paris. 
[que] está constituido por el forjado en bruto del desencofrado». ${ }^{38}$ Por otro lado, la disposición en paralelo hacia las vistas de la E.1027 y su apropiación del horizonte a través de la gran cristalera del salón que se abre a la terraza contrasta con la disposición en perpendicular y el encasillamiento de las vistas de la propuesta de Le Corbusier, si bien es cierto que ésta trata de maximizar el número de viviendas y por ello se adosan entre sí. El sintagma de la fenêtre en longueur es reelaborado con enorme soltura en la E.1027: una fachada de múltiples membranas en las que la horizontalidad queda enfatizada por el sistema de toldos que avanzan al primer plano de la fachada -a plomo con la barandilla- recortando el hueco rasgado horizontalmente cuando están desplegados, enmarcando con dicho gesto, la gran cristalera de la fachada sur que recorre la mayor parte de la fachada sur de suelo a techo.

Sin embargo, las propuestas de 1949 de Le Corbusier para Cap-Martin no pasarían de la fase de proyecto. Tuvo que esperar unos pocos años más hasta conseguir edificar algo allí, el cabanon, según él un regalo de cumpleaños para su mujer: su «pequeño castillo» en la Costa Azul como a él gustaba referirse con cierta dosis de ironía y ascetismo al mismo tiempo. Se trataba de una extraña cabaña de madera adosada a una pequeña tasca que regentaba RobertRebutato quien cedió el terreno a Le Corbusier, casualmente colindante ladera arriba con la parcela de la E.1027; algo que considerando los antecedentes no se puede pasar por alto. La elección del lugar no puede ser inocente, ¿por qué precisamente a escasos 20 metros de la E.1027? ¿no había ninguna otra parcela en todo el paraje? La primera decisión de proyecto para la Maison en bord de mer había sido precisamente la elección de un lugar que además de un espléndido paisaje tuviera el requisito de extraordinario aislamiento ${ }^{39}$, un lugar escogido por Gray "por ser inaccesible e invisible desde los alrededores» como recuerda Peter Adam. Colomina describe la actitud invasiva de la decisión en los siguientes términos: «Al imponer su visión desde arriba, estableció su dominio sobre el lugar de la casa de Gray. El cabanon no era más que una plataforma de observación, una especie de caseta de perro guardián $»^{40}$.

38. Gray, Eileen, BAdOvici, Jean., «De l'Eclecticisme au doute», Op. Cit., Ibidem.

39. A pesar de que Gray condujese coche (e incluso fuese una de las pioneras en pilotar aeroplanos ya desde 1913), la elección del lugar incluía la inaccesibilidad con el coche; como señala Espegel (Aires Modernos, op. cit., p.86) «La vivienda es una máquina separada del mundo a través de una cierta distancia que debe recorrerse a pie». Si a eso añadimos que tampoco se incluye el teléfono a pesar de que la vivienda disfruta de las instalaciones domésticas más avanzadas de la época la intención de aislamiento es definitiva.

40. Colomina, Beatriz, Op. cit. p. 50. [la cursiva es mía]. 
Es bien sabido que una de las formas recurrentes de los conquistadores para simbolizar su conquista ha sido apropiarse de sus lugares sagrados e imponer su propio símbolo de credo sobre ellos. Ejemplos a lo largo de la historia podemos encontrarlos en todas las culturas y civilizaciones; acaso uno de los más notables lo encontremos en la Mezquita-Catedral de Córdoba por lo que tiene de simbólico y de doble profanación. Sobre la catedral de San Vicente de la época visigótica -de la que no se deja nada- mandó Abderrahman I construir la mezquita que fue sucesivamente ampliada. A su vez, sobre parte de la mezquita se erige la actual catedral en distintas etapas desde la reconquista de Córdoba hasta el siglo XVI, constituyendo el símbolo arquitectónico más claro de la Reconquista ${ }^{41}$.

Si además de considerar el cabanon pensamos que a escasos metros Le Corbusier terminaría edificando las Unité de Camping en 1957 la elección del lugar no puede ser casual. La posición dominante ladera abajo sobre el diseño de Gray queda enfatizada por la importancia que otorgaba a los huecos hacia las vistas desde cabanon que en sus primeros bosquejos aparecen figuras erguidas mirando hacia el exterior, algunas de ellas con prismáticos ${ }^{42}$. La provocación añadida que suponía la elección del lugar y su proximidad a la E.1027 no pasó inadvertida para Gray; como apunta Adam: «Eileen always deeply resented this further intrusion. She pretended not to understand what he had contended with this simple attractive modular house. She called it 'that awful shack'». Es evidente que el conjunto de intervenciones proyectadas o ejecutadas por Le Corbusier en Cap-Martin evidencian una actitud de apropiación o colonización del lugar intentando crear un marco corbusierano ${ }^{43}$ aunque el conjunto no resulte precisamente armonioso. La profanación del rincón de aislamiento de la E.1027 parece evidente, sin embargo ¿qué credo arquitectónico trataba de imponer el cabanon? Desde luego, no el canon de modernidad

41. La famosa frase atribuida a Carlos V a su visita a Córdoba «Habéis destruido lo que era único en el mundo, y habéis puesto en su lugar lo que se puede ver en todas partes» subraya la brutalidad de la intervención pero conviene recordar que la actual catedral ocupa en planta una parte menor que el resto de la mezquita. De la primera catedral de San Vicente, en cambio, parece ser que de lo único de lo que sirvió fue de material de construcción para la propia mezquita. Dos sensibilidades bien distintas, desde luego.

42. RAUlt, Jasmine, Op. cit., p. 162.

43. Espegel apunta refiriéndose a ello : «Este edificio [Unité de Camping] fue proyectado por Le Corbusier en 1957 en una propiedad de Robert Rebutato, que le había cedido otra pequeña parcela donde construyó el Cabanon. El estrecho y largo edificio del camping, de dos plantas construidas sobre pilotis, no sólo ha destruido el aislamiento visual de la E.1027 sino que ha creado, junto con el Cabanon, un marco corbusierano. Las pinturas murales con que el maestro suizo tatuó los muros de la E.1027 causan el mismo efecto.» (EsPEgEL, Carmen. Aires Modernos, Op. cit., p.25) 
que Le Corbusier había capitaneado: el cabanon era la negación de la modernidad, poco más que un prototipo industrializado disfrazado de log cabin, otra incoherencia más.

¿Cuál es, pues, el verdadero significado del cabanon?, ¿cómo quería que se interpretara Le Corbusier? En la actitud propagandística característica de los escritos de Le Corbusier el suizo se refería a la claridad proyectual que emanaba de su sistema modular generado a partir de la antropometría idealizada en el modulor. En el texto ${ }^{44}$ del nuevo sistema escribía:

El 30 de diciembre de 1951, en la esquina de una mesa de un pequeño chiringuito de la Costa Azul, dibujé, para regalárselo a mi mujer con motivo de su cumpleaños, los planos de una cabañita que al año siguiente construí sobre un peñasco batido por las olas. Estos planos (los míos) fueron hechos en 3/4 de hora. Son definitivos; nada fue cambiado; la cabañita fue realizada con una puesta en limpio de aquel dibujo. Gracias a El Modulor, la seguridad en el caminar fue total.

Sin embargo, la realidad no se ajustaba al relato interesado del texto. Puede que, en efecto la concepción inicial de la cabaña hubiera sido diseñada por Le Corbusier en los tres cuartos de hora a los que se refería (la verdad es que el proyecto tampoco tiene gran cosa), pero el desarrollo del proyecto mantuvo ocupadas hasta a cinco personas durante varios meses. Entre ellos estaban Jean Prouvé y Charles Barberis, dos pioneros del diseño industrial. Blanc ${ }^{45}$ sugiere que la idea original de Le Corbusier consistía en desarrollar 'un prototipo para su futura repetición en serie', una especie de unidad mínima de habitación prefabricada. El exterior basto y rudo apenas si llegaba a la estética de una cabaña realizada con troncos; el interior, en cambio, estaba tratado con esmero, cuidadosamente diseñado con contrachapados de madera y un cierto aire de sofisticación. Sin embargo, esta contradicción entre interior y exterior no parece evidenciar la predicada sinceridad constructiva. Tampoco el aspecto desaliñado y aparentemente rústico del exterior obedece a ese espíritu de sinceridad constructiva que el mito de la cabaña de Laugier -con el que a veces se ha asociado- parecía sugerir. La cabaña del abad, con los arquetipos estructurales de correa y pie derecho, había servido de justificación para la gramática de esqueleto y piel que Le Corbusier tanto había contribuido a definir. Blanc añade ${ }^{46}$ :

\footnotetext{
44. Le Corbusier, Le Modulor 2. Paris, Editions L'Architecture d'Aujourd'hui, 1950, p. 154. (Cit. por BlanC, Philippe. «Cabanon:Roquebrune-Cap-Martin, Francia», ARQ, 66, Agosto 2007, Universidad Católica de Chile, Chile, pp. 88-93).
}

45. BlanC, Philippe, 2007, op. cit., p. 88.

46. Blanc, Philippe, 2007, op. cit., p. 89. 
El Cabanon, en contraste con lo que su aspecto indica, fue completamente prefabricado y minuciosamente supervisado por el arquitecto. Su fabricación se realizó en los talleres de Barberis en Ajaccio, en Córcega. Fue transportado en piezas por vía marítima desde Ajaccio y luego por tren hasta la estación de Cap-Martin. Rebutato se encargó del transporte de las piezas hasta el terreno de La Estrella de Mar.

El cabanon no se puede entender más que como patología. Nada de lo que hay en él responde a los cánones del dictado corbusierano. De los cinco puntos de la arquitectura no queda ni tan siquiera el rescoldo; hasta el proverbial desmembramiento en esqueleto y piel se ve traicionado al utilizar los troncos de madera ${ }^{47}$ como cerramiento y estructura portante de forma indiferenciada. Pero si lo analizamos en clave de su variada producción coetánea -la Unité d'Habitation en Marsella, la casa del Doctor Curruchet en Río de la Plata, la Villa Shodhan en Ahmedabad o incluso su polémica Capilla de Ronchampresulta completamente inaudito ${ }^{48}$ :

What impulses came together in this 'final dwelling'? Noble savage? Walden Pond? Mount Athos Monk? Was this cabin a solution to the frugal Simplicity, the perfect «communality discipline' of the monastic life that had so attracted him ever since his first visit to the Carthusian monastery outside Florence in $1907 ?$

Intentar atribuir al cabanon una nobleza arquitectónica de la que carece emparentándolo con Thoreau, Rosseau o con la vida monástica de los ortodoxos del Monte Athos no resulta razonable y desde un punto de vista crítico es insostenible.

Pretender que las reducidas dimensiones puedan mermar la calidad arquitectónica no es un argumento válido; espacios de dimensiones similares han conseguido una calidad incomparable (ver por ejemplo lo que consigue Sou Fujimoto en $15 \mathrm{~m}^{2}$ con su Wood House, en Kumamura; refugio mínimo construido sinceramente en madera).

Por otro lado, analizada fríamente la cabaña de Le Corbusier tiene demasiadas imperfecciones (Figs. 5 y 6): la extraña conexión con la tasca de Rebutato, la angostura del vestíbulo con esa puerta, su alineación con respecto al paso a la zona «vividera» (es mucho decir) que se inmiscuye en la privacidad puesto que visualmente se conecta con la zona de dormir, la ausencia de una puerta que independizara el vestíbulo de la zona vividera, el espacio para el

47. Hubo una fase durante el desarrollo del proyecto en la que el cerramiento proyectado estaba acabado con chapa de aluminio pero finalmente se adoptó el tratamiento con troncos de madera (ZAKNIC, Ivan, op. cit., p. 57).

48. ZAKNIC, Ivan, op. cit., Ibidem. 


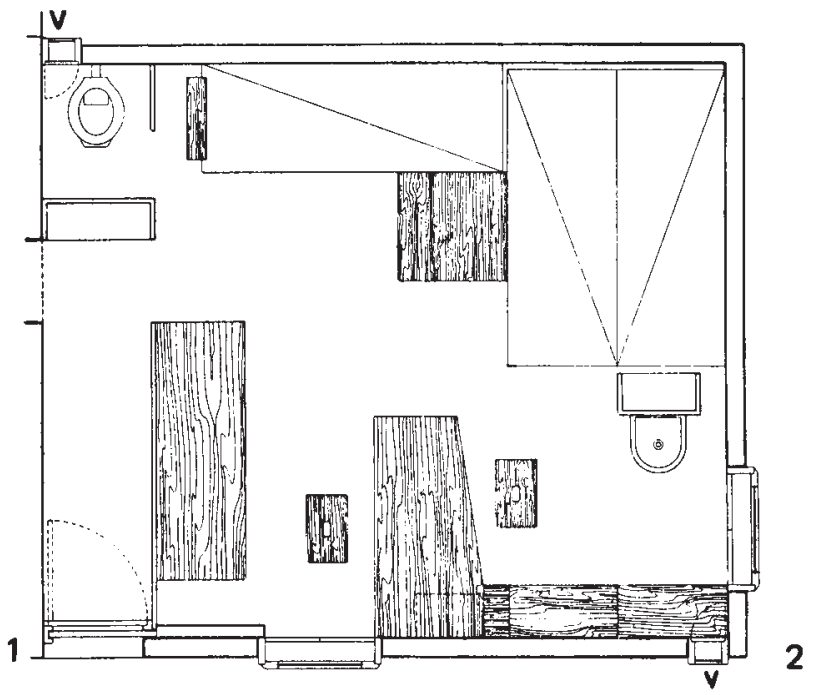

Fig. 5. Planta del Cabanon de Le Corbusier. (plano publicado en Le Corbusier, Willy Boesiger)

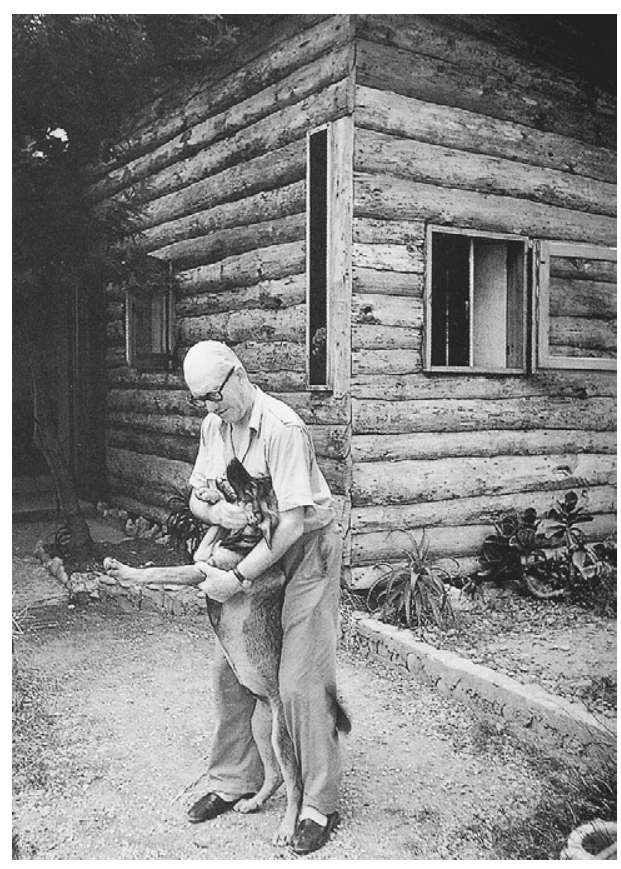

Fig. 6. Le Corbusier frente a su Cabanon.

(foto publicada en «Cabanon: Roquebrune-Cap-Martin, Francia», Philippe Blanc) 
inodoro cuyas dimensiones estrictas son innecesarias, por no mencionar las cuestiones de ventilación y el hecho de que dé directamente al espacio vividero habiendo como hay un vestíbulo al que podría conectarse para evitar dicha relación, la proximidad de la cama al aseo -con el cabecero cerca-, la ausencia de ducha, la falta de coherencia en el tratamiento de los materiales al exterior -la piel de troncos, el remate de la cubierta con chapa ondulada y el cuidado tratamiento interior con contrachapados de madera-, etc.

Todo lo que rodea a las intervenciones de Le Corbusier en Cap-Martin parece inexplicable. La referencia al vernáculo de una historia de arquitectura popular que había alimentado buena parte de su actividad durante los años 40 tampoco es sostenible, ¿a qué arquitectura vernacular se refiere el cabanon? ¿a las casas de madera escandinavas o a las $\log$ cabin de los colonos norteamericanos?; desde luego no al vernáculo mediterráneo, otro desprecio más hacia el lugar. El fingido aislamiento monacal en el que Le Corbusier se recluye miserablemente (y con él recluye a su mujer, Yvonne) en su «mon château» supone otra contradictio in terminis con su adosamiento parasitario a la tasca de Rebutato que únicamente suple la ausencia de cocina en su refugio mínimo pero no autosuficiente. Lo cierto es que Le Corbusier tras la muerte de su mujer y desde que la E.1027 estuvo en «manos amigas» pasaba allí temporadas enteras hasta su muerte: debía estar mejor en su interior que en su château. En todo caso, aún pudiendo justificar por la benignidad de la climatología estival que el mirador natural en el exterior fuera la verdadera «arquitectura» vividera y no proyectada del cabanon, relegando éste a un mero interior a modo de refugio mínimo, tampoco su tratamiento al exterior o la ausencia de algún lugar sotechado como protección frente al fuerte sol veraniego justifican la solución adoptada.

El contraste del cabanon con la sutileza de la E.1027 no puede ser mayor; tiene cierta lógica pensar que una influyó en el otro y quizás, de forma inconsciente, Le Corbusier estuviera respondiendo a muchas de las cuestiones planteadas por el diseño de Gray, un diseño que era sutilmente crítico con los preceptos del canon corbusierano de los años 20. El nombre de la Unité de Camping construida por Le Corbusier en 1957 junto a la cabaña ies una referencia al 'le style camping' de Gray o una denominación confusa? El objetivo declarado por Gray de maximizar el confort en un espacio mínimo ${ }^{49}$ ¿es también cuestionado por las reducidas dimensiones de su cabanon? No hemos querido comparar la arquitectura de la E.1027 y el cabanon porque

49. Gray escribía después a propósito de la E.1027 «House envisaged from a social point of view: minimum of space, maximum comfort» Gray archive, Victoria and Albert Museum, London (cit. por Constant, Caroline. Op. cit., p.269). 


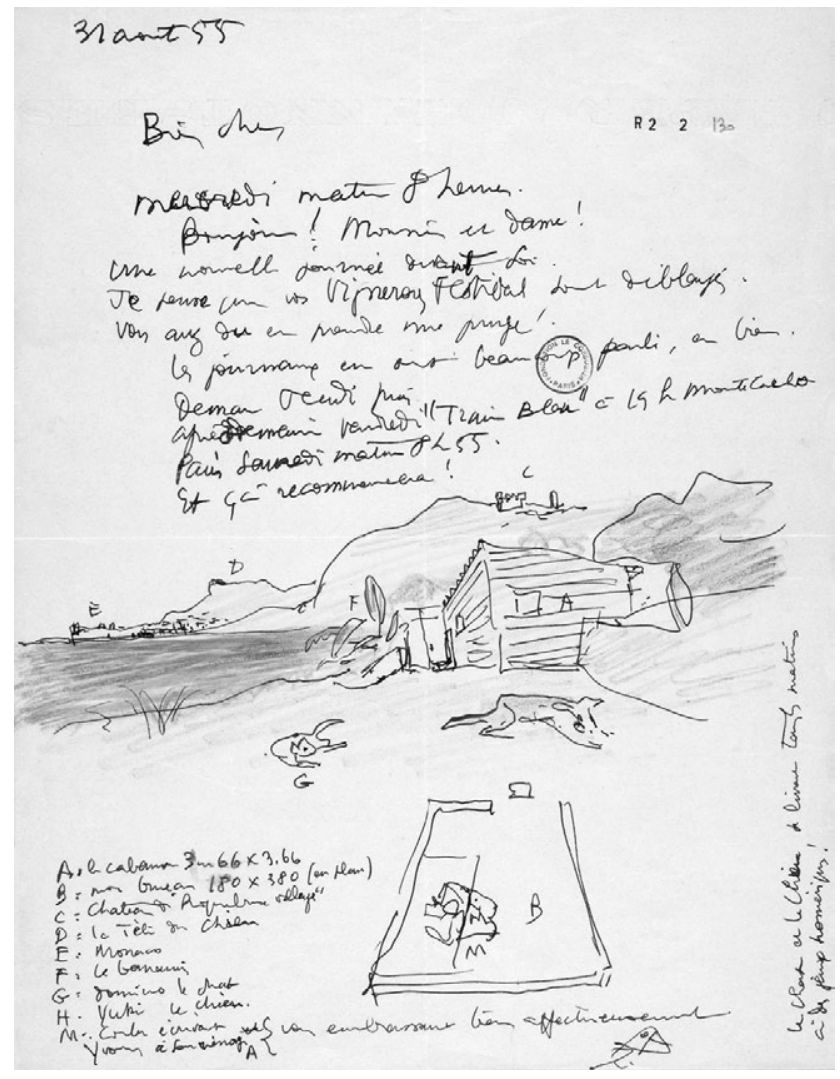

Fig. 7. Carta de Le Corbusier a su hermano 31 de agosto de 1955. (publicada en «Cabanon: Roquebrune-Cap-Martin, Francia», Philippe Blanc)

sencillamente son planteamientos y escalas que resultan incomparables. Obviar su conexión, por otro lado, aunque sea en el nivel del subconsciente, parece aventurado. Quizás la mala conciencia de Le Corbusier pueda explicar cómo quiso negar permanentemente una presencia tan obvia como la de la E.1027 a escasos 20 metros de su cabanon. Incluso en un dibujo que hace en una carta ${ }^{50}$ dirigida a su hermano aparece la cabaña ligeramente esbozada en el entorno donde se apuntan todas las referencias más claras en el lugar (el mar, Montecarlo, el Castillo de Roquebrune, la «cara de perro»-una cima montañosa que se divisa en la lejanía-); se incluyen incluso una platanera, su

50. LE CORBUSIER, Carta dirigida a su hermano fechada el 31 de agosto de 1955 (ver BLANC, Philippe, 2007, op. cit., p. 93). 
gato, su perro, y hasta la planta de su barraca de trabajo ${ }^{51}$ en la que se retrata a sí mismo dibujando. A pesar de lo descriptivo del dibujo y de las anotaciones con letras del alfabeto que apoyan la narración de lo dibujado con la correspondiente leyenda, se omite la E.1027, que debería aparecer en la visual hacia Montecarlo.

Respecto de las manipulaciones a las que nos referíamos antes son variadas y algunas de ellas contaron con la colaboración necesaria de la historiografía de la modernidad que, en buena medida, había estado alineada con los postulados de Le Corbusier durante años ${ }^{52}$. No nos detendremos demasiado en ellas pues resultan de mayor interés sus intervenciones arquitectónicas en contraste con la E.1027. La manipulación comienza desde el momento de la publicación de los murales de Le Corbusier en 1946 y 1948 en la que, como ya hemos tenido ocasión de comentar, no se hacía referencia alguna al nombre de Eileen Gray como autora de la villa. En la revista Interiors en el número correspondiente a junio de 1948 en la que se publica un artículo con el título «Le Corbusier, muralist» en los pies de foto de los murales se leía: «Murales, interiores y exteriores, ejecutados en técnica de grafito sobre yeso blanco, en una casa diseñada por Le Corbusier y P. Jeanneret, Cap. Martin, 1938 ${ }^{53}$. Parece poco probable que fuera Badovici quien facilitara las fotografías después de la polémica que tanta amargura le había producido, por lo que ¿quién si no Le Corbusier facilitó a la publicación las fotos de los murales? ¿Fue acaso ajeno a la manipulación -por omisión- sobre la autoría? Durante años la crítica atribuyó en exclusiva a Badovici la autoría de la casa, a pesar de que en la primera publicación de la misma en L'Architecture Vivante en el número monográfico de otoño-invierno de 1929 dedicado a la E.1027: Maison en bord de mer, quedaba clara la coautoría de la misma. Todavía en 1981 en la revista Casa Vogue, en el no. 119 se lee: «Firmatta Eileen Gray y Le Corbusier» y se atribuye la autoría de un sofá diseñado por Gray al propio Le Corbusier ${ }^{54}$. Sta-

51. Un cobertizo aparentemente prefabricado que hizo colocar tiempo después a unos metros de su refugio mínimo para poder trabajar que contribuía aún más a degradar el preciado lugar. Otra incoherencia más de su actividad en Cap Martin: la mayor parte del cabanon está destinado a lugar de trabajo sin embargo Le Corbusier tuvo que añadir la segunda caseta para poder trabajar. Incluso el cobertizo para los útiles de jardinería proyectado en chapa por Gray en su E.1027 es más digno y más sincero constructivamente que el cabanon, no pretende ser nada distinto de lo que realmente es.

52. TOURnikiotis, Panayotis. La historiografía de la arquitectura moderna. Madrid. Ed. Mairea/Celeste, 2001. (Tit. Orig. The Historiography of modern Architecture, Massachusetts Institute of Technology, 1999)

53. Colomina, Beatriz, op. cit. p. 50.

54. Colomina, Beatriz, op. cit. Ibidem. 
nislaus von Moos pensaba que Le Corbusier había tomado parte activa en el diseño de la villa ${ }^{55}$ sobre la que había escrito a propósito de los murales ¡cómo no $!^{56}$. Por otro lado, en muchas de las historiografías la vivienda o no aparece o ni siquiera se nombra a Eileen Gray como es fácil de comprobar; tal vez la sombra de Le Corbusier sobre la arquitectura de papel fuera tan alargada como la proyección pública de su propia arquitectura.

Las manipulaciones continuaron sobre el objeto de deseo fuera de los textos especializados en el ámbito material años después cuando, tras la muerte intestada de Jean Badovici, la propiedad pasó a manos de una hermana monja que vivía en Rumanía que no tenía interés en la villa ${ }^{57}$. Le Corbusier vio entonces la posibilidad de adquirir la vivienda o de conseguir que algún amigo se hiciera con ella, probablemente con objeto de salvaguardar sus preciados frescos como sugiere Constant ${ }^{58}$ :

Between 1958 and 1960 Le Corbusier actively sought «to find a solution for the purchase of the Badovici house» by soliciting potential buyers from Switzerland, explaining to Willy Boesiger that «some have thought of making a museum out of the house». His concern was clearly for the murals and their preservation rather than the fate of the house itself. In 1960 he contacted Madame Schelbert, sending her photographs, and that summer she purchased the villa.

Parece necesario subrayar cómo Le Corbusier sugiere a Willy Boesiger -conocido estudioso de su obra con quien tenía trato- que la E.1027 podría convertirse en museo, para contemplar sus murales claro está. Finalmente con la adquisición de la vivienda por parte de su amiga, Madame Schelbert, quien se haría finalmente con la propiedad. Pero conviene recordar cómo lo consiguió. Adam $^{59}$ se refiere al relato de la propia Schelbert en los siguientes términos:

Según testimonio de Mme. Schelbert, amiga próxima a Le Corbusier, cuando la casa salió a subasta pública en Menton cuatro personajes pujaron por ella, tres de los cuales eran: un enviado del Banco de Francia, Aristóteles Onassis y la propia Mme. Schelbert, que finalmente resultó la compradora. La cifra más alta la ofreció Onassis pero Le Corbusier, que había permanecido en la

55. EsPegel, Carmen, 2006, Op. Cit., p. 126.

56. Von Moos, Stanislaus. «Le Corbusier as a Painter», Oppositions, 19/20 (1980), p. 106. (cit. por EsPEgel, Carmen. Heroinas del espacio, Op. cit., p.126).

57. Aparentemente durante la dictadura comunista entonces en el poder, los ciudadanos rumanos no podían poseer propiedades en el extranjero y el dinero de la subasta fue recibido por un enviado del gobierno rumano <http://purecontemporary.blogs.com/ behind_the_curtains/2007/10/eileen-gray-1st.html>, consultado el 08-03-2011.

58. CONSTANT, Caroline, Op. cit., p. 279.

59. AdAm, Peter, Eileen Gray, Architect/designer: A Biography, Op. cit., pp. 359. (cit. por ESPEgEL, Carmen, Aires Modernos, op. cit, p. 8). 
sombra durante las negociaciones, desapareció un momento con el comisario $\mathrm{y}$, cinco minutos más tarde, la casa fue vendida a su amiga.

Le Corbusier había conseguido finalmente preservar sus murales con la adquisición de la casa por parte de Mme. Schelbert. Un dato más a propósito de la pugna entre Gray y Le Corbusier, incluso años después a propósito de la E.1027 lo apunta Adam ${ }^{60}$ indicando cómo se le prohibió expresamente a Eileen Gray que recogiera cualquier pieza de mobiliario, considerando que el mobiliario formaba parte integrante de la vivienda aunque, tiempo después, Le Corbusier le ofrecería dinero a Gray -hemos de suponer que a modo de compensación- que ella renunció aceptar. Pero ¿por qué le ofrecía dinero Le Corbusier a Gray si era Mme. Schelbert la que había adquirido en la subasta la vivienda con todos sus enseres? Quizás la respuesta pueda deberse al hecho de que durante sus últimos años de vida, Le Corbusier pasaba temporadas enteras en la E.1027 -gracias a la generosidad de su amiga también debemos suponer- y a finales del mismo año en que se subastó solicitó permiso a su nueva dueña para retocar sus murales, cosa que hizo. Adam ${ }^{61}$ también ha apuntado un detalle revelador a propósito de la manipulación de Le Corbusier: «For many years Mme. Schelbert thought that the house and the furniture were designed by Le Corbusier, and he never seemed to have corrected her impression», añadiendo otro dato relevante a propósito de lo que, enfrentamientos aparte, realmente pensaba Le Corbusier a propósito del diseño integral de la E.1027 entre arquitectura, interiorismo y mobiliario: «Mme. Schelbert had looked after the furniture. She always remembered Le Corbusier's dictum 'They are very special and rare'».

Parece evidente que la villa producía en Le Corbusier una verdadera obsesión que se prolongó a lo largo de toda su vida. La colonización de la E.1027 por medio de los murales no fue suficiente; el maestro también quiso batirse contra el reto en hormigón armado que suponía la construcción de la E.1027 como revisión crítica a muchos de sus planteamientos arquitectónicos en el plano de la arquitectura. Y así intentó llevar a cabo distintas intervenciones arquitectónicas alrededor de la Maison en bord de mer, casi todas ellas de dudoso valor. La presencia de la E.1027 integrándose y haciendo suyo el lugar para el que fue concebida ¿imponía demasiado incluso al arbiter elegantiorum de la modernidad o quizás todo se redujera a un problema de mala conciencia?

60. ADAM, Peter, 1989, Op. cit., p. 152.

61. ADAM, Peter, 1989, Op. cit., p. 152. 


\section{Crítica de género: la arquitectura de Eileen Gray en la E.1027}

Sin embargo, nos interesa aquí el plano de la arquitectura y las implicaciones que el espacio sofisticado y delicado de la E.1027 suponían, como crítica de facto a buena parte de los planteamientos de la línea corbusierana que acabaría imponiéndose entre las distintas corrientes que discurrían en el seno de la vanguardia arquitectónica de la época. Sólo así podemos entender la pugna entre Le Corbusier y Gray a propósito de la E.1027. Una pugna que sólo puede estar a la altura en lo que se refiere a su actividad pictórica, no en sus intervenciones arquitectónicas como hemos podido analizar. Sorprendentemente el Goliat de nuestra historia, el reputado maestro de la arquitectura, hubo de batirse con sus pinceles frente a un David convertido en arquitecto novel procedente del mundo del interiorismo y el diseño. Algo que recuerda vivamente la pugna entre Borromini y Bernini en la piazza Navona, con su Santa Agnese y la fuente de los Cuatro Ríos, respectivamente.

En lo referente a la autoría de la villa, si consideramos la manifiesta afinidad de planteamientos entre Badovici y la arquitectura de Le Corbusier de los años 20 y observamos la crítica sutil que la E. 1027 supone frente a ellos, parece lógico conceder el mayor protagonismo a Gray en el diseño de la misma. Lo

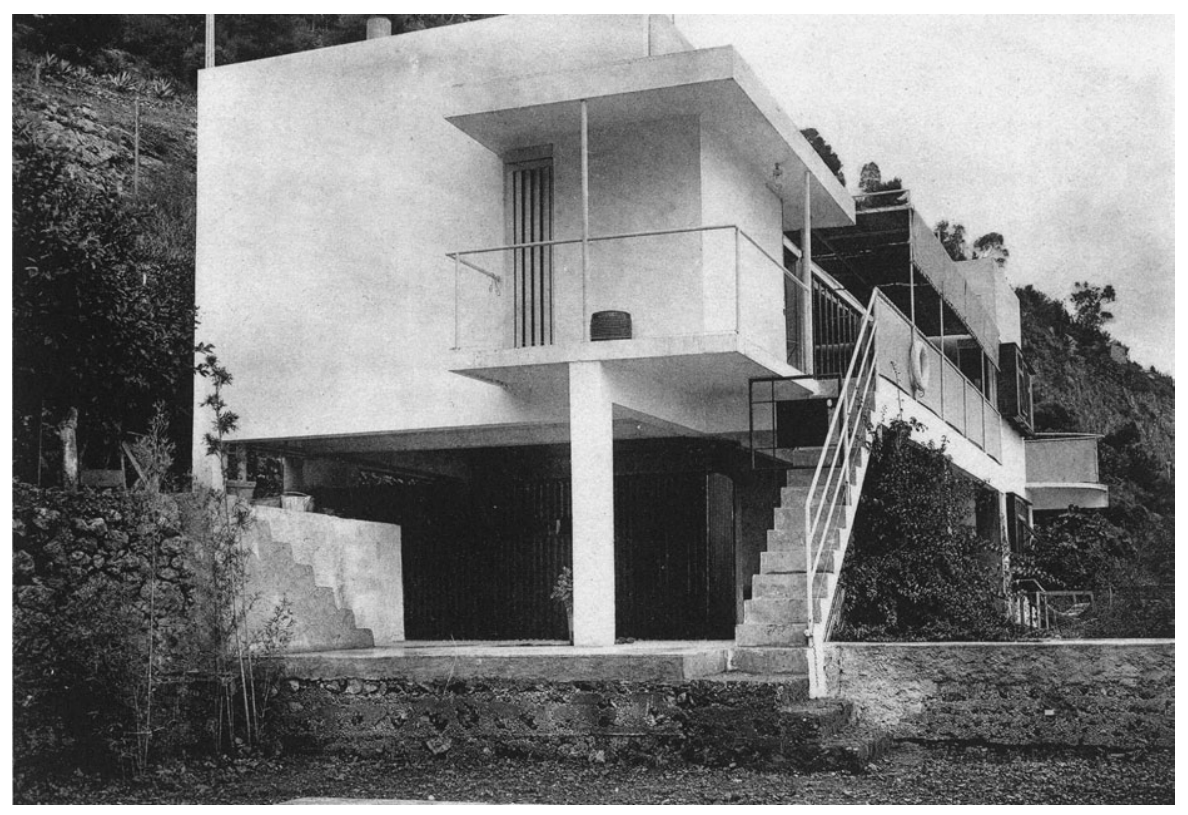

Fig. 8. E.1027 relación entre plantas y terraza cubierta «sous les pilotis». (foto publicada en L'Architecture Vivant, 1929) 
probable es que Badovici básicamente asesorase en las cuestiones técnicas por su formación y mayor experiencia como arquitecto, y el diseño global correspondiese a Gray, quien además estuvo al pie del cañón durante la ejecución de la obra de forma prácticamente exclusiva. Al parecer, Badovici contribuyó con las dos decisiones de proyecto que más vinculan la E.1027 con dos de los cinco preceptos corbusieranos ${ }^{62}$ : "Badovici suggested that the main living level be raised on pilotis and the spiral stair extended to the roof, its form derived from Vladimir Tatlin's Monument to the Third Internationale (1910-20)». Sin embargo, ni siquiera estos dos puntos son seguidos con el rigor establecido en el canon funcionalista. En efecto, el piano nobile de la vivienda está elevado sobre los pilotis de la planta inferior pero la planta únicamente queda liberada bajo el cuerpo principal de la edificación -la gran sala polivalente en la que se ha convertido el estar-, produciendo así una terraza cubierta al abrigo del sol mediterráneo, un espacio complementario al jardín al descubierto con el que se vincula apropiándose de las excelentes vistas al mar. Este recurso formal también puede vincularse con las villas palladianas y la arquitectura

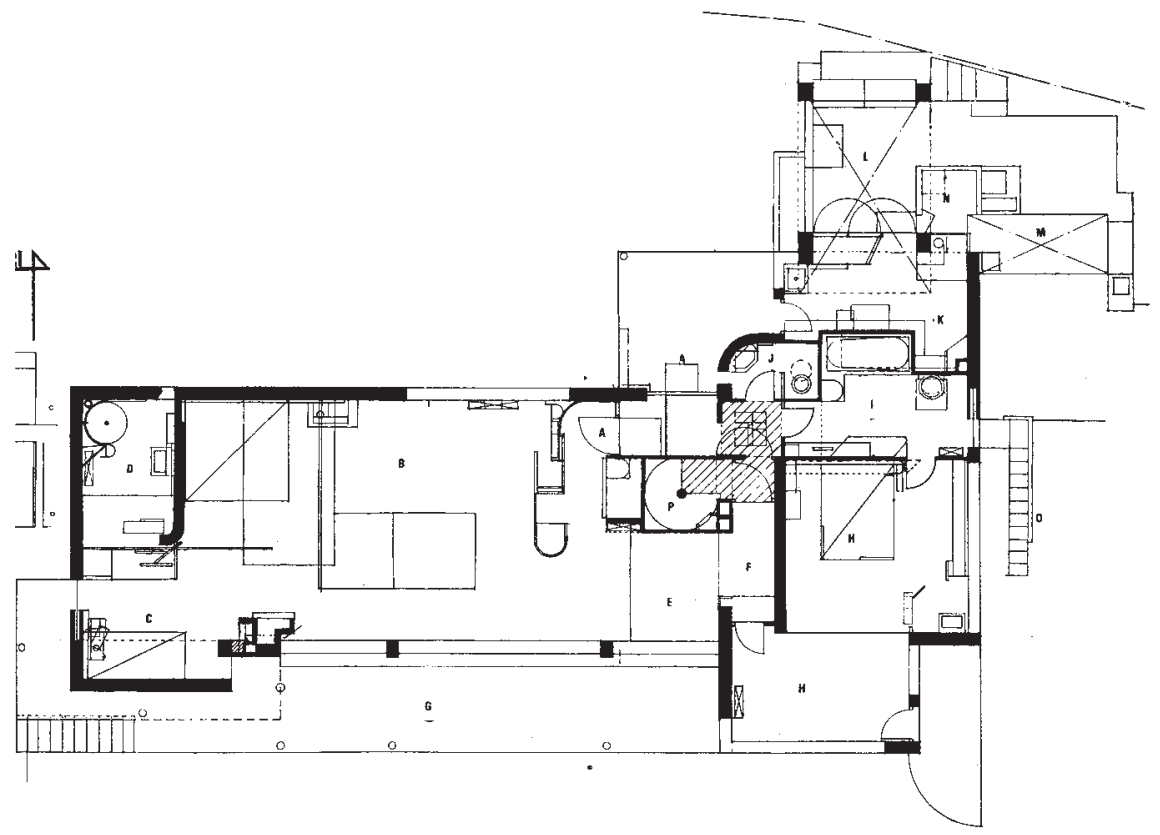

Fig. 9. Planta principal de la E.1027.

(publicada en Aires Modernos, Carmen Espegel)

62. Constant, Caroline, Op. cit., p. 269. 
palaciega renacentista; como en éstas, la entrada principal está en la cota del piano nobile.

La separación del volumen edificatorio principal del bancal superior -que se hizo coincidir con el nivel del piano nobile- produce una suerte de patio inglés que permite la ventilación cruzada por debajo de la terraza sous les pilotis y refuerza la separación de la promenade de acceso a la entrada del cuerpo edificatorio como gesto de privacidad. A pesar de la elevación de la planta principal sobre los pilotis, la sintaxis empleada en toda la casa es sobre todo muraria ${ }^{63}$, y mucho más vinculada a la articulación del espacio interior con el exterior, así como a los distintos usos que se van ordenando a partir de las estancias celulares que se agregan entre sí. La retórica está mucho más próxima -como casi toda la casa, si se estudia en profundidad- a la arquitectura De Stijl.

En cuanto a la cubierta ajardinada que se resuelve con el escultórico remate de la caja de escalera al atravesar el forjado de cubierta, como bien ha señalado Espegel ${ }^{64}$, tampoco se elabora mucho más allá que para facilitar su acceso:

La cubierta ajardinada está desprovista de relevancia funcional, ya que se encuentran en otras partes de la casa los elementos que la justificarían: solarium, terraza con vistas, jardín o umbráculo. La ausencia de peto o barandilla (tiene sólo un mínimo resalte para ocultar las pendientes de la cubierta) y de vegetación, le resta protagonismo como espacio vividero, aunque le confiere una mayor elegancia en el alzado.

Por otro lado, volcada como está la vivienda a la privacidad el «quinto alzado» que está constituido por la cubierta, de tener utilidad real, funcionaría como plataforma de exhibición, lo que contradeciría el planteamiento de partida; incluso el solarium se esconde en el jardín en uno de los bancales, a resguardo de las miradas indiscretas.

En cuanto a otro de los tres puntos canónicos, la planta libre, aquí está interpretada como articulación del espacio, y es evidentemente heredera de la arquitectura neoplasticista y de la «destrucción orgánica de la caja» de Wright; es decir a la descomposición de la forma cerrada. La apertura no es la consecuencia de haber desmembrado la arquitectura en estructura y cerramientos, como sucede en la arquitectura funcionalista, sino la elaboración

63. «La casa descansa sobre pilotis, si bien estos carecen de independencia al ser cuadrados, gruesos y pertenecer todavía al lenguaje del muro, al machón.», EsPEgEL, Carmen, Aires Modernos, Op. cit., p. 156.

64. Epegel, Carmen. Aires modernos. Op. cit., p. 156.

Feminismo/s 17, junio 2011, pp. 259-295 


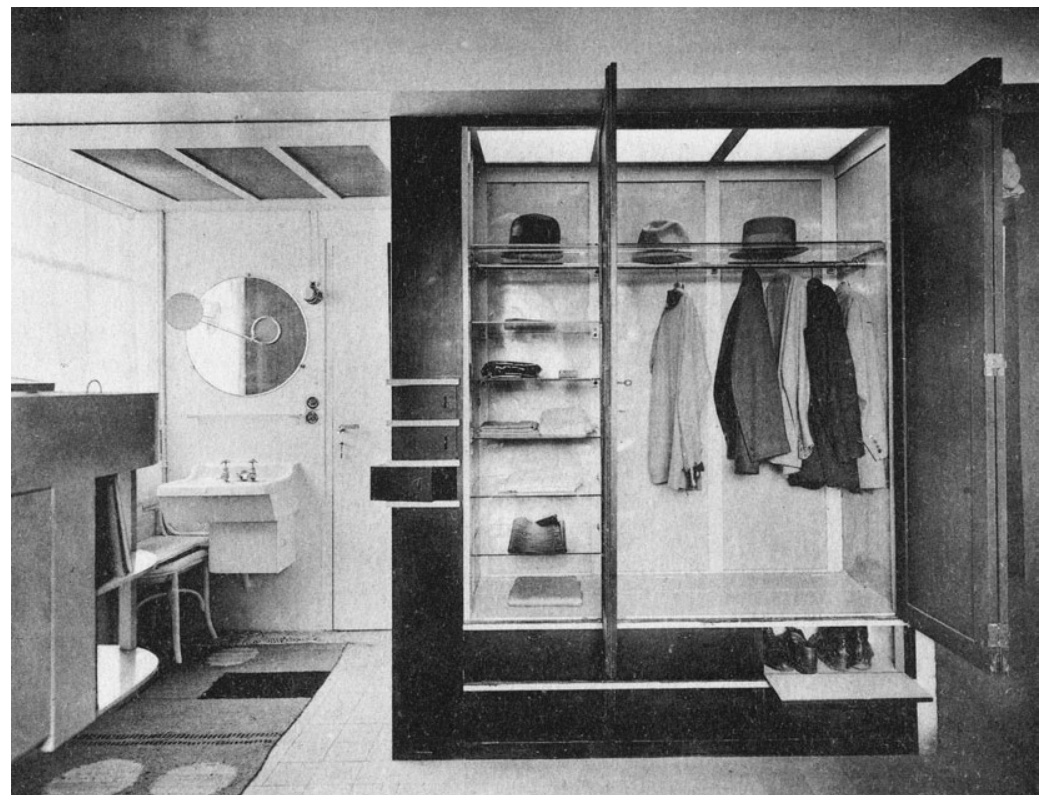

Fig. 10. Dormitorio de invitados. (publicada en Aires Modernos, Carmen Espegel)

de unos recorridos en torno a células funcionales que se ordenan a partir de distintos grados de privacidad y la resolución de las tensiones con el lugar ${ }^{65}$ :

Both interior and exterior of E.1027are characterized by a new interdependence of the parts. Architectural components and furnishings are rarely perceived as bounded or distinct; rather, their presence is understood in relation to adjoining elements. Gray's fascination with opacity and indecipherability led her to focus on the surface of the elements, their colours, textures, and reflective qualities, rather than their profile, modelling, or placement in a legible space. She never isolated the individual element or made it represent the totality of the ensemble. The result is a richly realized totality of space.

La arquitectura de Gray no se puede entender sin esa concepción de obra de arte total -gesamtkunstwerk- de raíces musicales wagnerianas, pero que ya había anticipado Wright a principios de siglo en el campo de la arquitectura y que sería un ideal a abrazar en la época del diseño de la Bauhaus con grandes defensores como Gropius. Sin duda, sus orígenes como diseñadora e interiorista la habían hecho cultivar un aprecio por la calidad de los materiales, los

65. CONSTAnt, Caroline, Op. cit., p. 273. 
colores y las texturas que más tarde extendería a su actividad arquitectónica. Los límites entre sus piezas de mobiliario, sus detalles de interiorismo y su arquitectura son tan difusos que no hay una separación real entre unos y otros: todos conforman una elaborada polifonía. La relación de Gray con el neoplasticismo data de su relación con Oud y Wils quienes habían quedado cautivados con la riqueza de los materiales y las texturas empleadas en combinación con una marcada abstracción formal de carácter geométrico en su Boudoir Monte Carlo exhibido en el XIV Salon des Artistes Decorateurs en 1923 en París. El reconocimiento pronto supuso la publicación de algunos de sus diseños en la prestigiosa revista holandesa Wendigen. La aplicación de los principios neoplasticistas a su arquitectura ya aparece en su primer proyecto profesional -la casa para un Ingeniero- realizado inmediatamente antes de la E. $1027^{66}$ :

Employing selected components of Le Corbusier's Maison Citrohan -pilotis, strip Windows, and free plan- in a critical manner, she was inspired by Theo Van Doesburg's «sixteen points toward a plastic architecture» to reject the singular closed volumes and typological formal constructs of Le Corbusier's early theoretical projects in favour of dynamic balance of elements, capable of mediating the opposition between interior and exterior.

Por otro lado, la concepción corbusierana de la vivienda como machine d'habiter, también sería revisada críticamente por Eileen de manera clara. Para ella la arquitectura debía estar al servicio del individuo, pero además debía relacionarse con todo su ser; con su experiencia corporal, con la gravedad de su materialidad y así escribiría: «A house is not a machine to live in. It is the shell of a man, his extension, his release, his spiritual emanation. Not only its visual harmony, but its entire organization, all the terms of the work, combine to render it human in the most profound sense.» La referencia al precepto del maestro suizo parece bastante directa e inequívoca como para evidenciar su posición respecto de los fríos interiores del funcionalismo.

La fachada libre es interpretada en la E.1027 como consecuencia de la descomposición de la forma en planta; por tanto, es una consecuencia lógica que también se emparenta más con la arquitectura neoplasticista y el canon de Van Doesburg que con la idea de la fachada que se articula libremente por haber sido liberada de su función portante de Le Corbusier. La solución estructural de la E.1027 es de las partes más débiles del proyecto, si se la considera en términos de la rigidez normativa del modelo funcionalista pero no

66. Constant, Caroline, Op. cit., p. 268. 
lo es tanto si pensamos en la duplicidad de la carga repartida tanto en muros como en soportes.

Por último, respecto de la fenêtre en longuer, también aquí Gray da muestras sobradas de una interpretación libre del maestro suizo. Los huecos son variados, muchos de ellos con voluntad de rasgarse horizontalmente, sin embargo la transición del exterior al interior está sumamente elaborada. Una sucesión de filtros y membranas separan el exterior de la terraza principal hacia el interior de la gran sala. El gran hueco se rasga prácticamente a lo largo de la fachada sur del estar pero también se rasga verticalmente de suelo a techo. Al exterior, la única fachada que realmente tiene la villa -sólo visible desde el mar-, la imagen de los toldos desplegados sugieren la horizontalidad de la fenêtre en longuer que acompaña la tensión horizontal que anima toda la composición. Sin embargo, este es sólo el primer filtro que gradúa la intensidad del soleamiento en la terraza y en el interior de la vivienda. El gesto de rasgar hasta el suelo el hueco únicamente en la zona más pública indica también una dosificación en los grados de privacidad y la voluntad de vincular esta estancia con el entrono próximo y el encuentro de las rocas con el mar. Por otro lado, la ventana con carpinterías en acordeón permite abrir la sala completamente a la terraza y con ello apropiarse más íntimamente del lugar aún desde el interior de la villa.

En la E.1027, las tensiones con el lugar se resuelven a partir de la articulación libre en planta en el sentido descompositivo. Así, interior y exterior se entrelazan sugiriendo itinerarios que recuerdan la idea de Le Corbusier de promenade architecturale. A este respecto conviene recordar lo que escribe Van Doesburg ${ }^{67}$ respecto de la relación entre huecos y muros, exterior e interior:

La nueva arquitectura ha horadado la pared, suprimiendo así la dualidad interior- exterior. Las paredes ya no sostienen, se han convertido en puntos de apoyo. De ello resulta una planta nueva, una planta abierta; totalmente distinta de la del clasicismo, porque los espacios interiores y exteriores se penetran [entrelazan].

Solo que en el paseo arquitectónico de Gray -y a diferencia de lo que sucede en Le Corbusier- no está concebido como una sucesión visual de imágenes que convenientemente encuadradas por la arquitectura articulan el recorrido. Se trata más de la interpenetración entre el exterior y el interior lo que establece relaciones entre las vistas y los usos por un lado, y entre el individuo

67. VAn Doesburg, Theo. «La evolución de la arquitectura moderna en Holanda», Principios del nuevo arte plástico y otros escritos. Murcia, Ed. C.O.A.T.M., 1985 (Tit. Orig. Grondbegrippen van de nieuwe beeldende kunst; Tijdschrift voor Wijsbegeerte XIII, 1919), p. 115. 
y su habitar cada uno de los espacios, por otro, lo que genera el recorrido tanto por dentro como por fuera de la vivienda. Así la propia Gray expresaría su desacuerdo respecto del reduccionismo visual en el entendimiento de la arquitectura: «The art of the engineer is not enough if it is not guided by the primitive needs of men. Reason without instinct. We must mistrust merely pictorial elements if they are not assimilated by instinct», en palabras que bien podrían ir dirigidas al maestro suizo.

Buena parte de la crítica que se ha hecho al Estilo Internacional tiene que ver con su insensibilidad para con el lugar -sobre todo en el caso de las propuestas urbanísticas-. El ejemplo de Le Corbusier resulta paradigmático en este sentido, pero incluso su visión idealizada de una arquitectura modélica también tenía cierto sentido de desapego respecto del lugar sobre el que se actuaba. La E.1027 se acomoda y hace suyo el lugar de muchas maneras, la casa no podría estar en otro sitio distinto del que está. Quizás sean las circulaciones el punto más débil de la casa, cómo se resuelve el ingreso en la casa en un zaguán cubierto pero abierto que obliga a varias puertas o, acaso más grave sea la desvinculación de ambas cocinas -en especial la de invierno- a algún paso interior. Quizás conviene recordar las sabias reflexiones de Espegel ${ }^{68}$ respecto del valor de la E.1027:

La Maison en bord de mer consigue su identidad insertándose en la tradición (no formal) mediterránea, bebiendo de ella sus logros esenciales, y en cierta manera reinventándola; pero es auténtica en la fidelidad que guarda consigo misma y con su tiempo (Movimiento Moderno, hormigón armado, planta libre, imagen marítima) [...] El proyecto se utiliza como arma de distinción y de resistencia contra la uniformidad cartesiana moderna que niega toda tradición.

Resulta paradójico el final de la E 1027. Su restauración reciente -por parte del gobierno francés que finalmente adquirió la vivienda- dado que se encontraba en muy malas condiciones de conservación se debe a la existencia de los polémicos murales de Le Corbusier; en la actualidad sólo se conservan cinco de ellos. Tal vez, después de todo, quien hizo bastante por ocultar, manipular y desfigurar el diseño original de la villa ha contribuido de forma fortuita a la preservación de la E.1027. Quizás, en un futuro soñado podamos imaginar la villa restaurada y liberada de la carga figurativa de los murales de Le Corbusier que, con la actual tecnología, podrían ser trasladados para restaurar el sentido original de la obra tal como la proyectó Gray.

68. Espegel, Carmen, Aires Modernos, Op. cit., p. 268. 
La buena arquitectura como la buena crítica no tiene género porque se centra en el objeto -la cosa en $\mathrm{si}^{69}{ }^{69}$; el género es introducido cuando el sujeto -que sí lo tiene- usurpa la objetividad del análisis imponiendo su visión personal en el hecho interpretativo. Si en esta historia ha de prevalecer una crítica de género, creo que debe ser la que Eileen Gray realizó con el diseño y la construcción de la E.1027 sobre los rígidos cánones en los que Le Corbusier y la crítica afín a sus postulados trataron de encorsetar la riqueza polifónica del Movimiento Moderno, no la de sus intérpretes.

\section{Referencias bibliográficas}

ADAM, Peter. «Eileen Gray and Le Corbusier», 9H, 8(1989,) pp. 150-153.

ADAM, Peter. Eileen Gray, Architect/designer: A Biography (Rev. Ed.). Londres, Ed. Thames and Hudson, 2000 (1987).

BADovicI, Jean, «Peinture Murale ou Peinture Spatiale.», L'Architecture d'Adjourd'hui, 8, no , 3 (1937).

BADOVICI, Jean, carta a Le Corbusier, fechada el 2 de julio de 1941, Fundación Le Corbusier.

BLanc, Philippe. «Cabanon:Roquebrune-Cap-Martin, Francia», ARQ, 66, Agosto 2007, Universidad Católica de Chile, Chile, pp. 88-93

Colomina, Beatriz, «Líneas de Batalla: E. 1027», en Pasajes, $2^{\circ}$ semestre 2001, Univ. de Buenos Aires. Centro de Estudios Amancio Williams., pp. 47-55.

CONSTANT, Caroline. "The Nonheroic Modernism of Eileen Gray», Journal of the Society of Architectural Historians, Vol. 53, Nº. 3 (Sep. 1994), pp. 265-279.

ESPEGEL, Carmen. Aires modernos. E. 1027: maison en bord de mer Eileen Gray y Jean Badovici 1926-1929. Madrid, Ed. Mairea Libros, 2010

EsPegel, Carmen. Heroinas del espacio. Mujeres arquitectos en el Movimiento Moderno. Valencia, Ed. Generales de la Construcción, 2006.

GrAY, Eileen, BADOviCI, Jean. «De l'Eclecticisme au doute». Londres, Da Capo Press, inc. \& Trewin Copplestone Publishing Ltd., vol. 1928-1929, 1975, y planchas pp.17-38 y pp. 27-59 (reimpresión de la monografía E.1027: Maison en bord de mer publicada en L'Architecture Vivante, número Otoño-invierno, (1929), Ed. Albert Morance, Paris).

69. MiRAndA, Antonio, 2008, Columnas para la resistencia. Madrid, Ed. Mairea. Hubiera sido deseable en aras de la crítica y de acuerdo con los principios enunciados por Miranda -de quien me reconozco deudor- haber dedicado más extensión al juicio crítico sobre la propia E.1027 que a los hechos y las peripecias que rodean a la E.1027 y a sus autores con el propio Le Corbusier. Sin embargo, el artículo trata de desvelar, en primera instancia, las razones de la actitud de Le Corbusier y de la crítica para con la E.1027, lo que ha obligado a exponer y analizar detenidamente los hechos para apuntar las causas que los originaron; las limitaciones de extensión han producido el resto. 
LE CORBUSIER, «Unité», L'Architecture d'Adjourd'hui, 19, 1948.

LE Corbusier, carta a Badovici fechada el 1 de enero de 1950. Fundación Le Corbusier.

Le Corbusier, Le Modulor 2. Paris, Editions L'Architecture d'Aujourd'hui, 1950, p. 154.

Miranda, Antonio, 2008, Columnas para la resistencia. Madrid, Ed. Mairea

RaUlT, Jasmine. «Occupying E.1027. Reconsidering Le Corbusier's «Gift» to Eileen Gray, Space and Culture, Vol. 8, 2 (May 2005), pp. 160-179.

RYKWERT, Joseph. «Eileen Gray: two Houses and an Interior, 1926-1933», Perspecta, Vol. 13/14 (1971), pp. 67-73.

TOURNIKIOTIS, Panayotis. La historiografía de la arquitectura moderna. Madrid. Ed. Mairea/Celeste, 2001. (Tit. Orig. The Historiography of modern Architecture, Massachusetts Institute of Technology, 1999).

VAn Doesburg, Theo. «La evolución de la arquitectura moderna en Holanda», Principios del nuevo arte plástico y otros escritos. Murcia, Ed. C.O.A.T.M., 1985 (Tit. Orig. Grondbegrippen van de nieuwe beeldende kunst; Tijdschrift voor Wijsbegeerte XIII, 1919), p. 115.

ZAKNIC, Ivan. «Le Corbusier Sans Fin», Journal of Architectural Education, Vol. 42, 3 (Spring 1989), pp. 49-59.

<http://purecontemporary.blogs.com/behind_the_curtains/2007/10/eileen-gray1st.html>, consultado el 08-03-2011. 



\title{
SINGULARIDAD, NATURALISMO Y MOVIMIENTO. LA APORTACIÓN DE ZAHA HADID AL CONTEXTO ARQUITECTÓNICO ACTUAL
}

\author{
LAURA MuÑoz PÉREZ \\ Universidad de Salamanca
}

Recibido: 09/02/2011

Aceptado: 20/05/2011

\section{Resumen}

Zaha Hadid aporta al mundo de la arquitectura del siglo XXI trabajos cargados de originalidad, fuerza, espectacularidad y vanguardia que son enjuiciados con desigual fortuna por críticos y especialistas según sea la particular concepción de la constructiva que cada uno de ellos desarrolle. A la dificultad intrínseca de resultar novedoso, exigente y cumplidor en una tarea tan sometida a constante escrutinio como la edificatoria, Hadid le une su condición de mujer, ampliando y complicando el número de factores a los que su vida profesional ha de enfrentarse para lograr alcanzar su objetivo: ser considerada entre las grandes estrellas del firmamento arquitectónico internacional y todo gracias a los méritos formales, simbólicos y expresivos de sus creaciones.

Palabras Clave: Zaha Hadid, arquitectura, siglo XXI, mujer.

\begin{abstract}
Zaha Hadid brings the architectural world of the XXI century works full of originality, strength, spectacular and avant-garde that are judged with mixed fortune by critics and specialists depending on the particular conception of the construction that each of them develops. To the intrinsic difficulty of being innovative, demanding and achiever in a task under constant scrutiny as the edification, Hadid joins her womanhood, expanding and complicating the number of factors to which her career has to face to achieve her goal: to be considered among the great international architectural stars and all thanks to the formal, symbolic and expressive merits of her creations.
\end{abstract}

Keywords: Zaha Hadid, architecture, XXI century, woman. 

«Nadie piensa que el paisaje natural sea extraño, porque lo creó Dios; en cambio, si lo creo yo, la gente piensa que es extraño».

Zaha Hadid ${ }^{1}$

Superar las barreras impuestas, romper con los tabúes, dinamitar ciertas normas o sobrepasar muchos límites. Ésa ha venido siendo la historia de la mujer desde el comienzo de los tiempos. Con más o menos éxito según las ocasiones, circunstancias y coyunturas históricas, siempre con tremendo esfuerzo y encarando con seguridad y optimismo la dureza de sólidos prejuicios sociales, culturales y de género, las féminas se enfrentan a su vida y a su carrera profesional no sólo como etapas de un proceso de realización (aunque también) sino, en muchas ocasiones, como una aventura y un desafío que las reivindica, más allá de su sexualidad, como seres humanos plenos de capacidades, aptos para afrontar cualquier reto y culminarlo con una victoria o, en su defecto, con un aprendizaje a partir del cual continuar la lucha con renovados afanes. Ello es extensivo a todos los ámbitos de la vida en los cuales la mujer quiere o ha querido dejar constancia de sus intereses, ya se trate de aquellos que afectan a su formación y educación, a su desarrollo personal o profesional o incluso a sus aficiones y pasiones. Los miles de años y de avances que en ellos se han sucedido en materia de desarrollo femenino han ido dibujando una situación actual que, pese a sus aún incontables injusticias, latentes dejes machistas, evidentes agravios comparativos e indeseables situaciones lamentables de las que las mujeres son víctimas, permite perfilar un estado de esperanza presente y futura que, con lógica, tenderá a irse asentando y cimentando en más sólidas realidades conforme pase el tiempo y, con él, se consoliden los valores de igualdad y equidad de oportunidades en que se deberían estar educando las nuevas generaciones.

A la espera de que las excepcionalidades de hoy se conviertan en cotidianeidad próximamente, es preciso observar el papel pionero y, por ello,

1. «Phaeno Science Center» en Jodidio, Philip. Architecture now!. Vol. V. Colonia, Taschen, 2007, p. 248. 
arriesgado, controvertido y sometido a escrutinio, que muchas féminas desempeñan en su desenvolvimiento personal y profesional, teniendo que demostrar, a cada paso, no sólo su valía o talento sino pareciendo que han de justificar su éxito o brillantez y, en esa medida, habiendo de soportar mayor número y más duras críticas que sus colegas masculinos ante iguales condiciones. Si bien la cantidad de parcelas a las que es aplicable esta realidad resulta enorme, en el caso que nos ocupa el mundo de la arquitectura sirve a la perfección para patentizar estos apriorismos, pues en él se concentra un sector profesional mayoritaria y tradicionalmente masculino en el que el papel de la mujer, de tímido y excepcional, está pasando a adquirir un protagonismo acusado y, con ello, se van generando ciertas suspicacias, maledicencias o comentarios en los medios especializados que tanto tienen que ver con las afinidades estilísticas o técnicas hacia unos u otros autores como con ciertos residuos de clasificación de géneros que aún ven con extrañeza el hecho, a todas luces natural, de que una mujer pueda dedicarse, en plenitud de capacidades y originalidad, a labores de proyección y creación arquitectónica.

Zaha Hadid (Bagdad. Irak, 1950), como máximo exponente de todo lo anterior (al menos en lo que a popularidad, repercusión mediática y reconocimiento crítico se refiere) $)^{2}$, patentiza y concreta, en su persona, los enunciados de carácter general que hasta ahora se han ido desgranando, resultando pues un particularmente interesante fenómeno de estudio que conjuga los dos polos prioritarios que persigue iluminar este artículo: la arquitectura y la mujer y, a la postre, la relación de la segunda con la primera pero no tanto en términos de uso y disfrute o de adecuación de la constructiva a las peculiaridades socio-históricas femeninas cuanto en cuestiones de planificación, imaginación y desarrollo, que una mujer puede hacer de los asuntos arquitectónicos. Sin embargo, como ello supondría analizar y contemplar en panorámica la extensa carrera de $\mathrm{Hadid}^{3}$, se pretende ir más allá de la simple semblanza biográfica y proyectual de la autora para pasar a seleccionar tan sólo un grupo de sus trabajos que resultan significativos en particular, en concreto aquellos en los que su toque personal, inevitablemente femenino pero, por encima de

2. No en vano recibió en 2004 el Premio Pritzker de Arquitectura, máximo galardón existente en cuanto a distinción y reconocimiento de la práctica constructiva internacional. En la historia del trofeo se trata de la primera y única mujer que lo ha merecido en solitario (la autora japonesa Kazuyo Sejima lo obtiene, en 2010, como parte del equipo SANAA, del que también es miembro el arquitecto Ryue Nishizawa).

3. Que abarca casas, hoteles, pabellones para exposiciones, bibliotecas, filarmónicas, óperas, restaurantes, teatros y otras creaciones, algunas de ellas de enorme trascendencia popular y crítica como el Centro Rosenthal de Arte Contemporáneo (Cincinnati, 19972003) o el MAXXI. Museo de las Artes del siglo XXI (Roma, 1998-2009). 
ello, caracterizador y único de su estilo como artista, se trasluce en formas tópica y tradicionalmente masculinas, esto es, espacios que en forma pero, sobre todo en fondo, tendemos a asociar a actividades alejadas de lo que los cánones nos dictan como propio de mujeres (lo sensible, lo dulce, lo sensitivo...). Así pues, parece de especial interés y notable impacto considerar cómo la mente arquitectónica de una fémina contempla composiciones tales como centros deportivos, estaciones de ferrocarril, parques de bomberos, aparcamientos, viaductos y puentes, fábricas de automóviles, institutos científicos o tribunales de justicia, por citar sólo algunos ejemplos de lo que una construcción potente, seria, fuerte -masculina, pues- puede simbolizar. Muchos de estos trabajos no van a pasar, a lo largo de los años, de resultar proyectos irrealizados, bocetos de explosiva personalidad en los que Hadid ha ido trasluciendo su particular lenguaje creativo, alejado de corsés constructivos o de clichés arquitectónicos asociados a su condición sexual. Entre ellos, y siempre en el marco de lo bidimensional, es preciso hacer referencia, por ejemplo, al edificio de oficinas Kurfürstendamm 70 (Berlín, 1986), al puente habitable sobre el río Támesis (Londres, 1996) ${ }^{4}$, a un centro para el campus del Instituto Tecnológico de Illinois (Chicago, 1998) ${ }^{5}$ o a la irrealizada terminal de pasajeros del aeropuerto de Zagreb (2008), por citar sólo algunos.

Entre lo materializado, y para respetar el orden cronológico de las obras objeto de interés en el presente texto, es preciso comenzar el repaso a este recorrido por lo masculino-femenino en la obra de Hadid en Weil am Rhein (Alemania), localidad en la que la arquitecta trabaja, entre 1990 y 1994, en la creación de la estación de bomberos de Vitra (actual museo de mobiliario). Al cometido a desempeñar por el edificio y a la claridad de los recorridos interiores de éste, rasgos que se erigen como improntas básicas del diseño, la autora impone aquí, a la hora de precisar el resultado, su específica relación con un entorno definido que lo condiciona pero al que, al tiempo, la obra se pliega. En efecto, este equipamiento se erige en el extremo de un complejo industrial soportado sobre una estructura urbana lineal, básicamente horizontal, que se continúa en el paisaje circundante de campos de cultivo y viñedos. Así pues, para prolongar y acentuar estas huellas, Hadid recurre a formas que, por otro lado, suelen ser definidoras de su quehacer arquitectónico, esto es, módulos

4. «Habitable bridge» en BETSKY, Aaron. Zaha Hadid. The complete buildings and projects. Nueva York, Rizzoli, y Londres, Thames \& Hudson, 1998, pp. 135-139 y «Habitable bridge» en Zaha Hadid. Complete works. Projects and documentation. Vol. II. Nueva York, Rizzoli y Londres, Thames \& Hudson, 2004, p. 28.

5. «Campus centre» en Zaha Hadid. The complete..., op. cit., pp. 164-167 y «New Campus Centre» en Zaha Hadid. Complete works. Vol. II..., op. cit., p. 96. 


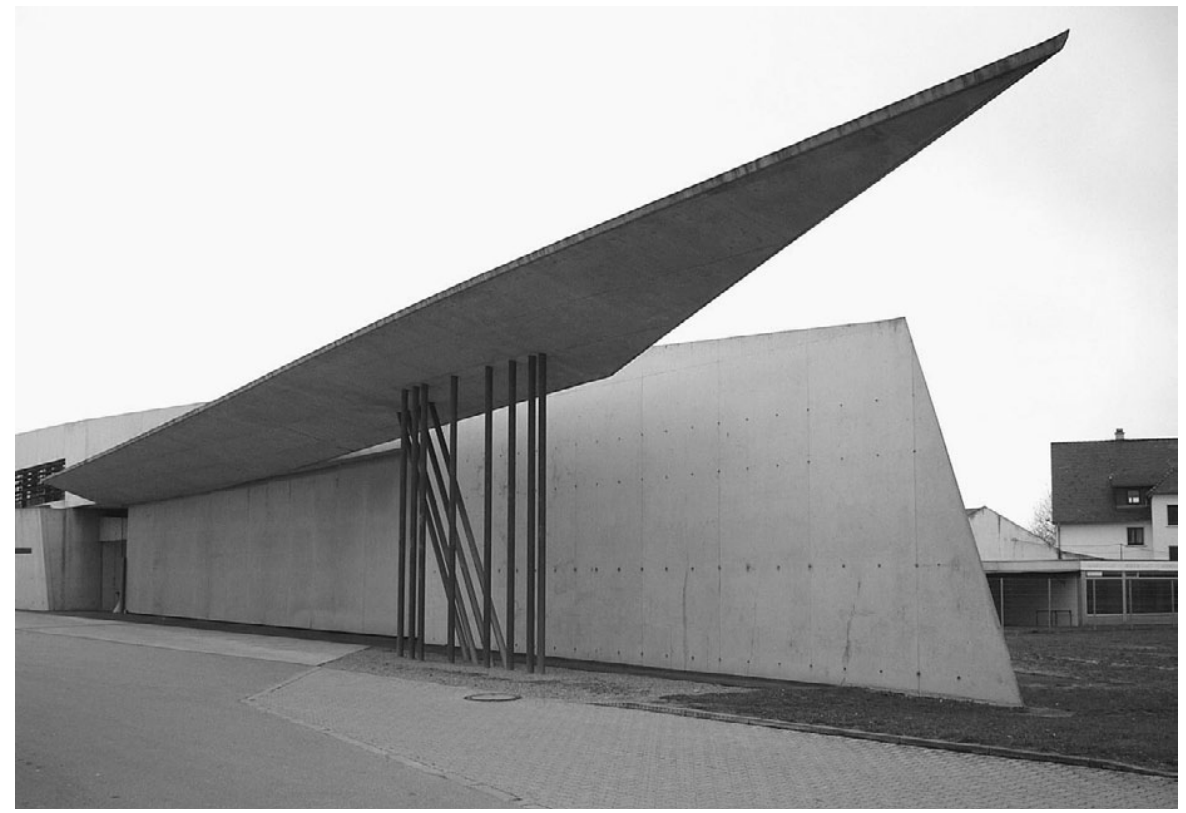

Figura 1.

expandidos en superficie, que no en altura, imbricados entre sí pero desplazados de sus ejes, deslizantes y con sus líneas directrices, netas y cortantes, perfectamente marcadas (figura 1). Sin embargo, un exceso de mimetismo con el entorno hubiera podido provocar el desleimiento del resultado en el todo colectivo que lo rodea, razón por la cual, para evitar dicha absorción, la simplicidad que emanan los trazos protagonistas se exacerba hasta el punto de obtener un resultado muy austero, casi abstracto en términos artísticos, tan simple, preciso y carente de distracciones que, pese (o quizás gracias) a su extremo desapercibimiento, resulta difícil de obviar, de reconocer y de apreciar.

El protagonismo recae en la línea y, con ella, en los volúmenes a los que dan forma sus muros-pantalla ${ }^{6}$, de modo que no hay nada accesorio, ningún añadido superfluo (cantoneras, marcos...) más allá de la pura estructura construida. Ésta, además, está fabricada con hormigón armado visto y completada, en los puntos de iluminación, mediante grandes paneles de cristal sin armazón, de tal modo que ni formas ni materiales o texturas perturban la límpida

6. «Vitra. Estación de protección contra incendios». El Croquis, 52, Madrid, 1992, pp. 110-125. 


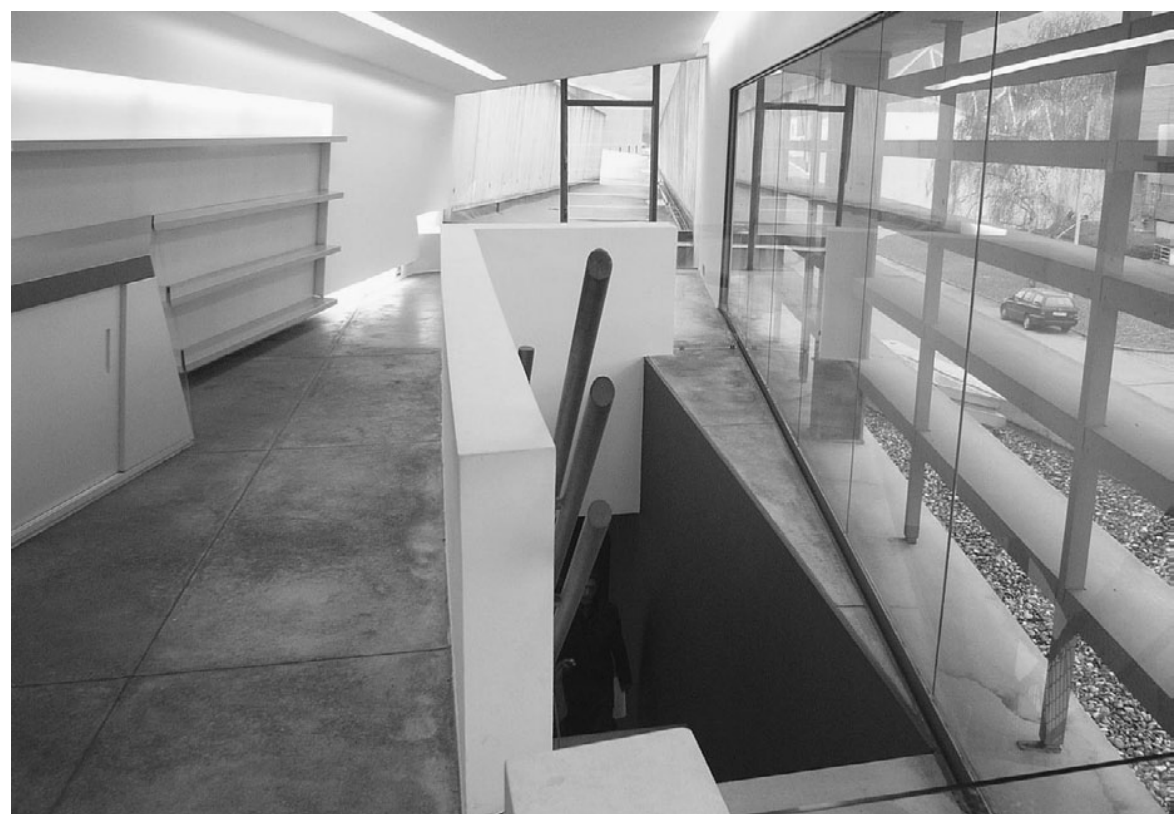

Figura 2.

impresión de fuerza, tensión, velocidad y seguridad que, tan ajustada a su primigenia función, transmite el potente y masculino complejo alemán, listo para la acción ${ }^{7}$ (figura 2).

La estación de bomberos de Vitra, pese al deseo específico de Hadid por acentuar su personalidad a través del ritmo de sus volúmenes, resulta a la postre brusca en su conjunto y si bien desde una perspectiva aérea es perfectamente reconocible como un edificio o, incluso, como un paisaje de esta autora (con sus formas grácilmente relacionadas, desplazadas con suavidad, como resbalando sobre la superficie del plano), no consigue imponer a su contexto su movimiento y su tempo de manera tan grácil a como lo han logrado algunas de sus creaciones más recientes, razón por la cual es lógico pensar que, en un exceso de formalismo y hermetismo, la arquitecta resulta menos personal, inspirada e inspiradora que cuando da rienda suelta a sus personales (aunque algunos crean que blandas y femeninas) estructuras. El movimiento congelado del que se habla al hacer referencia al

7. «Vitra fire station» en Zaha Hadid. Complete Works. Major and recent works. Vol. I. Nueva York, Rizzoli y Londres, Thames \& Hudson, 2004, pp. 60-83. 
centro $^{8}$ germano, resulta un oxímoron difícil de cuadrar. Y de matizarlo hacia la fluidez se encargará Hadid en trabajos venideros. De hecho, así lo van confirmando algunos de sus otros proyectos últimos como el aparcamiento e intercambiador Terminus Hoenheim-Nord ${ }^{9}$ que diseña para Estrasburgo (Francia) y que se materializa entre 1998 y 2001.

Como en el caso anterior, la composición y su consecuente perfil gira en torno al vehículo, a la necesidad que tenemos en las sociedades desarrolladas del mismo, a su uso y abuso, al espacio que ocupa y a la facilidad que exigimos para tomarlo y dejarlo cuando nos resulta necesario. Precisamente de paliar los excesos que tendemos a cometer como usuarios del automóvil se encarga el gobierno de la localidad francesa, quien tratando de minimizar el impacto ecológico, económico y hasta psicológico que los recorridos en coche pueden provocar a individuos y colectivos, propone la creación de este intercambiador, un gran enclave de fomento del transporte público ${ }^{10} \mathrm{o}$, en su defecto, de otro más natural y no contaminante como la bicicleta.

De diseñar este lugar se encarga Hadid porque en ella ven los promotores de la obra a la autora idónea para transformar una infraestructura necesaria, práctica y básicamente funcional en un espacio con el que la ciudad y sus habitantes se identifiquen, al tiempo que en un nuevo icono urbano que sirva para dar la bienvenida a los visitantes a Estrasburgo. Su ya conocida capacidad para conjugar lo útil con lo estéticamente determinante sin duda ejerce un peso notable a la hora de conferirle la posibilidad de materializar este trabajo y ella lo afronta a partir de pautas muy similares a las ya observadas en el ejemplo alemán. En efecto, y como en dicho caso, es el contexto el que coadyuva al resultado pretendido, sentando los apriorismos del diseño. Aquí Hadid se encuentra condicionada, como es natural, por el nudo de comunicaciones que da consistencia al intercambiador pero también por un enclave que, en los límites de la ciudad, no acaba de ser urbano para convertirse en rural. Así pues, campo, vías de tranvía, carreteras, industrias y algunas viviendas se coaligan para generar un entorno complicado al que hubiera sido sencillo imponerse con un diseño grandilocuente tanto en formas como en materiales. Sin embargo, consciente de ese peligro, la autora vuelve a leer el contexto como en Alemania y lo hace en clave de respeto y armonía pero, al tiempo,

8. «Estación de bomberos de Vitra». El Croquis, 73-1, Madrid, 1995, pp. 38-61 y «Vitra fire station» en Zaha Hadid. Complete works. Vol. II..., op. cit., pp. 62-67.

9. Junto con otros equipamientos menores como taquilla, aseos, aparcamiento de bicicletas o sala de espera.

10. Desde allí parten trenes de cercanías, tranvías y autobuses. 


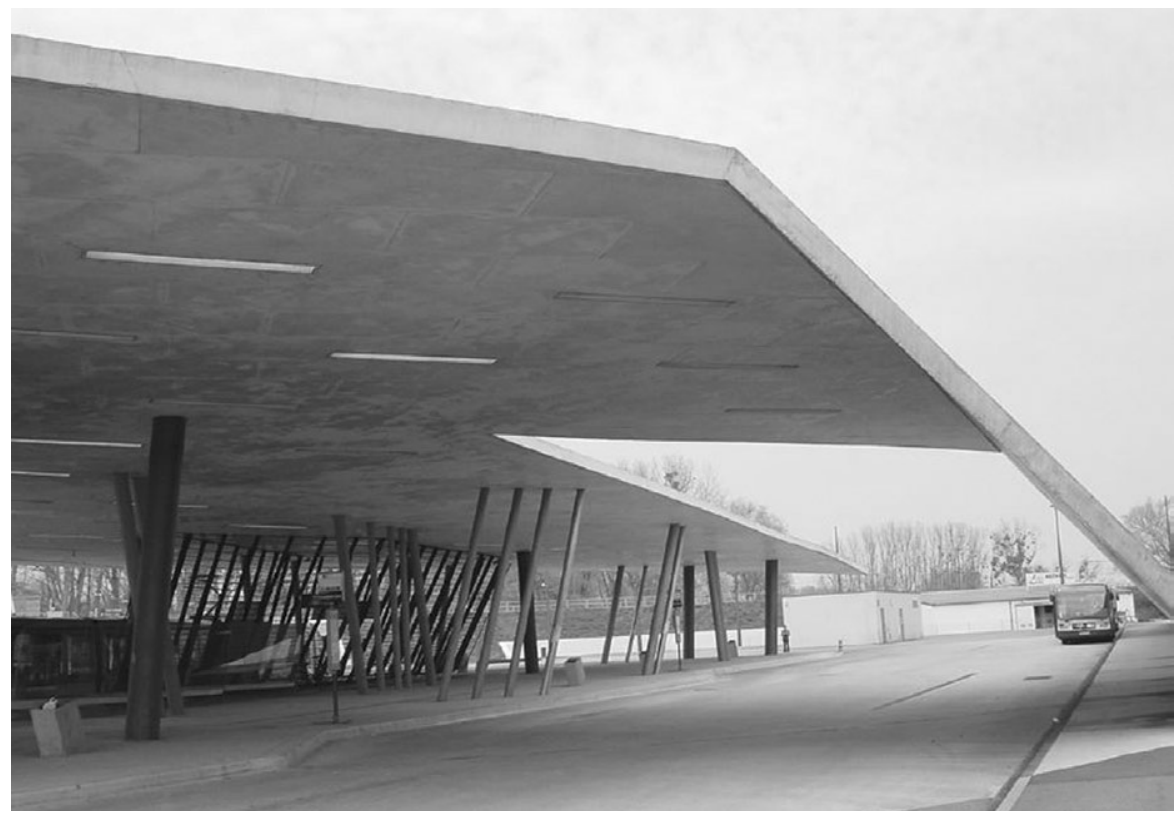

Figura 3.

con la suficiente fuerza como para que su proyecto no pase desapercibido y sí domine, en términos de grandeza, su escenario.

Recurriendo una vez más al hormigón armado como material, aprovecha aquí su aspecto masivo, telúrico y rotundo para dibujar con él las formas de las marquesinas y andenes (figura 3); cuerpos que parecen surgir de la tierra (y a la que, por tanto, homenajean $)^{11}$. Sin embargo, dichos volúmenes, pese a la simplicidad y radicalidad de sus líneas cortantes, sustituyen la armonía con la superficie de la obra alemana por una ruptura del plano mediante una explosiva diagonal que atraviesa, cual cráter, todo el solar. Pese a que los componentes y algunos de los materiales de trabajo son los mismos, el resultado gana así, con esta nueva concepción, en dramatismo y fuerza, en personalidad y magnificencia, en dinamismo y singularidad ${ }^{12}$. A ello hay que añadir el

11. En una entrevista concedida en 2001 Zaha Hadid expresa su interés por «la formación de las placas geológicas y por la arqueología», algo que se evidencia en este trabajo pero que también vertebra otros muchos de sus proyectos previos y posteriores. Ver MostafaVi, Mohsen. «El paisaje como planta». El Croquis, 103, Madrid, 2001, p. 20.

12. Por estos y otros factores la obra y su autora resultan galardonadas con el prestigioso Premio Mies van der Rohe (de Arquitectura Contemporánea de la Unión Europea) en su edición de 2003. 


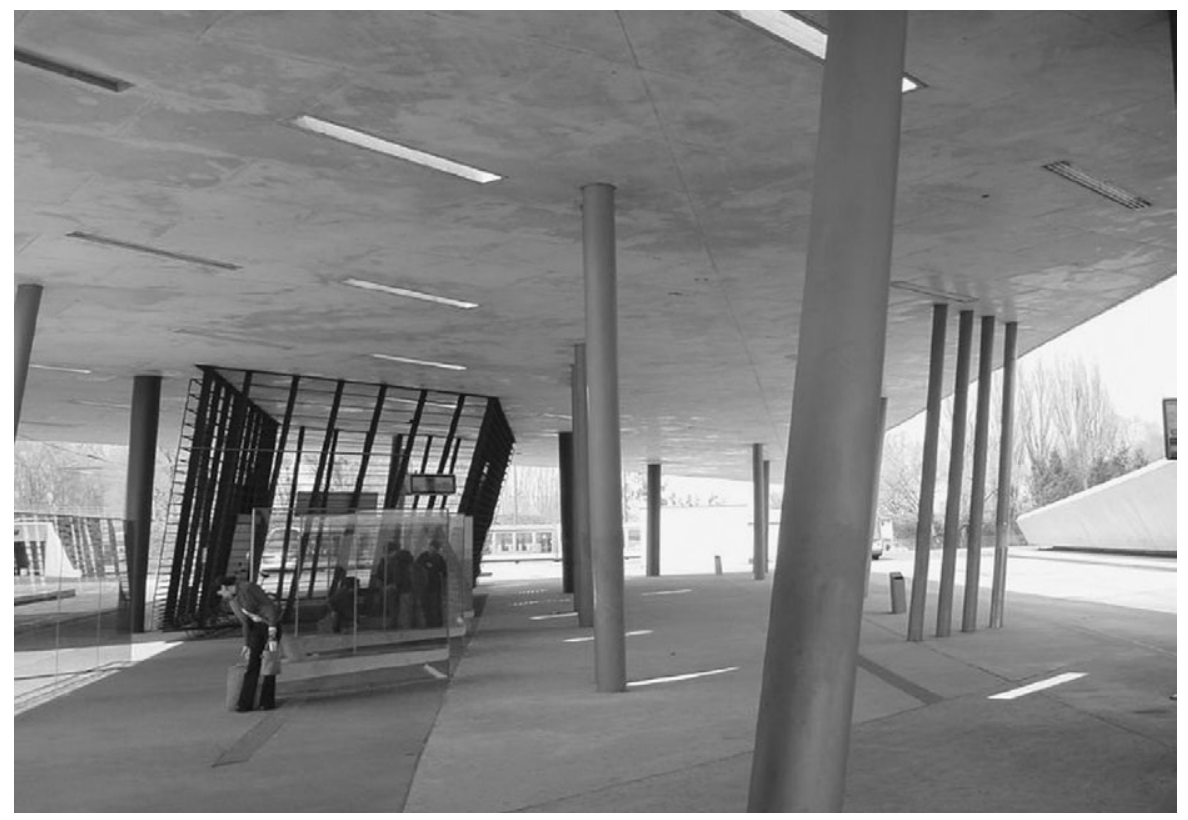

Figura 4.

empleo de pilares metálicos inclinados y una colocación precisa tanto de los apliques luminosos como de los huecos de iluminación natural, de modo que luces y soportes colaboran a la impresión zigzagueante y quebradiza -a la par que unitaria- del conjunto ${ }^{13}$ (figura 4); un conjunto personal en términos de imposición al escenario y en la energía, la correlación y fluctuación de los volúmenes los cuales, pese a que aún no son los ondulantes (tópicamente pues, más femeninos) que tienden a tipificar la arquitectura de Hadid, sí resultan naturalistas, emanados de la madre tierra como erupción física de su fuerza ${ }^{14}$.

De nuevo la naturaleza, con su conjunción de lo masculino y lo femenino, con la oposición y armonía de contrarios que brinda el equilibro al planeta,

13. Acentuada aún más, si cabe, por el continuo fluir de autobuses, personas, bicicletas y tranvías, que fortifican la sensación incesantemente móvil del intercambiador. Ver «Aparcamiento y terminal de tranvías Hoenheim-Nord». El Croquis, 103, Madrid, 2001, pp. 140-157.

14. Otro tanto le ocurre, aunque a menor escala, al espacio de aparcamiento, en el que las líneas divisorias de las distintas plazas, aun perfectamente ordenadas y sistematizadas, parecen muescas infligidas al asfalto con violencia y desenfreno. Ver «Intercambiador, Estrasburgo (Francia)». AV Monografías, 91, Madrid, 2001, pp. 98-103 y «Car park and terminus Hoenheim-Nord» en Zaha Hadid. Complete works. Vol. I..., op. cit., pp. 42-59. 


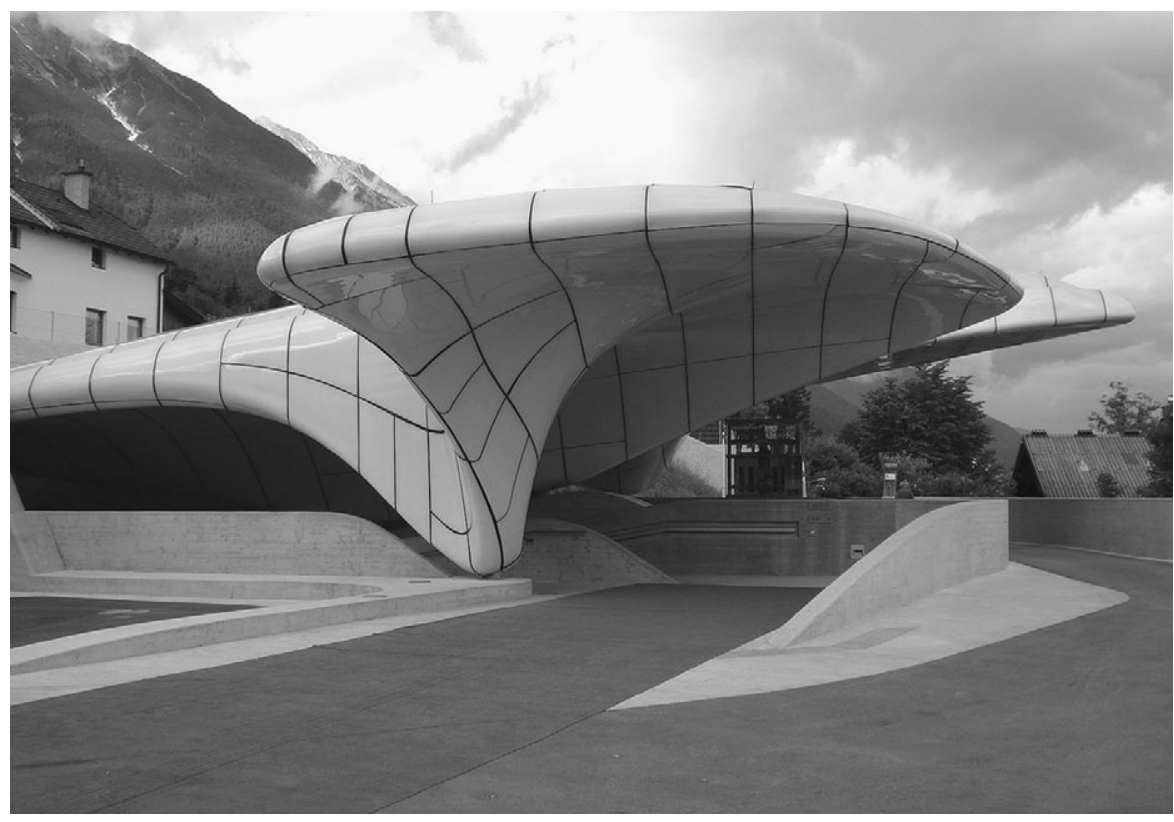

Figura 5.

resulta inspiradora a Hadid en un nuevo equipamiento urbano que, lejos de materializar o simbolizar su trivial dulzura de mujer, hace del valor, el arrojo, la capacidad de superación y la fuerza su razón de ser. Nos referimos a las cuatro estaciones (figura 5), el funicular Nordpark ${ }^{15}$, el puente Innsbruck $(2004-2007)^{16}$ y la pista de saltos de esquí del monte Bergisel (1999-2002) ${ }^{17}$ (figura 6) que crea en Innsbruck (Austria). Igual que en los ejemplos ya entrevistos, nada mejor que el entorno en que radica el trabajo para definir la obra en cuestión de energía y analogía. Así pues, son ahora las montañas nevadas y los desprendimientos de nieve a ellas asociados los elementos estimulantes para Hadid quien, en virtud de tales formas, opta por dibujar esquemas

15. Tras ganar el concurso convocado al efecto.

16. «Un alud congelado de Zaha Hadid en Tirol». Arquitectura Viva, 113, Madrid, 2007, p. 7.

17. Esta última acompañada de una cafetería y una terraza-mirador. La obra es fruto del éxito de Hadid en un concurso de arquitectos en el que se alza con el primer premio (diciembre 1999). Ver «Pista de saltos de esquí en Bergisel». El Croquis, 103, Madrid, 2001, pp. 194-197; «Bergisel ski jump» en Jodidio, Philip. Architecture now! Vol. III. Colonia, Taschen, 2008 (2005), pp. 192-197 y «Bergisel sky jump» en Zaha Hadid. Complete works. Vol. I..., op. cit., pp. 118-129. 


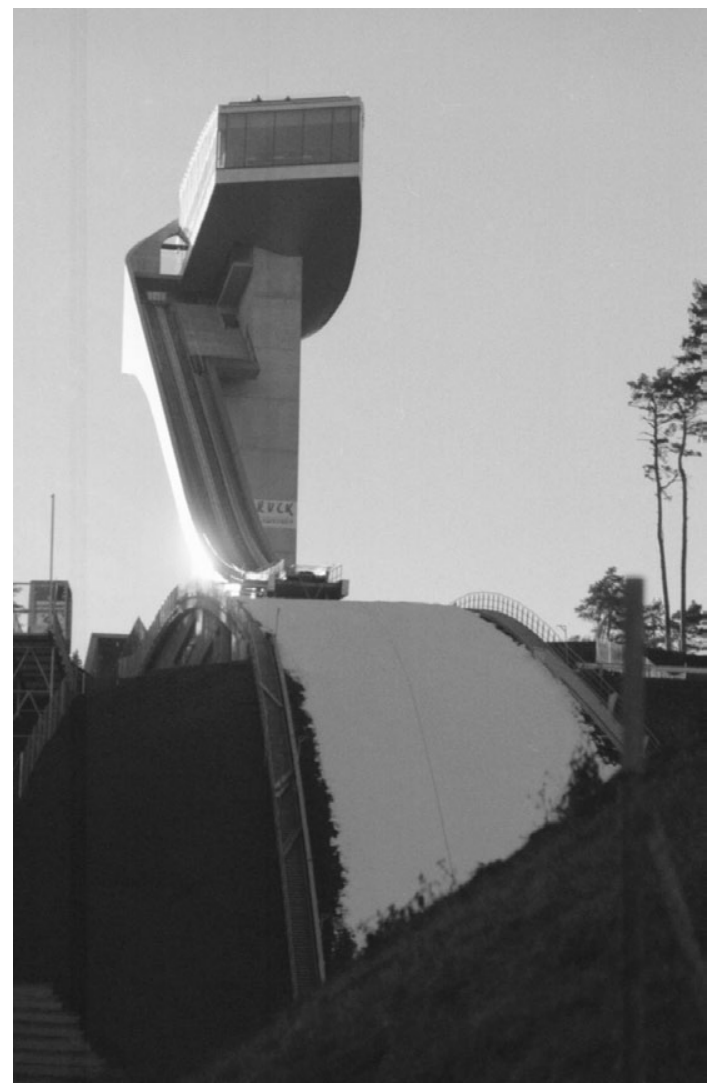

Figura 6.

ondulados y redondeados a partir del vidrio, material que más y mejor se asocia a la cualidad transparente y fría del hielo. Consciente de lo difícil que resulta competir con la magnificencia de las grandes alturas cubiertas de nieve, la arquitecta propone aquí, con mayor evidencia que en otros ejemplos, un caso de mímesis con el contexto de modo que, antes de querer completar sus formas naturales con las impuestas de modo artificial, el resultado se plantea en términos de sometimiento y admiración ${ }^{18}$. De hecho, no son escasas

18. No obstante, la pista de saltos de esquí pronto se define como un nuevo hito significativo del perfil de Innsbruck; detalle éste prácticamente ineludible al trabajo realizado, en cualquier lugar del mundo, por los arquitectos más consagrados a escala internacional cuyas obras, de tales, pasan en breve a ser consideradas nuevos monumentos urbanos o paisajísticos de los enclaves en que se asientan (y ello incluso de modo no pretendido, pues no en vano Hadid insistió, en su planteamiento del trabajo, en su afán de «realzar 
las comparaciones entre estos equipamientos y grandes esculturas heladas -a escala arquitectónica- nacidas de los caprichos de la naturaleza ${ }^{19}$. En efecto, todos ellos dibujan formas que, en mayor o menor grado de complicación, hacen de la línea ondulada una constante en la que los bultos se contraen o expanden dibujando pliegues aerodinámicos que sirven a la orografía específica de cada enclave -más o menos compleja, más o menos inclinada, más o menos sometida a las necesidades de uso (sobre todo en el caso de la pista de saltos...) $)^{20}$. Fluidez y ligereza compensan la fuerza y pesadez de sus anteriores diseños y demuestran la versatilidad de Hadid a la hora de manifestar con sus obras su capacidad como arquitecta al servicio de cualquier necesidad constructiva del mundo real, aquel que, lejos de tópicos o limitaciones de género, precisa cubrir todo un espectro de exigencias con autores que, más allá de su sexo, han de ser competentes en sus resultados.

El organicismo que suele tipificar las definiciones de los trabajos de Hadid (y que, más allá del tópico, es una realidad en sus bocetos, proyectos y dibujos) es evidente en los diseños austriacos, definidos con términos como fluctuantes, móviles o transparentes. Idénticos adjetivos se aplican también a otra de sus «potentes»-funcional y simbólicamente- composiciones: la fábrica y salón de exposiciones que en Leipzig (Alemania) diseña para la consolidada corporación BMW entre 2001 y $2005^{21}$. En efecto, y pese a la multiplicidad de funciones del centro (o quizá como consecuencia de ello), éste actúa como un nudo plástico de fuerzas-equipamientos que se interconectan entre sí y con el contexto industrial de los alrededores hasta generar no tanto un resultado constructivo aislado como una fibra fluida y articulada en la que predominan la claridad, sencillez y eficacia (tan germanas por otro lado) de las comunicaciones. A partir de dos trazos que, en forma de ángulo, parecen buscar su acoplamiento $^{22}$, la energía se canaliza dentro de los espacios pero se irradia en todas las direcciones, incluso en el vacío que queda entre ellos o en los extremos en que parecen difuminarse las elásticas líneas. Sólo así el conjunto expresa la impronta de velocidad que de hecho transmite, «como si estuviera

el paisaje» con él. Ver «Pista de esquí de Bergisel» en WeLLS, Matthew. Rascacielos. Las torres del siglo XXI. Rivas-Vaciamadrid, H. Kliczkowski, 2005, pp. 104-109.).

19. Se comparan, en efecto, con la «imagen de un chorro congelado que manara de la ladera de la montaña».

20. Sólo posibles gracias al empleo, en su diseño, de programas informáticos parejos a los empleados en la industria del automóvil, la naval o la aeronáutica. Ver «Lenguas de hielo». Arquitectura Viva, 114, Madrid, 2007, pp. 88-93.

21. Merced alzarse vencedora en el concurso celebrado en abril de 2002.

22. Y que se dedican, cada uno, a las dos principales funciones del complejo: showroom y centro de producción de la marca. 


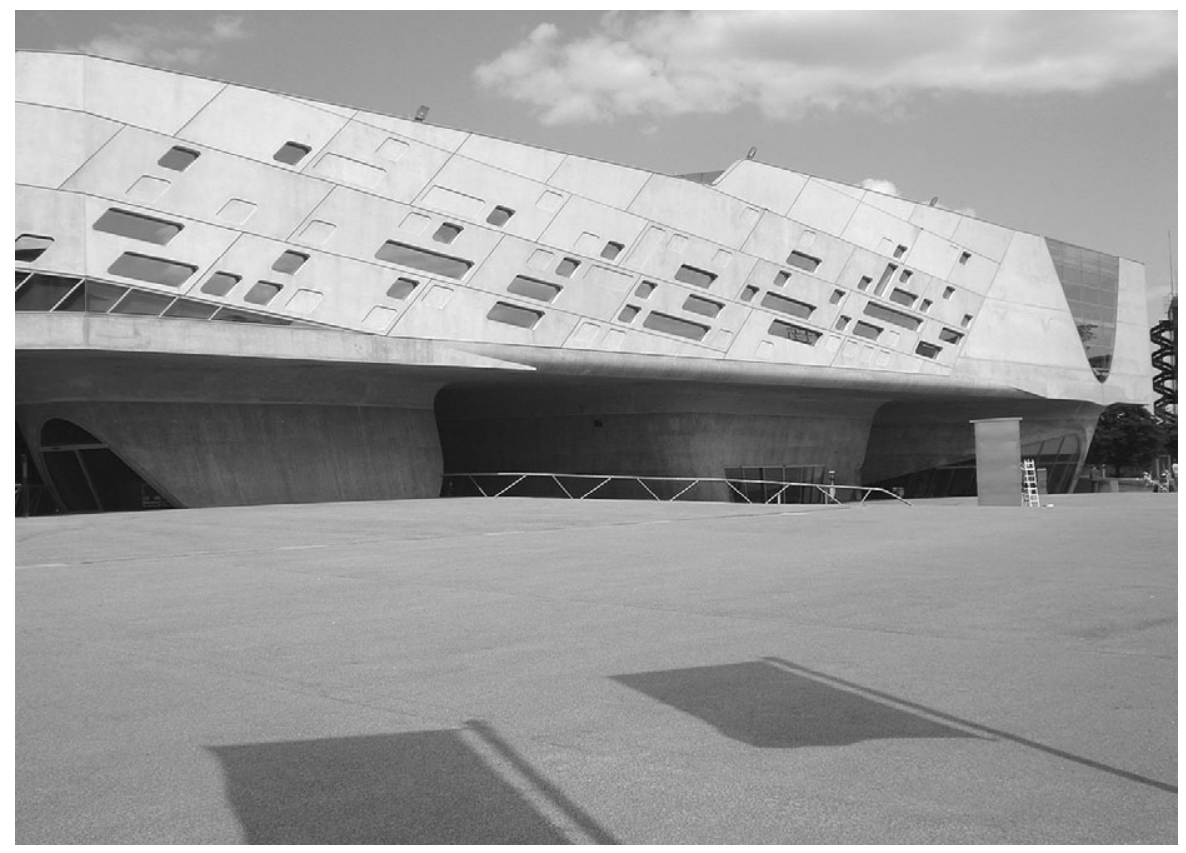

Figura 7.

a punto de arrancar a rodar, al igual que los automóviles que se fabrican en su interior ${ }^{23}$.

Una vez más la señal orgánica, de ascendencia botánica por su aparente caos, que tiende a caracterizar la obra de Hadid, es puesta de manifiesto en un complejo insólito que es descrito en términos naturalistas por los expertos, quienes recurren a comparaciones con ramas, brazos, serpientes, erupciones de la corteza terrestre o tentáculos para expresar la fuerza centrípeta del dise$\tilde{n} \mathrm{O}^{24}$. Pese a que se trata de una impronta lógica en la trayectoria de su autora, lo cierto es que ese afán de protagonismo explícito que observa el centro responde aquí a su asumida categoría de edificio matriz de un complejo de naves industriales del que forma parte, lo que le lleva no sólo a ocupar la máxima

23. «BMW plant Leipzig-central building» en JODIDIO, Philip. Architecture now! Vol. IV. Colonia, Taschen, 2009 (2006), p. 123.

24. «Serie Z». Arquitectura Viva, 106, Madrid, 2006, pp. 52-59; «BMW plant central building» en Zaha Hadid. Complete works. Vol. I..., op. cit., pp. 160-171 y «Zaha Hadid: un centro BMW 'fluido'» en <http://www.domusweb.it/it/architecture/zaha-hadid-uncentro-bmw-fluido/>, publicado el 03-05-2002 y consultado el 05-02-2011. 
y más enrevesada superficie posible sino también a multiplicar su altura con respecto a los bloques vecinos para así no dejar lugar a la más mínima duda sobre su condición estrella $a^{25}$. La necesidad práctica de conducir y dirigir los flujos humanos y de transporte a través de este gran centro $^{26}$ se une pues a condicionantes de tipo simbólico y expresivo que tan caros son a la arquitecta, cómoda a la hora de articular trabajos cargados de tan distintos condicionantes. Lo funcional, efectivo, rápido, competitivo o resolutivo se unen a lo fácil, sencillo, cómodo, sociable, abierto o accesible en un resultado que, más allá de su posible validez o interés, pretende erigirse en prototipo de un modelo de espacio laboral con visión de futuro y afán de perfección y trascendencia.

Si bien ya entra dentro de la tónica constructiva de Hadid, merece la pena hacer mención también aquí al empleo de materiales consolidados por el uso y, en ese sentido, accesibles y asequibles, garantía de éxito y fiabilidad además de una prueba más de cómo desde la seguridad de principios sólidos y establecidos, no problemáticos, es posible seguir iluminando al mundo constructivo con propuestas insólitas. Así, la estructura sustentante recurre al hormigón armado y a las vigas de acero, siendo este último, junto al aluminio, el encargado de envolver las superficies y cerrar las cubiertas aunque en aras de la máxima permeabilidad, transparencia y democratización del espacio, el vidrio se erige también, como es lógico, en componente indispensable.

Sin abandonar Alemania, el Centro de la Ciencia Phaeno de Wolfsburg (200027-2005) incide en muchos de los principios conceptuales ya desarrollados a lo largo de este texto en los ejemplos comentados pues, no en vano, es retratado en los medios como un "paisaje fruto de procesos geológicos aún por concluir $»^{28}$. Semejante descripción evoca, como de hecho ocurre, a una nueva formación masiva de hormigón (en forma de malla romboidal casetonada en algunos puntos) en la que predominan los trazos lanzados y proyectados con fuerza que chocan, antes que confluyen, en agudos ángulos, algunos desarrollando sorprendentes voladizos (figura 7). La capacidad para imponerse y dominar el solar triangular -habilidad que algunos podrían encontrar masculina en su rotundidad-queda de nuevo de manifiesto en el trabajo de

25. Y generando además entre los críticos un nuevo símil literario: el de las estructuras de Hadid comparadas con ballenas. Ver «Top gear». The architectural review, 1300, Londres, 2005, pp. 50-61.

26. Pues, no en vano, el edificio es atravesado por la cadena de producción de la fábrica de vehículos, que queda a la vista de visitantes y empleados.

27. En enero de ese año la propuesta de Hadid logra el triunfo en el concurso internacional convocado al efecto.

28. «Centro de la Ciencia, Wolfsburg (Alemania)». AV Monografías, 107, Madrid, 2004, pp. 70-77.

Feminismo/s 17, junio 2011, pp. 297-319 


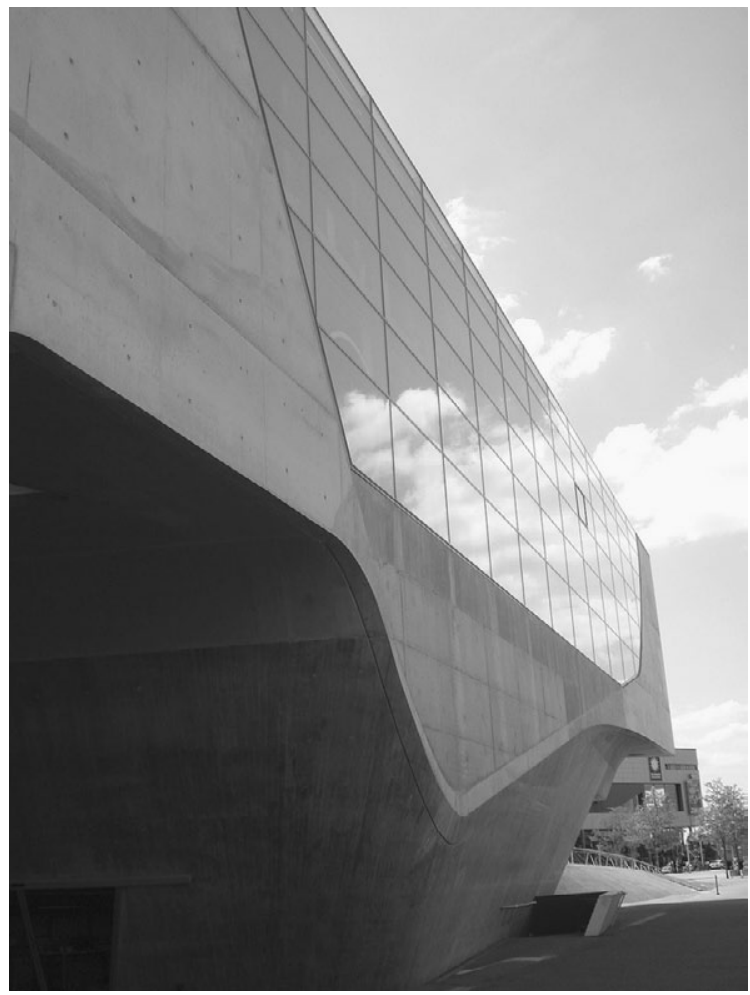

Figura 8.

Hadid, cargado de la energía, dinamismo y potencia que tan adecuadas resultan a la caracterización simbólica del centro ${ }^{29}$. Sin embargo, y pese a su rotundidad (figura 8), como en casos anteriores la arquitecta ha manifestado su explícita voluntad de tener en cuenta un contexto predeterminado que ha estudiado con atención y al que ha tratado de satisfacer ${ }^{30}$. La sospecha entre sus críticos, una vez más también, es si realmente lo ha conseguido o el ímpetu y magnitud de su creación (y de su ego) sobrepasa y fagocita cuanto la rodea.

Más allá de estas reflexiones, ya repetidas en otros puntos de esta disertación, la máxima novedad radica aquí en la combinación de los vectores fluidos y complejos, al tiempo que aparentemente caóticos o convulsos propios

29. Que aglutina, además, un aparcamiento subterráneo, una cafetería, una tienda, un restaurante y un auditorio.

30. «Fenómeno físico». Arquitectura Viva, 101, Madrid, 2005, pp. 54-63. 
de esta autora, con un conjunto de diez conos estructurales asimétricos que atraviesan en vertical los alzados, fragmentándolos, al tiempo que los soportan, elevan la cota de superficie del edificio ${ }^{31}$, canalizan las circulaciones del centro (con accesos y pasillos) ${ }^{32}$ y permeabilizan visual y físicamente la planta baja hasta otorgarle, casi, categoría de plaza pública. Por añadidura, e incidiendo en la inspiración naturalista del proyecto, la presencia de estos troncos de cono o embudos se compara con la de los cráteres de una superficie volcánica que facilitan al espectador, mediante un único golpe de vista, una sensación panorámica y diagonal de los diferentes estratos del edificio ${ }^{33}$.

Cuando la impronta futurista pero también sospechosamente repetitiva de algunos de estos trabajos de Hadid parece hacer mella en la capacidad de sorprender de su autora, ésta se redime de las opiniones de quienes ven en su reciente quehacer cierta sensación de desgaste con el diseño del pabellón puente con destino a la Expo 2008 de Zaragoza; infraestructura que, además de principal acceso, estrella arquitectónica de la cita y meta codiciada de ingenieros por su complejidad, potencia y reciedumbre, reafirma la versatilidad de Hadid a la hora de hacerse responsable de toda clase de encargos, incluidos aquellos que, como éste, traen aparejados un componente ingenieril (y, en ese sentido, práctico, eficiente, robusto) que inconsciente e injustamente parece reñido con la categoría estética de un resultado original nacido de la mente de una mujer.

La obra, firmada también por el constante y fiel colaborador de Hadid, Patrick Schumacher ${ }^{34}$, es considerada por el jurado del concurso celebrado en 2005 la más adecuada de las cuarenta y una soluciones presentadas ${ }^{35}$ para unir los 260 metros que separan los distintos recintos del complejo ferial con la ciudad de Zaragoza (a través del barrio de la Almozara) salvando al río Ebro y haciéndolo a través de una estructura que, como se verá, no responde a la vertiente fugaz o efímera de otros de los pabellones de la cita sino que adquiere visos de permanencia ${ }^{36} \mathrm{y}$, por tanto, de representatividad, visión de

31. A siete metros por encima del nivel del suelo.

32. «Phaeno Science Center Wolfsburg» en Arquitectura para la cultura. Barcelona, Links, 2006, pp. 106-117.

33. «Centro de la Ciencia en Wolfsburg». El Croquis, 103, Madrid, 2001, pp. 198-213 y «Phaeno Science Centre» en Zaha Hadid. Complete works. Vol. I..., op. cit., pp. 144-159.

34. Y asistida por la firma de ingenieros Ove Arup.

35. Entre las que también figuran las de grandes nombres de la constructiva actual como Rafael Moneo o Richard Rogers.

36. Al término de la muestra se pretende convertirlo en un museo del agua y su relación con las nuevas tecnologías. «Pabellón puente Zaragoza». AV Proyectos, 25, Madrid, 2008, pp. 67-83. 


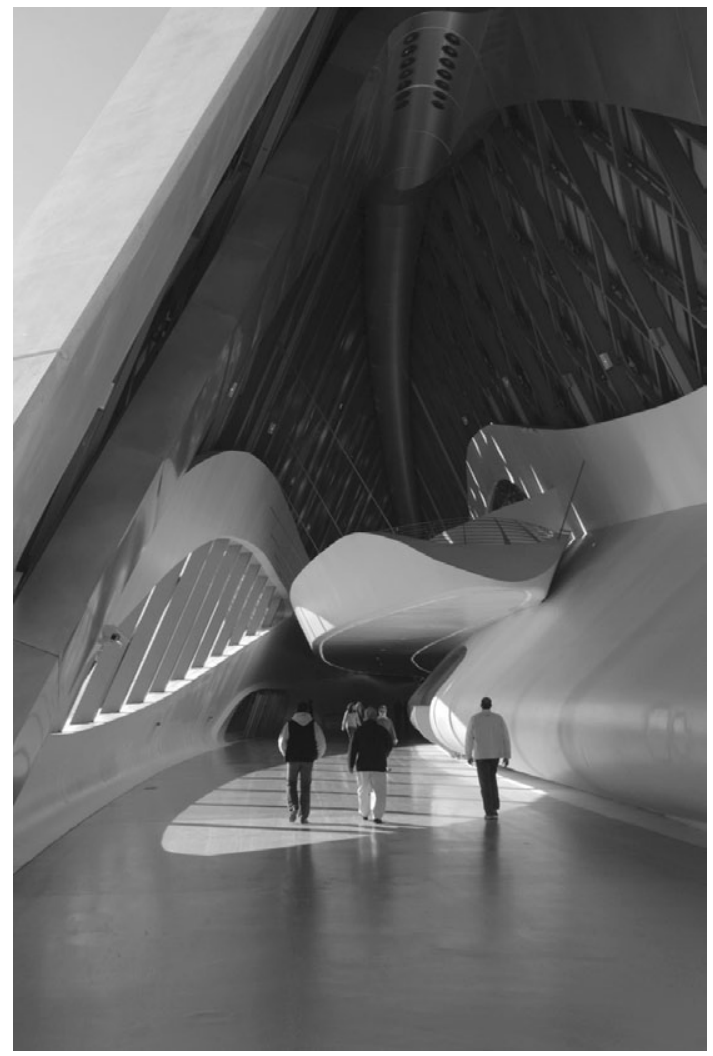

Figura 9.

futuro y compromiso con la proyección de una imagen fresca y futurista de la capital aragonesa. Esa combinación de desenfado y riesgo, de modernidad no pretenciosa adquiere pues, de la mano de las dinámicas obras de Hadid, carta de naturaleza en un trabajo que, como otros de esta autora, expresa su carácter vanguardista desde la admiración por la naturaleza y las formas en que ésta se desenvuelve. Además, en el caso presente hay que tener en cuenta el leitmotiv de la cita zaragozana, que no es otro que el agua como fuente de vida y energía, como recurso indispensable para la existencia humana, como emoción y diversión y, por ello, más que protagonista, resulta la homenajeada de un encuentro en el que todo ocurre a su alrededor.

Combinando los apriorismos del encargo con las particularidades, ya definidas, del quehacer de Hadid, no extraña el resultado, a la vez fluido y orgánico; un pabellón-puente líquido en su fluctuación, móvil y reptante, cual 
serpiente que, pese a esa evidente referencia naturalista, encuentra otras más acusadas, como aquellas que la comparan con la flor del gladiolo (figura 9) o con la superficie escamosa pero tersa y brillante del lomo de un tiburón. En efecto, las superficies exteriores del caparazón se envuelven mediante placas romboidales de FRC (Fibre Reinforced Composite) solapadas que rememoran el aspecto lustroso, duro y metálico de la piel de un escualo.

A partir de semejante aspecto se diseña una estructura que, además de unir mediante una pasarela peatonal las dos orillas del río sirve, como se ha comentado, de recinto expositivo a la exhibición maña ${ }^{37}$; usos ambos que pretende mantener toda vez que Agua para el desarrollo finalice el 14 de septiembre de $2008^{38}$. Sin embargo, más allá de su funcionalidad, lo que ha atraído la atención sobre este ejercicio es la capacidad de Hadid de infundir energía y elegancia a una macro-estructura que, por sus características, desarrolla unas particularidades técnicas importantes. Así, por un lado, a partir de un tronco común y desde una isla ubicada en el centro del Ebro (que actúa como único apoyo del puente $)^{39}$, la superficie se desgaja en tres capullos, cada uno de ellos diseñado como un recinto autónomo y más o menos abierto que desarrolla una función expositiva o actúa como conductor de los flujos circulatorios (figura 10). A estos señalados símiles orgánicos se unen algunos más, como aquellos que insisten en el carácter ligero, casi volátil del resultado (contrario a su esencia estable $)^{40}$; resultado que por su fluidez parece azotado por la característica Tramontana que suele soplar en Zaragoza ${ }^{41}$.

Los problemas a que se ha enfrentado Hadid con este trabajo, al igual que le ha ocurrido en otros lugares en los que ha desplegado su inventiva, han sido de orden económico (por los ingentes y disparados costes de sus intervenciones), de tipo técnico (por su manifiesta dificultad de realización) ${ }^{42}$ y en materia de indigestión visual. Del mismo modo que en las obras alemanas aquí analizadas, incluso quienes alaban su fantasía se quejan de la

37. «¿Qué mejor lugar que un pabellón sobre el agua para montar una exposición que tiene el agua por protagonista?», razona Enric Batlle, uno de los arquitectos del Grupo Experiencia, redactores del Plan de la Candidatura de la Expo'08.

38. La exposición se inauguró el 14 de junio de ese mismo año.

39. «Pabellón puente Zaragoza». AV Proyectos, 12, Madrid, 2005, pp. 12-19.

40. En la sinuosidad, interconexión, continuidad y conectividad insiste Hadid en sus reflexiones sobre una obra que hace realidad, más de una década después, su proyecto de puente habitable, como el diseñado para el Támesis en Londres. Ver p. 4 de este artículo y HADID, Zaha. «Pabellón Puente de Zaha Hadid Architects para la EXPO Zaragoza 2008» en Puentes de España. Tránsitos de culturas. Barcelona, Lunwerg, 2009, pp. 207-208.

41. «Gladiolo con escamas». Arquitectura Viva, 117, Madrid, 2007, pp. 32-37.

42. Con los consiguientes problemas de plazos que ello conlleva, entre otros inconvenientes. 


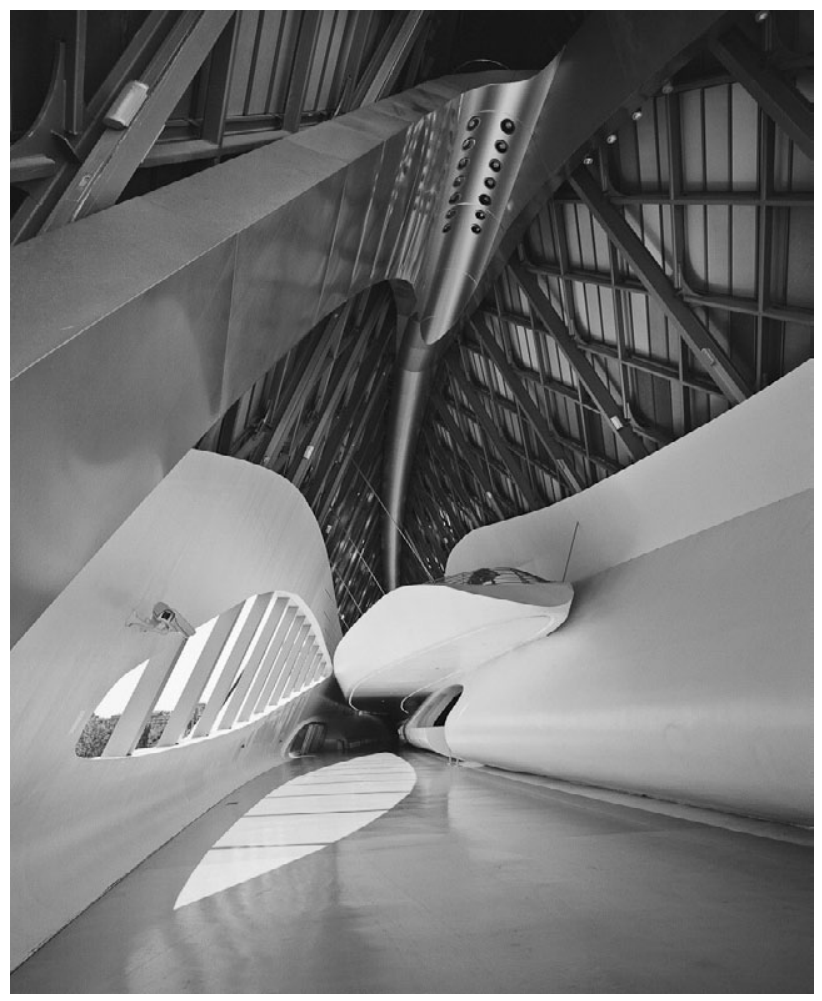

Figura 10.

incompatibilidad de la misma con las más mínimas dosis de modestia o desapercibimiento, lo que se traduce en una «incontinencia expresiva $»^{43}$ que no a todos agrada pero a la que parece que muchos especialistas, amplios sectores de público y la práctica totalidad de los promotores no pueden resistirse ${ }^{44}$. El golpe de efecto que supone la presencia en Zaragoza de este icono de la constructiva del tercer milenio resarce cuantos quebraderos de cabeza y críticas pueda suscitar el proceso y su resultado; hecho confirmado porque, pese a todo, Hadid sigue recibiendo encargos y ganando concursos en los más variados rincones del planeta, ratificando que los retos a que su estudio y sus clientes

43. Moix, Llàtzer. Arquitectura milagrosa. Hazañas de los arquitectos estrella en la España del Guggenheim. Barcelona, Anagrama, 2010, p. 17.

44. Un completo y punzante estudio del largo, difícil y farragoso proceso de construcción del pabellón-puente de Zaragoza es el ofrecido por Moix, Llátzer, op. cit., pp. 113-132. 
se enfrentan se ven recompensados en presencia pública, protagonismo mediático y polémica arquitectónica.

Los trabajos aquí analizados no son más que algunos de los muchos que podrían glosar este recorrido atípico y desmitificador en torno a la carrera constructiva de Hadid. A ellos, aunque sólo en la categoría de citas, hemos de añadir varios más, todavía en proceso de desarrollo y definición como, por ejemplo, el puente Sheikh Zayed en Abu Dhabi (1997-i2010?), la estación de tren de alta velocidad Napoli-Afragola de Nápoles (2003-i2012? $)^{45}$, la terminal marítima de Salerno $(2000-i \text { ? })^{46}$ o el juzgado de lo civil para la futura Ciudad de la Justicia de Madrid $^{47}$, pendiente desde 2007 de que mejore la coyuntura económica general, sumida en una grave crisis internacional, que permita dotarlo de la financiación necesaria para su materialización.

Todos, y aun los que están por venir, conforman una trayectoria profesional que, pese a las polémicas, críticas y controversias tan habituales por otro lado en el mundo actual de la arquitectura de los grandes popes internacionales, no es posible leer en clave tópicamente femenina, pues si bien la sensualidad, la ondulación, la ligereza y la suavidad caracterizan muchos de los trabajos de Hadid, lo cierto es que la fuerza, el impulso, la osadía o la potencia también resultan epítetos adecuados a sus construcciones, alejadas así de cualquier lugar común que tenga que ver con su condición de mujer. De este modo, cuanto de femenil pueda tener el trabajo de Hadid tiene más que ver con su sensibilidad como ser humano y artista o con su concepción de la originalidad arquitectónica que con su género, si bien es cierto que tan peculiar noción estética se ha convertido en una seña de identidad que, a la hora de ser definida, se ve cómodamente representada en los valores comentados, repetidos hasta la saciedad, con más o menos variantes, por cuantos especialistas y críticos enjuician su trabajo.

Si bien el objetivo del artículo era plantear la arquitectura de Hadid en términos de equidad con el resto de arquitectos encumbrados al más alto escalafón de la pirámide mundial del éxito constructivo (la mayoría de ellos hombres), minimizando pues el impacto que en su obra tiene el hecho de ser mujer, es preciso analizar su progresión en un aspecto que, este sí, guarda

45. «Estación de metro Napoli-Afragola». AV Proyectos, 30, Madrid, 2008, pp. 8-9; «NapoliAfragola High-Speed Train Station» en Zaha Hadid. Complete works. Vol II..., op. cit., p. 24 y «Hadid progetta la nuova stazione di Napoli» en <http://www.domusweb.it/it/ architecture/hadid-progetta-la-nuova-stazione-di-napoli/>, publicado el 06-10-2003 y consultado el 05-02-2011, entre otras referencias.

46. «Maritime Terminal» en Zaha Hadid. Complete works. Vol II..., op. cit., p. 51.

47. «Juzgados de lo civil del Campus de la Justicia, Madrid». AV Proyectos, 21, Madrid, 2007, p. 14. 
fuertes vínculos con las dificultades y particularidades que pueden llegar a experimentar las féminas en su recorrido profesional. En efecto, la arquitecta, como cualquier mujer trabajadora, independiente y, en ese sentido, triunfadora, ha alcanzado ese punto de gloria no sólo gracias a su esfuerzo, tesón, capacidad, suerte o inteligencia (pues en ello se encuentra en condiciones de igualdad con sus colegas masculinos) sino que, además, ha debido lidiar con ciertos paternalismos condescendientes, veladas críticas a su temperamento caprichoso (como si no existiera la figura del divo) y comentarios sentimentalistas los cuales responden a una imagen tópica, quizá también inconsciente, que tiende a asociar la figura del arquitecto con un prototipo que no se corresponde, todavía para algunos, con la doble condición de Hadid de artista y mujer. El paradigma convencional de la figura del proyectista queda pues hecho añicos de la mano de una creadora quien en sus obras, además, también ha tratado de dinamitar cualquier imagen preconcebida o convencional que pudiera tener el espectador del siglo XXI acerca de qué es la arquitectura en el mundo actual.

\section{Referencias Bibliográficas}

Arquitectura para la cultura. Barcelona, Links, 2006.

BETSKY, Aaron. Zaha Hadid. The complete buildings and projects. Nueva York, Rizzoli, y Londres, Thames \& Hudson, 1998.

JoDidio, Philip. Architecture now! Vol. III. Colonia, Taschen, 2008 (2005).

JODIDIO, Philip. Architecture now! Vol. IV. Colonia, Taschen, 2009 (2006).

Jodidio, Philip. Architecture now! Vol. V. Colonia, Taschen, 2007.

MoIX, Llàtzer. Arquitectura milagrosa. Hazañas de los arquitectos estrella en la España del Guggenheim. Barcelona, Anagrama, 2010.

Puentes de España. Tránsitos de culturas. Barcelona, Lunwerg, 2009.

WeLLS, Matthew. Rascacielos. Las torres del siglo XXI. Rivas-Vaciamadrid, H. Kliczkowski, 2005.

Zaha Hadid. Complete Works. Major and recent works. Vol. I. Nueva York, Rizzoli y Londres, Thames \& Hudson, 2004.

Zaha Hadid. Complete works. Projects and documentation. Vol. II. Nueva York, Rizzoli y Londres, Thames \& Hudson, 2004.

\section{Referencias Hemerográficas}

«Aparcamiento y terminal de tranvías Hoenheim-Nord». El Croquis, 103, Madrid, 2001, pp. 140-157.

«Centro de la Ciencia en Wolfsburg». El Croquis, 103, Madrid, 2001, pp. 198-213. 
«Centro de la Ciencia, Wolfsburg (Alemania)». AV Monografías, 107, Madrid, 2004, pp. 70-77.

«Estación de bomberos de Vitra». El Croquis, 73-1, Madrid, 1995, pp. 38-61.

«Estación de metro Napoli-Afragola». AV Proyectos, 30, Madrid, 2008, pp. 8-9.

«Fenómeno físico». Arquitectura Viva, 101, Madrid, 2005, pp. 54-63.

«Gladiolo con escamas». Arquitectura Viva, 117, Madrid, 2007, pp. 32-37.

«Intercambiador, Estrasburgo (Francia)». AV Monografías, 91, Madrid, 2001, pp. 98-103.

«Juzgados de lo civil del Campus de la Justicia, Madrid». AV Proyectos, 21, Madrid, 2007, p. 14.

«Lenguas de hielo». Arquitectura Viva, 114, Madrid, 2007, pp. 88-93.

Mostafavi, Mohsen. «El paisaje como planta». El Croquis, 103, Madrid, 2001, p. 20.

«Pabellón puente Zaragoza». AV Proyectos, 12, Madrid, 2005, pp. 12-19.

«Pabellón puente Zaragoza». AV Proyectos, 25, Madrid, 2008, pp. 67-83.

«Pista de saltos de esquí en Bergisel». El Croquis, 103, Madrid, 2001, pp. 194-197. «Serie Z». Arquitectura Viva, 106, Madrid, 2006, pp. 52-59.

«Top gear». The architectural review, 1300, Londres, 2005, pp. 50-61.

«Un alud congelado de Zaha Hadid en Tirol». Arquitectura Viva, 113, Madrid, 2007, p. 7.

«Vitra. Estación de protección contra incendios». El Croquis, 52, Madrid, 1992, pp. 110-125.

\section{Referencias Informáticas}

«Hadid progetta la nuova stazione di Napoli» en <http://www.domusweb.it/it/architecture/hadid-progetta-la-nuova-stazione-di-napoli/>, publicado el 06-102003 y consultado el 05-02-2011.

«Zaha Hadid: un centro BMW 'fluido'» en <http://www.domusweb.it/it/ architecture/zaha-hadid-un-centro-bmw-fluido/>, publicado el 03-05-2002 y consultado el 05-02-2011. 



\section{Asunción Oliva Portolés}

\section{Vetas de Ilustración. Reflexiones sobre feminismo e Islam, de Cèlia Amorós Puente, (Madrid, Cátedra, 2009, 312 p.)}

Quien comience la lectura de este libro, en el que se habla de feminismo y del Islam, puede suponer que representa una cisura respecto a las obras anteriores obras de Cèlia Amorós. Y, sin embargo, esta impresión es totalmente equivocada. Vetas de Ilustración es, ante todo, una obra poliédrica, de múltiples caras, vértices y aristas entre las que la autora elige seguir una, la vincula con otras, apareciendo nuevas cuestiones, nuevas conclusiones y nuevos interrogantes, aunque siempre, por debajo de todo ello, se sienta fluir el mismo río de inquietudes que Amorós ha manifestado en sus libros anteriores. Por eso esta obra se puede considerar una continuación de La gran diferencia ${ }^{1}$ en donde no sólo insiste en su crítica al pensamiento de la diferencia sexual para poder reivindicar la igualdad entre mujeres y varones, sino también hace hincapié en las ideas de identidad y subjetividad, de género y de sujeto, de patriarcado y de «contextos de Ilustración», cuestiones que constituyen el preludio de Vetas, obra que, a su vez, entronca con Mujeres e imaginarios de la globalización ${ }^{2}$. En esta reseña me sería imposible comentar todos los aspectos que componen el libro, de modo que voy a fijarme en los cinco ejes conceptuales que considero imprescindibles para entender la finalidad del ejercicio de pensamiento crítico que la autora realiza.

El primero de estos ejes es el de la cultura. Desde el primer capítulo se impone como cuestión esencial la crítica al multiculturalismo (al que Amorós opone el concepto de multiculturalidad) y para ello analiza esta noción desde la perspectiva de dos destacados autores dentro de la antropología cultural: Claude Lévi-Strauss y Clifford Geertz. La autora señala que, aunque hoy

1. Amorós, C., La gran diferencia y sus pequeñas consecuencias...para la lucha de las mujeres, Madrid, Cátedra, 2005

2. Amorós, C., Mujeres e imaginarios de la globalización. Reflexiones para una agenda teórica global del feminismo, Editorial Homo Sapiens, Rosario, 2008. 
resulta ya difícil poner en cuestión seriamente la unidad de la especie humana, no parece ocurrir lo mismo con la unidad de las culturas. ${ }^{3}$ Lévi-Strauss contempla la cultura como el conjunto de sistemas simbólicos, entre los que ocupan un primer plano el lenguaje y las estructuras de parentesco. En una de sus primeras obras, Tristes Tropiques (1955), afirma que el conjunto de las costumbres de un pueblo forma sistemas, los cuales no existen en número ilimitado ni se crean de la nada, sino que se escogen ciertas combinaciones dentro de un repertorio ideal que él cree que sería posible reconstruir. Considera que en cada sistema (de parentesco, mitológico, etc.) se ponen en funcionamiento los a priori de la función simbólica de la mente humana y después habría que encajar estos sistemas diferentes en un orden que sería el propio de cada sociedad. La unidad de todos los sistemas (el orden de los órdenes) es más precaria que la de cada sistema por separado: la primera es una unidad de segundo orden mientras que la segunda constituiría la verdadera unidad estructural. ${ }^{4}$

El antropólogo francés reconoce la influencia que ejerció en su concepción de su método la obra de la escuela de Praga, especialmente la fonología estructural de Troubetzkoi y Jakobson. Lévi-Strauss considera la lingüística como la ciencia social más avanzada y desde tal perspectiva procede, en primer lugar, a aplicar el método de la lingüística fonológica a la antropología y, en particular, a los sistemas de parentesco. De esta forma, ya en La estructuras elementales del parentesco (1949) afirma que la estructura de éste tendría «una invariante estructural: la relación respectiva de deudor y acreedor que asumen los varones al intercambiar mujeres de acuerdo con la prescripción de la exogamia.»

En sus primeras obras, la ya citada Tristes Tropiques y Anthropologie structurale (1958) el antropólogo francés hablaba de las culturas estudiadas por los etnógrafos como armoniosas, al menos en un pasado incontaminado, y parecía sentir nostalgia de una sociedad «cristalina». En obras posteriores, como

3. Amorós, C., Vetas de Ilustración, p. 30. Esta cuestión ya fue tratada brillantemente por Amorós desde una perspectiva diferente en su contribución al libro editado por C.Gómez y J.Muguerza, La aventura de la moralidad (Alianza, 2007) en el capítulo «Ética y Antropología». Allí, en el apartado que titula «¿Puede la Antropología identificar universales éticos?» hace una magnífica lectura de L'essai sur le don de M. Mauss donde destaca las diferencias entre Lévi-Strauss, en su ensayo «Introducción a la obra de Marcel Mauss», y el propio Mauss, analizando luego la reconstrucción en clave existencialista que hace Sartre en Cahiers pour une morale de la «reciprocidad mediada» a partir de las concepciones de Mauss.

4. Amorós, obra citada, p. 34. 
en Le regard eloigné $e^{5}$, parece reconocer que el elemento de distorsión de la unidad y coherencia de las culturas estriba en la historia y siente cierta nostalgia de un mundo en el que las diversas culturas pudieran existir sin emitir juicios de valor sobre las demás. Llega a decir: «la lucha contra todas las formas de discriminación participa del mismo movimiento que arrastra a la humanidad hacia una civilización mundial, destructora de los viejos particularismos a los que corresponde el honor de haber creado los valores estéticos y espirituales que otorgan su valor a la vida.» ${ }^{6}$ Así, Lévi-Strauss acaba por dar pie a una visión multiculturalista.

Clifford Geertz, al que se considera el creador de la «antropología simbólica», comparte con el estructuralismo lévi-straussiano la tesis de la cultura como un sistema de símbolos, pero, a diferencia de su antecesor, Geertz no está interesado en los símbolos en sí mismos sino en el modo en el que los símbolos pueden explicar los procesos sociales y, por eso, propone un concepto de cultura esencialmente semiótico. «Creyendo con Max Weber que el hombre es un animal inserto en tramas de significación que él mismo ha tejido, considero que la cultura es esa urdimbre y que el análisis de la cultura ha de ser por lo tanto, no una ciencia experimental en busca de leyes, sino una ciencia interpretativa en busca de significaciones.» El elemento interpretativo es fundamental para él. Geertz que, al igual que Lévi-Strauss, tuvo una primera formación en filosofía, se considera influido por Weber; de hecho sus primeros trabajos de campo fueron en Indonesia y Java, y con ellos intentaba poner a prueba la hipótesis de que, al igual que la ética protestante influyó en el desarrollo del capitalismo y la modernización en Europa, algo parecido podría ocurrir en Indonesia con el islamismo moderado. Geertz mantiene que la Antropología debe limitarse a hacer «interpretaciones plausibles» del significado de la trama simbólica que es la cultura, a partir de la descripción densa ${ }^{7}$ de la mayor cantidad de puntos de vista que sea posible conocer respecto a un mismo suceso. ${ }^{8}$ Es decir, no considera que todos los elementos de la trama

5. París, Plon, 1983.

6. La cita está tomada del libro de Amorós que comento, p. 39.

7. La noción de «descripción densa» (thick description) la toma Geertz del filósofo del lenguaje Gilbert Ryle. Amorós la explica en la p. 44 del libro que comento.

8. «En el intento de lanzarme a esa integración desde el terreno antropológico para llegar así a una imagen más exacta del hombre, deseo proponer dos ideas: la primera es la de que la cultura se comprende mejor no como complejos de esquemas concretos de conducta [...], como ha ocurrido en general hasta ahora, sino como una serie de mecanismos de control -planes, recetas, fórmulas, reglas, instrucciones (lo que los ingenieros de computación llaman «programas») - que gobiernan la conducta. La segunda idea es la de que el hombre es precisamente el animal que más depende de esos mecanismos de control extragenéticos, que están fuera de su piel, de esos programas 
cultural posean el mismo sentido para todos los miembros de una sociedad, sino que pueden ser interpretados de diferentes modos, dependiendo bien de la posición que ocupen en la estructura social, bien de condicionamientos sociales y psíquicos anteriores, o bien, del mismo contexto.

Geertz también estuvo influido por el «segundo» Wittgenstein, como nos advierte Amorós. Para el antropólogo americano los símbolos no se estudian para acceder a los procesos mentales sino como formaciones de los fenómenos sociales. El antropólogo debe desenredar el tejido de los significados e interpretarlos. «La cultura es pública porque el significado es público», afirma Geertz. «Y, justamente, en la medida en que el conocimiento es público, puede ser interpelado», dice nuestra autora. ${ }^{9}$ La visión de la cultura de Geertz, según Amorós, deja de ser una totalidad auto-referida para abrirse a posibles interacciones con las demás.

Nuestra autora vuelve a Lévi-Strauss: «El autor de La estructuras elementales considera que la relación entre las culturas no es precisamente una buena cosa.» $\mathrm{Y}$ es esto lo que inspira las tesis multiculturalista de las culturas como totalidades homogéneas y completas, con lo que se niega la interacción entre ellas y, por tanto, la posibilidad de interpelación, lo que no ocurre con la concepción de Geertz. Y sin la interpelación intercultural no podremos llegar a un concepto de multiculturalidad. Interpelación que debe ser simétrica y no asimétrica, como en tantos casos ocurre. ${ }^{10}$

El segundo aspecto a destacar, estrechamente vinculado con el anterior, es el de la identidad cultural. Según el antropólogo francés Denis Cuche ${ }^{11}$, la moda de la identidad surgió en la década de los 70 como «exaltación de la diferencia» y se ha desarrollado ampliamente con las teorías de Taylor y los comunitaristas. Sin embargo, al estudiar la identidad, Amorós va más atrás: Rousseau es el que posibilita la emergencia de los individuos mediante el

culturales para ordenar su conducta. Ninguna de estas ideas es enteramente nueva, pero una serie de recientes puntos de vista registrados tanto en antropología como en otras ciencias (cibernética, teoría de la información, neurología, genética molecular) las ha hecho susceptibles de una enunciación más precisa y les ha prestado un grado de apoyo empírico que antes no tenían La concepción de la cultura desde el punto de vista de los «mecanismos de control» comienza con el supuesto de que el pensamiento humano es fundamentalmente social y público, de que su lugar natural es el patio de la casa, la plaza del mercado y la plaza de la ciudad.» Geertz, C. «El impacto del concepto de cultura en el concepto del hombre» en La interpretación de las culturas, Barcelona Gedisa, 1989, pp. 43-59.

9. Amorós, obra citada, p. 48.

10. Ibídem, p. 104-109.

11. Cuche, D., La notion de culture dans les sciences sociales, París, Repères, La Découverte, 2001. 
contrato social pero en realidad lo que reconoce es el «individualismo viril juramentado» dejando libre el espacio para las nuevas identidades adscriptivas, esto es, las mujeres» La mujer así recibirá el encargo de conservar lo auténtico como una identidad adscriptiva prescrita por quien fue un crítico radical de toda identidad adscriptiva» ${ }^{12}$, condenando así a las mujeres a la heteronomía moral. La identidad masculina se convierte así en identidad canónica. Afortunadamente mujeres como Mary Wollstonecraft van a impugnar esta argucia de Rousseau.

La célebre definición de Sartre «la libertad es lo que nosotros hacemos de lo que han hecho de nosotros» da pie a Amorós a sostener que, si bien la identidad se relaciona con lo que han hecho de nosotros, es decir, connota pasado y determinación adscriptiva, la subjetividad, que tiene que ver con la libertad, se relaciona con lo que hacemos con aquello que nos ha venido dado y, por tanto, implica futuro, proyecto y elección. Pues bien, lo mismo los varones como las mujeres deberíamos tener tantos referentes de identidad como dimensiones de subjetividad. ${ }^{13}$ Las identidades, pues, no están incrustadas en nosotros, están atravesadas de mediaciones crítico-reflexivas: las subjetividades no son volátiles, deben trascender los muchos estratos simbólicos que tenemos en depósito. Sin embargo, la situación actual no es esa: las mujeres están obligadas a conservar «lo auténtico», tienen lo que M. Le Doeuff llama sobrecarga de identidad, y uno de los aspectos en que esto se pone de relieve es en la vestimenta femenina. Cèlia Amorós analiza el velo islámico desde la teoría de los símbolos de Peirce, así como las razones de los partidarios de resignificar esta prenda y de otras formas de cubrirse aún más agobiantes. Lo que se desprende de sus argumentos es lo que ella denomina el «voluntarismo del significado»: así, existiría la resignificación prudencial, la refuncionalización del velo o la resignificación estoica. ${ }^{14}$ Pero el voluntarismo del significado tiene unos límites: la autora señala una dificultad en el nivel sintáctico, ya que el uso del velo no funciona en el vacío sino que se ve contrapuesto a la vestimenta del varón que puede ser del tipo que él quiera. En el nivel pragmático vemos que quienes tienen autoridad para imponer el vestido modesto a las mujeres son los varones, que así se aseguran el respeto de los demás hombres cubriendo a su mujer. Pues no hay que olvidar que detrás del velo está toda una forma de vida, un «juego de lenguaje» (Wittgenstein) que impone sumisión frente a libertad, signos de identidad frente a subjetividad,

12. Amorós, obra citada, p. 76.

13. Amorós, obra citada, p. 78-79.

14. Ibidem, p. 84-89

Feminismo/s 17, junio 2011, pp. 321-329 
asignación al espacio privado frente a la libre circulación. Por tanto esas resignificaciones no pueden ocultar la «forma de vida» en la que se inscriben. ${ }^{15}$

El tercer aspecto que voy a considerar es la oposición entre Ilustración solipsista e Ilustración alternativa. Parece que cuando hablamos de Ilustración nos referimos sólo a la occidental. Por tanto, si creemos que el feminismo es un hijo no querido de la Ilustración, aunque éste la impugne desde dentro, puede dar la impresión de que en otras culturas no occidentales el feminismo no tendría cabida. Pero eso sería considerar que la Ilustración es sólo un producto de Occidente y, por tanto, las otras culturas tendrían que imitar al modelo (sería la «Ilustración solipsista»). Pues bien, para Cèlia Amorós existe Ilustración en el momento en que se generan determinados procesos críticoreflexivos que dan lugar a ciertas abstracciones con virtualidades universalizadoras. Esto suele ocurrir cuando entran en crisis determinadas legitimaciones y se plantea la necesidad de recurrir a otras nuevas. ${ }^{16} \mathrm{~A}$ estos procesos los llama «vetas de Ilustración» y se trata de analizar cómo y cuándo aparecen en otras culturas.

Sophie Bessis, quien realiza una durísima crítica a la dominación de Occidente ${ }^{17}$ pero que no puede renunciar a los principios ilustrados porque, como señala, son los que le posibilitan realizar esta misma crítica, habla de la búsqueda de universales que puedan acercar a los seres humanos por encima de sus diferencias. «¿Hasta qué punto hay que defender la diversidad cultural, es decir, defender sus singularidades? ¿Hay que considerar que existen unos universales -más allá de esas especificidades- capaces de proporcionar una visión común de la condición humana y de nuestro destino común, o no?» ${ }^{18}$ « ¿Cómo fabricar un universal que integre las aportaciones de la modernidad occidental sin que por ello se confunda con la hegemonía de Occidente?»Y

15. Hace poco tiempo en Madrid tuvo que declarar ante el juez una musulmana en relación con el suceso de la explosión suicida de Leganés que siguió al 11-M. Esta mujer se presentó con burka y sólo accedió, después de negociar con ella, a descubrir la cara ante el juez. Me quedé atónita cuando declaró a la prensa que todo el revuelo montado por su atuendo era «debido a la ignorancia». ¿Qué es lo que ella cree que ignoramos? ¿Que en países como Afganistán y parte de Pakistán el burka es obligatorio para las mujeres y las niñas bajo pena de muerte? En el caso de esta mujer y de algunas más que empiezan a reivindicarlo «voluntariamente» en algunos países europeos no es posible ninguna resignificación. Es una injuria respecto a todas aquellas que se ven obligadas a llevarlo.

16. Amorós, obra citada, p. 233.

17. S. Bessis, Occidente y los Otros. Historia de una supremacía, Madrid, Alianza Editorial, 2002.

18. S. Bessis, Las emergencias del mundo: economía, poder, alteridad, Oviedo, Nobel, 2007 , p. 146-150. 
afirma: «Querámoslo o no existe algo que podríamos llamar cultura universal en formación, basada en los valores fundadores de la modernidad: la igualdad de dignidad y de derechos de todos los humanos, cualesquiera que sea su sexo, raza, condición social, religión etc., que es una idea nueva en el mundo. ¿Querrán negarla porque trastoca muchas culturas?» Amorós concuerda con ella en la idea de que los universales que a partir de esa reflexión se generen deberán ser post-hegemónicos (respecto a Occidente) y post-reactivos (en lo que conciernen a los Otros de Occidente).

El cuarto aspecto que voy a comentar es cómo se manifiestan estas vetas de Ilustración, sobre todo en la cultura que más ha estudiado, la islámica. La autora examina la figura de Qasim Amin, el «Stuart Mill egipcio», como lo llama, y la influencia que tuvo del reformador M. Abduh. Indaga también en todo un conjunto de obras escritas por mujeres, antes y después de Amin, así como se refiere a las luchas de las mujeres egipcias por sus derechos, incluso frente a los nacionalistas que no los respetaban. Dentro de este proceso destaca una figura relevante, la de Taha Husayn, que con una beca estudia en la Sorbona y lee en esa Universidad una Tesis en 1919 sobre la obra de Ibn Jaldún. Sus críticas al atraso de Egipto y la publicación en 1926 de su obra La poesía pre-islámica le hicieron objeto de la ira de muchos pensadores en su país, aunque unos años más tarde fuera reconocido como uno de los más importantes intelectuales egipcios. Su concepción de la razón (que era claramente ilustrada) le llevó a afirmar que la razón egipcia es auténticamente mediterránea por sus interrelaciones profundas con el pensamiento griego; por tanto, entre el egipcio y el europeo no existe ninguna diferencia. ${ }^{19}$ Su figura se sitúa en la intersección de dos culturas a las que desea conciliar. ${ }^{20}$

Vetas de Ilustración existen, pues, en Q. Amin y en T. Husayn, así como en muchas mujeres egipcias declaradamente feministas: Huda Sha'arawi, Doria Shafik y, en la actualidad, Nawal-el-Saadawi. Además, la autora examina detalladamente las ideas de M. Abed al-Yabri, filósofo marroquí, quien propone hoy una revisión del legado filosófico de la cultura árabe con particular insistencia en la obra de Averroes y desde planteamientos que podemos

19. Las referencias a Taha Husayn están tomadas de la obra de M. Nour Eddine Affaya, Occidente en el pensamiento árabe moderno, Fundació CIDOB, Barcelona, 1995.

20. La vida y la obra de la feminista egipcia Doria Shafik que presentó una Tesis en la Sorbona sobre «La femme et le droit religieux de L'Égypte contemporaine» en 1940 tiene algunos puntos en común con la de Taha Husayn. Cf. mi libro La recuperación de una voz marginada: Doria Shafik, feminista egipcia, en Huerga \& Fierro Editores, de pronta publicación. 
considerar ilustrados ${ }^{21}$ Para este autor «no existe una modernidad universal [...] sino múltiples modernidades, diferentes de una época a otra y de un lugar a otro.» Cèlia Amorós interpreta esta frase en el sentido de que hay que buscar vetas de Ilustración en diferentes culturas y épocas y, si fuera posible, hacerlas converger en un horizonte de racionalidad y emancipación humanas. ${ }^{22}$

Por último, voy a comentar la noción, ya introducida por la autora en obras anteriores aunque en ésta la desarrolle más ampliamente, de lo que denomina «los relevos en las heterodesignaciones patriarcales». «La heterodesignación es la adjudicación a un conjunto definido de individuos por parte de otro conjunto determinado de una serie de predicaciones que tienen sobre el primero un efecto de estereotipia». Los designadores asumen la posición de sujetos. Los designados son «los otros». En determinados momentos de desgaste político de los cimientos de legitimidad que sustentaban los antiguos poderes, el primer gesto del grupo de los varones emergentes será el de impugnar los discursos y las prácticas patriarcales ejercidos por el grupo de hombres a los que se quiere relevar. El grupo que quiere remplazar en el poder a los anteriores, toma también el relevo del discurso hegemónico acerca de las mujeres. La feminidad normativa del grupo de varones emergentes se establece en función de la polémica y la lucha por el poder contra los antiguos patriarcas. ${ }^{23}$ Amorós pone gran cantidad de ejemplos; yo me voy a ceñir sólo a dos. El caso de Egipto, en donde la desestabilización de las heterodesignaciones patriarcales desde mediados del siglo XIX hasta la mitad del XX hizo emerger ámbitos nuevos en los que las mujeres tenían más capacidad de maniobra para la autodesignación. En ese momento ya no sirve la legitimación tradicional, sino la racional (Weber), y así lo entienden Q. Amin y las feministas que escriben y luchan en esa época.

El otro caso es el de los emigrados magrebíes en Francia. El patriarcado tradicional se ha resentido en la segunda generación de emigrantes y el poder patriarcal ha dado paso al «sistema de los hermanos», como denuncia Fadela Amara. En este caso no ha habido pacto entre los hermanos para matar al padre y consensuar el "contrato sexual» (Pateman) sino que los padres emigrantes han sido desechados y destruidos por el paro y los hermanos han heredado ese despojo de poder y, en su impotencia, se han hecho fuertes en el último reducto que les quedaba: el control de las mujeres.

21. Al-Yabri, Mohammed Abed, Crítica de la razón árabe. Nueva visión sobre el legado filosófico andalusí, Barcelona Icaria, 2001. También del mismo autor, El legado filosófico árabe. Alfarabí, Avicena, Avempace, Averroes, Abenjaldún, Editorial Trotta, Madrid, 2006.

22. Amorós, obra citada, p. 255.

23. Amorós, obra citada, p. 258-259 
Así, hemos ido viendo como estos cinco ejes están vinculados entre sí: es preciso profundizar en una noción de cultura que haga posible criticar el multiculturalismo «fuerte» que, hoy por hoy, es el más extendido y ello nos lleva a examinar las identidades culturales y la forma de entenderlas, no como caparazones que llevamos sobre todo las mujeres sin poder despojarnos de ellas, sino atravesadas por referentes de subjetividad que nos permitan la interpelación cultural simétrica. Todo ello nos conduce a enjuiciar la Ilustración desde la perspectiva crítico-reflexivo que ella misma introduce, lo que significa que no tiene por qué ser un proceso único, sino que es posible rastrear las potenciales «vetas» de Ilustración en las demás culturas y la forma en la que surgen, especialmente en momentos de erosión de las bases de legitimidad de los antiguos «designadores», que ven cómo es rebatido su patrón de feminidad normativa a fin de imponer otro más conveniente para aquellos que quieren relevarles en el poder.

Sé que en esta reseña sólo he podido apuntar algunas de las grandes líneas de esta obra y que quedaría mucho por comentar. Pero lo importante es que la autora deja hebras sueltas que sabemos que seguirá explorando en las investigaciones por venir. Y eso es lo que todos deseamos y esperamos. 

José Laborda Yneva. «Compartir la vida»

\section{La ciudad compartida de María-Ángeles Durán y Carlos Hernández Pezzi; (Consejo Superior de los Colegios de Arquitectos de España, Madrid, 1998, 245 y 331 páginas.)}

Hace ya algunos años, en los últimos meses de 1998, el Consejo Superior de los Colegios de Arquitectos de España publicó La ciudad compartida, un proyecto editorial compuesto por dos libros con un mismo título aunque con diferentes subtítulos. Si convenimos, de momento, en utilizar el orden alfabético de los apellidos de sus respectivos autores, hemos de decir que el primero de esos libros, compuesto por la socióloga María-Ángeles Durán, añadía el subtítulo Conocimiento, afecto y uso. El otro libro, preparado por el arquitecto Carlos Hernández Pezzi, prefería referirse a El género de la arquitectura en su adición al título. Hasta aquí la referencia fiel al empeño editorial.

Luego, el repaso de las intenciones, objetivos y resultados ofrecidos por cada uno de ambos autores necesita nuevos matices. Una y otro revelan con claridad la diferencia de sus percepciones, de su formación intelectual y de sus vínculos con el género que les es propio. Durán se muestra más consecuente, más dueña de sus saberes y, desde luego, mucho más cercana al afecto. Pezzi, por su lado, antepone su costumbre de abordar las cosas desde un enfoque masculino que se esfuerza por conseguir un acercamiento a los matices del género. No hay casi comparación posible entre ambos textos: ni las referencias que manejan ni las formas de decir ni tampoco la capacidad de persuadir con sus respectivas razones son semejantes. Hemos de preferir a Durán, desde luego; su exposición y conclusiones van a resultarnos objetivamente más sugerentes.

Tal vez no sea éste el momento más que de avisar de nuevo sobre este doble empeño; hacerlo con mayor detenimiento requeriría más tiempo y espacio. Pero releídos hoy, catorce años después de haber sido redactados ambos textos y doce de haber sido publicados, nos produce la sensación de encontrarnos con la elocuente vigencia de ambas actitudes, precursoras entonces 
del inminente siglo XXI e inmersas ahora en un contexto de candente vigencia. Nada o casi nada ha cambiado en estos años.

Seguramente, a la hora de encontrar textos de referencia para afianzar sobre ellos nuestra actitud contemporánea ante la urgencia de compartir la arquitectura y, con ella, la construcción de la ciudad, los textos de Durán y Pezzi pueden permitirnos, casi a la manera histórica, conocer de primera mano el estado de la cuestión del género en la arquitectura que compone la ciudad.

Ambos trabajos fueron el resultado de un proceso aún más pretérito, el programa NOW, siglas inglesas de 'Programa de Igualdad de Oportunidades para las Mujeres', cuyo origen debe encontrarse en diciembre de 1992. Fue una iniciativa financiada por la Unión Europea y el Consejo Superior de los Colegios de Arquitectos de España, atenta a las transformaciones profesionales y culturales de la arquitectura en Europa ante la progresiva intervención de la mujer en la arquitectura. Un equipo multidisciplinar interesado en la práctica del urbanismo y la arquitectura decidió trabajar conjuntamente sobre ello, desde la perspectiva de las mujeres que participan en las diferentes disciplinas que intervienen en la construcción de la ciudad.

Un primer resultado de ese impulso novedoso fueron los cursos 'Urbanismo y mujer', desarrollados en Andalucía y Castilla la Mancha en 1993 y 1994, cuyas conclusiones advirtieron sobre la discriminación de hecho que habían de afrontar las mujeres en la práctica profesional de la arquitectura, al mismo tiempo que reconocieron que el grado de compromiso alcanzado por las mujeres sobre los problemas urbanos superaba ya con creces al de muchos hombres dedecados por entero al ejercicio del planeamiento y la arquitectura.

Así, el proyecto editorial La ciudad compartida, publicado a continuación, vino a añadir conexiones entre disciplinas alejadas de las expectativas de los arquitectos; pero fueron necesarios dos libros para ello, no pudo concluirse un texto compartido pese a la intención de compartir la ciudad. Durán lo explica con delicadeza pero con precisión: «No hemos podido llegar hasta el final tal como lo planteamos al principio, revisando y rehaciendo juntos cada una de las páginas, pero el grado de nuestra influencia es mucho mayor que el que puedan sugerir dos volúmenes separados.»

Quienes decidan leer entre líneas, podrán interpretar esa falta de acuerdo ante una intención inicial común: autores distintos, formaciones diferentes, puntos de vista consecuentes con sus diversas actitudes ante unos mismos hechos, libros separados. ¿No se trataba de compartir?

Pues bien, me ha parecido adecuado concluir este breve recuerdo sobre la reciente historiografía del proceso de concurrencia entre las opciones positivas hacia el ineludible propósito de compartir la arquitectura que construye la 
ciudad, con la transcripción de la reseña que publiqué en abril de 1999 sobre los libros de Durán y Pezzi:

«Nos hemos acostumbrado a entender la ciudad como un artificio necesario, un compendio de circunstancias donde, sin apenas proponérnoslo, nos encontramos envueltos en ritmos que no nos pertenecen. Olvidamos tal vez que es en la ciudad donde tiene lugar la vida: un proceso privado e irrepetible de cuyo acierto dependemos. La ciudad aparece ante nosotros como un ámbito externo donde nos relacionamos, sin apenas contar con medios que nos permitan adaptar su pulso a nuestra vida; por el contrario, somos nosotros quienes casi siempre debemos someternos a nuestra elección urbana y aceptar como inevitable una forma de vivir ajena a nuestra forma de sentir. Seguramente nuestra opción estriba en compartir, compartir la ciudad, compartir la vida y tratar de convertir nuestro entorno cercano en fundamento indispensable de convivencia.

Por eso resulta tan estimulante la intención de este libro, que ha hecho del compartir su argumentos. En dos volúmenes independientes de recogen las reflexiones del arquitecto Carlos Fernández Pezzi, muestra de la diferencia entre su manera de sentir las cosas, diferencia también entre la forma de expresión de la mujer y el hombre.

La ciudad de Durán aparece como recinto de la vida, como lugar de acogida del transmitir. Hay en su discurso una elegancia consciente, un dejar pasar definido por la calidad humana que el respeto proporciona a quienes poseen argumentos pero prefieren escuchar. Pero ¿qué hacer cuando ya la gramática al masculino los plurales compartidos? Seguramente es la actitud lo que cuenta. Porque, ante un transcurso de evolución supuestamente civilizada que pospone sistemáticamente lo femenino, es preciso buscar en la actitud personal la intención de compartir.

Durán lo hace a través de un texto repleto de ideas, ideas que convienen al habitante de la ciudad y que parecen fluir de un sentido consciente de que la persuasión reside en la inteligencia más que en el acto dirigido. Un reflejo patente de la diferencia es el esfuerzo que el hombre debe realizar para ponerse en el lugar de la mujer y la naturalidad conoce y reflexiona sobre el papel del hombre. Y es que el varón es consciente de que termina en sí mismo; debe llevar a cabo su proyecto de vida con ritmo anhelante, deseoso de dejar huella de las cosas, incapaz de la transmisión de la vida que sí posee con creces la mujer. Un libro, el de Durán, que sugiere el afecto como resultado del conocimiento y aborda el uso de la ciudad con la naturalidad del compartir.

Hernández Pezzi, leído tras Durán, denota en su texto la voluntad del varón por definir y reparar uno a uno los agravios seculares que lo masculino 
ha inferido a lo femenino en la comprensión y formación de la ciudad. Una disculpa explícita que implica el reconocimiento de una postergación atávica. Es la definición del género lo que le ocupa. ¿De qué género es la ciudad? ¿Cuál es el género de la arquitectura? Nombre femeninos ambos, vistos desde siempre con ojos masculinos y reflejo del atraso de lo urbano con relación a otras formas de conocimiento o expresión: la filosofía, el arte, la biología, cuyos conceptos se han visto radicalmente transformados cuando se han abordado con la sensibilidad de conseguir encuentro. La ciudad, la arquitectura, en cambio, permanecen en manos del hombre, ajenas casi al pulso real de la vida. Ciudades repletas de actitudes prepotentes y apresuradas, de irreflexión sobre el sentido práctico de las cosas, de barreras conscientes e inconscientes ante cuanto significa de veras cobijo, tolerancia, acogida. Ciudades que ignoran que su único fin es ayudar a compartir la vida.» 


\section{Eloi Grasset Morell. «Literatura i feminisme»}

\section{L'hora violeta de Montserrat Roig (Tarragona, Ed. Arola, 2010, 328 p.)}

Ciertamente, podríamos partir del simple hecho que Montserrat Roig es alguien que escribe -sea cual sea la extensión: novelista, periodista, crítica...-, pero eso en la modernidad, ya no asegura casi nada. Diremos, con más acierto, que Montserrat Roig es una escritora, y esta provocativa -por tautológica- frase, esconde muchas más preguntas que respuestas.

El escritor es alguien que absorbe las razones de un mundo que se le indigesta y las convierte en una interpelación, un gesto. A partir de aquí, la literatura se convierte en su único propósito y diremos con R. Barthes que, en este sentido, escribir es un verbo intransitivo. Como explica M. À. Francés, Montserrat Roig asume el compromiso crítico con su tiempo y el país que le rodea, pero rechaza la idea según la cual su obra debe ser un reflejo de la realidad. En todo caso, la literatura deberá presentarse como interpelación, pero nunca como enmienda.

Quizás por esta razón, por entender que la escritura moderna pasa por la reelaboración y la invención y no por la reconstrucción de un mundo externo, Roig fue acusada de feminismo tibio. Pero su labor es muy otra, en su caso no se trata de convertir la literatura en modelo o bandera, sino replantear desde el texto la relaciones que se generan en el mundo. Como explica M.À. Francés, Roig no tiene ninguna intención de hacer realismo feminista como se le pedía desde la crítica, sino que tan sólo pretendía reelaborar el mundo desde el lenguaje. Su ocupación es plantear, preguntar, pero en ningún caso enseñar o dar lecciones. El utillaje es el mismo para las dos funciones, sí, pero los modelos no pueden ser más distintos. En este sentido, el feminismo para Roig parece convertirse en un «mecanismo» de lectura que se propone desde cierta exterioridad para formular otra «versión» del mundo.

Todo esto queda bien expuesto y clarificado en este libro, y siempre se agradece cuando se consigue conciliar el rigor con la claridad para fraguar un 
discurso comprensible y ágil. Porque no se trata en este caso de aplicar a un objeto de estudio - parte de la obra de M. Roig- las pautas que proporcionan las tradiciones críticas en las que pretende inscribirse el libro, sino de pensar de nuevo aquello que se quiere analizar. Y de esta manera la autora va haciendo surgir las distintas constantes estilísticas y temáticas de las primeras obras de Roig que encuentran en L'hora violeta su colofón. Según M. À. Francés, esta novela culmina el proceso de construcción intertextual que articula sus cuatro primeros libros.

La intertextualidad se convierte en una noción esencial para comprender las correspondencias entre las distintas obras de Roig. Así, podremos entender que el texto ya no puede ser un receptáculo que protege un sentido «oficial», sino el espacio para un sentido inestable. La lectura de M. À. Francés intenta explicitar, desde la crítica, cómo se concretan estas correspondencias. Dar nombre a lo que Foucault llamaba «phenomène de bibliothèque» y que supone convocar en el texto cualquier otro libro, fragmento diferido, desplazado, pero señalado desde las posibilidades llameantes que ofrece el deseo. Y desde este deseo convocará todo autor su escritura, como nos recuerda M. À. Francés. Del deseo de M. Roig nos queda la traza de la escritura, y en este punto es donde corresponde vindicar el ejercicio del crítico y del investigador, que deberán intentar dilucidar por donde transita esta escritura ya desatada.

A lo largo de todo el volumen, queda claro y demostrado que todo discurso incorporado en la obra de Roig, lleva asociado un diálogo entre el narrador y el destinatario: la noción bajtiniana de «dialogismo», también reclamada en el libro, nos sirve para entender de manera clara que todo texto surgirá de la relectura, el desplazamiento y la condensación de otros.

La concurrencia de diferentes y variadas tipologías de personajes en las distintas obras tratadas es un camino utilizado por la novelista para mostrar la confluencia de las distintas voces. Como explica M. À. Francés, esta polifonía permite desmenuzar toda posible visión compacta del mundo. Las conciencias convocadas en el texto, ya que la polifonía no solo nos habla de la pluralidad de voces sino también de conciencias, no luchan para imponerse sino que se proponen como posibilidad «otra», al tiempo que se combinan en cada particular circunstancia que acontece. Cada personaje, y el estudio de sus actos -el análisis pormenorizado de todas las distintas voces que aparecen en el libro entendemos que tiene esta función-, se muestran en los textos como conciencia escindida, liberada, perteneciente a otra voz, sin convertirse en una reproducción de la conciencia del autor.

A través de la confrontación de las voces de los personajes o de su adulteración, Roig consigue discutir los discursos oficiales instalados. Ésta es la 
función con la que la autora convoca La Odisea en L'hora violeta. Francés nos muestra de qué manera la obra de Homero servirá de marco referencial para poner de manifiesto la poca importancia que, desde los orígenes de la historia y la literatura, se ha otorgado a la versión femenina de los hechos. Esta conciencia crítica de la histórica subordinación femenina será un primer paso para cuestionar los modelos arquetípicos de mujer y en este sentido cabe resaltar el trabajo analítico sobre las distintas tipologías de personajes que despliega este libro.

Como no podía ser de otra manera, Roig también escribe para comprenderse a sí misma. La novelista se proyecta en sus obras, y este ejercicio crítico es síntoma de su postura y la de sus personajes respecto a la realidad. Por esta razón sus personajes incorporan la contradicción en su discurso y parecen estar instalados entre la realidad y el deseo. Trabajar a partir de la propia experiencia y conseguir manipularla es una manera construirse una identidad compacta. La literatura también puede servir para eso. 



\section{RESEÑA BIO-BIBLIOGRÁFICA}

\section{Yolanda Agudo Arroyo}

Socióloga. Doctora por la Universidad Nacional de Educación a Distancia. Actualmente, profesora del Departamento de Teoría, Metodología y Cambio Social de la Facultad de Ciencias Políticas y Sociología de la UNED. Secretaria Académica del Instituto Universitario de Educación a Distancia de la UNED. Combina su docencia con investigaciones sobre los vínculos entre la educación superior y el empleo desde la perspectiva de género y sobre metodología de la investigación.

\section{Juan Bravo Bravo}

Dr. arquitecto por la Universitat Politècnica de València, profesor del Departamento de Composición Arquitectónica de dicha Universidad. Actualmente imparte docencia de «Estética e Historia del Diseño» en el Grado en Ingeniería en Diseño Industrial y Desarrollo de Productos y de «Cultura e Historia de la Arquitectura» en el Master en Conservación del Patrimonio Arquitectónico. Sus campos de investigación se centran en el ámbito de la Historia del Diseño, en concreto sobre el espacio doméstico; y también en Historia de la Arquitectura española del siglo Xx, en particular en la recuperación de la modernidad tras la Guerra Civil y la autarquía.

\section{Roser Casanovas}

Arquitecta (2007) por la ETSAB-UPC; Máster (2008/09) por FPC-UPC, con la tesina «La gestió de la vida quotidiana a les colònies tèxtils catalanes». Es colaboradora permanente (2005) del estudio Montaner Muxí arquitectes. Es coordinadora acadèmica (2009) del Máster Laboratorio de la Vivienda del siglo XXI; y docente del mismo con «taller: La casa sense gènere» $\mathrm{y}$ con «Urbanística I: 5 recorridos por Barcelona». Es dinamizadora (2006) del taller «La experiencia de la mujeres en el entorno cotidiano» (ICD) y desde el 2006 forma parte del Col-lectiu punt6, grupo que trabaja en la aplicación de la perspectiva de género en el urbanismo y en la arquitectura. 


\section{Pilar Chías Navarro}

Arquitecta por la Escuela Técnica Superior de Arquitectura de la Universidad Politécnica de Madrid desde 1978. Fue doctorada por la misma Universidad en 1993 por su investigación sobre «La Ciudad Universitaria de Madrid: génesis y realización», y desde entonces se ha dedicado esencialmente a investigar sobre temas vinculados con el Patrimonio y el territorio en España, así como en Europa, América y Filipinas. Sobre estos temas pertenece a varios comités científicos internacionales, y ha realizado numerosas publicaciones y exposiciones de repercusión internacional, varias de ellas premiadas. En relación con la docencia, es co-directora, con el doctor Javier Rivera, del prestigioso «Máster en Restauración, Rehabilitación y Gestión del Patrimonio» de la Universidad de Alcalá. Tras una etapa de dieciocho años como profesora titular en la Universidad Politécnica, desde 2005 es catedrática en la Escuela Técnica Superior de Arquitectura y Geodesia de la Universidad de Alcalá, de la que también es directora desde el año 2007 y miembro del Consejo de Gobierno y del Consejo Social.

\section{Adriana Ciocoletto}

Arquitecta (1997) FADU- UBA, Màster (2003) UB. Es integrante del Col-lectiu punt6 (2006), grupo que trabaja en la aplicación de la perspectiva de género en el urbanismo y en la arquitectura. Es dinamizadora (2006) del taller «La experiencia de la mujeres en el entorno cotidiano»(ICD). Es docente del Máster Laboratorio de la Vivienda del Siglo XXI, FPC-UPC (2006) en los cursos «La casa sin género»y «Urbanismo participativo». Es colaboradora (2009) del CPSV-UPC en la investigación «Inmigración, vivienda y Ciudad». Actualmente desarrolla la investigación «Indicadores urbanos para la evaluación de los espacios cotidianos desde la perspectiva de género».

\section{Marta Fonseca Salinas}

Arquitecta (1988) Universidad Nacional de Colombia. Es integrante del Collectiu punt6 (2006), grupo que trabaja en la aplicación de la perspectiva de género en el urbanismo y en la arquitectura. Es dinamizadora (2006) del taller «La experiencia de la mujeres en el entorno cotidiano» (ICD). Es docente del Máster Laboratorio de la Vivienda del Siglo XXI, FPC-UPC (2006) en el curso «La casa sin género». Es colaboradora habitual de la arquitecta Zaida Muxí en estudios de urbanismo y género. Compagina estos trabajos con la redacción de proyectos arquitectónicos. 


\section{Blanca Gutiérrez Valdivia}

Socióloga (2006) por la Universidad Complutense de Madrid. Máster en Gestión y Valoración Urbana (2007/08) por la Universidad Politécnica de Cataluña, donde actualmente realiza la tesis doctoral «El género del espacio: calidad de vida urbana y roles de género». Trabaja como investigadora en el Centro de Política de Suelo y Valoraciones donde desarrolla investigaciones sobre inmigración, segregación, condiciones residenciales y uso del espacio público. Actualmente desarrolla la investigación «Indicadores urbanos para la evaluación de los espacios cotidianos desde la perspectiva de género». Desde el 2009 forma parte del Col-lectiu punt6.

\section{Carlos Hernández Pezzi}

Arquitecto. (ETSAM, UPM 1978). Dr. Arquitecto en Proyectos Arquitectónicos (UPM Madrid 2008). 2 hijas. Arquitecto y Urbanista en ejercicio. Premio de Rehabilitación Palacio de Valdeflores IAMujer 1988. Proyectos Vivienda pública y privada. Málaga y Cádiz. Arquitecto Municipal en Málaga y Fuengirola. Arquitecto Provincial 1983-1988 y 2010-2011. Escritor, articulista y crítico. Premio Madrid Urbanismo (1999) por libro «La Ciudad compartida» (1998); «Ciudades contra burbujas» 2010 Investigador en Proyecto Excelencia 2010 «La Arquitectura Andalucía desde una perspectiva de género» Universidad Granada 2011-2015.

\section{Carlos Luis Marcos Alba}

Arquitecto y en la actualidad es profesor en la titulación de arquitectura de la Universidad de Alicante. Ha impartido clases en la E.T.S. de Arquitectura de Madrid -en donde cursó sus estudios- y en la Universidad Alfonso X el Sabio. Compagina sus actividades profesional e investigadora publicando con regularidad sus resultados en revistas especializadas y congresos internacionales. En 2009 obtuvo el título de doctor en Arquitectura y Proyectos de Arquitectura por la Universidad Politécnica de Madrid por su tesis «Espacio material: la arquitectura como extensión topológica». Asimismo, en 1992 cursó el Diploma Year en la Bartlett School of Architecture de Londres. 


\section{Andrés Martínez Medina}

Arquitecto (1985) y doctor (1994) por la Universitat Politècnica de València. Profesor de la UA desde 1994, titular del a.c. Composición Arquitectónica desde 2000. Premio COACV por su tesis. Tiene 1 sexenio. Imparte materias en los 3 ciclos: Historia y Teoría de la Arquitectura, y del Patrimonio Arquitectónico Valenciano. Entre sus libros, capítulos y artículos destacan: La arquitectura de la ciudad de Alicante, 1923-1943 (1998), Guía de arquitectura de la provincia de Alicante (1999, en la web-UA), Arquitectura del Sol (2002); Registro de Arquitectura del s. XX (2002); Dibujos y arquitectura de López González (2008); Poblados de colonización de la «zona de Levante» (2008). Ha intervenido en el patrimonio y dirigido proyectos de investigación.

\section{María Melgarejo Belenguer}

1990. Arquitecta por la Escuela Técnica Superior de Arquitectura de Valencia. Universidad Politécnica de Valencia.

2005. Doctora arquitecta por la Escuela Técnica Superior de Arquitectura de Barcelona. Universidad Politécnica de Cataluña.

Desde 1995, profesora titular de artes plásticas y diseño. Generalitat Valenciana.

En la actualidad, profesora en la escuela de arte y superior de diseño de Valencia, en la especialidad diseño de interiores.

Es autora de diversos artículos y publicaciones y ha impartido conferencias en distintos organismos.

\section{Laura Muñoz Pérez}

Estudió la licenciatura de Historia del Arte en la Facultad de Geografía e Historia de la Universidad de Salamanca (1994-1998), doctorándose en la misma en 2004 con la máxima calificación. Desde entonces es profesora del Departamento de Historia del Arte de dicha universidad. Especialista en arte contemporáneo, ha asistido a numerosos congresos y seminarios del mismo tema tanto en calidad de oyente como de invitada o ponente. Asimismo, ha completado su trabajo con visitas a centros extranjeros (Newberry Library, Chicago) y con una investigación constante que ha dado sus frutos en libros y artículos. 


\section{Zaida Muxí Martinez}

Arquitecta (1989) FADU-UBA. Doctora Arquitecta (2002) por la Escuela Técnica Superior de Arquitectura de Sevilla. Profesora titular de Urbanismo de la Escuela Técnica Superior de Arquitectura de Barcelona. Codirectora junto Josep Maria Montaner del Máster Laboratorio de la vivienda del siglo XXI en la ETSAB desde el 2004. Colabora como experta en género, arquitectura y urbanismo para el Institut Català de les Dones (Instituto Catalán de las Mujeres) en trabajos de participación de diferentes colectivos de mujeres en Cataluña. Forma parte del Col-lectiu Punt 6. Es autora de numerosas publicaciones sobre la ciudad global, espacio público y urbanismo con perspectiva de género entre otros temas.

\section{Javier Ruiz Sánchez}

Doctor Arquitecto y Profesor Titular de Urbanismo en la Escuela de Arquitectura de Madrid. Ha compaginado la labor docente e investigadora con la actividad profesional como urbanista tanto como redactor de planes como desde la administración pública. Es autor de publicaciones diversas sobre la relación entre la planificación comprensiva, la planificación sectorial y los desarrollos urbanos, la naturaleza evolutiva de la ciudad y del territorio y su concepción como sistemas complejos. Ha impartido cursos y conferencias en centros y universidades de España, Europa y América, tales como la Universidad de La Serena (Chile), Universidad de Chile, Universidad de La Plata (Argentina), Universidad de Los Andes en Bogotá o el Institut d'urbanisme de Paris.

\section{Inés Sánchez de Madariaga}

Doctora en Arquitectura. Profesora Titular de Urbanismo de la Escuela de Arquitectura de Madrid y actualmente Directora de la Unidad de Mujeres y Ciencia, Gabinete de la Ministra de Ciencia e Innovación. Es MSc. por la Universidad de Columbia en Nueva York y ex becaria Fulbright. Ha sido Visiting Scholar en la Universidad de Columbia, Nueva York, y en la London School of Economics and Political Science, así como Jean Monnet Visiting Professor en la Escuela de Arquitectura de la Universidad de Weimar-Bauhaus. Ha sido Asesora Ejecutiva de la Ministra de Vivienda y Subdirectora General de Arquitectura. Es miembro del Comité Ejecutivo de la Asociación Europea de Investigación Urbanística y representante de España en el Grupo de Helsinki, que asesora a la Comisión Europea. Es fundadora y directora del primer grupo de investigación español sobre género, urbanismo y arquitectura, en la Universidad Politécnica de Madrid. Es autora de seis libros y una treintena de artículos. 


\section{Francisco José Sánchez Medrano}

Arquitecto por la Escuela de Valladolid y Doctor por la Politécnica de Valencia. Ha efectuado diversos proyectos de Restauración y Rehabilitación (Colegio Mayor Azarbe, Iglesia de la Palma, Convento de San Ginés de la Jara, Convento de San José de Caravaca, Molinos del Campo de Cartagena). En la actualidad es Subdirector de la Escuela de Arquitectura de la UCAM en Murcia.

\section{Pilar Vallalta Martínez}

Licenciada en Arqueología e Historia Antigua por UMU 1986. Restauradora de Material Arqueológico por la Escuela de Conservación y Restauración de BBCC de Madrid 1989. Ha realizado Proyectos de conservación y restauración en la Región de Murcia: Medina Siyasa, La Casa de la Fortuna, Casa Salvius y Muralla Púnica, etc. Ha restaurado en el MAM de Murcia, en Arqua de Cartagena, en Museos municipales de Cartagena, Cieza, Cehegín, Aguilas, Lorca, etc. Desde 2003 es restauradora de la empresa Arquitectura, Trabajos de Restauración y Arqueología SLP. Ha publicado sus trabajos en diversas revistas especializadas. 
La revista Feminismo/s se publica semestralmente. Está abierta a las aportaciones del personal investigador que compone el Centro de Estudios sobre la Mujer de la Universidad de Alicante, así como a toda la comunidad académica. La organización editorial se realiza a través de números monográficos, estando prevista en su caso, la publicación de algunos números en los que se presente una miscelánea de artículos. El carácter de la publicación, al igual que la del Centro de Estudios sobre la Mujer, es multidisciplinar.

\section{NORMAS EDITORIALES DE LA REVISTA FEMINISMO/S}

1. Los trabajos, que necesariamente deberán ser producto de investigación original, se presentarán en soporte magnético utilizando el procesador de textos Word, y además impresos en la forma habitual.

2. Los artículos serán redactados con letra Times New Roman de 12 puntos y con un interlineado de un espacio y medio.

3. El título del artículo irá centrado y en letra mayúscula de 12 puntos. El nombre del autor del trabajo se pondrá unas líneas debajo del título, a la derecha, en letra de 10 puntos y mayúscula. Justo debajo se escribirá el nombre de la Universidad o, en su defecto, la ciudad a la que el autor/a pertenece, en letra minúscula de 10 puntos.

Un ejemplo sería:

SEXISMO Y VIOLENCIA: LA SOCIALIZACIÓN A TRAVÉS DE LOS VIDEOJUEGOS

ENRIQUE J. DÍEZ GUTIÉRREZ

Universidad de León 
4. La extensión de los artículos será entre 15 y 18 páginas.

5. La primera línea de cada párrafo irá sangrada.

6. Las citas en el texto con una extensión superior a tres líneas irán sangradas, sin entrecomillar y en letra de 10 puntos. Las citas de menor extensión se integrarán en el texto, entrecomilladas y con letra de 12 puntos.

7. Los títulos de libros y de revistas citados irán en letra cursiva. Los títulos de artículos o capítulos de libros se consignarán entre comillas.

8. Las notas serán a pie de página, con letra de 10 puntos e interlineado sencillo.

9. Las referencias bibliográficas se harán siempre en nota a pie de página y no en el texto. El modelo para las citas de libros será el siguiente:

ARRÁEZ, José Luis (coord.). No te di mis ojos, me los arrebataste. Ensayo sobre la discriminación, misoginia y violencia contra las mujeres desde la literatura. Alicante, Colección Lilith, 2010.

10. Las citas de artículos o capítulos de libros se realizarán según el siguiente modelo:

GORDANO, Cecilia. «Construyendo sentido sobre internet en el espacio de la diáspora: mujeres latinas inmigrantes en Granada». Feminismo/s 14 (2009), pp. 143-162.

CRAMPE-CASNABET, Michelle: «Las mujeres en las obras filosóficas del siglo XVIII», en Georges Duby y Michelle Perrot (dirs.): Historia de las Mujeres, vol. 3, Madrid, Taurus, 2000, pp. 344-384.

11. Si una obra ya ha sido citada con anterioridad, en la referencia bibliográfica se omitirá el título y se citará de la siguiente manera:

BERENGUER, Elisa. Op.cit., p. 345.

Si se citan a lo largo del trabajo diferentes obras de un/a mismo/a autor/a, se identificará el título del trabajo al que se hace referencia en cada ocasión:

BERENGUER, Elisa. La investigación feminista... Op.cit., p. 345.

Si se cita varias veces seguidas la misma obra, se omitirán el título y el nombre del/de la autor/a y se seguirá el siguiente modelo de citación:

BERENGUER, Elisa. La investigación feminista... Op.cit., p. 345.

Ibíd., p. 22.

Ibíd., p. 35.

Para citar mismo autor/a, misma obra, misma página: Ibidem. 
12. Las webs se citarán de acuerdo con el siguiente modelo:

$<$ http://www.cis.es/cis/opencms/ES/2_barometros>, consultado el 19-06-2008.

13. Los diferentes apartados del texto se ordenarán siguiendo la numeración arábiga $(1,2,3, \ldots)$ y el título de cada uno de ellos irá en letra mayúscula y en negrita. Los subapartados se numerarán de la siguiente manera: 1.1, $1.2,1.3$, etc. y sus títulos irán en minúscula y en negrita.

14. Al final de cada texto se incluirán unas «Referencias bibliográficas». El sangrado de la bibliografía irá en Francesa.

15. Los artículos irán acompañados de un resumen de 10 líneas en español y en inglés, de unas palabras clave en español y en inglés, así como de un breve currículum del autor/ de la autora (8 líneas).

16. Las fotografías e imágenes deben entregarse en formato digital, separadas del texto, en formato tif, con una calidad de 300 puntos por pulgada. Deben ir identificadas convenientemente según sean citadas en el texto.

17. Todos los trabajos serán sometidos a informes anónimos de especialistas de reconocido prestigio externos al Consejo Editorial y a la Universidad de Alicante. Los informes son la base de la toma de decisiones sobre la publicación de los artículos, que corresponde en última instancia al Consejo Editorial.

18. Se ruega acompañar los originales con la dirección postal de la autora o autor, así como su correo electrónico.

19. Los trabajos no aceptados para su publicación serán devueltos a petición de la autora o autor.

Remitir los trabajos a:

Redacción de Feminismo/s

Centro de Estudios sobre la Mujer

Universidad de Alicante

Apdo. 99 - 03080 Alicante

e-mail: cem@ua.es 

La revista Feminismo/s es publica semestralment. Està oberta a les aportacions del personal investigador que compon el Centre d'Estudis sobre la Dona de la Universitat d'Alacant, i també a tota la comunitat acadèmica. L'organització editorial es porta a terme a través de números monogràfics, i també està prevista, si és el cas, la publicació d'alguns números en què es presenta una miscel-lània d'articles. El caràcter de la publicació, igual que la del Centre d'Estudis sobre la Dona, és multidisciplinari.

\section{NORMES EDITORIALS DE LA REVISTA FEMINISMO/S}

1. Els treballs, que necessàriament hauran de ser producte d'investigació original, es presentaran en suport magnètic utilitzant el processador de textos Word i, a més, impresos en la forma habitual.

2. Els articles seran redactats amb lletra Times New Roman de 12 punts i amb un interlineat d'un espai i mig.

3. El títol de l'article estarà centrat i en lletra majúscula de 12 punts. El nom de l'autor del treball es posarà unes quantes línies davall del títol, a la dreta, en lletra de 10 punts i majúscula. Justament a sota s'escriurà el nom de la Universitat o, en defecte d'això, la ciutat a la qual pertany l'autor/a, en lletra minúscula de 10 punts.

Un exemple seria:

SEXISMO Y VIOLENCIA: LA SOCIALIZACIÓN A TRAVÉS DE LOS VIDEOJUEGOS

ENRIQUE J. DÍEZ GUTIÉRREZ Universidad de León 
4. L'extensió dels articles serà entre 15 i 18 pàgines.

5. La primera línia de cada paràgraf estarà sagnada.

6. Les citacions en el text amb una extensió superior a tres línies estaran sagnades, sense posar entre cometes, i en lletra de 10 punts. Les citacions de menys extensió s'integraran en el text, entre cometes i amb lletra de 12 punts.

7. Els títols de llibres i de revistes esmentats estaran en lletra cursiva. Els títols d'articles o capítols de llibres es consignaran entre cometes.

8. Les notes seran a peu de pàgina, amb lletra de 10 punts i interlineat senzill.

9. Les referències bibliogràfiques es faran sempre en nota a peu de pàgina i no en el text. El model per a les citacions de llibres serà el següent:

ARRÁEZ, José Luis (coord.). No te di mis ojos, me los arrebataste. Ensayo sobre la discriminación, misoginia y violencia contra las mujeres desde la literatura. Alicante, Colección Lilith, 2010.

10. Les citacions d'articles o capítols de llibres es faran segons el model següent:

GORDANO, Cecilia. «Construyendo sentido sobre internet en el espacio de la diáspora: mujeres latinas inmigrantes en Granada». Feminismo/s 14 (2009), pp. 143-162.

CRAMPE-CASNABET, Michelle: «Las mujeres en las obras filosóficas del siglo XVIII», en Georges Duby y Michelle Perrot (dirs.): Historia de las Mujeres, vol. 3, Madrid, Taurus, 2000, pp. 344-384.

11. Si una obra ja ha estat esmentada abans, en la referència bibliogràfica s'ometrà el títol i se citarà de la manera següent:

BERENGUER, Elisa. Op.cit., p. 345.

Si se citen al llarg del treball diferents obres d'un/a mateix/a autor/a, s'identificarà el títol del treball a què es fa referència en cada ocasió:

BERENGUER, Elisa. La investigación feminista... Op.cit., p. 345.

Si se citen diverses vegades seguides la mateixa obra, s'ometran el títol i el nom de l'autor o l'autora i se seguirà el següent model de citació:

BERENGUER, Elisa. La investigación feminista... Op.cit., p. 345.

Ibíd., p. 22.

Ibíd., p. 35.

Per a citar mateix autor/a, mateixa obra, mateixa pàgina: Ibidem. 
12. Les webs se citaran d'acord amb el model següent:

<http://www.cis.es/cis/opencms/ES/2_barometros/>, consultat el 19-06-2008.

13. Els diferents apartats del text s'ordenaran seguint la numeració aràbiga $(1,2,3, \ldots)$ i el títol de cada un d'aquests estarà en lletra majúscula i en negreta. Els subapartats es numeraran de la manera següent: 1.1, 1.2, 1.3, etc. i els seus títols estaran en minúscula i en negreta.

14. Al final de cada text s'inclouran unes «Referències bibliogràfiques». El sagnat de la bibliografia serà en francesa.

15. Els articles estaran acompanyats d'un resum de 10 línies en espanyol i en anglès, d'unes paraules clau en espanyol i en anglès, i també d'un breu currículum de l'autor o 1 'autora (8 línies).

16. Les fotografies i imatges han de lliurar-se en format digital, separades del text, en format tif, amb una qualitat de 300 punts per polzada. Han d'estar identificades convenientment segons siguen esmentades en el text.

17. Tots el treballs seran sotmesos a informes anònims d'especialistes de reconegut prestigi externs al Consell Editorial i a la Universitat d 'Alacant. Els informes són la base de la presa de decisions sobre la publicació dels articles, que correspon en última instància al Consell Editorial.

18. Es demana acompanyar els originals amb l'adreça postal de l'autora o autor, i també la seua adreça electrònica.

19. Els treballs no acceptats per a publicar-los seran tornats a petició de l'autora o autor.

S'han de remetre els treballs a:

Redacció de Feminismo/s

Centre d'Estudis sobre la Dona

Universitat d'Alacant

Apt. 99 - 03080 Alacant

A/e: cem@ua.es 

Feminismo/s is published on a biannual basis, and encourages contributions from researchers at the Centre for Women's Studies of the University of Alicante, as well as from the academic community as a whole. The journal is generally published in issues devoted to a single subject, although occasional issues containing articles on a range of subjects may also be published. Both the journal and the Centre for Women's Studies are multidisciplinary in nature.

\section{FEMINISMO/S: EDITORIAL POLICY AND GUIDELINES}

1. All works should be original, and should be submitted both on a CD-ROM or floppy disk containing a Microsoft Word file, and in printed form. The name of the file and its author should be written on the disk label.

2. Articles should be written in 12 point Times New Roman letter font and with 1.5 line spacing.

3. The title of the article should be centred on the page and written in 12 point upper-case letters. The name of the author should appear a few lines below the title and also on the right, in 10 point upper-case letters. The name of the university or city should come just below this and in 10 point lowercase letters.

See the following example:

SEXISMO Y VIOLENCIA: LA SOCIALIZACIÓN A TRAVÉS DE LOS VIDEOJUEGOS

ENRIQUE J. DÍEZ GUTIÉRREZ Universidad de León

Feminismo/s 17, junio 2011, pp. 345-355 
4. Articles should be between 15 and 18 pages in length.

5. The first line of each paragraph should be indented.

6. Quotations in the text of over three lines in length should be indented, without quotation marks, and in 10 point letter size. Shorter quotations should be run on, in quotation marks, as part of the body of the text, and in 12 point letter size.

7. Titles of cited books and journals should be written in italics. Titles of articles and chapters of books should be enclosed in quotation marks.

8. Footnotes should appear at the bottom of the page, in 10 point letter size and with single line spacing.

9. Bibliographical references should always appear as footnotes and not in the body of the text. See the following model for citing books:

ARRÁEZ, José Luis (coord.). No te di mis ojos, me los arrebataste. Ensayo sobre la discriminación, misoginia y violencia contra las mujeres desde la literatura. Alicante, Colección Lilith, 2010.

10. Articles and chapters of books should be cited as in the following example: Gordano, Cecilia. «Construyendo sentido sobre internet en el espacio de la diáspora: mujeres latinas inmigrantes en Granada». Feminismo/s 14 (2009), pp. 143-162.

CRAMPE-CASNABET, Michelle: «Las mujeres en las obras filosóficas del siglo XVIII», en Georges Duby y Michelle Perrot (dirs.): Historia de las Mujeres, vol. 3, Madrid, Taurus, 2000, pp. 344-384.

11) If a work has already been cited, its title is omitted in subsequent references, as follows:

BERENGUER, Elisa. Op.cit., p. 345.

If different works by the same author are cited, then the title should be given in each reference:

BERENGUER, Elisa. La investigación feminista... Op.cit., p. 345.

If the same work is cited several times in succession, both the title and author's name should be omitted and the following model adopted:

BERENGUER, Elisa. La investigación feminista... Op.cit., p. 345.

Ibíd., p. 22.

Ibíd., p. 35.

To quote same autor, same work, same page: Ibidem. 
12. Web references should be given as follows: $<$ http://www.cis.es/cis/opencms/ES/2_barometros/>, consulted on 19-06-2008.

13. Different sections of the text should be ordered using Arabic numerals $(1,2,3$, etc.) and section headings should be written in capital letters and bold type. Sub-sections should be numbered as follows: 1.1, 1.2, 1.3, etc.; sub-section headings should be written in lower-case letters and bold type.

14. A «Bibliographical references» section will appear at the end of each text. This should be indented in French style.

15. Articles should be accompanied by an abstract of about 10 lines in Spanish and English, with keywords in Spanish and English, and a short CV of the author (8 lines).

16. Photographs and graphic items should be submitted on a CD-ROM or floppy disk, separate from the text, in TIF format and with an image quality of 300 dots per inch. They should be clearly labelled according to their position in the text.

17. All contributions are evaluated anonymously by specialists of recognised prestige external to the Editorial Board and the University of Alicante. The reports sent in by these specialists form the basis for decisions concerning the publication of articles, which are ultimately made by the Editorial Board.

18. Contributions should be submitted with the author's postal and e-mail addresses.

19. Works not accepted for publication may be returned to the author on request.

Please send contributions to:

Redacción de Feminismo/s

Centro de Estudios sobre la Mujer

Universidad de Alicante

Apdo. 99 - 03080 Alicante

e-mail: cem@ua.es 



\section{Números anteriores publicados}

Feminismo/s 1. Feminismo y multidisciplinariedad. Helena Establier (coord.)

Feminismo/s 2. Imagin/ando a la mujer. Pilar Amador Carretero (coord.) y Mónica Moreno Seco (ed.)

Feminismo/s 3. Mujer y participación política. Mónica Moreno Seco y Clarisa Ramos Feijóo (coords.)

Feminismo/s 4. Writing, memoirs, autobiography and history. Silvia Caporale Bizzini (coord.)

Feminismo/s 5. Habitar / escribir / conquistar el espacio. Teresa Gómez Reus (ed.)

Feminismo/s 6. Violencia estructural y directa: mujeres y visibilidad. Carmen Mañas Viejo (coord.)

Feminismo/s 7. Hèléne Cixous: Huellas de intertextos. Maribel Peñalver Vicea y Rosa María Rodríguez Magda (eds.)

Feminismo/s 8. Mujeres y derecho. Nieves Montesinos Sánchez y $\mathrm{M}^{\mathrm{a}}$ del Mar Esquembre Valdés (coords.). Nieves Montesinos Sánchez (ed.)

Feminismo/s 9. Género, conflicto y construcción de la paz. Reflexiones y propuestas. Eva Espinar Ruiz y Eloisa Nos Aldás (coords.)

Feminismo/s 10. Medicines i Gènere. El torsimany necessari. Elizabeth Mora Torres, Albert Gras i Martí (coords.)

Feminismo/s 11. La representación/presencia de la mujer en los Medios de Comunicación. Sonia Núñez Puente (coords.) y Helena Establier Pérez (ed.)

Feminismo/s 12. Mujeres en democracia. Nieves Montesinos Sánchez y Ma del Mar Esquembre Valdes (coords. y eds.)

Feminismo/s 13. Mujeres y diversidad funcional (discapacidad): construyendo un nuevo discurso. Carmen Mañas (coord.)

Feminismo/s 14. Género y nuevas tecnologías de la información y la comunicación. Eva Espinar Ruiz (Coord.)

Feminismo/s 15. ¿Feminismo de la igualdad y feminismo de la diferencia? Elena Nájera (Coord.)

Feminismo/s 16. Género e imagen del poder en la historia contemporánea. Mónica Moreno Seco y Alicia Mira Abad (Coords.) 


